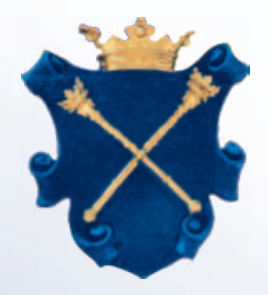

LINGVARIA

Rocznik (XII) 2017 


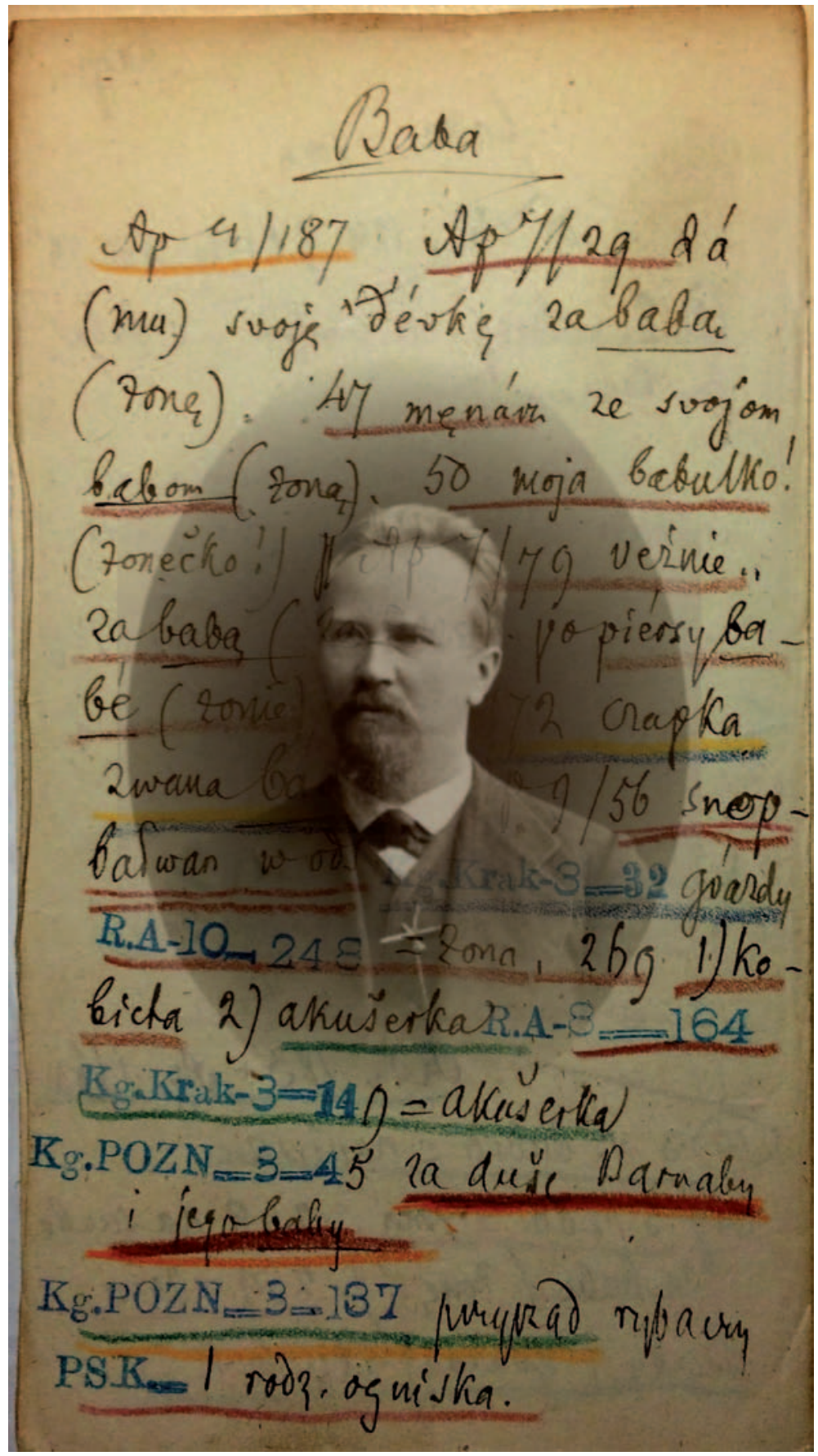

Z dziejów Słownika gwar polskich Jana Karłowicza... 
LingVaria 



\section{LingVaria}

PÓŁROCZNIK WYDZIAŁU POLONISTYKI

UNIWERSYTETU JAGIELLOŃSKIEGO

ROK XII (2017), NR 2 (24) 


\section{Rada Naukowa}

prof. Jolanta AnTAs (Uniwersytet Jagielloński, Kraków), prof. Jan FELLERER (University of Oxford), проф. Євгенія А. Карпіловська (Національна академія наук України,

Київ), prof. Krystyna Kleszczowa (Uniwersytet Śląski, Katowice), prof. Halina Kurek (Uniwersytet Jagielloński, Kraków), prof. Janina Labocha (Uniwersytet Jagielloński, Kraków), prof. Koji Morita (Tokyo University of Foreign Studies, Section of Polish Studies, Tokyo), prof. Anna Pajdzińska

(Uniwersytet Marii Curie-Skłodowskiej, Lublin), prof. Renata Przybylska (Uniwersytet Jagielloński, Kraków)

\section{Redakcja}

prof. Mirosław SKARŻYŃsKi (redaktor naczelny), dr hab. Maciej RAK (zastępca redaktora naczelnego), dr Tomasz KurdyŁA (sekretarz redakcji), dr Anna Czelakowska

\section{Adres redakcji \\ "LingVaria”}

Wydział Polonistyki UJ, ul. Gołębia 20, 31-007 Kraków, pok. 33a

e-mail: lingvaria@vp.pl www.lingvaria.polonistyka.uj.edu.pl www.akademicka.pl/lingvaria

ISSN 1896-2122

Wersją pierwotną (referencyjną) czasopisma jest wersja elektroniczna

(C) Copyright by the Jagiellonian University and individual authors

Wydawca:

„Księgarnia Akademicka” Sp. z o.o.

ul. św. Anny 6, 31-008 Kraków

e-mail: akademicka@akademicka.pl

www.akademicka.pl

„Księgarnia Akademicka” prowadzi sprzedaż i prenumeratę „LingVariów”

Publikacja wydana dzięki środkom Wydziału Polonistyki Uniwersytetu Jagiellońskiego

Redakcja: Justyna WójCıK

Korekta: Judyta WAŁĘGA

Skład i łamanie: Małgorzata MANTERYs-RaCHWA£

Opracowanie graficzne okładki: Paweł SEPIELAK

Tłumaczenie streszczeń na ang.: Kamil STACHOWsKI 


\section{SPIS TREŚCI}

\section{Zagadnienia ogólne}

Zuzanna ToPolıńska: Przyimki - ich miejsce w opisie gramatycznym $\ldots . . .99$

\section{Polszczyzna współczesna}

Anna Czelakowska: Wiedza kulturowa a opis leksykograficzny w jednojęzycznym słowniku języka polskiego . .................. 19

Ewa RUDNICKA: Kategoria stylu w badaniach metaleksykograficznych ..... 37

Jacek SzczePAniaK: Wartościowanie jako praktyka komunikacyjna (na przykładzie tekstów prasowych z dziedziny gospodarki i ekonomii) ... 57

\section{Polszczyzna historyczna}

Stanisław Koziara, Renata Przybylska: Gość czy obcy? Od przekazu ewangelicznego (Mt 25, 31-46) do polskich przekładów biblijnych. Problemy ekwiwalencji

Dorota MaSŁej: Głos w dyskusji o tekście staropolskim. Znad kanonów

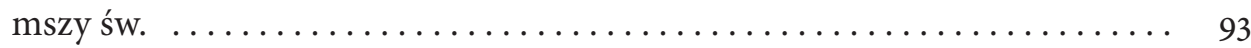

Piotr Sовотка, Magdalena Żaвоwsка: Wyodrębnianie, dekodowanie i klasyfikacja historycznych jednostek języka ...

Kinga TuTAK: Funkcje dwukropka w polskich opracowaniach normatywnych

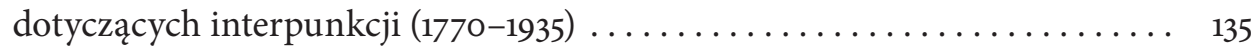

\section{Słowiańszczyzna}

Zbigniew BABIK: W poszukiwaniu tzw. centrum toponimii (wczesno)słowiańskiej - przypadek ziem polskich. Cz. II . . . . . . . . . . 153

Norbert Ostrowski: Od comitativu do spójnika. O pochodzeniu słowiańskiego spójnika $i$ oraz litewskiego ir 'i; też' 


\section{Etymologia}

Marek Stachowsкi: Polskie pantałyk i jego wschodniosłowiańskie, słowackie i morawskie odpowiedniki - uwagi o pochodzeniu . . . . . . . . . . . . 179

Krzysztof Tomasz Witczak: Łacińskie lōrum w świetle etymologii ........ 185

\section{Socjolingwistyka}

Ewa DzIĘGIEL: Odmiany terytorialne i społeczne współczesnego języka polskiego na Ukrainie ............................. 199

Mirosława Sagan-Bielawa: Język jako element świadomości społecznej (na przykładzie Polski po 1918 roku) . . . . . . . . . . . . . . . . 211

\section{Dialektologia}

Irena Bogocz: Východolašská nářečí versus gwara zachodniocieszyńska, czyli dialektologiczna wojna o Zaolzie . ................... 227

Katarzyna KonczewsKa: Słownictwo związane z obróbką lnu i tkactwem w gwarach Grodzieńszczyzny na tle gwar podlaskich ............. 245

\section{Z przeszłości językoznawstwa}

Maciej RAK: Z dziejów Słownika gwar polskich Jana Karłowicza. Kartoteka i działania wydawnicze ........................ 263

\section{Debiuty naukowe}

Joanna WoŁoszyn: Czasownikowe wykładniki nakłaniania kogoś do czegoś z perspektywy semantycznej. Rekonesans badawczy . . . . . . . . . . 291 
ZAGADNIENIA OGÓLNE 

Zuzanna Topolińska

Makedonska Akademija na Naukite i Umetnostite, Skopje

zuzana@manu.edu.mk

\section{PRZYIMKI - ICH MIEJSCE W OPISIE GRAMATYCZNYM}

Słowa klucze: przyimek, grupa imienna, semantyka przypadka, derywacja semantyczna Keywords: preposition, nominal phrase, semantics of cases, semantic derivation

Nie ulega wątpliwości, że przyimek - choć konwencjonalnie graficznie od niej oddzielony - jest integralną częścią grupy imiennej. Nie ulega też wątpliwości, że funkcjonalnie należy on do gramatycznych środków wyrazu kategorii przypadka. Chciałabym w tym tekście przyjrzeć się, czy i jak ewoluowała funkcja przyimka na gruncie polskim od wyodrębnienia się polszczyzny kolejno ze wspólnoty prasłowiańskiej i zachodniosłowiańskiej do dziś i jakie aktualnie jest jego miejsce w opisie gramatycznym języka polskiego, realizowanym w ramach teorii „od znaczenia do formy".

Od wielu lat, obok polszczyzny, zajmuję się językiem macedońskim i właśnie sytuacja macedońska skierowała moją uwagę na status przyimków w ogóle, a szczególnie na ich status we współczesnym języku polskim. Jak wiadomo, macedoński mutatis mutandis podobnie jak bułgarski - nie ma dziś fleksji przypadka, a funkcję gramatycznych wykładników stosunków przypadkowych przejęły w znacznej mierze przyimki. W odróżnieniu od polszczyzny, która dziedziczy w prostej linii prasłowiański podział typów deklinacyjnych rzeczownika oparty na kryterium jego rodzaju gramatycznego, macedoński wypracował nowy, złożony podział, który łączy go z pozostałymi językami tzw. ligi bałkańskiej, a także z większością języków zachodnioeuropejskich. Jest to podział uzależniony prymarnie od charakterystyki referencyjnej rzeczownika jako członu konstytutywnego grupy imiennej 
w ramach opozycji /+/- określony/ (ang. /+/- definite/), przy czym „określony” to tyle co 'jednoznacznie zidentyfikowany dla autora tekstu'; innymi słowy, grupa imienna /+ określona/ to grupa, której referentem jest jednoznacznie zidentyfikowany denotat pojęcia generycznego, które ta grupa nazywa. Wykładnikiem określoności jest rodzajnik lub inne powołane do tej funkcji zaimki (shifters). W związku z tym macedoński ma dzisiaj dwa semantyczne (i formalne) paradygmaty przypadka: /+ def/ i /- def/. Jeżeli przyjmiemy, że wspólnym mianownikiem semantycznym dla kategorii przypadka jest rola semantyczna referenta danej grupy imiennej w zdarzeniu ${ }^{1}$, które jest referentem obejmującej tę grupę propozycji, wówczas przyjdzie nam stwierdzić, że wykładnikiem lub współwykładnikiem części stosunków przypadkowych zarówno w wypadku grup określonych, jak i nieokreślonych jest przyimek; konkretnie w grę wchodzi datiw, instrumental i lokatiw, czyli poza tym zestawem pozostają jedynie nominatiw i akuzatiw ${ }^{2}$, przy czym sygnałem formalnym nominatiwu jest kongruencja $\mathrm{z}$ predykatem werbalnym, a w wypadku akuzatiwu wykładnikiem w paradygmacie /+ def/ jest prepozytywna klityka zaimkowa ${ }^{3}$. Jak z tego wynika, paradygmat /+ def/ ma bogatszy zestaw wykładników formalnych.

Analiza sytuacji macedońskiej zwróciła moją uwagę na „współpracę” przyimka z końcówką przypadkową w polszczyźnie, tj. na polskie konstrukcje przypadkowe, w których przyimek kontroluje odpowiednią końcówkę przypadkową; mam na myśli konstrukcje jak czekam na ciebie, tęsknię za toba, posłałem po ciebie, zakochatem się $w$ tobie itp., itd.; nie przypadkiem odpowiednie grupy imienne reprezentuje w moich przykładach zaimek osobowy. Otóż w naszym Centrum Badawczym Lingwistyki Arealnej (w skrócie ICAL) przy Macedońskiej Akademii Nauk i Sztuk rozwijamy ostatnio teorię derywacji semantycznej. Jako zwolennicy gramatyki pisanej „od treści ku formie", a nie odwrotnie, jesteśmy zdania, że nowe derywaty (semantyczne i) formalne powstają $\mathrm{w}$ rezultacie impulsów semantycznych zrodzonych $\mathrm{w}$ procesie naszej konceptualizacji świata, ergo derywacja formalna to zgramatykalizowany wynik derywacji semantycznej. Nasze dotychczasowe próby poświęcone derywacji semantycznej (i formalnej) od prasłowiańskich rdzeni werbalnych oznaczających pierwsze podstawowe aktywności człowieka na planecie Ziemia, a więc opanowywanie przestrzeni i czasu, podstawowe procesy mentalne itp., zdają się potwierdzać przyjęte przez nas i przedstawione wyżej założenia. Stąd postawiłam sobie pyta-

1 Przez „zdarzenie” (event) rozumiem tutaj wspólną nazwę dla różnych referentów propozycji, takich jak 'stan', 'proces', 'aktywność' itd.

2 Przyimek jest również wykładnikiem stosunku genetywnego, jednak genetiw - ze względu na jego adnominalną pozycję - nie należy w moim pojęciu do paradygmatu przypadka.

3 Aby przybliżyć czytelnikowi ten egzotyczny dla Polaka system, podaję poniżej oba paradygmaty przypadkowe rzeczownika студент w języku macedońskim: /+ def/: $\mathrm{N}$ студентот, D му на студентот, А го студентот, I со студентот, L до, на, од, за... студентот; klityki му i 20 pochodzą z paradygmatu zaimka osobowego 3 os. r.m.; /- def/: N cmудент, D на студент, А студент, I со студент, L до, на, од, за... студент... 
nie, jak przedstawia się derywacja semantyczna paradygmatu przypadka i związana $\mathrm{z}$ nią derywacja semantyczna przyimków. Poniższy tekst jest próbą odpowiedzi na to pytanie.

Znana jest lokalistyczna teoria przypadka, czyli - innymi słowy - teoria, która referentów konstrukcji argumentowych danej propozycji - poza człowiekiem sprawcą - widzi jako wycinki przestrzeni, które ten człowiek poznaje, pokonuje, wykorzystuje dla swoich celów... Jest to zgodne ze wspomnianym wyżej założeniem, że opanowywanie przestrzeni i podporządkowywanie jej swoim celom należy do pierwszych aktywności człowieka na Ziemi, czy to człowieka nomady, czy człowieka rolnika... Łatwo też przyjąć, że konstrukcje, które były odbiciem orientacji człowieka w przestrzeni, okazały się przydatne również jako wyraz orientacji w czasie, tj. wyraz ustalania linearnej czy też paralelnej lokalizacji zdarzeń na osi czasu. Wczesny zanik bezprzyimkowego lokatiwu jasno wskazuje, że odpowiednie wyrażenia argumentowe to w pierwszej linii „przyimkowe grupy imienne”. Narzuca się wniosek, że punktem wyjścia ewolucji semantycznej interesujących nas wyrażeń jest informacja o orientacji człowieka w przestrzeni i - pierwszy krok / pierwsza metafora na drodze derywacji semantycznej - informacja o orientacji człowieka w czasie ${ }^{4}$. Dotyczy ona ról semantycznych wyrażeń argumentowych i funkcji przyimka jako dominującego, niekiedy jedynego wykładnika (semantycznego i) gramatycznego tych ról.

$\mathrm{W}$ naszej próbie rekonstrukcji derywacji semantycznej grup imiennych dominowanych przez przyimek jako kolejny krok narzuca się przyjęcie w funkcji lokalizatorów nie tylko wycinków przestrzeni „naturalnej”, ale też wszelkich przedmiotów materialnych pozostających w określonej relacji przestrzennej w stosunku do interesujących nas obiektów, co oznacza, że funkcję lokalizacji mogą pełnić nie tylko wyrażenia typu za rzeką, pod lasem, na szczycie góry itp., ale też wyrażenia za domem, pod szafą, przy płocie itp. Rośnie też, w miarę cywilizacyjnego bogacenia się świata, w którym żyje dana wspólnota ludzka, a więc i bogacenia się języka, grupa wyróżnionych przedmiotów materialnych, których prymarną funkcją jest lokalizacja innych przedmiotów, tj. grupa kontenerów, jak pudełko, walizka, skrzynia... czy w szerszym sensie - mieszkanie, dom, wieś, miasto... - ten typ lokalizacji w polszczyźnie obsługuje, wyróżniony funkcjonalnie, przyimek w/we...

4 Wypada przypomnieć, że w ramach przyjętej tu teorii opisu gramatycznego minimalny komunikat językowy to propozycja, której odpowiednikiem formalnym jest zdanie. Propozycję konstytuuje predykat, który implikuje odpowiednią liczbę argumentów zapisanych w jego strukturze semantycznej; predykat to pojęcie generyczne, element naszej konceptualizacji świata, jego wykładnikiem formalnym jest leksem lub gramatycznie zorganizowana grupa leksemów; argument to referencyjnie związany denotat nazwanego pojęcia generycznego, jego odpowiednikiem formalnym jest grupa imienna (a więc znów leksem lub gramatycznie zorganizowana grupa leksemów); argumenty mogą być przedmiotowe (jeśli ich referentem jest przedmiot materialny) lub propozycjonalne (jeśli ich referentem jest zdarzenie). Jest to teoria, w pewnych punktach „dobudowana", przedstawiona w akademickiej Gramatyce współczesnego języka polskiego (GWJP 1984). 
Kolejny ważny dla nas krok na drodze derywacji semantycznej to uznanie za lokalizatory nie tylko nieruchomych (tj. przynajmniej w danym momencie) jednoznacznie zlokalizowanych przedmiotów materialnych, ale też „ruchomych” organizmów żywych, przede wszystkim najwyżej umieszczonych w tej hierarchii istot ludzkich. Derywacja może dotyczyć związanego z daną osobą wycinka przestrzeni, takich jak mieszkanie, miejsce pracy itp., jak w wyrażeniach Jedziemy do ciebie, Byt u mnie Jurek itp. - w tym wypadku na uwagę zasługuje aktualna wąska na gruncie polskim rola przyimka $u$; obok starych reliktowych wyrażeń, jak $u$ progu domu, u progu lata w sensie 'na początku, w punkcie wejścia', mamy dzisiaj wyrażenia takie jak u mnie, u nich, tj. 'w moim, w ich mieszkaniu/domu', ale też zwroty jak Czeszę się u pana Zenona, Kupuję zawsze u moich sasiadów itp.

Nie brak również wyrażeń, w których istota ludzka odgrywa literalnie funkcję lokalizatora, por. np. Na tobie wszystko wygląda dobrze czy Uważaj, łaża po tobie mrówki itp. Jednak właściwa koncentracja na istotach ludzkich jako lokalizatorach, na powierzchni tekstu sformalizowanych w postaci zaimków osobowych lub imion własnych, dotyczy operacji mentalnych; por. takie wyrażenia, jak tęsknię za toba, martwię się o ciebie, zakochałem się $w$ Marii od pierwszego wejrzenia, podziwiam go, zazdroszcze mu, wierze mu, licze się z nim..., w pracy wszyscy go cenia... itp. nosicielem danej postawy mentalnej, najczęściej emocjonalnej, jest autor tekstu, ewentualnie osoby trzecie, natomiast lokalizatorem/obiektem emocji czy oceny jest jednoznacznie zidentyfikowany człowiek, często adresat tekstu.

Przyjrzyjmy się, które elementy semantycznego paradygmatu kategorii przypadka są w polszczyźnie, we wszystkich lub tylko w niektórych (których?) wariantach odpowiednich ról semantycznych, kontrolowane przez przyimki:

- nominatiw, z prymarną rolą agensa, ex definitione kontroli przyimka nie przyjmuje;

- datiw, niegdyś często w roli celu, dziś praktycznie jedynie w roli adresata, beneficjenta akcji; w funkcji lokalizującej wiąże się jedynie z przyimkiem $k u$, jako referentów ma najczęściej ludzi i jest w tym związku specyficznie nacechowany stylistycznie;

- akuzatiw, obiekt akcji, jest neutralny w stosunku do opozycji /+/- hum/; w funkcji lokalizującej forma akuzatiwu jest kontrolowana przez przyimki (por. niżej); po negacji w funkcji automatycznego wariantu pozycyjnego pojawia się forma genetiwu;

- instrumental w swojej tradycyjnej funkcji preferuje referentów nieożywionych i nie przyjmuje kontroli przyimka, natomiast w lokalizującej funkcji komitatywnej jest obowiązkowo kontrolowany przez przyimek z/ze i statystycznie często łączy się z referentami /+ hum/;

- lokatiw, jak wiadomo, jest obowiązkowo kontrolowany przez przyimek i trwa, niemal bez wyjątku, przy swojej, szeroko rozumianej, funkcji lokalizującej; przez lokatiw rozumiem tu nie tylko, w myśl tradycyjnego opisu gramatycznego, 
statyczną lokalizację typu na... czy w/we..., ale wszystkie konstrukcje lokalizujące, tj. konstrukcje, w których grupa imienna kontrolowana przez przyimki „współpracujące” z końcówką przypadkową nazywa lokalizatora, a więc:

- genetywne konstrukcje lokalizacji dynamicznej z przyimkami do, od, przez $z^{5} \ldots$ czy statycznej z przyimkiem $u$ (por. wyżej),

- datywne konstrukcje lokalizacji statycznej z przyimkiem $k u$, w których dominują dzisiaj lokalizatory /+ hum/,

- instrumentalne konstrukcje komitatywne, z koincydencją w miejscu i czasie rozumianą jako forma lokalizacji,

- tradycyjne lokatywne konstrukcje lokalizacji statycznej z przyimkami na, w/we...,

- konstrukcje, w których końcówka przypadkowa dominuje nad przyimkiem, decydując odpowiednio o statycznym lub dynamicznym charakterze lokalizacji, tj. typ kryję się pod dach vs kryję się pod dachem, czy też o lokalizacji w przestrzeni realnej lub mentalnej, typ opieram się o ścianę vs myślę o tobie... itp.

Powyższy przegląd zdaje się potwierdzać sukcesywną ewolucję od lokalistycznej koncepcji przypadka, lokującej człowieka i otaczające go obiekty w przestrzeni, do koncepcji antropocentrycznej, wskazującej na dominującą w naszej konceptualizacji świata pozycję człowieka. Nie muszę dodawać, że sytuacja macedońska potwierdza ten kierunek ewolucji.

Utrzymując swoją podstawową funkcję statycznej i/lub dynamicznej lokalizacji przestrzennej, przyimki w drodze derywacji semantycznej ewoluują funkcjonalnie od wykładników lokalizacji w przestrzeni naturalnej do lokalizacji w przestrzeni społecznej, i wreszcie - w przestrzeni mentalnej.

Przegląd materiału staropolskiego zebranego w: (Zapomniane konstrukcje 1971-1978) pokazuje wyraźnie drogę derywacji semantycznej przyimków i wzrost ilości konstrukcji wyrażających lokalizację społeczną lub mentalną w stosunku do wyjściowych konstrukcji lokalizujących w przestrzeni naturalnej. Niestety siatka terminologiczna i przeprowadzona w ramach tej siatki klasyfikacja przykładów utrudnia podsumowanie ewolucji wykładników konkretnych pozycji semantycznego paradygmatu przypadka ${ }^{6}$.

Wspomniałam wyżej, że w moim pojęciu genetiw, z tytułu swojej pozycji adnominalnej, nie należy do paradygmatu przypadka rozumianego jako rola semantyczna argumentu konstytuującego daną propozycję predykatu? W związku

5 Nie zajmuję się tutaj wtórną derywacją semantyczną reprezentowaną przez przez kauzatywne, jak w: przez ciebie zawsze się spóźniam itp.

6 Podsumowanie takie powinno się znaleźć w nowych opracowaniach polskiej składni historycznej, a mogłoby być dobrym tematem szeregu prac dyplomowych. Na opracowanie czeka również dystrybucja i paralele znaczeniowe w relacji: przyimek $\sim$ prefiks werbalny.

7 Konkretnie widzę $\mathrm{w}$ adnominalnych konstrukcjach $\mathrm{z}$ genetiwem transformy zdań opartych na predykacie 'habere', por. Topolińska (w druku). 
z proponowaną tu rekonstrukcją ewolucji semantycznej przypadka i roli przyimka na drodze tej ewolucji warto bliżej przyjrzeć się dystrybucji i składni genetiwu. Otóż, o ile „czysty” genetiw ogranicza się dziś w polszczyźnie do funkcji adnominalnej jako genetiw szeroko pojętego posesora (typ dom Pawła, matka Hani, zmartwienie Jurka...), o tyle genetiw kontrolowany przez przyimek bez przeszkód funkcjonuje w pozycji adwerbalnej, por. piszę / tęsknię do ciebie / do mojej przyjaciółki, do Ani, oddalam się od domu / od tego sposobu myślenia, chętnie chodzę do teatru..., a także, wyłącznie w stosunku do referentów /+ hum/: Zawsze dobrze czuję się u was itp. - wszystkie przykłady z jednoznaczną funkcją lokalizującą. Notabene, zaimki osobowe, które zachowały maksymalnie bogatą fleksję w językach - jak macedoński - gdzie praktycznie zanikła fleksja rzeczownika, w pozycji adnominalnej w funkcji genetiwu posługują się przymiotnikiem dzierżawczym. Jak wiemy, również nomina propria w pozycji adnominalnej często bywają reprezentowane przez przymiotnik z nacechowanymi sufiksami „rodzajowymi”-ov-, -in-. Stąd wniosek, że grupy imienne notorycznie /+ def/ tracą swój status grup imiennych i przybierają formę adiektywnych modyfikatorów, jeśli przyjdzie im znaleźć się w stosunku zależności syntaktycznej od innej grupy imiennej, podczas gdy w pozycji adwerbalnej, tj. w funkcji wyrażenia argumentowego i w stosunku zależności syntaktycznej od verbum, są kontrolowane przez przyimki. Jest to kolejny ważny argument wykluczający genetiw z paradygmatu przypadka, a zarazem ilustracja, jak przyimki sukcesywnie przejmują funkcje końcówek przypadkowych.

W świetle przedstawionych tu faktów wydaje się logiczne, że miejsce przyimków w opisie gramatycznym języka to jeden z podstawowych rozdziałów tekstu poświęconego grupie imiennej i formom gramatykalizacji semantycznej kategorii przypadka.

\section{Literatura}

GWJP 1984: Z. Topolińska (red.), Gramatyka współczesnego języka polskiego, t. 1: Składnia, Warszawa 1984.

KopeČNÝ F., 1973, Etymologický slovník slovanských jazykư. Slova gramatická a zájmena, t. 1, Praha.

Topolińska Z., w druku, Czy genetiw to przypadek?, [w:] Wyraz i zdanie w językach słowiańskich, Wrocław.

Zapomniane konstrukcje: Z. Klemensiewicz, K. Pisarkowa, J. Konieczna-Twardzikowa, Zapomniane konstrukcje składni staropolskiej, 1966; Z. Klemensiewicz, A. Kałkowska, K. Pisarkowa, J. Twardzikowa i in. (oprac.), Zapomniane konstrukcje składni średniopolskiej, 1971, 1972, 1973; A. Kałkowska i in. (oprac.), Zapomniane konstrukcje składni nowopolskiej, 1974, 1975, 1977, Wrocław. 


\section{Prepositions - their place in the description of a language \\ Summary}

The author argues that prepositions are an integral part of nominal phrases, and their graphic treatment as autonomous words is purely a lexicographic convention. They have maintained their primary meaning which is localization of material objects and events in space and time, and they subsequently evolved to also express localization in the social world and in the mental world. In a grammatical description of a language they should be discussed together with the semantic and formal structure of nominal phrases. 

POLSZCZYZNA WSPÓŁCZESNA 



\section{WIEDZA KULTUROWA A OPIS LEKSYKOGRAFICZNY W JEDNOJĘZYCZNYM SŁOWNIKU JĘZYKA POLSKIEGO'}

Słowa klucze: leksykografia, słowniki ogólne, wiedza o świecie, wiedza encyklopedyczna, informacja kulturowa

Keywords: lexicography, general dictionaries, knowledge of the world, encyclopaedic knowledge, cultural information

1. Rozwój semantyki w latach 70. XX w. oraz będące jego wynikiem dyskusje przyczyniły się do zasadniczych zmian w koncepcjach opisów leksykograficznych w jednojęzycznych słownikach języka polskiego, tzw. objaśniających. Naczelny postulat Macieja Grochowskiego, zgodnie z którym wyrażenia będące hasłami w słownikach językowych powinny być wyjaśniane także za pomocą wyrażeń języka naturalnego, nie zaś terminologii specjalistycznej (Grochowski 1982), odegrał w leksykografii rolę chyba kluczową, choć wywoływał różnego typu wątpliwości językoznawców i leksykografów². Odejście od objaśnień encyklopedycznych na rzecz językowych miało się bowiem wiązać z rezygnacją z przedstawiania właściwości desygnatów, do których

1 Artykuł jest rozwinięciem szkicowej i okrojonej o przykłady koncepcji przedstawionej w tekście Informacja kulturowa w ogólnym słowniku języka polskiego, czyli jeszcze o tradycji okiem leksykografa, złożonym w tym roku w jubileuszowym tomie „Annales APC”.

2 Sprawę tę dyskutowali, zgłaszając pewne ograniczenia i zależności w praktycznym zastosowaniu tego postulatu, m.in. Andrzej Bogusławski (1988: 74-79), Mirosław Bańko (2001: 123-142), Piotr Żmigrodzki (2008: 130-135). 
się odnoszą opisujące je jednostki leksykalne, i ograniczeniem informacji do tego, czego uzasadnienie umożliwi odpowiednia procedura (Grochowski 1988).

Tymczasem słownik ogólny jest zależny od pewnego typu wiedzy encyklopedycznej. Zawężenie definicji wyłącznie do właściwości językowych interpretowanych wyrażeń i pozbawienie ich rozmaitych odniesień z zakresu wiedzy o świecie, choć nadałoby owemu opisowi cechy uniwersalności, ograniczałoby też ogląd zjawisk, których odnotowanie $\mathrm{w}$ jednojęzycznym słowniku ogólnym $\mathrm{z}$ różnych przyczyn jest celowe. Dyskusji powinien podlegać jedynie zakres powyższych informacji oraz ich miejsce w strukturze słownika.

1.1. Z punktu widzenia współczesnego językoznawstwa znaczące wydaje się zwłaszcza stanowisko leksykografii wobec utrwalonej językowo wiedzy kulturowej, choć tę ostatnią zasadniczo będę rozumieć w artykule in aczej niż w nurcie etnolingwistycznym zapoczątkowanym przez Jerzego Bartmińskiego (1984) i innych pracach z szeroko pojmowanej lingwistyki kulturowej (m.in. Wierzbicka 1985; Bartmiński 1988; Tokarski 1993; Anusiewicz 1994; Bartmiński, Niebrzegowska-Bartmińska 2008). Koncepcja Bartmińskiego (1984), również postulująca odejście od encyklopedyzmu, wyróżniała się - zbieżnym z propozycjami Jurija Apresjana (1972) oraz Lidii Jordanskiej i Igora Mielczuka (1988) - uwzględnianiem w definicjach semantycznych wiedzy „potocznej”, „zdroworozsądkowej”. Ta ostatnia miała oznaczać nie tylko językowe rozumienie opisywanych w słowniku wyrazów, ale przede wszystkim zakodowany w przekazie językowym danej społeczności sposób postrzegania rozmaitych pojęć, to znaczy zbiór wyobrażeń i przekonań tworzących swoiste nawarstwienia kulturowe w leksykalnym systemie języka. Niestety próba częściowego już wprowadzenia do słowników opisu semantycznego bliskiego językowi potocznemu i uwzględniającego pewien zakres owych sądów (zastosowanego w niektórych hasłach SWJP i dosyć konsekwentnie w ISJP) spotkała się z różnego rodzaju krytyką zarówno językoznawców, jak i odbiorców słownika (zob. Bańko 2001: 132; Żmigrodzki 2010a). Tak w wypadku USJP, jak i powstającego obecnie WSJP jej wpływ na koncepcję opisu leksykograficznego był już ograniczony. Zarówno koncepcja IJSP, jak i WSJP, mimo starań o zachowanie jak największej zgodności definicji z ilustracją materiałową i ustaleniami naukowymi, zasadniczo zostawiają też poza opisem leksykograficznym to, co kluczowe dla propozycji Bartmińskiego składniki konotacyjne jednostek.

Zdaniem Piotra Żmigrodzkiego, głównego autora koncepcji WSJP, można mówić o kilku przyczynach tego, że założenia tzw. naiwnego obrazu świata, jak czasem określa się ów odzwierciedlony w leksyce zbiór przekonań, zostały przyjęte przez leksykografów z umiarkowanym entuzjazmem. Uznaje on, że obraz językowo-kulturowy jest bogaty w pewnej grupie jednostek, przede wszystkim nazw dobrze znanych człowiekowi zwierząt, roślin, zjawisk i gatunków naturalnych itd. (Żmigrodzki 2008: 131, 2010a). Na to nakłada się zasadnicza wątpliwość co do kształtu 
owego językowego obrazu świata współcześnie, kiedy potoczny sposób postrzegania przeciętnego użytkownika języka miesza się z elementami wiedzy naukowej zdobytej podczas edukacji oraz wiedzy kulturowej czerpanej z przekazów medialnych.

1.2. Choć argumentom tym nie można odmówić racji, odnoszę wrażenie, że leksykografia, w dążeniu do obiektywnych definicji językowych, zaczęła wpadać $\mathrm{w}$ kolejną pułapkę metodologiczną. Eliminacja wiedzy encyklopedycznej z opisu semantycznego przy sceptycyzmie wobec stereotypów wyobrażeniowych i „naiwnych" właściwości wyrażeń przełożyła się na zbyt częste odrzucanie poza słownik wszelkiego typu wiedzy o świecie. Tymczasem unikanie w opisie leksykograficznym składników, które mogą zostać uznane za element pozajęzykowy (co przenosi ciężar ewentualnej informacji językowo-kulturowej na ilustrację materiałową), eliminuje też objaśnienia cenne dla użytkowników mniej świadomych ważnych niuansów kulturowych w użyciu niektórych pojęć z pól historii, religii, sztuki, tradycji, ale też rzeczywistości codziennej itd., które są znaczące w wypadku takich bytów językowych, jak szlachta, bezpieka/bezpieczeństwo, wspótpraca, sklep za żóttymi firankami, orzeł/ orzełek, dresiarz, majówka, zmywak itd.

Wydaje się, że z podejścia kulturowego w słownikach języka ogólnego zrezygnowano nazbyt pochopnie, choć z perspektywy słownika jednojęzycznego wiedzy kulturowej nie powinno się zawężać do językowego obrazu świata i informacji kulturowej w rozumieniu Bartmińskiego (Bartmiński, Niebrzegowska-Bartmińska 2008)3 ${ }^{3}$ czy też konotacji (Tokarski 1988). Kultura obejmuje bowiem wszelką umysłową i artystyczną działalność człowieka oraz wytworzone w ten sposób artefakty i koncepcje, jak również tradycję, zwyczaje, sposoby pracy itd. ${ }^{4}$ Wiedza o ich znaczeniu dla konkretnej społeczności znajduje odbicie w języku i umożliwia rozumienie kontekstów wypowiedzi oraz świadome funkcjonowanie w tej społeczności. Artykuł służyć ma więc poddaniu dyskusji, czy w ogólnym słowniku języka polskiego powinno znaleźć się miejsce na informację z zakresu takiej wiedzy kulturowej, podaną w sposób eksplicy tny, czyli jako element struktury hasła poza dokumentacją materiałową

3 „Informacja kulturowa”, o jakiej piszą autorzy, również sprowadza się w istocie do „informacji wierzeniowej” (Bartmiński, Niebrzegowska-Bartmińska 2008: 75), oznacza bowiem „nieoparte na doświadczeniu zmysłowym wyobrażenia i przekonania ludzi, dotyczące przedmiotów i zjawisk rzeczywistości, w tym zwłaszcza przekonania jawnie wierzeniowe, oraz konwencjonalne zachowania i umowne (dyktowane przekonaniami) sposoby używania przedmiotu" (ibid.: 67).

4 Por. definicje kultury w ISJP, USJP, WSJP. Tak szerokie pojęcie obejmuje zatem zarówno kulturę wysoką, jak i kulturę popularną oraz codzienną.

5 Pragnę w tym miejscu serdecznie podziękować całemu Zespołowi Pracowni WSJP, którego uwagi do wstępnego zarysu przedstawionej tu propozycji wpłynęły na jej obecny kształt. 
2. Jeśli przyjąć wzgląd praktyczny słownikarstwa, odpowiedź na powyższe pytanie powinno się uzależnić również od tego, kim miałby być projektowany adresat dzieła. Słownik tworzony jest zwykle z myślą o odbiorcach przeciętnych, mających co najmniej średnie wykształcenie ogólne, jednak jego użytkownicy nie ograniczają się do tej grupy. Autorzy dużego słownika ogólnego, opisującego materiał językowy zebrany z kilku dekad, muszą brać pod uwagę, że wśród użytkowników rodzimych znajdzie się kilka pokoleń o różnej językowej i kulturowej orientacji w zmieniającej się rzeczywistości.

Odrębną grupą są odbiorcy niebędący rodzimymi użytkownikami języka (bądź nieużywający go jako języka codziennej komunikacji). Na przykład analizy elektronicznego WSJP pokazują, że już pięć lat temu odwiedzali go czytelnicy z 60 krajów świata, przy czym ogólna liczba użytkowników spoza Polski wynosiła 8\% (Kozioł-Chrzanowska 2012: 348), od tego czasu zaś zainteresowanie słownikiem wzrastało. Odbiorców, dla których dany język nie jest językiem rodzimym, odsyła się zwykle do słowników pedagogicznych, tych jednak brak w Polsce, gdzie funkcję tę pełnią z konieczności nowsze metodologicznie słowniki ogólne. Choć glottodydaktycy zgłaszają propozycje zawartości słowników „dla osób uczących się” (np. Seretny 2007), problem braku objaśnień kulturowych jest przez nich pomijany ${ }^{6}$. Włączenie informacji kulturowej do słownika jest natomiast jednym z postulatów słowników pedagogicznych anglo- i niemieckojęzycznych (por. Hass-Zumkehr 2001: 13-18; Atkins, Rundell 2008: 426-427). Przykładem takiego niemieckiego słownika ogólnego może być Langenscheidt Großwörterbuch Deutsch als Fremdsprache, który obok definicji, w osobnych ramkach informacyjnych - wprowadza także wiadomości kulturowe, m.in. o polityce, historii, świętach i tradycjach, realiach niemieckich oraz życiu codziennym, uzupełniając je czasem ilustracjami

Rozwiązaniem alternatywnym może być opracowanie odrębnego słownika omawiającego zagadnienia kulturowe, skierowanego także do osób uczących się̧, jak nieukończony od kilkunastu lat Mały leksykon kultury polskiej dla cudzoziemców Grażyny Zarzyckiej i Mirosława Jelonkiewicza9. Jednak nawet gdyby ów słownik zo-

6 Nie zmieniają tego faktu glottodydaktyczne koncepcje lingwakultury (Zarzycka 2004a) i leksykultury (Ligara 2009), związane z badaniem i wskazywaniem słownictwa nacechowanego kulturowo, czyli zawierającego oprócz znaczenia słownikowego treści dostrzegalne tylko dla przedstawicieli danej kultury. Niestety wydaje się, że ich przydatność dla leksykografii jest ograniczona, podobnie jak etnoligwistycznej koncepcji kulturemów.

7 Ujęcie informacji kulturowej w ramowej części oraz elementach pozahasłowych (tj. uzupełniających hasło ramkach) słowników pedagogicznych języka niemieckiego zob. Bielińska 2008.

8 Także tego typu słowniki są obecne w leksykografii zachodniej. Np. zróżnicowane informacje obejmujące zarówno kulturę wysoką, jak i masową zawierają Longman Dictionary of English Language and Culture i Oxford Guide to British and American Culture. Część haseł z tych słowników włączana jest także do elektronicznych wydań słowników ogólnych danego wydawcy (zob. np. ldoceonline.com).

9 Prace nad Małym leksykonem... zaowocowały jedynie kilkoma artykułami związanymi z jego koncepcją (np. Zarzycka 2004b) oraz wstępnym indeksem haseł (Zarzycka, Jelonkiewicz 2004). 
stał ostatecznie w Polsce wydany, to z zarysu jego dotychczasowej koncepcji można wnioskować, że objaśniałby raczej zagadnienia samej kultury niż języka. Tymczasem, aby słownik mógł odgrywać rolę „środka komunikacji” między przedstawicielami różnych kultur oraz różnych pokoleń - co postulował Żmigrodzki (2010b: 37) - powinny w nim zostać dobrze opisane fakty językowe należące do ogólnej kompetencji kulturowej, jak wyrażenia bezpieka/bezpieczeństwo czy też $z$ kluczem/kluczami na szyi - niezależnie od tego, czy miejsce tych objaśnień rozpatrywać w opisie semantycznym czy poza nim, jak we wspomnianym słowniku niemieckim.

Wydaje się, że optymalny jednojęzyczny słownik ogólny musi pokazywać nie tylko semantyczne, prozodyczne, morfologiczne i syntaktyczne właściwości leksemów. Konieczne jest wskazanie również ich właściwości pragmatycznych (w tym ograniczeń stylistycznych) i opatrzenie ich uzupełniającymi objaśnieniami z zakresu kultury. Dopiero taki słownik, uzupełniony o materiał ilustracyjny w postaci potwierdzonych materiałowo utrwalonych połączeń, cytatów, frazeologizmów będzie mógł pełnić funkcję słownika aktywnego, pozwalającego nie tylko na poznanie znaczenia leksemu, ale też na jego dalsze użycie w oparciu o przedstawione reguły - słownika umożliwiającego mniej biegłym językowo użytkownikom (ale również np. tłumaczom i redaktorom) nie tylko rozumienie tekstów, ale też ich tworzenie. Postulat ten w dobie słowników elektronicznych, których nie ogranicza już liczba stron druku ${ }^{10}$, przestaje być tylko „marzeniem leksykografów”. Wydaje się, że rozwiązania techniczne, na które pozwala leksykografia elektroniczna, mogą sprawić, że jego realizacja nie utrudni korzystania z leksykonu pozostałym użytkownikom, a zarazem nie stanie się on jeszcze jednym zamysłem metodologicznym, którego wdrożenie dla pełnego zasobu językowego jest praktycznie niewykonalne.

3. Uwzględnienie w objaśniającym słowniku języka polskiego utrwalonych językowo elementów kulturowych wiąże się oczywiście z ustaleniem:

1) które hasła powinny zawierać elementy informacji kulturowej,

2) jak szczegółowy powinien być opis desygnatów, do których się odnoszą,

3) w jakich polach mikrostruktury haseł element ten powinien być obecny.

Ograniczenie informacji kulturowej do definicji w wielu przypadkach wydaje się bowiem niewystarczające, a często też na tle obecnych konwencji leksykograficznych nieuzasadnione metodologicznie.

3.1. Bez pełnej analizy materiału odpowiedzi na pierwsze pytanie można udzielić jedynie na podstawie ogólnej charakterystyki. Widziałabym tu przede wszystkim trzy typy takich jednostek, wyodrębnione ze względu na stopień uzasadnienia w opisie leksykograficznym postulowanej informacji. Odrębną grupą byłyby natomiast

10 O ograniczeniach i korzyściach związanych z podstawową formą elektroniczną słownika ogólnego, takiego jak WSJP, dla różnych użytkowników zob. np. Czelakowska 2012, 2016. 
obiekty językowe, których zapewne w większości przypadków nie można uznać za jednostki nieciągłe (np. wydarzenia marcowe, musztarda i ocet, gest Kozakiewicza), co - zgodnie z przyjętą obecnie w leksykografii metodologią - podważałoby ich (ewentualny) słownikowy status. Ze względu na brak miejsca nie będą one jednak tu rozważane.

3.2. P. Żmigrodzki, który jako pierwszy podjął wątek słownika jako środka komunikacji między pokoleniami i między kulturami, próbował wskazać grupę jednostek, których opis leksykograficzny informowałby „o warunkach życia w Polsce, zwyczajach, stosunkach społecznych [...] w ogóle lub tylko w pewnych okresach historycznych" (ibid.: 36). Wyróżnił wśród nich: 1) takie, których zdefiniowanie jest niemożliwe bez odwołania się do składników kulturowych (np. bigos, Wielkanoc, sobótka) czy konwencji prawnych (jak docent), 2) nazwy wytworów przemysłowych i tzw. archaizmów rzeczowych (np. muszkiet, patefon, żelazko), zapominane w polszczyźnie w związku z zanikaniem ich desygnatów, informujące zatem o „szeroko pojętej tradycji i historii”, 3) jednostki i połączenia związane $\mathrm{z}$ historią i polską rzeczywistością przełomu XX i XXI w. (podzielone na kilka dalszych grup i będące właściwym przedmiotem jego artykułu), np. bikiniarz, docent marcowy; bananowa młodzież, bilety towarowe; popiwek; wydarzenia marcowe, plan Balcerowicza; czerwona kartka, a więc takie, które charakteryzuje przede wszystkim chronologiczne zawężenie użycia, czasem też ograniczenie stylistyczne, ale przede wszystkim silny związek z rzeczywistością pozajęzykową ${ }^{11}$.

Opisane przez Żmigrodzkiego jednostki mogą być mimo wszystko rozpatrywane jako jedna grupa pojęć odnoszących się do desygnatów z zakresu historii, tradycji, zwyczajów i artefaktów wytworzonych przez cywilizację. Wyrażenia końca XX w. wiążą się bowiem ze światem znanym starszemu pokoleniu użytkowników współczesnej polszczyzny w podobny sposób jak muszkiet, patefon i husaria ze światem (dawno) minionym, tak więc wykazują podobne zależności w opisie leksykograficznym, zarówno właściwości dookreślających znaczenie (tj. wskazania zakresu terytorialnego, chronologicznego itp.), jak i ograniczeń pragmatycznych. Utworzenie ich definicji oznacza zatem określenie wystarczającego i adekwatnego językowego kształtu pojęcia, którego desygnat w taki czy inny sposób musi być przedmiotem opisu w encyklopedii.

Jednostki, których definicja wymaga składników kulturowych, można wskazać w różnych grupach semantycznych, np.:

Wielkanoc, święcone, baranek, kolęda; sobótka, wianki, imieniny, rosót;

szlachta, husaria, kosynier, ułan; demolud, bezpieka, nomenklatura;

11 Utrudniający określenie, czy znaczenie globalne danej jednostki nie wynika wyłącznie ze znajomości pewnych konwencji społecznych bądź prawnych, nie zaś z wiedzy językowej (ibid.). 
sklep za żóttymi firankami, konsumy, pewex, manhattan; degolówka, dzwony, (super)perysy, legginsy; fajfy, prywatka, party; fonograf, pager, walkman itd.

Jednostki w poszczególnych grupach nie są homogeniczne. Grupa pierwsza opisuje pojęcia z zakresu polskich tradycji, świąt i obyczajów, jednak o większym lub mniejszym stopniu utrwalenia i różnym zasięgu terytorialnym i chronologicznym. W grupie jednostek związanych $\mathrm{z}$ historią można wskazać te funkcjonujące jedynie $\mathrm{w}$ tradycji historycznej, o których wiedza jest utrwalona pokoleniowo, oraz te wiązane z okresem PRL, pamiętane przez średnie pokolenie użytkowników języka, ale nie zawsze już zrozumiałe dla osób młodszych. Znalazły się tu zarówno jednostki neutralne stylistycznie, jak i mające wartościowanie pozytywne bądź negatywne. Grupa trzecia zawiera nazwy artefaktów, obiektów i sytuacji otaczającego świata. I znów można dokonać w niej podziału chronologicznego (nazw odnoszących się do desygnatów przedwojennych, PRL-owskich i ostatniego 20-lecia) lub pragmatycznego.

3.3. Nawet $\mathrm{w}$ odniesieniu do jednostek, $\mathrm{w}$ których informacje o cywilizacyjnych i kulturowych właściwościach desygnatu determinują opis semantyczny, często nie można mówić o bezdyskusyjnych składnikach znaczenia, weryfikowalnych za pomocą testów semantycznych, a w związku z tym o identycznych sposobach charakterystyki leksykograficznej.

3.3.1. Przeciwnie, np. w wypadku jednostki Wielkanoc 'święto, które chrześcijanie obchodzą na pamiątkę zmartwychwstania Chrystusa' można mieć uzasadnione wątpliwości, czy to, że nie ma ono stałej daty i wypada w marcu lub w kwietniu $\mathrm{w}$ niedzielę po pierwszej wiosennej pełni Księżyca (fakt ten jest odnotowywany m.in. przez SJPD, ISJP, USJP i WSJP), jest istotnym elementem znaczenia. Jeszcze bardziej niepewna jest relewantność dla tego pojęcia informacji zawartej w WSJP: 'w Kościele Katolickim trwające dwa dni' Jednak nawet to ostatnie objaśnienie ze względu na różnice w liczbie dni świętowania podczas Wielkanocy w Polsce oraz niektórych krajach europejskich warto zaznaczyć eksplicytnie w opisie leksykograficznym, tłumaczy ono bowiem kolokację drugi dzień Wielkanocy czy też przynależne do derywatu połączenie Poniedziałek Wielkanocny. W takiej sytuacji bardziej obiektywnym rozwiązaniem wydaje się przeniesienie treści tych uzupełniających objaśnień do wydzielonej ramki wiedzy i kompetencji kulturowej, np. o treści:

Wielkanoc nie ma stałej daty, przypada w marcu lub kwietniu w niedzielę po pierw-

szej wiosennej pełni Księżyca i w Kościele katolickim trwa dwa dni.

Pozostałe informacje kulturowe związane z Wielkanocą mogłyby być przekazane przez dobór odpowiednich kolokacji i cytatów ${ }^{12}$, choć decyzja w tym zakresie należałaby już do redaktora hasła.

12 Mogłyby one zapewne zastąpić końcową część definicji zawartej w SWJP: 'największe kościelne święto chrześcijańskie, następujące po okresie Wielkiego Postu, obchodzone na pamiątkę 
3.3.2. Jednak już w wypadku wielu nazw świąt mniejszej rangi, obyczajów, potraw itd., takich jak wianki czy imieniny, wprowadzenie nazbyt szerokiej informacji z zakresu wiedzy o świecie grozi zawężeniem definicji, nie tylko ze względu na zmiany rzeczywistości w zakresie tych obyczajów, ale też z uwagi na różne rozumienie tych pojęć $\mathrm{w}$ różnych regionach Polski. Wianki, jak sądzę, zmieniają znaczenie z 'obyczaju, polegającego na puszczaniu wianków na wodę wieczorem 23 czerwca (w wigilię św. Jana), połączonego z wróżbami' (SWJP, podobnie ISJP, USJP, WSJP) na 'zabawę odbywaną w noc świętojańską, nawiązującą do dawnego święta sobótki'. Co zaskakujące, cechą definicyjną tego pojęcia może nie być już nawet to, że zabawa ta ma miejsce nad rzeką. Natomiast choć powszechne obchodzenie w Polsce imienin utrwalają połączenia pamiętać, zapomnieć o (czyichś) imieninach, obchodzić imieni$n y, z$ okazji imienin itd., to z uznaniem tego elementu za definicyjny nie zgodzi się zapewne większość mieszkańców Śląska. Zarazem katolicka specyfika tego święta, mniej znanego poza polskimi granicami, przemawiałaby za odnotowaniem jego popularności w naszym kraju. W tych wątpliwych wypadkach informację semantyczną ograniczoną do najważniejszych i najtrwalszych cech charakterystycznych mogłyby zatem uzupełniać odpowiednie noty wiedzy i kompetencji kulturowej.

3.3.3. Również $\mathrm{w}$ jednostkach $\mathrm{z}$ pola historia definicja przeładowana wiedzą encyklopedyczną może zniekształcać lub zawężać rozumienie tych pojęć. Interesującym przykładem wydaje się szlachta, której definicja stricte językowa może chyba zostać zawarta w kilku składnikach, np.: 'warstwa społeczna wywodząca się z rycerstwa, wyróżniająca się najczęściej posiadaniem dziedzicznej ziemi'. Zarazem sem często nasuwający się w pierwszej kolejności, tj. brak konieczności pracy fizycznej czy też zawodowej/zarobkowej, wykonywanej dla innych, jest chyba tylko konotacją (jeśli pamiętać o istnieniu szlachty zagrodowej) ${ }^{13}$. Tymczasem definicja tej jednostki we współczesnych słownikach ogólnych jest dość obszerna, por.:

'stan społeczny wywodzący się z rycerstwa, obdarzony dziedzicznym prawem własności ziemi oraz innymi prawami i przywilejami nadawanymi przez władców' (USJP, podobnie SWJP).

'Szlachta to dawniej warstwa społeczna wywodząca się z rycerstwa, obdarzona przez władców dziedzicznym prawem posiadania ziemi i innymi przywilejami w zamian za obowiązek służby wojskowej' (ISJP, zbliżona w WSJP).

zmartwychwstania Chrystusa, będące wyrazem radości z jego zwycięstwa nad złem i śmiercią, odkupienia ludzkich grzechów oraz otrzymanej nadziei na życie wieczne w raju'.

13 Choć z drugiej strony może to budzić wątpliwości wobec wiedzy, że podjęcie przez szlachcica zawodów kupieckich groziło kiedyś utratą praw szlacheckich. $W$ obu wypadkach jest to jednak informacja ważna ze względu na funkcjonujące obecnie użycie tego wyrazu w znaczeniu 'grupa osób, która epatuje zabawowym trybem życia za pieniądze, których nie zarobiła samodzielnie, sama zaś nie pracuje’. 
Rozstrzygnięcie, czy przywileje są informacją relewantną dla tego pojęcia czy też jest to reperkusja dwuznacznej definicji przepisywanej za SJPD przez kolejnych leksykografów (jeszcze zgodnie z SW szlachcic to 'przedstawiciel stanu rycerskiego, człowiek dobrze urodzony') ${ }^{14}$, wydaje się arbitralne, choćby ze względu na kolokację przywileje szlacheckie. Oczywiście także w tym wypadku sekcja wiedzy kulturowej może zawierać obszerniejsze wiadomości, np. właśnie o przywilejach tego stanu, obowiązku służby wojskowej na rzecz władcy i braku potrzeby pracy zarobkowej. Może ją uzupełnić wzmianka o prawach społecznych, posiadaniu herbu, jak również rozwarstwieniu polskiej szlachty ${ }^{15}$.

3.3.4. Definicje pojęć odnoszących się do artefaktów, obiektów i zjawisk związanych z codziennością poza opisem realnoznaczeniowych cech desygnatów implikują wprowadzenie w opisie słownikowym informacji o ograniczeniach chronologicznych i terytorialnych wyrażeń (por. Żmigrodzki 2010b). Na przykład definicja jednostki dzwony 'spodnie rozszerzane od kolan w dół' (zbliżona stylistycznie w USJP i ISJP) może wydać się niedostateczna leksykografowi obserwującemu liczne konteksty typu:

W niektórych szkołach panuje moda na lata siedemdziesiąte i pewna bliska mi nastolatka szokuje swoją mamę nosząc spodnie dzwony i nylonowe koszule (NKJP).

Z kolei ograniczonej chronologicznie definicji z WSJP 'spodnie o nogawkach stopniowo rozszerzających się od kolan ku dołowi, popularne w latach 70. XX wieku’ można zarzucić nieścisłość, gdyż od tego czasu tego rodzaju spodnie modne były już przynajmniej kilkakrotnie. Łatwo jej jednak uniknąć, np. uzupełniając ów składnik o dodatkową informację, jak choćby 'pierwotnie należące do stylu hippisowskiego lat 70. XX wieku', bądź objaśnienie to przenosząc do pola wiedzy i kompetencji kulturowej, jeśli rzecz ma potwierdzenie w materiale językowym.

Choć nadmierna informacja pozajęzykowa w polu definicji tej ostatniej grupy pojęć grozi zawężeniami znaczenia, zwłaszcza w odniesieniu do jednostek opisujących wynalazki technologiczne, często zmieniające cechy realnoznaczeniowe (a więc np. wygląd i sposób działania), por. telefon, ma ona pewne uzasadnienie.

14 Por. 'klasa społeczna wywodząca się z rycerstwa, mająca dziedziczne przywileje i prawa nadane przez panujących; w Polsce wyodrębniona w XIV w., mająca do XIX wieku przewagę gospodarczą i polityczną nad innymi klasami' (SJPD), co w kontekście pierwszego zilustrujących cytatów „W żadnym prawie sąsiednim państwie szlachta nie wywierała tak wielkiego wpływu na rządy i nie korzystała z tylu praw i przywilejów, jak w Polsce" mogło nadawać wyrazowi przywilej również funkcję perswazyjną.

15 Podobnie jak w rosyjskim słowniku aktywnym (Apresjan 2014) pole to mogłoby służyć również informowaniu o systemie odniesień, a więc zbiorów, na których tle należy wyróżnić dane wyrażenie, w tym wypadku nie tylko magnaterii i szlachty drobnej, ale też pozostałych warstw społecznych w ówczesnej Polsce. 
Wiedza o nich nie zawsze jest bowiem dostępna w encyklopediach i rozróżnienie np. chronologiczne między bliskimi pojęciami (por. fajf, prywatka, dyskoteka, party) umożliwia jedynie adekwatny opis w słowniku ogólnym.

3.3.5. Opis leksykograficzny niektórych jednostek, szczególnie tych związanych z rzeczywistością XX i XXI w., oprócz definicji i noty kulturowej powinien zostać opatrzony odpowiednimi kwalifikatorami i notami pragmatycznymi, związanymi z nacechowaniem (np. demolud, bezpieka) i rzeczywistym tekstowym użyciem tych wyrażeń.

W wypadku hasła bezpieka definicja 'aparat bezpieczeństwa w PRL ${ }^{16}$ jest zależna od adekwatnego objaśnienia bezpieczeństwa. Definicja tego ostatniego w USJP 'organa władzy mającej pieczę nad sprawami bezpieczeństwa publicznego ${ }^{{ }_{17}}$ jest w tym wypadku niewystarczająca, gdyż brak pełniejszej wiedzy o referencie jednostki bezpieczeństwo 2 wpłynie na różnice w jej rozumieniu przez starsze i młodsze pokolenie użytkowników polszczyzny. Nawet definicje z nowszego metodologicznie ISJP:

Bezpieka to aparat bezpieczeństwa w PRL. Słowo potoczne, wyrażające niechęć lub pogardę (przy haśle bezpieczeństwo: 'Siły bezpieczeństwa, organy bezpieczeństwa itp. to organy władzy ochraniające ustrój przed zamachami na podstawowe instytucje polityczne państwa'),

pomijają kluczowy składnik wyjaśniający przyczynę owej pogardy i „niechęci”, a raczej mieszanki strachu i nienawiści, czyli terror, którym posługiwała się bezpieka w celu wyeliminowania ewentualnych zagrożeń dla władzy i ustroju.

Choć definicja zawarta w WSJP może zostać uznana za przeładowaną szczegółami z zakresu wiedzy o świecie, por.:

pot. pogard. 'specjalne służby w państwach totalitarnych, oficjalnie strzegące bezpieczeństwa publicznego, w istocie terroryzujące społeczeństwo, zwalczające opozycję i chroniące władzę i panujący ustrój',

$\mathrm{w}$ istocie oddaje ona sens najczęstszej obecnie aktualizacji tekstowej tego znaczenia. Również nota pragmatyczna „Używane najczęściej w odniesieniu do Urzędu Bezpieczeństwa oraz Służby Bezpieczeństwa w PRL” wyjaśnia znajdujące poświadczenie w korpusie użycia związane z zawężeniem współczesnego sensu tej jednostki czy też w istocie może jego rozszerzeniem do wszelkich służb specjalnych w państwach totalitarnych.

16 Por. pot. pogard. 'aparat bezpieczeństwa (UB, później SB) w PRL' (USJP).

17 Nieadekwatne jest tu także określenie 'organy władzy', gdyż organami władzy są Sejm, Senat oraz rząd, nie zaś służby użyteczności publicznej, choć w tym akurat wypadku hiperonim może oddawać konotację jednostki, por. pan władza pot. żart. 'policjant, dawniej: milicjant' (USJP). 
Zawężanie znaczeń jednostek nadużywanych w określonych kontekstach leksykalnych i składniowych nie powinno być pomijane przez leksykografa, gdyż może prowadzić do utrwalenia się tych szczegółowych użyć, jak w wypadku wyrazów agent ('tajny pracownik instytucji i służb powołanych do ochrony porządku publicznego lub zbierania informacji dotyczących obcych państw') czy wspótpraca ('wykonywanie zadań na zlecenie instytucji i służb chroniących narzuconą władzę lub panujący ustrój, np. UB lub SB', odpowiadające znaczeniowo wyrazowi kolaboracja). Fakt ten może zostać odnotowany w polu pragmatycznym, do decyzji leksykografa pozostaje natomiast, czy celowe jest informowanie np. o przejawach owej współpracy w polu informacji kulturowej.

3.4. Bardziej dyskusyjna jest strategia opisu leksykograficznego symboli. O tym, że w wypadku dobrze potwierdzonych językowo użyć o znaczeniu symbolicznym należy informować eksplicytnie, może przekonywać przykład jednostki orzeł. W haśle o tym kształcie nie wystarczy bowiem odnotowanie definicji znaczenia 'duży drapieżny ptak o zakrzywionym dziobie' (z ewentualnymi innymi cechami dystynktywnymi). Znaczenie motywowane 'znak o kształcie tego ptaka' wydaje się czymś więcej niż regularnym semantycznym derywatem vs produktem operacji opartej na mechanizmie uniwersalnego przesunięcia odwzorowania ikonicznego, którego obecność w słowniku można pominąć, jak w wypadku misia 'wizerunku/zabawki' (uzasadnienie takiej decyzji zob. Czelakowska 2014). O jego leksykalizacji może świadczyć liczny materiał językowy, np. orzeł piastowski, orzeł w koronie, orzeł czy reszka, także dla derywatu: legionowy orzełek, orzełek bez korony, czapka, paszport $z$ orzełkiem. Jednak jeśli definicja wtórnej jednostki orzeł będzie wspólna dla różnych symboli o podobnym kształcie, np.:

orzeł 2 'symbol o kształcie ptaka przypominającego orła, będący znakiem herbowym i godłem różnych państw i narodów, w tym Polski',

ograniczenie się do ilustracji materiałowej nie odda konotacji tego symbolu, wykorzystywanych w rozmaitych przekazach narodowo-patriotycznych, np. haśle $z a$ orła w koronie! $!^{18}$

Z jednostką tą wiąże się zresztą sprzeczność między wiedzą językową i wiedzą specjalistyczną, ponieważ symbolem umieszczonym w polskim godle jest prawdopodobnie bielik - niebędący orłem. Tak więc również w haśle opisującym tę jednostkę pole informacji kulturowej mogłoby zawierać objaśnienie symboliki orła i komentarz o znaczeniu tego symbolu. Dokumentacja materiałowa mogłaby być wówczas adekwatna do definicji ogólnej, a więc zawierać nie tylko orła piastowskiego itd., ale również orły niemieckie oraz dwugłowe.

18 Hasło nb. zostało wykorzystane na nowo w $2017 \mathrm{r}$. w tytule singla wydanego przez grupę raperów tworzących muzykę o wydźwięku narodowościowym. 
Niestety to, czy materiał językowy daje podstawę do wyodrębnienia utrwalonego kulturowo znaczenia (paradoksalnie, podobnego opisu wymagałoby chyba hasło swastyka) czy o użyciach symbolicznych informować jedynie w nocie pragmatycznej (buława?, falanga?), za każdym razem będzie wymagało odrębnej decyzji leksykografa.

3.5. Ostatnia grupa jednostek omówionych $\mathrm{w}$ artykule jest najbardziej dyskusyjna, wiąże się bowiem z pozaznaczeniową wiedzą kulturową, która może zostać uznana za „znaczenie nieracjonalne” odbijające „światopogląd potoczny” (Chlebda 1993) czy po prostu element konotacyjny wskazanych niżej przykładów ${ }^{19}$. Od tego ostatniego różni ją, jak sądzę, zależność od wiedzy o świecie, ograniczonej społecznym zasięgiem, jednak nierzadko odmiennej od tzw. wiedzy potocznej, i możliwość opisania poza "językowym obrazem świata” (także ze względu na inny stopień utrwalenia, zależny od zmian w otaczającej rzeczywistości). Do informacji tych należy wiedza, że jednostka garsoniera (w przeciwieństwie do kawalerki) jest używana także w odniesieniu do mieszkania służącego do odbywania lub organizowania potajemnych spotkań erotycznych, zmywak to w licznych kontekstach nie tylko 'praca w restauracji, w barze lub w stołówce polegająca na myciu naczyń i sztućców' (WSJP), ale też szerzej 'praca zarobkowa poniżej kwalifikacji i najczęściej za granicą ${ }^{20}, m a-$ giel zaś - ze względu na specyfikę sytuacji z dawnych maglarni - po prostu 'miejsce wymiany informacji oraz przekazywania towarzyskich plotek'. We wszystkich wskazanych przypadkach istotne dziś językowo składniki semantyczne wydają się fakultatywne dla znaczenia i zaskakiwałyby w definicji - jednak w rezultacie informacja ta jest w leksykonach pomijana ${ }^{21}$. Tymczasem słownik ogólny wydaje się najwłaściwszym miejscem na objaśnienie i rejestrację szczególnego rozumienia tych pojęć w polszczyźnie danego okresu.

19 Przy rozumieniu konotacji za Tokarskim (1988: 42) jako „charakterystyki, jaką [jednostka leksykalna - A.C.] L przypisuje swojemu referentowi i która nie wchodzi do jego definicji”, nie zaś w rozumieniu Apresjana (2012: 67) jako utrwalonej w danej grupie językowej oceny obiektu rzeczywistości, której wykładnikiem jest dane słowo (a dokładniej nieistotne, ale ustabilizowane cechy pojęcia, które ów leksem nazywa, wyrażające tę ocenę).

20 Por. np. „Generałowie na zmywaku [...] Zamiast honorów polscy generałowie musieli po wojnie... pracować fizycznie w pocie czoła” (Natemat.pl); „Czasami nazywa się ich »pokoleniem skazanych na zmywak«. To dlatego, że często zaczynają w magazynach na budowach, czasem jako kelnerzy, kelnerki, jako sprzątacze i sprzątaczki lub myjąc naczynia w restauracjach” (Finanse.wp.pl). „Eksperci biją na alarm. Najlepiej wykształceni ludzie wyjeżdżają na Zachód. Jedyna praca, jaka ich tam czeka, to "zmywak«, więc ludzie ci tracą kompetencje" (Dziennik.pl). Podobnych cytatów można znaleźć w Internecie sporo, często w tytułach i nagłówkach artykułów.

$21 \mathrm{Nb}$. możliwość uwzględnienia niektórych cech konotowanych w definicjach haseł w słowniku ogólnym uzasadniał Bańko (2001: 140), wcześniej zaś m.in. Apresjan (1972), Bartmiński (1984) i tzw. szkoła lubelska oraz Anna Wierzbicka, pisząca o „dowodach leksykalnych” (1993: 59), ale w dziale „informacji encyklopedycznej” zaświadczone językowo „stereotypy wyobrażeniowe” gotów był zamieszczać nawet Bogusławski (1988: 78). 
Wskazane przykłady dobrze oddają praktyczne wątpliwości leksykografa postawionego wobec semantycznych postulatów kręgu strukturalistycznego, wymagających odróżnienia narzędzi językowych od działań na tych narzędziach (Bogusławski 2008).

Jeśli poddać analizie korpusowej np. jednostkę trzepak, pozwalającą się wstępnie zdefiniować jako 'konstrukcja przeznaczona do trzepania dywanów', okaże się, że jej użycie w kontekście trzepania dywanów znaleźć w NKJP najtrudniej. Potwierdza to analiza liczbowa konkordancji. Wyszukiwarka PELCRA w korpusie zrównoważonym - na 271 łącznych wystąpień wyrazu trzepak - w kontekście wyrazu dywan znajduje 20 wystąpień (13 akapitów), w tym kilka połączeń trzepak na dywany, trzepak do dywanów oraz akapitów, w których jedna z form leksemu zostaje powtórzona lub dywan pojawia się w odległym kontekście. Konkordancji adekwatnych do zaproponowanej definicji jest łącznie 7, co stanowi 2,6\% analizowanego materiału korpusu zrównoważonego. Pozostałe w większości (ponad 200 wystąpień) ilustrują użycia (utrwalone w różnego typu tekstach, w tym najnowszych) tego leksemu w kontekstach miejsca zabawy oraz spotkań i rozmów dzieci i młodzieży, a więc na sposób, $\mathrm{w}$ jaki obiekt ten utrwalił się w pamięci osób wychowanych w drugiej połowie XX w.

Wydaje się, że wobec zmiany rzeczywistości pozajęzykowej w XXI w. wychowanie pod trzepakiem w ciągu najbliższej dekady może stracić przejrzystość znaczeniową $a^{22}$, co z punktu widzenia komunikacji międzypokoleniowej czy międzykulturowej uzasadnia rejestrację tego faktu w słowniku ogólnym. Obiektywizm opisu semantycznego wymaga chyba jednak przeniesienia tej informacji w całości do sekcji pozasemantycznej, np. właśnie pola wiedzy i kompetencji kulturowej. Podobne rozwiązanie można przyjąć, aby zapisać potencjalnie niedefinicyjne składniki znaczenia jednostek korporacja, dresiarz, remiza, lebioda itd.

4. Informacja kulturowa w słownikach ogólnych jedynie w pewnym zakresie wydaje się więc związana z opisem semantycznym. Służyć jej mogą różne pola mikrostruktury haseł, w tym oczywiście ilustracja materiałowa, która powinna być reprezentatywna dla badanych przez leksykografa danych źródłowych. Rozwiązaniem alternatywnym bądź uzupełniającym dla wielu jednostek, zwłaszcza tych, w których materiał nie daje wystarczających podstaw do uznania danej cechy za definicyjną, może być wprowadzenie odrębnego objaśnienia w sekcji pozasemantycznej, np. „wiedzy i kompetencji kulturowej” lub „objaśnień kulturowych”, poprzedzających w opisie leksykograficznym dokumentację językową ${ }^{23}$.

22 Podobnie jak potoczny termin sieć trzepakowa 'osiedlowa sieć komputerowa tworzona amatorsko'.

23 WSJP informacje o okolicznościach pozajęzykowych towarzyszących powstaniu danej jednostki leksykalnej rejestruje w polu „Pochodzenie”. Niestety ogranicza je do jednostek nieciągłych, np. takich jak babski comber; w takim kształcie nie mogą więc oddać wszystkich wskazanych w artykule aspektów omawianego problemu. 
Przedstawiona propozycja nasuwa co najmniej kilka problematycznych kwestii. Pierwszą jest opracowanie listy jednostek wymagających konsekwentnego zapisania eksplicytnej informacji kulturowej, a także metodologicznych szczegółów jej kształtu. Wiąże się to z koniecznością współpracy przy tworzeniu tej listy z zespołem kulturoznawców i rozważeniem przydatności dla leksykografii językoznawczych badań z tego zakresu, zwłaszcza dotyczących kulturemów, czyli słów kluczy służących (samo)identyfikacji konkretnej społeczności, którym w planie treści przypisuje się pojemne znaczenia pozwalające zrozumieć specyfikę tej społeczności (regionalnej, etnicznej lub narodowej) (Rak 2015). Wyróżnianie jakiegoś kulturemu nie musi bowiem rozstrzygać o informacji kulturowej w haśle o danym kształcie w słowniku języka ogólnego. Osobnej uwadze należy poddać pojęcia o silnych fakultatywnych składnikach znaczenia związanych $\mathrm{z}$ wiedzą o świecie współczesnym, nie zawsze w sposób satysfakcjonujący opisane w słownikach ogólnych.

Drugą sprawą jest określenie stopnia dokładności przedstawionych objaśnień i dostosowanie ich nie tylko do strategii opisu leksykograficznego haseł. Decydować będą tu też niestety czynniki zewnętrzne - podporządkowane informacji lingwistycznej miejsce w opisie, to, że autorami owych objaśnień będą przede wszystkim leksykografowie, a także czas, jakiego będzie wymagało opracowywanie dodatkowej sekcji w słowniku, przy świadomości, że nie zastąpi ona (i nie ma tego celu) dostępnych w Internecie encyklopedii.

Dyskusyjne jest również, czy do sekcji tej mogłyby zostać włączone utrwalone językowo konotacje pojęć. Wydaje się jednak, że nawet jeśli w przyszłości ogólne słowniki uwzględniałyby w opisie leksykograficznym pojęcia konotowane przez daną jednostkę, mogłyby stanowić one odrębne pole, jak w aktywnym słowniku języka rosyjskiego tworzonym obecnie pod redakcją Apresjana (2014).

Pozostaje też problem ewentualnego miejsca w leksykonie wspomnianych już obiektów językowych, których jednostkowość jest sprawą kontrowersyjną, por. wydarzenia marcowe, ocet i musztarda, z kluczem/kluczami na szyi itd. Ich rozumienie globalne związane jest przede wszystkim z wiedzą o świecie, są jednak silnie ustabilizowane językowo i należą do kompetencji komunikacyjnej, obecnie (jeszcze) czytelnej dla większości użytkowników polszczyzny. Czy jednak względy praktyczne i dążenie do opracowania leksykonu rejestrującego jak najszerszy zakres zjawisk językowych powinny decydować o rezygnacji z rudymentarnych postulatów metodologicznych? 


\section{Literatura}

AnusiewiCz A., 1994, Lingwistyka kulturowa. Zarys problematyki, Wrocław.

Apresjan Ju., 1972, Definiowanie znaczeń leksykalnych, [w:] A. Wierzbicka (red.), Semantyka i słownik, Wrocław, s. 39-57.

ApresJAn Ju., 2012, Konotacje jako składnik pragmatyki słowa. (Ujęcie leksykograficzne), [w:] idem, $Z$ warsztatu leksykografa, Warszawa, s. 64-88.

Apresjan Ju., 2014: Ю.Д. Апресян (ред.), Активный словарь русского языка, т. 1: А-Б, Москва.

AtKins B.T.S., Rundell M., 2008, The Oxford Guide to Practical Lexicography, Oxford.

BAŃKo M., 2001, Z pogranicza leksykografii i językoznawstwa. Studia o słowniku jednojęzycznym, Warszawa.

BARTMIŃski J., 1984, Definicja leksykograficzna a opis języka, [w:] K. Polański (red.), Słownictwo w opisie języka, Katowice, s. 9-19.

BARtmiński J., 1988, Definicja kognitywna jako narzędzie opisu konotacji słowa, [w:] idem (red.), Konotacja, Lublin, s. 169-183.

Bartmiński J., Niebrzegowska-Bartmińska S., 2008, Miejsce informacji kulturowej $w$ znaczeniu słowa $i w$ rekonstrukcji językowego obrazu świata, [w:] M. Bogusławska, G. Szwat-Gyłybowa (red.), Bunt tradycji - tradycja buntu. Ksiega dedykowana Profesorowi Krzysztofowi Wrocławskiemu, Warszawa, s. 65-77.

Bielińska M., 2008, Słownik pośrednikiem między kulturami? Analiza jednojęzycznych słowników języka niemieckiego jako obcego, [w:] A. Kątny (red.), Kontakty językowe i kulturowe w Europie. Sprach- und Kulturkontakte in Europa, Gdańsk, „Studia Germanica Gedanensia" 17/1, s. 255-266.

BogusŁawski A., 1988, Język w słowniku. Desiderata semantyczne do wielkiego słownika polszczyzny, Wrocław.

BogusŁawski A., 2008, Semantyka, pragmatyka. Leksykografa głos demarkacyjny, Warszawa.

Chlebda W., 1993, Słownik a „dwuoczne postrzeganie świata”, [w:] J. Bartmiński, R. Tokarski (red.), O definicjach i definiowaniu, Lublin, s. 195-205.

CzelakowsKa A., 2012, Wielki słownik języka polskiego PAN jako słownik elektroniczny, "Język Polski” XCII, z. 5, s. 336-347.

Czelakowska A., 2014, Polisemia regularna - między semantyka a kontekstem, „LingVaria" nr 1 (17), s. 45-58, [on-line:] http://dx.doi.org/10.12797/LV.09.2014.17.03.

CzelakowsKa A., 2016, Nieufnym okiem prawnika, czyli najnowszy (elektroniczny) słownik języka polskiego Polskiej Akademii Nauk z punktu widzenia wykładni językowej, „Kwartalnik Sądowy Apelacji Gdańskiej” nr 2, s. 7-27.

Grochowsкi M., 1982, Zarys leksykologii i leksykografii. Zagadnienia synchroniczne, Toruń.

Grochowski M., 1988, Podstawowe zasady definiowania wyrażeń w słowniku jednojęzycznym, [w:] W. Lubaś (red.), Wokół słownika współczesnego języka polskiego. Materiały konferencji w Paszkówce, 26-28 XI 1986 r., Wrocław, s. 45-62.

Hass-Zumkehr U., 2001, Deutsche Wörterbücher - Brennpunkt von Sprach- und Kulturgeschichte, Berlin - New York.

ISJP: M. Bańko (red.), Inny słownik języka polskiego, Warszawa 2000.

Jordanskaja L., Mielczuk I., 1988, Konotacja w semantyce lingwistycznej i leksykografii, [w:] J. Bartmiński (red.), Konotacja, Lublin, s. 9-34. 
KozIoŁ-Chrzanowska E., 2012, Funkcjonowanie Wielkiego słownika języka polskiego PAN w Internecie, „Język Polski” XCII, z. 5, s. 348-352.

LIGARA B., 2009, Leksykultura w ujęciu Roberta Galissona a nauczanie kompetencji kulturowej, [w:] W.T. Miodunka, A. Seretny (red.), W poszukiwaniu nowych rozwiąań. Dydaktyka języka polskiego jako obcego u progu XXI wieku, Kraków, s. 51-61.

NKJP: Narodowy Korpus Języka Polskiego, [on-line:] www.nkjp.pl.

RAK M., 2015, Co to jest kulturem?, „LingVaria” nr 2 (20), s. 305-316, [on-line:] http://dx.doi. org/10.12797/LV.20.2015.20.23.

Seretny A., 2007, Quo vadis, lexicographia paedagogica?, „Prace Filologiczne” LIII, S. 503-512.

SJPD: W. Doroszewski (red.), Słownik języka polskiego, Warszawa 1958-1969.

SW: J. Karłowicz, A. Kryński, W. Niedźwiedzki (red.), Słownik języka polskiego, Warszawa $1900-1927$.

SWJP: B. Dunaj (red.), Współczesny słownik języka polskiego, Warszawa 2009 (CD-ROM).

ToKArski R., 1988, Konotacja jako składnik treści słowa, [w:] J. Bartmiński (red.), Konotacja, Lublin, s. 35-53.

ToKARski R., 1993, Słownictwo jako interpretacja świata, [w:] J. Bartmiński (red.), Wspótczesny język polski. Encyklopedia kultury polskiej XX wieku, t. 2, Wrocław, s. 335-387.

USJP: S. Dubisz (red.), Uniwersalny słownik języka polskiego, Warszawa 2004 (CD-ROM).

Wierzbicka A., 1985, Lexicography and Conceptual Analysis, Ann Arbor.

WierzbickA A., 1993, Nazwy zwierząt, [w:] J. Bartmiński, R. Tokarski (red.), O definicjach i definiowaniu, Lublin, s. 251-267.

WSJP: P. Żmigrodzki (red.), Wielki słownik języka polskiego PAN, [on-line:] www.wsjp.pl.

ZARZYCKA G., 2004a, Lingwakultura - czym jest, jak ja badać i „otwierać”?, [w:] A. Dąbrowska (red.), Wrocławska dyskusja o języku polskim jako obcym, Wrocław, s. 435-445.

ZarzycKa G., 2004b, Mały leksykon kultury polskiej dla cudzoziemców. Opis koncepcji, [w:] W.T. Miodunka (red.), Kultura w nauczaniu jezzyka polskiego jako obcego. Stan obecny programy nauczania - pomoce dydaktyczne, Kraków, s. 151-161.

ZarzyCKa G., JELONKIEwiCZ M., 2004, Indeks haset do Małego leksykonu kultury polskiej dla cudzoziemców, [w:] W.T. Miodunka (red.), Kultura w nauczaniu języka polskiego jako obcego. Stan obecny - programy nauczania - pomoce dydaktyczne, Kraków, s. 161-171.

ŻMigrodZKi P., 2008, Słowo - słownik - rzeczywistość. Z problemów leksykografii i metaleksykografii, Kraków.

ŻMigrodzki P., 2010a, „Definicja leksykograficzna a opis języka” - ćwierć wieku później. Jeszcze o roli naiwnego obrazu świata w definiowaniu, [w:] W. Chlebda (red.), Etnolingwistyka a leksykografia. Tom poświęcony profesorowi Jerzemu Bartmińskiemu, Opole, s. 33-40.

ŻMIGRODZKI P., 2010b, Jednojęzyczny słownik ogólny jako środek komunikacji międzykulturowej (na marginesie prac nad Wielkim słownikiem języka polskiego PAN), „Biuletyn Polskiego Towarzystwa Językoznawczego" LXVI, s. 35-49. 


\section{Cultural information versus lexicographic description in a monolingual dictionary of Polish Summary}

The paper speculates whether the lexicographic description in a general dictionary of Polish should contain explicit information about cultural knowledge petrified in the language. The author believes that this kind of commentary is important from the point of view of mediation between generations and cultures, and it can help create an active dictionary. An analysis of words from various fields (Wielkanoc 'Easter', szlachta 'nobility', dzwony 'bell-bottoms', bezpieka 'security services', orzet 'eagle', magiel 'mangle', trzepak 'carpet hanger', and others) illustrates and justifies this desideratum, assuming that cultural information will be only partially connected with the semantic description. Such information should be incorporated in different fields within the microstructure of an entry, including material illustration. For many units, the introduction of an explanation in an extrasemantic section "cultural knowledge and competence" can be used as an alternative or supplementary solution. 

Ewa Rudnicka

Uniwersytet Warszawski, Warszawa

ewa.rudnicka@uw.edu.pl

\section{KATEGORIA STYLU W BADANIACH METALEKSYKOGRAFICZNYCH}

Słowa klucze: leksykografia polska, tekstowość słownika, kategoria stylu, styl w leksykografii, stylometria, komponenty stylu

Keywords: Polish lexicography, textuality of a dictionary, the category of style, style in lexicography, stylometry, components of style

Celem niniejszego artykułu jest refleksja nad zastosowaniem kategorii stylu w badaniach metaleksykograficznych - możliwością i zasadnością wprowadzania jej do badań. Dociekanie zróżnicowania stylowego na gruncie opracowań słownikowych wydaje się nie tylko ciekawe, lecz także istotne poznawczo, zwłaszcza że nowe narzędzia do przetwarzania języka naturalnego, w tym wypadku - narzędzia stylometryczne, dają możliwość analizy wybranych elementów stylu w opracowaniach leksykograficznych.

\section{Słownik jako tekst}

Rzadko myśli się o słowniku jako tekście i zasadniczo nie operuje się określeniem tekst w odniesieniu do słownika jako całości czy nawet do podstawowej jednostki strukturalnej słownika, jaką jest artykuł hasłowy (słownikowy). Tak przynajmniej rzecz się przedstawia $w$ polskich pracach metaleksykograficznych. Znamienne jest więc, że w jednym z artykułów Aleksandra Cieślikowa (2006: 65), analizując adekwatność doboru przykładów i definicji, używa określenia tekst słownikowy. Rozumie przez to właśnie artykuł hasłowy².

1 Można jeszcze oczywiście zastanowić się nad doprecyzowaniem nomenklatury. Zważywszy bowiem na swoistą budowę opracowań słownikowych, można by dla nazwania całości opracowania 
W badaniach zachodnich uczonych na tekstowy aspekt słowników zwrócono natomiast uwage w latach 70. XX w., o czym pisze m.in. Herbert Wiegand (1990). Pionierami w tym zakresie byli badacze francuscy, którzy opisywali słowniki w kategoriach zbiorów krótkich tekstów dydaktycznych (Dubois, Dubois 1971) bądź traktatów filozoficznych (Rey-Debove 1971). Z kolei w rozwijającej się w latach 70. i 8o. metaleksykografii niemieckiej kładziono akcent na rozpatrywanie istoty kondensacji treści w przekazie słownikowym (Ising 1978; Wiegand 1983; Wolski 1986). Ostatnie dekady obfitują zaś, zwłaszcza na gruncie amerykańskim i francuskim, w rozważania na temat intertekstualności. O wadze zagadnienia może świadczyć specjalny numer tematyczny „International Journal of Lexicography” z 1989 r. (IJL), w którym znalazły się prace m.in. Thomasa B.I. Creamera, Rogera J. Steinera, Paula di Virgilio, Ladislava Zgusty oraz tekst Williama Frawleya pod znamiennym tytułem The dictionary as text.

\section{Kategoria stylu w leksykografii}

Założenie, że słowniki są tekstami, pozwala wprowadzić do badań metaleksykograficznych kategorię stylu. Dobrym zaś punktem wyjścia do rozważań na temat tego, co składa się na styl w wypadku słowników, jakie elementy stylu uwidaczniają się w opracowaniach leksykograficznych i jakie są czynniki determinujące style w leksykografii, jest rozpatrywanie stylu w ujęciu tekstologicznym oraz semiotyczno-kulturowym (Zdunkiewicz-Jedynak 2008: 14-16).

O tym, że można mówić o stylach w leksykografii, najlepiej świadczy zestawienie ogólnej definicji stylu w ujęciu Zygmunta Saloniego (EJO: 576-578) z przykładami artykułów hasłowych z różnych słowników. Saloni definiuje styl jako „sposób ukształtowania tekstu w ramach tej samej zawartości komunikacyjnej w zależności od wyboru różnych środków synonimicznych należących do danej odmiany języka" (ibid.). Natomiast różnorodność ukształtowania opisu leksykograficznego o tej samej zawartości komunikacyjnej obrazuje zestawienie choćby kilku artykułów hasłowych z różnych słowników opisujących tę samą jednostkę leksykalną.

używać nazwy makrotekst, dla podkreślenia zaś nieautonomiczności pojedynczego artykułu hasłowego - nazwy mikrotekst. Terminów makro- i mikrotekst używam paralelnie do terminów makro- i mikrostruktury. Artykuł hasłowy pojmowany jako mikrotekst to słownikowa całostka, kompletny, choć nie autonomiczny tekst powstały w efekcie realizacji odpowiedniego dla danej jednostki leksykalnej modelu mikrostruktury. Natomiast makrotekst to wynik realizacji przyjętego modelu makrostruktury. 
Klekotac, kolatac, grzechotaé, brzq̨ać; klaskać, klapać (o bocianie); śle grać na instrumencie muaycznym. brzdąkać; przen., paplać, gadać bezustanku, trajkotac; k. komu nad glową = zanudzać go gadaniną;-k. \&., bulgotać, wrzeé, kotluwac \&.

Słownik ilustrowany języka polskiego M. Arcta, Warszawa 1916

klekotać ndk IX, oczę a. ocę, ocze a.

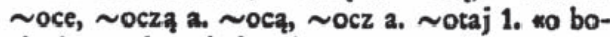
cianie: wydawak charakterystyczny i powtarzający się dźwięk, powstający przy kłapaniu dziobem»: Na suchym konarze jesionu, tuż przy domu, bocian zadzieral co chwila dziób do góry, kładł długz szyję wzdłuż grzbietu aż do ogona, a potem oddzierając ją powoli, klekotal. WEYs. Józ. Puszcza 217.

2. «wydawać dźwięk powstający przy uderzaniu o siebie twardych przedmiotów; o maszynach, motorach będących w pracy: wydawać loskot, warkot; terkotać, grzechotaćm: W pokoju obok klekotala maszyna do pisania. KoNw. Bud.6. Rozeszli się: on do "Sępa", inżynier do samolotu, który klekotal na malym gazie. Przekr. 539, 1955. W zbożach klekotały żniwiarki. NAix. Z. Gran. 123. Thum ubrany byl nikczemnie, klekotaly po chodnikach drewniane wojenne trepy. Strug Krzyz I, 253. Krowy szly wolno, klekocąc drewnianymi kolatkami, zawieszonymi u szyi. ZAP. G. Krzyż 42. Minstrelowie murzyńscy klekocą w kastaniety, przy każdym ognisku słychać odgłosy bębnów. SIENK. Now. III, 155. Z daleka z gościńca dolatywał turkot bryczek i klekotanie wózków chlopskich, toczących się do miasteczka. KonopN. Now. H, 53 .

3. pot. «mówié dużo i glośno; trajkotać, paplać, klepaćw: Epizod ten tak szyblko przemknąl, że go nikt nie postrzegl, do czego zapewne pomogło nieustanne klekotanie językowe samej kasztelanowej, DzIERzK. Rodzina 65.

- fraz. daw. Klekotaḱ komu głowę edręczyć kogo prośbami, pytaniami, żądaniami itp.; zawracać komu glowę swoimi kłopotami»: Klekoczesz mi głowe, że ci trzeba bydlęcia, a kiedy przyszedl czas, kupić go nie chcesz. PruS Plac. 25. Gdzie się obrócę, klekoczą mi wszyscy glowę, ażeby grać. ChopIN Wyb.39.// L

Słownik języka polskiego,

red. W. Doroszewski, Warszawa 1958-1969 klèkotać cz. nd., czt. klekotam, -tasz (kle$\operatorname{koc}(\mathbf{z})$ e, -c(z)esz), $c z p$. -tał, tr. -taj \|klekoc(z).-x. wydawać głuchy dźwięk (o ptakach) : bociany klekoczą; przen. starcze piersi klekotają= starcy odzywają się bezdźwięcznym, przykrym głosem. 2. uderzać o coś z tępym odgłosem: młyn klekoce. 3. grać na rozklekotanym instrumencie muzycznym: klekotać na pianinie. 4. jedno i to samo w kółko powtarzać: ciągle mi o tym klekoczesz i klekoczesz. - $\$ r$. XV 'wydawać dźwięk głuchy'; XVI L 'ts'; XVII K klekotać lub glegotać 'o ptakach'; XVII L przen. 'paplać, trajkotać'. $d z ́ w n$ - ps: ksl klekotac 'o bocianie: klaskać, i kolatać', $g$ t klekotać, $c z$ klokotati 'bełkotać, klaskać (o bocianie)', sla klekotet', $m r$ klehotáty, br klekotatý, wr klekótat', klikát' 'krzyczeć', sle klekotati 'klaskać'; klenkati 'dźwięczeć'; kleketati 'krakać', sch kleketati, cs klekotati 'szczękać zębami'. - r. klaská́, klepać, klapat. 2. klepat́, klaskat. 3. klepat, brzdqkat, walic, brzakać. 4. paplac, klepat, trajkotat, bajdurzye, gadać, ględzić, pleśt.

Nowy słownik języka polskiego,

red. T. Lehr-Spławiński,

Warszawa 1938-1939

kle·ko'tać, 'cze lub ‘ce, ‘kocz. 1 Kiedy bocian cz NoK klekocze, to wydaje charakterytyczny dźwięk, otwierając i zamykając dziób.

2 Jesli jakaś rzecz klekocze, to wydaje charak- cz Nox terystyczne miarowe dźwięki, ponieważ uderza - coś lub jej części uderzają o siebie. Przestatc klekotac maszyna do pisania... Sadzit hlehoczqc sandatami po asfalcie... Ze wschodu dobiegto kleko. tanie broni ręcznej.

3 Mowimy, że ktoś klekocze, jeśli mówi dużo lub cz NoK bez zastanowienia. Siedziat $z a$ nami na furze $[(B / A B Y)]$ $i$ klekotat jak najęty... Powotujọc się na prasę zagranicznq klekotalismy te same sformułowania... Od rana do wieczora klekotała, żebym pozwolil jej wyjechat.

Inny słownik języka polskiego, red. M. Bańko, Warszawa 2000 
klekotać $c z$. ndk IIa, oczę $\|\sim o c e, \sim o c z e\| \sim o c e, \sim o c z \| \sim \operatorname{taj}$ 1. 'o bocianie: kłapiąc dziobem wydawać dźwięk, powtarzający się zazwyczaj kilka razy': Na łące klekotał bocian. 2. 'wydawać dźwięk powstający przy uderzaniu o siebie twardych przedmiotów, o pracujących maszynach bądź ich częściach: terkotać, grzechotać': Klekotał stary kierat. Klekotała maszyna do szycia. Klekotał silnik auta. 3. 'mówić dużo, głośno, szybko; trajkotać, paplać': Ciaggle klekotała z sąsiadkami.

Stownik współczesnego języka polskiego, red. B. Dunaj, Warszawa 1996

Dla wyostrzenia różnic mogących występować między słownikowymi ujęciami warto jeszcze sięgnąć po słownik adresowany do zgoła innych odbiorców, mianowicie do dzieci:

klekotać 1. Mówimy, że bocian klekocze, kiedy wydaje charakterystyczny głos, przypominający „kle, kle”.

2. Kiedy jakaś rzecz klekocze, to jej części uderzają o coś lub o siebie, wydając powtarzające się dźwięki.

Wóz klekotat na drodze.

M. Krajewska, Mój pierwszy prawdziwy stownik, Warszawa 2000

Podane artykuły hasłowe opisują to samo słowo, jednak bardzo się między sobą różnią. Jeśliby zaś wziąć pod uwagę także inne słowniki ogólne polszczyzny², zróżnicowanie okazałoby się jeszcze większe.

Przegląd opisów jednego słowa w różnych opracowaniach uzmysławia nam przede wszystkim zmiany zachodzące $\mathrm{w}$ semantyce i pragmatyce jednostek leksykalnych, zarazem jednak uświadamia to, że opis w tym samym typie opracowania nawet mimo niezmienności desygnatu (wszak znaczenia podstawowe często pozostają niezmienne) może się znacznie różnić pod względem środków wyrazu, a zatem słowniki mogą prezentować różny styl opisu.

$\mathrm{W}$ informacjach semantycznych autorzy korzystają z rozmaitych sposobów wyodrębniania definicji i ich formułowania ${ }^{3}$ (stosują cudzysłów definicyjny lub inny

2 Warto porównać także opisy w słownikach: SL, SWil, SJPRyk, SW, SJPSz, PSWP, USJP. SL nie rozbudowuje opisu nadmiernie, ale operuje konkretnym autentycznym materiałem, stosuje minimalne kodowanie informacji fleksyjnych (podobnie postępowano w SWil, SW), swobodnie przykrawa i modyfikuje oryginalne cytaty. Dla odmiany SJPSz i USJP operują mocno skondensowanymi artykułami, bazującymi na kodowanej informacji fleksyjnej, dość mocno sformalizowanych definicjach i minimalistycznych egzemplach kolokacyjnych. W PSWP informacja fleksyjna jest rozbudowana ze względu na odejście od tradycyjnych technik skracania, a jako egzempla występują bardzo często zdania układane przez samych leksykografów. Itd.

3 Oczywiście na dobór definicji (czyli uwzględnienie wszystkich znaczeń wyrazu lub tylko części znaczeń) zasadniczy wpływ ma stan języka w danym momencie. Innym czynnikiem istotnym jest 
krój pisma, sięgają po różne typy definicji, korzystają z mniej lub bardziej usystematyzowanego sposobu definiowania, ze ściśle określonych fraz definicyjnych). W wypadku klekotać definicje ograniczają się do podawania synonimów lub minimalnych syntagm ${ }^{4}$ (np. spośród powyższych słowników - SIJPArct: 'paplać, gadać bez ustanku, trajkotać; SWJP: 'mówić dużo, głośno, szybko; trajkotać, paplać', z innych opracowań - SL: 'brząkać, glegotać'; SWil: 'świegotać, paplać', 'źle grać, brząkać), zawierają rozwinięte syntagmy o charakterze analitycznym (np. NSJPLehr: 'uderzać o coś z tępym odgłosem'; SJPD: 'o bocianie: wydawać charakterystyczny i powtarzający się dźwięk, powstający przy kłapaniu dziobem'; ISJP: 'Kiedy bocian klekoce, to wydaje charakterystyczny dźwięk, otwierając i zamykając dziób’; także PSWP: 'mówić dużo i szybko, często nie kontrolując wypowiadanych słów') albo składają się zarówno z synonimów, jak i bardziej rozwiniętych syntagm (np. SW: 'kołatać, trajkotać, grzechotać, brząkać, głuchy brzęk wydawać'; SJPSz: 'powodować wydawanie dźwięku przez uderzenie o siebie twardych przedmiotów; o maszynach, motorach itp. będących w ruchu, pracujących: wydawać łoskot, warkot; stukotać, terkotać, grzechotać'; USJP: 'mówić dużo i głośno, często bez zastanowienia; trajkotać, paplać).

Z kolei w sposobie podawania informacji fleksyjnych można zauważyć różne umiejscowienie tych informacji, rozmaity sposób ich kodowania, wykorzystywanie (bądź nie) zróżnicowanych systemów nazewnictwa przypadków gramatycznych, odsyłanie (bądź nie) do odmiennego rodzaju wzorów fleksyjnych, podawanie skrótowych lub pełnych form gramatycznych itd. Na przykładzie wybranego tu czasownika zauważymy, że na informacje fleksyjne składają się albo same końcówki fleksyjne (lub zakończenia) wybranych form koniugacyjnych (np. SW: ta a. cze a. $\times_{c e}$ tał; ISJP: ·cze lub ·ce, ·kocz), albo końcówki fleksyjne (zakończenia) wybranych form, na ogół bez określenia, o jaką formę chodzi, wraz z kodowaną informacją ${ }^{5}$ o typie fleksyjnym wyrazu (np. SWil: ał, a, v. oce, v. cze, sn. nd.; SJPD: ndk IX, oczę a. ocę, ocze a. oce, oczą a. ocą, ocz a. otaj; SJPSz: ndk IX, oczę a. ocę, oczesz a. ocesz, ocz ( otaj), otał; SWJP: cz. ndk IIa, oczę $\| \sim$ ocę, ocze $\| \sim$ oce, $\sim$ ocz $\|$ $\sim$ taj; USJP: ndk $\cdot I X, \sim$ oczę ( ocę), oczesz ( ocesz), ocz, al, a. I am, asz, ają, $\sim a j, \sim a ł)$, albo pełne postaci wybranych form koniugacyjnych, na ogół bez określenia, o jaką formę chodzi, wraz z informacją o typie fleksyjnym wyrazu i dodatkową

też podejście metodologiczne - słownik, w którym z założenia kodyfikuje się także historyczne, już niefunkcjonujące znaczenia wyrazu, będzie oczywiście uwzględniał wszystkie możliwe używane znaczenia. Jednak okazuje się, że nawet między słownikami, których założenia metodologiczne są takie same lub zbliżone, występują różnice w doborze definicji.

4 W omówieniu poszczególnych zagadnień (definiowania, opisu fleksyjnego, egzemplifikacji) dla pełniejszego obrazu sięgam po przykłady także ze słowników nieprzywołanych powyżej.

5 Informacją kodowaną nazywam informację wyrażoną w systemowo przyjętym dla danego opracowania kodzie, wykorzystującym określony zasób skrótów i sposobów ich tworzenia (np. przez ucięcie postępujące). 
informacją fonetyczną (PSWP: czas. niedokonany; klekoczę || klekocę, klekoczesz \| klekocesz, klekocz, klekotał, klekotaliśmy [klekotaliśmy], klekotalibyśmy [klekotalibyśmy]), albo wreszcie mamy do czynienia $\mathrm{z}$ wariantem mieszanym (SL: -ał, -a, et klekoce, intrans. ndk.; NSJPLehr: cz. nd., czt. klekotam, -tasz (klekoczę, -c(z)esz), czp. -tał, tr. -taj \| klekoc(z)) ${ }^{6}$.

Zróżnicowanie w egzemplach ${ }^{7}$ rozciąga się natomiast od minimalnych kolokacji (np. SWil: Młyn klekoce; NSJPLehr: bociany klekocza), przez rozwinięte zdania preparowane (np. SJPSz: Klekotała nie naoliwiona maszyna do szycia; SW: Woda w garnku klekocze ś; NSJPLehr: ciagle mi o tym klekoczesz i klekoczesz) i modyfikowane cytaty nielokalizowane lub lokalizowane (np. ISJP: Od rana do wieczora klekotała, żebym pozwolit jej wyjechać8; SL: Pszczótki póty klekocecie, Aż snem od was związany Spi człek, jak zarzezany. Groch. W. $353^{\circ}$ ), aż do oryginalnych, rozbudowanych, lokalizowanych cytatów pełnozdaniowych (np. SJPD: Na suchym konarze jesionu, tuż przy domu, bocian zadzierał co chwila dziób do góry, kładł długa szyje $w z d t u \dot{z}$ grzbietu aż do ogona, a potem oddzierając ja powoli, klekotał. WeYs. Józ. Puszcza 217).

Podobne zróżnicowanie można obserwować w wypadku każdego z elementów mikrostruktury. Widzimy różnice między poszczególnymi słownikami także w sposobie podawania informacji pragmatycznych (np. stosowanie skrótów kwa-

6 Słownikowa charakterystyka fleksyjna czasowników jest względnie prosta, inaczej przedstawia się ta kwestia w wypadku innych części mowy. Bardziej skomplikowany leksykograficznie jest np. opis rzeczowników, przy których charakterystyce wykorzystuje się również kodowane oznaczenia form przypadków fleksyjnych. Prostszy natomiast jest opis przymiotników czy przysłówków.

7 Ze względu na nieprecyzyjność stosowanych zwyczajowo określeń typu przykłady, przykłady użycia, ilustracja materiałowa, ilustracja cytatowa i ich nieadekwatny zakres posługuję się terminem egzemplum, którego zakres obejmuje wszystkie typy informowania o użyciu jednostki hasłowej, także dawne sygle (por. Rudnicka 2010: 111-112). Termin ten zaczął się przyjmować w metaleksykografii (np. w pracach Łukasza Borchmanna, Moniki Pawelec-Skurzyńskiej, Piotra Wierzchonia, Ewy Woźniak).

8 Praktyka podawania w ISJP jako egzemplów zdań zaczerpniętych z korpusu, częstokroć zmodyfikowanych w mniejszym czy większym stopniu, jest dość powszechna, podany przykład jest jednak o tyle ciekawy, że odpowiedniego zdania w korpusie NKJP (do którego został włączony korpus PWN-owski) nie ma, można je natomiast znaleźć w artykule Aleksandry Domogały, która zdanie to buduje na użytek analizy semantycznej słowa klekotać. Mamy więc do czynienia z ciekawym wypadkiem cytowania zdania wymyślonego, niebędącego elementem żadnej naturalnej wypowiedzi. Zdanie zresztą jest dłuższe i przez Domogałę oznaczone jako wadliwie zbudowane w języku polskim, ponieważ brzmi: ${ }^{*}$ Od rana do wieczora klekotała, żebym pozwolit jej wyjechać, ale nic przy tym nie powiedziała (Domogała 2013: 34).

9 Zabiegi modyfikowania cytatów przez Lindego bez oznaczania ingerencji w tekst z jednoczesnym podaniem lokalizacji cytatu były normą w jego słowniku. W tym wypadku zdanie pochodzące z Wirydarza Stanisława Grochowskiego brzmi w oryginale następująco: Przez was [pszczółeczki - E.R.] trudów człek zbywa, $\mid g d y$ w drodze odpoczywa,| bo w to trafić umiécie,| iż go łacno uśpicie,| trudy prace w nim gładząc,| do snu wdzięcznego radząc;| więc póty klekocecie,| aż się w smysty wkradniecie:| tak snem od was związany| śpi człek jak zarzezany (Grochowski 1997: 45). 
lifikatorowych, włączanie kwalifikatorów do definicji, różne uwzględnianie informacji o zakresie używalności słowa), informacji leksykalnych (m.in. uwzględnianie bądź nieuwzględnianie relacji wyrazowych, np. synonimii, czy syntagmatycznych, jak łączliwość wyrazowa), informacji etymologicznych (np. pomijanie tych informacji, różny zakres ich uwzględniania - przy słownictwie wyłącznie obcym lub przy wszystkich możliwych jednostkach) itd. Nie bez znaczenia jest również zróżnicowanie rodzajów kroju pisma i rozkład treści w artykule hasłowym (czynniki te nie przesądzają rzecz jasna o stylu, ale wyodrębniają lub uwypuklają poszczególne typy informacji słownikowej i elementy mikrostruktury, podkreślając pewne cechy stylowe).

Wszystkie tego rodzaju różnice świadczą o stosowaniu w danym słowniku odrębnej stylistyki. Wybór każdego ze wspomnianych środków, jak również rezygnacja $\mathrm{z}$ danego środka wyrazu, jest wyborem stylistycznym.

\section{Komponenty stylu leksykograficznego, czyli co się składa na styl słownika}

W literaturze obcojęzycznej o stylu w leksykografii pisał H. Wiegand (1990). Przedmiotem refleksji uczynił on zmianę stylu leksykograficznego między materiałem opracowanym przez Jacoba Grimma do pierwszego wydania Das Deutsche Wörterbuch (z tomów publikowanych w latach 1854-1862) a tym samym materiałem zawartym w edycji poprawionej słownika (wyd. 1965-1983). Styl słownikowy według Wieganda jest stałą (ustaloną) konwencją, zgodnie z którą dokonują się - jak to ujmuje autor - akty objaśniania $h_{n}$ (tj. formułowanie tekstów słownikowych) i zgodnie z którą są ustrukturyzowane efekty tychże aktów objaśniania (Wiegand 1990: 122-124). Do stylistycznych środków wyrazu (stylistic devices) w leksykografii Wiegand zalicza takie elementy, jak: 1. stały (ustalony) sposób formułowania poszczególnych segmentów tekstu, 2. porządek segmentów tekstu, mikrostruktura słownikowa, 3. dobór segmentów tekstu, 4. wprowadzanie nowych segmentów tekstu do praktyki leksykograficznej, 5. stosunek między językiem opisywanym w słowniku a językiem słownikowego opisu, 6. objętość segmentów tekstowych w obrębie artykułu słownikowego, 7. zwiększona objętość artykułów hasłowych opisujących pewne typy lematów, 8. typografia (ibid.: 124). Jak widać, autor zwraca uwagę przede wszystkim na sposób zorganizowania informacji w poszczególnych aktach objaśniania, a kwestię stylu rozpatruje w nawiązaniu do Austinowskiej teorii aktów mowy.

Na nieco szersze potraktowanie stylu w odniesieniu do słowników pozwala podejście tekstologiczne i semiotyczno-kulturowe, które bynajmniej nie stoi w sprzeczności z wyżej przedstawionym podejściem strukturalno-pragmatycznym. Ponieważ $\mathrm{w}$ tym ujęciu styl jest rozumiany jako ponadtekstowa i ponadgatunkowa całość znakowa (Bartmiński, Niebrzegowska-Bartmińska 2012: 113), wydaje się, że jest ono poznawczo bogatsze. Dlatego też poniższe refleksje nad komponentami stylu zostały oparte przede wszystkim na koncepcji Jerzego Bartmińskiego. 
By scharakteryzować styl, Bartmiński rozróżnia wartości stylu i tekstowe eksponenty stylu. Przez wartości stylu należy rozumieć wszelkie treści, jakie niesie wybór danego stylu, czyli co znaczy dany styl jako taki, czemu służy, co komunikuje odbiorcy decyzja autora o wyborze takiego, a nie innego stylu. Natomiast eksponenty stylu związane z samą materią, zawartością są dwojakie - sygnały i wykładniki. Sygnały stylu, mające charakter językowy bądź pozajęzykowy (np. rozczłonkowanie tekstu, jego typografia), dają informację o ogólnej przynależności tekstu do pewnego stylu językowego. Wykładniki stylu zaś, mające wyłącznie językowy charakter (np. typ słownictwa, określone konstrukcje składniowe czy leksykalne itd.), służą realizacji przyjętych w danym stylu zasad czy inaczej kategorii stylistycznych (takich jak abstrakcyjność, obrazowość, ścisłość, jednoznaczność, obiektywizm, emocjonalność itd.). W odniesieniu do materii słownikowej komponenty stylu można przedstawić następująco ${ }^{10}$ :

Schemat 1. Komponenty stylu słownikowego

\section{KOMPONENTY STYLU SLOWNIKOWEGO}

wartości

- ontologia (racjonalność, punkt widzenia)

- intencjonalność

- zasady stylistyczne

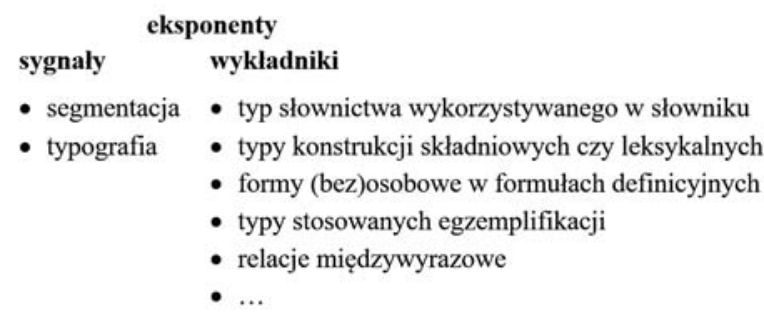

Źródło: opracowanie własne.

Komponenty wskazujące na styl słownika tworzą trzy zasadnicze filary: ideowy (wartości), strukturalno-edy torski (sygnały) i językowy (wykładniki). Poniżej zostanie szkicowo przedstawiona odnośność wybranych elementów stylu do opracowań leksykograficznych. Ze względu na ograniczoną objętość artykułu uwagę pokrótce poświęcę ontologii leksykograficznej (jedna z wartości stylu), segmentacji tekstu (jeden z sygnałów stylu), a także leksyce w definicjach i typom egzemplifikacji (dwa spośród wykładników stylu) ${ }^{11}$.

10 Przy czym w odróżnieniu od Bartmińskiego przyjmuję, że sygnały mają charakter niejęzykowy (głównie strukturalny i graficzny), natomiast wykładniki - językowy.

11 Koncepcja kategorii stylu w leksykografii w ujęciu tekstologicznym i semiotyczno-kulturowym jest w dalszym ciągu dopracowywana z myślą o obszerniejszym studium. Niniejszy tekst stanowi zarys tej koncepcji, z czego wynika też jego ogólnikowość w niektórych partiach. 


\subsection{Ontologia leksykograficzna jako jedna z wartości stylu}

Wartości stylu nie są wspólne wszystkim słownikom, choć można by tego oczekiwać. W każdy słownik wpisana jest jakaś wizja świata oraz wizja samego języka i jego relacji do świata, więc z każdym słownikiem wiąże się pewna ontologia, racjonalność, intencjonalność, pewien punkt widzenia ${ }^{12}$. Ontologia leksykograficzna (rozumiana jako sposób istnienia rzeczywistości, o której się mówi) jest w ogóle ontologią złożoną, w słowniku bowiem zawsze opisywany jest metaświat. Znajdujemy w nim zbiór słów, za którymi stoją zarówno świat realny, jak i fikcyjny, a także wyabstrahowany świat stanowiący inwariantną, „uśrednioną”, typową konceptualizację każdego z tych dwóch światów ${ }^{13}$.

Niewątpliwie wszystkie słowniki cechuje realizm, jest to warunek konieczny dla tego typu tekstów, natomiast nie zawsze jest to ten sam realizm. O niektórych słownikach można powiedzieć, że cechuje je realizm „naiwny”14 (oparty na przekonaniu, że słowa odnoszą się do rzeczywistych bytów, a świat jest taki, jakim go postrzegamy, jak np. w MPPS) bądź realizm zdroworozsądkowy (oparty na postrzeganiu świata przez przeciętnego człowieka, ale zarazem cechujący się pewnym dystansem wobec słów jako nazw obiektów, które zawierają w sobie niekiedy intersubiektywną interpretację świata, jak np. w ISJP, gdzie np. operatory typu zwykle, często wskazują na niewyraźność granic zakresu desygnacyjnego danej jednostki, a frazy definicyjne typu $x$-em nazywamy... sygnalizują pewną subiektywizację określeń). Bywają zaś takie, w których można się dopatrzyć realizmu scjentystycznego (opartego na naukowym postrzeganiu i kategoryzowaniu świata oraz ustanawianiu relacji między słowami a desygnatami zgodnie z zasadami naukowymi, w szczególności z logiką, jak np. w SJPD, SJPSz, USJP).

Dobrze obrazują to przykłady charakterystyki rzeczownika kaczeniec:

MPPS:

kaczeniec. Kaczeńce to kwiaty rosnące nad brzegami strumieni lub rzek, żółte jak małe kaczki.

ISJP:

kaczeniec [...]. Kaczeniec to żółty kwiat rosnący na podmokłych łąkach i na brzegach rzek.

12 Wszystkie te kwestie wiążą się z zagadnieniem słownikowego obrazu świata, o którym pisała szerzej Jadwiga Puzynina (1993).

13 Por. Muszyński 1996: 31-37; Wierzbicka 2006: 41-42, 300-302.

14 Pojęcia realizmu „naiwnego" używam w znaczeniu, w jakim funkcjonuje od dawna w niektórych nurtach językoznawstwa, podobnie z pojęciem realizmu scjentystycznego (por. Apresjan 2000: 66-67; Bartmiński, Niebrzegowska-Bartmińska 2012: 115-116, 120; Bogusławski 1988: 111-112, 127-128; Wierzbicka 1969 i in.). Pojęcie realizmu zdroworozsądkowego traktuję jako podejście pośrednie, pod pewnymi względami bliskie realizmowi naiwnemu, w innych zaś scjentystycznemu. 
USJP:

kaczeniec bot. «Caltha, roślina o żółtych kwiatach i dużych, lśniących liściach, rosnąca na podmokłych łąkach, na brzegach rzek, kwitnąca wczesną wiosną; knieć».

Znamienne wydaje się to, że realizm naiwny i zdroworozsądkowy nie wymagają właściwie rozgraniczania i określania statusu definiendum i definiensa. Czytając takie definicje, można mieć wrażenie, że nie czyta się informacji o słowach, tylko o bytach. W wypadku opisu w duchu realizmu naiwnego możliwe jest nawet uwzględnianie informacji na temat swoistej antropocentrycznej percepcji i konceptualizacji obiektów i zjawisk, jak wzmianka o tym, że kaczeńce są żółte jak małe kaczki, z czym - w domyśle - wiąże się ich nazwa. Realizm scjentystyczny natomiast narzuca rozgraniczenie między słowami a opisami słów. Niemożliwe jest przenikanie się definiendum i definiensa, co znajduje jednoznaczne odzwierciedlenie nawet na poziomie graficznym: metajęzykowy status ontologiczny jest w wypadku definicji podkreślony np. cudzysłowami definicyjnymi.

Przy badaniu wartości stylu ważne jest, by mieć świadomość tego, że dobór takich czy innych wartości przesądza o formie i zawartości całego słownika, choć oczywiście nie każdy artykuł hasłowy musi zawierać przejawy określonego stylu. Oznacza to, że o wartościach stylu słownikowego w danym opracowaniu orzeka się na podstawie poświadczeń zawartych w wybranych artykułach hasłowych. Niestety wiąże się to także z ograniczeniem możliwości pełnego obiektywizmu w badaniu wartości stylu.

\subsection{Segmentacja tekstu jako jeden z sygnałów stylu}

Wśród eksponentów stylu wyróżnia się sygnały, składające się na filar strukturalno-edytorski stylu leksykograficznego, oraz wykładniki, tworzące filar językowy stylu. Sygnałami stylu w słownikach są niewątpliwie takie środki, jak segmentacja i typografia ${ }^{15}$. W wypadku segmentacji znaczenie mają: 1) szpaltowy rozkład tekstu i obecność żywej paginy, 2) rozczłonkowanie tekstu na artykuły hasłowe i związane z tym gniazdowanie artykułów hasłowych bądź jednostek leksykalnych, jak również 3) mikrostruktura artykułu hasłowego, za której wspólny mianownik można uznać schemat słowo - objaśnienie - [egzemplifikacja]. Segmentacja może mieć charakter systemowy w mniejszym lub większym stopniu albo swobodny, co idzie w parze z takimi cechami stylowymi, jak analityczność i naukowość ujęcia lub esencjonalność i potoczność. Różnice w tym zakresie uwidaczniają się w szczególności przy obserwacji rozczłonkowania na artykuły hasłowe oraz mikrostruktury poszczególnych haseł.

15 Zagadnienie segmentacji i typografii słownikowej niewątpliwie wymaga osobnego studium, tu jednak zostanie ono omówione dość ogólnie ze względu na ograniczenia redakcyjne. 
W ogólnym rozkładzie tekstu charakterystyczna dla słowników jest dwuszpaltowość, obserwujemy ją w większości opracowań, choć zdarza się też układ wieloszpaltowy, jak w niektórych wydaniach SIJPArct. Zupełnie wyjątkowa jest natomiast jednoszpaltowość, jak np. w Słowniku synonimów polskich Adama Stanisława Krasińskiego (SSPKr 1885). Jedną szpaltę główną mają także MPPS i ISJP, towarzyszy jej jednak szpalta pomocnicza $z$ informacjami gramatycznymi. Szpalty pomocnicze są zresztą ciekawym rozwiązaniem zastosowanym dopiero we współczesnych słownikach. Tego rodzaju marginalia, umieszczane przy odpowiednich artykułach hasłowych, zawierają dodatkowe informacje na temat poszczególnych jednostek leksykalnych (głównie informacje fleksyjne i składniowe, lecz także leksykalne), wykraczające, jak można mniemać, poza standardowe potrzeby czy oczekiwania przewidywanych odbiorców słownika.

Żywa pagina to także cecha typowa dla słowników, rzadko się zdarza, że nie występuje (zwłaszcza w słownikach ogólnych). Informacje w niej zawarte dotyczą materiału na danej stronie, stopień ich szczegółowości bywa jednak różny. Niekiedy podawane są początkowe i końcowe hasła $z$ danej rozkładówki (SJPSz, ISJP, USJP) albo ze strony (SW, SJPD, PSWP) lub nawet z danej szpalty (np. SL), niekiedy zaś informacja jest ograniczona do paru inicjalnych liter wyrazu pierwszego i ostatniego na danej stronie (SJPRyk, SIJPArct, NSJPLehr) czy paru inicjalnych liter pierwszych wyrazów w szpalcie (SWil).

Rozkład tekstu nie zawsze jest w pełni decyzją autora (podobnie jak typografia), znaczący udział ma w tym zakresie wydawca, więc można by się wahać, czy ten element traktować jako przejaw stylu. Jednakże jeśli wziąć pod uwagę, że słowniki są dziełami zbiorowymi i styl całości jest wypadkową nie tylko założeń wypracowanych przez redaktora naukowego, które niewątpliwie tworzą podwaliny stylu, lecz także sposobu wyrażania się wszystkich członków zespołu, to wydaje się, że również wkład wydawcy można uwzględnić jako element stylu. Dwuszpaltowość i inne sposoby rozkładu tekstu oraz rodzaj żywej paginy świadczyłyby o konwencjonalności stylu lub jego oryginalności (np. zastosowanie szpalt pomocniczych i marginaliów), a także wskazywałyby na szczegółowość ujęcia, co w oczywisty sposób składa się na ogólny styl opracowania.

Rozczłonkowanie tekstu na artykuły hasłowe to pochodna użytkowego charakteru słowników, a także metody pracy słownikarskiej, w której bardzo istotną rolę odgrywały jeszcze do niedawna uporządkowane alfabetycznie wypisy i kartoteki. Taki sposób porządkowania racjonalnie został przeniesiony z wypisów i kartotek do opracowań leksykograficznych, które były swoistymi wyciągami z materiału zawartego w kartotekach, odpowiednio dobranego i opracowanego. Gniazdowanie, które stanowi wyróżnik niektórych słowników (np. SL i ISJP), świadczyłoby o systemowym spojrzeniu na język jako zbiór jednostek powiązanych ze sobą, w pewnym sensie nawet synsemantycznych, wiązałoby się także z ekonomizacją przekazu i pewną jego skrótowością. Autonomizację artykułów hasłowych można natomiast uznać za 
świadectwo takich cech stylu, jak przywiązywanie wagi do szczegółu i do przekazu informacji stanowiących całostkowe pakiety.

Złożoność modelu mikrostruktury i rozgraniczanie segmentów mikrostrukturalnych pozwalają obserwować realizowanie w stylu leksykograficznym takich cech, jak systemowość opisu słownikowego lub jego swobodność. Zasadniczo w słownikach daje się zauważyć dążenie do systemowości, które nasila się z biegiem czasu i rozwojem warsztatu leksykograficznego. W związku z tym swobodność jest ważnym sygnałem informującym np. o etapie kształtowania się warsztatu leksykograficznego, o specyficznym adresacie opracowania lub ideowych założeniach związanych z ontologią, racjonalnością i punktem widzenia. Ponadto kolejność uwzględnionych w mikrostrukturze elementów może świadczyć o ważności informacji składającej się na dany element, a w dalszej kolejności - o słownikowej racjonalności czy punkcie widzenia.

Nie bez znaczenia w określaniu stylu są też parametry kwantytatywne, czyli objętość poszczególnych segmentów tekstowych w obrębie artykułu słownikowego, o której wspominał Wiegand (1990: 124). Rozbudowany element egzemplifikacyjny zawierający cytaty (jak np. w słownikach SL, SW, SJPD) wskazuje na dokumentacyjność opracowania, natomiast ograniczony i złożony z kolokacji świadczyłby o pragmatyczności opracowania i nastawieniu instruktażowym (tzn. słownik ma podpowiadać, jak budować zdania z wykorzystaniem danej jednostki).

Ogólnie rzecz biorąc, warto zauważyć, że w zakresie sygnałów stylu (zwłaszcza dotyczących struktury) konwencje słownikowe są w miarę zbieżne i stabilne historycznie - pod tym względem słowniki wyraźnie się wyróżniają na tle innych typów tekstów.

\subsection{Leksyka w definicjach i typy egzemplifikacji jako wykładniki stylu w słownikach}

Ostatnią grupą komponentów stylu są jego tekstowe wykładniki, obejmujące np. typ słownictwa wykorzystywanego w segmentach zarówno odautorskich, jak i inkorporowanych (tzn. w egzemplach w formie cytatów), określone konstrukcje składniowe czy leksykalne stosowane w segmentach definicyjnych, egzemplifikacyjnych i in., długość wypowiedzeń, a zwłaszcza obecność specjalnych formuł definicyjnych (w wypadku definicji kontekstowych), formy (bez)osobowe czasowników w definicjach, operowanie określonym typem egzemplifikacji, sposób kodowania informacji gramatycznych, sposób i miejsce uwzględniania relacji międzywyrazowych (zwłaszcza synonimii). Zwrócimy uwagę na najważniejsze prawidłowości w funkcjonowaniu dwóch elementów: leksyki w definicjach i typów egzemplifikacji.

$\mathrm{W}$ wielu słownikach leksyka wykorzystywana w segmentach definicyjnych ma charakter neutralny (niekiedy naukowy) i dosłowny, nieobrazowy (tzn. bez metaforyki i porównań), czasem abstrakcyjny, najczęściej zaś stosowanym modelem jest 
genus proximum et differentia specifica (często w formie rozwiniętej, wieloczłonowej), tak np. w NSJPLehr, SJPD:

NSJPLehr:

kropidło [...] 1. narzędzie służące do kropienia, szczególnie w kościele (wodą święconą) $[\ldots]$.

SJPD:

armaniak [...] «napój alkoholowy otrzymywany z wina albo wytłoczyn winogronowych przez ich destylację, produkowany w Armagnac» [...].

kropidło [...] 1. «narzędzie służące do kropienia wodą święconą, zwykle składające się z długiej drewnianej rączki i pęczka podłużnych wiórków z miękkiego drewna; wszelkie narzędzie do kropienia, opryskiwania czego».

Tego typu zapisy byłyby przejawem stylu popularnonaukowego lub naukowego. Z kolei korzystanie z ujęcia obrazowego, porównań, przywoływania konkretów przybliżałoby słowniki do stylu potocznego, co można obserwować m.in. w SJPSz czy ISJP:

SJPSz:

armaniak [...] «francuski napój alkoholowy otrzymywany przez destylację wina, podobny do koniaku» $[\ldots .$.$] .$

kozodój [...] «Caprimulgi, rząd ptaków nocnych i zmierzchowych, o niewielkim dziobie otwierającym się bardzo szeroko i o ubarwieniu upierzenia jak u sów; obejmuje około stu gatunków, w Europie występują tylko gatunki z rodziny kozodojów właściwych, np. lelek kozodój».

ISJP:

aligator [...]. Aligator to drapieżny gad podobny do krokodyla, ale o krótszym i szerszym pysku. Aligatory żyją w rzekach i bagnach Ameryki i Azji.

kropidło [...]. Kropidło to przedmiot przypominający miotełkę, którego ksiądz używa do kropienia wodą święconą [podkreślenia - E.R.].

Wymownym wykładnikiem stylu są także egzempla. W słowniku mogą być one cytatami z anotacją źródłową (lokalizacją), cytatami modyfikowanymi (z anotacją bibliograficzną lub bez niej), przykładami preparowanymi, kolokacjami (Rudnicka 2010: 113-114). Już sam wybór określonego typu egzemplum ma charakter stylistyczny. O słownikach korzystających wyłącznie z cytatów anotowanych można mówić, że kładą nacisk na oryginalność i wskazują na charakter literacki czy dokumentacyjny (przy czym zwykle dokumentują normę wysoką), o opracowaniach bazujących na zdaniach preparowanych czy kolokacjach można natomiast powiedzieć, że kładą nacisk na prototypowość użyć i szablonowość języka, a tym samym wskazują na charakter praktyczny i dydaktyczny słownika. Lektura każdego z typów opracowań jest inna, kontrastowe pod tym względem są choćby SL i SJPRyk (np. hasło klęska) czy SJPD i SJPSz (np. hasło krosta). 
Oprócz tego możliwych jest jeszcze kilka rozwiązań pośrednich, np. sięganie po cytaty $\mathrm{z}$ jednoczesną ingerencją $\mathrm{w}$ ich formę i $\mathrm{z}$ ograniczeniem anotacji do danych osobowych, jak ma to miejsce np. w SW, czy sięganie po cytaty jako „inspirację” do spreparowania na ich podstawie (tzn. z wykorzystaniem słownictwa czy konstrukcji z cytatu) przykładu funkcjonalnego słownikowo. Skrócone i pozbawione anotacji bibliograficznej zdania nie odwracają uwagi od istotnych informacji zawartych w artykule hasłowym, pozwalają się skupić na języku i jego typowych konstrukcjach. Taki sposób egzemplifikacji został wykorzystany w ISJP (w tym wypadku także warto przyjrzeć się np. hasłu klęska).

Powyższe rozważania mogą się nie wydawać niczym nowym na gruncie metaleksykografii. Wszak od lat wnikliwie opisuje się w niej elementy warsztatu leksykograficznego twórców poszczególnych opracowań, zwłaszcza w studiach monograficznych poświęconych pojedynczym słownikom. Dotychczas jednak nie przypisywano tym elementom wartości stylistycznej.

\section{Eksponenty stylu i aplikacje stylometryczne}

Na koniec warto wspomnieć o interesującej metodologicznie możliwości wykorzystania w badaniach stylistycznych, zwłaszcza w badaniu eksponentów stylu, aplikacji stylometrycznych. Rozwój językoznawstwa statystycznego i rozpowszechnienie aplikacji do przetwarzania języka naturalnego zachęcają do wypróbowania na materiale słownikowym nowych narzędzi automatycznych, w tym także narzędzi do analizy stylu. Wprawdzie stylometria automatyczna znajduje zastosowanie głównie w analizach tekstów literackich (Eder 2014; Rybicki 2014), jednak użycie narzędzi stylometrycznych $\mathrm{w}$ analizach materiału leksykograficznego również daje wyniki skłaniające do refleksji nad sposobami badania słowników. W tym wypadku użyteczność narzędzi stylometrycznych sprawdzano, wykorzystując aplikacje Stylo ${ }^{16}$ oraz Jasnopis ${ }^{17}$.

Testowy materiał leksykograficzny stanowiło 50 wyrazów opisanych jako hasła słownikowe w jedenastu opracowaniach leksykograficznych wybranych do badania: SL, SJPRyk, SWil, SW, NSJPLehr, SJPD, SJPSz, PSWP, SWJP, ISJP, USJP. Z opracowanej listy haseł na literę $K$ zawartych we wszystkich słownikach zostało wybranych

16 Narzędzie pod nazwą Stylo zostało stworzone przez badaczy z konsorcjum CLARIN-PL i jest dostępne na platformie konsorcyjnej (http://ws.clarin-pl.eu/demo/stylo2.html). Analizy prowadzone w aplikacji Stylo opierają się na założeniu, że statystyczne obserwowanie i porównywanie częstości użyć elementów językowych o najwyższej frekwencji tekstowej pozwala scharakteryzować styl pojedynczego autora oraz badać stylistyczne pokrewieństwo tekstów różnego autorstwa.

17 Jasnopis (http://www.jasnopis.pl/) nie jest zasadniczo narzędziem stylometrycznym, mierzy jedynie poziom trudności tekstu w 7-stopniowej skali, zaleca się stosowanie go do sprawdzania tekstów użytkowych. W analizach szczególną rolę odgrywa długość słów i ich liczba w wypowiedzeniu. 
pierwszych 50 haseł występujących w każdym ze słowników (przy czym w wypadku haseł gniazdowych każdy wyraz w gnieździe był traktowany jako osobne hasło, tak jak jest to $\mathrm{w}$ większości słowników). Ze względu na typ narzędzi z artykułów hasłowych wybrano do analizy wyłącznie segmenty niekodowane - definicje oraz egzemplifikacje. Analizowano całościowo te elementy dla wszystkich słowników, po czym analizie poddano także każdy z segmentów osobno. Wykonano cztery rodzaje testów: 1) klasyczną analizę autorstwa, 2) rozszerzoną analizę autorstwa, 3) analizę stylu gramatycznego, 4) analizę grup podobieństwa treści. Oprócz tego wykonano analizy za pomocą Jasnopisu, z których wykorzystano dane kwantytatywne dotyczące długości poszczególnych elementów mikrostruktury.

Wyniki uzyskane w testach obrazują (w wyborze) poniższe tabele oraz wykresy:

Tabela 1. Wybrane parametry kwantytatywne słowników wg Jasnopisu ${ }^{18}$
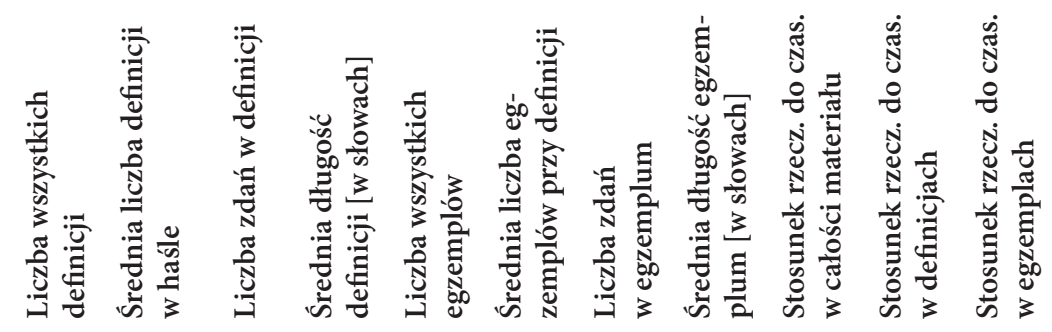

\begin{tabular}{lccccccccccc}
\hline $\begin{array}{l}\text { 1807 Linde (SL) } \\
\text { 1854 Rykaczew- } \\
\text { ski (SJPRyk) }\end{array}$ & 138 & 2,46 & 1,06 & 7 & 202 & 1,46 & 1,00 & 9 & 2,58 & 3,08 & 2,38 \\
$\begin{array}{l}\text { 1861 Wileński } \\
\text { (SWil) }\end{array}$ & 141 & 2,52 & 1,01 & 8 & 118 & 0,84 & 1,00 & 4 & 4,65 & 5,84 & 3,58 \\
\hline $\begin{array}{l}\text { 1900 Warszaw- } \\
\text { ski (SW) }\end{array}$ & 271 & 4,84 & 1,01 & 6 & 466 & 1,72 & 1,03 & 7 & 3,43 & 6,05 & 2,69 \\
$\begin{array}{l}\text { 1938 Lehr } \\
\text { (NSJPLehr) }\end{array}$ & 156 & 2,79 & 1,00 & 7 & 90 & 0,58 & 1,00 & 7 & 7,17 & 17,45 & 2,86 \\
\hline $\begin{array}{l}\text { 1958 Doroszew- } \\
\text { ski (SJPD) }\end{array}$ & 130 & 2,32 & 1,00 & 10 & 349 & 2,68 & 1,14 & 14 & 2,95 & 7,92 & 2,44 \\
$\begin{array}{l}\text { 1978 Szymczak } \\
\text { (SJPSz) }\end{array}$ & 125 & 2,23 & 1,00 & 11 & 138 & 1,10 & 1,00 & 3 & 6,70 & 9,48 & 3,84 \\
$\begin{array}{l}\text { 1994 Zgółka } \\
\text { (PSWP) }\end{array}$ & 297 & 5,30 & 1,00 & 15 & 671 & 2,26 & 1,01 & 6 & 4,50 & 7,22 & 3,19 \\
$\begin{array}{l}\text { 1996 Dunaj } \\
\text { (SWJP) }\end{array}$ & 123 & 2,20 & 1,00 & 11 & 150 & 1,22 & 1,01 & 4 & 5,04 & 7,93 & 2,84 \\
\hline
\end{tabular}

18 Daty przy nazwiskach autorów/redaktorów słowników oznaczają rok wydania tomu z literą $K$. 


\begin{tabular}{|c|c|c|c|c|c|c|c|c|c|c|c|}
\hline & 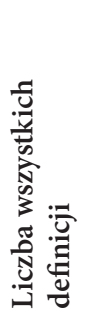 & 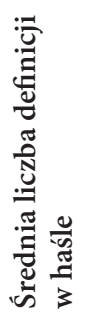 & 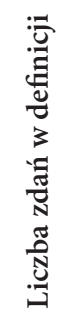 & 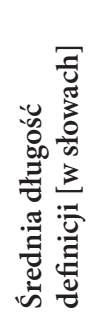 & 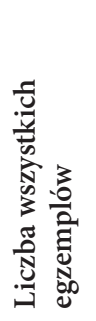 & 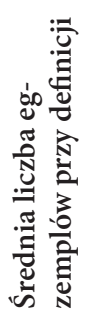 & 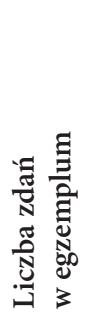 & 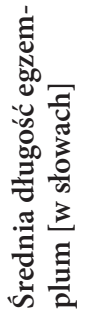 & 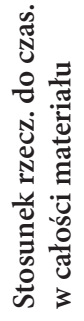 & 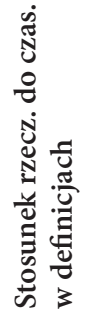 & 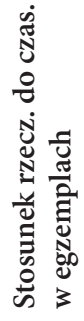 \\
\hline $\begin{array}{l}2000 \text { Bańko } \\
\text { (ISJP) }\end{array}$ & 99 & 1,77 & 1,09 & 13 & 118 & 1,19 & 1,03 & 7 & 2,80 & 3,36 & 2,15 \\
\hline $\begin{array}{l}2003 \text { Dubisz } \\
\text { (USJP) }\end{array}$ & 140 & 2,50 & 1,00 & 9 & 147 & 1,05 & 1,01 & 3 & 6,41 & 10,50 & 3,42 \\
\hline
\end{tabular}

Źródło: opracowanie własne na podstawie wyliczeń aplikacji Jasnopis.

Zestawienia stylometryczne przedstawione w Schemacie 2 pozwalają stwierdzić dobrą korelację między wynikami analiz automatycznych a tradycyjnymi obserwacjami eksponentów i wartości stylu w odniesieniu do większości słowników. Z analiz wynika, że w badaniu stylu szczególnie użyteczne są takie parametry, jak liczba definicji w haśle, długość definicji, liczba egzemplów, ich długość oraz stopień nominalności w materiale tekstowym. Zwróćmy uwagę na kilka prawidłowości.

Średnia liczba definicji w haśle koreluje z wnikliwością opisu semantycznego będącą pochodną ogólnej wizji systemu leksykalnego i leksykograficznego (niekiedy też $\mathrm{z}$ uwzględnianiem $\mathrm{w}$ artykule hasłowym wielu jednostek typu frazeologizmy lub wyrażenia terminologiczne). Słowniki nastawione na utylitaryzm, podręczność i maksymalną przystępność dla przeciętnych użytkowników języka na ogół mają niskie wyniki pod tym względem (ISJP, SJPRyk), natomiast słowniki dokumentacyjne, aspirujące do wyczerpującego opisu języka, mają wyniki wyższe (PSWP, SW). Ponadto warto zwrócić uwagę na liczbę zdań w definicji ${ }^{19}$. Standardem w leksykografii są definicje jednozdaniowe, dlatego wszelkie odchylenia od tego modelu są warte uwagi, mogą wskazywać na nowatorstwo stylowe słownika w danym okresie i zastosowanie środków sprzyjających łatwiejszemu odbiorowi przekazu (ISJP, SL, SJPRyk). W parze z podręcznym charakterem opracowania i chęcią możliwie przystępnego opisu znaczenia często idzie też długość definicji - dłuższe definicje spotykamy w słownikach „popularnych” (PSWP, ISJP).

19 Ze względu na automatyczność analiz jako zdanie traktowano w tym wypadku wypowiedzenie zamknięte kropką lub znakiem sygnalizującym koniec definicji jako równoważnikiem kropki (tj. np. cudzysłowem ostrokątnym lub definicyjnym), co na tym poziomie ogólności wydaje się właściwe. Delimitację wypowiedzeń definicyjnych można rzecz jasna potraktować także w inny sposób - np. rozważać rolę delimitacyjną średników w definicji - jest to jednak zagadnienie wymagające osobnego studium. 
Schemat 2. Zbieżności stylowe słowników według Stylo - klasyczna analiza autorstwa w dendrogramie (górny) i analiza stylu gramatycznego w skalowaniu wielowymiarowym (dolny), analizowany wariant podstawowy obejmujący całość materiału tekstowego (definicje i egzempla)
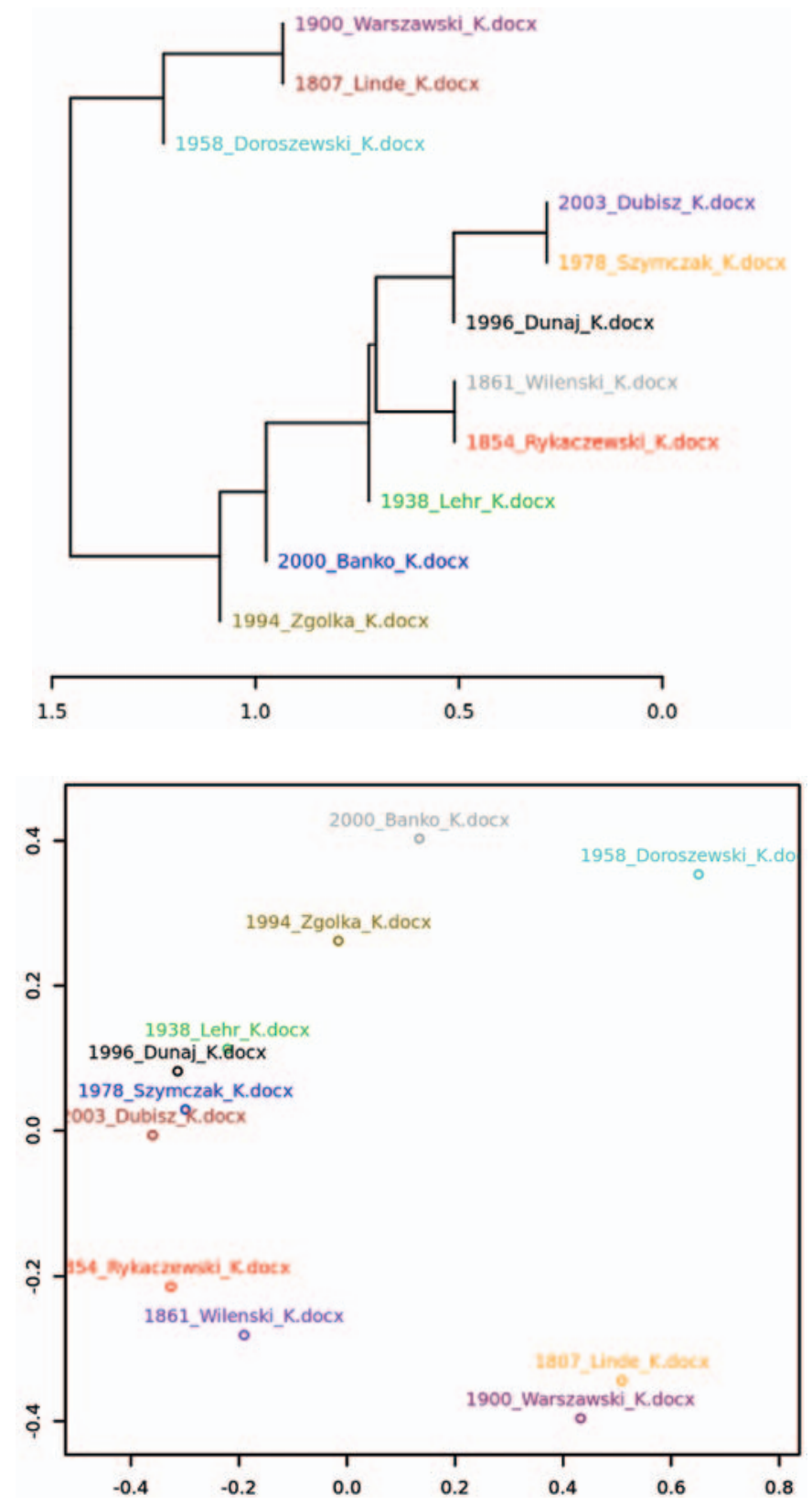

Źródło: opracowanie własne z zastosowaniem aplikacji Stylo. 
O stylu możemy też wnioskować na podstawie stosunku długości definicji do długości egzemplum. Na ogół w słownikach informacyjno-potocznych definicje są dłuższe od egzemplów, ograniczonych do podstawowych modeli syntaktyczno-syntagmatycznych (SJPSz, USJP, SWJP). Natomiast w słownikach, w których te proporcje są odwrócone, na ogół przywiązuje się dużą wagę do literackości i pewnego artyzmu wypowiedzi egzemplifikacyjnych (SJPD, SL, SW).

Z kolei formalizm stylu i wysoki stopień systematyzacji opisu przejawia się m.in. dużym odsetkiem rzeczowników i wysoką wartością stosunku rzeczowników do czasowników (NSJPLehr, USJP, SJPSz), szczególnie wysokimi wartościami cechują się definicje słownikowe. Większy odsetek czasowników w mikrotekstach słownikowych koreluje zaś z pewną swobodą opisu, wyższym stopniem przystępności i „przyjazności w lekturze” (SL, ISJP).

Co się tyczy zbieżności stylistycznych między słownikami, wynikających z analiz Stylo, to uśrednienie wyników czterech testów w całym materiale tekstowym wskazuje na największe podobieństwo w następujących parach: SJPSz - USJP, SWil - SJPRyk, SJPSz - SWJP, SL - SW, w definicjach z kolei w parach SJPD - SJPSz, SWil - SJPRyk, SWil - SW, SJPRyk - SW, SJPD - USJP, a w obrębie egzemplów w parach SJPSz - USJP, SJPRyk - SJPSz, SJPRyk - USJP, SL - SW. Skomentowanie podobieństwa stylometrycznego każdej z par słowników wymagałoby obszernego studium. Niewątpliwie jednak prawidłowości te mają pokrycie także w lekturze słowników i częstości występowania w nich tożsamych bądź podobnych sformułowań. Ujawnienie takich zbieżności świadczy więc o użyteczności analiz stylometrycznych w badaniach stylu słownikowego, choć na tym etapie studiów właściwe wydaje się zachowanie stosownej ostrożności wobec metod wyłącznie automatycznych.

Powyższe rozważania nie pozwalają wprawdzie na wyodrębnienie i nazwanie stylu każdego ze słowników, umożliwiają jednak postawienie hipotezy o funkcjonowaniu w polskiej leksykografii pewnych typów stylowych. Wydaje się też, że w wypadku opracowań leksykograficznych trudno mówić o czystości stylowej poszczególnych dzieł, raczej daje się zauważyć zjawisko chimeryzmu stylowego bazującego na kilku podstawowych elementach stylowych, mianowicie: naukowych, potocznych i literackich. Kombinacje i proporcje wykorzystanych elementów pozwalają domniemywać funkcjonowanie takich typów stylowych, jak m.in. informacyjno-popularny (np. ISJP), naukowo-instruktażowy (np. USJP), naukowo-dokumentacyjno-literacki (np. SJPD).

\section{Wnioski}

Kategoria stylu wydaje się w słownikarstwie bardzo użyteczna, pozwala bowiem na przyjęcie nowej perspektywy wzbogacającej nurty badawcze metaleksykografii. Umożliwia podjęcie studiów dotyczących m.in. zmian stylów słownikowych, czyn- 
ników determinujących te style, istotności i wartości kulturowej zmian stylów, wyodrębnienia podstawowych stylów występujących w różnych nurtach leksykograficznych, użyteczności automatycznych analiz stylometrycznych ${ }^{20}$.

Wydaje się, że szczegółowe rozpatrywanie słowników w taki sposób, jak szkicowo zaprezentowano na przykładzie wybranych komponentów, z myślą o wartości stylistycznej każdego z nich, otwiera pole dla ciekawych studiów porównawczych, pomaga lepiej zrozumieć celowość rozwiązań zastosowanych w każdym z opracowań, a tym samym może dać pełniejszy obraz dorobku polskiej leksykografii.

\section{Literatura}

Apresjan Ju.D., 200o, Semantyka leksykalna. Synonimiczne środki języka, Wrocław.

Bartmiński J., Niebrzegowska-Bartmińska S., 2012, Tekstologia, Warszawa.

BogusŁaWski A., 1988, Język w słowniku. Desiderata semantyczne do wielkiego słownika polszczyzny, Wrocław.

Cieślikowa A., 2006, Dobór przykładów a definicje w artykułach hasłowych: obłuda, ufność, wiara $i$ wierność, „Prace Filologiczne” LI, s. 65-76.

DomogaŁA A., 2013, Rzecz o „stowie” w świecie ludzi i zwierząt (na przykładzie odzwierzęcych czasowników mówienia), „Linguarum Silva” t. 2, s. 31-53.

Duвoıs J., Duвoıs C., 1971, Introduction à la lexicographie. Le dictionnaire, Paris.

EDER M., 2014, Metody ścisłe w literaturoznawstwie i pułapki pozornego obiektywizmu przykład stylometrii, „Teksty Drugie” nr 2, s. 90-105.

EJO: K. Polański (red.), Encyklopedia językoznawstwa ogólnego, Wrocław 1999.

Grochowsкi S., 1997, Wirydarz abo Kwiatki rymów duchownych o dziecięciu Panu Jezusie, wyd. J. Dąbkowska, Warszawa.

IJL: „International Journal of Lexicography” 1989, 2 (3).

IsING G., 1978, Textverdichtung und Redundanz in der Lexikographie, „Wissenschaftliche Zeitschrift der Wilhelm-Pieck-Universität Rostock” 27 „Gesellschafts- und sprachwissenschaftliche Reihe" 12, s. 9-13.

ISJP: M. Bańko (red.), Inny słownik języka polskiego, Warszawa 2000.

MPPS: M. Krajewska, Mój pierwszy prawdziwy stownik, Warszawa 2000.

MuszyŃski Z., 1996, Światy za stowami. Ich natura i porzadek, [w:] R. Grzegorczykowa, A. Pajdzińska (red.), Językowa kategoryzacja świata, Lublin, s. 27-45.

NKJP: Narodowy Korpus Języka Polskiego, [on-line:] nkjp.pl.

NSJPLehr: T. Lehr-Spławiński (red.), Nowy słownik języka polskiego, Warszawa 1938-1939.

PSWP: H. Zgółkowa (red.), Praktyczny stownik współczesnej polszczyzny, Poznań 1994-2005. Puzynina J., 1993, Obrazświata w dziele leksykograficznym M.A. Troca (1764), [w:] I. Kunert (red.), Studien zur polnischen Literatur-, Sprach- und Kulturgeschichte im 18. Jahrhundert: Vorträge der 3. deutsch-polnischen Polonistenkonferenz, Tübingen, April 1991, Köln, s. $71-87$.

20 Należy oczywiście przy tym pamiętać, że porównywanie słowników wymaga uwzględnienia różnic między zasadami hasłowania, ponieważ zakresy pojęcia artykułu hasłowego nie są ekwiwalentne, to zaś jest możliwe jedynie w toku analiz filologicznych, nie zaś automatycznych. 
ReY-Debove J., 1971, Étude linguistique et sémiotique des dictionnaires français contemporains, Paris - La Haye.

RudNicka E., 2010, Leksykograficzne egzemplum. Sposoby wykorzystania cytatów i kolokacji w polskich słownikach ogólnych, [w:] I. Burkacka, R. Pawelec, D. Zdunkiewicz-Jedynak (red.), Słowa - kładki, na których spotykają się ludzie różnych światów, Warszawa, s. 111-126.

Ry BICKI J., 2014, Pierwszy rzut oka na stylometryczna mapę literatury polskiej, „Teksty Drugie" nr 2, s. 106-128.

SIJPArct: Słownik ilustrowany języka polskiego M. Arcta, Warszawa 1916.

SJPD: W. Doroszewski (red.), Słownik języka polskiego, Warszawa 1958-1969.

SJPRyk: E. Rykaczewski (oprac.), Słownik języka polskiego podług Lindego i innych nowszych źródet, Berlin - Poznań 1866.

SJPSz: M. Szymczak (red.), Słownik języka polskiego, Warszawa 1978-1981.

SL: S.B. Linde, Słownik języka polskiego, Warszawa 1807-1814.

SSPKr: A.S. Krasiński, Słownik synonimów polskich, Kraków 1885-1981.

SW: J. Karłowicz, A. Kryński, W. Niedźwiedzki (red.), Słownik języka polskiego, Warszawa 1900-1927.

SWil: A. Zdanowicz i in. (red.), Słownik języka polskiego, Wilno 1861.

SWJP: B. Dunaj (red.), Słownik współczesnego języka polskiego, Warszawa 1996.

USJP: S. Dubisz (red.), Uniwersalny słownik języka polskiego, Warszawa 2003.

WIEgAND H.E., 1983, Was ist eigentlich ein Lemma? Ein Beitrag zur Theorie der lexikographischen Sprachbeschreibung, [w:] idem (red.), Studien zur neuhochdeutschen Lexikographie III, Hildesheim, s. 401-474.

Wiegand H., 1990, Dictionary styles: a comparison between the dictionary of Jacob Grimm and Wilhelm Grimm and the revised edition, [w:] E. Antonsen (red.), The Grimm brothers and the Germanic Past, Amsterdam - Philadelphia, s. 115-139.

WierzbickA A., 1969, Dociekania semantyczne, Wrocław.

Wierzbicka A., 2006, Semantyka. Jednostki elementarne i uniwersalne, Lublin.

Wolski W., 1986, Partikellexikographie. Ein Beitrag zur praktischen Lexikologie. With an English summary, „Lexikographica”, 14, Tübingen.

ZdunKieWICZ-JedYNAK D., 2008, Wykłady ze stylistyki, Warszawa.

\section{The category of style in metalexicographic research Summary}

The paper discusses the category of style and the validity of its application to dictionaries. The author begins by considering the question of textuality of dictionaries and whether it is possible to analyse them in line with other texts. By invoking concrete examples, she indicates works which use diverse means of expression to convey the same content, which suggests that the category of style may also be applied in the field of lexicography. The author attempts to determine what it would involve to identify style in a dictionary, which components of style may come into play here, and examines the possibilities of observation and interpretation of selected components. Finally, the paper discusses the usefulness of automatized stylometric tools in stylistic research into dictionaries. 


\section{WARTOŚCIOWANIE JAKO PRAKTYKA KOMUNIKACYJNA (NA PRZYKŁADZIE TEKSTÓW PRASOWYCH Z DZIEDZINY GOSPODARKI I EKONOMII)}

Słowa klucze: wartościowanie, praktyka komunikacyjna, reguły, medialność, znaczenie wartościujące Keywords: evaluation, communicative practice, rules, mediality, evaluative meaning

\section{Wstęp}

[...] jesteśmy istotami oceniającymi, aksjologicznie interesownymi i nie dany nam jest całkowicie kontemplatywny stosunek do świata [...]. Bez wartości nie mielibyśmy żadnych faktów [...], bez wartości nic by nas nie interesowało, bez nich wreszcie nic by dla nas nie miało sensu. Nie istnieje zatem żadna całkowicie neutralna aksjologicznie perspektywa poznawcza [...] (Szahaj 2007: 159-160).

Postulat uwzględnienia wymiaru etycznego w badaniach naukowych swoje pełniejsze zastosowanie znalazł w kulturo- i literaturoznawstwie pod koniec XX w. ${ }^{1}$ Była to reakcja na bezwzględną dominację w nauce ideologii scjentystycznej, która etykę

zepchnęła w sferę nienaukową czy wręcz antynaukową, rozpowszechniając nader skutecznie przekonanie, że poznanie powinno zawsze być wolne od wartości (ibid.: 159).

1 Michał Januszkiewicz (2012: 205) uznał, że ethical turn bez wątpienia „należy obecnie do najważniejszych zjawisk współczesnej kultury [...]". 
Zmiana optyki, czyli odejście od owego „jedynie słusznego” punktu widzenia w badaniach, miała na celu umożliwienie eksploracji nowych (lub dotychczas niedostrzeganych, pomijanych) obszarów oraz wzmocnienie obrazu nauki jako

przedsięwzięcia ludzkiego, a zatem jako pełnego zaangażowania etycznego i politycznego, a jednak nieprowadzącego do opłakanych skutków w postaci wojny każdego z każdym czy bezwzględnej rywalizacji o władzę (ibid.: 161).

Zwrot etyczny, za którym opowiadał się Andrzej Szahaj, nie dokonał się całościowo, nie dopełnił się w humanistyce, w tym w językoznawstwie. Nie znaczy to jednak, że koncepcja odejścia od „sterylnego” spojrzenia na język, tzn. analizowania wyłącznie zjawisk językowych, i powiązania aktywności naukowej z pewnymi zobowiązaniami etycznymi, które wynikają z kontekstowego osadzenia przedmiotu badań, nie znalazła zwolenników. Świadczy o tym chociażby bogata literatura z zakresu tzw. lingwistyki aksjologicznej (aksjolingwistyki), której prekursorkami były na gruncie polonistycznym Jadwiga Puzynina (1992, 2003) i Elżbieta Laskowska (1992, 2010), a dołączyli do nich m.in. Jerzy Bartmiński (2003, 2008) i anglista Tomasz P. Krzeszowski (1997). Szeroko rozumiany dyskurs aksjologiczny jest obecny w językoznawstwie od lat, choć w różnym zakresie. Cechuje go heterogeniczność perspektyw poznawczych, która implikuje liczne próby definiowania pojęcia „wartościowanie”.

W niniejszym tekście chciałbym skoncentrować się na społecznym wymiarze wartościowania jako praktyki językowej i komunikacyjnej, która będąc zbiorem celowych aktywności, opiera się na pewnych intersubiektywnych regułach (strukturach, wzorcach oraz zasadach funkcjonowania). Mają one charakter eksplicytny lub implicytny i osadzone są w określonym kontekście społeczno-kulturowym. W swoich rozważaniach odwołam się do kulturoznawczo i socjologicznie ufundowanych teorii praktyk (społecznych), gdyż uważam, że również językoznawstwo może postrzegać te praktyki jako podstawowe formy działań komunikacyjnych, społecznego porozumiewania się, w których najpełniej przejawia się istota ,językowości człowieka" (Godlewski, Mencwel, Sulima 2003: 2). Swoje refleksje teoretyczne chciałbym uzupełnić analizą wybranych tekstów/komunikatów prasowych z gospodarki i ekonomii. Temu zakresowi komunikacyjnemu z reguły przypisuje się wysoki stopień racjonalności. W związku z tym często wychodzi się z założenia, że teksty dotyczące tych dziedzin cechują rzetelność, rzeczowość i obiektywność, utożsamiana z brakiem elementów wartościujących (w ramach tzw. paktu faktograficznego), oraz bezpośredni przekaz. To jednak błędne wyobrażenie, zmieniają się bowiem oczekiwania odnośnie do funkcji i misji mediów:

[...] dziś, a najprawdopodobniej będzie to trend stały - zaczyna liczyć się nie jakość, którą ma informacja w danym medium, ale skuteczność dotarcia przekazu do założonego odbiorcy i zysk, także społeczny lub wizerunkowy, jaki osiągają dziennikarz lub zleceniodawca $[. .$.$] (Warchala 2015: 12).$ 
Ważnymi wskaźnikami stają się więc: lepsza postrzegalność i przyswajalność komunikatu, zwiększenie zainteresowania tematem lub większa efektywność w wywoływaniu określonych postaw u odbiorcy.

\section{Wartościowanie}

W ogólnym rozumieniu wartościowanie jest operacją mentalną, względnie mentalno-emocjonalną (lub zbiorem operacji mentalnych), której efektem jest przyjęcie postawy akceptacji lub odrzucenia w odniesieniu do danego obiektu - osoby, przedmiotu, miejsca lub procesu - w oparciu o określone kryteria lub oczekiwania normatywne (najczęściej presuponowane) (por. Keller 2008: 10). Operacja ta może, lecz nie musi zostać zakomunikowana.

Wartościowanie w swej istocie zbliżone jest do działania poznawczego, gdyż „każdy akt kognitywny - jak pisze Oleg Leszczak (2002: 36) - z punktu widzenia aksjologii pragmatycznej jest z zasady aktem wartościowania”. Trudno wyznaczyć tu jednoznaczną linię demarkacyjną.

W ujęciu semiotycznym, a więc i lingwistycznym, wartościowanie może być interpretowane jako akt materializacji procesu kognitywnego (kognitywno-afektywnego), który dzięki przypisaniu określonej postaci medialnej staje się postrzegalny, zyskuje status integralnego komponentu codziennego komunikowania. Obok informowania, które nie jest przecież przekazywaniem wiedzy całkowicie obiektywnej, czyli jedno-jednoznacznie odwzorowującej rzeczywistość, wartościowanie zaliczane jest do podstawowych form działalności językowej. Jako część składowa różnorodnych zjawisk komunikacyjnych jest wszechobecne, powszechnie podejmowane i istotne dla członków danej wspólnoty komunikatywnej. Dotyczy to zarówno komunikacji bezpośredniej, jak i realizowanej poprzez konkretne medium ${ }^{2}$. Wartościujemy, aby przekazać nasze nastawienie, nasz punkt widzenia i/lub żeby wpłynąć na postawę, względnie nastawienie odbiorcy. Akty wartościowania i akty opisu, jak wspomniano wyżej, są przy tym w praktyce komunikacyjnej często nierozłączne.

Patrząc z kolei na funkcjonowanie mediów z perspektywy teorii dyskursu Michela Foucaulta, wartościowanie można potraktować jako część procesu in-formowania, który nie jest li tylko opisem rzeczywistości, ale stawia sobie za cel także formowanie świadomości odbiorcy.

Społeczny charakter wartościowania odróżnia je od osądu smaku, który nie implikuje ani racjonalnej dyskusji, ani uzasadnienia, gdyż jest oceną deskryptywną, której kryteria prawdziwości pozostają znane tylko osobie ją formułującej, nie mają charakteru intersubiektywnego (por. Keller 2008: 11).

2 Media to nie tylko urządzenia, „technologie komunikacyjne”, lecz przede wszystkim systemy środków i metod, które nakładają pewne ograniczenia w procesie komunikacji, pozostawiają swoje ślady, ale także oferują nowe możliwości wyrazu. 


\section{Praktyka komunikacyjna}

Praktyki komunikacyjne rozumiem jako zbiory poszczególnych aktywności (komunikacyjnych), podejmowanych z zamiarem osiągnięcia założonych celów, jak również jako zbiory reguł (czy też wzorców) określających środki i sposoby lub strategie realizowania danych działań komunikacyjnych (por. Wendland 2015: 97).

Pojęcie praktyki nie jest nowe, od lat funkcjonuje w socjologii, kulturoznawstwie, antropologii, literaturoznawstwie, także w analizie konwersacyjnej, gdzie zyskało status jednego z pojęć podstawowych. Z perspektywy lingwistycznej pojęcie praktyki, choć dość heterogeniczne, umożliwia inne - pełniejsze - spojrzenie na takie zjawiska, jak język, tekst, komunikacja, zachowania itp. Precyzyjniejszy opis ich istoty staje się możliwy dzięki uwzględnieniu kategorii procesualności, materialności i medialności (por. Deppermann, Feilke, Linke 2016: 1).

Jako kategoria analityczna praktyka społeczna podkreśla materialny, wynikający z określonej medialności przekazu wymiar funkcjonowania, przede wszystkim komunikowania, w społeczeństwie (wspólnocie), które bazuje na wiedzy implicytnej, praktycznej (know how, tacit knowledge). Pozwala ponadto uwidocznić relacje między indywiduum a społeczeństwem, tym, co jednostkowe, a tym, co kulturowo i społecznie usankcjonowane.

Podstawą do zdefiniowania pojęcia praktyki jest funkcjonalna, opierająca się na działaniu, uwrażliwiona na wymiar medialny (medialnościowy) teoria języka i jego użycia, która jest równocześnie teorią praktyki komunikacyjnej. Koncepcja ta nie traktuje języka jako statycznego, bezpośrednio dostępnego obiektu poznania w rozumieniu langue, lecz widzi w nim dynamiczny konstrukt, który uwarunkowany jest społecznie, kulturowo i medialnie oraz zależy od kompetencji intelektualnej (wiedza, doświadczenie itp.) danego podmiotu poznania.

Język jest praktyką społeczną służącą ekspresji znaczeń. Jako praktyka czy instytucja społeczna język jest ,intersubiektywny”, ,konwencjonalny” i „,normatywny”. Innymi słowy, locus języka to pierwotnie kolektyw, a nie jednostki; formy językowe wyłaniają się historycznie (konwencja) dzięki akceptacji przez wspólnotę (normatywność). Z kolei „ekspresja znaczeń” to zarówno komunikacja znaczeń intersubiektywnie dostępnych, jak i próba wyrażania znaczeń bezprecedensowych, czyli wykraczających poza normę (Pawelec 2008: 107).

Tego rodzaju perspektywa uwzględnia wymiar performatywny naszego komunikowania. Szeroko rozumianej kompetencji nie można bowiem poszukiwać poza performancją, lecz tylko w niej (por. Stetter 2005). Lingwistyczne spojrzenie na język, które obiekt badań postrzega zawsze w konkretnym otoczeniu społecznym i kulturowym oraz uwzględnia jego medialność, można nazwać lingwistyką praktyki językowej. 


\section{Wartościowanie jako praktyka komunikacyjna}

Wartościowanie jako praktyka kieruje się określonymi regułami i jak każda praktyka ma swoje elementy składowe. Należą do nich przede wszystkim:

a) podmiot wartościujący: osoba/instytucja o określonej pozycji i kompetencji oraz powiązanej z tym odpowiedzialności (np. profesjonalista),

b) obiekt ${ }^{3}$ wartościowania,

c) adresat/odbiorca (profesjonalista lub laik mający określoną kompetencję intelektualną, tj. językową i epistemiczną),

d) kryteria wartościowania (normy, standardy ewaluatywne),

e) medialność przekazu i powiązane z nim formy komunikacji jako medialnie zdeterminowane warunki ramowe (por. np. Dürscheid 2003); np. teksty prasowe cechują takie kryteria, jak pisemność, asynchroniczność, jednokierunkowość, dystans przestrzenny i charakter publiczny,

f) środki i strategie ewaluowania,

g) cel.

Wspomniane wyżej reguły pełnią funkcję drogowskazu, dzięki któremu wiadomo, jak postępować $w$ danej praktyce, lecz podobnie jak drogowskaz nie są całkowicie jednoznaczne: interpretacyjną jasność otrzymują dopiero w konkretnym użyciu (por. Derra 2010: 354). Istota reguły przejawia się „W codziennej praktyce grania" (Wittgenstein 1953/2005: 118). Kierowanie się regułą lub też podążanie za nią nie jest przy tym ani działaniem jednorazowym, ani działaniem pojedynczego człowieka: reguły są pewnymi nawykami, zwyczajami i instytucjami wspólnymi dla określonej zbiorowości. Reguły wstępnie kształtują daną praktykę, określają kryteria poprawności. W konkretnym akcie komunikacji nabyte (przyswojone) lub wyuczone wzorce są więc powtarzane, dzięki czemu w danej wspólnocie komunikatywnej może zostać osiągnięta pewna zgodność zachowań, jak twierdzi niemiecka filozof Sybille Krämer (2001: 129). Świadczy to o performatywnym charakterze praktyk: przez wielokrotne użycie (stosowanie reguły jest iteratywne) dokonuje się utrwalenie reguły, jej stabilizacja. Nie wyklucza to jednak możliwości wprowadzania mniej lub bardziej kreatywnych modyfikacji w konkretnej realizacji.

Z lingwistycznej perspektywy można mówić o specyficznych parametrach znaczenia wartościującego. Należą do nich:
a) walencja (kierunek) $\mathbf{E P}_{\mathrm{w}}$ : przyjemny (+) - nieprzyjemny (-); pozytyw- ny - negatywny,
b) natężenie (stopień aktywacji, intensywność) $\mathbf{E P}_{\mathbf{N}}$ : mocny (+) - słaby (-),
c) relew ancja $\mathbf{E P}_{\mathrm{R}}$ : zgodny z celem $(+)$ - niezgodny z celem $(-)$,
d) ocena kognitywna $\mathbf{E P}_{\mathrm{K}}$ : poważany $(+)$ - niepoważany $(-)$,
e) rodzaj oczekiwania $\mathbf{E P}_{\mathrm{O}}$ : oczekiwany $(+)$ - nieoczekiwany (-).

3 Pojęcie „obiekt” obejmuje zarówno osoby, jak i przedmioty, procesy, zdarzenia, celowe działania itp. 
Powyższe parametry to komponenty cząstkowe, które nie muszą występować w przypadku każdego znaczenia wartościującego: mają one charakter gradualny i zmienny, w zależności od określonych czynników wewnętrznych i zewnętrznych.

\section{Analiza}

Przystępując do analizy, możemy zadać następujące pytania: w jaki sposób, przez jakie strategie i środki realizowane są praktyki wartościujące w komunikacji publicznej poruszającej zagadnienia gospodarcze i ekonomiczne? Na ile precyzyjnie i za pomocą jakich kategorii można je opisać?

Do analizy wybrane zostały teksty prasowe, a więc istniejące w przestrzeni mediów masowych (mediosferze), które za Iwoną Loewe (2015: 253) nazwać można mediotekstami. Pod względem funkcji są to teksty informacyjne i/lub opiniotwórcze, pod względem formy realizacji tematu są to teksty deskryptywne, argumentacyjne i w niektórych przypadkach eksplikatywne. Materiał badawczy jest semiotycznie złożony: medioteksty składają się z reguły ze znaków konwencjonalnych, tj. pisma drukowanego i obrazów statycznych. Analizowany będzie materiał pozyskany z artykułów prasowych z miesięcznika gospodarczego „Forbes”4 od stycznia 2013 do stycznia $2014 \mathrm{r}$.

Czasopismo „Forbes” uznać można w tym przypadku za zbiorowy podmiot wartościujący, który tworzą autorzy poszczególnych tekstów. Odbiorcami/ adresatami są w większości profesjonalni czytelnicy5.

\section{Monomodalne praktyki wartościujące}

Zawyżone wartości kontraktów i zmowy przetargowe sprawiły, że Polska i Unia Europejska mogły przepłacić 5 mld euro za „modernizację” infrastruktury drogowej („Forbes” III 2013: 24).

Analizowana wypowiedź ma charakter monomodalny (lub też monokodalny) została zrealizowana werbalnie za pomocą pisma drukowanego, choć w wydaniu

4 „Forbes” jest prestiżowym amerykańskim magazynem (ukazuje się od 1917 r.) o tematyce biznesowej o zasięgu globalnym (ma oczywiście wydania lokalne, na polskim rynku od 2004 r.). Jego autorami są znawcy problematyki, często autorytety w swojej dziedzinie. Magazyn znany jest z rankingów wszelkiego rodzaju (od najbogatszych ludzi świata po najlepiej zarabiające gwiazdy show-biznesu), komentarzy, opinii oraz często analiz dotyczących trendów i konkretnych rozwiązań mikroekonomicznych (pochodzą często z wersji amerykańskiej).

5 „Forbes” skierowany jest przede wszystkim do osób zajmujących kierownicze stanowiska (menedżerów średniego i wyższego szczebla). 
papierowym towarzyszy jej również zdjęcie autostrady w budowie. Nie jest ono jednak częścią konstytuującą działanie ewaluacyjne, pełni wyłącznie funkcję ilustracyjną. Semantyczny rdzeń wartościowania tworzą trzy leksemy o ujemnym ładunku aksjologicznym: zawyżone, zmowy i przepłacić. Cechuje je więc negatywny kierunek oceny $\mathbf{E P}_{\mathrm{w}(-)}$, średni stopień intensywności $\mathbf{E P}_{\mathrm{N}(++)}$, negatywna relewancja (niezgodność z celem) $\mathbf{E P}_{\mathrm{R}(-)}$ i negatywna ocena kognitywna $\mathbf{E P}_{\mathrm{K}(-)}$. Znaczenie wartościujące można zapisać w sposób następujący:

$\mathbf{E}\left[(\mathbf{S}, \mathbf{O}),\left(\mathbf{E P}_{\mathrm{W}(-))}, \mathbf{E P}_{\mathrm{N}(++)}, \mathbf{E P}_{\mathrm{R}(-)}, \mathbf{E P}_{\mathrm{K}(-)}\right)\right]$ - podmiot wartościujący (S) wykazuje negatywne nastawienie $(\mathrm{E})$ wobec obiektu $(\mathbf{O})$, które konstytuują wskazane parametry $\left(\mathrm{EP}_{ \pm}\right)$.

Powyższy negatywny osąd wzmocniony jest przez element graficzny - cudzysłów, który w tej praktyce sygnalizuje użycie ironii (krytyka) w ocenie podejmowanych działań.

Podobną strategię konstruowania osądu ewaluatywnego można stwierdzić w następnym przykładzie:

Kurtyna opadła, a publiczność wpadła w stupor, kiedy 12 lutego, po ogłoszeniu wyników finansowych TP SA kurs tej spółki spadł o 30 procent („Forbes” III 2013: 48).

W tym przypadku do nazwania niepożądanej i nieoczekiwanej reakcji adresatów (publiczności) - osłupienia - wykorzystano element słownictwa specjalistycznego (medycyna, psychologia) stupor, dzięki czemu opis zintensyfikowano. W celu określenia zjawiska będącego przyczyną negatywnej reakcji - redukcji wartości akcji przedsiębiorstwa - posłużono się wyrażeniem metaforycznym, typowym dla ekonomicznego i gospodarczego zakresu komunikacji: kurs spadt. Podane dane liczbowe precyzują, uwiarygodniają i wzmacniają negatywną ocenę.

Chciałbym zauważyć, że leksemy spadek/spadać, wzrost/wzrastać są ważnymi elementami konstytuującymi praktyki wartościowania w obszarze gospodarczo-ekonomicznym. Kierunek oceny (walencja) jest przy tym uzależniony od wyrażenia określającego, często przydawki dopełniaczowej. I tak wzrost kapitału ewokuje osąd pozytywny, wzrost zadłużenia zdecydowanie negatywny. Potencjał ewaluatywny ujawnia się więc dopiero w konkretnym użyciu (kontekście).

W rankingu korupcji Ukraina znalazła się na 144. miejscu wśród 177 sklasyfikowa-

nych krajów i sąsiaduje z Nigerią („Forbes” I 2014: 30).

Przykład ten jest wypowiedzią jednoznacznie konstatywną, deskryptywną, pozbawioną konwencjonalnych elementów wartościujących (z wyjątkiem leksemu korupcja, który komponent negatywnie wartościujący zawiera w swoim znaczeniu, ma więc wyraźny wymiar aksjologiczny). Ma jednak równocześnie charakter (niejawnie) performatywny, gdyż celem wypowiedzi nie jest wyłącznie stwierdzenie faktu, lecz także jego ocena, dokonana implicytnie przez odbiorcę, a zrealizowana przez 
wskazanie miejsca w grupie państw i zestawienie aspirującej do członkostwa w Unii Europejskiej Ukrainy z Nigerią.

Były pięściarz wchodzi do grona takich osób, jak członkowie rodu Kennedych, Bushów, Michael Bloomberg, Arnold Schwarzenegger, Stan Tymiński („Forbes” I 2014: 28).

Wypowiedź formalnie deskryptywna, ale implicytnie wartościująca (pozytywnie) przez zestawienie obiektu oceny z ludźmi sukcesu, osobami, które piastowały wysokie (najwyższe) funkcje polityczne, zbudowały fortuny lub odniosły sukces w show-biznesie (wartość, kryterium oceny).

W omawianych przypadkach mamy do czynienia zarówno z osądami deskryptywnymi, opartymi na parametrach ze świata zewnętrznego (warunki prawdziwości, zgodność ze zbiorem faktów), jak i osądami ewaluatywnymi, oznaczającymi określone stanowisko wobec danego obiektu, stosownie do przyjętych kryteriów, niebędących częścią znaczenia wypowiedzi ani niewyrażonych eksplicytnie (por. Keller 2008: 10). Praktyki wartościowania mogą przy tym być związane z wiedzą implicytną (i implicytnymi umiejętnościami), mogą również być działaniem bazującym na eksplicytnych regułach.

\section{Multimodalne praktyki wartościujące}

W przykładzie 1 (s. 66) centralne modalności znaków (pismo drukowane, obraz i grafika) wchodzą w interakcję z modalnością peryferyjną, z kolorami (por. Antos, Opiłowski 2015: 15). Tekst pisany i grafiki pozostawię bez komentarza, uwagę zogniskuję na obrazach i kolorach.

Na płaszczyźnie przestrzenno-składniowej ${ }^{6}$ komponent werbalny i wizualny nie nakładają się, uaktywniany jest wzorzec linearny, który w wymiarze informacyjnym umożliwia realizację zasady komplementarności: obraz komentuje, ilustruje przekaz językowy. W zasadzie nie powstają tu nowe treści semantyczne lub dyskursywne. Niemniej można dopatrzyć się aktywowania dodatkowych wymiarów semantycznych w sferze aksjologicznej, np. w przypadku połączenia informacji o ujemnym wzroście gospodarczym w Europie z fotografią starszego mężczyzny, prawdopodobnie emeryta - sądząc po postawie - dość zmęczonego życiem. Wzrost gospodarczy w USA obrazują młode, atrakcyjne i konsumencko aktywne kobiety. Pozytywną informację o malejącej liczbie osób bezrobotnych wzmacnia zdjęcie z hali produkcyjnej, jednoznaczność negatywnej oceny rosnącej stopy bezrobocia w Europie podkreśla z kolei zdjęcie osób stojących w kolejce do hiszpańskiego urzędu pracy.

6 W celu opisania komunikacyjno-funkcjonalnej synergii elementów werbalnych i wizualnych $\mathrm{w}$ analizowanych praktykach wartościowania bazuję na koncepcji i terminologii opracowanej przez Hartmuta Stöckla (2011: 56-61). 
Podmiot wartościujący, używając określonego koloru, odwołuje się do wiedzy wspólnej dla uczestników komunikacji: i tak kolor zielony w naszym kręgu kulturowym konwencjonalnie łączony jest $\mathrm{z}$ tym, co pozytywne (zysk), czerwony z kolei odnoszony jest do zjawisk niepożądanych, negatywnych (strata). $Z$ reguły zastosowanie określonego koloru wzmacnia lub precyzuje komunikat werbalny przez dodanie komponentu konotatywnego ${ }^{7}$. Funkcja ta realizowana jest i w tym przypadku (zielony lub czerwony kolor strzałek).

MFW myli się zawsze. Mylił się w latach 9o. w Argentynie i Brazylii, mylił się w Korei Południowej oraz Tajlandii i myli się dziś: w Grecji i Portugalii. Zawsze te same złe kuracje. Zawsze lekarstwa gorsze od choroby („Forbes” II 2013: 24).

W analizowanym przykładzie osąd deskryptywny i osąd ewaluatywny są rezultatem synergii języka i obrazu w tekście. Na płaszczyźnie werbalnej uwagę zwraca użycie zaimka przysłownego upowszechniającego zawsze, będącego słowem o dużej mocy, zaliczanym do wielkich kwantyfikatorów, które ograniczają (wykluczają wyjątki) i generalizują, w omawianym przykładzie dodatkowo wzmocnionym przez potrójną reduplikację. Posłużono się także leksemem aksjologicznym $z \nmid y$, wyrażającym jednoznacznie negatywną ocenę, oraz lekko zmodyfikowanym cytatem autorstwa Francisa Bacona: Lekarstwo bywa gorsze od choroby, który w codziennej komunikacji funkcjonuje jako skrzydlate słowa.

Jak już wspomniano, wartościowanie jest aktem refleksji intelektualnej i niekoniecznie wiąże się z doznaniami natury afektywnej czy emocjonalnej. Dlatego praktyki ewaluatywne, które odnoszą się do wartości natury moralnej/etycznej, estetycznej lub pragmatycznej, należy oddzielić od praktyk afektywnych, które manifestują lub tematyzują stany emocjonalne (uczucia) nadawcy. Praktyki wartościowania mogą jednak również wykorzystywać strategie emocjonalizacji w celu wzmocnienia osądu ewaluatywnego i/lub aktywowania określonych procesów emocjonalnych u odbiorcy i wywołania u niego zamierzonego nastawienia emocjonalnego. Można więc mówić o potencjale lub profilu emotywnym danego tekstu i o emocjonalizacji jako świadomej strategii kreowania komunikatu przez producenta ${ }^{8}$. Funkcję tę realizują bez wątpienia zdjęcia, pochodzące z różnych lat $(1997,2002,2010)$ i miejsc (Tajlandia, Argentyna, Hiszpania), będące integralną częścią komunikatu (zob. przykład 2, s. 66). Są to bardzo sugestywne obrazy, które w płaszczyźnie retoryczno-semantycznej tworzą wraz z tekstem pisanym logiczną całość opartą na relacji przyczyna-skutek.

7 Według Gerda Antosa i Romana Opiłowskiego (2015: 19) dzięki kolorom jako „submodalnościom tekstualnym" może dokonać się dodatkowa semiotyzacja i semantyzacja określonych relacji język-obraz.

8 Szerzej na temat emocjonalizacji jako stylistycznej strategii tworzenia tekstów zob. Szczepaniak 2010. 
Jeśli wziąć pod uwagę profil magazynu, mamy tu do czynienia z radykalną krytyką, negatywnym wartościowaniem o wysokim natężeniu. Można przypuszczać, że celem w powyższym przypadku jest nie tylko sformułowanie osądu ewaluatywnego, ale także przekazanie czy wręcz narzucenie swojej wizji przedstawianego zagadnienia. Analizowany komunikat werbalno-wizualny ma więc bez wątpienia także charakter perswazyjny.

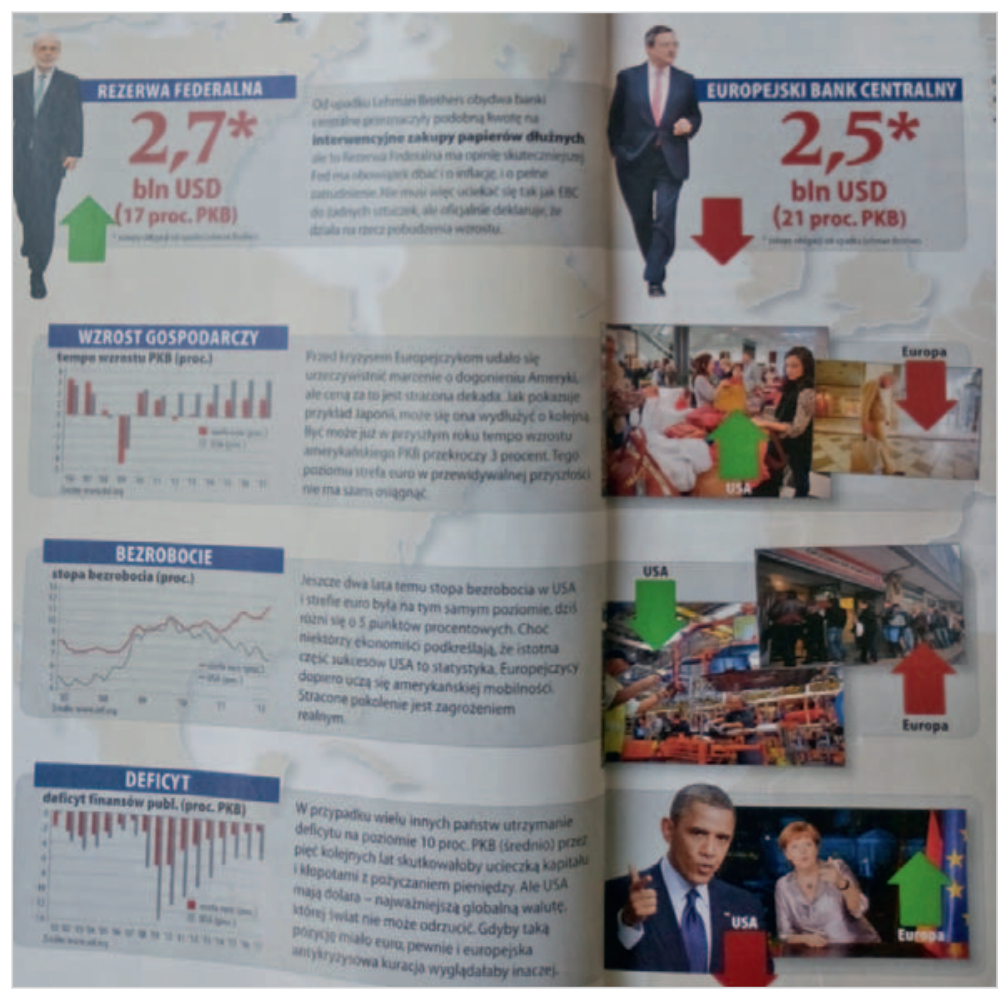

Przykład 1. Źródło: „Forbes” II 2013: 14-15.

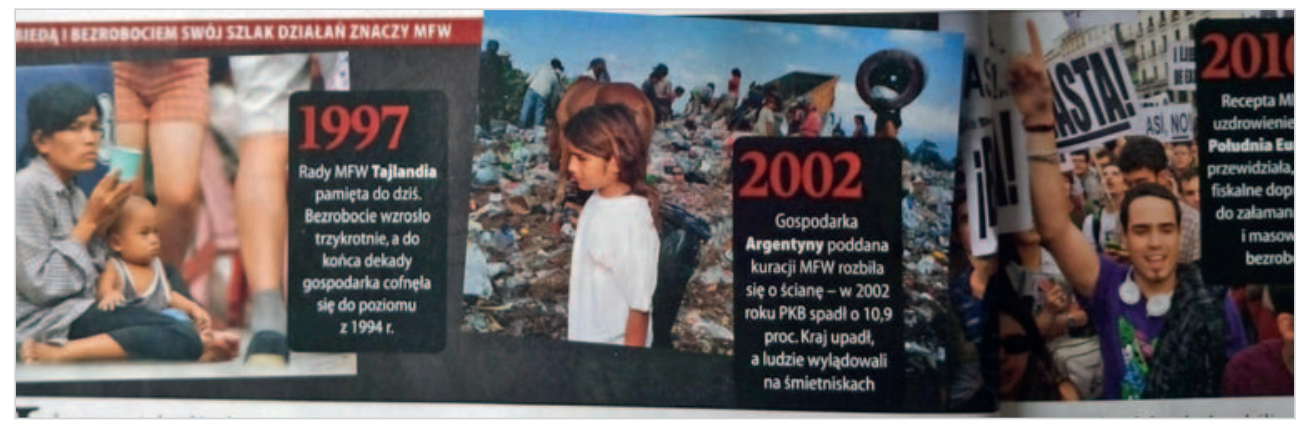

Przykład 2. Źródło: „Forbes” II 2013: 24-25. 


\section{Konkluzja}

Praktyki komunikacyjne jako powtarzalne i rozpoznawalne wzorce, konstelacje lub formaty nadają strukturę działaniom werbalnym, parawerbalnym i niewerbalnym, $\mathrm{w}$ tym przypadku wartościującym. Rozwijają się zawsze w konkretnych medialnych warunkach ramowych (techniczno-technologicznych, przestrzennych, materiałowych itp.), mają więc zawsze konkretną i jednorazową realizację. Materialność (medialność) jest czynnikiem współkonstytuującym daną praktykę, warunkiem jej zaistnienia. Ponadto praktyki potrzebują współtworzących je uczestników (aktorów), którzy mają określone prawa, obowiązki, pozycję społeczną, rolę, wiedzę i umiejętności.

Jak już wspomniano, praktyki wplecione są w społeczno-kulturowe konteksty działań, które określają ich zadania, cele oraz funkcje. Z kolei te konteksty są niejako (współ)tworzone i potwierdzane przez określone praktyki jako struktury przeżyte (gelebte Strukturen, por. Deppermann, Feilke, Linke 2016: 7).

Wartościowanie jako praktyka komunikacyjna jest zmaterializowaniem procesów kognitywnych lub kognitywno-afektywnych w znakach przynależnych do różnych systemów semiotycznych, może więc mieć charakter multimodalny. Osąd ewaluatywny jest wówczas efektem synergii centralnych modalności znaków, jak pismo i obraz, oraz peryferyjnych, jak np. kolory. Tak semiotycznie złożony komunikat może, lecz nie musi zostać w pełni odczytany/rozszyfrowany przez odbiorcę zależy to od jego szeroko rozumianej wiedzy i kompetencji.

Lingwistyczna eksplikacja praktyk wartościujących, jak pokazały analizowane przykłady, może uwzględniać:

a) wymiar semantyczny (opis za pomocą parametrów znaczenia wartościującego),

b) wymiar pragmatyczny (analiza kategorii implicytności i performatywności wypowiedzi) i/lub

c) aspekty modalnościowe, wzajemne relacje między znakami o różnej modalności, które współkonstytuują sensy komunikatów.

\section{Źródła}

Cүрејко G., Sądny dzień musiał nadejść, „Forbes” III 2013, s. 48-52.

Cydejko G., Kliczko z mitu i bajki, „Forbes” I 2014, s. 28-30.

Jóźwik T., Ameryka już się odradza, Europa wciąż szuka dna, „Forbes” II 2013, s. 14-15.

Kowalik F., Lewatywa dla wszystkich, „Forbes” II 2013, s. 24-25.

Surmacz W., Krasnowska-SaŁustowicz V., Polska drogo ustawiona, „Forbes” III 2013, s. 24-30. 


\section{Literatura}

Antos G., OpiŁowski R., 2015, W drodze do lingwistyki obrazu. Kierunki rozwoju nowej subdyscypliny lingwistycznej z perspektywy polsko-niemieckiej, „Tekst i Dyskurs - Text und Diskurs" 8, s. 11-36.

BARTMiŃski J., 2003, Miejsce wartości w językowym obrazie świata, [w:] idem (red.), Język w kręgu wartości. Studia semantyczne, Lublin, s. 59-86.

BARTMiński J., 2008, Wartości i ich profile medialne, [w:] I. Kamińska-Szmaj, T. Piekot, M. Poprawa (red.), Ideologie w słowach i obrazach, Wrocław, s. 23-41.

Deppermann A., Feilke H., Linke A., 2016, Sprachliche und kommunikative Praktiken: Eine Annäherung aus linguistischer Sicht, [w:] iidem (red.), Sprachliche und kommunikative Praktiken, Berlin - Boston, s. 1-23.

Derra A., 2010, Wpływ późnego Wittgensteina na metody badań nad językiem, „Studia Semiotyczne" XXVII, s. 353-373.

DürscheID Ch., 2003, Medienkommunikation im Kontinuum von Mündlichkeit und Schriftlichkeit. Theoretische und empirische Probleme, „Zeitschrift für Angewandte Linguistik" 38, s. 37-56.

Godlewski G., Mencwel A., Sulima R. (red.), 2003, Antropologia słowa. Zagadnienia i wybór tekstów, Warszawa.

JANUSZKiewiCz M., 2012, Kim jestem ja, kim jesteś ty? Etyka, tożsamość, rozumienie, Poznań.

Keller R., 2008, Bewerten, „Sprache und Literatur” 102, s. 2-15.

Krämer S., 2001, Sprache, Sprechakt, Kommunikation. Sprachtheoretische Positionen des 20. Jahrhunderts, Frankfurt am Main.

Krzeszowski T.P., 1997, Angels and devils in hell. Elements of axiology in semantics, Warszawa.

LASKOWsKa E., 1992, Wartościowanie w języku potocznym, Bydgoszcz.

LASKOWSKA E., 2010, Akty wartościujaco-emotywne w komentarzach internetowych, [w:] G. Habrajska (red.), Od idei do inteligencji w działaniu. Aloszy - przyjaciele, Kielce, S. 241-252.

LeszCZAK O., 2002, Metodologiczne zasady wartościowania $i$ wartość jako koncept metodologiczny, [w:] E. Kasperski, D. Ulicka (red.), Dialog, komparatystyka, literatura. Profesorowi Eugeniuszowi Czaplejewiczowi w czterdziestolecie pracy naukowej i dydaktycznej, Warszawa, s. 35-65.

Loewe I., 2015, Mediotekst w naukach humanistycznych, „Tekst i Dyskurs - Text und Diskurs" 8, s. 253-255.

Pawelec A., 2008, Mentalizm w badaniach nad językiem, [w:] P. Stalmaszczyk (red.), Metodologie językoznawstwa. Współczesne tendencje i kontrowersje, Kraków, s. 105-131.

Puzynina J., 1992, Język wartości, Warszawa.

Puzynina J., 2003, Wokót języka wartości, [w:] J. Bartmiński (red.), Język w kręgu wartości. Studia semantyczne, Lublin, s. 19-34.

Stetter Ch., 2005, System und Performanz. Symboltheoretische Grundlagen von Medientheorie und Sprachwissenschaft, Weilerswist.

SтӧскL H., 2011, Sprache-Bild-Texte lesen. Bausteine zur Methodik einer Grundkompetenz, [w:] H. Diekmannshenke, M. Klemm, H. Stöckl (red.), Bildlinguistik. Theorien - Methoden - Fallbeispiele, Berlin, s. 45-70.

Szahaj A., 2007, Zwrot antypozytywistyczny dopełniony, „Teksty Drugie” nr 1-2, s. 157-163. 
Szczepaniak J., 2010, Emotionalisierung als Prinzip der Stilgestaltung, [w:] Z. Bilut-Homplewicz i in. (red.), Text und Stil, Frankfurt am Main, s. 315-325.

WARCHAla J., 2015, Na granicy prawdy i obiektywności. Informowanie czy perswadowanie $w$ dyskursie publicznym (medialnym). Szkic do problemu, „Studia Pragmalingwistyczne” 7, s. 9-26.

Wendland M., 2015, Praktyki komunikacyjne jako praktyki społeczne w ujęciu historycznym, [w:] idem (red.), Historia idei komunikacji, Poznań, s. 95-115.

Wittgenstein L., 1953/2005, Dociekania filozoficzne, Warszawa.

\section{Evaluation as a communicative practice (using the example of press texts in the fields of economy and economics) Summary}

The paper focuses on the social aspect of evaluation as a linguistic and communicative practice. Such evaluation is based on certain interindividual principles (structures, models, and rules of functioning) and develops always within concrete media conditions. Theoretical reflections are complemented by an analysis of selected press texts and releases in the fields of economy and economics from the "Forbes" magazine. The linguistic explication of mono- and multimodal evaluative practices takes into account the semantic aspect (parameters of evaluative meaning), the pragmatic aspect (implicitness and performativity of comment), and modal aspect (reciprocal relations between signs of different modality which co-constitute the meanings of releases). 

POLSZCZYZNA HISTORYCZNA 



\author{
Stanisław Koziara \\ Uniwersytet Pedagogiczny im. Komisji Edukacji Narodowej, Kraków \\ stan@up.krakow.pl \\ Renata Przybylska \\ Uniwersytet Jagielloński, Kraków \\ renata.przybylska@uj.edu.pl
}

\title{
GOŚĆ CZY OBCY? OD PRZEKAZU EWANGELICZNEGO (MT 25, 31-46) DO POLSKICH PRZEKŁADÓW BIBLIJNYCH. PROBLEMY EKWIWALENCJ
}

Słowa klucze: kategoria 'obcego', Biblia, polskie przekłady Biblii, ekwiwalencja przekładowa

Keywords: the category of 'foreigner', the Bible, Polish translations of the Bible, translational equivalence

W kontekście ożywionych dyskusji, jakie w ostatnim czasie toczą się wokół napływu do Europy fali uchodźców, dają o sobie znać także problemy natury językowej związane z niejednoznacznym określeniem statusu owej ludności (Przybylska, w druku). Jak się bowiem okazuje, użycie określonej nominacji może w tym wypadku pociągać za sobą niekiedy daleko idące konsekwencje nie tylko natury politycznej i społecznej, ale i moralnej. Dotyczy to także dyskusji toczonych w polskiej przestrzeni społecznej i religijnej, w których opowiedzenie się za określonym stanowiskiem wsparte bywa nierzadko argumentacją odwołującą się do autorytetu Biblii. Odwołaniom tym nie zawsze jednak towarzyszy trafne wskazanie konkretnego miejsca tekstu biblijnego i zawartego w nim przesłania. Niezależnie bowiem od obecnej w różnych miejscach

1 Udział autorów w powstaniu tego tekstu jest następujący: 50\% Stanisław Koziara, 50\% Renata Przybylska. 
ksiąg biblijnych problematyki uchodźczej i stosunku do OBCEGO podstawę w tym względzie stanowi w głównej mierze przekaz z kart Ewangelii św. Mateusza, ujęty $\mathrm{w}$ formę przypowieści o sądzie ostatecznym (Mt 25, 31-46), w której mowa o koniecznym do zbawienia świadczeniu uczynków miłości względem bliźniego. Obok ewangelicznych nakazów troski o głodnych, spragnionych, nagich, chorych oraz przebywających w więzieniu pojawia się nakaz przyjęcia $\mathrm{OBCYCH}$.

W uważnej lekturze tej przypowieści w jej najbardziej upowszechnionej i utrwalonej w polskiej kulturze wersji, czyli w staropolskim² ${ }^{2}$ przekładzie Biblii ks. Jakuba Wujka (BWuj), uderzające jest pewne niedopasowanie słowa gość do kontekstu i naruszenie oczekiwanego tu paralelizmu znaczeniowego. $Z$ jednej strony bowiem mamy wyliczenie dolegliwych egzystencjalnych doświadczeń jednostki ludzkiej, z drugiej - wskazanie uczynków miłosierdzia, które te dolegliwości znoszą:

Abowiem łaknąłem, a daliście mi jeść; pragnąłem, a napoiliście mię; byłem gościem, a przyjęliście mię [wyróżn. tu i dalej - S.K., R.P.]; nagim, a przyodzialiście mię; chorym, a nawiedziliście mię; byłem w więzieniu, a przyszliście do mnie (BWuj: Mt 25, $35-36)$.

Wyliczenie to obejmuje następujące, niewątpliwie dolegliwe doświadczenia: bycie głodnym, bycie spragnionym, bycie nagim, bycie chorym i bycie $\mathrm{w}$ więzieniu. $\mathrm{Na}$ tym tle może dziwić właśnie wspomniane bycie gościem - cóż bowiem dolegliwego czy przykrego miałoby się wiązać z tym doświadczeniem? W niniejszym opracowaniu chcemy to pozorne odstępstwo od wyliczonej „czarnej serii” życiowych sytuacji objaśnić w kontekście polskojęzycznych przekładów owej przypowieści.

Poniższe uwagi mają charakter ujęcia filologicznego, odwołującego się przede wszystkim do lingwistycznych procedur opisu, z koniecznym wykorzystaniem także określonych ustaleń w dziedzinie egzegezy i hermeneutyki biblijnej. Pierwszym celem niniejszego opisu jest próba rekonstrukcji językowego i kulturowego konteks$\mathrm{tu}$, jaki kryje się w podstawie tekstu kanonicznego rzeczonego przekazu ewangelicznego oraz ewolucji użytych na określenie OBCEGO nominacji. Drugim zaś, zasadniczym zadaniem tego opracowania jest filologiczna ocena świadectw językowych składających się na bogaty zbiór rodzimych nazw, które zostały użyte w polskich tłumaczeniach interesującej nas przypowieści o sądzie ostatecznym.

Dla potrzeb poniższej analizy przytoczmy zatem pełny tekst przypowieści o sądzie ostatecznym w wersji Biblii Tysiąclecia, pełniącej obecnie w polskim Kościele funkcję tekstu liturgicznego.

\section{Przypowieść o sądzie ostatecznym}

31. Gdy Syn Człowieczy przyjdzie w swej chwale, a z nim wszyscy aniołowie, wtedy zasiądzie na swoim tronie pełnym chwały.

2 Termin staropolski w artykule używany jest w znaczeniu bliższym ujęciu historycznoliterackiemu. 
32. I zgromadzą się przed Nim wszystkie narody, a On oddzieli jednych [ludzi] od drugich, jak pasterz oddziela owce od kozłów.

33. Owce postawi po prawej, a kozły po swojej lewej stronie.

34. Wtedy odezwie się Król do tych po prawej stronie: „Pójdźcie, błogosławieni u Ojca mojego, weźcie w posiadanie królestwo, przygotowane wam od założenia świata!

35. Bo byłem głodny, a daliście Mi jeść; byłem spragniony, a daliście Mi pić; byłem przybyszem, a przyjęliście Mnie;

36. byłem nagi, a przyodzialiście Mnie; byłem chory, a odwiedziliście Mnie; byłem w więzieniu, a przyszliście do Mnie”.

37. Wówczas zapytają sprawiedliwi: „Panie, kiedy widzieliśmy Cię głodnym i nakarmiliśmy Ciebie? spragnionym i daliśmy Ci pić?

38. Kiedy widzieliśmy Cię przybyszem i przyjęliśmy Cię? lub nagim i przyodzialiśmy Cię?

39. Kiedy widzieliśmy Cię chorym lub w więzieniu i przyszliśmy do Ciebie?” .

40. A Król im odpowie: „Zaprawdę, powiadam wam: Wszystko, co uczyniliście jednemu z tych braci moich najmniejszych, Mnieście uczynili”.

41. Wtedy odezwie się i do tych po lewej stronie: „Idźcie precz ode Mnie, przeklęci, w ogień wieczny, przygotowany diabłu i jego aniołom!

42. Bo byłem głodny, a nie daliście Mi jeść; byłem spragniony, a nie daliście Mi pić;

43. byłem przybyszem, a nie przyjęliście Mnie; byłem nagi, a nie przyodzialiście Mnie; byłem chory i w więzieniu, a nie odwiedziliście Mnie”.

44. Wówczas zapytają i ci: „Panie, kiedy widzieliśmy Cię głodnym albo spragnionym, albo przybyszem, albo nagim, kiedy chorym albo w więzieniu, a nie usłużyliśmy Tobie?".

45. Wtedy odpowie im: „Zaprawdę, powiadam wam: Wszystko, czego nie uczyniliście jednemu z tych najmniejszych, tegoście i Mnie nie uczynili”.

46. I pójdą ci na wieczną karę, sprawiedliwi zaś do życia wiecznego (BT: Mt 25, 31-46).

\section{Charakter i przesłanie biblijnej przypowieści o sądzie ostatecznym}

Przypowieść o sądzie ostatecznym pojawia się wyłącznie w tekście Ewangelii św. Mateusza i nie ma odpowiedników w pozostałych Ewangeliach synoptycznych, jak też w Ewangelii Janowej. Jej tekst sytuuje się w obrębie tzw. mowy eschatologicznej Jezusa (Mt 24, 1-25.46), w bezpośrednim sąsiedztwie przypowieści o dziesięciu pannach oraz przypowieści o talentach (Mt 25, 1-30). Wśród biblistów istnieją podzielone zdania w kwestii przynależności tego przekazu ewangelicznego do kolekcji autentycznych wypowiedzi samego Jezusa. Obiekcje rodzą te passusy, które odwołują się do apokaliptycznych scen „oddzielenia dobrych od złych”, wizji wiecznej kary i potępienia, z trudem - zdaniem części teologów - dające się pogodzić z duchem ewangelicznym (Hryniewicz 2016: 183-204). W sumie jednak wśród komentatorów przeważa dziś sąd, że niezależnie od możliwego włączenia przez ewangelistę nieautentycznych fragmentów przypowieść ta odpowiada głównemu przesłaniu nau- 
ki Jezusa na temat miłości względem bliźniego, której synteza najpełniej zawiera się w 40. wersecie tej części Mateuszowej Ewangelii: „Zaprawdę, powiadam wam: Wszystko, co uczyniliście jednemu z tych braci moich najmniejszych, Mnieście uczynili”3. Warto także podkreślić, że poza czynnością odwiedzania więźniów wszystkie uczynki, które wymienia Jezus w przypowieści o sądzie ostatecznym, tj. troska o ubogich, udzielanie gościny obcym i odwiedzanie chorych, należały do tradycyjnej etyki i podstawowych nakazów żydowskiej pobożności (Keener 2000: 69). Wreszcie uwagę zwraca kunsztowna strona retoryczna i kompozycyjna przypowieści, oparta na strukturze koncentrycznej, z licznie zaznaczonymi paralelizmami i układami symetrycznymi, które w dużej części nawiązują do cech hebrajskiej retoryki biblijnej (Meynet 2001, 2005).

\section{Kontekst nauki Kościoła}

Relacje względem bliźniego, o których mowa jest w ewangelicznej scenie sądu ostatecznego, znajdują pełne odzwierciedlenie w postaci uczynków miłosierdzia w tekście katechizmu katolickiego oraz w katechizmach innych wyznań chrześcijańskich. Najnowsze wydanie Katechizmu Kościoła katolickiego w dziale drugim części trzeciej stwierdza, że „uczynkami miłosierdzia są dzieła miłości, przez które przychodzimy z pomocą naszemu bliźniemu w potrzebach jego ciała i duszy" (Katechizm: 550-551). Pośród siedmiu uczynków miłosierdzia względem ciała czwarty z nich nakazuje, aby „podróżnych w dom przyjąć”, i sytuuje się obok pozostałych nakazów wprost nawiązujących do przypowieści o sądzie ostatecznym: „głodnych nakarmić”, „spragnionych napoić”, „nagich przyodziać”, „więźniów pocieszać”, „chorych nawiedzać".

\section{Hermeneutyczne i semantyczne konteksty przypowieści}

Mówiąc o przesłaniu, które zawiera się w ewangelicznej formule na temat OBCEGO, nie sposób abstrahować od szerszego kontekstu kulturowego samej przypowieści oraz wskazanych w niej nakazów moralnych. Tyleż konieczne, ile pomocne w tym wypadku jest odwołanie się do filologicznych koncepcji badań nad Biblią określanych jako Sitz in Leben, mających na celu odkrywanie kontekstu życiowego, tj. miejsca, czasu, warunków życia, klimatu, stosunków społecznych itd., w jakim osadzony

3 Syntetycznie ujęty zbiór współczesnych dyskusji teologicznych wokół tej przypowieści zawiera się w pierwszej części osobnego opracowania Anny Wierzbickiej, w którym autorka, odwołując się do koncepcji semantyki uniwersalnej, a także po części hermeneutyki biblijnej, zmierza do sformułowania eksplikacji pierwotnego sensu przypowieści (zob. Wierzbicka 2002: 148-164). 
jest dany fragment czy też gatunek tekstu biblijnego (Lohfink 1987: 21-40). Rozpatrując pod tym kątem ogół uczynków miłosierdzia, o których mowa jest w przypowieści o sądzie ostatecznym, można stwierdzić, że mamy tu do czynienia z nakazami moralnymi odnoszącymi się do najbardziej istotnych aspektów egzystencjalnych i doświadczeniowych człowieka w ogóle, a w szczególności mieszkańców szeroko pojętych terenów Ziemi Świętej. Kilka z tych nakazów dotyczy okoliczności związanych $\mathrm{z}$ biologią ludzkiego ciała. $\mathrm{W}$ owym czasie i w owych warunkach bowiem dostęp do wody, pożywienia, a także odzienia - w tamtym klimacie niezbędnego, bo chroniącego przed słońcem, wiatrem pustynnym, piaskiem - był podstawą i koniecznym warunkiem biologicznego przetrwania. Były to zatem czynniki egzystencjalne, decydujące o życiu i przetrwaniu. Natomiast pozostałe nakazy odnoszą się do wymiaru społecznego ludzkiej egzystencji - wskazują na najbardziej dotkliwe doświadczenia człowieka w życiu osobistym i społecznym, jakimi są choroba oraz więzienie, determinujące także jakiś rodzaj wykluczenia, sytuujące człowieka w obliczu doświadczeń granicznych. Odwołując się do koncepcji uniwersalizmu językowego Anny Wierzbickiej, można stwierdzić, że chodzi o te aspekty ludzkiej egzystencji, które mimo silnego zakotwiczenia w danej kulturze mają wymiar absolutnie ponadkulturowy i ponadczasowy (Wierzbicka 1991).

W tym kontekście ludzkich doświadczeń kwestia odniesienia się do OBCEGO może wydawać się niewspółmierna, wręcz drugorzędna wobec podstawowych czynników decydujących o przetrwaniu człowieka, jakimi są dostęp do wody, pożywienia czy doświadczenie choroby. Próba spojrzenia na omawianą przypowieść przez pryzmat hermeneutyki biblijnej pokazuje, że asymetria ta ma jednak w dużej mierze charakter pozorny. Nieprzypadkowość bowiem usytuowania moralnego nakazu przyjęcia OBCEGO w obrębie rzeczonej perykopy ewangelicznej należy odczytywać w duchu szerzej rozumianego „radykalizmu etycznego” nauki Chrystusa, która w świetle realiów ówczesnej rzeczywistości zmierzała do przełamania uprzedzeń, nierzadko wrogości, jaka wytworzyła się pomiędzy mieszkańcami Palestyny i regionów sąsiednich. W odniesieniu do sytuacji etnicznej i religijnej Palestyny w czasach Jezusa można wręcz mówić o braku dobrego sąsiedztwa ${ }^{4}$. Nader wymowna w tym kontekście jest biblijna scena z Ewangelii św. Jana opisująca spotkanie Jezusa z Samarytanką przy studni Jakubowej $(\mathrm{J} 4,1-26)$. Siła wymowy tej sceny, w której prośba Jezusa o podanie $\mathrm{Mu}$ wody wywołuje zdziwienie u Samarytanki, wyrasta właśnie

4 Palestyna w czasach Jezusa była mocno podzielona tak pod względem etnicznym, jak też religijnym, czego przyczyną była burzliwa i pełna konfliktów historia regionu. Sytuacja ta sprzyjała pojawianiu się na tym terenie tendencji ksenofobicznych, a także etnocentrycznych wzorców zachowań. Najostrzejsze podziały dotyczyły relacji między Żydami i Samarytanami. Dodatkowym czynnikiem podsycającym wzajemną nieufność, a nierzadko wręcz wrogość, było pozostawanie tych ziem w owym czasie pod okupacją Imperium Rzymskiego (zob. m.in. Daniel-Rops 2001; Theisen 2004; Dziadosz 2017: 19-39). 
z faktu spotkania się „reprezentantów” dwóch zwaśnionych ze sobą nacji, gdyż, jak mowa jest w Ewangelii, „Żydzi i Samarytanie unikają się nawzajem” (J 4, 9).

\section{Ksénos / hospes - grecka i łacińska podstawa źródłowa}

Jest sprawą oczywistą, że niemal od początku wszelkie przekazy zawierające się w kanonicznym tekście biblijnym znajdowały upowszechnienie w drodze przekładowej na poszczególne języki etniczne. Jak każdy proces translacyjny, przekład biblijny wpisuje się w całokształt uwarunkowań wielorakiej natury, w tym głównie lingwistycznej. Od właściwych odczytań określonych jednostek języka wyjściowego, ich trafnie dobranych ekwiwalentów w języku docelowym, zależeć może nie tylko przekładowe powodzenie owego procesu, ale nierzadko właściwe odczytanie zasadniczego sensu i głównej myśli oryginału. Sprawa nabiera tym większej wagi, gdy zabiegowi tego swoistego „przekodowania”, jakim jest przekład, podlega tekst o randze sakralnej, dla wiernych wyznaczający religijno-etyczną normę zachowań. Nie ulega wątpliwości, że taką rangę należy przypisać interesującej nas przypowieści z kart Ewangelii św. Mateusza, a ściślej tej jej części, gdzie czterokrotnie mowa jest o nakazie odniesienia się do OBCEGO. Omówienie nominacji dla tej kategorii rozpocząć należy od przywołania tekstu kanonicznego.

Odwołując się do podstawy tekstu greckiego, natrafiamy w tym miejscu na formę ksénos (NTgr), która zgodnie pojawia się we wszystkich czterech miejscach przypowieści (Mt 25, 35.38.43-44). Leksykograficzne źródła greki klasycznej rzeczownikowi ksénos przypisują wiele znaczeń:

1. 'gość, zwł. o stosunku przyjaźni i gościny',

2. 'o stronach udzielających lub korzystających z gościnności',

3. 'cudzoziemiec, zwł. tułacz, zbieg, obcokrajowiec, przybysz',

a także

4. 'najemnik, zwł. żołnierz' (Sg-p III: 228).

Jednakże w kontekście omawianych tu miejsc z przypowieści o sądzie ostatecznym leksykony greki nowotestamentowej zawężają ów krąg znaczeń do: 'obcy, cudzoziemiec, tułacz, przybysz' (WSG-PNT: 415), podkreślając tym samym czynnik negatywnego doświadczenia, jakim jest poczucie wyobcowania czy wręcz bezdomność. Dodajmy, że w synonimicznym polu leksykalnym do gr. ksénos sytuować mogą się leksemy: állotriós 'cudzy, obcy'; bárbaros 'obcy, mówiący obcym językiem'; heteros 'inny, drugi'; paroikos 'mieszkający obok, obcy, cudzoziemski', mające poświadczenia w innych częściach Nowego Testamentu. Nie sposób wreszcie pominąć faktu, że to właśnie gr. ksénos dało podstawę pojęciu ksenofobia, oznaczającemu 
'przesadną niechęć lub wrogość w stosunku do obcych', z kolei zaś od gr. bárbaros bierze początek lingwistyczny termin barbaryzm 'wyraz lub konstrukcja składniowa przeniesiona z obcego języka', a także barbarzyńca 'człowiek dziki, pierwotny, nieucywilizowany' (SWO).

Z uwagi na rangę, jaką zyskał łaciński tekst Biblii w tłumaczeniu św. Hieronima (Wulgata), będący przez wiele wieków podstawą w przekładach katolickich na języki narodowe, należy także zwrócić uwagę na obecne w tym tekście ekwiwalenty greckiego ksénos. Jak się okazuje, i w tym wypadku mamy do czynienia ze zgodnym oddaniem wszystkich czterech miejsc ewangelicznych przez formę hospes (Vlg), której krąg denotacyjny, podobnie jak w grece, był szeroki i wyraz ten mógł mieć znaczenia:

1. 'osoba połączoną z inną trwałym związkiem wynikłym z udzielenia gościnności', 2. 'druh, stary przyjaciel',

3. 'gospodarz podejmujący przybyłych',

4. 'gość,

ale też

5. 'przybysz, obcy, wędrowiec' (Sł-p II: 732-733).

Godzi się zauważyć, że w bliskim znaczeniu do hospes sytuuje się łac. hostis, którego krąg odniesień ma o wiele bardziej jednoznaczną i negatywną wymowę, tj. 'obcy, wróg, nieprzyjaciel' (Sł-p), lecz nazwa ta nie pojawia się w łacińskim tekście omawianej przypowieści5.

\section{Polska seria przekładowo-biblijna - materiałowa podstawa opracowania}

Wieloznaczność zarówno gr. ksénos, jak też łac. rzeczownika hospes mogły otwierać przed tłumaczeniami na języki narodowe różne lekcje przekładowe. Taki też stan ujawniają polskie tłumaczenia interesującego nas fragmentu tekstu biblijnego. Dla celów niniejszego omówienia bliższemu oglądowi poddane zostaną zarówno dawne,

5 Łac. hostis rozwinęło się z pie. * ghost-i-s, który na gruncie prasłowiańskim przyjął postać * gostb, stąd pol. gość. Znamienny jest jednak fakt, że owa wspólna, praindoeuropejska podstawa ufundowała w niektórych językach tej rodziny dwa zgoła odmienne kręgi znaczeń, gdzie łac. hostis znaczy 'wróg, nieprzyjaciel', zaś prasł. ^gostb, a więc i pol. gość - 'przybysz, ktoś mile widziany’. Zdaniem niektórych stwarza to podstawę do wskazania na odmienny u Rzymian i Słowian stosunek do obcych; bardziej ksenofobiczny u Rzymian okresu królów i wczesnej republiki, natomiast o wiele bardziej gościnny i otwarty u Słowian, w myśl zasady: Gość w dom, Bóg w dom (Walczak 2016: 12-17). 
jak i nowsze tłumaczenia. Łącznie ekscerpcją objęte zostały 34 teksty polskich przekładów Ewangelii św. Mateusza ${ }^{6}$.

W wypadku tłumaczeń staropolskich kolekcję tę tworzy 10 tekstów powstałych w latach 1551-1632, na które złożyły się tak pełne przekłady Biblii, jak i osobne wydania Nowego Testamentu lub też samej Ewangelii św. Mateusza7. Grupa pełnych Biblii objęła dwa tłumaczenia katolickie, tj. Biblię Leopolity (BL) oraz Biblię w tłumaczeniu ks. Jakuba Wujka (BWuj), a także trzy przekłady powstałe w środowisku protestanckim: Biblię brzeską (Bbrz), Biblię nieświeską Szymona Budnego (BBud) oraz Biblię gdańską (Bgd). Kolekcję tę uzupełniają: najstarszy, protestancki tekst Ewangelii św. Mateusza w przekładzie Stanisława Murzynowskiego (MtMurz), pierwszy katolicki tekst Nowego Testamentu (NTSzarf), osobne wydanie Nowego Testamentu ks. Jakuba Wujka (NTWuj) oraz dwa protestanckie przekłady Nowego Testamentu: Szymona Budnego (NTBud) i Marcina Czechowica (NTCzech). Wielość i zróżnicowanie konfesyjne owych prac stanowi w znacznej mierze pokłosie ducha reformacji i kontrreformacji, a także podejmowanych na tej płaszczyźnie rywalizacji międzywyznaniowych.

$\mathrm{W}$ dziejach rodzimej translatoryki biblijnej przekłady te mają różny status. Pośród tłumaczeń katolickich szczególną rangę zyskała Biblia Wujka w jej pełnym wydaniu z roku 1599, która przez ponad trzy i pół wieku (366 lat) pełniła funkcję tekstu podstawowego i liturgicznego, z czasem stając się także kanwą, na której wyrosły zręby polskiego stylu biblijnego, odciskającego trwałe ślady tak w polszczyźnie literackiej, jak i potocznej (Bieńkowska 2002; Koziara 2013). Nie sposób pominąć również faktu szczególnej pozycji, jaką pośród tłumaczeń staropolskich zajęła $B i$ blia gdańska z roku 1632, która na wzór katolickiej Biblii Wujkowej na kilka wieków zyskała u protestantów polskich rangę tekstu podstawowego (Lisowski 2010; Szurek 2013). Ta szczególna, wielowiekowa pozycja Biblii Wujka oraz Biblii gdańskiej stała się źródłem upowszechnienia określonych wersji przekładowych, w tym również interesującego nas fragmentu przypowieści o sądzie ostatecznym.

Okres od XVII do XIX stulecia nie stwarza okazji do śledzenia dalszych losów interesujących nas nominacji biblijnych. Wspomniana ranga i długotrwała obecność Biblii Wujkowej niemal w funkcji tekstu kanonicznego wśród polskich katolików sprawią, że na kolejne tłumaczenia przyjdzie poczekać prawie aż do połowy XX w. Analogiczna sytuacja dotyczyła także środowiska protestanckiego, które na nowe tłumaczenie Biblii zdobyło się dopiero w latach 7o. ubiegłego wieku.

6 Korpus ten obejmuje niemal wszystkie dotychczasowe tłumaczenia rodzime Ewangelii św. Mateusza, samodzielne lub wchodzące w skład większych kolekcji bądź całości tłumaczeń Biblii w języku polskim. Dla celów ekscerpcyjnych wykorzystano zazwyczaj pierwsze wydania owych tekstów.

7 W toku opracowania posłużono się tradycyjnymi nazwami poszczególnych tłumaczeń oraz ich skrótami. Pełne tytuły wraz z datą wydań tychże przekładów oraz rozwiązaniem użytych skrótów znajdują się na końcu opracowania. 
Zasadnicza zmiana, skutkująca przyrostem wręcz w postępie geometrycznym nowych polskich tłumaczeń biblijnych, dokonała się w ogromnej mierze za sprawą nowatorskich kierunków w dziedzinie egzegezy biblijnej, których początki datują się już na przełom XIX i XX w., a także nowych nurtów wyrosłych z ducha soborowego aggiornamento (Sobór Watykański II). Obserwuje się więc ożywione prace przekładowo-biblijne zainicjowane przez teologów i biblistów, lecz krąg osób podejmujących w ostatnich dziesięcioleciach trud tłumaczenia ksiąg natchnionych na język polski wyraźnie się poszerzył o pisarzy, poetów, a także filologów. Cechą równie znamienną jest wielokonfesyjny charakter owych prac, obejmujący na równi tłumaczenia powstałe $\mathrm{w}$ środowisku katolickim, protestanckim, jak też inicjatywy o charakterze ekumenicznym oraz ponadwyznaniowym. Wreszcie nie bez znaczenia pozostaje włączenie w obszar przekładu Pisma Świętego wielorakich współczesnych metod oraz technik translacyjnych.

Wyrosła na tej podstawie nader bogata seria przekładowa obejmuje kilkanaście przekładów powstałych po roku 1945, na które złożyło się sześć pełnych tłumaczeń Pisma Świętego, w tym cztery katolickie: Biblia Tysiąclecia (BT), Biblia poznańska (Bpoz), Biblia warszawsko-praska (Bwp) oraz Biblia paulistów (Bpaul), obok protestanckiej Biblii warszawskiej (Bwar) oraz przekładu dokonanego przez członków wspólnoty Świadków Jehowy (PNŚ). Dorobek ten poszerza się o równie bogatą listę osobnych tłumaczeń Nowego Testamentu bądź kolekcji lub pojedynczych ksiąg nowotestamentowych, w tym Ewangelii św. Mateusza ${ }^{8}$. Z całą pewnością status i społeczny zasięg owych prac przekładowych jest nierównorzędny - od inicjatyw oficjalnych o znacznym stopniu upowszechnienia po dokonania mające wręcz charakter prywatny (Szczepińska 2005). Nie ulega jednak wątpliwości, że szczególna pozycja w tej serii przypadnie katolickiej Biblii Tysiąclecia, tłumaczeniu powstałemu dla uczczenia milenium chrztu Polski, które przejęło po Biblii Wujkowej rolę tekstu podstawowego i liturgicznego (Pietkiewicz 2015; Koziara 2016).

\section{Ksénos / hospes - polskie ekwiwalenty przekładowe}

Tak ukształtowany korpus tekstowy stwarza okazję do prześledzenia losów interesującej nas formuły ewangelicznej odnoszącej się do kategorii OBCEGO. Już na początku przyjdzie stwierdzić, że krąg rodzimych ekwiwalentów w stosunku do gr. ksénos i łac. hospes przedstawia zbiór form zróżnicowanych, o dość charakterystycznej repartycji. Faktem tyleż znamiennym, ile zaskakującym jest zgodność wszystkich dziesięciu tłumaczeń staropolskich, tak katolickich, jak i protestanckich,

8 Pełna lista tych tłumaczeń wraz z wykazem użytych dla ich identyfikacji skrótów znajduje się w końcowej części niniejszego opracowania. 
w których w obrębie trzeciej formuły omawianej perykopy ewangelicznej użyty został rzeczownik gość.

Zgoła inaczej (tak pod względem ilościowym, jak jakościowym) kształtuje się zasób ekwiwalentów gr. ksénos i łac. hospes w późniejszych i najnowszych rodzimych tłumaczeniach interesującej nas formuły. $\mathrm{W}$ odniesieniu do poszczególnych translacji układ tych form przedstawia się następująco:

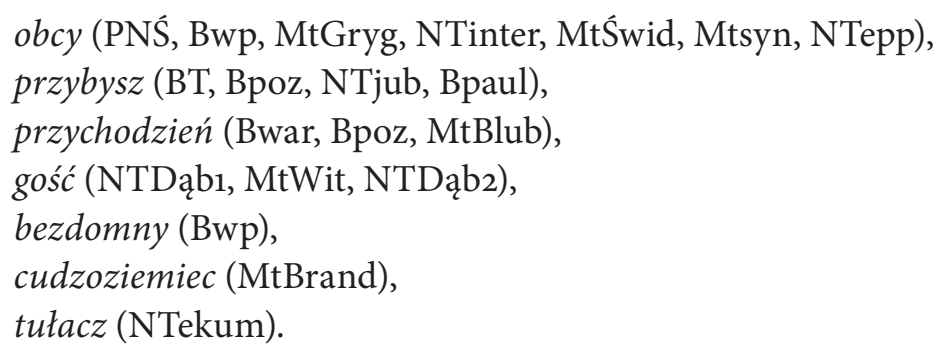

Krąg ten dodatkowo wzbogacają dwie formy gwarowe: kaszubskie cëzy 'obcy' (Mtkasz) oraz góralskie niepili 'nie swój, obcy' (NTpodh). W jednym z nowszych tłumaczeń pojawia się także nominacja wielowyrazowa obcy przybysz (NTewan). Wart uwagi jest fakt, że w niektórych tłumaczeniach sięgnięto w tej funkcji po formy opisowe:
ten, kto jest na obczyźnie (NTKow),
ten, kto znalazł się na obczyźnie (NTKow),
ten, kto jest w podróży (NTpar),
ten, kto jest bez domu (Bwp),

pośrednio jedynie odwołujące się do źródłosłowu greckiego. W pojedynczych wypadkach brak jednolitej lekcji przekładowej dotyczy tego samego tekstu (NTKow, Bpoz, Bwp).

Z prześledzenia niemal wszystkich ekwiwalentów gr. ksénos i łac. hospes, jakie pojawiają się polskich przekładach, dają się wyprowadzić pewne wnioski natury ogólniejszej. Po pierwsze, cechą znamienną, wyznaczającą, rzec by można, pierwszy etap w historii rodzimych poszukiwań przekładowych odpowiedników dla gr. ksénos i łac. hospes, jest konsekwentne użycie formy gość we wszystkich tłumaczeniach staropolskich, w tym także w katolickiej Biblii Wujka (1599) oraz protestanckiej Biblii gdańskiej (1632), które to translacje na kilka wieków wyznaczyły swoiste wzorce polskiego stylu biblijnego, utrwalając także w powszechnej świado-

9 Dla celów ekscerpcji odpowiednich miejsc staropolskich tłumaczeń Ewangelii św. Mateusza wykorzystano specjalną bazę elektroniczną obejmującą ogół polskich tłumaczeń Ewangelii powstałych do końca XVI w. (zob. ewangelie.uw.edu.pl/teksty). 
mości nie tylko wiernych określone wersje przekładowe (Bieńkowska 2002; Koziara 2002, 2013).

Odejście od tej linii przekładu, co nastąpiło dopiero w translacjach XX-wiecznych i najnowszych, można $\mathrm{z}$ kolei określić jako drugą fazę $\mathrm{w}$ historii polskich tłumaczeń gr. ksénos i łac. hospes. Na całość pola leksykalnego tej grupy ekwiwalentów tłumaczeniowych złożyło się w sumie kilka jednostek. Jak zostało to pokazane, prymarna funkcja tym razem przypadła formie $o b c y$ (7), obok rzadszych lub tylko pojedynczych wystąpień leksemów: przybysz (5), przychodzień (3), gość (3), bezdomny (1), tułacz (1), cudzoziemiec (1) oraz gwarowych cëzy (1) i niepili (1). Tak ukształtowany paradygmat wariantów tłumaczeniowych wskazuje na wyraźne przewartościowanie w obrębie polskich ekwiwalentów gr. ksénos i łac. hospes w omawianej przypowieści ewangelicznej. Oznacza ono, skądinąd w pełni zasadne, poniechanie w nowszych tłumaczeniach staropolskiej formy gość i zwrócenie się w kierunku jednostek i znaczeń w różnym stopniu odnoszących się do przesłania tekstu kanonicznego. Uwagę przyciąga tu forma przybysz użyta we wszystkich wydaniach Biblii Tysiąclecia, tłumaczeniu, które od z górą pół wieku pełni w polskim Kościele funkcję podstawowego tekstu liturgicznego.

Z semantycznego punktu widzenia odsłania się w efekcie zasób form nie w pełni stycznych znaczeniowo. Tak zgodne opowiedzenie się za formą gość w całej grupie tłumaczeń staropolskich może wskazywać na przesunięcie interesującej nas formuły biblijnej w stronę odczytań niezupełnie przystających do znaczeń i kontekstu kulturowego tekstu kanonicznego. Tylko w części daje się to uzasadnić faktem, że rzeczownik gość widziany przez pryzmat leksykonów języka staropolskiego oraz polszczyzny XVI w. odsłania o wiele szerszy w tych okresach zakres znaczeniowy, obejmujący takie znaczenia, jak: 'przybysz, obcy, cudzoziemiec, pielgrzym, wędrowiec, bliżej nieokreślony człowiek, zaproszony w gościnę, bywalec karczmy' (SStp, SPXVI).

Współcześnie gość to również słowo wieloznaczne, WSJP podaje cztery jego znaczenia:

1. 'osoba, która odwiedza kogos';

2. 'osoba, która została zaproszona dokądś i jest uczestnikiem czegoś', np. gość zjazdu, gość radia Zet, gość wieczoru;

3. 'osoba, która przybywa do jakiegoś miejsca, żeby skorzystać ze świadczonych tam usług', np. gość hotelu, gość restauracji;

4. 'mężczyzna, którego mówiący bliżej nie zna lub do którego ma określony stosunek emocjonalny', np. spotkałem jednego gościa, który powiedziat, gdzie to jest.

Z kolei SJPD, wcześniejszy o ponad pół wieku, notujący słownictwo od połowy XVIII w., uwzględnia następujące znaczenia gościa: 
1. 'osoba przybyła lub przybywająca do kogo $\mathrm{w}$ gościnę, $\mathrm{w}$ odwiedziny, $\mathrm{z}$ wizytą; zaproszony (czasem też przygodny) uczestnik przyjęcia, balu, imprezy rozrywkowej;

2. 'klient w restauracji, kawiarni, hotelu, lokalu usługowym itp. (dawniej także w sklepie), kuracjusz w zakładzie leczniczym w miejscowości uzdrowiskowej; wczasowicz, wycieczkowicz';

3. pot. 'o kimś bliżej nieznanym lub często lekceważąco o kimś znanym; osobnik'; 4. przestarz. 'przybysz, obcy: dawniej w szczególności - obcy kupiec'.

Widać, że rozwój znaczeniowy tego wyrazu doprowadził do osłabienia i przesunięcia na dalszy plan, a w niektórych kontekstach wręcz zatarcia komponentu znaczeniowego 'obcy'; dziś gość to raczej ktoś, kto przychodzi do nas, ale jest nam znany lub został specjalnie zaproszony, jest oczekiwany i pożądany, najczęściej na jego przyjście gospodarze szczególnie się przygotowują. Być gościem to dziś sytuacja w większości przypadków przyjemna, kojarzona zwłaszcza z przyjęciami, balami i innymi imprezami, o których mowa jest w SJPD. Gość zyskał więc pozytywną dominantę znaczeniową, której dawniej nie miał.

Z kolei obcy jest dziedzictwem prasłowiańskim, pierwotnie niosącym sens 'nie swój', z którego stopniowo wyłoniły się dwie dominanty: 'nie swój, czyli cudzy' oraz 'nie swój, czyli wspólny' (SEBor). Cudzy zaś oznaczało nie tylko 'należący do kogoś innego, będący własnością kogoś innego', lecz w staropolszczyźnie także 'nienależący do określonego kręgu ludzi (np. rodziny, plemienia, wsi), przedmiotów lub spraw; obcy' (ibid.). W przeszłości zatem obcy i cudzy w pewnych kontekstach funkcjonowały jako bliskoznaczniki, a nawet swoje równoznaczniki, zresztą każdy z nich stał się z osobna podstawą nazwy dla 'człowieka nie stąd, nie „swojaka”, czyli odpowiednio cudzoziemca i obcokrajowca. W nowszej polszczyźnie obcy używany jako zsubstantywizowany przymiotnik 'obcy człowiek' oznacza kogoś, kto 'nie należy do danego środowiska, rodziny itp.', to 'mieszkaniec, obywatel innego kraju; cudzoziemiec, obcokrajowiec' (SJPD). W SW objaśniany jest za pomocą charakterystycznego ciągu synonimów: nie swojski, nie domowy, nie nasz, nie swój, nietutejszy, niekrajo$w y$, postronny, zagraniczny, cudzoziemski. Bycie obcym nie konotuje czegoś miłego i przyjemnego, jak bycie gościem. Przeciwnie - bycie obcym jest jednym z trudnych doświadczeń egzystencjalnych człowieka.

Z całą pewnością zatem we współczesnej polszczyźnie w poczet bliskoznaczników nie da się zaliczyć form gość i obcy. Już leksykony od czasów Lindego, a w całej rozciągłości najnowsze, pod hasłem gość w prymarnym znaczeniu nie wskazują na jego dawne odniesienie do OBCEGO (SL, SW, SJPD, USJP). Nie sposób zatem nie zauważyć, że zakres znaczeń i odniesień rzeczownika gość uległ w polszczyźnie na przestrzeni wieków istotnym zmianom. Przejawem więc anachronizmów oraz braku świadomości dokonanych przewartościowań rzeczownika gość są pojedyncze świadectwa jego użycia w nowszych tłumaczeniach rzeczonej sceny ewange- 
licznej (NTDąb1, NTDąb2, MtWit) ${ }^{10}$. Osobnego komentarza domaga się pozostała grupa nazw składająca się na pole leksykalno-znaczeniowe nowszych ekwiwalentów gr. ksénos i łac. hospes. Są nimi leksemy: przybysz, przychodzień, bezdomny, tułacz, cudzoziemiec, których kręgi odniesień także nie wskazują na jednostki równoznaczne i o tym samym zabarwieniu emotywnym.

Najbardziej neutralne, pozbawione konotacji wartościujących, zwłaszcza zabarwienia negatywnego, są jednostki: przybysz o czytelnym znaczeniu strukturalnym 'ten, kto przybył (skądś)' i przychodzień o podobnej strukturze znaczeniowej 'ten, kto przychodzi (skądś); obie formacje są pochodne od czasowników i należą do kategorii słowotwórczej nazw subiektów czynności. Przychodzień jest słowem w ogóle bardzo rzadkim, a dziś wręcz przestarzałym ${ }^{11}$, zbudowanym podobnie jak znacznie silniej obecny we współczesnej polszczyźnie przechodzień. Oba wyrazy: przybysz i przychodzień nie precyzują, skąd dana osoba przybywa czy przychodzi. Równie dobrze może to być ktoś z najbliższej wioski, jak i z obcego, odległego kraju, tego nie wiadomo. Inaczej wybrzmiewa słowo cudzoziemiec, również mające czytelną strukturę 'ten, kto jest z cudzej ziemi', określające jednoznacznie, że przybysz nie jest z tej (czyli naszej) ziemi, ale z innej, cudzej. Zatem w tle tej nazwy ujawnia się pojęciowy podział na nasze i cudze.

Tułacz to kolejna formacja odczasownikowa 'ten, kto się tuła', słowo stare, obecne już w słownictwie staropolskim; jest to nazwa subiektu oparta na pierwszym znaczeniu czasownika tułać się 'przenosić się z miejsca na miejsce, nie mając własnego domu ${ }^{12}$. Czasownik ten występuje w połączeniach składniowych typu: tułać się od jednego miejsca do drugiego, po jakichś miejscach. Akcentuje bezcelowość, brak miejsca jako celu wędrówki, do którego z nadzieją można by zmierzać. Wyraz ten dla Polaka ma bardzo głębokie konotacje kulturowe, związane zwłaszcza z dyskursem romantycznym i Wielką Emigracją ${ }^{13}$. Nie sposób rozwijać tu tego wątku, warto jednak zaznaczyć, że wiąże się z nim postawa politowania dla kondycji takiego przybysza, a nawet odcień współczucia, co jest jeszcze wzmacniane w nazwie pochodnej tułaczyna (SW). Tułacz pojawia się też w Biblii Wujka, w innych jeszcze niż rozważane tu przez nas miejscach, por. np. „tułaczem i zbiegiem będziesz na ziemi” (BWuj:

10 Pojawienie się wariantu gosśc we współczesnych tłumaczeniach nowotestamentowych ks. Eugeniusza Dąbrowskiego (NTDąb1, NTDąb2) należy tłumaczyć faktem, że biblista ten należał do zagorzałych zwolenników tłumaczeń z podstawy łacińskiej Wulgaty oraz podtrzymania ducha języka Biblii Wujka.

11 W NKJP udokumentowanych jest zaledwie 36 użyć, przede wszystkim z utworów Stefana Żeromskiego, jedno z Konrada Wallenroda Adama Mickiewicza i kilka z prasy współczesnej.

12 Drugie znaczenie tego czasownika to: 'włóczyć się, błąkać się' (USJP). W SW mamy interesującą definicję synonimiczną: 'wałęsać się, nie mając przytułku, błądzić, błąkać się, poniewierać się po świecie'.

13 Na przykład w Paryżu w okresie Wielkiej Emigracji powołano do życia Towarzystwo Naukowe Polaków Tułaczów (por. edupedia.pl/words/index/show/492796_slownik_literatury_polskiej-_ emigracja.html). 
$\mathrm{Rdz} 4$, 12). Cytat ten ujawnia pojmowanie tułactwa jako zła, kary, przekleństwa. Nie ma wątpliwości, że pod względem aksjologicznym bycie tułaczem jest oceniane jako coś złego wśród wszelkich doświadczeń, jakie mogą spotkać człowieka. Tej ujemnej oceny nie ma w poprzednio omawianych bliskoznacznikach.

Pozostaje jeszcze skomentować zsubstantywizowany przymiotnik bezdomny, akcentujący to, że przybywający skądś człowiek to ktoś, kto nie ma swojego domu. Wyraz ten jest do dziś dnia żywy, pragmatycznie osadzony w dyskursie o jednym z wciąż nierozwiązanych problemów społecznych - ludzi, którzy nie mają gdzie mieszkać, żyją na ulicach, nocują pod mostami itp. Ujemna ocena aksjologiczna wpisana w referencyjne znaczenie tego słowa jest oczywista.

Marginalne dla naszych rozważań propozycje nominacji: ten, kto jest w podróży i ten, kto jest / znalazł się na obczyźnie zupełnie inaczej ujmują status takich osób. Bycie w podróży, choć może łączyć się, a w przeszłości na pewno łączyło się z wieloma niewygodami i dolegliwościami, nie jest czymś złym ze swej istoty, podróż może też przebiegać przecież wśród swoich, na swojej ziemi, zresztą podróż zakłada dotarcie w pewnym momencie do upragnionego celu. Co innego bycie na obczyźnie, w które od razu wpisany jest nie tylko dyskomfort, ale i lęk przed tym, co obce, poczucie rozłąki, tęsknoty itd.

Warto jeszcze skomentować ekwiwalent tłumaczeniowy pojawiający się w przekładzie Nowego Testamentu na gwarę podhalańską: niepili (NTpodh). Na Podhalu „niepili, niepilec, niepilok to głównie ktoś obcy, nienależący do naszej społeczności. Zwykle tak mówi się o kimś, kto się ożenił z dziewczyną z naszej wsi. Jest to zawsze nacechowane negatywnie, z wyraźną niechęcią"14. Najkrócej można powiedzieć, że niepili to „nie swój, nie krewny”. Tu zatem mocno wybrzmiewa trudny status osoby przybywającej z zewnątrz do danej społeczności, doświadczającej tego, że jest obca.

Omówione powyżej lekcje przekładowe zmierzają zatem, jak widać, do zróżnicowania semantycznego profilowania biblijnego przekazu, zmieniającego wręcz przesłanie etyczne, jakie zawiera się w omawianej perykopie ewangelicznej na temat odniesienia się do OBCEGO. Polskie ekwiwalenty omawianych tu nominacji OBCEGO odzwierciedlają bowiem różne sposoby odczytania tejże perykopy i nierozłącznie z tym związane różne interpretacje zawartego w niej przesłania etycznego - od łatwego stosunkowo do wypełnienia nakazu udzielenia doraźnej, krótkiej gościny komuś, kto jest akurat w podróży, do wymagającego wręcz heroizmu wezwania do udzielenia własnego domu OBCEMU.

14 Te informacje zawdzięczamy profesorowi Józefowi Kąsiowi, autorowi monumentalnego Ilustrowanego leksykonu gwary i kultury podhalańskiej (Kąś 2015-2016) (hasło Niepili w opracowaniu). Za ich udzielenie składamy podziękowanie. 


\section{Skróty}

\section{Teksty biblijne - podstawa grecka i łacińska}

NTGR: Novum Testamentum Graece et Latine, red. E. i E. Nestle, B. i K. Aland, Stuttgart 1984. VLG: Biblia Sacra iuxta Vulgatam versionem, red. R. Gryson, Stuttgart 1994.

\section{Teksty biblijne - przekłady polskie (układ chronologiczny)}

MtMurz: Ewangelia wedle Mateusza świętego na polski przełożona i objaśniona, tłum. S. Murzynowski, Królewiec 1551, edycja i oprac. I. Winiarska-Górska, [on-line:] ewangelie.uw.edu.pl/teksty.

NTSzarf: Nowy Testament polskim językiem wyłożony, Kraków 1556, edycja i oprac. Sz. Gruda, [on-line:] ewangelie.uw.edu.pl/teksty.

BL: Biblia, to jest Ksieggi Starego i Nowego Zakonu na polski język [...] nowo wyłożone, tłum. J. Leopolita, Kraków 1561, edycja i oprac. A. Kępińska, [on-line:] ewangelie.uw.edu.pl/ teksty.

Bbrz: Biblia święta. To jest Księgi Starego i Nowego Zakonu, Brześć 1563, edycja i oprac. A. Kępińska, [on-line:] ewangelie.uw.edu.pl/teksty.

NTBud: Biblia. To jest ksiegi starego i nowego Przymierza [...] na polski przełożone, tłum. Sz. Budny, Nieśwież 1570, edycja i oprac. E. Kwapień, [on-line:] ewangelie.uw.edu.pl/ teksty.

BBud: Biblia. To jest księgi starego i nowego Przymierza [...] na polski przełożone, tłum. Sz. Budny, Nieśwież 1572, edycja i oprac. E. Kwapień, [on-line:] ewangelie.uw.edu.pl/ teksty.

NTCzech: Nowy Testament. To jest wszystkie pisma nowego Przymierza, tłum. M. Czechowic, Kraków 1577, edycja i oprac. A. Korycińska przy współpr. I. Winiarskiej-Górskiej, [on-line:] ewangelie.uw.edu.pl/teksty.

NTWuj: Nowy Testament Pana naszego Jezusa Chrystusa, tłum. J. Wujek, Kraków 1593, edycja i oprac. I. Wiencek przy współpracy A. Kępińskiej, [on-line:] ewangelie.uw.edu.pl/ teksty.

BWuj: Biblia to jest Księgi Starego i Nowego Testamentu, [...] na polski język znowu z pilnością przełożone [...], tłum. J. Wujek, Kraków 1599, edycja i oprac. P. Pokora przy współpracy I. Winiarskiej-Górskiej, [on-line:] ewangelie.uw.edu.pl/teksty.

BgD: Biblia Święta. To jest Księgi Starego i Nowego Przymierza [...], na polski pilnie i wiernie przettumaczone, Gdańsk 1632.

NTDĄв1: Pismo Święte Nowego Testamentu, tłum. (z Wulgaty) i oprac. E. Dąbrowski, Poznań 1946.

MtGryg: Ewangelie i Dzieje Apostolskie, tłum. F. Gryglewicz, Katowice 1947.

NTKow: Pismo Święte Nowego Testamentu, tłum. S. Kowalski, Warszawa 1957.

MтWтт: Dobra Nowina według Mateusza i Marka, tłum. i oprac. W. Witwicki, Warszawa 1958.

NTDĄB2: Pismo Święte Nowego Testamentu, tłum. (z j. grec.) i oprac. E. Dąbrowski, Poznań 1960.

BT: Pismo Święte Starego i Nowego Testamentu w przekładzie z języków oryginalnych, oprac. zespół biblistów polskich pod red. benedyktynów tynieckich, Poznań 1965.

Bpoz: Pismo Święte Starego i Nowego Testamentu, w przekładzie z języków oryginalnych ze wstępami i komentarzami oprac. zespół pod red. M. Petera i M. Wolniewicza, Poznań 1973-1975. 
Bwar: Biblia to jest Pismo Święte Starego i Nowego Testamentu, nowy przekł. z j. hebr. i grec. oprac. przez Komisję Przekładu Pisma Świętego, Warszawa 1975.

MtBrand: Ewangelia według Świętego Mateusza, tłum. R. Brandstaetter, Warszawa 1986.

NTDyn: Nowy Testament, nowy przekł. z j. grec. na współczesny j. pol., Warszawa 1991.

NTpar: Słowo Życia. Parafraza Nowego Testamentu we współczesnym języku polskim, Warszawa 1991.

NTINTER: Grecko-polski Nowy Testament. Wydanie interlinearne z kodami gramatycznymi, tłum. R. Popowski, M. Wojciechowski, „Prymasowska Seria Biblijna”, Warszawa 1993.

MtBlub: Ewangelia według św. Mateusza, tłum. i oprac. J. Homerski, Lublin 1995.

MTŚwid: Ewangelia według św. Mateusza, w nowym przekł. A. Świderkówny, Kraków 1995.

BwP: Pismo Święte Starego i Nowego Testamentu, w przekł. z j. oryg., oprac. K. Romaniuk, Warszawa 1997.

MTsyn: Synopsa czterech Ewangelii w nowym przekładzie polskim, tłum. i oprac. M. Wojciechowski, „Prymasowska Seria Biblijna”, Warszawa 1997.

PNŚ: Pismo Święte w przekładzie Nowego Świata, Nadarzyn 1997.

NTuub: Nowy Testament. Przekład na Wielki Jubileusz Roku 20oo, tłum. i oprac. R. Popowski, „Prymasowska Seria Biblijna”, Warszawa 2000.

NTeкum: Pismo Święte Nowego Testamentu i Psalmy. Przekład ekumeniczny z języków oryginalnych, Warszawa 2001.

NTpodH: Nowy Testament. Dzieje Apostolskie, Listy Apostolskie, Apokalipsa, w przekł. M.M. Torbiarz na gwarę górali skalnopodhalańskich z Zakopanego, Poznań - Zakopane-Krzeptówki 2005.

NTewan: Nowe Przymierze. Pismo Święte Nowego Testamentu, przekł. z j. grec. A. Hannig, P. Zaremba, Poznań - Bydgoszcz 2007.

Bpaul: Pismo Święte Starego i Nowego Testamentu. Najnowszy przekład z języków oryginalnych z komentarzem, oprac. Zespół Biblistów Polskich, Częstochowa 2008.

Mtкasz: Ewanielie na kaszëbsczi tołmaczonë, z greczi przeł. na kaszëbsczi jãzëk ò. A.R. Sikora OFM, Gduńsk 2010.

NTEPP: Nowy Testament. Ekumeniczny przekład przyjaciół, tłum. M. Czajkowski i in., Warszawa 2016.

\section{Literatura}

Bieńkowska D., 2002, Polski styl biblijny, Łódź.

Daniel-Rops H., 2001, Życie codzienne w Palestynie w czasach Chrystusa, Warszawa.

DzIAdosz D., 2017, „I wy byliście przybyszami...” (Kpł 19, 34). „Obcy” w religijnym i społeczno-kulturowym kontekście Biblii Hebrajskiej, „Ethos” nr 1 (117), s. 19-39, [on-line:] http:// dx.doi.org/10.12887/30-2017-1-117-03.

Hryniewicz W., 2016, Nadzieja woła głośniej niż lęk. Eseje wokół nauczania Jezusa historycznego, Kielce.

Katechizm: Katechizm Kościoła katolickiego, Poznań 1994.

KĄś J., 2015-2016, Ilustrowany leksykon gwary i kultury podhalańskiej, Bukowina Tatrzańska.

KeEner C.S., 200o, Komentarz historyczno-kulturowy do Nowego Testamentu, red. nauk. wyd. pol. K. Bardski, W. Chrostowski, „Prymasowska Seria Biblijna”, Warszawa. 
KozIara S., 2002, Rola Biblii Gdańskiej w kształtowaniu stylowej odrębności polszczyzny biblijnej, „Myśl Protestancka” nr 3-4, s. 69-80.

Koziara S., 2013, Rola Biblii Jakuba Wujka $w$ dziejach kultury polskiej, [w:] R. Słowiński (red.), Biblia Jakuba Wujka w życiu i kulturze narodu polskiego. Artykuły opracowane na podstawie referatów wygłoszonych na sesji naukowej pt. „Biblia Jakuba Wujka w życiu i kulturze narodu polskiego" w Poznaniu w dniu 25 października 2012 r., Poznań, s. 41-64.

KozIARa S., 2016, Biblia Tysiąclecia wobec tradycji polszczyzny biblijnej - uwagi jubileuszowe, „Język Polski” XCVI, s. 15-31.

Lisowski T., 2010, Sola scriptura. Leksyka Nowego Testamentu Biblii gdańskiej (1632) na tle porównawczym. Ujęcie kwantytatywno-dystrybucyjne, Poznań.

Lohfink G., 1987, Rozumieć Biblię. Wprowadzenie do krytyki form literackich, Warszawa, S. 21-40.

Meynet R., 2001, Wprowadzenie do hebrajskiej retoryki biblijnej, Kraków.

Meynet R., 2005, Język przypowieści biblijnych, „Myśl Teologiczna”, t. 51, Kraków.

NKJP: Narodowy Korpus Języka Polskiego, [on-line:] nkjp.pl.

Pietkiewicz R., 2015, Biblia Polonorum. Historia Biblii w języku polskim, t. 5: Biblia Tysiąclecia (1965-2015), Poznań.

Przybylska R., w druku, Uchodźca $i$ inne nazwy ludzi opuszczających swój kraj.

SEBor: W. Boryś, Słownik etymologiczny języka polskiego, Kraków 2005.

SG-P: Z. Abramowiczówna (red.), Słownik grecko-polski, Warszawa 1958.

SJPD: W. Doroszewski (red.), Słownik języka polskiego, Warszawa 1958-1969.

SL: S.B. Linde, Słownik języka polskiego, wyd. 2, Lwów 1854-1860.

SŁ-P: M. Plezia (red.), Słownik łacińsko-polski, Warszawa 1998-1999.

SPXVI: Słownik polszczyzny XVI wieku, t. I-IV, red. komitet redakcyjny, t. V-XVII, red. M.R. Meyenowa, t. XVIII-XXXIV, red. F. Pepłowski, t. XXXV-XXXVI, red. K. Mrowcewicz, P. Potoniec, Wrocław - Warszawa - Kraków 1966-2012.

SSTP: S. Urbańczyk (red.), Słownik staropolski, Kraków 1953-2002.

SW: J. Karłowicz, A.A. Kryński, W. Niedźwiedzki (red.), Słownik języka polskiego, Warszawa 1900-1927.

SWO: J. Tokarski (red.), Słownik wyrazów obcych, Warszawa 1980.

SzCZEPIŃsKA B., 2005, Ewangelie tylekroć tłumaczone... Studia o przekładach i przekładaniu, Gdańsk.

Szurek M.M., 2013, Z dziejów polszczyzny biblijnej. Biblia Wujka (1599) a Biblia Gdańska (1632). Studium komparatywne, Kraków.

Theisen G., 2004, Czasy Jezusa. Tło społeczne pierwotnego chrześcijaństwa, Kraków.

USJP: S. Dubisz (red.), Uniwersalny słownik języka polskiego, Warszawa 2003.

WalczaK B., 2016, Językoznawstwo - dyscyplina humanistyczna, „Annales Universitatis Paedagogicae Cracoviensis” 210 „Studia Linguistica” XI, s. 12-17.

WierzBickA A., 1991, Uniwersalne pojęcia ludzkie i ich konfiguracje w różnych kulturach, „Etnolingwistyka” 4, s. 7-40.

Wierzbicka A., 2002, Przypowieść o Sądzie Ostatecznym, [w:] eadem, Co mówi Jezus? Objaśnianie przypowieści ewangelicznych $w$ słowach prostych i uniwersalnych, Warszawa, s. $148-164$.

WSG-PNT: R. Popowski, Wielki słownik grecko-polski Nowego Testamentu, Warszawa 1995. WSJP: P. Żmigrodzki (red.), Wielki słownik języka polskiego PAN, [on-line:] wsjp.pl. 
Ekwiwalenty gr. ksénos i łac. hospes w polskich przekładach biblijnych

\begin{tabular}{|c|c|c|c|c|c|c|}
\hline \multirow{2}{*}{ Lp. } & \multirow{2}{*}{ Przekład } & \multirow{2}{*}{$\begin{array}{c}\text { Przynależność } \\
\text { konfesyjna } \\
\text { przekładu }\end{array}$} & \multicolumn{4}{|c|}{ Miejsca biblijne } \\
\hline & & & Mt 25, 35 & Mt 25, 38 & Mt 25, 43 & Mt 25, 44 \\
\hline 1. & MtMurz & protestancki & gość & gość & gość & gość \\
\hline 2. & NTSzarf & katolicki & gość & gość & gość & gość \\
\hline 3. & $\mathrm{BL}$ & katolicki & gość & gość & gość & gość \\
\hline 4. & Bbrz & protestancki & gość & gość & gość & gość \\
\hline 5. & NTBud & protestancki & gość & gość & gość & gość \\
\hline 6. & BBud & protestancki & gość & gość & gość & gość \\
\hline 7. & NTCzech & protestancki & gość & gość & gość & gość \\
\hline 8. & NTWuj & katolicki & gość & gość & gość & gość \\
\hline 9. & BWuj & katolicki & gość & gość & gość & gość \\
\hline 10. & Bgd & protestancki & gość & gość & gość & gość \\
\hline 11. & NTDąb1 & katolicki & gość & gość & gość & gość \\
\hline 12. & MtGryg & katolicki & $o b c y$ & obcy & $o b c y$ & $o b c y$ \\
\hline 13. & NTKow & katolicki & $\begin{array}{l}\text { [ktoś, kto] } \\
\text { znalazł się na } \\
\text { obczyźnie }\end{array}$ & $\begin{array}{l}\text { [ktoś, kto] } \\
\text { jest na } \\
\text { obczyźnie }\end{array}$ & $\begin{array}{l}\text { [ktoś, kto] } \\
\text { znalazł się na } \\
\text { obczyźnie }\end{array}$ & $\begin{array}{l}\text { [ktoś, kto] } \\
\text { jest na } \\
\text { obczyźnie }\end{array}$ \\
\hline 14. & MtWit & laicki & gosść & gosść & gość & gosśc \\
\hline 15. & NTDąb2 & katolicki & gość & gość & gość & gość \\
\hline 16. & BT & katolicki & przybysz & przybysz & przybysz & przybysz \\
\hline 17. & Bpoz & katolicki & przychodzień & $\begin{array}{l}\text { [ktoś, kto] } \\
\text { przybyt }\end{array}$ & przychodzień & przybysz \\
\hline 18. & Bwar & protestancki & przychodzień & przychodzień & przychodzień & przychodzień \\
\hline 19. & MtBrand & katolicki & cudzoziemiec & cudzoziemiec & cudzoziemiec & cudzoziemiec \\
\hline 20. & NTdyn & ekumeniczny & tułacz & tułacz & tułacz & tułacz \\
\hline 21. & NTpar & protestancki & $\begin{array}{l}{[\text { ktoś, kto] }} \\
\text { jest } \\
\text { w podróży }\end{array}$ & $\begin{array}{l}\text { [ktoś, kto] } \\
\text { jest } \\
w \text { podróży }\end{array}$ & $\begin{array}{l}\text { [ktoś, kto] } \\
\text { jest } \\
\text { w podróży }\end{array}$ & $\begin{array}{l}\text { [ktoś, kto] } \\
\text { jest } \\
\text { w podróży }\end{array}$ \\
\hline 22. & NTinter & katolicki & $o b c y$ & $o b c y$ & $o b c y$ & $o b c y$ \\
\hline 23. & MtBlub & katolicki & przychodzień & przychodzień & przychodzień & przychodzień \\
\hline 24. & MtŚwid & katolicki & $o b c y$ & $o b c y$ & $o b c y$ & $o b c y$ \\
\hline 25. & Bwp & katolicki & $o b c y$ & $o b c y$ & $\begin{array}{l}\text { [ktoś, kto] } \\
\text { jest bez domu }\end{array}$ & bezdomny \\
\hline 26. & Mtsyn & katolicki & $o b c y$ & $o b c y$ & $o b c y$ & $o b c y$ \\
\hline
\end{tabular}




\begin{tabular}{|c|c|c|c|c|c|c|}
\hline \multirow{2}{*}{ Lp. } & \multirow{2}{*}{ Przekład } & \multirow{2}{*}{$\begin{array}{c}\text { Przynależność } \\
\text { konfesyjna } \\
\text { przekładu }\end{array}$} & \multicolumn{4}{|c|}{ Miejsca biblijne } \\
\hline & & & Mt 25, 35 & Mt 25, 38 & Mt 25, 43 & Mt 25, 44 \\
\hline 27. & PNŚ & $\begin{array}{l}\text { wyznanie } \\
\text { Świadków } \\
\text { Jehowy }\end{array}$ & $o b c y$ & $o b c y$ & $o b c y$ & $o b c y$ \\
\hline 28. & NTjub & katolicki & przybysz & przybysz & przybysz & przybysz \\
\hline 29. & NTekum & ekumeniczny & tułacz & tułacz & tułacz & tułacz \\
\hline 30. & NTpodh & katolicki & niepili & niepili & niepili & niepili \\
\hline 31. & NTewan & protestancki & obcy przybysz & obcy przybysz & obcy przybysz & obcy przybysz \\
\hline 32. & Bpaul & katolicki & przybysz & przybysz & przybysz & przybysz \\
\hline 33. & Mtkasz & katolicki & cëzy & cëzy & cëzy & cëzy \\
\hline 34. & NTepp & ekumeniczny & $o b c y$ & $o b c y$ & $o b c y$ & $o b c y$ \\
\hline
\end{tabular}

\section{Guest or foreigner? From the evangelical message (Mt 25, 31-46) to the Polish translations of the Bible. Problems of equivalence Summary}

The paper tries to draw attention to problems related to accurate conveyance in translation of certain forms and ideas contained in the Bible. It focuses on a fragment of the parable of the final judgment from the Gospel of St. Matthew (Mt 25, 31-46) which speaks about acts of love towards neighbours. Besides the evangelical command to care for the hungry, thirsty, naked, sick, and imprisoned, it contains an order to accept a FOREIGNER, described in the Greek and Latin text of the Bible as ksénos and hospes, respectively. The first goal of this paper is to attempt a reconstruction of the linguistic and cultural context in which those names for the FOREIGNER were used. The second, essential, goal is to philologically evaluate a collection of native equivalents of those foreign words which appear in 34 Polish translations of the Gospel of St. Matthew, from Old Polish to newer and contemporary renderings. The remarks presented in the paper are philological in nature and primarily refer to linguistic descriptive procedures, with a necessary utilization of certain findings in the fields of exegesis and Biblical hermenutics. 



\section{GŁOS W DYSKUSJI 0 TEKŚCIE STAROPOLSKIM. ZNAD KANONÓW MSZY ŚW.}

Słowa klucze: tekst staropolski, glosa, tłumaczenie w średniowieczu, kanon mszy św., funkcja tekstu, intencja pisarza

Keywords: Old Polish text, gloss, translation in the Middle Ages, Canon of the Mass, function of the text, intention of the scribe

Niniejsze rozważania są inspirowane artykułem Tomasza Miki Tekst staropolski jako odmienny obiekt badań? W poszukiwaniu narzędzi opisu, w którym zaproponował on nowe spojrzenie na teksty dawne:

Uważam, że tekst staropolski, w szczególności średniowieczny tekst rękopiśmienny, jest innym obiektem badawczym niż późniejsze teksty. Ujawniają to zarówno ostatnio prowadzone badania, jak również próba odniesienia zdobyczy współczesnej tekstologii do tekstu średniowiecznego (Mika 2015: 235),

przyczyn ich odmienności upatrując przede wszystkim „w samych tekstach (postać tekstu) i w sytuacji ich powstawania i funkcjonowania" (ibid.: 236).

T. Mika wskazuje kilka typów zabytków, wobec których nowa perspektywa myślenia o tekście staropolskim jest szczególnie interesująca. Należą do nich zabytki glosowane:

Podobnie atrakcyjne wydaje się odniesienie pytań tekstologicznych do tekstów glosowanych, zarówno jedno-, jak i dwujęzycznych. Czy glosy są częścią tekstu? A jeśli tak, to czyjego (problem ,jedności nadawcy")? Glosy bywały przecież wpisywane przez kolejne ręce, często po długim czasie od zapisania tekstu głównego. Jeśli uznać je za część tekstu, to jak opisać nadawcę takiego tekstu? Czy i jak glosowanie zmieniało 
funkcję i przeznaczenie tekstu (powszechnie uważa się na przykład polskie glosy w kazaniach łacińskich za dowód przygotowania do ich głośnej realizacji w języku wernakularnym)? Pytania można by mnożyć. Być może wskazywany tu kierunek pozwoli na usprawnienie narzędzi opisu w sytuacjach najtrudniejszych, kiedy glos jest tak dużo i tak są związane już nie tylko z tekstem głównym, ale i pomiędzy sobą, że zaczynają tworzyć odrębny tekst. [...] Czy układające się w pełne tłumaczenie glosy wpisane inną ręką to inny tekst (co za tym idzie - inny język, inny odbiorca, nowy układ intencji i funkcji)? Czy glosatorów traktować li tylko jako użytkowników rękopisu, czy też jako nadawców wtórnych? (ibid.: 241-242, 246-247).

Badacz formułuje problemy na dość wysokim poziomie ogólności. Rzecz wymaga dokładnego rozważenia $\mathrm{w}$ odniesieniu do poszczególnych średniowiecznych tekstów, a szczególnie interesująca wydaje się w przypadku jednej, dotąd niemal nieopisanej grupy zabytków glosowanych ${ }^{1}$, odnośnie do których badacze używają sformułowań „bardzo liczne glosy”, „glosy układające się w tekst” etc. W zachowanych polskich (polsko-łacińskich) średniowiecznych zabytkach znajduje się kilka rękopisów, które opisywane są w taki właśnie sposób²:

1. Tzw. Kazania augustiańskie (rkps Biblioteki Jagiellońskiej, sygn. Akc 110/56). Są to 24 karty pochodzące $\mathrm{z}$ większego zbioru łacińskich kazań; pierwsze trzy zawierają bardzo liczne polsko-łacińskie (z przewagą polskich) dopiski marginalne i interlinearne, które, jak piszą Wiesław Wydra i Wojciech Rzepka, „tworzą prawie kompletny przekład tekstu łacińskiego" (2004: 108).

2. Rękopis Biblioteki Narodowej, sygn. 3019 III. Zawiera on kazania, zbiory egzemplów oraz lekcje ewangeliczne. Nad jedną z nich „nadpisane zostały obfite glosy polskie, które tworzą prawie kompletny przekład wersetów 1-9 XXI rozdziału Ewangelii wg św. Mateusza" (ibid.: 84).

3. Tzw. Ewangeliarz kanoników regularnych w Krakowie (rkps Biblioteki kanoników regularnych w Krakowie, sygn. 933). W kodeksie zapisano 107 kazań, z których osiem rozpoczyna się fragmentem ewangelii opatrzonym „obfitymi glosami polskimi, tworzącymi prawie ciągły przekład [...] perykop" (Pietkiewicz 2013: 35).

4. Kanony mszy św. Wśród zachowanych 17 średniowiecznych redakcji zawierających polskie glosy do kanonu mszy św. znajduje się siedem, o których pisze się jako o „prawie kompletnym tłumaczeniu kanonu rzymskiego” (Leńczuk 2013: 6) czy też „zapisach [...], które ze względu na ich spójność można uznać za teksty” (ibid.: 69); są to rękopisy: IV, VI, VIII, XII, XIV, XVI³. W ten sposób pisze się też o rękopisie III, jednak w tym przypadku polskie tłumaczenie nie ma formy

1 Dotychczas charakteryzowano tylko poszczególne zabytki, co więcej, niemal żaden z nich nie został poddany analizie i całościowo opisany.

2 Problem ten sygnalizowałam już na marginesie rozważań nad propozycją wydania Kazań augustiańskich, zob. Masłej (w druku).

3 Numeracja zgodnie z wydaniem Mariusza Leńczuka (2013). 
glos do tekstu łacińskiego. Mariusz Leńczuk stwierdza, że ,jest to wypadek wyjątkowy, ponieważ polski tekst istnieje w nim praktycznie bez swojej łacińskiej podstawy" (ibid.: 65).

Dodajmy, że do tego specyficznego typu zabytków należą tylko rękopisy pierwotnie wyłącznie łacińskie (także kopie tekstów łacińskich, w których już znajdują się nieliczne polskie glosy wciągnięte do tekstu głównego ${ }^{4}$ ). Taki system „rozbudowanego glosowania" jest zatem bezpośrednio związany z procesem adaptowania określonych tekstów do języka polskiego (także z przygotowaniem ich do realizacji w języku narodowym) i ściśle wiąże się z dokonującym się w średniowiecznej Polsce procesem wernakularyzacji5.

Przedstawiony powyżej sposób mówienia o tych zabytkach pozwala sądzić, że są one ze względu na kryterium formalne (miejsce wpisania na karcie) uznawane za glosy, z drugiej strony ich postać (stopień rozbudowania) każe badaczom myśleć o nich jako o tekstach. Jest to jednak myślenie wynikające wyłącznie z kształtu oraz liczby dopisków. W świetle nowych badań nad tekstem staropolskim wydaje się, że nie jest to jedyne kryterium, na którego podstawie można uznać tego typu zapisy za teksty.

Pytanie postawione przez Mikę (2015: 241): „czy i jak glosowanie zmieniało funkcję i przeznaczenie tekstu" trzeba w przypadku tego typu zabytków uzupełnić o kolejne pytania: kiedy proces glosowania prowadził do powstania kolejnego tekstu, kiedy (z dzisiejszej perspektywy) możemy mówić o odrębnym, nowym tekście? Co decyduje o jego odrębności i co powinno cechować dany zapis, aby mógł on zostać uznany za tekst? Każdy z wymienionych tu zabytków musi być traktowany osobno. Wszystkie bowiem są do siebie podobne zewnętrznie, natomiast - jak pokaże przedstawiona $\mathrm{w}$ niniejszym artykule analiza wybranych kanonów mszy św. ${ }^{6}$ - nie wystarczy patrzeć na nie przez pryzmat zagęszczenia oraz liczby glos, by udzielić odpowiedzi na sformułowane pytania.

Jak wiadomo, tylko nieliczne polskojęzyczne zabytki średniowieczne są znane z wielu redakcji (por. Wydra 1973; Leńczuk 2013; Masłej 2016). Kanon mszy św. jest jednym $\mathrm{z}$ tych tekstów, które przetrwały w wielu XV-wiecznych odpisach w wersji łacińskiej, a w $17 \mathrm{z}$ nich znajdują się mniej lub bardziej liczne polskie glosy będące tłumaczeniem odpowiednich słów lub całych fragmentów tekstu łacińskiego. $\mathrm{Na}$ każdy z tych zabytków badacze patrzą przez pryzmat całej grupy: ze względu na różną liczbę glos poszczególne warianty charakteryzuje się pod względem ilościowym, używa się w ich kontekście sformułowań opisujących je jako „pojedyncze glosy” lub nawet „prawie kompletne przekłady”. Trzeba zauważyć, że w opisie glos jako „prawie

\footnotetext{
4 Tak jest w przypadku Kazań augustiańskich.

5 Studium na temat funkcjonalności i przydatności tego terminu na gruncie polskich badań historycznojęzykowych jest w przygotowaniu.

6 Analiza pozostałych wskazanych zabytków - w przygotowaniu.
} 
kompletnego przekładu" presuponuje się tekstowość 7 i, co szczególnie ważne, intencję glosatora. O wszystkich tych zabytkach pisze się bowiem, że

tekst polski miał służyć przede wszystkim duchowieństwu parafialnemu, co w sposób bezpośredni wiąże się z ustawami synodalnymi nakazującymi archidiakonom w czasie wizytacji egzaminowanie księży z rozumienia modlitw kanonu (Leńczuk 2013: 58, wyróżnienie - D.M.).

Umieszczenie wszystkich zabytków z tej grupy na jednej linii: pojedyncze glosy kompletne tłumaczenie jest zbyt daleko idącym uogólnieniem, zacierającym specyfikę poszczególnych zabytków, co pokażę na wybranych (właśnie według kryterium ilościowego) czterech rękopisach z tej grupy: Mszy III, Mszy IV, Mszy XII i Mszy XVI. Dlatego też analiza tych zabytków obejmie, oprócz kompletności tłumaczenia, także inne elementy: postać graficzną, składnię, podstawę tłumaczenia.

\section{Postać graficzna}

Jak wspomniałam, wyjątkowy we wskazanej grupie jest rękopis Mszy III. Tylko tutaj tłumaczenie kanonu mszy św. zostało zapisane nie (jak w pozostałych przypadkach) między liniami, nad odpowiednimi fragmentami łacińskiego tekstu, ale osobno poszczególne fragmenty znajdują się przeważnie na górnym lub dolnym marginesie kart: 2r, 4r, 5v, 6r, 8ra, 8rb, 11vb, 13vb, 15vb, 16ra, 25vb, 30vb, 32rb, 33va, 33vb, 35rb, $37 \mathrm{ra}, 37 \mathrm{rb}, 39 \mathrm{rb}, 42 \mathrm{ra}, 44 \mathrm{rb}, 44 \mathrm{va}, 44 \mathrm{vb}, 45 \mathrm{ra}, 45 \mathrm{rb}$.

Zestawienie kart, na których znajdują się polskie ustępy, uwidacznia brak linearności całego tłumaczenia. Jest ono rozpisane na 19 kart (znajdujących się wśród pierwszych 45 kart zabytku), w skrajnym przypadku dwa polskie fragmenty - ściśle związane ze sobą pod względem tematycznym, mowa bowiem o konsekracji chleba i konsekracji wina - dzieli 9 kart tekstu łacińskiego ${ }^{8}$. Dopiero ułożenie kolejnych polskich części w jedną całość w edycji (zob. ibid.: 180-199) pozwala stwierdzić, że tworzą one kompletne tłumaczenie łacińskiego tekstu kanonu.

7 M. Leńczuk zauważa: „Używane w literaturze przedmiotu sformułowania: »tłumaczenie kanonu«, "przekład kanonu« oraz »staropolski kanon« sugerują, że polski tekst kanonu jest kompletny, logiczny, spójny gramatycznie i składniowo oraz że funkcjonował autonomicznie, czyli istniał samodzielnie, bez swojej łacińskiej podstawy. Tak jednak nie było" (Leńczuk 2013: 55) - niestety myśli tej autor nie rozwija.

8 Zapiska na k. 16r kończy się słowami: Tocz yest prawe czyalo moye, kolejny fragment, który zaczyna się słowami: Takesz gdysz weczrzaal · yest wsząw yten preswyatli kelych wszwąte ytesz welebne rancze swoye, znajduje się na k. 25 r (zob. Leńczuk 2013: 183). 


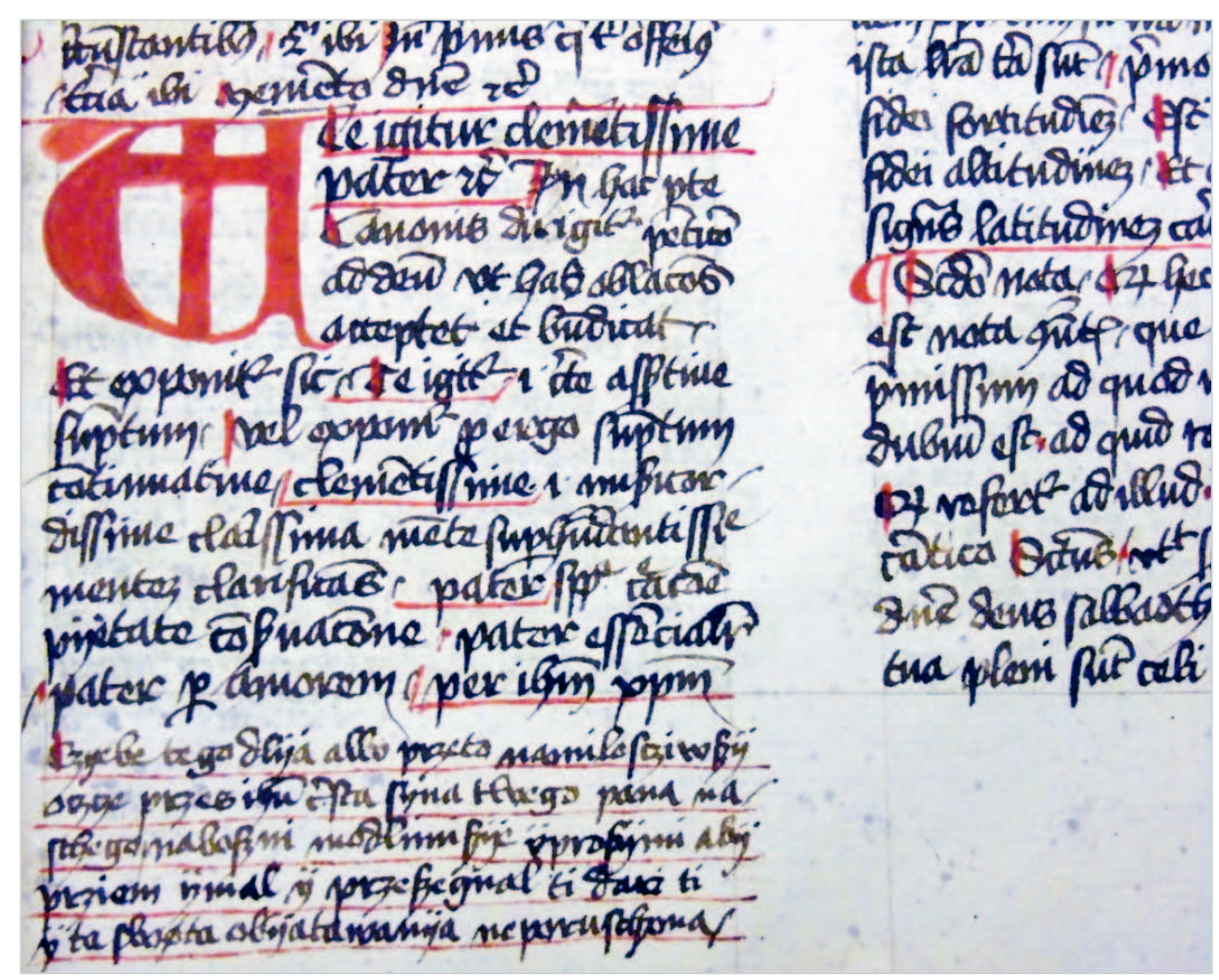

Fot. 1. Rękopis Zakładu Narodowego im. Ossolińskich we Wrocławiu, sygn. 208o/II, fragment k. $2 r^{9}$

Pozostałe analizowane kanony zawierają polskie słowa zapisane $\mathrm{w}$ formie glos interlinearnych. Rękopis Mszy IV najpewniej od początku przygotowany był do dalszej pracy, sam główny tekst zapisany został bowiem z podwójną interlinią (od początku pozostawiono $\mathrm{w}$ nim miejsce na dopiski), a glosy już od pierwszej linii rękopisu wpisywane były w interliniach wysoko, w taki sposób, aby można było wprowadzić kolejne dopiski:

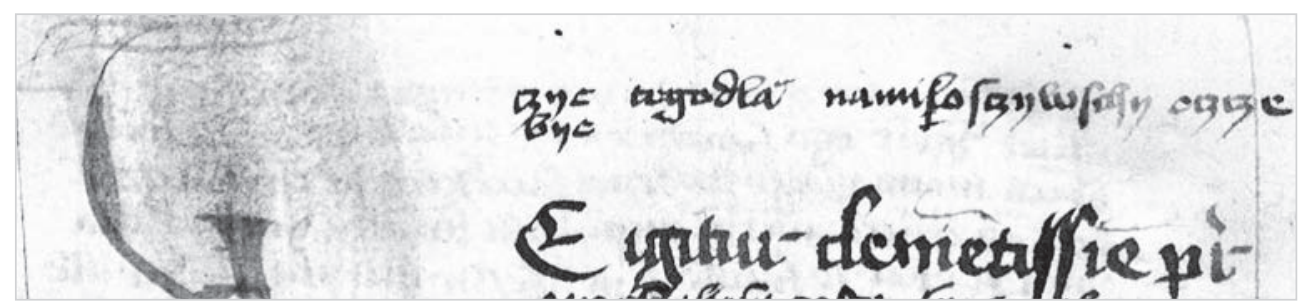

Fot. 2. Rękopis Biblioteki Jagiellońskiej, sygn. Akc. 150/54, fragment k. 244V

9 Wszystkie fotografie pochodzą z edycji M. Leńczuka (2013). Autor zgodził się na ich reprodukcję $\mathrm{w}$ artykule. 
Bardzo istotny jest sposób zapisu polskich tłumaczeń nad poszczególnymi łacińskimi słowami. Wielokrotnie wyraz jest dzielony i przenoszony do linii niżej po to, by kolejne dopisane słowo znajdowało się dokładnie nad swoim łacińskim odpowiednikiem. Widać to na fot. 2: pierwszy wyraz, łaciński zaimek te, ma w zapisie wielkie $T$, które nie było glosowane. Nad drugą literą, wielkim $E$, pomieszczono zatem całe tłumaczenie wyrazu, dzieląc je na dwie linie czye | bye, dzięki czemu dokładnie nad kolejnym łacińskim wyrazem igitur skryba mógł zapisać kolejny polski odpowiednik (tegodla). Jest to szczególnie znaczące w takich fragmentach, jak przedstawiony na fot. 3 :

\section{Thosige Oawan $=1$ Sonvay of?

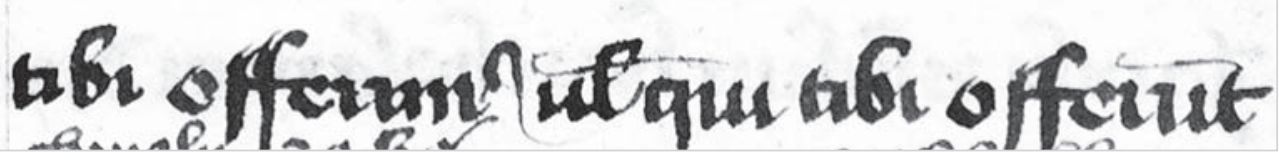

Fot. 3. Rękopis Biblioteki Jagiellońskiej, sygn. Akc. 150/54, fragment k. 245r

Nad zapisanym $\mathrm{z}$ abrewiacją czasownikiem offerun $n^{\text {tur }}$ dopisano $\mathrm{w}$ dwóch liniach uzgodnione gramatycznie polskie tłumaczenie, stosując znak podziału: dawa $=\mid m y$. Trzeba zwrócić uwagę na to, że kolejne trzy łacińskie słowa: ut qui tibi nie są glosowane, nie zostały przetłumaczone, a mimo to skryba wprowadził wspomniane dzielenie wyrazu. Wyraźnie widać, że taki zapis nie wynikał z prostego myślenia o ilości miejsca (o konieczności zmieszczenia odpowiedniej partii polskich dopisków w linii), ale był sposobem umieszczania tłumaczenia wyrazów w tym konkretnym typie zabytków. Dowodzi to, że sam glosator nie myślał o zapisywaniu tekstu, lecz precyzyjnie planował zapis tłumaczenia poszczególnych słów.

Istotne jest tu przeznaczenie tych dopisków. W literaturze przedmiotu podkreślano, że glosy polskie do kanonu mszy św. mogły być zapisywane przez studentów (tak twierdzili Aleksander Brückner, Bogdan Bolz i Wanda Żurowska-Górecka, Paweł Sczaniecki, zob. Leńczuk 2013: 57-58), bardzo często wypływały też z niewykształcenia kleru oraz konieczności elementarnego zrozumienia sprawowanej liturgii, np. w kontekście przygotowania do egzaminu (ibid.: 58-59), co wyjaśnia tak dokładny sposób zapisywania tłumaczeń.

W tej perspektywie bardzo ciekawe wydaje się tłumaczenie wyrażenia pro ecclesia sancta | catholica w Mszy IV. Jest tu ono przetłumaczone jako zaczyrkew swantø albo zazgromadzenÿe wyernego krzesczyansthwa|krzeszczyansthwa. Powtórzenie rzeczownika krześcijaństwo wynika właśnie z dydaktycznego (szkolnego) charakteru pracy skryby oraz z jego dbałości o oddawanie poszczególnych słów. Fragment zgromadzenie wiernego krześcijaństwa znajduje się nad łacińskim ecclesia sancta za- 
pisanym w jednej linii, zaś kolejny wers tekstu zaczyna się od przymiotnika catholica przetłumaczonego raz jeszcze przez rzeczownik krześcijaństwo.

Podobny układ (sposób zapisu), choć z mniejszą dbałością, zastosowano w zapisie Mszy XVI:

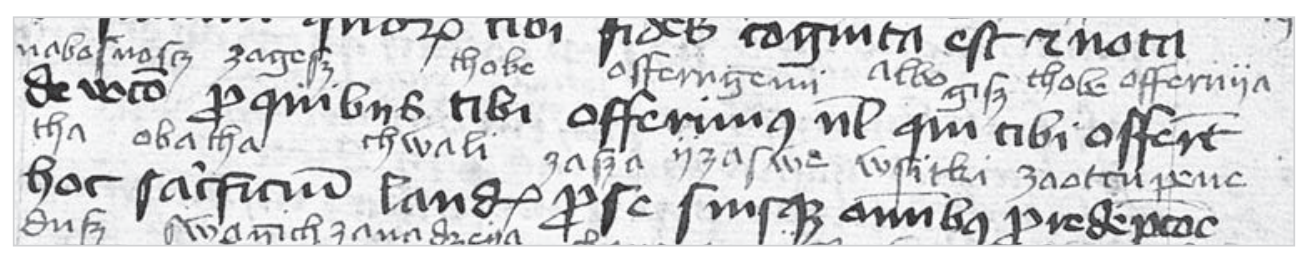

Fot. 4. Rękopis Biblioteki Narodowej w Warszawie, sygn. Akc. 9889, fragment k. 68r

W tym zabytku nie dzielono wyrazów między liniami - nie ma na to miejsca, zapewne rękopis w momencie jego tworzenia nie był przeznaczony do komentowania lub glosowania. Nie tylko nie przewidziano na dopiski miejsca w interliniach, ale także pozostawiono wąskie marginesy; ponadto tekst łaciński zapisano mniej starannie niż w analizowanym wyżej rękopisie Biblioteki Jagiellońskiej. I tutaj jednak ogląd postaci graficznej pozwala dojść do wniosku, że glosator przekładał nie tekst, ale poszczególne wyrazy, których tłumaczenie notował bezpośrednio nad łacińskimi słowami, zachowując między polskimi dopiskami takie odstępy, jakie wynikają z długości poszczególnych zapisów łacińskich ${ }^{10}$.

Rękopis Archiwum Archidiecezjalnego w Gnieźnie, czyli Msza XII, z pewnością (podobnie jak Msza IV) był od początku przeznaczony do dalszej pracy. Przy zapisie tekstu łacińskiego zachowano podwójną interlinię oraz szerokie marginesy. Glosator jednak wykorzystał je nie tylko do nadpisywania polskich odpowiedników nad poszczególnymi fragmentami łaciny, ale także do zapisywania łacińskich komentarzy do tekstu kanonu, co czyni sytuację jeszcze bardziej skomplikowaną. Przykład znajduje się na fot. 5:

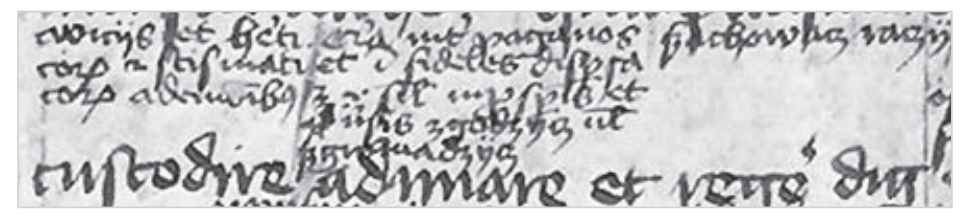

Fot. 5. Rękopis Archiwum Archidiecezjalnego w Gnieźnie, nr MS 6o, fragment k. 5rb

Nad łacińskim fragmentem custodire adunare et regere glosator zapisał łaciński komentarz, na którego końcu zamieścił dwa polskie czasowniki połączone łacińskim

$10 \mathrm{Na}$ „szkolność” zapisu wskazuje też fakt, że w tym rękopisie niektóre wyrazy polskie naśladują grafię łacińską, np. offerugemi (zob. fot. 4). Za tę uwagę bardzo dziękuję prof. Tomaszowi Mice. 
spójnikiem: zgodzycz uel szgromadzycz, będące, jak się wydaje, uzgodnionym gramatycznie tłumaczeniem łacińskiego czasownika adunare 'zjednoczyć, połączyć, skupić, zebrać. Polsko-łaciński fragment nie jest, co ważne, w żaden sposób graficznie oddzielony od łacińskiego komentarza, lecz stanowi jego kontynuację. Sama postać graficzna - umieszczenie części tłumaczenia na końcu lacińskiego komentarza - nie pozwala myśleć o zapisywaniu przez glosatora polskiego tekstu kanonu. Pierwszy czasownik, custodire 'strzec, zachować, pilnować, nie został przetłumaczony w oczekiwanym przez nas miejscu (znajduje się tu tylko fragment łacińskiego komentarza). Dopiero nad czasownikiem regere pisarz umieścił polskie słowo szachowacz. Ze względu na wskazany już sposób graficznego rozmieszczenia tłumaczonych wyrazów można się spodziewać, że zachować ma w rękopisie odpowiadać łacińskiemu czasownikowi regere 'rządzić, kierować ${ }^{\prime 1}$. W tym przypadku skryba zamienił kolejnością polskie czasowniki i to ostatni z nich nie został przełożony, choć z rozmieszczenia polskich słów nad łacińskim tekstem można by wnioskować inaczej.

\section{Składnia}

Jako świadectwo tego, że zapisywane przez glosatorów tłumaczenia w ich intencji bardzo często nie miały być tekstami, można potraktować także gromadzenie odpowiedników leksykalnych w poszczególnych zabytkach. Niektóre łacińskie fragmenty kanonu są tłumaczone na kilka sposobów, także w obrębie jednego rękopisu, co zaobserwował M. Leńczuk:

Zarówno w tekście traktatu, glosach łacińskich do kanonu, jak i w glosach polskich odnajdujemy nagromadzenie wyrazów bliskoznacznych o różnym stopniu bliskoznaczności, których zadaniem było jak najwierniejsze przybliżenie sensu modlitwy (ibid.: 68).

Według niego gromadzenie słów mogło wynikać z dopracowywania i aktualizowania „polskiego tekstu kanonu” kopiowanego ze starszych odpisów i uwspółcześnianego przez kolejnych pisarzy (zob. ibid.: 69, 79). W dwóch analizowanych tu zabytkach (Msza III, Msza IV) wielokrotnie pojawia się kilka (dwa lub więcej) odpowiedników leksykalnych ${ }^{12}$.

Polskie tłumaczenie kanonu w Mszy III, zapisane linearnie na marginesach, nie ma - jak w przypadku pozostałych zabytków - formy glos znajdujących się bezpośrednio nad poszczególnymi słowami lub konstrukcjami łacińskimi. Jest tu jednak

11 W Słowniku staropolskim wyłącznie na podstawie materiału z kanonu mszy św. uznano, że jednym ze znaczeń staropolskiego czasownika zachować jest 'prowadzić, kierować, regere, dirigere'. Wydaje się, że zaproponowana w niniejszym artykule interpretacja także jest zasadna.

12 W Mszy XII tylko w jednym miejscu, nad łacińskim rzeczownikiem sacrificium na k. 7va, zapisano w ciągu dwa tłumaczenia: obyatha offyera. 
wiele takich dopisków, co do których można domniemywać, że początkowo miały formę notowanych obok siebie lub pod sobą wariantów tłumaczeniowych, które ostatni skryba połączył w jedną całość, stosując typowy w takich sytuacjach spójnik albo (por. Twardzik 1994: 161-162; Gesner 2011: 94-95), np.:

czyebe tegodlya albo przeto namiloscziwszy oczcze (k. 2r), wspamątay albo pomni pane (k. 5v), zawykupyene albo zazbawenye duszch swych (k. 6r), roszgodz albo sądzy ytesz od wecznego potampenya nas wytargacz albo wirwacz (k. 11v).

W niektórych fragmentach widać, jak wciągnięcie glosy - drugiego wariantu zaburza składnię, np. na k. 8r zapisano następujący fragment:

pamyøcz czcząc albo chwaløcz napirzwey falebney albo slawøtney pa ${ }^{\mathrm{n}}$ ni dzewicze mariey matky bezey ypana naszego ih ${ }^{\text {es }} \mathrm{u}$ crista.

Jeśli uznać, że czasownik chwaląc został zapisany jako drugi wariant tłumaczenia łacińskiego memoriam venerantes, w przedstawionym fragmencie dostrzeżemy zdanie z właściwą rekcją (czcić pamięć + Gen.): pamięć czcząc \{albo chwaląc\} napirwej falebnej albo sławetnej pani dziewice. Widać też, że glosator nadpisujący wyraz chwaląc pracował rozpoznaną już techniką „wyrazową" - nie przeszkadzał mu brak gramatycznego uzgodnienia nadpisanego imiesłowu z przyłączaną grupą imienną.

W Mszy IV odpowiedniki leksykalne zapisywane są jeden pod drugim ${ }^{13}$ lub obok siebie. Niektóre z nich są wprowadzane wyrażeniem funkcyjnym albo, jednak między częścią odpowiedników nie ma żadnego spójnika. Wówczas, odczytane jako ciągły tekst, burzą spójność i budowę składniową (trudno spodziewać się budowanych asyndetycznie szeregów składniowych).

Nie da się wskazać zależności między sposobem zapisania odpowiedników (jeden pod drugim lub obok siebie) a ich wprowadzaniem do komponowanej całości, co obrazuje fragment przedstawiony na fot. 6 . Nad dwoma następującymi po sobie czasownikami łacińskimi accipite oraz manducate zapisano po dwa odpowiedniki: weszmyczye | przymyczye oraz wzyvaycze | albo geczczye.

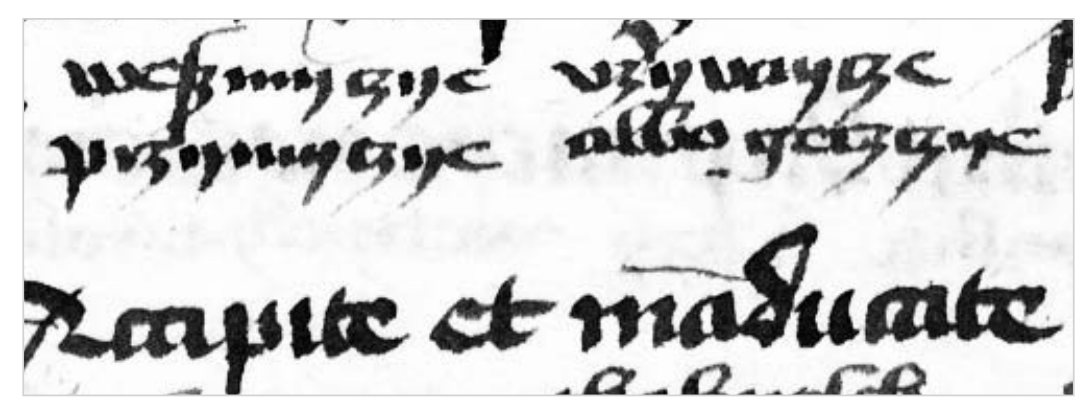

Fot. 6. Rękopis Biblioteki Jagiellońskiej, sygn. Akc. 150/54, fragment k. 246v

13 Np.: naprzo\{o\}d które dayemi obyatuyemy thobye (k. 244v), naprzothku napyrwey (k. 245r). 
Niekiedy zapisywane są obok siebie nie tylko odpowiedniki leksykalne, ale także dwie formy tego samego wyrazu, np. na k. 244v (zob. fot. 7), gdzie łacińskiej formie habeas odpowiadają dwie formy polskie: ma oraz miałby. Cała konstrukcja wygląda następująco: yako przyemnø ma myalby y przeszegnalby ty dary ${ }^{14}$. Jeśli przyjąć założenie o budowaniu przez skrybę tekstu, należałoby odczytywać ją linearnie, co w sposób oczywisty daje fragment niespójny gramatycznie i cechujący się nadmiarowością leksykalną. Skryba jednak tekstu nie budował, lecz gromadził odpowiedniki.

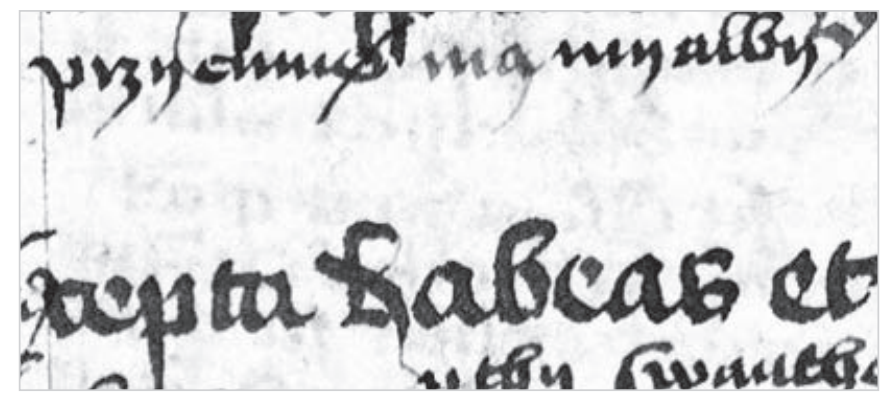

Fot. 7. Rękopis Biblioteki Jagiellońskiej, sygn. Akc. 150/54, fragment k. 244V

Podobne wnioski można wyciągnąć na podstawie analizy fragmentu tłumaczenia Mszy IV, które przedstawia fot. 8:

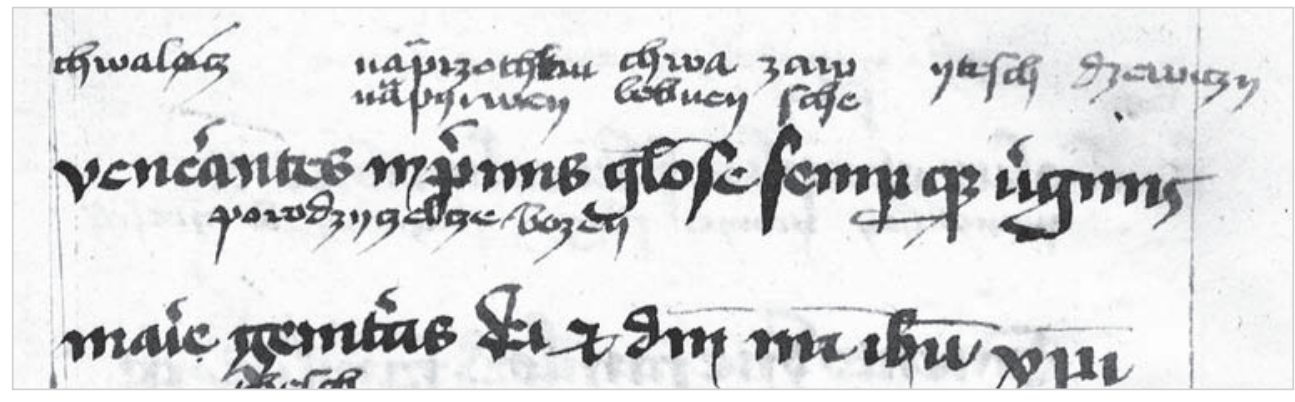

Fot. 8. Rękopis Biblioteki Jagiellońskiej, sygn. Akc. 150/54, fragment k. 245V

Łaciński fragment venerantes in primis gloriose semperque virginis marie glosator przetłumaczył jako chwaløcz na przothku napyrwey chwalebney zawsche ytesch dzewiczy, przy czym dwa tłumaczenia łacińskiego in primis znajdują się jedno pod drugim: na przothku | napyrwey. W całym rękopisie, jak już wspomniałam, glosy zapisywane były od góry, można zatem sądzić, że w pierwszej kolejności pisarz wpi-

14 W transkrypcji formę trybu oznajmującego ujęto w nawiasy kwadratowe i uznano za zbędną, zob. Leńczuk 2013: 211. 
sał tłumaczenie na przodku, w drugiej - napirwej. Być może i tu gromadził on w ten sposób różne odpowiedniki leksykalne, podobnie jak czynił to wielokrotnie, np.:

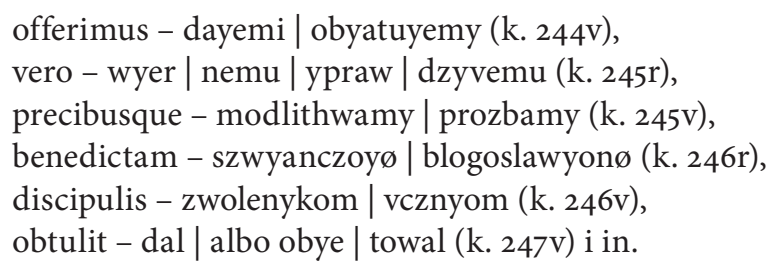

W przytoczonym wyżej fragmencie istotne jest także dosłowne tłumaczenie słów gloriose semperque virginis. W łacinie spójnik que (oznaczający między innymi 'i, oraz, także') przyłączany jest do zakończenia wyrazu, którego bezpośrednio dotyczy, w polskich konstrukcjach odpowiednik tego spójnika oczywiście poprzedza dany wyraz. Tymczasem zarówno w tym, jak i w wielu pozostałych tłumaczeniach kanonu mszy św. ${ }^{15}$ (co ważne - także w Mszy III, zapisanej osobno) oddano łacińską strukturę: chwalebnej zawsze i też dziewicy, co wprost pokazuje dbałość nie o budowanie tekstu zgodnie z polską składnią, ale właśnie o dokładne tłumaczenie wyrazów i konstrukcji łacińskich, także pod względem układu elementów językowych. W polszczyźnie nie tylko zachowywany jest łaciński szyk, ale także oddawane są dokładnie formy gramatyczne. W omówionym fragmencie venerantes in primis gloriose semperque virginis marie tłumacz zachował łacińską rekcję venerare + Dat. (venerare gloriose virginis), $\mathrm{w}$ glosie bowiem mamy chwalić + Dat. (chwalić chwalebnej dziewicy) zamiast chwalić + Acc. M. Leńczuk pisze, że w kanonach

miejsc, w których polski tekst respektuje właściwości gramatyczne tekstu łacińskiego, jest zdecydowanie więcej od tych, w których polskie glosy pod względem gramatycznym nie są ścisłym tłumaczeniem łaciny (2013: 73)

\section{Kompletność tłumaczenia}

W literaturze przedmiotu wielokrotnie podkreślano niepełność poszczególnych redakcji, pisano np. o „prawie kompletnym przekładzie”, co może świadczyć o niewyrażonym explicite założeniu badaczy, że ktoś zamierzał stworzyć kompletny

15 Np. zapis nad fragmentem Memento domine famulorum famularumque tuarum w Mszy IV (oraz podobnie w Mszy III) wygląda następująco: pamøthay panye slug sluzebnyczk ytesch twich (k. 245r).

16 Jednak M. Leńczuk przeciwstawia je nie formom właściwym polszczyźnie, ale takim, które „zachowywały jedynie wartość semantyczną tłumaczonego wyrazu [...]. W wypadku glos objaśniających, które jedynie przybliżały ogólne znaczenie łacińskiego leksemu, tłumacz nie brał pod uwagę jego cech gramatycznych" (2013: 73). 
przekład. Rozważając problem tekstu w odniesieniu do tej grupy zabytków, warto zwrócić uwagę na miejsca wymagające - z dzisiejszej perspektywy - uzupełnienia. Trzeba bowiem pamiętać, że polskie tłumaczenia z założenia nie musiały być kompletne, ponieważ nie miały one funkcjonować bez łacińskiej podstawy. Jak wiadomo, w średniowieczu przekładanie kanonu mszy św. nie wypływało z chęci sprawowania eucharystii w języku narodowym, ale przede wszystkim z potrzeb praktycznych, zwłaszcza dydaktycznych ${ }^{17}$. Wobec tego można sądzić, że tłumaczenia na język wernakularny zawsze były nierozerwalnie związane z tekstem łacińskim.

Najbardziej kompletny jest, także ze względu na postać graficzną, zapis Mszy III. Mamy tutaj do czynienia z tłumaczeniem, w którym nie oddano zaledwie kilku wyrazów z łacińskiej podstawy, co, poza nielicznymi wyjątkami, nie zaburzyło pod względem składniowym spójności polskiego tekstu.

W rękopisie Mszy IV glosator zostawiał miejsca na uzupełnienie tytułów oraz imion, zarówno tych aktualizowanych na bieżąco w ustnej realizacji łacińskiego tekstu, np. szslugø thwym <papa nostro $M>y$ thesch [...] (zob. fot. 9), jak i tych zapisanych $\mathrm{w}$ tekście głównym ${ }^{18}$ :

y tesch dzewiczy <marie> porodzyczelcze bozey <et domini nostri ihesu xpisti> Thesch <et beatorum apostolorum ac martyrum tuorum Petri et Pauli Andree Jacobi Johanis Thome Jacobi Philipi Bartholomei...> (k. 245v, zob. fot. 10).

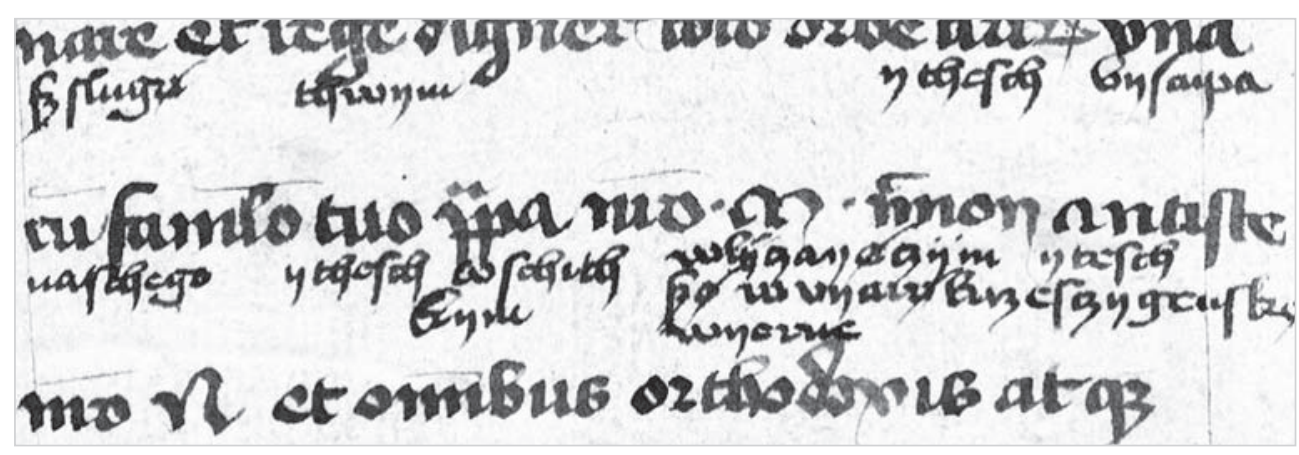

Fot. 9. Rękopis Biblioteki Jagiellońskiej, sygn. Akc. 150/54, fragment k. 244V

17 Obszernie - w oparciu o całą dostępną literaturę przedmiotu - pisze o tym M. Leńczuk, przywołując liczne źródła potwierdzające nieznajomość łaciny wśród kleru i wymogi rozumienia kanonu mszy przez księży (ibid.: 57-64).

18 Choć niekiedy zapisuje imiona Maryi i Chrystusa, por. np.: tego crista szyna thwego pana naschego blogoslawyonego (Msza IV: k. 247r). 


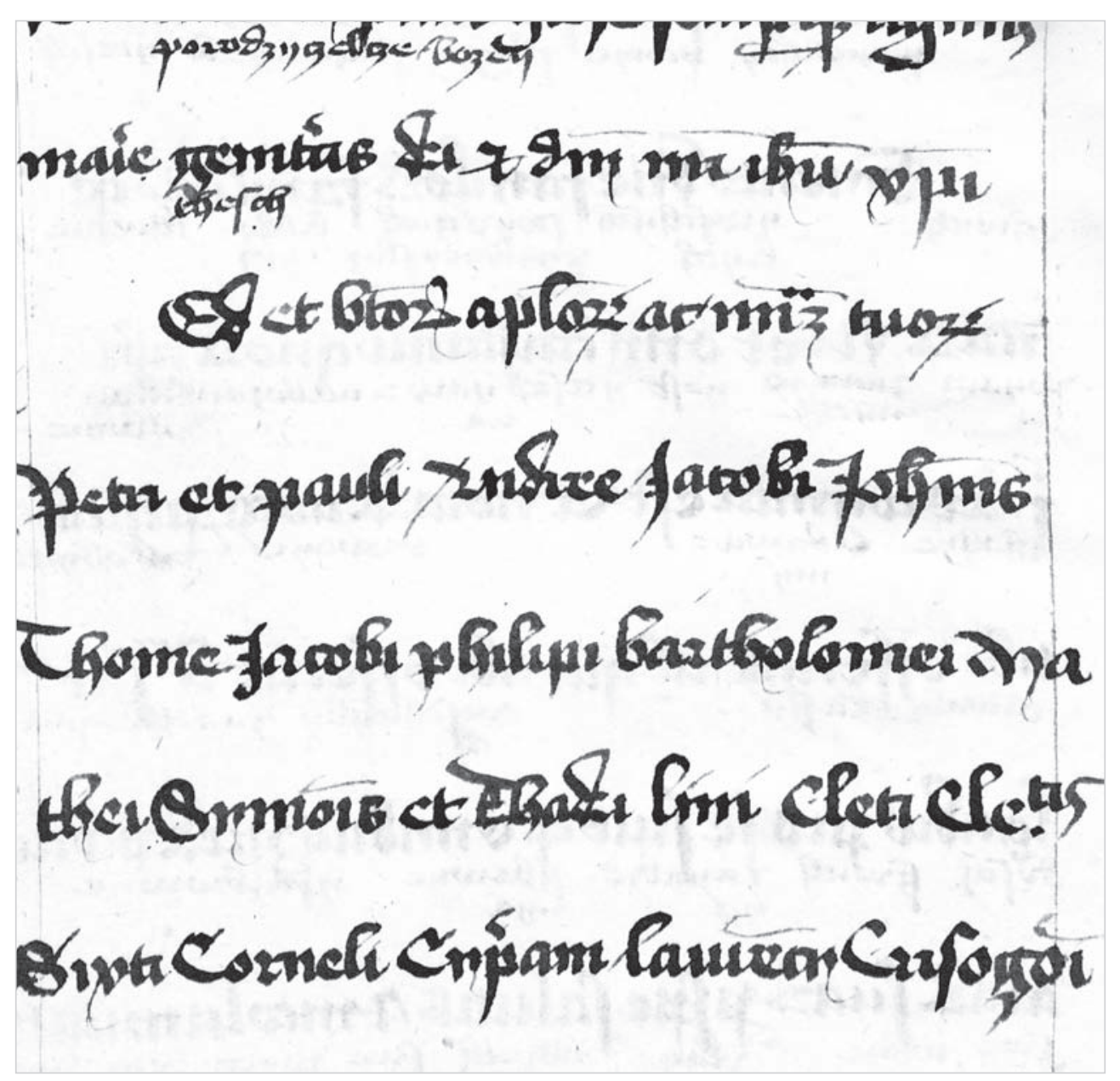

Fot. 10. Rękopis Biblioteki Jagiellońskiej, sygn. Akc. 150/54, fragment k. 245V

Podobnie rzecz ma się w obu pozostałych rękopisach, czyli w Mszy XII i Mszy $X V I$, w których pomija się tłumaczenie konwencjonalnych zwrotów, np. per ihesum cristum filium tuum dominum nostrum (Msza XII: k. 5ra), per eundem Christum dominum nostrum (Msza XVI: k. 68v), oraz imion papieża, biskupa i króla: papyezyem nyaschim <Martino $>$ ysbiskupem nyaschem <Sbigneo $>$ yskrolyem nyaschem $<$ Wladislao> (Msza XII: k. 5rb; zob. fot. 11). 


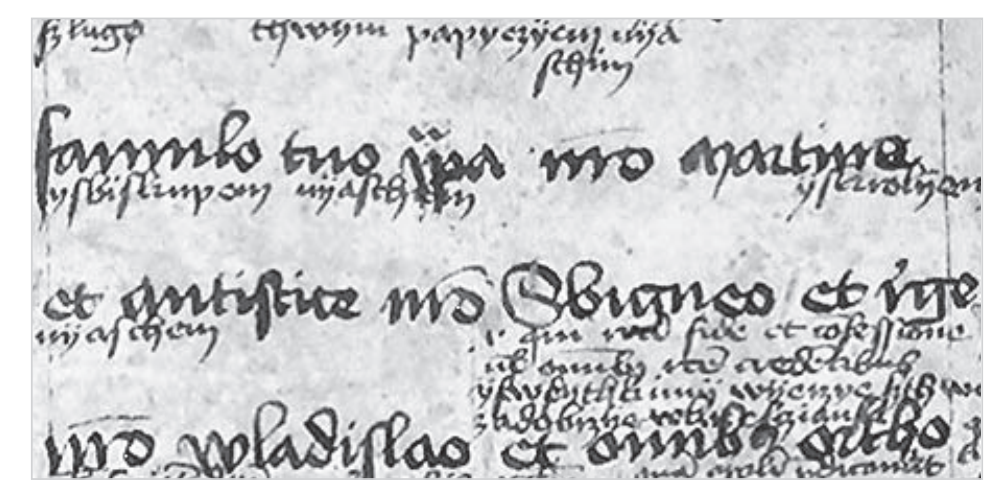

Fot. 11. Rękopis Archiwum Archidiecezjalnego w Gnieźnie, nr MS 6o, fragment k. 5rb

To, że pisarz nie tłumaczy nazw własnych związanych z konkretnym momentem dziejów (imię władcy lub papieża) bądź terytorium (imię biskupa), zdaje się dowodzić, że zwyczajowo nie przekłada się elementów oczywistych, niepotrzebnych, w tym także pewnych formuł. Można również sądzić - zwłaszcza w odniesieniu do Mszy XII, gdzie pisarz nie tłumaczy imion znajdujących się w łacińskim tekście - że celem jest przełożenie językowych składników schematu ${ }^{19}$, który będzie funkcjonalny w wielu sytuacjach, jest wystarczający do nauki, zrozumienia łacińskiego kanonu mszy św., a nie do jego realizacji w postaci tego konkretnego, zapisanego na karcie tekstu. Jest to oczywiste ze względu na przeznaczenie i wykorzystywanie tego typu rękopisów.

W tym miejscu warto zwrócić uwagę na sposób, w jaki współcześnie wydaje się staropolskie kanony mszy św. Zdradza on przekonanie wydawców, że prezentują one tekst. Dlatego zapisy niepełne, ale zawierające bardzo dużą liczbę glos (z omawianych tu rękopisów mowa przede wszystkim o Mszy XII i Mszy XVI, które wymagają najwięcej uzupełnień), są w wielu miejscach obficie uzupełniane, by z dzisiejszej perspektywy mogły zostać uznane za kompletne i spójne. W ten sposób utrwala się przekonanie o tekstowości tych zabytków.

19 Schemat rozumiem tutaj jako ukształtowany, niepodlegający zmianom (ustabilizowany) tekst, w którym występują miejsca pozostawione do obligatoryjnego wypełnienia (aktualizowania) podczas jego ustnej realizacji. W przypadku kanonu mszy św. takimi miejscami, uzupełnianymi podczas odprawiania liturgii, są imiona papieża, biskupa, zmarłych, świętego z danego dnia. W schemacie przyjmują one formę zwrotów lub fraz: „wraz ze sługą Twoim Papieżem naszym N. i Biskupem naszym N.”, „Pomnij, Panie, na sługi i służebnice Twoje N.N.”, w realizacji są uzupełniane aktualnymi danymi w zależności od czasu i miejsca sprawowania liturgii oraz intencji mszalnej. 


\section{Podstawa tłumaczenia. Świadomość tekstu}

Rozważając charakter polskich dopisków do łacińskiego kanonu mszy św., trzeba mieć na uwadze także podstawę tłumaczenia. Może nią być albo sam łaciński tekst kanonu, albo tekst wraz z łacińskimi komentarzami ${ }^{20}$. Ważne jest, że w przypadku łacińskiej podstawy mówimy o tekście kanonu mszy św., który jest tłumaczony. Efektem tłumaczenia nie jest natomiast, jak pokazały analizy, polski tekst, ale zbiór tłumaczeń poszczególnych wyrazów lub konstrukcji. Wynika to z intencji glosatora i z funkcji polskich glos do kanonu.

W poszczególnych redakcjach łacińskiej podstawy można zaobserwować nieliczne rozbieżności. Analiza M. Leńczuka wykazała, że są to przede wszystkim różnice leksykalne (zwłaszcza w obrębie wyrażeń funkcyjnych), a także uzupełnienia $\mathrm{w}$ stosunku do podstawowego tekstu. Wynikają one $\mathrm{z}$ równoległego funkcjonowania wariantów tekstu, niekiedy także ze środowiska, w którym powstał dany odpis (Leńczuk 2013: 45-52). Spostrzeżenia M. Leńczuka warto uzupełnić uwagą o charakterze genologicznym. Zapisany tekst łaciński jest najczęściej schematem wypełnianym w zależności od potrzeb w realizacji ustnej. Miejsca zmienne (np. imię papieża) są przygotowane do uzupełnienia, w tekście łacińskim czytamy np.: papa nostro $\mathrm{N}$. Niekiedy jednak (tak jest w wypadku Mszy XII) mamy do czynienia z realizacją, w której wszystkie takie miejsca są uzupełnione konkretnymi informacjami, aktualnymi w momencie tworzenia danej redakcji.

W dwóch zatem perspektywach (1. podstawą tłumaczenia jest tekst kanonu lub tekst kanonu oraz komentarze, 2. podstawą tłumaczenia jest schemat lub jego realizacja) należy rozważyć świadomość podstawy tłumaczenia u polskich glosatorów.

Kwestia różnego podejścia skrybów do tłumaczonego tekstu jest w sposób szczególny widoczna w dwóch zabytkach: Mszy XII oraz Mszy XVI. Jak już wspomniałam, glosator Mszy XII dopisywał do tekstu głównego nie tylko jego polskie tłumaczenie, ale także łacińskie komentarze. W modlitwie za Kościół (In primis) w Mszy XII czytamy: cum famulo tuo papa nostro Martino et antistite nostro Sbigneo et rege nostro Wladislao et omnibus orthodoxis \{id est qui vera fide et confesione vel omnibus vere credentibus\} atque catholice et apostolice fidei cultoribus (k. $5 \mathrm{rb}$ ). Fragment ujęty $\mathrm{w}$ nawiasy klamrowe skryba ciasno wpisał w interlinii nad zapisem et omnibus ortho (zob. fot. 12). Pod nim, w trzeciej i czwartej linijce w interlinii oraz w kolejnej linii nad drugą częścią łacińskiego słowa orthodoxis, znajduje się polskie tłumaczenie: ysewsythkimy wyerzye szthwer $\mathrm{L}_{\text {dzonimy }}$ zadobrzye $w$ krzescziansk $\mathrm{L}_{\text {skyey wyerze }}$ zywøczye (k. 5rb).

Warto ponownie zwrócić uwagę na układ graficzny tłumaczenia. Jest on świadectwem tego, że zapisywane w interliniach polskie odpowiedniki nie miały układać

20 Przy czym komentarze mogą być zapisane w interliniach, jak w wypadku Mszy XII, lub wciągnięte do tekstu głównego, jak w wypadku Mszy XVI. 
się w ciąg, ważne było natomiast ich zapisywanie w odpowiednim miejscu na karcie. Trzeba też zauważyć, że pisarz tłumaczy zarówno tekst główny, jak i fragmenty łacińskiego komentarza zapisanego między liniami (tłumaczenia łacińskich glos do kanonu mszy św. M. Leńczuk nazywa metaglosami (ibid.: 80-84)).

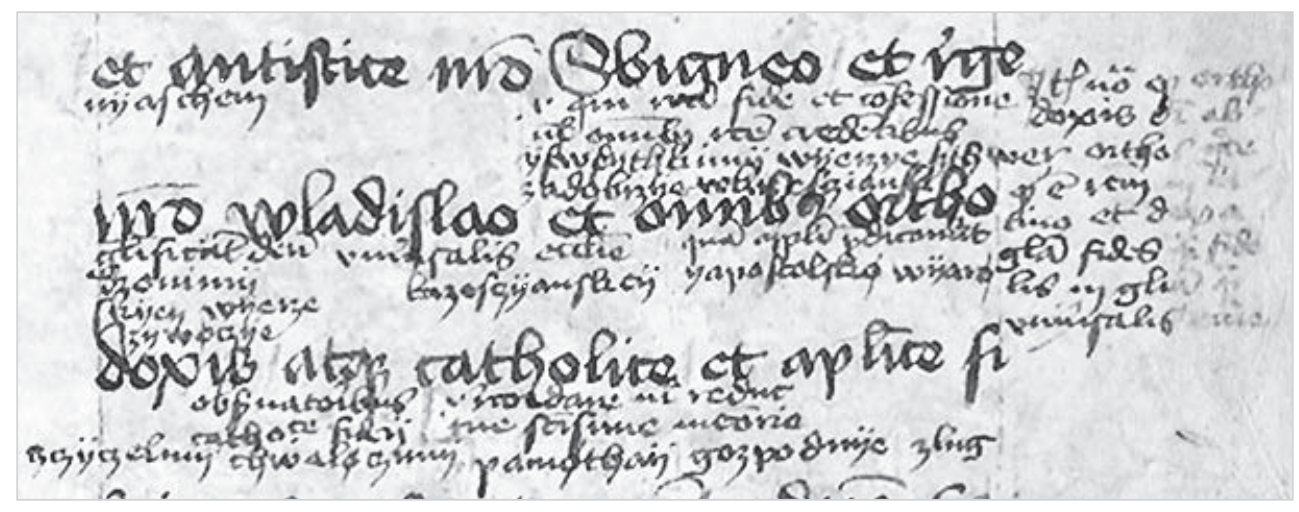

Fot. 12. Rękopis Archiwum Archidiecezjalnego w Gnieźnie, nr MS 6o, fragment k. 5rb

Zupełnie inaczej jest w rękopisie Mszy XVI. Tutaj w łaciński tekst główny zostały włączone elementy (niekiedy obszerne) genetycznie nieprzynależące do kanonu mszy św., np. na k. 68r:

Rogamus ac petimus Hic te erige Vti accepta habeas et benedicas hec do + na // Adhec dona faciat vnam crucem cum duobus digitis ita que in dextera sunt desuper et medius subtus ad hec + munera facias secundam crucem terciam ad hec san + cta sacrifcia Illibata

lub na karcie 68v:

Quam oblacionem tu deus in omnibus quesumus bene + dictam \{super totum facias vnam crucem secundam ad Adscrip + tam $\mathrm{Ra}+$ tam racionabilem acceptabilem que facere digneris vtnobis quartam hic ad cor + pus super hostiam quintam ad et sangtuis fiat dilectissimi fily tui domini nostri ihesu xpisti hic accipiat hostiam in manus et tunc dicet $[\ldots]$.

Wytłuszczone tutaj elementy nie należą do kanonicznego tekstu mszy św. i ich glosator nie przetłumaczył, skupił się na glosowaniu słów oraz konstrukcji wyłącznie z łacińskiego kanonu.

Przedstawiona analiza prowadzi do wniosku, że mimo iż w obu zabytkach znajdowały się i tekst kanonu, i komentarze (zapisane w interliniach lub wciągnięte do tekstu głównego), dla obu pisarzy co innego było podstawą tłumaczenia. Skryba Mszy XII tłumaczył zarówno tekst kanonu, jak i dopisywane do niego łacińskie glosy. Być może najważniejsze było dla niego zrozumienie jak największej liczby ele- 
mentów łacińskich zapisanych na karcie. Jeśli przyjąć tę hipotezę, można sądzić, że glosowanie służyło nauce łaciny, i uznać podejście glosatora za bardzo szkolne. Tłumaczenie słów i konstrukcji tak z kanonu, jak i z komentarzy także w tym świetle nie może być zatem uznane za budowanie tekstu. Natomiast dla glosatora Mszy XVI istotny był tylko kanoniczny tekst łaciński. Pierwszy skryba, twórca tekstu głównego, poprzez wciągnięcie do zapisywanego tekstu elementów genetycznie obcych zbudował bardziej obszerną całość (wykraczającą poza tekst kanonu), glosator zaś konsekwentnie pomijał w tłumaczeniu wszystkie te fragmenty. Choć nie stworzył polskiego tekstu (co wykazały dotychczas przedstawione analizy), to jednak miał znacznie większą świadomość podstawy tłumaczenia niż pisarz Mszy XII.

Jeśli chodzi o drugą perspektywę (schemat - jego realizacja), we wcześniejszej analizie Mszy XII starałam się dowieść, że tłumaczone były elementy składające się na schemat, a nie jego realizacja. Oczywiście nie da się stwierdzić tego z całą pewnością, trzeba bowiem brać pod uwagę wspomniany już szkolny zapis, w którym tłumaczono nie tylko tekst kanonu, ale także komentarze. Wydaje się jednak, iż nie bez znaczenia jest to, że pisarz tak uważnie oddający wszystkie łacińskie słowa szczegółowe informacje pozostawił nieprzetłumaczone ${ }^{21}$. Może to świadczyć właśnie o oczywistej potrzebie tłumaczenia elementów i struktur schematu, a nie jego konkretnej realizacji.

Przedstawione analizy pozwalają stwierdzić, że w odniesieniu do zabytków obficie glosowanych możemy mówić albo o tłumaczeniu pojedynczych słów/konstrukcji oraz o gromadzeniu odpowiedników leksykalnych, albo o próbie tworzenia przekładu tekstu. Aby uznać dany zbiór dopisków za tekst, nie wystarczy zatem odwołać się do podstawowego - i dotąd najczęściej jedynego - kryterium ilościowego (związanego z kompletnością tłumaczenia, liczbą glos). W świetle nowych badań nad tekstem staropolskim wydaje się, że trzeba je uzupełnić o kryteria wynikające $\mathrm{z}$ dwóch cech definicyjnych tekstu: funkcję tworzonej przez skrybę całości oraz intencję pisarza. Tu zaś pomocna jest wiedza historyczna oraz kulturowa dotycząca sposobów funkcjonowania zabytków danego typu oraz analiza składniowa zapisków.

Trzeba bowiem zauważyć, że przy uwzględnieniu intencji autora oraz funkcji całości spójność i kompletność nie są warunkami koniecznymi do uznania danego zabytku za tekst. W przypadku kanonów mszy św. wynika to między innymi z podstawowych cech zabytków tego typu. Jak stwierdzono wcześniej, tłumaczenia kanonu nie funkcjonowały w oderwaniu od łacińskiej podstawy. Tutaj to ona przynajmniej z perspektywy współczesnego odbiorcy (także edytora) - gwarantuje spójność tłumaczenia, pozwala dzisiejszemu wydawcy na proste uzupełnienie nieprzetłumaczonych miejsc, a tym samym (bardzo często) na budowanie lub utrwalanie przekonania o tekstowości tych zabytków. Tymczasem w wielu przypadkach

21 W pozostałych rękopisach również nie tłumaczono tych formuł, ale najczęściej pomijano je w całości. 
nawet przetłumaczenie wszystkich łacińskich słów oraz konstrukcji składniowych nie powinno decydować o tym, by polskie dopiski uznać za tekst. Wydaje się, że trzeba o nich mówić jako o kompletnym zbiorze glos. Przemawia za tym zarówno ich postać graficzna (nadpisywanie pojedynczych słów czy konstrukcji bezpośrednio nad ich łacińskimi odpowiednikami), jak i gramatyczna: dokładne oddawanie łacińskich konstrukcji oraz form fleksyjnych (niezgodne z polską gramatyką) oraz gromadzenie wielu odpowiedników leksykalnych jednego elementu.

\section{Źródła}

Msza III, rkps Zakładu Narodowego im. Ossolińskich we Wrocławiu, sygn. 2080/II.

Msza IV, rkps Biblioteki Jagiellońskiej, sygn. Akc. 150/54.

Msza XII, rkps Archiwum Archidiecezjalnego w Gnieźnie, nr MS 60.

Msza XVI, rkps Biblioteki Narodowej w Warszawie, sygn. Akc. 9889.

\section{Literatura}

GeSner A., 2011, Glosy w Rozmyślaniu przemyskim. Wyniki analizy formalnej i perspektywy badań, „Kwartalnik Językoznawczy” nr 3, s. 89-97.

LeŃCZuk M., 2013, Staropolskie przekazy kanonu Mszy Świętej. Wariantywność leksykalna, Warszawa.

MasŁej D., 2016, Modlitwa Pańska w polskim średniowieczu. Znad staropolskich rękopisów, Poznań.

MASŁEj D., w druku, Zbiór glos czy tekst? Kazania augustiańskie jako problem edytorski i naukowy, [w:] K. Borowiec i in. (red.), Jak wydawać teksty dawne?, „Staropolskie Spotkania Językoznawcze”, t. 2, Poznań.

Mika T., 2015, Tekst staropolski jako odmienny obiekt badań? W poszukiwaniu narzędzi opisu, „LingVaria” nr 2 (20), s. 235-250, [on-line:] http://dx.doi.org/10.12797/LV.10.2015.20.18.

Pietkiewicz R., 2013, Tradycja rękopiśmienna polskich przekładów biblijnych od XIII do XVI wieku, „Wrocławski Przegląd Teologiczny” nr 2 (21), s. 29-50.

Twardzik W., 1994, Glosy w „Rozmyślaniu przemyskim”, „Teksty Drugie” nr 3, s. 155-165.

Wydra W., 1973, Polskie dekalogi średniowieczne, „Silva Medii et Recentioris Aevi”, nr 2, Warszawa.

Wydra W., Rzepka W.R., 2004, Chrestomatia staropolska. Teksty do roku 1543, wyd. 3, Wrocław. 


\section{A contribution to the discussion on Old Polish text. Analysing the Canons of the Mass Summary}

The paper analyses selected mediaeval Canons of the Mass from a text linguisctic perspective. It focuses on four monuments which are considered glosses from the point of view of the formal criterion (the placement on the page), and texts from the point of view of their shape (the degree of development). The analysis includes the graphical shape of the annotations, the syntax of the Polish passages with respect to the Latin prototype, the base and the completeness of the translation. This multi-faceted analysis leads to the conclusion that mediaeval Polish glosses to the Canons of the Mass consitute not a text but a complete collection of glosses. This conclusion is justified by both their graphical and grammatical shape: verbatim rendering of Latin constructions and inflections (inconsistent with Polish grammar), and accumulation of multiple lexical equivalents of a single element. When working with this kind of monuments, one needs to take into account not only the quantitative criterion (completeness of the translation) but also the function of the whole that the scribe created, and the intention of the author. 

Piotr Sobotka

Uniwersytet Mikołaja Kopernika, Toruń

psobotka@umk.pl

Magdalena Żabowska

Uniwersytet Mikołaja Kopernika, Toruń

zabowska@umk.pl

\section{WYODRĘBNIANIE, DEKODOWANIE I KLASYFIKACJA HISTORYCZNYCH JEDNOSTEK JĘZYKA}

Słowa klucze: historyczna jednostka języka, lingwistyka statyczna, lingwistyka dynamiczna, klasyfikacja składniowo-semantyczna części mowy, zaimki, wyrażenia metatekstowe

Keywords: historical unit of language, static linguistics, dynamic linguistics, syntactic and semantic classification of parts of speech, pronouns, metatextuals

W dwóch artykułach (por. Sobotka 2017a, 2017b) zaproponowano wprowadzenie do badań historycznojęzykowych terminu historyczna jednostka języka: omówiono w nich m.in. główne metody rekonstrukcji takich jednostek, tzn. metodę rekonstrukcji wewnętrznej i rekonstrukcji historyczno-porównawczej (Sobotka 2017a) oraz opisano sposoby odtwarzania znaczenia jednostek historycznych za pomocą narzędzi wypowiedzeniowych (struktur informacyjnych) i składniowych z uwzględnieniem nadrzędnego kryterium metod rekonstrukcji (Sobotka 2017b). Przedmiotem niniejszego artykułu jest prezentacja i zoperacjonalizowanie pojęcia historycznej jednostki języka oraz opis problemów związanych $\mathrm{z}$ wyodrębnianiem takich bytów (przede wszystkim w odniesieniu do wyrażeń nieodmiennych), a także wstępny projekt klasyfikacji dawnych jednostek nieodmiennych. Część materiałową artykułu poprzedzają przyjęte w nim podstawowe założenia teoretyczne. 
1. W badaniu języka zasadniczo stosuje się dwa typy obserwacji (na których podstawie formułuje się sądy ogólne): analityczny i syntetyczny. Zastosowanie łącznie jednego i drugiego możliwe jest jedynie w wypadku badania języków współczesnych ${ }^{1}$, ponieważ analiza, zakładająca rozłożenie elementów języka na składowe oraz wiążąca się z prowadzeniem obserwacji na kolejnych poziomach o coraz większym stopniu szczegółowości, w sposób konieczny wymaga kompetencji językowej, i to nie w jakimś ogólnym zarysie, lecz na każdym poziomie istnienia języka (od planu wyrażania po plan treści, czyli na płaszczyźnie fonologicznej, morfologicznej, leksykalnej, syntaktycznej, semantycznej i pragmatycznej). W odniesieniu do języka dawnego ujmowanego systemowo nie analizuje się danego zjawiska czy podsystemu, lecz je syntetyzuje, czyli rekonstruuje. Przede wszystkim ustala się podstawowe elementy systemu (w prezentowanym tu ujęciu: historyczne jednostki języka) i ich własności, określa się reguły ich dystrybucji, zakłada możliwe ścieżki ewolucji, ewentualnie charakteryzuje się ich kontekst i definiuje zasady ich oddziaływania z kontekstem. Taki sposób podejścia pozwala na odtworzenie na podstawie tekstów, bez dostępu do pewnych danych na temat rzeczywistych jednostek języka ${ }^{2}$, systemu jako całości. Podstawowym bowiem przedmiotem opisu badań lingwistycznych jest system języka. W formułowaniu wniosków na temat elementów systemu nie chodzi o wskazywanie różnorodnych funkcji danego wyrażenia w zależności od kontekstu, ale o wskazanie konstytuującej dane wyrażenie funkcji, którą ono spełnia niezależnie od typu tekstu lub gatunku tekstu. Także w obserwacjach historycznojęzykowych (nie tylko więc w ujęciach współczesno-synchronicznych) możliwy jest systemowy (nieizolowany) opis elementów języka. Dowodem na istnienie systemu są:

(1) dla elementów nieznaczących - reguły fonologii, a w aspekcie dynamicznym prawa głosowe i ogólne reguły analogiczne, np. prawo Kuryłowicza-Mańczaka (Kuryłowicz 1945-1949; Mańczak 1978),

(2) dla elementów znaczących - reguły tworzenia semantycznie poprawnych konstrukcji, a w aspekcie dynamicznym - regularne wzorce motywacyjne (por. Zalizniak 2008), np. 'chwycić/pojąc' $\rightarrow$ 'zrozumieć', por. pol. pojąć, ros. понять, fr. saisir, comprendre, ang. to catch .

$\mathrm{W}$ ujęciu historycznojęzykowym system (zwłaszcza w aspekcie semantycznym) może być jedynie rekonstruowany (syntetyzowany) na poziomie funkcjonalnym,

1 Model odgórno-oddolny, który przewiduje zarówno analizę, jak i syntezę, to m.in. teoria Igora Mielczuka SENS $\Leftrightarrow$ TEKST (Мельчук 1974; Mel'čuk 1982, 2001, 2012, 2013, 2015). W dużej mierze stanowi ona źródło inspiracji dla prezentowanej w tym artykule propozycji opisu jednostek historycznych.

2 Przyjmujemy za Andrzejem Bogusławskim rozumienie terminu jednostka języka (por. Bogusławski 1976, 1988, 2008). Zważywszy na to, że w żadnym wypadku o dawnych wyrażeniach nie da się z całą pewnością orzec, że są one takimi a takimi jednostkami języka, terminu jednostka języka nie da się zoperacjonalizować w odniesieniu do tekstów dawnych. 
nie zaś na poziomie pojęciowo-funkcjonalnym, nie dysponujemy bowiem metodami seryjnego wydzielania takich kategorii, jak np. agentywność, kauzatywność, następstwo, przyczynowość, współzależność itd. Jednostką opisu historycznojęzykowego nie jest jednostka języka / leksem³, lecz intuicyjnie zakładana realizacja formalno-treściowa pojęcia (jednostka historyczna) - dany (jednosegmentowy bądź wielosegmentowy) kształt służący do wyrażania rekonstruowanej treści. Historyczną jednostką języka może być wyrażenie dziedziczone (o historycznej ciągłości na gruncie jednego języka) lub zapożyczone albo utworzone w danym języku za pomocą mechanizmów derywacji bądź kompozycji czy innych tego typu przekształceń ${ }^{4}$. Również jako specyficzne historyczne jednostki języka należy traktować dziedziczone bądź zapożyczone elementy znaczące języka umożliwiające takie przekształcenia (afiksy bądź segmenty „odczuwane” jako afiksy). Jednostka historyczna ma zarówno wymiar statyczny, jak i dynamiczny. W języku wszystko się zmienia, synchronia jest zjawiskiem pozornym - to „szczególny przypadek ruchu w warunkach minimalnych zmian" (Baudouin de Courtenay 2016: 39). Na diachroniczne badanie języka składa się zatem nie tylko rekonstrukcja procesów i tendencji językowych (aspekt dynamiczny diachronii), lecz również obserwacja tego, co jest historycznie trwałe i stabilne (aspekt statyczny diachronii).

Ze statycznego punktu widzenia historyczna jednostka języka to kształt tekstowy w jego rzeczywiście semantycznym aspekcie - znaku językowego złożonego z formy i z przypisanej jej treści, powiązanej w niektórych wypadkach z zakresem nazw. Od strony dynamicznej jednostka taka ma formę niestabilną, lecz możliwą do umotywowania za pomocą: (a) zmian regularnych, (b) przekształceń analogicznych bądź (c) zmian nieregularnych spowodowanych frekwencją, zawiera ona ponadto potencjalne komponenty semantyczne i gramatyczne, często niewykrywalne w analizie statycznej (zazwyczaj tekstowej), które są z jednej strony dziedziczone od etymonu (w uproszczeniu można je nazwać komponentami etymologicznymi), z drugiej zaś odkrywane jako dziedziczone dopiero w jednostce powstałej z analizowanej jednostki historycznej, będącej etymonem dla nowego wyrażenia (w uproszczeniu określamy je komponentami asocjacyjnymi). Jednostkę historyczną języka obserwujemy zatem w trzech wymiarach: w stanie aktualnym (statycznym), w procesie zmiany, której efektem jest stan aktualny, oraz w procesie zmiany, która doprowadzi do przekształcenia stanu aktualnego w inny stan. W badaniu należy uwzględnić również tendencje dynamiczne, które są widoczne w jednostkach powstałych z jednostek wyjściowych/aktualnych (np. leksykalizację czy gramatykalizację). Podstawowymi metodami wyodrębniania historycznych jednostek języka są

3 Minimalny system tworzą cztery jednostki języka (co pozwala na zbudowanie proporcji) - w analizie współczesno-synchronicznej system jest odtwarzany na podstawie dostępnych relacji paradygmatycznych i syntagmatycznych. 
rekonstrukcja wewnętrznojęzykowa i rekonstrukcja historyczno-porównawcza (szerzej zob. Sobotka 2017a).

Do podstawowych zadań lingwistyki historycznej w jej ujęciu statycznym należy wyodrębnianie jednostek historycznych i wyróżnianie klas funkcjonalnych. Dla ujęcia dynamicznego $\mathrm{z}$ kolei zagadnienie klas prawdopodobnie ma zupełnie inne znaczenie (będzie tu raczej chodziło o przechodzenie takich a takich klas w inne). Przyjrzyjmy się pod tym względem przykładowi z Rozmyślania przemyskiego (RP):

(1) Odpowiedziawszy pan jego i rzekł jemu: «Sługo zły a leniwy! Wi<e>działeś, iże żnę ja, gdziem nie siał, a zbiram, czegom nie rozsypał. Tegodla miałeś polecić <moje pieniądze> kamsorom albo tem, co pieniądze przemieniają, a ja przyszedwszy zaprawdę wziąłbych me pieniądze z zyskiem». A zatym rzekł swym sługam: «Weźmicie od niego funt moj i dajcież temu, ktory [pięć] <dziesięć> funtow ma. Boć każdemu, ktory ma, będzie dano opwito; ktory ni ma, i to, co ma, będzie odjęto (RP 490/9-22).

Edytorzy tego zabytku, idąc za rękopisem, zdecydowali się na zapis łączny zatym, traktując to słowo jako partykułowy (?)5 wykładnik nawiązania (por. RP III: 420), por. odpowiedni fragment w rękopisie:

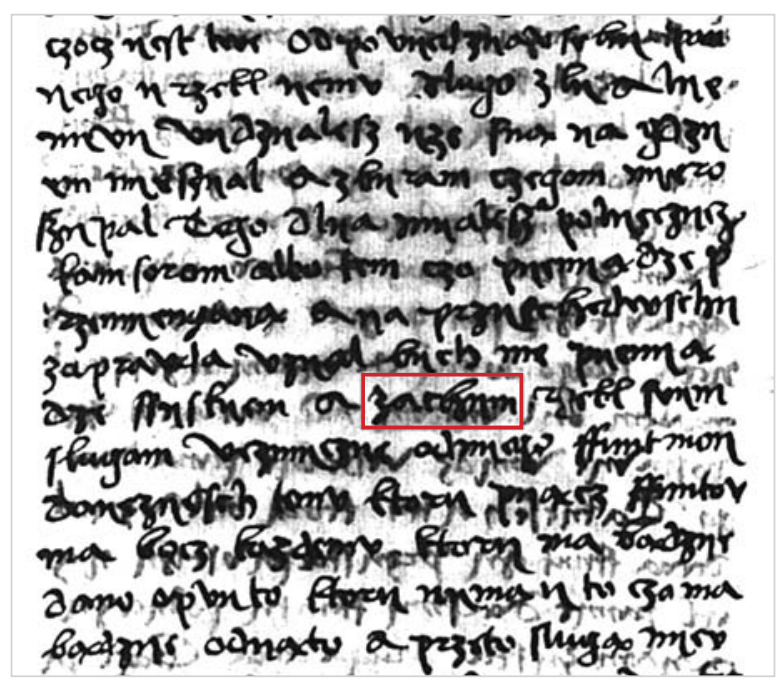

Współczesna polska partykuła zatem ma charakter wynikowy: za jej pomocą mówiący wskazuje, że gdy jest tak, że zachodzi dany stan rzeczy, to można również powiedzieć, że zachodzi inny stan rzeczy (por. Grochowski, Kisiel, Żabowska 2014: 216-218), np. Seanse byly tanie, a zatem przyciagaly wielu chętnych (NKJP). $\mathrm{Z}$ historycznego punktu widzenia $z a t e m$ to połączenie przyimka $z a$ i zaimka w na-

5 Ze względów dystrybucyjno-semantycznych nie mógłby to być spójnik: spójniki nie kookurują ze sobą, a przecież omawiane zdanie rozpoczyna spójnikowe - jak się zdaje - $a$. 
rzędniku tem/tym ${ }^{6}$. Przyimek $z a$ z narzędnikiem m.in. wyrażał w strukturze zdania stosunek przyczynowy (por. Pasoń 1976: 27-28), natomiast zaimek pełnił właściwą sobie funkcję deiktyczno-anaforyczną. Krystyna Kleszczowa (2014: 133), omawiając XVI-wieczną partykułę zatem/zatym, pisze: „źródłem partykuły zatem jest anaforyczne użycie zaimka to" i dodaje w przypisie:

$\mathrm{Na}$ anaforyczny źródłosłów polskich partykuł zwrócił mi uwagę Piotr Sobotka (2014b), omawiając analogiczne przykłady w artykule: Partykuły greckie - pochodzenie i wybrane problemy opisu.

Wyrażony wówczas przez Sobotkę sąd nie w pełni oddaje istotę rzeczy, czego ewidentne potwierdzenie odnajdujemy w przykładzie (1). Wyrażeniu zatym odpowiadają $\mathrm{w}$ paralelnych tekstach ewangelicznych łac. itaque $e^{7}$ oraz gr. oũv $v^{8}$. Pierwsze z nich nosi dość wyraźne znamiona tekstowego operatora wnioskowania, powstałego $\mathrm{w}$ wyniku połączenia zaimka ita $\mathrm{z}$ operatorem -que, drugie natomiast jest niejasnego pochodzenia, a jego wartość w języku greckim koiné również należy łączyć $\mathrm{z}$ wnioskowaniem, wyrażaniem konkluzji. Porównanie zatym $\mathrm{z}$ jego odpowiednikami łacińskim i greckim pozwala sformułować częściową hipotezę na temat funkcji tekstowej polskiego wyrażenia, lecz nie daje odpowiedzi na pytanie o jego naturę funkcjonalno-pojęciową: nie wiemy bowiem, czy mamy do czynienia ze zleksykalizowaną jednostką partykułową, czy może z konstrukcją jednostek, a jeśli to drugie, to jakie funkcje pełnią w tej konstrukcji przyimek i zaimek; tej wątpliwości zresztą nie rozwieją paralelne teksty, nawet gdyby skonstruowane były na zasadzie pełnej odpowiedniości leksykalno-gramatycznej z tekstem polskim. Interpretacja fragmentu w myśl zasad zaproponowanych wyżej (obserwacja stanu aktualnego, rekonstrukcja procesu zmiany przed stanem aktualnym i po nim) pozwala postawić hipotezę analityczną (przyimkowo-zaimkową). Wydaje się, że mamy tu do czynienia z konstrukcją, w której zaimek pełni funkcję prosentencjalną, a całość możemy rozumieć następująco: 'za tym, co zostało powiedziane [w poprzedniej wypowiedzi], powiem: .... Zaimek to ma więc charakter nie tyle anaforyczny, ile prosentencjalny i zdaje się mieć wartość referencyjno-wypowiedzeniową, jego sens można

6 Różnica między tym a tem świadczy o dawnym mieszaniu się narzędnika i miejscownika.

7 Respondens autem dominus eius dixit ei: Serve male et piger, sciebas, quia meto, ubi non semmo et congrego, ubi non sparsi; oportuit ergo te committere pecuniam meam nummulariis, et veniens ego recepissem utique quod meum est cum usura. Tollite itaque ab eo talentum et date ei, qui habet decem talenta; omni enim habenti dabitur, et abundabit; ei autem, qui non habet, et quod videtur habere, aufere Et inutilem servum eicite in tenebras exteriores; illic erit fletus et stridor dentium (Mt 25, 26-30).

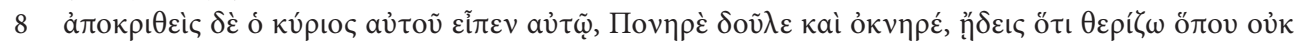

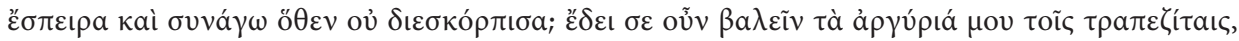

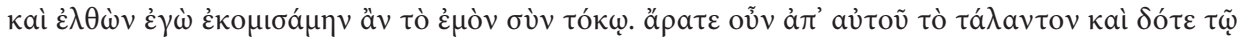

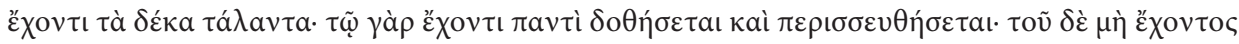

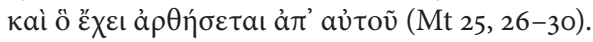


zrekonstruować jako 'to, co zostało powiedziane'. Ustalenia te opierają się również na uwzględnieniu możliwej metatekstualizacji tej konstrukcji, czego nie wykluczają XVI-wieczne przykłady użycia tego kształtu. Przyimek $z a$ z kolei nie musi pełnić funkcji przyczynowej. Może także wskazywać na współzależność zdarzeń lub ich kolejność albo zastępowanie jednych stanów rzeczy innymi ${ }^{9}$. Również z tych funkcji mogły wyewoluować sensy metatekstowe, por. ' $z a$ (= w powiązaniu $z)$ tym, co zostało powiedziane, że x, powiem y', 'za (= po) tym, co zostało powiedziane, że x, powiem y' czy ' $z a$ (= zamiast) tym, co zostało powiedziane, że x, powiem y'. Rozważany kontekst mógłby być interpretowany zgodnie ze wszystkimi wskazanymi funkcjami. Trudno rozstrzygnąć, z którą funkcją za mamy do czynienia w przytoczonym kontekście. Ostateczna weryfikacja postawionej tu hipotezy na temat funkcjonalnego statusu zatym nie jest jednakże możliwa, ponieważ nie jest możliwe odtworzenie właściwości prozodycznych omawianego fragmentu RP, nie przesądza ich także miejsce w zdaniu analizowanego wyrażenia ani jego bezpośredni kontekst leksykalny. Ustalenia Wacława Twardzika wymagałyby następującej obligatoryjnej realizacji suprasegmentalnej: A zatym 'rzekt, w proponowanym tu odczytaniu możliwe byłoby przyłożenie fakultatywnego akcentu do zaimka, por. A za'tym 'rzekł. Ponadto łączny zapis przyimka i zaimka nie przesądza jeszcze o leksykalizacji tej i innych konstrukcji, o czym też niżej.

Prezentowane tu ujęcie polega $\mathrm{w}$ pewnej mierze na projekcji tego, co w języku znane, zwłaszcza zachodzących w nim procesów, na to, co nieznane. Nie proponujemy jednak porównywania stanu współczesnego $\mathrm{z}$ minionym, bowiem $\mathrm{w}$ wypadku rzutowania (którego często nie da się uniknąć) zawsze pozostajemy w porządku współczesnym. Obiekty języka nie prowadzą żywota niezależnego od naszego ich postrzegania. Proponujemy więc statyczno-dynamiczną charakterystykę historycznej jednostki języka, biorącą w syntezie pod uwagę nie tylko dane tekstowe, wraz z uwzględnieniem obserwacji kontekstu zakładanej jednostki i jej dystrybucji w danym tekście (znalazłoby się tu również zestawienie i porównanie wszystkich wystąpień danego kształtu w tym tekście), lecz i to, co doprowadziło do powstania takiej, a nie innej jednostki o danej funkcji tekstowej, i wreszcie to, co się z nią stanie w przyszłości językowej. Uwzględniamy przy tym uniwersalne mechanizmy właściwe wszystkim etapom życia języka.

2. Wyodrębnianie i dekodowanie historycznych jednostek języka jest zawsze działaniem jednostkowym: właściwie do każdego kształtu poświadczonego w danym okresie rozwojowym języka powinno się podchodzić indywidualnie, mając na uwadze możliwość zmian formalno-treściowych. Obie czynności wymagają interpreta-

9 Zdzisława Krążyńska (2010: 57-62) wśród nieprzestrzennych konstrukcji z przyimkiem $z a$ wyróżnia m.in.: (1) quasi-przestrzenne, (2) wyrażające uprzedniość, związek, (3) czasowe. Nasze odczytanie zatem nie odbiega od możliwych staropolskich funkcji $z a$ wskazanych przez Krążyńską. 
cji i uważnej oraz możliwie jak najszerszej krytyki źródeł (czego wzór odnajdujemy m.in. w: Wanicowa 2009). Zwróćmy uwagę poniżej na kilka przykładów.

Źródło rękopiśmienne czy drukowane może zawierać błędne użycia bądź wyrażenia o cechach idiolektalnych lub specyficznych. Interpretacja danego faktu językowego winna być skonfrontowana z zamysłem autorskim. Wydawcy Żywota Pana Jezu Krysta Baltazara Opeca do wyraźnego przefto z karty $\mathrm{Q}_{5}$ dodają informację o różnicy między edycją Wietora a edycją Unglera i Sandeckiego, w której w omawianym miejscu występuje dawne i etymologicznie umotywowane przeto 'dlatego' (por. cz. proto) ${ }^{10}$ :

(2) Tamże odpowiedając, sam mowi: „O, jaciem, miły Jezu, przyczyna twej boleści, jamci zasłużenie twego zabicia i twej niewinnej śmierci”. Przezto ${ }^{8}$ wywoławając, mowi: „O, dziwnego sądu położenie, o niewymownej ${ }^{j}$ tajemnice bożej ${ }^{10}$ zrządzenie! Oto zgrzeszył niesprawiedliwy, a za to skaran sprawiedliwy, przestąpił winny, a ubit jest za to niewinny, obraził niemiłościwy, za to skazan na śmierć lutościwy" (Opec 1522/2014: 398).

${ }^{7}$ twej niewinnej - twe niewinne 1522S. ${ }^{8}$ Przezto - Przeto 1522S. ${ }^{9}$ niewymownej - niewymowne 1522S. ${ }^{10}$ bożej - boże $1522 \mathrm{~S}$.

Por. druk Wietora:

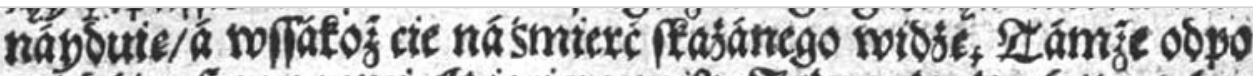

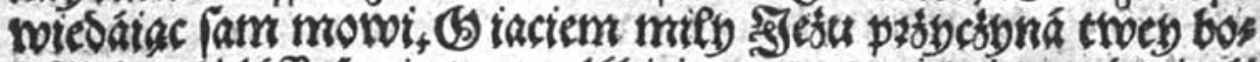

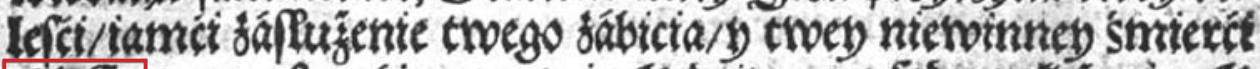

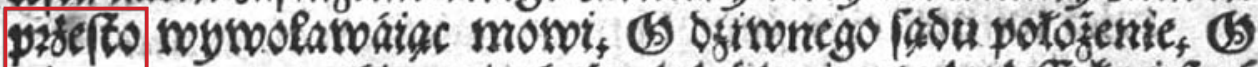

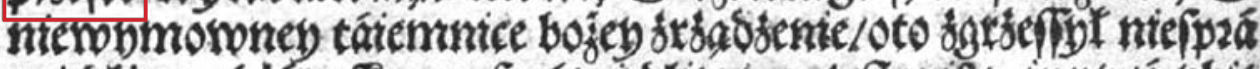

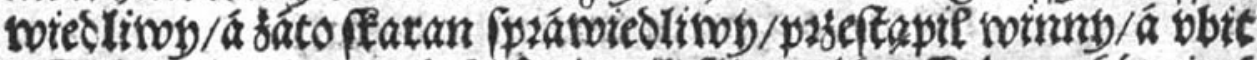

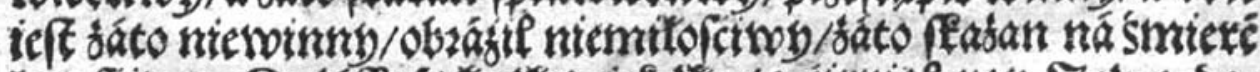

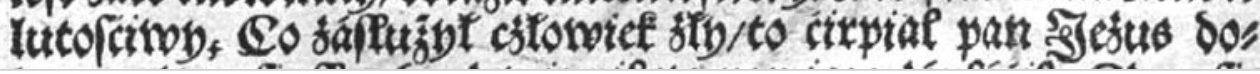

„Emendacja” Sandeckiego nie ma charakteru czysto formalnego, bowiem przeto to spójnik wnioskowania, zleksykalizowana jednostka powstała $\mathrm{z}$ połączenia przyimka ${ }^{\star}$ per 'przez' i pierwotnie wskazującego zaimka ${ }^{\star}$ to. W przykładzie (2) mamy prawdopodobnie do czynienia z deleksykalizacją przeto lub z próbą wyeksponowania jednego z członów historycznego derywatu, który - jak w przykładzie (1) należałoby uznać za konstrukcję przyimka i zaimka prosentencjalnego o znaczeniu: 'to, co zostało powiedziane'. Przy czym przez pełni tu zapewne funkcję wynikową lub wskazuje na jakiś rodzaj zależności między jednym a drugim wysłowieniem: 'ze

10 Przyimek przez jest etymologicznym złożeniem dwóch przyimków ${ }^{\star}$ per i ${ }^{\star} s$ b. 
względu na [to, co rozgłoszone ${ }^{11}$. Zauważmy, że tę interpretację wspiera kontekst z konstrukcją pleonastyczną wywoławając, mowi (szerzej na ten temat i na temat funkcji zaimków użytych przy takich układach apozycyjnych zob. Sobotka 2017b). A zatem należałoby w tym miejscu postulować istnienie dwóch historycznych jednostek języka, zapisywanych łącznie, odróżniających się od przeto, również obecnych w edycji Wietora, por. np. Przeto wielebny ociec, święty Frańciszek, nie zinąd dostapit cnot rozmaitych (Opec 1522/2014: 130), por.: 'prze + to (x), nie: prze (lub z) y', co przemawia za interpretacją przyimkowo-zaimkową omawianej konstrukcji.

W. Twardzik (1997) zauważył pewną prawidłowość związaną ze skracaniem zapisów staropolskich, której Ireneusz Bobrowski nadał następującą formułę:

Jeżeli początek następnego (po spacji) wyrazu zaczyna się tym samym znakiem (znakami), którym (którymi) kończy się wyraz poprzedni, znak (znaki) możesz zapisać tylko raz - albo na początku drugiego wyrazu, albo (rzadziej) na końcu pierwszego wyrazu (Bobrowski 2005: 382).

O lex Durani i związanych z nim trudnościach w wydzielaniu jednostek historycznych pisano wielokrotnie, dlatego ograniczymy się do przytoczenia jednej z wypowiedzi, por. np.:

Zarówno konstrukcja stworzyć ziemie, jak stworzyć z ziemie jest w średniowieczu jak najbardziej naturalna. Odczytanie zapisu z Kazań gnieźnieńskich: gest gy on szeme byl stworzil (174r/9) jako jest ji on $\boldsymbol{z}$ ziemie był stworzył jest możliwe jedynie dzięki zrozumieniu sensu zdania. Podobnie izbi ty wbostue nestiscoual (Kśw, cr 23, 37) tradycyjnie - i słusznie - czytamy $\boldsymbol{w}$ ubostwie, już nawet nie zauważając, że przyimek $w$ oraz pierwszą głoskę wyrazu ubóstwo trzeba było zobaczyć w jednym znaku graficznym (Mika 2015: 238).

Zwróćmy uwagę na jeszcze jeden przykład, w którym zaimek nie pełni swej zwyczajowej funkcji wskazywania obiektu w planie przedmiotowym. I w tym wypadku chodzi o wyodrębnienie wyrażenia, stanowiącego od strony historycznej niejako węzeł między składnią zdania a składnią wypowiedzenia. W opracowaniu Prawdziwego wyobrażenia trojga dzieci barzo strasznych i dziwnych... Jerzego Kroczaka (2007) czytamy:

(3) Kiedy ta zasłona na twarzy leżała, tedy nosa, oczu, ust nie możono widzieć i nie możono poznać, jeśli $<\mathbf{c}>\mathbf{o}$ pod tą zasłoną było.

11 W ujęciu Z. Krążyńskiej (2001: 34-39) najbliższe naszej interpretacji byłyby konstrukcje z tym przyimkiem transformujące cechę „ukierunkowanie”. 
Edytor poprawił występującą w oryginale literę $t$ na $c$ (por. Blasius 1578):

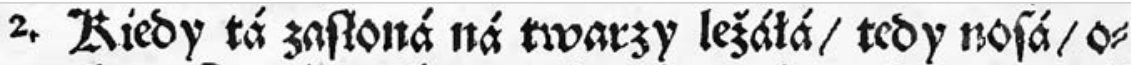

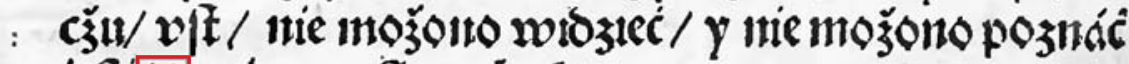 ieflito poo to zinfoita byto.}

Emendacja byłaby uzasadniona, gdyby wyraz to w sąsiedztwie operatora pytajnego jeśli 'czy' miał referencję przedmiotową. Wydaje się jednak, że należy ten zaimek odczytywać jako metatekstowy o znaczeniu 'to, co zostało wyliczone, powiedziane ${ }^{{ }_{12}}$.

Kolejną przeszkodą w rozumieniu tekstu i wyodrębnieniu składających się na niego jednostek są swego rodzaju faux amis, por. Kazanie na dzień Bożego Narodzenia z Kazań świętokrzyskich:

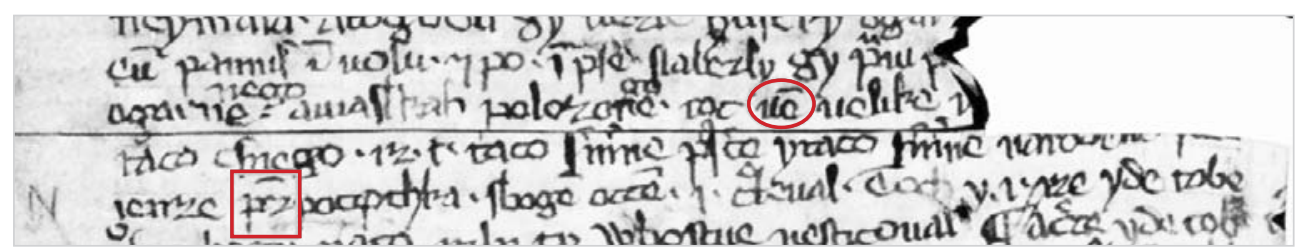

Niniejszy fragment transkrybowany bywa następująco:

(4) Naleźli ji, prawi, p<ieluszkami ... >

ogarnienego • a w jasłkach położonego • Toć wiem wielikie u<bostwo krola $>$ tako csnego • iż jeść • tako śmierne przyście i tako śmierne narodzenie • Syna Bożego,\# jenże przez początka $\bullet$ z Bogiem Oćcem • jeść • krolewał • Toć $\mathrm{i} \bullet$ jeść • iże idzie tobie (za: Mika 2012: 221-222).

Użyte w nim słowa wiem, przez przypominają współczesną formę 1. sg. praes. ind. czasownika wiedzieć oraz przyimek np. o funkcji związanej z komunikowaniem czasu trwania jakiegoś zdarzenia. Retrospektywne wyodrębnianie elementu funkcyjnego języka, niemającego przecież poza współczesnym porządkiem żadnej racji bytu, rodzi pokusę zbadania, w jaki sposób ten obiekt $\mathrm{z}$ współczesnego punktu widzenia prezentuje się w przeszłości. Powyższy przykład pokazuje, że podejście takie może być mylące. Pierwsza z niejasnych form to nie czasownik parentetyczny, lecz konektor o funkcji wyjaśniającej i uzupełniającej wcześniej przekazaną informację, na co też wskazuje kontekst całej wypowiedzi, druga natomiast, do dziś przechowywana w gwarach polskich, odpowiada współczesnemu przyimkowi bez, o czym świadczy również dopełniaczowa rekcja.

12 Zarówno za wskazanie przykładu, jak i za trop interpretacyjny dziękujemy Panu lic. Marcinowi Podlaskiemu, uczestnikowi seminarium, które Piotr Sobotka prowadzi na Wydziale Filologicznym UMK. 
Niemałą trudność wydzielania historycznych jednostek języka rodzi problem leksykalizacji i gramatykalizacji pierwotnych konstrukcji. W Żywocie Pana Jezu Krysta Opeca znajdujemy formy zapisane jako ni jedney oraz być (por. k. $\mathrm{Q}_{2} v$ ):

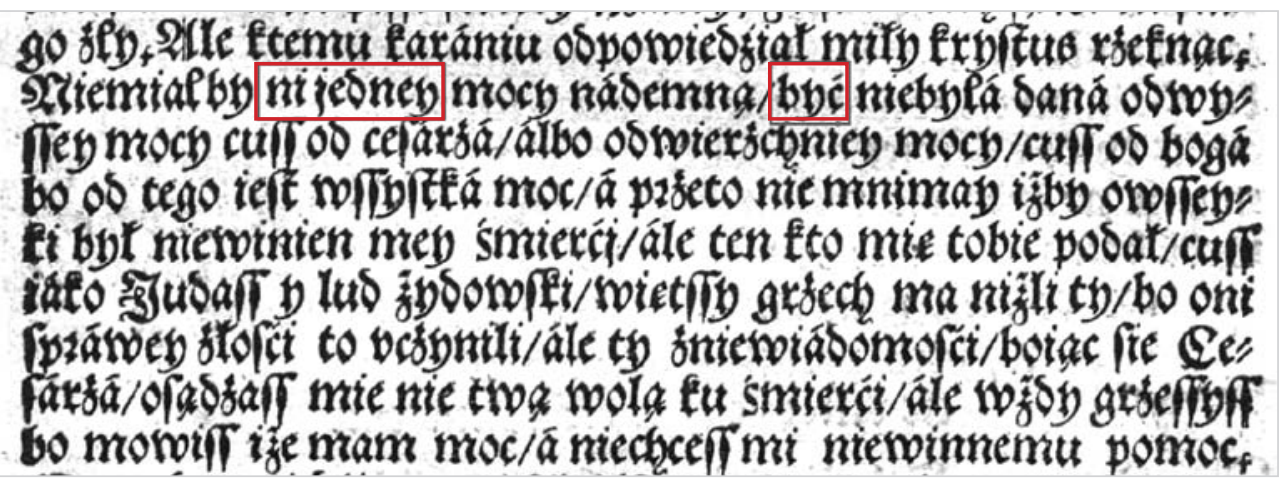

Edytorzy zabytku proponują następującą lekcję tego fragmentu:

(5) Ale k temu karaniu odpowiedział miły Krystus, rzeknąc: Nie miałby ni jednej mocy nade mną, być nie była dana od wyszej mocy, cusz od cesarza albo od wierzchniej mocy, cusz od Boga, bo od tego jest wszystka moc, a przeto nie mnimaj, iżby owszejki był niewinien mej śmierci, ale ten, kto mię tobie podał, cusz jako Judasz i lud żydowski, więtszy grzech ma niżli ty, bo oni z prawej złości to uczynili, ale ty z niewiadomości, bojąc sie cesarza, osądzasz mie nie twą wolą ku śmierci, ale wżdy grzeszysz, bo mowisz, iże mam moc, a nie chcesz mi niewinnemu pomoc (Opec 1522/2014: 388).

Istnieje subtelna różnica między ni jednej (= 'ani jednej') a nijednej (= 'żadnej'). W wydaniu Sandeckiego pierwsze z omawianych wyrażeń zostało zastąpione formą $\dot{z} a d n e$, drugie natomiast pozostało niezmienione. Jeśli uznamy, że Sandecki właściwie zrozumiał sens tej wypowiedzi, to pozorną konstrukcję ni jedney należałoby uznać za zleksykalizowany przymiotnik. Z kolei być, które oczywiście nie ma nic wspólnego $\mathrm{z}$ bezokolicznikiem o tej samej postaci, można interpretować dwojako: albo jako konstrukcję spójnika z zaimkiem osobowym w celowniku $b y$-ć(i), albo jako konstrukcję $z$ odzaimkowym operatorem -ć. Forma trzecioosobowa czasownika zdania nadrzędnego podpowiada, że mamy w tym wypadku do czynienia z odzaimkowym metaoperatorem.

Na zakończenie tego przeglądu trudności związanych z wyodrębnianiem i dekodowaniem historycznych jednostek języka zwróćmy uwagę na przykład świadczący o hipotetyczności rekonstrukcji formalno-treściowej dokonywanej w interpretacji:

(6) Żydowie jedno ji uźrą tako zabitego a tako umęczonego, kromia aczby byli kamieniem twardości, tożby sie nad nim smiłowali, ale jedwo ji uźrą, smiłują się nad nim i puszczą ji (RP 835/20-25). 
W cytowanym zdaniu pojawia się zagadkowe słowo kromia, które w rękopisie zostało zapisane jako kromya:

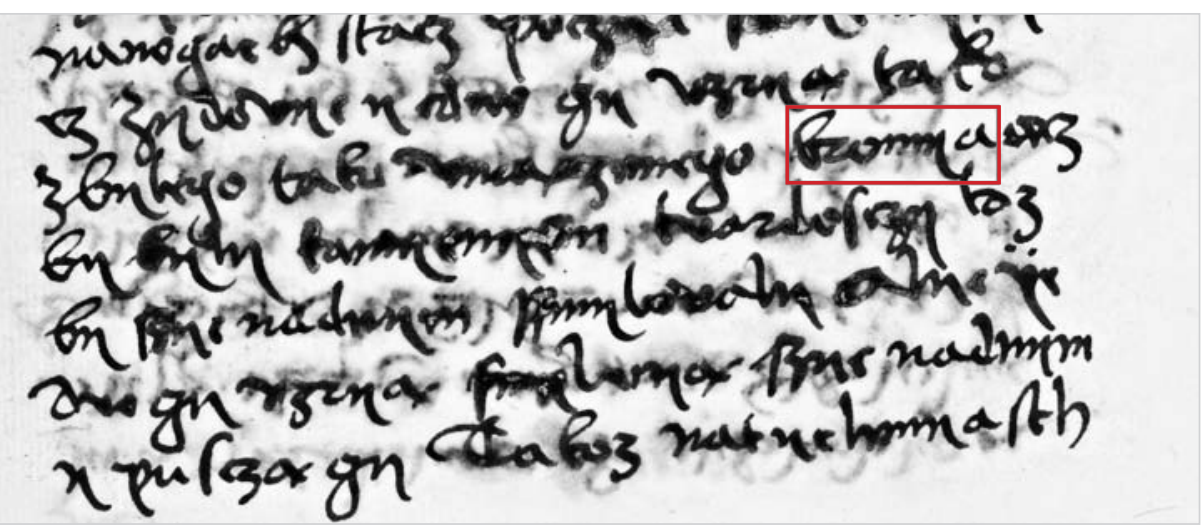

Prawdopodobnie mamy w tym wypadku do czynienia z jednostką przysłówkową lub odprzysłówkową, o czym świadczy zakończenie kontynuujące końcówkę lokatiwu $\left({ }^{*}-\check{e}\right)$. Niemniej warto porównać ten wyraz z podobnym przyimkiem o postaci krom, o którym Aleksandra Janowska (2015: 22) pisze:

Mamy więc przykłady pełnej leksykalizacji przyimków dla, prócz, krom, podług itd., gdyż nie sposób na podstawie ich budowy odczytać pochodzenia tych leksemów.

O podobnej trudności będziemy mówić i w omawianym tutaj przykładzie. Wyrażenie kromia z przykładu (6) ma swoje odpowiedniki np. w dawnym języku czeskim czy słowackim, por. tie dvere zamknuté boli, kremä kl'účovou dierkou videli, že..., a z odcieniem adwersatywnym notowane jest $\mathrm{w}$ dolnołużyckim, por. nic tak jako ja chcu, krome jako ty chces s' $^{r_{13}}$. Sens stp. kromia, którym w przykładzie (6) wprowadzane jest zdanie wtrącone, bliski jest chyba znaczeniu spójnikowemu, jak w przykładach słowackim i łużyckim, choć równie dobrze można by znaczenie tego wyrazu odtworzyć jako frazę metatekstową 'biorąc to, co mówię, na margines/skraj' (por.

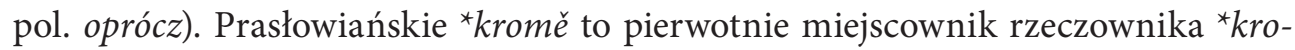
ma 'krawędź, skraj', następnie zadwerbializowany, w efekcie czego możliwe stały się przekształcenia o charakterze metatekstowym. Być może nie należy on do warstwy narracyjnej tekstu, lecz otwiera prawostronnie miejsce dla komentarza do tego tekstu.

Historyczne jednostki języka - jak to w niewielkim wymiarze i przede wszystkim w aspekcie dynamicznym zostało pokazane na kilku powyższych przykładach są rekonstruowane za pomocą wielowymiarowych narzędzi ${ }^{14}$. Mimo że proces

13 Przykłady słowacki i łużycki za: Kopečný, Šaur, Polák 1980: 377.

14 Pomijamy tu celowo opis jednostek za pomocą narzędzi interpretacji zakładanej jednostki w jej otoczeniu tekstowym, uwzględniający m.in. wszystkie wystąpienia danego kształtu w badanym 
syntezy formalno-znaczeniowej odbywa się tu w pewnym sensie w trzech wymiarach (aktualnym, przedaktualnym = etymologicznym i poaktualnym = asocjacyjnym), to jednak nie chodzi o interpretację panchroniczną, bowiem w istocie sens tych działań ogniskuje się wokół jednostki aktualnej. Historyczna ciągłość tej jednostki wymaga uwzględnienia w opisie jej komponentów dziedziczonych, które z różnych względów mogą być związane z możliwymi funkcjami sekundarnymi pełnionymi przez jednostkę, oraz komponentów asocjacyjnych, które ujawnią się dopiero w działaniu, w procesie ewolucji. Te z kolei komponenty również mają charakter sekundarny w momencie aktualnym. Historyczne jednostki języka mogą funkcjonować na różnych poziomach (zdaniowym lub wypowiedzeniowym, uwzględniającym poziom nieprzedmiotowy wypowiedzi) właśnie ze względu na ich dynamiczną labilność, co z aktualnego punktu widzenia można przedstawić za pomocą ekspozycji albo funkcji prymarnych lub sekundarnych ${ }^{15}$. Rozróżnianie obu tych funkcji odbywa się na płaszczyźnie językowej, czyli wymaga pewnych kryteriów formalnych. Wydaje się, że niektóre kategorie semantyczno-gramatyczne, jak prosentencjalność, kauzatywność, następstwo, przyczynowość, współzależność, mogą być w wypadku historycznych jednostek języka odkrywane przede wszystkim w procesie syntezy, uwzględniającym statyczny i dynamiczny aspekt diachronii.

3. Klasyfikacja jednostek języka polega na wyodrębnieniu spośród całego zasobu leksykalnego kilku bardzo ogólnych klas wyrazowych, które tworzą podstawowy poziom składników gramatycznych języka (por. Wajszczuk 2010: 15). W ujęciu wyłącznie dynamicznym stałych klas wyrazowych nie ma. Mamy tu bowiem do czynienia z ciągłym ruchem: zaimki zmieniają się w spójniki czy partykuły (por. Sobotka 2014a, 2014b), imiesłowy się adiektywizują bądź adwerbializują ${ }^{16}$, adwerbia stają się przyimkami lub partykułami itd. Nieodmienne zaimki i przysłówki chętnie nasycają się nowymi treściami bądź eksponują swoje funkcje sekundarne i zaczynają pracować na wyższych niż przedmiotowy poziomach języka (por. też Danielewiczowa 2012: 98; Żabowska 2015: 73-84). To w tej grupie obserwujemy największe zmiany, ale także wyrażenia autosyntagmatyczne odmienne podlegają takim przemianom, choć znacznie rzadziej niż wyrażenia niefleksyjne, por. podoba $\rightarrow$ podobny $\rightarrow$ podobno. Ostatnim piętrem tego procesu jest wewnętrznie zhierarchizowany poziom metatekstowy (na tym jednak nie kończy się proces zmian, ponieważ

tekście. Niemniej jednak uważamy, że dzięki takim obserwacjom możliwe jest pozyskiwanie jednej ze zmiennych służących rekonstrukcji jednostki historycznej. Ten rodzaj obserwacji wydaje się szczególnie podatny na możliwe ekstrapolowanie danych współczesnych na dawne, zwłaszcza jeśli wnioski wyciąga się na podstawie niehomogenicznych i w gruncie rzeczy nieporównywalnych źródeł, por. np. wszak w SStp oraz jednak w SPXVI i Sobotka 2015b.

15 Rozumienie funkcji za Jerzym Kuryłowiczem, por. np. Kuryłowicz 1936, 1945-1949, 1948, 1964.

16 Na temat procesów adwerbializacyjnych w językach słowiańskich P. Sobotka przygotowuje odrębne opracowania: referat na XVI Międzynarodowy Kongres Slawistów oraz książkę pt. The Slavic Adverb. Processes of Adverbialization. 
i w obszarze nieprzedmiotowym dochodzi niekiedy do przekształceń, za pomocą których możliwe jest „zdeleksykalizowanie” metatekstowe, por. prawdę mówiąc $\rightarrow$ prawdę pisząc (częste w wypowiedziach na forach internetowych), krótko mówiąc $\rightarrow$ krótko piszac). W przykładowym ujęciu dynamicznym (por. “ui -k̂nuo- 'rozciągnięty, rozprzestrzeniony' $\rightarrow{ }^{*} u i-s-o$ - 'cały' $\rightarrow{ }^{\star} v b \chi z$ 'ts.' $\rightarrow{ }^{\star} v b x a k o \rightarrow v$ v̌ak/wszak) otrzymujemy być może wpisującą się w pewną tendencję ścieżkę zmian: zaimek $\rightarrow$ konektor (zob. niżej) $\rightarrow$ partykuła spajająca. Weryfikacja tej drogi przekształceń kategorialnych i ewentualne jej potwierdzenie innymi przykładami wymagają ścisłego powiązania badań dynamicznych ze statycznymi. Jednak już na podstawie zaprezentowanych wyżej przykładów można powiedzieć, że zaimkowość pierwotnego wyrażenia w tym łańcuchu przemian musiała być wzbogacona o jakieś komponenty epistemiczno-emfatyczne, które częściowo dają się zrekonstruować dzięki analizom zaimkowych $a k$-formacji (por. Sobotka 2015a, 2015b).

Klasyfikowanie historycznych jednostek języka ze statycznego punktu widzenia badań diachronicznych tylko częściowo może nawiązywać do podobnych działań przedsiębranych w analizach współczesnych jednostek języka. Całkowita adaptacja jednego spośród czterech głównych modeli podziału na części mowy jest niemożliwa. W modelu semantycznym (por. np. Szober 1923; Milewski 1965) podstawowe piętro podziału opiera się na kryterium samodzielności semantycznej (jednostki języka dzieli się na autosemantyczne i synsemantyczne), w modelu fleksyjno-dystrybucyjnym (np. Saloni 1974) podstawowym wyznacznikiem działu jest odmienność wyrażeń języka, w modelu składniowym (Laskowski 1984; Wróbel 1996; Zaron 2009) pierwsze piętro klasyfikacji opiera się na odróżnieniu wyrażeń wchodzących w jakiekolwiek relacje składniowe z innymi (syntagmatyki, wśród których znajdują się autosyntagmatyki i synsyntagmatyki) od wyrażeń poza związkami składniowymi (niesyntagmatyki), natomiast w modelu funkcjonalno-semantycznym (por. Wajszczuk 1997, 2005, 2010) głównym kryterium jest otwieranie jakiejkolwiek pozycji (leksemy vs paraleksemy) oraz otwieranie pozycji nacechowanych semantycznie bądź wchodzenie na takie pozycje przez jednostkę języka (syntaktemy vs parataktemy).

Klasyfikacja historycznych jednostek języka ze względu na fragmentaryczność danych zarówno semantycznych, jak i gramatycznych winna opierać się na kryterium semantycznym wspieranym przez kryterium syntaktyczno-funkcjonalne. W wypadku tzw. tradycyjnego podziału semantycznego nie da się wprowadzić satysfakcjonujących rozróżnień w stosunku do nieodmiennych części mowy, nie jesteśmy w stanie m.in. przy nieoczywistych i niekompletnych kontekstach systemowo odróżniać przysłówka od partykuły czy spójnika, przysłówka od przyimka itp. (zazwyczaj robimy to intuicyjnie). Adaptacja podziału funkcjonalno-semantycznego Jadwigi Wajszczuk również wymaga wprowadzenia wielu korektur wynikających z ograniczeń interpretacyjnych dawnego materiału. Przyjrzyjmy się uproszczonemu modelowi częściowo inspirowanemu klasyfikacją J. Wajszczuk (2010), uwzględniającemu przede wszystkim miejsce wyrażeń nieodmiennych w całym zasobie leksykalnym oraz wyznaczającemu ich typy: 


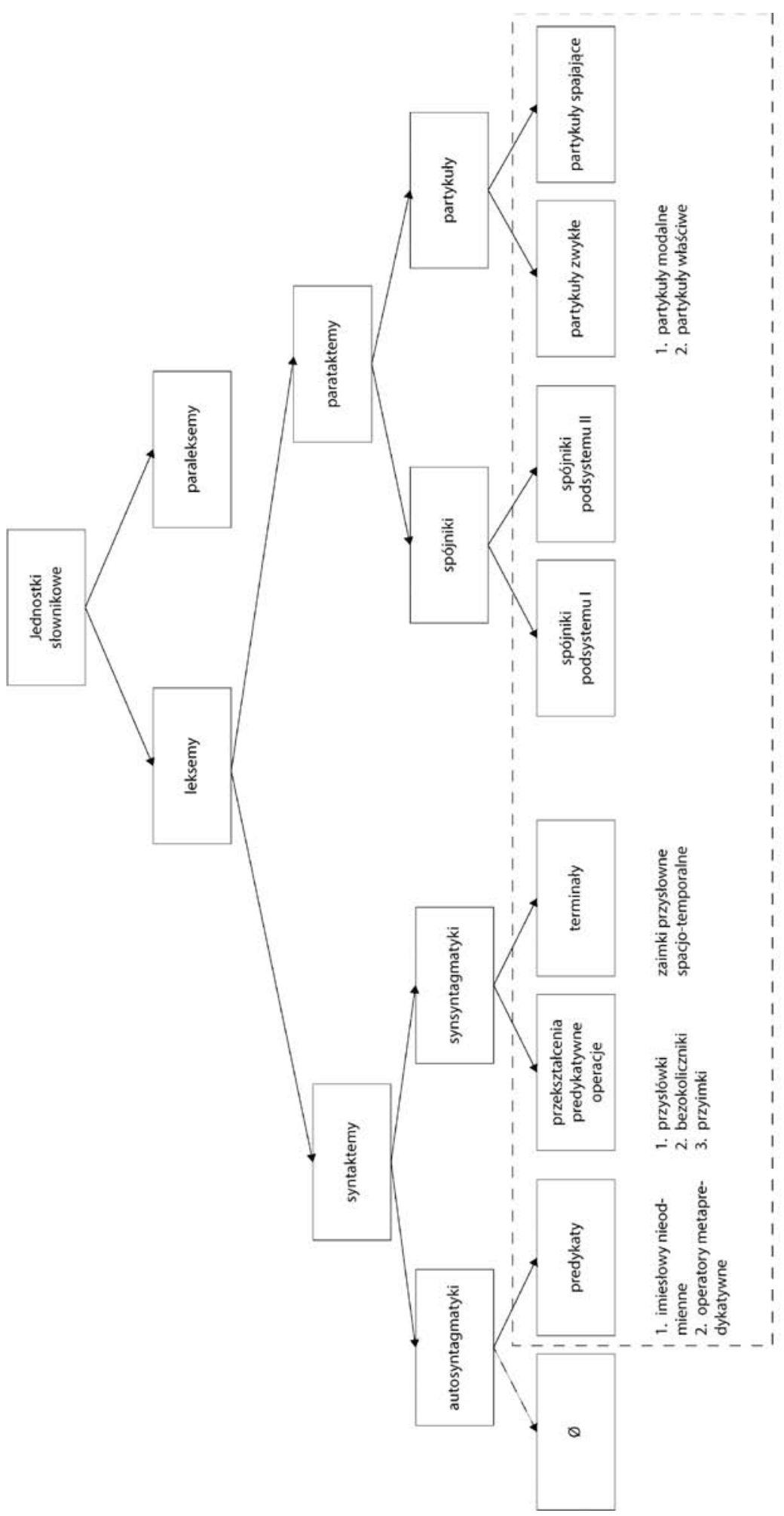


Wadą tego podziału w ewentualnej próbie dostosowania go do badań historycznojęzykowych okazuje się jego szczegółowość i charakter analityczny, który wymaga badawczego podejścia odgórnego, niemożliwego w całej rozciągłości - jak to zostało powiedziane wyżej - do zastosowania na materiale stanowiącym dla nas zagadkę - na palimpseście, którego kanonicznej warstwy nie sposób ustalić. Można jednak, wychodząc od konkretnych kategorii, przetestować podejście oddolne oparte na syntezie, w której każdą z kategorii definiuje się na podstawie kryterium funkcjonalnego. W stosunku do klasyfikacji „synchroniczno-funkcjonalnych” jednostek języka klasyfikacja historycznych jednostek języka z jednej strony musi być uproszczona, z drugiej zaś powinna przewidywać miejsce dla „pośrednich”, czyli niejasnych interpretacyjnie bytów tekstowych, które za Danešem (1985: 146-186) będziemy określać jako restryktory, kontekstualizatory i konektory.

Zakładany zasób nieodmiennych kategorii leksykalnych to: nieodmienne participium, metaoperator, przysłówek, infinitivus, przyimek, zaimek niefleksyjny, spójnik, partykuła, restryktor, kontekstualizator, konektor ${ }^{17}$. Dla części użyć tych jednostek w ujęciu historycznym rodzaj zdań, w których występują, nie jest relewantny, dla innych $\mathrm{z}$ kolei jest. $\mathrm{W}$ pierwszym wypadku będziemy mieli do czynienia $\mathrm{z}$ różnymi formalizacjami tej samej relacji semantycznej, w drugim zaś - z użyciem niezależnym konstrukcji składniowej jako całości (np. a.c.i.). Ponadto niejednokrotnie trudno - jak to pokazują konkretne przykłady - oddzielić na materiale historycznym zwykłe użycie np. participium i tym samym uznanie tego kształtu za formę czasownika, a nie jednostkę, czy infinitivu od: w pierwszym wypadku np. konstrukcji pleonastycznej z participium jako koniecznym elementem (zob. problematyczny - mimo zaproponowanej tu interpretacji - przykład (2)) czy w drugim np. od układu zbliżonego do nominativus cum infinitivo jako wykładnika modalności epistemicznej wahania, zawieszenia asercji, por.:

(7) Jesus miły dzieciątko widział sie k niem rękę podnosić a przymować ich dary a podniowszy swą rękę prawą k niem, jakoby je żegnając i weźrał na nie (RP 77, 7-11).

Interpretacja n.c.i. w powyższym zdaniu jest nieoczywista, ponieważ orzeczenia widzieci sie, choć spełniającego semantyczne wymogi składni n.c.i., nie można od strony gramatycznej traktować jako bezspornie biernego, jest to bowiem użycie medio-pasywne, a ponadto szyk omawianego zdania nie odpowiada zwyczajowemu szykowi n.c.i., między agensem czynności widzenia się a infinitivem występuje tu cały szereg innych składników: referencjalne uszczegółowienie agensa, orzeczenie

17 Ograniczenie zakresu analizowanych jednostek do wyrażeń nieodmiennych dzieli zaimki na odmienne i nieodmienne, które funkcjonalnie mogą być jednorodne, por. też stopniowanie tradycyjnie rozumianych przysłówków. Mimo to nieodmienność w ujęciu semantyczno-funkcjonalnym jest istotnym kryterium klasyfikacji ze względu na to, że wyrażenia nieodmienne nie tworzą dwustronnych związków składniowych, więc wymagają innego sposobu syntezy niż poprzez opis zależności syntaktycznych z innymi elementami zdania. 
i dopiero fraza infinitywna, ale z wyeksponowanymi na pierwszej i drugiej pozycji składnikami adiunktywnymi. Trudno też powiedzieć, czy pisarz Rozmyślania... znał ten łaciński wzorzec składniowy z jego interpretacją modalną. Niemniej jednak, gdyby przedstawiona hipoteza była trafna, to $\mathrm{w}$ zdaniu Jezus najpierw zdaje się podnosić ręce i przyjmować dary (jakkolwiek było to cudowne dziecko, to zaraz po urodzeniu chyba nie miało ono tyle siły, aby unieść „złoto, mirrę i kadzidło”), a dopiero potem rzeczywiście podnosi rękę i błogosławi trzem królom ${ }^{18}$.

Problem oddzielenia formy jakiejś odmiennej jednostki od nieodmiennej jednostki historycznej, pochodnej od tej formy, jest bardzo złożony i na obecnym etapie badań chyba niemożliwy do systemowego rozstrzygnięcia. W materiale historycznym będziemy mieli zatem równokształtne participia-formy i participia-jednostki, odmienne zaimki i wtórne spójniki pochodne od zaimków itd. W każdym takim wypadku należy dokonać interpretacji danego wyrażenia z uwzględnieniem faktu, że status bycia jednostką przysługuje tylko tym kształtom, które uznamy za symetryczne od strony formalnej i funkcjonalnej zarazem.

Każdą z wymienionych wyżej kategorii formalno-treściowych definiujemy za pomocą charakterystyki funkcjonalnej, która w tym miejscu jest prezentowana z konieczności jedynie skrótowo, bez jej rozwijania i szczegółowego opisu przykładów:

Zestaw wskazanych klas nie pokrywa się z innymi propozycjami podziału wyrażeń nieodmiennych (por. np. Grochowski 1984), nie jest bowiem podziałem gramatycznym na tak zwane klasy części mowy, lecz wyróżnioną na podstawie kryteriów logiczno-funkcjonalnych siatką wszystkich możliwych kategorii funkcjonalno-semantycznych, do jakich mogą należeć wyrażenia zarówno dawne, jak i współczesne. A zatem przykładowo relatory znajdą się w kategorii restryktorów, a korelaty zaimków względnych w kategorii zaimków niefleksyjnych, natomiast operatory pytań rozstrzygnięcia będą konektorami. Wydaje się natomiast, że pozostające poza tym ujęciem operatory trybu i modyfikatory deklaratywności można interpretować jako wyrażenia stanowiące efekt działań nadawcy na wyrażeniach, które podstawowo pełnią inne uwzględnione tu funkcje, por. ale $\dot{z}, g d z i e \dot{z}$, oby. Nasza klasyfikacja nie uwzględnia metakomentarzy w rodzaju współczesnych polskich by tak rzec, co się $t y c z y$, których pojawienie się $\mathrm{w}$ tekście związane jest $\mathrm{z}$ aktualną realizacją tego, co chce powiedzieć nadawca. Ponadto status tego typu wyrażeń (jednostka językowa, użycie, operacja) nie został dotychczas konkluzywnie rozstrzygnięty w literaturze przedmiotu ${ }^{19}$.

18 Tę hipotezę wspierają pośrednio dwa fakty. Po pierwsze, w odpowiedniku łacińskim omawianego fragmentu występuje bierna forma czasownika videbatur, por. Iesus puer videbatur manus elevare, a po drugie, Felix Keller, tłumacząc ten fragment na niemiecki, użył - zapewne zgodnie z sugestiami Wacława Twardzika - czasownika modalnego scheinen 'wydawać się', por. Das liebe Jesuskind schien die Hand zu ihnen zu heben und ihre Gaben anzunehmen (por. RP I: 151). 


\begin{tabular}{|c|c|c|}
\hline $\begin{array}{c}\text { Kategoria } \\
\text { funkcjonalna }\end{array}$ & Charakterystyka funkcjonalna & Przykład użycia \\
\hline $\begin{array}{l}\text { nieodmienne } \\
\text { participium }\end{array}$ & $\begin{array}{l}\text { jednostka odczasownikowa, otwiera } \\
\text { miejsce prawostronnie, dziedziczona } \\
\text { od czasownika strona nie ma charakte- } \\
\text { ru relewantnego }\end{array}$ & $\begin{array}{l}\text { A jako sa przyszli ku wrotom mieskiem, } \\
\text { uźrzeli niosąc umarłego jedynego syna } \\
\text { matki swej, a ta była wdowa a tegoż } \\
\text { istnego syna nasilnie płakała } \\
\text { (RP 220/12-16) } \\
\text { (por. Petrov, Twardzik 2014) }\end{array}$ \\
\hline metaoperator & $\begin{array}{l}\text { determinant predykatu, odnoszący się } \\
\text { do obiektu językowego i do nadawcy, } \\
\text { w przeciwieństwie do przysłówka } \\
\text { otwiera miejsce np. dla przymiotnika } \\
\text { czy infinitivu itd. (tym samym np. } \\
\text { staropolski intensyfikator barzo nie } \\
\text { zostanie uznany za przysłówek) }\end{array}$ & $\begin{array}{l}\text { A gdy sie to przedanie stało w Jerusalem, } \\
\text { to było prawie } w \text { ten czas, } w \text { ktory byt } \\
\text { Bog światłość stuneczna stworzyt } \\
\text { (RP 516/14-17) }\end{array}$ \\
\hline przysłówek & $\begin{array}{l}\text { determinant czasownika (określa } \\
\text { czasownik lub jest do czasownika do- } \\
\text { dawany jako jego „dookreślnik”, choć } \\
\text { czasownik nie wymaga przysłówka } \\
\text { i nie otwiera dla niego miejsca, a zatem } \\
\text { przysłówek niejako wywołuje cza- } \\
\text { sownik, wymagając czasownikowego } \\
\text { „uzupełnienia”) }\end{array}$ & $\begin{array}{l}\text { a nie poznaliście jego, ale ja znaje jej, pa- } \\
\text { kli rzku: Nie z<n>aje jego, będę podobien } \\
\text { wam łgacz... (EwKReg } 42 \text { za: SStp) } \\
\text { (nb. przykład trudny do interpretacji, } \\
\text { wydaje się, że użycie pakli w tym zdaniu } \\
\text { nosi wyraźne ślady czeskie, wszystkie } \\
\text { polskie konteksty wskazują wg A. Sło- } \\
\text { body na użycia spójnikowe w zdaniach } \\
\text { warunkowych (zob. Pawelec 2015: 106)) }\end{array}$ \\
\hline infinitivus & $\begin{array}{l}\text { determinant czasownika, otwierający } \\
\text { miejsce prawostronnie z formalną } \\
\text { blokadą miejsca lewostronnego, choć } \\
\text { z możliwą lewostronną kookurencją } \\
\text { przypadka, np. accusatiwu (por. skład- } \\
\text { nia a.c.i.), nominalny, nieodmieniający } \\
\text { się derywat czasownikowy }\end{array}$ & $\begin{array}{l}\text { Tako na środę obiecał sie przy nich } \\
\text { być a oni wszytcy mieli wielikg radość } \\
\text { (RP 496, 23-25) }\end{array}$ \\
\hline przyimek & $\begin{array}{l}\text { (sub)morfem, otwiera prawostronnie } \\
\text { miejsce dla końcówki przypadka, } \\
\text { wskazując na relację między obiektami }\end{array}$ & $\begin{array}{l}\text { Studnia była blisko Nazareta, } \boldsymbol{k} \text { niejże } \\
\text { chodziasze często <Jesus> a nosił wodę } \\
\text { swej matce (RP 123/3-5) }\end{array}$ \\
\hline $\begin{array}{l}\text { zaimek } \\
\text { niefleksyjny }\end{array}$ & $\begin{array}{l}\text { prymarny lub wtórny determinant } \\
\text { referencjalny spacjo-temporalny lub } \\
\text { prosentencjalny }\end{array}$ & $\begin{array}{l}\text { Jesus miłe dziecię wynidąc sam s } \\
\text { miasta ni miat nijednego nagabania od } \\
\text { onego źwierzęcia, ale jako sie k niemu } \\
\text { przyb<l>iżyt, tako lew poklęknąwszy na } \\
\text { swa kolana dał jemu chwałe, a gdzie-on- } \\
\text {-koli przyszedt, tu naśladując lizał jego } \\
\text { stopy (RP 138/5-11) } \\
\text { (nb. możliwe do interpretacji jako } \\
\text { zaimek niefleksyjny wyrażenie tako jest } \\
\text { prawdopodobnie konektorem) }\end{array}$ \\
\hline spójnik & determinator prawo- i lewostronny & $\begin{array}{l}\text { Ten isty obłok s nimi szedt, gdziekolwiek } \\
\text { oni szli, a gdzie stali albo siedzieli, to on } \\
\text { takież nad nimi stał (RP 87, 16-19) }\end{array}$ \\
\hline
\end{tabular}




\begin{tabular}{|c|c|c|c|}
\hline \multicolumn{2}{|c|}{$\begin{array}{c}\text { Kategoria } \\
\text { funkcjonalna }\end{array}$} & Charakterystyka funkcjonalna & Przykład użycia \\
\hline \multicolumn{2}{|c|}{ partykuła } & wyrażenie dorematyczne & $\begin{array}{l}\text { A wrociwszy sie lepak }<\text { do dzieciattka }> \\
\text { dali sa jemu chwatę a pokłoniwszy sie } \\
\text { jego matce } z \text { wielikiem weselim... } \\
\text { (RP 77/22-24) }\end{array}$ \\
\hline \multirow{3}{*}{ 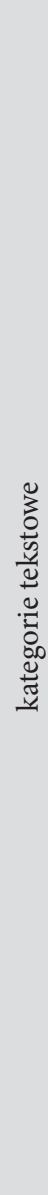 } & restryktor & $\begin{array}{l}\text { ogranicza siłę wypowiedzi do tego, co } \\
\text { jest objęte restryktorem (pseudospój- } \\
\text { nik ze znaczeniem predykatywnym) }\end{array}$ & $\begin{array}{l}\text { Maryja dziewica ostawszy }<\ldots>\text { poczęła } \\
\text { w swym żywocie }<\text { Boga }>\text {, jen }<\text { kroluje }> \\
\text { na niebie, na ziemi i } w \text { morzu, teże stwo- } \\
\text { rzył wszytki rzeczy < ... }>(\operatorname{RP} 51 / 21-23)\end{array}$ \\
\hline & $\begin{array}{l}\text { konteks- } \\
\text { tualizator }\end{array}$ & $\begin{array}{l}\text { wiąże zdanie z kontekstem (wyrażenie, } \\
\text { podobnie jak dwie pozostałe kategorie } \\
\text { tekstowe, o niejasnym statusie; zazwy- } \\
\text { czaj słowa tego rodzaju klasyfikuje się } \\
\text { jako przysłówki, przysłówki dozda- } \\
\text { niowe, spójniki lub partykuły, łączą } \\
\text { bowiem cechy tych czterech kategorii) }\end{array}$ & $\begin{array}{l}\text { „Miły synku, wspomieni na to, iżci ciebie } \\
\text { jednego mam, a tė̇ na ony słowa, ktorem } \\
\text { ja od ciebie słyszała, iżem przez boleści } \\
\text { być miała, też dzisia zbyć nie mogę. } \\
\text { Ślubowałeś, iżbych była petna miłości, } \\
\text { a wszakom w szwej żałości petna. Obie- } \\
\text { całeś przy mnie być, a dziś mię chcesz } \\
\text { samę zostawić w wielikim udręczeniu, } \\
\text { bo wim, iże twe słowo zasie ić nie może; } \\
\text { podobnie ziemi i niebu przeminać sie } \\
\text { niżli twemu słowu (RP 502/8-20) } \\
\text { (nb. pierwszy z tych kontekstualiza- } \\
\text { torów W. Twardzik interpretuje jako } \\
\text { spójnik) }\end{array}$ \\
\hline & konektor & $\begin{array}{l}\text { łączy nie tyle składniowo, ile } \\
\text { semantycznie zdania z tekstem } \\
\text { (por. spójnik niewłaściwy, partykuła } \\
\text { niewłaściwa, przysłówek w funkcji } \\
\text { łączącej, modalizator) }\end{array}$ & $\begin{array}{l}\text { Kiedyż jest to miły Jesus mowił a nikt } \\
\text { jemu nie [o]dpowiedział, tedy poczęli } \\
\text { mowić niektorzy Jerosolimianie rzekąc: } \\
\text { „Wszako to jest, ktoregoż szukaja ubić. } \\
\text { Owa już jawnie mowi a nic jemu nie } \\
\text { mowia. Zaprawdę abo sa poznały nasze } \\
\text { ksiązęta, iże to jest krystus? Ale tego } \\
\text { wimy, skąd jest, a krystus kiedy przydzie, } \\
\text { nikt nie wie, skąd będzie” } \\
\text { (RP 457/10-20) } \\
\text { (nb. Alina Kępińska (2015: 167-184) } \\
\text { interpretuje abo jako partykułowy ope- } \\
\text { rator pytania rozstrzygnięcia) }\end{array}$ \\
\hline
\end{tabular}

4. Językoznawstwo historyczne w wielu aspektach różni się od językoznawstwa opisowego, m.in. przedmiotem badań i związaną z nim terminologia. Zależność „analiz" historycznojęzykowych od teorii wypracowywanej na gruncie synchronicznym może przynosić wielorakie korzyści, lecz może również upraszczać sposób widzenia przedmiotu opisu. Językoznawca historyczny, zanim przystąpi do pracy, winien wpierw poprawnie wyodrębnić obiekt swych badań, co wydaje się jednym z najtrudniejszych zadań lingwistyki zorientowanej na rekonstrukcję przeszłości języka. 


\section{Literatura}

Baudouin de Courtenay J., 2016, Autobiogram, [w:] Materiały do dziejów polskiego językoznawstwa, t. 2: Jan Baudouin de Courtenay. Teksty mniej znane, wybór i oprac. M. Skarżyński, „Biblioteka LingVariów”, t. 21, Kraków, s. 23-57.

Blasıus J.T., 1578, Prawdziwe wyobrażenie Troyga dzieći barzo strasznych, ktorym podobne nie wiem aby kiedy były widziane na świećie..., Wrocław.

Bobrowski I., 2005, Lex Durani, „Polonica” XXIV-XXV, s. 382-383.

BogusŁawski A., 1976, O zasadach rejestracji jednostek języka, „Poradnik Językowy” nr 8, S. 356-364.

BogusŁaWski A., 1988, Preliminaria gramatyki operacyjnej, „Polonica” XIII, s. 163-223.

BogusŁaWsKi A., 2008, Semantyka, pragmatyka. Leksykografa głos demarkacyjny, Warszawa.

DANeš F., 1985, Věta a text. Studie ze syntaxe spisovné češtiny, Praha.

Danielewiczowa M., 2012, W głąb specjalizacji znaczeń. Przysłówkowe metapredykaty atestacyjne, Warszawa.

Grochowsкi M., 1984, Projekt klasyfikacji syntaktycznej polskich leksemów nieodmiennych, „Polonica” X, s. 73-97.

Grochowski M., Kisiel A., Żabowska M., 2014, Słownik gniazdowy partykuł polskich, Kraków.

JANOwsKa A., 2015, Kształtowanie się klasy polskich przyimków wtórnych, Katowice.

KĘPIŃsKa A., 2015, Polskie operatory pytajne w ujęciu diachronicznym, Warszawa - Katowice.

KleszczowA K., 2014, Zaimkowy rodowód wybranych partykut, [w:] A. Moroz, P. Sobotka, M. Żabowska (red.), Maiuscula linguistica. Studia in honorem professori Matthiae Grochowski sextuagesimo quinto dedicata, Warszawa, s. 131-140.

KopeČnÝ F., ŠAUR V., POLÁK V., 1980, Etymologický slovník slovanských jazykü. Slova gramatická a zájmena, t. 2: Spojky, častice, zájmena a zájmenná adverbia, Praha.

KrążYŃsKa Z., 2001, Staropolskie konstrukcje z przyimkami. Cz. II (po, przez, prze, mi(e)mo, nad, wz, pod, przed, za, o, miedzy + acc.), Poznań.

KrążYŃska Z., 2010, Staropolskie konstrukcje z przyimkami. Cz. IV (nad, pod, przed, za, miedzy, z + instr., o, przy, na, w + loc.), Poznań.

Kroczak J. (red.), 2007, Staropolskie przepowiednie i mirabilia, „Bibliotheca Curiosa”, t. 2, Wrocław.

KuryŁowiCz J., 1936, Dérivation lexicale et dérivation syntaxique (Contribution à la théorie des parties du discours), „Bulletin de la Société de Linguistique de Paris” 37 (110), s. 79-92.

KuRYŁOWICZ J., 1945-1949, La nature des procés dits „,analogiques”, „Acta Linguistica” 5, nr 1, S. $15-37$.

KuryŁowicz J., 1948, Zagadnienie klasyfikacji przypadków, „Sprawozdania z Czynności i Posiedzeń Polskiej Akademii Umiejętności” 49, nr 9, s. 475-478.

KuryŁowicz J., 1964, The Inflectional Categories of Indo-European, Heidelberg.

LASKOwski R., 1984, Funkcjonalna klasyfikacja leksemów: części mowy i kategorie imienne, [w:] R. Grzegorczykowa, R. Laskowski, H. Wróbel (red.), Gramatyka współczesnego języka polskiego. Morfologia, Warszawa, s. 26-37, 149-169.

MańczaK W., 1978, Les lois du développement analogique, „Linguistics” 205/16, s. 53-60, [on-line:] https://doi.org/10.1515/ling.1978.16.205.53.

MeL'Čuk I.A., 1982, Lexical Functions in Lexicographic Description, „Proceedings of the Annual Meeting of the Berkeley Linguistics Society" nr 8, s. 427-444, [on-line:] http:// dx.doi.org/10.3765/bls.v8io.2038. 
Mel'čuk I.A., 2001, Communicative Organization in Natural Language: The Semantic-communicative Structure of Sentences, Amsterdam - Philadelphia.

Mel'Čuk I.A., 2012, Semantics. From Meaning to Text. 1, Amsterdam - Philadelphia.

Mel'Čuk I.A., 2013, Semantics. From Meaning to Text. 2, Amsterdam - Philadelphia.

Mel'čuk I.A., 2015, Semantics. From Meaning to Text. 3, Amsterdam - Philadelphia.

Mika T., 2012, „Kazania świętokrzyskie” - od rękopisu do zrozumienia tekstu, Poznań.

Mika T., 2015, Tekst staropolski jako odmienny obiekt badań? W poszukiwaniu narzędzi opisu, „LingVaria” nr 2 (20), s. 235-250, [on-line:] http://dx.doi.org/10.12797/LV.20.2015. 20.18.

Milewski T., 1965, Językoznawstwo, Warszawa.

NKJP: Narodowy Korpus Języka Polskiego, [on-line:] nkjp.pl.

Opec B., 1522/2014, Żywot Pana Jezu Krysta (1522), wyd. W. Wydra, R. Wójcik, Poznań.

Pasoń A., 1976, Syntaktyczne sposoby wyrażania przyczyny w historii języka polskiego, Wrocław.

PAWElec R. (red.), 2015, Słownik zapomnianych wyrażeń funkcyjnych, Warszawa.

Petrov I.N., Twardzik W., 2014, Gdyby przysięgły człowiek widział kogo raniąc barzo, czyli o staropolskich imiesłowach nieodmiennych czasu teraźniejszego w funkcji biernej, „Język Polski” XCIV, s. 63-68.

RP: Rozmyślanie przemyskie. Transliteracja, transkrypcja, podstawa łacińska, niemiecki przekład, wyd. F. Keller i W. Twardzik, t. I-III, Weiher - Freiburg im Breisgau.

SAlONi Z., 1974, Klasyfikacja gramatyczna leksemów polskich, „Język Polski” LIV, s. 3-13.

Sовотка P., 2014a, Od zaimka do wyrażenia funkcyjnego. Dzieje prasłowiańskiego zaimka ${ }^{*}$ vbs-akъ i jego kontynuantów, [w:] A. Moroz, P. Sobotka, M. Żabowska (red.), Maiuscula linguistica. Studia in honorem professori Matthiae Grochowski sextuagesimo quinto dedicata, Warszawa, s. 141-161.

Sовотка P., 2014b, Partykuły greckie - pochodzenie i wybrane problemy opisu, [w:] K. Kleszczowa, A. Szczepanek (red.), Wyrażenia funkcyjne w perspektywie diachronicznej, synchronicznej i porównawczej, Katowice, s. 133-167.

Sовотка P., 2015a, 'Each of...' or 'Almost Each of...' The Origin and the Initial Function of the Suffix*-ak-in Depronominal, Deadjectival, and Denumeral Formations, [w:] I. Janyšková, H. Karlíková (red.), Etymological Research into Old Church Slavonic, „Studia Etymologica Brunensia", t. 18, Praha, s. 347-360.

Sовотка P., 2015b, Współdziałanie podsystemów języka w perspektywie badań etymologicznych. Znaczenie i rozwój słowiańskich zaimków ${ }^{\star} \mathrm{vb} \backslash$ akъ $i$ *edьnakъ, „Linguistica Copernicana" 12, s. 157-211, [on-line:] http://dx.doi.org/10.12775/LinCop.2015.007.

Sовотка P., 2017a, Jednostka opisu jezzyka dawnego, [w:] M. Pastuchowa, M. Siuciak (red.), Historia języka wXXI wieku - stan i perspektywy, Katowice.

Sовотка P., 2017b, Komentarz językowy a interpretacja i rozumienie tekstu dawnego, [w:] T. Mika, K. Borowiec, D. Masłej (red.), Jak wydawać teksty dawne, Poznań.

SPXVI: Słownik polszczyzny XVI wieku, t. I-IV, red. komitet redakcyjny, t. V-XVII, red. M.R. Meyenowa, t. XVIII-XXXIV, red. F. Pepłowski, t. XXXV-XXXVI, red. K. Mrowcewicz, P. Potoniec, Wrocław - Warszawa - Kraków 1966-2012.

SSTP: S. Urbańczyk (red.), Słownik staropolski, Kraków 1953-2002.

Szober S., 1923, Gramatyka języka polskiego, wyd. 2 zm. i uzup., Lwów - Warszawa.

TwARDZIK W., 1997, O uważniejszym aniżeli dotychmiast tekstu staropolskiego czytaniu i jakie z niego pożytki płyna rozprawa śliczna i podziwienia godna, Kraków. 
WAjszczuk J., 1997, System znaczeń w obszarze spójników polskich. Wprowadzenie do opisu, Warszawa.

Wajszczuk J., 2005, O metatekście, Warszawa.

Wajszczuk J., 2010, Functional Class (so Called „Part of Speech”) Assignment as a Kind of Meaning-Bound Word Syntactic Information, „Cognitive Studies / Études cognitives” 10, s. 15-33, [on-line:] https://doi.org/10.11649/cs.2010.001.

Wanicowa Z., 2009, Ignota, dubia, reperta. Czytać i rozumieć staropolszczyznę, Kraków.

Wróвel H., 1996, Nowa propozycja klasyfikacji syntaktycznej polskich leksemów, [w:] idem (red.), Studia z leksykologii i gramatyki języków slowiańskich. VI Polsko-Szwedzka Konferencja Slawistyczna, Mogilany 1-3 października 1995, Kraków, s. 53-60.

Zalizniak A.A., 2008, A Catalogue of Semantic Shifts: Towards a Typology of Semantic Derivation, [w:] M. Vanhove (red.), From Polysemy to Semantic Change. Towards a Typology of Lexical Semantic Associations, Amsterdam - Philadelphia, s. 217-232.

Zaron Z., 2009, Problemy składni funkcjonalnej, Warszawa.

ŻAвоwsкA M., 2015, O godzeniu przeciwieństw - funkcja wyrażeń jednocześnie $i$ zarazem w języku naturalnym oraz $w$ testowaniu hipotez semantycznych, „Linguistica Copernicana" 12, s. 71-105, [on-line:] http://dx.doi.org/10.12775/LinCop.2015.003.

Мельчук И.А., 1974, Опыт теории тингвистических моделей «Смысл-Текст». Семантика, синтаксис, Москва.

\section{Delimitation, decoding and classification of historical language units Summary}

The main goal of the article is to present different kinds of problems connected with the identification of the language units in Old and early Middle Polish texts, and with the various manifestations of their functional interpretation. The authors propose the term 'historical unit of language' that is understood in both dynamic and static aspects of diachrony. The major sources of these units are inherited expressions, borrowings and internal creations. The historical language unit is bilateral in nature and its semantic features consist of three dimensions: etymological, actual, and associative components. The article examines metatextual units and processes of metatextualization, as well as uses the example of Rozmyślanie przemyskie, Żywot Pana Jezu Krysta and other texts to show such problems as cohesion of the text and its comprehensiveness, especially in syntactic and utterance levels. In the second part of the article the authors present functional division of the Old Polish lexicon based on combinational and semantic characteristics of units in question, i.e. on those properties that are responsible for the tasks to be accomplished by a given class of expressions in making up a higher order unit, i.e. a syntagm. The authors centre on uninflected language units, proposing eight sentence classes and three discursive classes. Among them: uninflected participles, metapredicative operators, adverbs, infinitives, prepositions, uninflected pronominal substitutes of space and temporal expressions and whole sentences, conjunctions, particles and restrictors, contextualizators, connectors. 

Kinga Tutak

Uniwersytet Jagielloński, Kraków

kingatutak@interia.pl

\title{
FUNKCJE DWUKROPKA W POLSKICH OPRACOWANIACH NORMATYWNYCH DOTYCZĄCYCH INTERPUNKCJ (1770-1935)
}

\begin{abstract}
Słowa klucze: interpunkcja polska, opracowania normatywne dotyczące przestankowania Keywords: Polish punctuation, prescriptive works on punctuation
\end{abstract}

Przedmiotem artykułu jest charakterystyka funkcji dwukropka i jego pozycji w zbiorze znaków interpunkcyjnych. Prezentowany artykuł jest dopełnieniem opracowania, które ukazało się w pierwszym numerze „LingVariów” z tego roku (zob. Tutak 2017). Dotyczyło ono tekstowych funkcji dwukropka na przykładzie Dziejów $w$ Koronie Polskiej Łukasza Górnickiego. Przy ustalaniu roli tego znaku interpunkcyjnego wychodziłam od analizy kontekstów, w których dwukropek występował w pierwodruku i w kolejnych edycjach. Konteksty te można było ująć w kilka grup wydzielonych głównie na podstawie kryterium semantycznego, co odpowiada charakterowi interpunkcji retoryczno-intonacyjnej. Po ustaleniu owych funkcji postanowiłam je porównać $\mathrm{z}$ funkcjami przypisywanymi dwukropkowi w polskich opracowaniach normatywnych dotyczących przestankowania. Dzieje w Koronie Polskiej ukazały się w 1637 r., a więc w okresie - jak pisze Jan Godyń (1996/2009: 217) - dojrzałości interpunkcji staropolskiej. Nie ma jednak z tego okresu żadnego opracowania o charakterze normatywnym dotyczącego przestankowania w języku polskim. Dlatego w rozprawie poświęconej grafii i interpunkcji w utworach dedykacyjnych przywołałam dwa źródła obcojęzyczne: Gramatykę czeską Optata, Gzella i Philomathesa z 1533 r. oraz traktat Alda Manucjusza Młodszego Interpungendi ratio 
Z 1561 r. $^{1}$ „Interpunkcyjna cisza w Polsce” (Foremniak 2014: 101) trwa aż do 2. połowy XVIII w., wtedy pojawiły się pierwsze uwagi o charakterze normatywnym w podręczniku Walentego Szylarskiego (1770).

Funkcje dwukropka i jego pozycję w zasobie znaków interpunkcyjnych omówiłam na podstawie polskich podręczników do gramatyki, zbiorów zasad pisowni oraz traktatów interpunkcyjnych wydanych do roku $1935^{2}$. Wiek XX odegrał bardzo ważną rolę w ewolucji polskiej myśli interpunkcyjnej, wówczas nasza interpunkcja została skodyfikowana i ujednolicona, i co istotne: normalizacja miała charakter instytucjonalny (za sprawą Komitetu Ortograficznego działającego przy Polskiej Akademii Umiejętności). W 1936 r. zostały zatwierdzone Zasady interpunkcji Stanisława Jodłowskiego, wydane rok wcześniej. To wtedy doszło do "gramatyzacji” interpunkcji3 , tj. do zastąpienia interpunkcji retoryczno-intonacyjnej interpunkcją syntaktyczno-logiczną (Tutak 2013: 125). Oznaki owego „przewrotu” można jednak zaobserwować już w 2. połowie XIX w.

Przebadałam kilkadziesiąt publikacji, które ukazały się od 2. połowy XVIII w. do lat 30. XX w. Uwzględniłam tylko te opracowania, w których pomieszczono uwagi na temat interpunkcji ${ }^{4}$.

Warto zwrócić uwagę na miejsce zajmowane przez interpunkcję w dawnych podręcznikach gramatyki. Jest ona łączona z ortografią, czyli pisownią, która stanowi końcowy dział podręcznika gramatyki. Takie rozwiązanie przyjęli twórcy XVIII-wieczni, tj. W. Szylarski i Onufry Kopczyński. W XIX w. interpunkcja zaczyna się emancypować wraz z kształtowaniem się nauki o zdaniach (Podracki 2007: 258, 2016: 21) i okresach. Ars punctandi wiąże się już nie tyle ze sztuką poprawnego pisania w ogóle, ile ze sztuką poprawnego komponowania zdań i okresów. Jak pisał Feliks Żochowski,

w każdym języku składnia jest najważniejszą częścią Mowni [tj. gramatyki - K.T.], albowiem pokazuje, jak naród, używający mowy, wyrabia swoje uczucia i myśli, jak

1 Pragnę jednak podkreślić, że nie wiadomo, czy i w jakim zakresie XVI- i XVII-wieczni wytwórcy książki korzystali z wymienionych prac.

2 Zróżnicowanie genologiczne wypowiedzi o interpunkcji realizuje się już w ich obudowie paratekstowej, zwłaszcza w tytułach i przedmowach lub wstępach. Podręczniki do gramatyki dotyczą zasad i reguł, według których jest zbudowany język, w tym także zasad użycia znaków przestankowych wraz z przykładami i komentarzem dostosowanym do poziomu odbiorcy. Natomiast „prawidła pisowni”, a zwłaszcza traktaty interpunkcyjne, mają za zadanie porządek panujący w zasobie znaków przestankowych „uchwycić, steoretyzować i ułożyć w system” (Wąsik 1919: 1).

3 Termin Stanisława Furmanika (1955: 465) powtórzony przez Irenę Bajerową (1986: 49).

4 Por. Źródła w bibliografii załącznikowej. Tytuły przytoczyłam w pełnym brzmieniu, ponieważ często znajdziemy w nich informacje dotyczące autora publikacji i jej przeznaczenia (czy jest to opracowanie ogólne, czy przeznaczone do użytku szkolnego). W każdy przypadku starałam się dotrzeć do pierwszego wydania, co nie zawsze było możliwe. Czasami świadomie rezygnowałam z pierwodruku na rzecz kolejnej edycji, ale poprawionej i uzupełnionej. 
je pojmuje i wyraża. [...] Chcąc składnią zgłębić i korzyść z niej odnieść; musiemy się obznajmić z myślami, zdaniami, okresami i znakami pisarskiemi (1852: 190-191).

Kolejność wymienianych przez autora Mowni... zagadnień jest nieprzypadkowa: interpunkcja została omówiona w drugiej części podręcznika po rozdziale zatytułowanym $O$ składni. Podobny układ zastosowała większość autorów gramatyk, m.in. Jan Bohdanowicz Dworzecki, Adam Krasiński, Józef Szostakowski, Tomasz Kurhanowicz, Józef Czajkowski, Teofil Żebrawski. Inne stanowisko wobec miejsca interpunkcji w składni można zaobserwować u Stanisława Gruszczyńskiego, Adolfa Kudasiewicza, Antoniego Krasnowolskiego (w Systematycznej składni języka polskiego 1897) oraz u Ignacego Steina i Romana Zawilińskiego5. Otóż uwagi dotyczące użycia znaków przestankowych towarzyszą w tych pracach analizie zdań (od pojedynczych do złożonych i okresów). Ignacy Boczyliński połączył te dwa sposoby ujęcia i opracowania zagadnień z zakresu interpunkcji, tzn. po omówieniu kolejnych typów zdań pomieścił uwagi o znakach przestankowych $\mathrm{w}$ „zdaniu prostem, rozwiniętem, ściągniętem, złożonem” oraz w okresie. Ponadto na końcu podręcznika znalazł się Dodatek zawierający m.in. dziewięciostronicowy szkic $O$ użyciu znaków w piśmie (Boczyliński 1882: 99-108). Z kolei Konstanty Rewoliński, choć uznał składnię za jedną z ważniejszych części Głoskowni... (1845: 1), zdecydował się podporządkować ją interpunkcji: „Dla ułatwienia pojęcia o przecinkowaniu, zastanówmy się nieco o zdaniach" (ibid.: 53); i dalej:

Tak przedwstępną udzieliwszy wiadomość o zdaniach, jako przygotowawczą i ułatwiającą poznanie zasad przecinkowania, nie bez korzyści wnijść możemy w gęsty las przepisów: tak o przecinku, średniku, dwukropku, jako i o punkcie, tudzież o myślniku, łączniku, znaku rozmowy i t.d. (ibid.: 67).

Autor Głoskowni... wymienił 13 znaków pisarskich, mamy tu więc do czynienia z dość skomplikowanym systemem, więcej znaków scharakteryzowali tylko Feliks Bentkowski i Józef Muczkowski (po 14). I tak F. Bentkowski omówił następujące znaki:

komma czyli przecinek, średnik, dwukropek, kropka, punkt czyli peryjod, a linea, a capite czyli ustęp od nowego wiersza, znak pytania, wykrzyknik, łącznik, rozłącznik czyli pauza, albo znak przerwanej mowy, lub znak myśli, znak opuszczonych głosek lub wyrazów, nawias, cudzysłów, znak rozmowy (interlokucyi), czyli znak wskazujący inną mówiącą osobę, apostrof (1830: 34-5).

Najmniej rozbudowane systemy liczą sześć znaków, tak jest u S. Gruszczyńskiego i A. Kudasiewicza. Liczba omawianych znaków zatem waha się od 6 do 14 .

5 Na takie rozwiązanie zdecydował się również Florian Łagowski w drugiej części (Praktycznej, jak głosi podtytuł) swojego traktatu (1895: 56-88). 
Powodem takiego zróżnicowania liczby elementów może być pewne zamieszanie związane z nomenklaturą. W XVIII w. funkcjonowały terminy: znaki ortograficzne (Szylarski) lub znamiona pisarskielpisowne (Kopczyński). Dzięki autorom dwóch samodzielnych opracowań polskiej interpunkcji: F. Bentkowskiemu i Florianowi Łagowskiemu upowszechniły się określenia znaki przecinkowe (Bentkowski) i znaki przestankowe (Łagowski). Termin Bentkowskiego został wyparty przez znaki interpunkcyjne, w którym wyraz określający urobiono od łac. interpunctio, prawdopodobnie za pośrednictwem niemieckiego (die) Interpunktion ${ }^{6}$ (Podracki 2007: 258, 2016: 21). W tym zestawie termin znaki pisarskie (ortograficzne) jest hiperonimem, określany przez niego zbiór obejmuje ogół znaków stosowanych w piśmie czy w dru$\mathrm{ku}$, natomiast znaki przestankowe/interpunkcyjne są częścią tego zbioru (Podracki 2007: 258, 2016: 20). Takie rozgraniczenie przeprowadził konsekwentnie dopiero A. Krasnowolski w Składni języka polskiego (mniejszej) z $1898 \mathrm{r}$.

Do znaków najpowszechniejszych, o ugruntowanej pozycji w kształtującej się normie, można zaliczyć: przecinek, średnik, dwukropek i kropkę - odnotowane we wszystkich opracowaniach. Niewielkie innowacje zaszły też $\mathrm{w}$ ich nazewnictwie (Foremniak 2014: 162).

Termin $d w u k r o p e k$ nie występował u Szylarskiego, w jego Grammatyce... pojawia się grupa nominalna z liczebnikiem dwie kropki (1770: 25). Złożenie $d w u k r o p e k$ wprowadził Kopczyński, który dołączył też (przynajmniej w Grammatyce dla szkót narodowych na klassę I z 1778 r.) równoległy termin łaciński duo puncta, oczywiście pisany rozdzielnie (1803: 4). Taka nazwa zwraca uwagę na postać graficzną znaku i pojawia się nie tylko w języku polskim, ale również w języku rosyjskim (двоеточиe), ukraińskim (двокрапка), także w językach romańskich (fr. deux-points, wł. due punti, hiszp. dos puntos, port. dois pontos). W języku niemieckim są dwa leksemy: Doppelpunkt oraz Kolon, i właśnie ta druga nazwa wydobywa wartość funkcjonalną znaku, kolon bowiem oznacza jednocześnie znak interpunkcyjny i człon okresu retorycznego. Termin ten zapisywany przez $c$ lub $k$ został wywiedziony z greki i jest widoczny do dziś w wielu językach europejskich, np. w języku angielskim i w językach skandynawskich. Tak pisała o tym rosyjska lingwistka Lubow L. Iofik:

W systemach interpunkcji języków europejskich tego czasu [XVI-XVII w. - K.T.] przyjęła się tradycja określania znaków przestankowych za pomocą terminów stosowanych przez autorów antycznych dla oznaczenia okresu i jego części. „Period” oznaczał i „okres”, i „kropkę” (znak końca okresu); „colon” - człon okresu (antykadencyjny i kadencyjny) oraz dwukropek wydzielający człony okresu; „comma” najmniejszy dział, odcinek, ogniwo okresu i przecinek zarazem. Jedynie określenie średnika - „semicolon” - nie miało bezpośredniego związku z antyczną teorią okresu, ale i ono nawiązywało do tej samej zasady i oznaczało "połowę kolonu”, "poło-

6 Interpunkcyja jako ekwiwalent przecinkowania pojawia się w Gramatyce... Antoniego Małeckiego (1863: 397) oraz Jak mówić... Antoniego Bema (1889: 287). 
wę członu”, czyli środek rozczłonkowania rozwiniętych kolonów (Иофик 1961: 100, tłum. K.T.).

Dwukropek wraz z trzema, a właściwie czterema pozostałymi znakami (przecinkowi w drukach utrwalonych „łacinką”, tj. antykwą lub kursywą, odpowiadał ukośnik w tekstach wydrukowanych czcionką gotycką) tworzył pewien podsystem znaków przestankowych. W tym hierarchicznym podsystemie dwukropek zajmował miejsce między średnikiem a kropką, co było zgodne z łacińskimi zasadami przestankowania wywodzącymi się z retoryki (Foremniak 2014: 122). Tak jest u Szylarskiego i Kopczyńskiego oraz u ich następców. Szylarski podał podstawową i najbardziej ogólną zasadę użycia dwukropka:

Do dwóch kropek jeszcze zupełniejszego trzeba sensu, jak do kreski z kropką, choć nie zgoła zakończonego, jak do Peryjodu; tamta bowiem po jakiej cząstce, ta zaś w połowie Peryjodu kładzie się,

do której dołączył konteksty szczegółowe: „gdy słowa słowom, albo sens sensowi sprzeciwiający się wyrażamy” oraz "gdy z tego na czym stajemy, wnieść można, że jeszcze więcej mówić mamy, jako, gdy co wyliczać, lub czyje słowa przywodzić” (1770: 27).

Szylarski bardzo trafnie rozpoznał i określił funkcje dwukropka, zrobił to moim zdaniem lepiej niż Kopczyński, który scharakteryzował znaki interpunkcyjne głównie prozodycznie (por. Podracki 2016: 19) i uznał dwukropek za „znak przestanku większego" (Kopczyński 1803: 4). Taką definicję dwukropka podał Kopczyński w Grammatyce na klassę I. Nieznacznie uzupełnił ją w Grammatyce na klassę II: „[Dwukropek pisze się - K.T.], gdzie większy jest przestanek głosu nieco spuszczonego"8 (1780: 50) i powtórzył w Grammatyce języka polskiego (1817: 26). Z kolei w Przypisach do Grammatyki na klasse druga (przeznaczonych dla nauczycieli) pojawiają się dwie funkcje dwukropka:

7 В системах пунктуации европейских языков этого времени установилась традиция называть знаки препинания терминами, принятыми у античных авторов для обозначения периода и его частей. „Period” означало и „период”, и „точку” (знак конца периода); „colon” - член периода (повышение и понижение) и двоеточие, разделявшее члены периода; „сотma” - мельчайшее деление, отрезок, звено периода и запятую. Только название точки с запятой - „semicolon” - не имело прямого соответствия в античной теории периода, но оно было основано на том же принципе и означало „половина колона”, „получлен”, т. е. средство расчленения колонов большого объема.

8 Warto zauważyć, że ani Kopczyński, ani jego następcy nie podjęli próby sprecyzowania czasu trwania pauzy przypisanej znakom interpunkcyjnym. Natomiast u XIX-wiecznych rosyjskich autorów gramatyk, np. u Aleksandra Wostokowa i Nikołaja Griecza, ten czas jest określony; i tak według Griecza „zamilknięcie lub pauza związana z kropką równa się czterem tempom lub taktom, związana $\mathrm{z}$ dwukropkiem - trzem taktom, średnik odpowiada dwóm taktom, a przecinek jednemu taktowi" (Умолчание, или пауза, при точке равняется четырем темпам, или ударам, при двоеточии трем, при точке с запятою двум, а при запятой одному, cyt. za: Иофuк 1961: 104, tłum. K.T.). 
Dwukropek pisze się naprzód, w biegu myśli po skończonej jakiej części, która przez Spójnik z następującą częścią nie wiąże się [...]. Po wtóre, gdy przypowieść, lub zdanie jakie poważne, lub wyszczególnianie rzeczy ma następować [...] (Kopczyński 1780: 243).

\section{Według S. Jodłowskiego}

mimo tak wyraźnie retorycznego traktowania interpunkcji, znajdujemy już u Kopczyńskiego zaczątki wiązania przestankowania ze składniową budową zdań (2002: 7).

Te zaczątki są widoczne jednak nie tyle w definicjach znaków interpunkcyjnych, ile w próbach określenia przeznaczenia i funkcji tych znaków, także dwukropka.

Przedstawię teraz i pokrótce omówię funkcje tekstowe przypisywane dwukropkowi przez autorów źródeł poświęconych zagadnieniom interpunkcji.

1. Dwukropek jako znak przytoczenia - tej roli dwukropka nie uwzględniają F. Żochowski, T. Żebrawski, Wincenty Dawid i Władysław Grzymałowski. W koncepcji F. Bentkowskiego, K. Rewolińskiego, J. Muczkowskiego i Stanisława Szobera chodzi nie tylko o dosłowne przytoczenie cudzych słów, ale też o przytoczenie streszczające: „Kładzie się dwukropek, gdy się przytacza wprost cudze słowa, albo na kształt cudzych wyrazów” (Bentkowski 1830: 59). Karol Mecherzyński „przytoczenie słów cudzych albo myśli” podporządkowuje zasadzie ogólnej: „Gdy na następujące w ciągu mowy wyrazy lub zdania zwrócić chcemy uwagę czytelnika” (1841: 71). U F. Łagowskiego, A. Krasnowolskiego i S. Szobera dwukropek jako sygnał przytoczenia łączy się z cudzysłowem². Ponadto A. Krasnowolski zwraca uwagę na strukturę takiej konstrukcji:

Po słowie, oznaczającym mówienie lub myślenie (verbum dicendi vel sentiendi), czyjeś zdanie może być przytoczone dosłownie, tj. w takiej formie, jak było powiedziane lub pomyślane, $\mathrm{z}$ temi samemi zaimkami osobowemi, bez spójnika podrzędnego (1897: 293).

I. Stein i R. Zawiliński ${ }^{10}$ zalecają użycie dwukropka wówczas, gdy w mowie niezależnej przytoczenie jest poprzedzone objaśnieniem (tj. zdaniem głównym) (1907: 38). Według F. Bentkowskiego dwukropek mógł wystąpić również po przytoczeniu (1830: 59-6o). Por. przykłady użycia dwukropka jako wykładnika przytoczenia:

Proste jest ale prawdziwe przysłowie: iż złe ziele najlepiej się krzewi (Czajkowski 1853: 249).

9 Takie połączenie pojawia się dopiero w 2. połowie XIX w. Warto zwrócić na nie uwagę, ponieważ dwukropek, który sygnalizował kontur intonacyjny i potencjał semantyczny wypowiedzi, został połączony ze znakiem, który jest właściwy wzrokowemu ujmowaniu wypowiedzi (przytoczonej). 
Prawo to święte na ziemi i niebie: Kochaj bliźniego, jak samego siebie! (Wąsik 1919: 57).

Jednej książki ustawicznego czytelnika boję się, mawiał święty Tomasz z Akwinu: przez co oznaczał, iż kto nie wiele, ale z uwagą dobrych ksiąg czyta, po takim się gruntownej nauki spodziewać należy ${ }^{11}$ (Bentkowski 1830: 59).

2. Dwukropek sygnalizujący wyliczenie - nie występuje u Tomasza Szumskiego, J. Szostakowskiego, I. Steina i R. Zawilińskiego. W opracowaniach F. Łagowskiego, A. Kudasiewicza, Antoniego Bema i A. Krasnowolskiego dwukropek w tej funkcji pojawia się w kontekście tzw. zdania ściągniętego, czyli takiego, które powstaje przez opuszczenie powtarzających się wyrazów, stanowiących jednorodne części zdania ${ }^{12}$ (Foremniak 2014: 212). Krasnowolski odnotował, że dwukropek występuje w takim zdaniu po wyrazach słowem oraz mianowicie, jeśli po tym ostatnim następuje wyliczenie szczegółów (1897: 236). Według I. Boczylińskiego dwukropek mógł zamykać wyliczanie (1882: 104). Por. przykłady kontekstów, w których dwukropek zapowiada wyliczenie:

Cnoty młodych zdobiące są: skromność, pobożność, cześć Bogu, Rodzicom i starszym winna (Szylarski 1770: 27).

Dwie rzeczy człowieka szlachcą: obyczaje i rozum (Wąsik 1919: 57).

3. Pozostałe funkcje dwukropka w zdaniach nie są wydzielane w sposób jednoznaczny i konsekwentny. Warto zauważyć, że XIX-wieczni autorzy opracowań interpunkcji przywołują - w całości lub częściowo - pierwszą z czterech zasad szczegółowych użycia dwukropka podanych przez F. Bentkowskiego:

Jeżeli po okresie lub propozycyi, która sama przez się wystawia sens zupełny, dodaje się inna propozycyja, bądź jako wniosek, służąca do rozszerzenia, rozwinięcia lub objaśnienia pierwszej; bądź jako wyobrażenie oddzielne, współrzędne, a najczęściej podrzędne: natenczas po propozycyi pierwszej kładzie się dwukropek (1830: 52).

K. Mecherzyński rozbija przytoczoną zasadę Bentkowskiego na trzy zasady cząstkowe:

Kładzie się dwukropek: 1. Po skończonym zdaniu, gdy bezpośrednio następuje inne, będące wyjaśnieniem lub rozwinięciem myśli poprzedniej. 2. Przy zwrocie myśli,

11 Feliks Bentkowski tak uzasadnia obecność dwukropka po przytoczeniu: „Dla dwóch przyczyn powinien tu być dwukropek: naprzód, że autor przytacza cudze wyrazy, używszy tylko przekładni, zamiast: Ś. Tomasz mawiał: Boję się... . Po wtóre, że skończona jest propozycyja, po której kropka byłaby zbyt wielkim przestankiem, a dwukropek jest właściwym" (Bentkowski 1830: 59-60).

12 Por. przykład z Dziejów w Koronie Polskiej Górnickiego: „A Dymitr snadź Konstantego sprawą / i doświadczeniem: Ostafieja dzielnością a męstwem: Świerczowskiego radą / i trwałością: Pretwica skorością / a czułością przeszedł" (1637: 86). Nagromadzenie symetrycznych członów wspiera tu figura retoryczna zwana hypozeugmą. 
czylitakzwanem przejściu od jednego wyobrażenia do drugiego.3. Gdyzzdań poprzednich wyprowadza się wniosek, osobne mieszczący w sobie wyobrażenie (1841: 70-71).

Z kolei według F. Łagowskiego:

Jeżeli zdanie jest wyjaśnieniem albo wynikiem (wnioskiem, skutkiem) zdania poprzedzającego, zwłaszcza gdy opuszczamy odpowiedni spójnik: więc, przeto, zatem i t.d., to oddzielamy je dwukropkiem (1895: 77).

Oryginalne, nieodnotowane we wcześniejszych podręcznikach funkcje dwukropka wprowadził A. Krasnowolski w Składni języka polskiego (mniejszej):

[...] przed zdaniem czasowem odwrotnem, zamiast przecinka, można użyć dwukropka; przed dopowiedzeniem pozornem, t. j. takiem, przed którem można dodać wyrazy to jest, jeśli jest położone na końcu zdania, kładziemy również dwukropek (lub myślnik) w zastępstwie przecinka; niekiedy kładzie się dwukropek między orzeczeniem a podmiotem (jeśli podmiot następuje po orzeczeniu), a zwłaszcza wtenczas, kiedy podmiotem jest bezokolicznik, lub kiedy podmiot przy orzeczeniu ogólnie jest zapowiedziany przez zaimek to lub oto (1898: 138).

Są to jednak funkcje drugorzędne i fakultatywne, co sygnalizują czasownik modalny można czy przysłówek niekiedy. Omówione w punkcie trzecim funkcje dwukropka ilustrują następujące przykłady:

Język, mówi Leibniz, jest zwierciadłem pojęcia: więc gdzie język ciemny i niezrozumiały, tam pojęcie złe, niepewne, a może żadne: i nauka, takim językiem wykładana, nie jest nauką, ale obłudą na zbałamucenie ludzi (Bentkowski 1830: 54).

Matematyka jest królową wszystkich nauk: jej ulubieńcem jest prawda, a prostota i oczywistość strojem (Bentkowski 1830: 52; Muczkowski 1849: 292; Łagowski 1895: 77).

Otworzył biskup publiczny sąd: zbiegło się miasto na widok tak niespodziewany i nadzwyczajny (Łagowski 1895: 77-78).

Dwukropek mógł stanowić jedyny, typograficzny wykładnik delimitacji tekstu i zarazem relacji między członami. Powrócę do cytowanej już zasady użycia dwukropka zaproponowanej przez Kopczyńskiego: „Dwukropek pisze się [...] w biegu myśli po skończonej jakiej części, która przez Spójnik z następującą częścią nie wiąże się [...]" (1780: 243). Zasadę tę podają za Kopczyńskim inni autorzy prac z zakresu interpunkcji, np. J. Bohdanowicz Dworzecki, T. Kurhanowicz, J. Czajkowski.

Dwukropek bywał też wiązany z otoczeniem leksykalnym zarówno lewostronnym, jak i prawostronnym. Kontekst lewostronny stanowiły te składniki, które niejako zapowiadały, implikowały pojawienie się dwukropka. A. Krasiński wymienił następujące elementy: to jest, rzekł, mówił, powiedział (1837: 76), S. Gruszczyński: jako to, to jest, następujący i podobne (1861: 27), A. Krasnowolski: wszystko, wszyscy, 
mianowicie, jako to (1898: 137), S. Jodłowski: mówić, powiedzieć, rzec, głosić, krzyczeć, pisać; mianowicie, na przykład; (jednem) słowem, krótko (mówiąc), ściśle (mówią), innemi słowy, inaczej mówiąc; przeciwnie, odwrotnie, na odwrót, owszem; więcej, mniej, lepiej, gorzej; co więcej, co ważniejsze, rzecz ciekawa i temu podobne (1935: 25, 95-96, 102, 168). Z kolei kontekst prawostronny tworzyły składniki wprowadzające człony, które następowały po dwukropku; u Józefa Królikowskiego to, tedy (1826: 124), u A. Krasińskiego: bo, albowiem, lecz, jednak (1837: 75), u K. Mecherzyńskiego: zgoła, słowem, wszystko, inaczej, owszem, przeciwnie, nawzajem, $z$ drugiej strony i temu podobne (1841: 72-73), u A. Kudasiewicza: wszystko, nic, stowem, zgoła (1863: 94), u F. Łagowskiego: to wszystko, zgoła (1895: 82). Są to (zwłaszcza w przypadku prawostronnego otoczenia leksykalnego dwukropka) tzw. wyrażenia funkcyjne ${ }^{13}$, ja włączam je do szerszej klasy elementów metatekstowych z komponentem 'mówię’ (za Anną Wierzbicką (1971/2008: 283-284) i Jeleną Paduczewą (Падучева 1996: 276-278)). Dwukropek (jak i pozostałe znaki interpunkcyjne) sygnalizował pewne operacje na tekście, a więc metatekstowe, służył porządkowaniu materii tekstowej i odpowiedniemu gospodarowaniu nią. Gdy dwukropkowi towarzyszył leksykalny wykładnik tych operacji, nie dochodziło do zdublowania funkcji typu meta-, ale do jej wzmocnienia, podkreślenia.

Autorzy opracowań interpunkcyjnych dostrzegali rolę, jaką dwukropek odgrywał w wewnętrznym podziale okresu retorycznego. Jak zauważył Jerzy Podracki, „pojęcie »okresu (periodu) « jest bardzo charakterystyczne dla gramatyk dziewiętnastowiecznych, choć jednocześnie wyjątkowo wiele jest w nim niejasności” (Podracki 2007: 174), co potwierdzają wybrane przykłady, a właściwie próby zdefiniowania okresu podejmowane przez XIX-wiecznych teoretyków:

\section{J. Królikowski:}

Peryjod, czyli okres, składa się z kilku członków od siebie zawisłych i tak połączonych, że dopiero na końcu zupełność myśli znajdujemy (1826: 117);

\section{J. Muczkowski:}

Okresem nazywamy zdania spółrzędne lub związane tak z sobą połączone, iż jednę myśl wyrażają (1849: 255);

\section{F. Żochowski:}

Połączenie znów kilku myśli w umyśle naszym w jednę rozleglejszą całość, z pojedynczych obrazków złożoną, i oddanie ich na zewnątrz zdaniami w tymże samym związku, nazywa się okresem, czyli peryjodem (1852: 192);

13 Por. prace zbiorowe (Grochowski 1995; Kleszczowa, Szczepanek 2014) podsumowujące doświadczenia badawcze związane z opisem jednostek funkcyjnych. W monografii z 2013 r. sformułowałam postulat, by przy tworzeniu listy „historycznych” wyrażeń funkcyjnych uwzględniać towarzyszące im znaki przestankowe (Tutak 2013: 113). 


\section{J. Czajkowski:}

Połączenie dwóch zdań za pomocą spójników odpowiednich sobie, tak, że po usłyszeniu jednego zdania, koniecznie drugiego oczekujemy, nazywa się okresem czyli peryjodem (1853: 241);

\section{W. Dawid:}

Okresem czyli peryjodem nazywamy myśl całkowitą, całość w sobie skończoną i zaokrągloną (1882: 119).

Niezależnie od tych różnych propozycji definicyjnych XIX-wieczni badacze byli zgodni co do tego, że okres wymaga szczególnych zasad przestankowania - oto uzasadnienie I. Boczylińskiego:

Znaki przestankowe nie tylko ułatwiają czytanie, lecz i zrozumienie okresu, bo wskazują jego budowę i przez to uwidoczniają związek wewnętrzny, w jakim wszystkie jego części pomyślane zostały i wypowiedziane w mowie. Im bardziej złożona forma całkowitej myśli, tem różnorodniejszych potrzebuje znaków do rozprzestankowania (1882: 83).

Gramatycy dostrzegali również ważną rolę dwukropka w okresie, znak ten bowiem wiązał człony periodu zwane z greckiego kolonami lub z łaciny membrami. Człony te rozwijały się w protasis (poprzednik) i apodosis (następnik), zaś rola dwukropka sprowadzała się do wydobywania i podkreślania ich jedności semantycznej, kompozycyjnej i intonacyjnej ${ }^{14}$.

Trzeba powiedzieć, że dwukropek w tej roli miał od 2. połowy XVI wieku groźnego konkurenta w postaci średnika. Próbowano pogodzić oba znaki, dokonać repartycji funkcji tych znaków, co chyba udało się F. Łagowskiemu, który sformułował taką oto zasadę:

Między następnikiem a poprzednikiem kładzie się dwukropek, gdy okres składa się z trzech lub więcej członków; gdy zaś z dwóch, to średnik zwykle się stawia (1895: 87).

Niespełna trzydzieści lat później Jan Łoś zalecał stosowanie w tej funkcji średni$\mathrm{ka}^{15}$. Por. przykłady użycia dwukropka w okresie:

Kiedy człowiek skruszony stałym jest w swojem postanowieniu; kiedy szkodę przez siebie wyrządzoną według możności nagradza; kiedy się odzwyczaja od złego, a do dobrego nawyka: natenczas nawraca się; na nowo żyć zaczyna i skłonności swe zmienia (Muczkowski 1849: 255; Szostakowski 1849: 130).

14 Według A. Małeckiego „jeżeli okres jest dłuższy, wtedy zwyczajnie dodaje się jeszcze do dwukropka myślnik (:-)" (1863: 399).

15 „Dawniej też dwukropkiem oddzielano pierwszą od drugiej części peryjodu czyli okresu. W tym ostatnim razie używamy dziś raczej średnika" (Łoś 1924: 44). 
Gdyby zebrać razem te zmarnowane krople, powstałyby morza; gdyby stopić te iskry, powstałyby słońca; gdyby związać te ruchy, powstałyby potęgi; gdyby skupić te radości, powstałyby szczęścia: a tymczasem człowiek stoi wobec swych losów łaknący, ciemny, bezsilny i nieszczęśliwy (Hełczyński 1929: 47).

Zauważmy, że autorzy XVIII- i XIX-wiecznych gramatyk i traktatów musieli się zmierzyć z bardzo trudnym zadaniem, chodziło przecież o wyprowadzenie i skodyfikowanie normy interpunkcyjnej. Docenić należy to, że prace dotyczące sztuki przestankowania wyrastały z praktyki wydawniczej, zbierały i systematyzowały to, co zostało sprawdzone w działalności wytwórców książki: drukarzy, korektorów, zecerów i innych. Ale - wypada dodać - wytwórców współczesnych autorom opracowań interpunkcyjnych. Autorzy ci, ilustrując swoje wywody przykładami z „celniejszych pisarzów polskich”, korzystali z wydań najnowszych, a więc ze zmodernizowanym przestankowaniem ${ }^{16}$. To, że „interpunkcyjna cisza w Polsce” trwała tak długo (półtrzecia wieku od ukazania się pierwszych druków), ma swoje negatywne skutki. Brak bowiem opracowań, które świadczyłyby o tym, w jaki sposób próbowano wówczas uporządkować polską interpunkcję.

$\mathrm{Na}$ zakończenie powrócę do zagadnienia „gramatyzacji” interpunkcji w kontekście funkcji pełnionych przez dwukropek. Otóż ten właśnie znak wraz ze zmianą zasady rządzącej użyciem znaków przestankowych (a chodziło o odwzorowywanie relacji składniowych i logicznych w strukturze zdania) zaczął tracić swoją

16 Por. dwie wersje fraszki Jana Kochanowskiego. Pierwszą wersją posłużył się O. Kopczyński (1817) dla zilustrowania użycia średnika:

Nagrobek Podlodowskiemu

By wedle cnót, i zacności,

Grzebiono umarłych kości;

Przystałoby leżeć Tobie

W złotym Podlodowski grobie.

Teraz cię licha mogiła,

Zacnego męża pokryła,

Ale sława sięga nieba;

Nie z grobu cię sądzić trzeba (Kopczyński 1817: 264).

$\mathrm{W}$ wersji znanej z pierwodruku średnik nie występował, zamiast niego pojawiały się ukośnik i dwukropek:

Epitafium Grzegorzowi Podlodowskiemu

By wedla cnót / i godności /

Grzebiono umarłych kości /

Przyszłoby dziś leżeć tobie

W złotym / PoDLODOWski / grobie.

Teraz cię licha mogiła

Znacznego męża przykryła:

Ale sława sięga nieba:

Nie z grobu cię sądzić trzeba (Kochanowski 1584: 112-113). 
rangę znaku polifunkcyjnego, wyznaczającego perspektywę proporcji pozostałych znaków, zwłaszcza w okresie. Pod koniec XIX w. A. Krasnowolski w Składni języka polskiego (mniejszej) wyróżnił trzy „znaki główne, których nigdy opuszczać nie wolno”, tj. przecinek, punkt i pytajnik. Dwukropek zaliczył do „znaków podrzędnych, poniekąd dowolnych, które często mogą być zastąpione przez punkt lub przecinek" (1898: 3). W latach 30. XX w. S. Jodłowski uznał dwukropek wyłącznie za znak wyszczególnienia „tego, co ktoś powiedział lub napisał”, także „szeregu osób, przedmiotów lub t.p., należących do jakiejś grupy" (1935: 25).

„Losy” dwukropka, które prześledziłam najpierw w konkretnym tekście z 1. połowy XVII w. i jego kolejnych edycjach, następnie w opracowaniach normatywnych dotyczących interpunkcji od 1770 do 1935 r., ilustrują "proces powolnego spłaszczania się pionowej interpunkcji retorycznej do poziomej, uwarunkowanej budową składniową” (Musiołek 1981: 43). S. Jodłowski określił dawną interpunkcję jako „pionową”, tzn. „wyznaczającą optycznie ustopniowanie członów jako nadrzędnych czy podrzędnych". Jak pisze, od tej interpunkcji

\begin{abstract}
zeszliśmy po linii najmniejszego oporu do monotonnej interpunkcji „poziomej”, ustawiającej wszystkie człony na jednym poziomie, oddzielającej jednakowo wszystkie człony przecinkiem, bez silenia się na optyczne ich ustopniowywanie. [...] Można śmiało powiedzieć, że znakiem „składniowym” stosowanym dziś w obrębie zdania jest prawie wyłącznie przecinek, który nie tylko nie może oddać ustawienia członów na odpowiednich stopniach konstrukcji, ale nawet nie strzeże granic członów wplecionych w inne (2002: 52).
\end{abstract}

\title{
Źródła
}

Traktaty interpunkcyjne

BentKowski F., 1830, O znakach przecinkowych w pismie czyli znakach pisarskich, Warszawa. ŁAGOWsKi F., 1895, O znakach pisarskich, Warszawa.

WĄsıK W., 1919, Interpunkcja polska. Traktat o znakach pisarskich a interpunkcji polskiej w szczególności, czyli Teorja przestankowania, Warszawa.

\section{„Prawidła pisowni”}

GrzymaŁowski W., 1913, Prawidła pisowni polskiej ułożone według uchwał Akademii Umiejętności w Krakowie z dodatkiem, zawierajacym pisownię autorów „Wielkiego słownika języka polskiego” ułożył [...], wyd. 4 przejrz. i uzup., „Książki dla Wszystkich”, nr 50, Warszawa.

HeŁCZyŃsKi J., 1929, Stawianie znaków przestankowych. Wskazówki praktyczne. Poradnik dla uczniów szkół średnich, Lwów - Warszawa.

JodŁowski S., 1935, Zasady interpunkcji. Prawidła, przykłady, wyjaśnienia, uzasadnienia, Lwów - Warszawa.

Łoś J., 1924, Zasady pisowni, [w:] idem, Zasady ortografji polskiej i słownik ortograficzny według zasad Polskiej Akademji Umiejętności, wyd. 3 rozszerz., Lwów, s. 3-57. 
MeCherZyŃski K., 1841, Prawidła pisania ułożył [...], Kraków.

Szober S., 1917, Pisownia polska. Jej historja, uzasadnienie i prawidła, Warszawa.

\section{Podręczniki gramatyki}

BEM A., 1889, Jak mówić po polsku czyli Gramatyka polska w zarysie popularnym przez [...], Warszawa.

BoCZyliński I., 1882, Zasady gramatyki języka polskiego według najnowszych wyników nauki i wskazówek dydaktyki ułożył [...], cz. 2: Składnia (Syntaksis). Z dodatkiem głównych prawideł pisowni, wyd. 2 popr., Warszawa.

Bohdanowicz Dworzecki J., 1824, Grammatyka ięzyka polskiego napisana przez [...], wyd. 2, Wilno.

Czajkowski J., 1853, Grammatyka języka polskiego. Zawiera: 1. Naukę rozbioru. 2. Naukę słoworodu i pisowni. 3. Naukę składni, wyd. 2, Warszawa.

DAWID W., 1882, Krótka grammatyka polska ułożyt [...], wyd. 5 pomn. i popr., Warszawa - Lublin.

GRUSZCZYŃSKI S., 1861, Nauka o zdaniu zawierająca rozbiór zdania pojedyńczego, złożonego i okresu, oraz prawideł szyku, ułożona na klasy średnie gimnazyów i szkół realnych, tudzież dla seminaryów nauczycielskich i wyższych szkót żeńskich przez [...], Poznań.

KopCzyńsKi O., 1803 (wyd. 1 1778), Grammatyka dla szkół narodowych na klassę I, Wilno.

KopCZYŃski O., 1780, Grammatyka dla szkół narodowych na klassę II, [Warszawa].

KopCZyŃsKi O., 1817, Grammatyka języka polskiego przez [...]. Dzieło pozgonne, Warszawa.

KRASIŃsKi A., 1837, Grammatyka polska dla dzieci krótko zebrana przez [...], Wilno - Warszawa.

KRASNOWOLSKI A., 1897, Systematyczna składnia języka polskiego, Warszawa.

Krasnowolski A., 1898, Składnia języka polskiego (mniejsza) przez [...], Warszawa.

KróLIKowski J., 1826, Proste zasady stylu polskiego rozmaitemi postrzeżeniami względem języka, dla użytku jasno, zwięźle, poprawnie, gładko i szczerze po polsku pisać chcacych, praktycznie w przykładach okazane, a wzorami rozmaitego toku i sposobu pisania, nauka o listach, wykładem pewnej liczby synonimów i kilku rozprawkami o języku, tudzież wyjaśnieniem pisowni dopetnione, przez [...], Poznań - Bydgoszcz.

KudAsiewicz A., 1863, Kurs trzeci nauki języka polskiego zawierajacy ortografiję i składnię. Przez [...], Warszawa.

Kurhanowicz T., 1852, Składnia i pisownia języka polskiego układu [...], do użycia szkolnego zastosowana i przez najwyższq władzę edukacyjna dla zakładów naukowych okręgu naukowego warszawskiego przeznaczona, Warszawa.

MAєеCKi A., 1863, Gramatyka języka polskiego większa przez [...], Lwów.

Muczkowski J., 1849, Gramatyka języka polskiego przez [...], wyd. 3 przerobione i pomnożone, Kraków.

REWOLIŃsKi K., 1845, Głoskownia czyli Grammatyka polska co do składni szyku, zgody i rzadu, o zdaniach, przecinkowaniu i przenośniach. Przez [...], Radom.

Stein I., Zawiliński R., 1907, Gramatyka języka polskiego dla szkót średnich, Kraków - Warszawa.

Szostakowski J., 1849, Polska grammatyka mniejsza ułożona przez [...], wyd. 2, Trzemeszno.

Szumski T., 1809, Dokładna nauka języka i stylu polskiego w dwoch częściach. Czesść pierwsza zawierająca Grammatykę i Deklamatorykę, do którey też należa Elementarz i Wzory charakterów, ułożone podług nayłatwieyszej metody do nauczenia się czytania i pisania; dla użytku młodzieży napisana i własnym kosztem wydana przez [...], Poznań. 
Szylarski W., 1770, Początki nauk dla narodowej młodzieży to jest Grammatyka języka polskiego ucząca, a tym samym pojęcie obcych języków, jako: łacińskiego, francuskiego, niemieckiego, włoskiego i innych ułatwiająca. Przez [...], Lwów.

[Żebrawski T.], 1876, Gramatyka praktyczna języka polskiego przez T.Ż., Kraków.

Żochowski F., 1852, Mownia języka polskiego przez [...], Warszawa.

\section{Literatura}

Bajerowa I., 1986, Polski język ogólny XIX wieku. Stan i ewolucja, t. 1: Ortografia, fonologia $z$ fonetyka, morfonologia, „Prace Naukowe Uniwersytetu Śląskiego w Katowicach”, nr 768 , Katowice.

Foremniak K., 2014, O sztuce przestankowania w Polsce i we Włoszech. Rozwój normy interpunkcyjnej od XVI wieku do współczesności, Warszawa.

Furmanik S., 1955, O interpunkcji $w$ drukach staropolskich, „Pamiętnik Literacki” XLVI, S. $426-468$.

GodyŃ J., 1996/2009, Retoryka w pieśni pasyjnej Władysława z Gielniowa, Psałterzu floriańskim $i$ Kazaniach $t z w$. świętokrzyskich (funkcje średniowiecznej interpunkcji), [w:] idem, Studia historycznojęzykowe, edytorskie, kulturalnojęzykowe, „Biblioteka LingVariów”, t. 4, Kraków, s. 217-231.

GóRnICKI Ł., 1637, Dzieie w Koronie Polskiey. Z przytoczeniem niektorych postronnych rzeczy: od Roku 1538. aż do Roku 1572. Przez J.M.P. Łukasza Gornickiego, Tykocińskiego y Wasitkowskiego Starostę, spisane. A teraz nowo wydane Przez J.M.X. Łukasza Gornickiego, Kanonika Wileńskiego Warmińskiego J.K.M. Sekretarza, Kraków.

Grochowsкi M. (red.), 1995, Wyrażenia funkcyjne w systemie i tekście. Materiały konferencji naukowej (Toruń 21-23 X 1993), Toruń.

JodŁowski S., 2002, Zasady interpunkcji. Podręcznik, oprac. nauk. i red. J. Godyń, wyd. nowe zm. i rozsz., Kraków.

Kleszczowa K., SzczePaneK A. (red.), 2014, Wyrażenia funkcyjne w perspektywie diachronicznej, synchronicznej i porównawczej, „Prace Naukowe Uniwersytetu Śląskiego w Katowicach", nr 3141, Katowice.

Kochanowski J., 1584, Fraszki, Kraków.

MusioŁeK K., 1981, Z dziejów kształtowania się normy interpunkcyjnej w pisowni polskiej, „Acta Universitatis Wratislaviensis. Studia Linguistica” 6, s. 43-61.

PODRACKI J., 2007, Konstrukcje złożone w gramatykach języka polskiego (rys historyczny), Warszawa.

PODRACKI J., 2016, Status interpunkcji w dawnych podręcznikach gramatyki języka polskiego, „Poradnik Językowy” nr 4, s. 19-30.

TuтAк K., 2013, O dedykacjach $w$ drukach polskich XVI i XVII w. (grafia i interpunkcja), „Biblioteka LingVariów”, t. 16, Kraków.

TuтAк K., 2017, Tekstowe funkcje dwukropka - na przykładzie Dziejów w Koronie Polskiej Łukasza Górnickiego, „LingVaria” nr 1 (23), s. 133-149, [on-line:] http://dx.doi.org/10.12797/ LV.12.2017.23.09.

WierzbickA A., 1971/20o8, Metatekst w tekście, [w:] D. Ostaszewska, R. Cudak (red.), Polska genologia lingwistyczna, „Zagadnienia i Problemy Współczesnej Genologii”, Warszawa, s. 281-296. 
Иофик Л.Л., 1961, Об основах английской пунктуации в связи с проблемой сложносочиненного предложения, „Вопросы Языкознания” nr 4, s. 99-104.

Падучева Е.В., 1996, Семантические исследования. Семантика времени и вида в русском языке. Семантика нарратива, Москва.

\section{Functions of the colon in Polish prescriptive works on punctuation (1770-1935) Summary}

The paper investigates the function assigned to the colon in Polish prescriptive works on the rules of punctuation published between 1770 and 1935. Following the authors of grammar textbooks, spelling rules and punctuation treatises, three primary functions of the colon have been distinguished: the colon as an indicator of a citation, enumeration, and as an announcement of the forthcoming explanation of the previous sentence. The colon could constitute the sole signal of text delimitation, but it was also sometimes paired with the lexical environment, especially with metatextual elements. Treatises on punctuations also emphasized the role played by the colon in the rhetoric period. 

SŁOWIAŃSZCZYZNA 

Zbigniew Babik

Uniwersytet Jagielloński, Kraków

zbigniew.babik@uj.edu.pl

\section{W POSZUKIWANIU TZW. CENTRUM TOPONIMII (WCZESNO)SŁOWIAŃSKIEJ - PRZYPADEK ZIEM POLSKICH. CZ. II ${ }^{1}$}

Słowa klucze: słowiańska leksyka toponimiczna, toponimia ziem polskich, dialektyzmy prasłowiańskie, modele migracji nosicieli dialektów prasłowiańskich, lokalizacja wyjściowego areału słowiańskiego

Keywords: Slavic toponymic terminology, Polish toponymy, Proto-Slavic lexical dialectisms, dispersal models of carriers of Proto-Slavic dialects, localization of the starting point of Slavic

Po przeszło pięciu latach pracy, jeszcze przed rozpoczęciem systematycznej kwerendy słowiańskich źródeł leksykalnych, udało mi się wyszukać ponad 400 wyrazów spełniających powyższe kryteria, przy czym leksemy powtarzające się w nie więcej niż trzech nazwach (grupa I) i bardziej produktywne (grupa II) pozostają do siebie w stosunku liczbowym mniej więcej 3:1. Materiał ten daje częściowo odpowiedź na wątpliwości co do stopnia rozpoznania rzeczywistej struktury leksyki gwarowej w XIX-XX w. Jak się okazuje, nazwy o etymonach z polskiego punktu widzenia „niemacierzystych” bardzo rzadko przekraczają liczbę 50 odrębnych gniazd. Lek-

1 Niniejszy komunikat, którego pierwsza część ukazała się w poprzednim numerze „LingVariów”, rozwija tezy przedstawione w prezentacji na krakowskim slawistycznym sympozjum etymologicznym w maju 2016 r. Części materiału ilustracyjnego tej prezentacji nie mogę jednak z braku miejsca przedstawić. Z tego samego powodu ograniczam cytowaną bibliografię do najważniejszych lub doraźnie niezbędnych pozycji. 
semy chetm i wąsosz, mieszczące się w przedziale 50-10o (chełm może osiąga nawet wyższą produktywność), zapewne jednak pozostawiły ślady leksykalne w XIX$\mathrm{XX}$ w. Pozornie bardzo produktywny ${ }^{*} k a l i s z^{2}$ jako etymon toponimów konkurował niewątpliwie z nazwiskiem, pochodnym prawdopodobnie od imienia Kalikst, a rzeczywista jego produktywność w nazwach polskich jest bardzo trudna do uściślenia. Inne produktywne $\mathrm{w}$ toponimii leksemy posiadające wiarygodne nawiązania leksykalne poza Polską ( ${ }^{\star}$ bardo 'podłużne wzniesienie, ${ }^{\star}$ czartor $(y) j a$ 'rozpadlina; wir?' czy *konotopa 'bagno') zapewne nie przekroczą bariery 50 odrębnych gniazd. Prawdopodobnie jedynie ${ }^{\star}$ toboła (chyba niewspółrdzenna z toboła jako rzadszym wariantem literackiego tobót), zapewne odpowiadająca rosyjskiemu gwarowemu terminowi тобо́лка 'niewielki kawałek pola lub łąki kolistego kształtu, wyznaczony jakimiś naturalnymi granicami', znanemu z gwar władymirskich $\mathrm{w}$ przekazach $\mathrm{z}$ lat 70 . XX w. (CРНГ XLIV: 159, s.v. Тобóлка 2.), osiąga produktywność powyżej stu gniazd. Innymi słowy, nie mamy żadnego w zasadzie przykładu wyrazu nieuchwyconego leksykalnie, a osiągającego ponadprzeciętną produktywność w nazewnictwie miejscowym i terenowym.

Pod względem struktury etymologicznej wyrazy rekonstruowane $\mathrm{z}$ toponimii na mocy zrównań z innosłowiańskim materiałem leksykalnym rozpadają się na kilka osobnych grup. Zdecydowanie największą, obejmującą około jednej trzeciej materiału (ponad 120 odrębnych przykładów) stanowią tzw. postverbalia, czyli derywaty „paradygmatyczne” prefigowanych form werbalnych, a także derywaty prefiksalne tworzone bezpośrednio od nominów (np. ${ }^{\star}$ bezdolø, ${ }^{\star}$ bezgor-, ${ }^{*}$ vazdolø lub ${ }^{\star} v$ znožbje). Spośród typowych prefiksów nominalnych ${ }^{*} s Q-$ (np. już zidentyfiko-

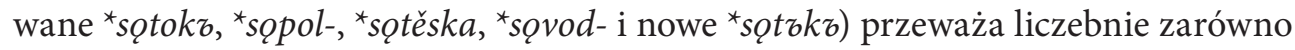
nad ${ }^{*} Q-\left({ }^{*}\right.$ ochab-, ${ }^{*}$ ovortz), jak i ${ }^{\star} p a-\left({ }^{*}\right.$ patolka, tylko w mikrotoponimie Patłoka, zob. materiał leksykalny w: Boryś 1975: 19). Nieliczną grupę stanowią "prasłowa”, tj. wyrazy leksykalnie i (lub) słowotwórczo (derywaty „prymarne”, odpierwiastkowe) niemotywowane na gruncie prasłowiańskim. Przykładami mogą być np. ${ }^{*}$ obəlø, prawdopodobnie ślad indoeuropejskiej nazwy 'pępka', zidentyfikowany w „etnicznym” ojkonimie Wąblany przez Bańkowskiego (1973) i Nalepę (1973: 188-190), dalej ${ }^{*}$ zavon'a $\left({ }^{*}\right.$ zavod-n-), motywująca dwie objaśniane dotąd na gruncie intuicji (zob. Rospond 1984: 401, s.v. Trzebnica) polskie Zawonie, wreszcie *odrø 'rodzaj rusztowania', lokalnie zaświadczony też w znaczeniu 'rozgałęzione drzewo', w nazwie słynnych z rezerwatu archeologicznego Odrów nad Wdą, czy też inne sytuacje szczególne (np. niedostrzegane dotąd małopolskie ślady toponimiczne apelatywu *agnędz 'topola czarna', którego - $d$ - wynikło z okazjonalnej kontaminacji z inną na-

2 Odpowiedniki (kalís i kaližz) występują w gwarach kajkawskich i wschodniosłoweńskich, najczęściej w znaczeniu 'sezonowe, podeszczowe błoto, w którym lubią chłodzić się świnie'. Przed laty błędnie oceniłem wymowę tych faktów leksykalnych, traktując je jako przekształcenie starszego kaluž- (Babik 2001: 140-141). 
zwą topoli (zob. o nim SP I: 151)). Stosunkowo nieliczne były derywaty z nieproduktywnymi ${ }^{3}$ formantami sekundarnymi, np. ${ }^{*}-E l-,{ }^{*}$ - nno, ${ }^{*}$-arz, ${ }^{*}$-uchr, ${ }^{*}$-anz i ${ }^{*}$-anb, ${ }^{*}$-bba. Jako wyjątkowe można określić złożenia z dwoma morfemami leksykalnymi

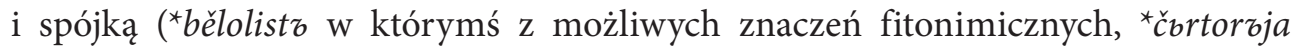
$\mathrm{i}{ }^{*}$ čbrtolomz ${ }^{4},{ }^{\star}$ dymokurz, ${ }^{\star}$ konotopa $\mathrm{z}$ wariantami, ${ }^{*}$ vyšegordz). Liczba zrównań przymiotnikowych (złożona forma przymiotnikowa w nazwie) nie przekracza dziesięciu. Nie uwzględniam zapożyczeń, z wyjątkiem zapożyczeń germańskich dających się lokować chronologicznie jeszcze w starożytności (tutaj należałyby apelatywy ${ }^{\star}$ pergyn'i czy $\left.{ }^{\star} k o l d e ̨ d z^{\prime} b\right)$.

Nadspodziewanie liczne okazują się przykłady toponimicznych użyć przenośnych wyrazów lepiej poświadczonych w innych znaczeniach. $Z$ odbicia tutaj niezaświadczonych znaczeń topograficznych tych wyrazów zwykle zdawano sobie oczywiście sprawę, znaczenia te rekonstruowano jednak częściej na podstawie własnej intuicji niż porównania $\mathrm{z}$ faktami słownikowymi innych języków słowiańskich. Metafory czy metonimie wychodziły najczęściej od części ciała $\left({ }^{*}\right.$ čelo, ${ }^{*}$ golent,${ }^{\star} k o r-$

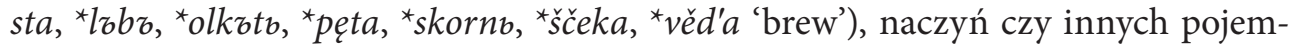

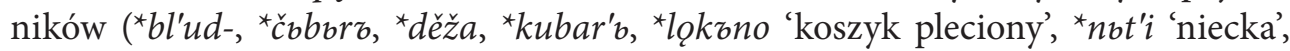
${ }^{*}$ skovorda, ${ }^{*}$ sosěk $k$, ${ }^{*}$ ulojb, ${ }^{*}$ vaganz), wreszcie innych przedmiotów domowych czy

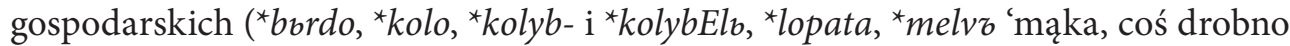
roztartego', ${ }^{*}$ selmę, ${ }^{*}$ těsto, ?*verteno).

Bardzo interesująco przedstawia się dystrybucja nazw wiązanych $\mathrm{z}$ apelatywami grupy I na terytorium Polski. Około 80\% spośród nich skoncentrowanych jest w pasie obejmującym około jednej czwartej-jednej trzeciej powierzchni kraju, ograniczonym Karpatami, Notecią oraz biegami Odry i Wisły, ale zasadniczo niedochodzącym do tych elementów granicznych. Chodzi zatem o zachodnią Małopolskę (zwłaszcza tereny jurajskie, dolinę Wisły czy okolice Gór Świętokrzyskich5), historyczną Wielkopolskę i środkowopolskie tereny położone pomiędzy

3 Np. derywatów na *-idlo / *-adlo jest w moim aktualnym materiale grup I i II sześć.

4 Przykład nowy, definiowany zrównaniem ukraińskiego gwarowego чортоло́ $\mathrm{m}$. 'drzewa połamane przez wichurę’ (Данилюк 2013: 143, Oryszcze w rejonie iwaniczewskim, za słowniczkiem Korzoniuk 1987) z polskimi toponimami Czartołomie (NMPol II: 198), Czartłomiki (Kozierowski 1916: 557) i Bogołomia (NMPol I: 251: niejasne, niewątpliwie jednak mamy tu eufemizujące wykolejenie pierwotnego ${ }^{\star}$ Czartołomia, por. Bogoryja $<{ }^{\star}$ Czartoryja).

5 Pozycja Wielkopolski budowana jest głównie przez materiały historyczne (nazwy z dzisiejszej perspektywy wymarłe), których znajomość zawdzięczamy przede wszystkim kwerendom Stanisława Kozierowskiego. Natomiast przykłady małopolskie zazwyczaj zachowane są po dziś dzień. Częściowo wynika to zapewne $\mathrm{z}$ lepszego niż w Wielkopolsce zachowania dawnej mikrotoponimii, wynikającego z kolei z mniejszych przekształceń tutejszego krajobrazu i większego jego nasycenia niezmiennymi elementami (np. rzeźby terenu). Najbardziej bodaj intrygująca była dla mnie wielka łatwość identyfikacji takich zrównań we współczesnych (XIX-XX w.) materiałach ojko- i mikrotoponimicznych z prawego dorzecza Pilicy (Opoczyńskie, północne przedpole Gór Świętokrzyskich itd.). 
nimi (gdzie zauważalne jest niewielkie rozrzedzenie, spowodowane zapewne słabszym rozpoznaniem źródłowym tamtejszej mikrotoponimii). Inaczej mówiąc, są to tereny lewego dorzecza górnej i środkowej Wisły oraz dorzecza górnej i środkowej Warty z lewym dorzeczem Noteci. Natomiast obszary Śląska, Mazowsza (zwłaszcza północnego), Pomorza (także wschodniego, skąd dysponujemy przeważnie niesubstytucyjnymi przekazami nazw) na tle tego obszaru sytuują się jako głębokie peryferie, $z$ wielkimi obszarami pozbawionymi zupełnie uchwytnego nazewnictwa dającego się zaliczyć do grupy I. Najbardziej intrygujący jest silnie peryferyczny status całego pasa wschodniego, po obu stronach granicy dzielącej w późnym średniowieczu areały Słowiańszczyzn zachodniej i wschodniej (zwłaszcza Podlasia, ale także Lubelszczyzny czy całego dorzecza Sanu). Inaczej mówiąc, systematyczne studia zdecydowanie nie potwierdzają opinii o szczególnej różnorodności podstaw apelatywnych słowiańskiego nazewnictwa Podkarpacia. Jak się wydaje, ten peryferyczny charakter nazewnictwa kontynuowany jest - z coraz większym słabnięciem badanego elementu w miarę posuwania się w kierunku wschodnim - również na wschód od granic Polski (por. niżej).

$Z$ rezultatów aktualnie odczuwanych przeze mnie jako niepowodzenia przedsięwzięcia wymieniłbym przynajmniej dwa. Pierwszym jest niemożliwość odnalezienia w nazewnictwie geograficznym ziem polskich odpowiedników dużej liczby występujących w innych językach wyrazów toponimicznych, których struktura i zasięgi zdecydowanie przemawiają (i zwykle znajduje to odzwierciedlenie w decyzjach badaczy leksyki prasłowiańskiej) za ich „prasłowiańskością”. Można tutaj, nie wdając się w bliższe szczegóły, wymienić takie przykłady, jak hipotetyczne, posiadające nawiązania w innych językach ${ }^{\star}$ barzaj, ${ }^{\star} c z e r c i e \dot{z},{ }^{\star} d t u b o k i,{ }^{\star} d r z a g w a$, ${ }^{*}$ grumień, ${ }^{*}$ moczwar-, ${ }^{*}$ mozerz[e] (ale Mozerski (młyn), Mazerzyn), ${ }^{*}$ omęt- ${ }^{*}$ omąt-

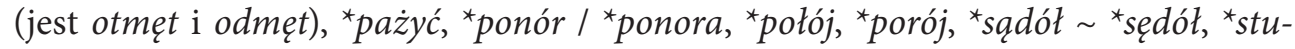
biel- < ${ }^{*}$ stubbl- (jest $\left[{ }^{*} z\right]$ dbiel < ${ }^{*}$ stzbbl-), ${ }^{*}$ wąłóg $\sim{ }^{*}$ węłóg, ${ }^{*}$ wierciep (por. zapożyczone wertep; jest natomiast wiartop-), ${ }^{\star}$ wrątek, ${ }^{\star} z a n o g a,{ }^{*} z y b$-. Jest to oczywiście elementem zjawiska szerszego - nieuchwytności na ziemiach północnosłowiańskich areału, w którym dałoby się wykazać ślady wszystkich (albo „prawie wszystkich”) rekonstruowanych dla prasłowiańskiego apelatywów toponimicznych ${ }^{6}$. Istnieją areały o dużym, ponadprzeciętnym zróżnicowaniu leksyki toponimicznej, nie udaje się jednak wyodrębnić areału iście „wspólnosłowiańskiego”. Brak śladów części starych wyrazów wynika zapewne z kilku przyczyn. Jedną może być nie zawsze perfekcyjne odzwierciedlenie w toponimii danego terenu używanej tutaj leksyki toponimicznej. Opisywano już sytuacje, gdy mimo wielowiekowego zapewne bytowania na określonym obszarze apelatywów nie tyle toponimicznych, co wręcz topograficznych są one w zasadzie nieuchwytne w jego nazewnictwie miejscowym (por. Harvalík 2014: 72

6 M.in. rzadkich wariantów wyrazów tutaj znanych, jak choćby ${ }^{\star} g z l b s$ obok ${ }^{\star} k z l p s$ 'łabędź', obficie udokumentowanego nazwami typu Kiełpino. 
o apelatywie vejvar < vývar, pierwotnie 'źródło’7). Podobnie można rzec o leksemie wrzodło < *verdlo 'trzęsawisko' < ‘źródło', pochodzenia niewątpliwie prasłowiańskiego, notowanym u nas tylko w puckim Strzelnie (zob. SEK V: 243, s.v. vřodło), na którego ślady nazewnicze nie natrafiłem dotąd w mojej kwerendzie źródłowej. Szereg innych przykładów można wskazać w materiale większych syntez polskiej leksyki geograficznej (Nitsche 1964; Kowalska 2011).

Drugim, bodaj ważniejszym powodem nieuchwytności tych wyrazów jest ułamkowy tylko stan naszej wiedzy o dawnej toponimii. Główną domeną, w której odkładały się wyrazy, było nazewnictwo terenowe (lasów, obiektów wodnych czy bagiennych, charakterystycznej rzeźby terenu i innych typów uroczysk); również kategoria ojkonimów tzw. topograficznych to dawne nazwy terenowe, ponawiane $\mathrm{w}$ nazwach powstających $\mathrm{w}$ sąsiedztwie osad. $\mathrm{O}$ ile $\mathrm{w}$ dawnych wiekach powstawały pewne kategorie źródeł pisanych, których ambicją/celem było zarejestrowanie wszystkich istniejących w danych granicach osad, z pewnością co najmniej aż do XVIII w. (Metryka Józefińska, choć i tu można dyskutować) nie było źródła, którego zamierzeniem byłoby zarejestrowanie całego nazewnictwa terenowego używanego na dużym, obejmującym setki osad obszarze. Nazwy terenowe zaświadczone przed tą dobą zostały zapisane najczęściej w opisach granic, co m.in. oznacza, że nawet $\mathrm{z}$ tych miejscowości, $\mathrm{z}$ których je poświadczono, dysponujemy tylko nazwami obiektów zahaczających o granicę, i to nie z całego jej obwodu (jako że zwykle opisywano tylko granice między kilkoma bezpośrednio sąsiadującymi wsiami, nie zaś wszystkie granice dookoła poszczególnych wsi). Jednocześnie można przyjąć, że większa część archaicznych (np. niejasnych z naszego punktu widzenia) nazw terenowych zapisanych przed XVIII w. nie przetrwała do wieku XX (zjawisko to szczególnie zaznaczyło się np. w Wielkopolsce), skąd w sposób niedwuznaczny wynika, że również część nazw istniejących jeszcze w XV-XVI w., ale niezanotowanych na piśmie (albo niewydobytych jeszcze z materiałów archiwalnych) nie dotrwała do naszych czasów, zginąwszy bez śladu. Ten właśnie masowy zanik dawnego nazewnictwa terenowego, którego nijak nie potrafimy powetować, uważam za najważniejszy czynnik determinujący niepełną znajomość dawnego, sięgającego wczesnego średniowiecza krajobrazu nazewniczego.

Drugim „niepowodzeniem”, falsyfikującym - przyznajmy - wyobrażenia podzielane u progu przedsięwzięcia, okazał się brak „rejonizacji” na ziemiach polskich nazw nawiązujących do dialektyzmów wschodnio-, południowo- i zachodniosłowiańskich. Mimo znacznej liczby występują one - w takiej właśnie kolejności

7 Odnotowano tylko izolowany derywat Vejvarka, natomiast nazw równych apelatywowi nie zarejestrowano. Polski odpowiednik tego wyrazu, funkcjonujący jako topograficzny regionalizm na Kielecczyźnie, użyty m.in. w Popiołach Stefana Żeromskiego i odnotowany w kartotece Słownika gwar polskich PAN (ale pominięty przez Nitschego 1964), w moim materiale powtórzył się trzykrotnie (jako plurale Wywary) właśnie na Kielecczyźnie. 
liczebnej ${ }^{8}$ - w sposób, który wydaje się zupełnie nieuporządkowany; nie można aktualnie stwierdzić, że nawiązania wschodnie skupiają się na wschodzie, południowe na południu itd. Interpretacja takiego rezultatu badania jest niepewna. Być może wyraźne zróżnicowanie leksykalne poszczególnych obszarów ukształtowało się dopiero we wczesnym średniowieczu, a zróżnicowanie istniejące wcześniej było zbyt słabe, by jego ślady w nazewnictwie mogły okazać się uchwytne po upływie co najmniej pięciu wieków. Prawdopodobna nikłość nawiązań wschodniosłowiańskich w toponimii czeskiej i północnosłowiańskich w nazewnictwie krajów południowosłowiańskich (por. niżej) może też sugerować, że doszło tutaj do odejścia silniej zróżnicowanej peryferii, a powstała w ten sposób luka została wypełniona przez ruchy odśrodkowe, co spowodowało zatarcie pierwotnie peryferycznego charakteru miejscowej toponimii poprzez domieszanie do niej pierwotnie bardziej „centralnego" elementu leksykalnego.

Systematyczne porównanie sytuacji panującej na ziemiach polskich z sytuacją na Białorusi i Ukrainie jest obecnie niemożliwe z powodu braku reprezentatywnych materiałów źródłowych, realne stało się natomiast wykonanie pewnych porównań o charakterze sondażowym. Funkcjonujące na Białorusi środowiska toponomastyczne na razie nie są w stanie wylegitymować się realizacją większych przedsięwzięć zespołowych. Zły jest także stan wiedzy o nazewnictwie rosyjskich obwodów sąsiadujących z Białorusią i Ukrainą (por. jednak Васильев 2012). Podobnie zła sytuacja na Ukrainie w ostatnich latach uległa wyraźnej poprawie. O ile dawniej systematyczne monografie ojkonimów powstawały jedynie w polskich środowiskach onomastycznych (Zaleski 1987; Pluskota 1998; Makarski 1999; Czapla 2011), autorzy ukraińscy zaś pod szyldem wprowadzających w błąd tytułów monografii przedstawiali głównie ogólne uwagi wzbogacone własnymi impresjami na temat nielicznych, dowolnie wybranych nazw, o tyle obecnie mamy już monografie regionalne opracowane na Ukrainie (np. Яцій 2015). Co najważniejsze, rozpoczęto również nieskoordynowane wprawdzie - akcje zbierania materiałów mikrotoponimicznych. Wydano już zbiory nazewnictwa północno-zachodniej części Ukrainy (Аркушин 2007) oraz obwodów czerkaskiego (Гаврилова, Денисенко 2010) i czernihowskiego (Павленко 2013), z których zdołałem jak dotąd zapoznać się tylko z ostatnim. Szczególnie dobrze rozpoznane wydaje się nazewnictwo terenowe Ukrainy Karpackiej (por. Rudnicki 1939; Hrabec 1950; Зборовський 2004; Габорак 2008; Сокіл 2008).

8 Mała liczba zrównań z językami zachodniosłowiańskimi wynika przede wszystkim z eliminacji z pola zainteresowania leksemów zaświadczonych apelatywnie w polskim. Przy wysokim stopniu pokrewieństwa leksykalnego języków tej grupy eliminacja materiału największego obszaru językowego musiała zrodzić takie, a nie inne konsekwencje. Natomiast znaczna przewaga nawiązań wschodnich nad południowymi chyba nie daje się rozsądnie wyjaśnić różnicami dostępnych korpusów leksyki tych języków, wymagając raczej założenia o znaczniejszym zubożeniu leksyki południowosłowiańskiej względem prasłowiańskiej („efekt założyciela”, eliminacja części dawnego słownictwa przez nowsze zapożyczenia sub-, super- i adstratowe, np. turcyzmy). 
Wiadomo też - dzięki upublicznianym autoreferatom - o powstających innych pracach materiałowych z dziedziny mikrotoponimii. Nie było, o ile mi wiadomo, bardziej systematycznych prób poszukiwania w tamtejszej toponimii słowiańskich archaizmów leksykalnych. Wydane w 1998 r. opracowanie Wiktora Szulhacza, którego zamiarem było podbudowanie tezy o archaicznym charakterze słowiańskiej hydronimii zachodniej części ukraińskiego Polesia (w dorzeczach Prypeci i Bugu), z punktu widzenia proponowanej tu metodologii okazało się spektakularną kompromitacją takiej tezy: autor nie przedstawił w zasadzie przykładów dających się zaliczyć do zdefiniowanych tutaj grup I i II (uchwytne nawiązania apelatywne jedynie poza ukraińskim), operując niemal wyłącznie nazwami motywowanymi materiałem ukraińskim oraz spekulacjami etymologicznymi zbytnio oderwanymi od słowiańskich faktów leksykalnych ${ }^{9}$, jedne i drugie uparcie i konsekwentnie określając zarazem mianem „prasłowiańskich”.

Pragnąc sprawnie zorientować się w sytuacji, wykonałem zatem kwerendę współczesnych wykazów nazw miejscowości w północnym pasie obwodów Ukrainy ${ }^{10}$, próbując niejako z marszu oddzielić te nazwy, które od strony leksykalno-nazwotwórczej tłumaczą się na gruncie naszej aktualnej wiedzy o ich języku „macierzystym", i wydobyć pierwiastek innosłowiański w pozostałym zasobie nazw mniej lub bardziej niejasnych. Procedura ta wykazała relatywnie niski udział słowiańskiego elementu "niemacierzystego" i jednocześnie jego spadek przy ruchu z zachodu na wschód (produktywność wahała się od 2-3 nazw w obwodach wołyńskim i rówieńskim do nie więcej niż 1-2 w żytomierskim, kijowskim, czernihowskim i sumskim ${ }^{11}$ ). Nie powinno to zresztą dziwić, jeśli zważyć, że produktywność archaicznych struktur nazwotwórczych ( ${ }^{*}$-bno, ${ }^{\star}$-bsk-), które w toponimii zachodniosłowiańskiej są jednym z głównych nośników archaicznego złoża etymonów, jest na wschodzie wyraźnie obniżona (por. Rospond 1969; Борек 1972). Na wschód od Wołynia skład ojkonimii ulega także jakościowej zmianie (upodabniając się znacząco do struktury ojkonimii np. Podlasia), co prawdopodobnie wiąże się z obniżeniem średniego rzeczywistego wieku nazw na tym obszarze, wynikającym z późniejszej metryki kolonizacji wewnętrznej, w decydującej mierze kształtującej współczesną

9 Np. względnie izolowaną nazwę jeziora Дímpo wywiedziono tam od czasownika *dě(ja)ti z prymarnym formantem *-tro, nie wskazując materiału leksykalnego zawierającego taką kombinację morfemów i nie próbując uwiarygodnić toponimicznego charakteru semantyki derywatu (Шульгач 1998: 72). Podobnych przykładów jest w książce co najmniej kilkanaście. Są też dość liczne etymologie wątpliwe od strony formalnej (np. łączenie hydronimu KyMá z ${ }^{*} k z l m-$ ).

10 Wiosną 2017 r. wykonałem podobny sondaż na całości ojkonimii białoruskiej (ok. 25 tys. nazw). Wykazał on, że w środkowej i wschodniej części tego kraju nasycenie jest nieznacznie, ale zauważalnie większe.

11 Wskazałbym stąd ojkonim Осоївкa, nawiązujący do nieznanej w toponimii polskiej południosłowiańskiej nazwy 'miejsca zacienionego', sygnalizowanej z dość licznych toponimów wschodniosłowiańskich (por. Васильев 2012: 456-457), ale nieuchwyconej tu apelatywnie. 
siatkę ojkonimów. Równie negatywne okazały się rezultaty kwerendy materiału historycznego z tego obszaru zawartego w książce Teresy Pluskoty (1998); przejrzenie jej nie pozwoliło zidentyfikować żadnego nowego przykładu. W sytuacji, gdy nawet sięgnięcie do materiałów historycznych nie powoduje istotnego zwiększenia liczby odkryć, należy ostatecznie rozstać się z mrzonkami o możliwości udokumentowania ponad- czy przeddialektalnego, „prasłowiańskiego” charakteru słowiańskiej warstwy nazewniczej północno-zachodniej Ukrainy ${ }^{12}$. Wszystko wskazuje na to, że mamy tu do czynienia z toponimią typu kolonialnego, zaszczepioną na wyraźnym substracie przedsłowiańskim, a ściśle nawiązującą do historycznie uchwytnej wschodniosłowiańskiej i ukraińskiej leksyki tego obszaru. Nawet jednak opóźnienie chronologii slawizacji historycznych ziem wschodniosłowiańskich nie wyjaśnia zadowalająco ubóstwa składu leksykalnego jej podstaw apelatywnych w porównaniu z sytuacją obserwowaną chociażby na również kolonialnych ziemiach Czech czy Słowacji. Nie tłumaczy ono m.in. braku w nazewnictwie śladów dziesiątków wyrazów toponimicznych znanych w rosyjskiej leksyce gwarowej, chociaż dawni nosiciele tych ostatnich (a przynajmniej ich części o rzeczywistej metryce prajęzykowej) zapewne przebywali przez pewien czas na dzisiejszym terytorium Ukrainy. Generalnie można mówić o małym zróżnicowaniu słowiańskiej bazy leksykalnej toponimów (osobliwie rekompensowanym przez zaskakująco dobre zachowanie niejasnych, w większości zapewne przedsłowiańskich formacji, realnie uchwytnych w funkcji makro- i mezohydronimów). Obok lokalnego zrywania ciągłości nazewniczej, związanego z wydarzeniami o charakterze katastroficznym w okresie średniowiecza i później (depopulacje wywołane najazdami ludów stepowych czy innymi wydarzeniami wojennymi), należy liczyć się również ze zjawiskiem, które roboczo określam jako „opóźniony start” słowiańskiej toponimii na nowych obszarach kolonialnych: w sytuacji osiedlenia grupy na terenie zasiedlonym już przez dawniejszych mieszkańców (lub w jego sąsiedztwie) nowi osadnicy mają nieograniczoną możliwość posługiwania się zapożyczonymi z substratu nazwami obiektów terenowych. Aktywność nazwotwórcza nie zamiera wówczas całkowicie, jednak z pewnością słabnie w porównaniu z sytuacją, gdy zasiedlone zostają rozległe obszary odludnione, a koloniści nie mają możliwości nawiązania do starszej tradycji nazewniczej. Wówczas to bowiem nazewnictwo terenowe jest tworzone na skalę masową od podstaw przez pionierów nowej fali osadniczej i dzięki temu ma szansę

12 Pogląd taki, głoszony najpierw przez slawistów niemieckich (np. Maxa Vasmera), następnie przez miejscowych autochtonistów czy wywodzącego się ze środowiska krakowskiego Zbigniewa Gołąba (np. 1992: 249-250), opierającego swe enuncjacje o „archaicznym jądrze hydronimii słowiańskiej" między Dnieprem, Prypecią i Karpatami na nadinterpretacji i absolutyzacji sugestii Olega N. Trubaczowa (Трубачев 1968; por. Babik 2001: 78), zyskał wielu zwolenników nie tyle ze względu na swoje walory wewnętrzne, co raczej ze względu na utrafianie w pozapoznawcze oczekiwania i idiosynkrazje niektórych środowisk. 
odłożyć się w nazewnictwie możliwie pełny przekrój realnie przez nich używanej leksyki toponimicznej.

Zupełnie inne są wrażenia $\mathrm{z}$ kontaktu $\mathrm{z}$ toponimią krajów zachodniosłowiańskich. I w Czechach, i na Słowacji opracowano - przynajmniej w aspekcie dokumentacyjnym - warstwę ojkonimów, a prace nad tzw. anojkonimami (z grubsza odpowiadającymi naszym mikrotoponimom) są bardzo zaawansowane; w obu wypadkach materiał mikrotoponimiczny jest/ma być prezentowany w Internecie. Nieco słabiej, zwłaszcza w Czechach, zaawansowane są prace nad hydronimią. Zarówno dotychczasowe wyniki poszukiwań prowadzonych przez innych badaczy (np. Blažek, Vondrová 2001), jak i moje sondaże na niektórych strukturach (np. na materiale Borka 1968) i przykładach izolowanych ${ }^{13}$ sugerują, że toponimia tych terenów - w przeciwieństwie do wschodniosłowiańskiej, której sytuacja w tej naukowej grze jest właściwie beznadziejna - może stanowić realną konkurencję dla starszego nazewnictwa słowiańskiego ziem polskich. Uderza także, że owe czeskie leksemy „niemacierzyste” stosunkowo częściej niż polskie znajdują swój historyczny obszar „macierzysty” w Słowiańszczyźnie południowej. Być może uda się wykazać nieznaczną przewagę nasycenia tym elementem ziem Polski środkowej, np. nad Kotliną Czeską (czego bynajmniej nie uważam za pewne), nie będzie to jednak z pewnością przewaga znacząca, wielokrotna.

Sytuacja rozwija się zatem w sposób zajmujący - z jednej strony możemy być świadkami bezwzględnej na gruncie toponomastycznej empirii delegitymizacji roszczeń toponimii wschodniosłowiańskiej do jakiejś ponadstandardowej pozycji na tle Słowiańszczyzny, z drugiej - ukształtowanie rysujących się obszarów najsilniejszego zróżnicowania złoża leksykalnego pochodzenia prasłowiańskiego w toponimii zapewne trudno będzie w umotywowany sposób cofnąć w całości do starożytności. Jeśli te tendencje utrzymają się i znajdą ostateczne potwierdzenie, zadaniem przyszłości będzie znalezienie uzasadnienia dla takiej nieoczekiwanej sytuacji empirycznej. Być może odpowiedzią okaże się właśnie - badana równolegle przez genetyków - rola czynnika ludnościowego przy kształtowaniu się wczesnośredniowiecznych społeczeństw słowiańskojęzycznych - duży udział użytkowników regionalnie zróżnicowanych dialektów prasłowiańskich w genezie Słowiańszczyzny zachodniej, kolonizujących obszary znacznie odludnione i tracących w konsekwencji późniejszych (przed)historycznych procesów integracyjnych dużą część swego pierwotnego zróżnicowania, kontrastujący z małymi grupami założycielskimi języków wschodniosłowiańskich, początkowo operującymi w obcym otoczeniu etnicznym.

13 Próbowałem m.in. poszukiwać w czeskiej mikrotoponimicznej hasłowej bazie danych śladów leksemów niezafiksowanych ani w polskim, ani w czeskim, a zidentyfikowanych przeze mnie już wcześniej w toponimii polskiej. 


\section{Literatura}

BАвІк Z., 2001, Najstarsza warstwa nazewnicza na ziemiach polskich (w granicach wczesnośredniowiecznej Słowiańszczyzny), Kraków.

BAŃkowski A., 1973, O staropolskim toponimie Wąblany, „Język Polski” LIII, s. 355-361.

BlažEK V., Vondrová M., 2001, Slovanské archaismy a dialektismy v toponymii Čech, "Čeština univerzália a specifika” 3, z. 1, s. 311-342.

BoreK H., 1968, Zachodniosłowiańskie nazwy toponimiczne z formantem -ьn-, Wrocław.

Boryś W., 1975, Prefiksacja imienna w językach słowiańskich, Wrocław.

Czapla A., 2011, Nazwy miejscowości historycznej ziemi lwowskiej, Lublin.

GoŁĄ Z., 1992, The origins of the Slavs. A linguist's view, Columbus.

HaRvalík M., 2014, Aktualní metodologické směry české onomastiky ve slovanském kontextu, „Onomastica” LVIII, s. 67-77.

Hrabec S., 1950, Nazwy geograficzne Huculszczyzny, Kraków.

Kowalska A., 2011, Apelatywne nazwy miejsc w dialektach polskich. Derywacja sufiksalna, Poznań.

KozIERowski S., 1916, Badania nazw topograficznych dzisiejszej archidyecezyi poznańskiej, t. 2: $P-\dot{Z}$, dodatek $A-\dot{Z}$, Poznań.

KozIERowski S., 1928, Badania nazw topograficznych na obszarze dawnej wschodniej Wielkopolski, t. 2, Poznań.

Makarski W., 1999, Nazwy miejscowości dawnej ziemi przemyskiej, Lublin.

Nalepa J., 1973, Opuscula Slavica 2. Krytyczne i metodyczne uwagi o nazwach miejscowych dawnego województwa sandomierskiego, Lund.

Nitsche P., 1964, Die geographische Terminologie des Polnischen, Köln - Graz.

NMPol: K. Rymut (red.), Nazwy miejscowe Polski. Historia, pochodzenie, zmiany, Kraków 1996-.

Pluskota T., 1998, Nazwy miejscowe ziem ruskich Rzeczypospolitej XVI-XVIII w. Toponimia Ukrainy i pogranicza polsko-ukraińskiego, Bydgoszcz.

Rospond S., 1969, Słowiańskie nazwy geograficzne z sufiksem *-bsk-, Wrocław.

Rospond S., 1984, Słownik etymologiczny miast i gmin PRL, Wrocław.

RuDNICKI J., 1939, Nazwy geograficzne Bojkowszczyzny, Lwów.

SEK: W. Boryś, H. Popowska-Taborska, Słownik etymologiczny kaszubszczyzny, Warszawa 1994-2010.

SP: F. Sławski (red.), Słownik prasłowiański, Wrocław 1974-2001.

ZALESKi J., 1987, Nazwy miejscowe Tarnopolszczyzny, słownik nazw oprac. E. Klisiewicz, Wrocław.

Аркушин Г.Л., 2007, Словник мікротопонімів імікрогідронімів північно-західної України та суміжних земель, т. I-II, Луцьк.

Борек Г., 1972, Восточнославянские топонимы с формантом -ьn-, [w:] Восточнославянская ономастика, Москва, s. 90-143.

Васильев В.Л., 2012, Славянские топонимические древности Новгородской земли, Москва.

Габорак М., 20о8, Назви гір і полонин Івано-Франківщини. Словник-довідник, Івано-Франківськ.

Гаврилова Т.О., Денисенко 3.М., 2010, Словник мікротопонімї Черкащини, Черкаси. 
Данилюк О.К., 2013, Словник народних географічних термінів Волині, Луцьк.

Зборовський П. (ред.), 2004, Топоніміка Турківщини, Львів.

Павленко С., 2013, Мікротопоніми Чернігово-Сіверщзини, Чернігів.

Сокіл Н., 2008, Мікротопонімія Сколівщини, Львів.

СРНГ: Словарь русских народных говоров, Ленинград 1965-.

Трубачев О.Н., 1968, Названия рек правобережной Украины. Этимология, словообразование, этническая интерпретация, Москва.

Шульгач В.П., 1998, Праслов'янський гідронімний фонд (фрагмент реконструкиї), Київ.

Яцій В.О., 2015, Ойконімія Івано-Франківської області, Київ.

\section{In search of the so-called "centre of (early) Slavic toponymy". The case of Poland. Part II Summary}

This two-part paper presents the theoretical assumptions, and gives an account of the current progress of a Slavistic appendix which is being prepared by this author for an as yet unwritten "Dictionary of Polish toponyms", an attempt to inventory and describe the entire lexical deposit of potentially Proto-Slavic origin contained in Polish place and terrain names. The aim of this research is to determine, based on the varying degree of its preservation in the toponymy of different regions, the place where Proto-Slavic vocabulary was formed.

The second part briefly presents the current results (after the identification of ca. 400 potential words), and discusses the non-uniform distribution of rare specimens of this vocabulary (suggestions about the privileged status of Podkarpacie have not been confirmed), as well as perspectives on the comparison between the diversity of toponymy of this area and the situation in the neighbouring territories which suggest, among others, the peripheral and local nature of East Slavic nomenclature. 

Norbert Ostrowski

Uniwersytet Jagielloński, Kraków

norbertas@poczta.onet.pl

\section{OD COMITATIVU DO SPÓJNIKA. O POCHODZENIU SŁOWIAŃSKIEGO SPÓJNIKA I ORAZ LITEWSKIEGO IR 'I; TEŻ'}

Słowa klucze: etymologia, składnia historyczna, języki bałtyckie i słowiańskie, gramatykalizacja, typologia

Keywords: etymology, historical syntax, Baltic and Slavic languages, grammaticalization, typology

1. Standardowa etymologia słowiańskiego spójnika $i$ głosi, że kontynuuje on locativus singularis ie. zaimka wskazującego ${ }^{\star} h_{1} e$ - i pozostaje w związku ze starogreckim spójnikiem warunkowym $\varepsilon i$ ' jeśli', czyli w skrócie ie. ${ }^{\star} h_{1} e-i>$ słow. $i$. Wprawdzie od strony dźwiękowej nic takiemu zestawieniu nie można zarzucić, to jednak od strony funkcjonalnej nie wytrzymuje ono krytyki. Gdyby bowiem przyjąć zrównanie stgr. $\varepsilon i$ ' 'jeśli' = słow. $i$, to rysują się trzy możliwości:

1) spójnik łączny rozwinął się ze spójnika warunkowego, czyli 'jeśli’ $\rightarrow$ 'i',

2) spójnik warunkowy pochodzi ze spójnika łącznego, czyli 'i’ $\rightarrow$ 'jeśli',

3) z loc. sg. zaimka wskazującego rozwinęły się niezależnie spójnik łączny i warunkowy.

Dla każdego z tych scenariuszy brak oparcia w dostępnym materiale typologicznym. Najczęściej bezpośrednim źródłem spójników łącznych są comitativa oraz partykuły addytywne (zob. Mithun 1988; Stassen 2000; Haspelmath 2007). Pozostałe źródła spójników łącznych we frazach nominalnych wymienia Stassen (2001), nigdy nie są to jednak spójniki warunkowe. Jeśli chodzi o wariant nr 2, to jak pokazała Elizabeth Traugott (1985), spójniki warunkowe mogą pochodzić m.in. z wyrazów sygnalizujących temat wypowiedzi w rodzaju pol. jeśli chodzi o; ang. given that itp. Taka 
była prawdopodobnie pierwotna funkcja łacińskiego $s i$ 'jeśli’ < sei, który kontynuuje dawny locativus zaimka wskazującego (ibid.). Tym samym łacina stanowi dobrą paralelę dla stgr. $\varepsilon i$ ' 'jeśli'. Nie ma natomiast przykładów na rozwój spójnik łączny $\rightarrow$ spójnik warunkowy. Jeśli wreszcie ktoś akceptuje możliwość nr 3, to musi wskazać scenariusz objaśniający, w jaki sposób doszło do takiej zmiany, a tego brakuje w istniejących opisach. W literaturze etymologicznej od ponad 100 lat wskazuje się również na bałtycki spójnik/partykułę addytywną ir (stprus. ir 'też', łot. ir 'też; nawet; i', lit. ir ' $\mathrm{i}$; też') jako możliwy kognat słowiańskiego $i$. Etymolodzy, chcąc zachować związek z formą grecką, przyjmują dla bałtyckiego rozwój: ${ }^{\star} e i-r>{ }^{\star} i e r>i r^{1}$. Ze względu na przeprowadzoną wyżej krytykę odrzucam zestawienie z greckim eí 'jeśli'. Poniżej wykażę, że litewsko-łotewski spójnik łączny ir 'i’ kontynuuje starszą formację ${ }^{\star} \bar{i}-r$, która z kolei jest wynikiem konflacji instr. sg. ${ }^{*} h_{1} i-h_{1}$ zaimka wskazującego (w funkcji instrumentalis sociativus) z postpozycją -r. Tym samym spójnik litewski ir oraz słowiański $i$ wpisują się w pospolity w językach świata schemat rozwojowy comitativus > spójnik łączny. Aby to wykazać, konieczna jest na początek analiza etymologiczna litewskiego czasownika yrà 'jest' (część 2). Natomiast gramatykalizacji spójników i oraz ir, a także paralelom typologicznym poświęcona będzie część 3 .

\section{Pochodzenie litewskiego yrà 'jest; są' i łotewskiego ir 'jest; są'}

Jednym z bardziej problematycznych zagadnień historycznego językoznawstwa bałtyckiego jest pochodzenie supletywnego czasownika lit. yrà 'jest; są' (i łot. ir 'jest; są'), por. paradygmat litewski:

$1 \mathrm{sg}$. esù 'jestem'

2 sg. esi 'jesteś'
1 pl. ẽsame ‘jesteśmy’

2 pl. ẽsate 'jesteście’

3 yrà 'jest; są?

W języku litewskim dawna forma trzeciej osoby, czyli ẽsti, została wyrugowana do sekundarnej funkcji czasownika habitualnego jako synonim būna 'bywa(ją)' (zob. Stang 1947/1970). Również w łotewskim dawne *esti (ie. ${ }^{\star} h_{1} e s-t i$ ) zostało zastąpione przez ir (stłot. jirā-g / dial. ira). Jak wykazali na materiale starolitewskim Christian Stang (ibid.), a później Gordon B. Ford (1967), pierwotnie yrà funkcjonowało jako czasownik egzystencjalny w rodzaju fr. il y a czy ang. there is. Ta obserwacja tekstowa pozwoliła Stangowi (1963/1970) na sformułowanie etymologii yrà jako formacji opartej na temacie zaimka wskazującego, rozszerzonego o postpozycję lokali-

1 W ten sposób stosunkowo niedawno czeski slawista Rejzek (2001). Niektórzy bałtyści preferują (błędnie) związek ir 'i; też' z partykułą pytajną ar, zob. część 3 .

2 We wszystkich językach bałtyckich w 3 osobie nastąpiła neutralizacja opozycji liczby, por. lit. vẽda 'prowadzi; prowadzą', nẽša 'niesie; niosą' etc. 
zującą -r. Pierwotną postać należy rekonstruować jako *īrá. Na długość -á wskazują stłot. girrahg $($ Mancelius $)=$ jirā- $g($ dial. ira $)($ Endzelin 1922: 556 $)$ oraz lit. dial. ýro-tès 'jest; są’ (LKŽ IV: 140), gdzie /o:/ < /a:/. Skrót w wygłosie *īrá > yrà tłumaczy się tzw. prawem Leskiena. Wewnętrzne - $r$ - zestawiał Stang z indoeuropejską postpozycją $-r$, która pojawia się po zaimkach, np.:

a) goc./stnord. hvar 'gdzie' $<{ }^{\star} k^{w} o-r$, stwniem. war 'gdzie' (por. niem. war-um 'dlaczego' < war-umbi): lit./łot. ku-r 'gdzie' < ${ }^{*} k^{w} u-r$,

b) awest. ava-rə 'tutaj' - temat zaimka jak w scs. ovz, pol. ów,

c) germańskie przysłówki od tematu zaimka ${ }^{\star}$ to-: goc. par 'tam', stnord. par 'ts.', stwniem. $d \bar{a}(r)$ (por. niem. da, ale daraus), stang. por (ang. there).

Jako paralelę dla yrà Stang podał oparte na temacie zaimków przysłówki litewskie au-rè 'oto gdzie' (stlit. auré 'ondzie' DP 318: 10) oraz anrẽ-kui 'oto gdzie', które etymologicznie stoją w związku odpowiednio ze scs. ovz oraz scs. onz (lit. anàs 'tamten'). Jak widać z przytoczonych powyżej przykładów, postpozycja $-r$ pojawia się po zaimkach, a ponieważ zaimki oraz przysłówki miejsca często występują w funkcji predykatywnej (zob. Diessel 1997, 1999: 10-11, 33-36; Petit 2010), etymologia Stanga zyskuje na prawdopodobieństwie. Ma ona właściwie tylko jedną słabość. Bez objaśnienia pozostaje końcowa samogłoska /a:/ w *īáa > yrà oraz /e/ w aurè 'oto gdzie' i anrẽ-.

W swoim artykule (Ostrowski 2017) zaproponowałem, aby aurè (i odpowiednio anrẽ-kui) uznać za formacje o strukturze: zaimek wskazujący + dwie postpozycje lokalizujące (-r oraz -è), gdzie -è jest etymologicznie tożsame z dzisiejszą końcówką loc. sg., por. lit. nam-è 'w domu'. Czyli rozwój aurè i anrẽ- przebiegał w skrócie następująco: ${ }^{\star}$ ava- $r>{ }^{*}$ ava- $r$-è $>$ aurè (synkopa /a/) i odpowiednio ${ }^{*}$ ana- $r>{ }^{*}$ ana- $r$-è $>$ $>$ anrẽ $^{-3}$ (zob. Stang 1963/1970: 209). To z kolei otwiera możliwości doprecyzowania etymologii ${ }_{i} r a \bar{~}>$ yrà, które analogicznie do aurè można objaśnić jako formację o strukturze: zaimek wskazujący + dwie postpozycje lokalizujące $(-r$ oraz $-\bar{a})$, czyli ${ }^{*} \bar{i}-r-\bar{a}$. Problemów nastręcza pochodzenie wygłosowego ${ }^{*}$-á. Okazuje się jednak, że postpozycja ta jest dobrze poświadczona w litewskim i łotewskim jako wykładnik jednego z przypadków lokalizujących, tzw. illativu, por. lit. dial. miškanà 'do lasu’4. Historycznie illativus należy objaśniać jako połączenie formy acc. sg. ${ }^{\star} m i s ̌ k a n ~(i e . a c-$ cusativus directionis) i postpozycji allatywnej -⿳亠丷a, por. także stlit. kanà (-g) 'dokąd' < $<{ }^{\star} k a n+-\bar{a}$ (acc. sg. ką 'kogo, co'< ${ }^{\star} k a n$ ). Tradycyjną etymologię bałtyckiego illativu, która głosi, że chodzi tu o fuzję accusativu z postpozycją -ná (tożsamą etymologicznie z przyimkiem słow. na) należy odrzucić z kilku powodów. Po pierwsze, odpowiednikiem słow. na jest w litewskim i łotewskim ablatywne (sic!) nuo 'od'. Po drugie, gdyby przyjąć za punkt wyjścia sekwencję acc. sg. ${ }^{*}$ miškan + postpo-

3 Należy pamiętać, że końcówka lokatywna -è kontynuuje dawną postpozycję lokalizującą *-en (chodziło pierwotnie o tzw. inessivus).

4 Por. stlit. Vardana 'w imię', daguna 'do nieba' i in. (Zinkevičius 1980: 256). 
zycja nuo 'od', to oczekuje się ablativu *miškanu 'z lasu' zamiast illativu miškanà 'do lasu'. Po trzecie, sięganie po materiał staropruski, jak to się dzieje w tradycyjnej etymologii illativu (por. stprus. no 'na'), jest błędem metodologicznym, który polega na ignorowaniu niewygodnych faktów litewskich i łotewskich, gdy te są niezgodne z założoną hipotezą („jeśli teoria nie zgadza się z faktami, tym gorzej dla faktów”).

Drugim przykładem obecności w językach bałtyckich allatywnej postpozycji -á jest litewski przysłówek čià 'tutaj' < ‘tj-̄́ (zob. Ostrowski 2014, 2017). Jest to fuzja zaimka wskazującego $t i^{5}$ i postpozycji allatywnej. Analogicznie zbudowane przysłówki z postpozycją allatywną - $d e$ odnajdujemy w stgr. $\dot{\varepsilon} v \vartheta \alpha \dot{\alpha} \delta \varepsilon$ 'tutaj; teraz' (< $\varepsilon^{\prime} v \vartheta \alpha$ 'tam' $+-\delta \varepsilon$ jak w olk $\alpha \alpha-\delta \varepsilon$ 'do domu') i scs. $s b$-de 'tutaj' (zaimek $s b$ 'ten' $+-d e$ ).

Komentarza jeszcze wymaga pochodzenie samej postpozycji allatywnej *-á. Etymologicznie jest ona tożsama z lit. spójnikiem o 'i; ale’ oraz słow. a 'i, ale’. Ciekawej paraleli typologicznej dostarcza partykuła/spójnik stgr. $\delta \dot{\varepsilon}$, która występuje $\mathrm{w}$ dwóch funkcjach: 1) postpozycji allatywnej, np. olk $\alpha$ - $\delta \varepsilon$ 'do domu', 2) spójnika adwersatywnego $\delta \varepsilon ́$ 'ale' (zob. Klingenschmitt 2008: 411) ${ }^{6}$. Spójnik słow. $a$ jest tradycyjnie objaśniany (np. Vasmer-Trubačev 1986 I) jako stary ablativus zaimka demonstratywnego ${ }^{\star} h_{1} e /{ }^{\star} h_{1} o$, por. awest. āat 'następnie, i, ale'. Funkcja ablatywna bałt. *ā widoczna jest jeszcze w lit. óda (1) / odà (4) 'skóra' i łot. âda 'skóra', które stanowią pierwotne złożenie o strukturze: ${ }^{\star} \bar{a}-$ 'od' $+{ }^{\star}-d \bar{a}<{ }^{\star} d e h_{2}$ - 'oddzielać', por. wed. áva adāt 'hat abgetrennt' (szczegóły Ostrowski 2014). Prymarne znaczenie *'to, co oddzielone' zachowało się jeszcze w fińskim vuota 'świeżo zdjęta skóra zwierzęca', które jest powszechnie uważane za pożyczkę bałtycką. Różnica znaczeniowa między ablatywnym $\bar{a}-\mathrm{w}{ }^{\star} \bar{a}-d \bar{a}$ oraz allatywnym $\bar{a}-\mathrm{w}{ }^{\star} t j-\bar{a}>c ̌ c i a ̀ ~ ' t u t a j ' ~ z n a j d u j e ~ o p a r c i e$ w licznych przykładach alternacji „allativus” : „ablativus”, por. m.in. „ablatywne” lit. at- w at-skirti 'oddzielać' obok ,allatywnego" at- w at-važiuoti 'przyjeżdżać, łot. iz 'od' : łat. iz 'na, do', lit. nuo 'od' : słow. na i in. (Ostrowski 2014, 2017).

Przeprowadzona analiza bałtyckiej postpozycji allatywnej *á pozwala doprecyzować pierwotną budowę i funkcje bałt. ${ }^{\star} \bar{i}-r-\bar{a}$. Był to na początku czasownik lokalizujący, który funkcjonalnie odpowiadał łac. adesse, a następnie - i ten stan mamy jeszcze uchwytny w XVI- i XVII-wiecznej litewszczyźnie - nabrał znaczenia egzystencjalnego. Rozwój jest zgodny z tym, co wiemy na temat relacji między zdaniami lokalizującymi i egzystencjalnymi, jakie obserwujemy w językach świata (zob. Lyons 1967; Clark 1978; Yong, Jie 2013). Współgra także z rozwojem stgr. ěvl, o którym Wackernagel (1924: 166) pisał:

Anfänglich bedeutete es 'ist (sind) darin'; von hellenistischer Zeit an 'ist vorhanden' mit ähnlicher Ausmerzung des lokalen Bedeutungsmoments wie in frz. il y a. Im

\footnotetext{
5 Por. Ti pasiutęs vaikas - neklauso 'To mały dzikus, nie słucha' (LKŽ XVI: 16o). Forma ti jest wynikiem monoftongizacji zaimka tai 'to', o czym szerzej Ostrowski (2014, 2015).

6 Szczegółowo o funkcjach stgr. $\delta \dot{\varepsilon}$ zob. Bakker 1993.
} 
Neugriechischen ist mit Umstellung der Vokale dafür ine eingetreten, und dies dient schlechtweg als Kopula 'ist' [...].

Związek między zdaniem lokalizującym a egzystencjalnym łatwo zrozumieć, pamiętając, że przy nienacechowanym szyku zdania struktura tematyczno-rematyczna jednego jest zwierciadlanym odbiciem struktury tematyczno-rematycznej drugiego, np. Zeszyt jest na stole (zdanie lokalizujące - gdzie jest zeszyt?) vs. Na stole jest zeszyt (zdanie egzystencjalne - co jest na stole?). O relacji między tymi dwoma typami zdań a zdaniami posesywnymi zob. także Benveniste (1960/1966) i Watkins (1967/1994).

\section{Bałtyckie *ī-r oraz słowiańskie $i$}

Przeprowadzona analiza litewskiego czasownika yrà rzuca światło na pochodzenie spójnika bałt. ir 'i’ i słow. $i$. Jak już zostało powiedziane w części 1, najczęstszym źródłem spójników łącznych są comitativa oraz partykuły addytywne (zob. Mithun 1988; Stassen 2000; Haspelmath 2007), por. przykład (1) z języka lango (Uganda), w którym kèdè może być zarówno spójnikiem, jak i przyimkiem komitatywnym:

(1) 'Okèlò òmàtò Okelo 3sg.drink.pfv cây kèdè càk 'Okelo drank tea and milk' tea and milk (Haspelmath 2007: 8).

Syntaktycznie cây kèdè càk reprezentuje przykład spójnika inicjalnego, czyli [cây] [kèdè càk] albo inaczej [A] [\& B], gdzie A i B to frazy nominalne, natomiast \& to spójnik, i jest to bodaj najczęstszy sposób łączenia fraz nominalnych w językach świata (Zwart 2005). Pozostałe możliwości monosyndetycznej kombinacji fraz nominalnych to [A \&] [B] oraz [A] [B \&], natomiast z przyczyn wskazanych przez Haspelmatha (2007) nigdzie nie jest poświadczony schemat [\& A] [B]. Spójnik bałt. ir 'i’ oraz słow. i reprezentują typ [A] [\& B], por. Janek, wysoki blondyn, i Ania, niska brunetka, natomiast nie ${ }^{\star} J a n e k i$, wysoki blondyn, Ania, niska brunetka oraz nie ${ }^{\star} J a n e k$, wysoki blondyn, Ania i, niska brunetka. Takie usytuowanie spójnika musi zostać wyjaśnione od strony diachronicznej.

W lit. yrà 'jest; są’ mamy zachowaną długość zaimka w pozycji heterosylabicznej przed postpozycją $-r$, natomiast w połączeniu tautosylabicznym oczekiwane ${ }^{{ }^{*} \bar{i}-r}$ regularnie skróciło się do ir. Co najmniej od czasów Karla Brugmanna krąży w literaturze przedmiotu hipoteza, zgodnie z którą spójnik bałtycki ir ma reprezentować stopień zanikowy partykuły ar '(partyk. pytajna) czy?; (partyk. addytywna) też’ (łot. ar 'też; czy?'), która dalej jakoby pozostaje w związku etymologicznym ze stgr. ä $\rho \alpha$ 'czy?; zatem; gdyż' Zestawienie litewsko-łotewskiego ar ze stgr. $\alpha \rho \alpha$ jest wadliwe metodologicznie. Po pierwsze, rekonstrukcja indoeuropeistyczna oparta wyłącznie na danych starogreckich i bałtyckich jest wysoce ryzykowna ze względu na późne świa- 
dectwo tych ostatnich. Po drugie, jeśli ktoś upiera się przy zestawieniu bałt. ar ze stgr. $\ddot{\alpha} \rho \alpha$, to powinien przedstawić scenariusz określający, jak doszło do powstania tych partykuł. Etymologia, która tego nie czyni, w rzeczywistości nic nie tłumaczy i tym samym jest niewiele warta. Po trzecie wreszcie, partykuła ar daje się łatwo objaśnić na gruncie bałtyckim jako sekwencja ${ }^{*} \bar{a}-r$ (zaimek + postpozycja $\left.-r\right)>a r$, gdzie $^{*} \bar{a}$ - stoi w związku ze spójnikiem słow. $a$, zob. wcześniejsze uwagi o bałt. ${ }^{*}-\bar{a}$.

Szczegółowy opis zmian funkcjonalnych spójnika $a$ przedstawię w odrębnym artykule, ale korzystając z okazji, zwrócę uwagę na kilka kwestii. Zauważmy, że elementy allatywne, a takie znaczenie daje się rekonstruować dla bałt. postpozycji *-á, mogą się rozwijać w kierunku partykuł addytywnych, por. ang. to 'do' obok too 'też', które są etymologicznie tożsame i pozostają w związku z przyimkiem słow. do. W ten sposób znajdujemy comparandum dla różnicy znaczeniowej allatywne *-á vs. addytywne *āar $r$ ar 'też' (por. lit. Nauja šluota gražiai šluoja, šluok su ražu, ár bus gražu (LKŽ I: 288) 'Nowa miotła pięknie czyści, czyść gałązkami, też będzie pięknie') ${ }^{7}$. Jak pokazują dane typologiczne (zob. Forker 2016), elementy addytywne często pojawiają się w kontekstach wyrażających opozycję semantyczną (ang. semantic opposition), np. Janek jest wysoki, a Wojtek niski ${ }^{8}$, oraz jako „przełącznik tematu wypowiedzi" (ang. topic switch), por. Spotkałem Anię i poszliśmy do kina. A słońce świeciło niemiłosiernie. W związku z tym jeśli założymy dla słow. spójnika $a$ starsze znaczenie addytywne, to łatwo wyjaśnimy jego funkcje we współczesnych językach słowiańskich, przy czym funkcja adwersatywna spójnika a (np. stary, a głupi) jest chronologicznie najmłodsza. W związku etymologicznym z a pozostaje oczywiście spójnik adwersatywny ale, który można łatwo objaśnić jako wynik wzmocnienia (ang. reinforcement) ${ }^{9}$ funkcji przeciwstawnej polifunkcjonalnego spójnika a za pomocą postpozycji restryktywnej -lěl-le, por. kaszubskie le 'tylko' i strus. $\pi r^{\prime}$ 'ledwo' (Boryś 2005: 282). W wielu językach świata partykuły restryktywne funkcjonują także jako spójniki adwersatywne, por. hol. maar 'tylko; ale' (König 1991: 106) oraz pol. Nie kupiłem bułek, tylko mleko. Tu należy oczywiście także pol. lecz z niejasną funkcjonalnie postpozycją -cz<*-če (Boryś 2005) ${ }^{10}$.

7 Akut w ár jest sekundarny i pochodzi z zaniku -gi w argi 'też'.

8 Przykłady ze spójnikiem $a$ w zdaniach wyrażających opozycję semantyczną odnajdujemy już w staroruskim, zob. Борковский, Кузнецов 20o6: 471. Poprzez opozycję semantyczną należy rozumieć przypadki, w których przeciwstawia się antonimy, np. 'wysoki' vs. 'niski', 'oni' vs. 'my' itd., ale to przeciwstawienie nie zaprzecza naszym oczekiwaniom (ang. denial of expectations), jak w zdaniu Janek jest niski, a dobrze gra w koszykówkę. Na podstawie naszej wiedzy o świecie oczekujemy, że skoro Janek jest niski, to nie powinien grać dobrze w koszykówkę i dlatego w tym właśnie zdaniu spójnik a jest właściwym spójnikiem adwersatywnym (więcej Malchukov 2004).

9 O pojęciu reinforcement zob. Lehmann 1995: 22-24.

10 Powszechnie łączy się ${ }^{*}-\check{c} e z$ ie. ${ }^{*}-k^{w} e$ 'i', ale to zestawienie musi być dobrze uzasadnione od strony funkcjonalnej, a punktem wyjścia powinna być skrupulatna analiza tekstowa wyrazów z postpozycją * ${ }^{*} \check{c}$. Dopiero wówczas etymologia ta będzie ciekawa i powie nam coś istotnego o rozwoju historycznym składni słowiańskiej. 


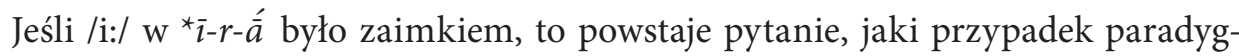
matyczny ta konkretna forma kontynuuje. Najoczywistszym kandydatem do tej roli wydaje się instr. sg. zaimka wskazującego, czyli ${ }^{\star} h_{1} i-h_{1}{ }^{*}{ }^{\star}$. Jeśli zgodzimy się, że był to instrumentalis, to cała etymologia układa się od strony funkcjonalnej. W językach bałtyckich i słowiańskich mamy dobrze poświadczony instrumentalis sociativus, por. przykład litewski (2) i staroruski (3):

(2) Vienas vaikas buvo gimęs ir antr-u vaikščiojau. jeden dziecko być urodzić się i drugi: instr. sg. chodzić

'Jedno dziecko urodziło się i z drugim chodziłam' (Ambrazas 2006: 255).

(3) Бъ же Мьстиславъ дебелъ тьлъмь, чьрмьнъ лицьмь, великома очима 'Mstislav was fat, red-faced with big eyes' (Schmalstieg 1995: 168).

Skoro w językach bałtyckich i słowiańskich mamy zaświadczony instrumentalis sociativus, to możemy wyjaśnić powstanie spójnika $i$, wychodząc od struktury, w której zaimek ten pełnił pierwotnie funkcję anaforyczną, czyli:
*[A] [ī B] 'A, z nim B' $\rightarrow$
$[\mathrm{A}][\& \mathrm{~B}]$ 'A i B'

Dalsza gramatykalizacja bałt. ${ }^{\star} \bar{i}-r>$ ir oraz słow. $i$ jako spójników zdaniowych pozostaje w związku z ich funkcją łączenia zdarzeń następujących jedno po drugim, czyli tzw. temporal succession („X, potem Y”) w terminologii Dixona (2009). Jako egzemplifikację podaję zdanie (4), pochodzące ze starolitewskiego tłumaczenia Biblii wg Johanna Bretkuna (koniec XVI w.), w którym mamy dwa spójniki: bei oraz ir. Pierwszy z nich był używany jako sygnał wskazujący na początek nowego wątku w narracji (podobnie jak niekiedy słow. $a$ ) ${ }^{11}$, stąd jego pozycja inicjalna w zdaniu ${ }^{12}$,

11 Ciekawej analizy użycia spójników $i$ oraz $a$ w tekstach staroczeskich dostarczyła praca Kacpra Owińskiego (2016). Z obserwacji autora wynika m.in., że w okresie staroczeskim spójnik $i$ funkcjonował w zdaniach wyrażających konsekutywność zdarzeń (jak w przykładzie (4)) oraz częściej służył do łączenia fraz nominalnych (często w funkcji wskaźnika „naturalnej współrzędności”) niż zdań. Z drugiej strony spójnik $a$ w funkcji spójnika łącznego częściej spajał zdania niż frazy nominalne, ale przede wszystkim funkcjonował jako partykuła zdaniowa sygnalizująca wprowadzenie do dyskursu nowej informacji. W tym sensie spójnik $a$ odpowiadał funkcjonalnie lit. bei z przykładu (4). Rozszerzenie przez spójnik a zakresu użycia w czeszczyźnie literackiej kosztem spójnika $i$ oraz wyrugowanie $i$ do funkcji partykuły addytywnej ('też) datuje Owiński na czasy Jana Husa. Teraz zadaniem slawistów jest dokonanie podobnej analizy spójników parataktycznych w innych językach słowiańskich. Dopiero wówczas będą możliwe kolejne uogólnienia natury diachronicznej.

12 O pochodzeniu lit. beĩ zob. Ostrowski (w druku). Do dzisiaj beĩ jest używane jako wykładnik tzw. „naturalnej współrzędności” (ang. natural coordination), np. tévas beĩ motina 'ojciec i matka', brolis beĩ sesuo 'brat i siostra'. Spójnik beĩ rozwinął się z fuzji spójnika łącznego be 'i' (por. stprus. $<$ bhe> 'und') i partykuły addytywnej ir 'też'. Dystrybucja beĩ w tekstach starolitewskich wskazuje, że miejscem jego powstania był obszar tzw. Małej Litwy (część dawnych Prus Wschodnich). 
natomiast ir łączył następujące po sobie wydarzenia i w tym użyciu odpowiada dokładnie słow. $i$, por.:

(4) Bei nueia Wiras isch Namu Leui, ir waede Dukterị Leui, ir ta Moterischke tapa nieschcze, ir pagimde Sunů, ir regedama berneli santị graszụ, paslepe anạ per tris menesius $(\mathrm{Wj} 2,1)$.

= A oto poszedł mąż z domu Lewiego, i poślubił córkę Lewiego, i ta kobieta stała się ciężarna, i urodziła syna, i widząc, że dzieciątko jest piękne, ukrywała je przez trzy miesiące.

Możemy więc przyjąć następujący schemat rozwojowy bałt. ir oraz słow. $i$ : 1) instr. sg. zaimka anaforycznego w funkcji komitatywnej $\rightarrow 2$ ) spójnik frazowy $\rightarrow$ 3) spójnik zdaniowy (pierwotnie jako wykładnik następstwa czasowego zdarzeń „i potem”).

Przedstawiony rozwój nie jest odosobniony. Frajzyngier (1996: 31-32) przyjmuje podobny schemat dla jednego z języków czadyjskich (język lele). Analogia to wprawdzie dosyć egzotyczna, ale na gruncie języków indoeuropejskich scenariusz comitativus $\rightarrow$ spójnik frazowy $\rightarrow$ spójnik zdaniowy jest reprezentowany przez stirl. ocus ' $i{ }^{13}$. Rodzi się przy tej okazji pytanie, czy dysponujemy materiałem etymologicznym, który potwierdziłby tzw. hierarchię Payne’a (1985: 5-6), tj.:

$$
\mathrm{S}(\text { entence })>\mathrm{V}(\text { erb }) \mathrm{P}(\text { hrase })>\mathrm{P}(\text { repositional }) \mathrm{P}(\text { hrase })>\mathrm{N}(\text { oun }) \mathrm{P}(\text { hrase })
$$

Głosi ona, że „individual coordination strategies are used to cover contiguous categories", czyli jakaś strategia, np. łączenie za pomocą interesującego nas tu spójnika $i$, nie może być zastosowana do łączenia fraz nominalnych (NP) i werbalnych (VP), jeśli za jej pomocą nie można łączyć fraz przyimkowych (PP). Historycznie więc, wychodząc od spójnika fraz nominalnych, kolejnymi etapami rozwoju powinny być spójnik fraz przyimkowych, fraz werbalnych i dopiero na końcu spójnik zdaniowy.

Bardzo ciekawej paraleli dla zmiany instr. sg. zaimka wskazującego $\rightarrow$ spójnik parataktyczny dostarcza wschodniolit. spójnik $\dot{e}$ 'a, natomiast’, np. Rado gaidys pupa, $\dot{\boldsymbol{e}}$ vištą žirnį 'Znalazł kogut fasolę, a kura groch'. Zgodnie ze standardową etymologią (np. Fraenkel 1962-1965) spójnik ten kontynuuje dawną formę instr. sg. zaimka wskazującego ${ }^{\star} h_{1} e-h_{1}$, poświadczonego m.in. w stgr. $\tilde{\eta}$ 'certainly, really' i stind. á 'blisko'. Wprawdzie $\dot{e}$ 'a, natomiast' nie jest spójnikiem łącznym, lecz przeciwstawnym $^{14}$, ale często $\mathrm{w}$ językach obserwujemy podobne przekształcenia funkcjonalne, por. stisl. enn > en (odpowiednik etymologiczny ang. and), które w najstarszych tekstach było jeszcze spójnikiem łącznym (np. festr mun slitna, enn freki renna 'Lina się zerwie i wilk pobiegnie’ [Wieszczba Wölwy] - Nedoma 2011: 146), aby następ-

13 Zob. Griffith 2011.

14 Ściślej rzecz ujmując, wskazuje na semantyczną opozycję. 
nie stać się spójnikiem zdań przeciwstawnych, a na końcu zdań porównawczych ${ }^{15}$. Przejście od spójnika łącznego do przeciwstawnego obserwujemy także w języku gockim, gdzie $i p$ 'i, ale', odpowiednik etymologiczny łac. et 'i', występuje często właśnie jako spójnik przeciwstawny, por. Jabai razdom manne rodjau jah aggile, ip friapwa ni habau... 'Jeśli językami ludzi mówiłbym i aniołów, a miłości nie miałbym.... Są wreszcie języki, gdzie nie odróżnia się formalnie spójników łącznych i adwersatywnych ${ }^{16}$, por. przykłady (5)-(6) z postpozycją -dal-de 'i, ale' z języka eweńskiego (Malchukov 2004):

(5) Udagadmar szaman-kobieta

'The shaman woman swam across the sea

tianni

popłynąć

namni, xaman-da xolun. morze szaman-CONJ podążył

(6) Dilgan-ni igre-ce-de enni angar bad'ikar okan. głos-jego brzmieć-PF-CONJ NEG otworzyć rano aż

'His voice was heard (inside the house), but he didn't open until morning'.

\section{Wnioski}

Słowiański spójnik łączny $i$ znajduje swój dokładny odpowiednik w bałtyckiej partykule/spójniku ${ }^{\star} \bar{i}-r>$ ir ' i; też', gdzie - $r$ jest pierwotną postpozycją lokalizującą. Punktem wyjścia była forma instr. sg. zaimka wskazującego, czyli ${ }^{\star} h_{1} i-h_{1}>i$, który służył do łączenia fraz nominalnych. Ponieważ języki słowiańskie (i bałtyckie) nie rozróżniają formalnie spójników zdaniowych i spójników frazowych, $i$ nabrał wtórnie funkcji spójnika zdaniowego.

\section{Skróty}

ang. - angielski; awest. - awestyjski; bałt. - bałtycki; fr. - francuski; goc. - gocki; hol. - holenderski; ie. - indoeuropejski; lit. - litewski; łat. - łatgalski; łot. - łotewski; niem. - niemiecki; pol. - polski; scs. - staro-cerkiewno-słowiański; słow. - słowiański;

15 Rozwój spójnik adwersatywny $\rightarrow$ spójnik zdań porównawczych jest dobrze rozpoznany w językach świata i reprezentuje schemat „antonimiczny” w terminologii Heinego (1997: 117), por. przykład z języka dakota:

Mastingcala king waste, tka singthela king sice

rabbit the good but rattle-snake the bad

'The rabbit is better than the rattle-snake'.

16 Podobnie jest w języku czeskim, gdzie spójnik a ma przede wszystkim znaczenie łączne, ale również przeciwstawne, przy czym w funkcji adwersatywnej jednak częściej pojawia się ale (zob. wcześniejsze uwagi o polskim ale). Jako spójnik łączny a sekundarnie rozszerzył swój zakres użycia kosztem $i$ (zob. przyp. 11). 
stang. - staroangielski; stgr. - starogrecki; stind. - staroindyjski; stirl. - staroirlandzki; stisl. - staroislandzki; stlit. - starolitewski; stłot. - starołotewski; stnord. - staronordycki; stprus. - staropruski; strus. - staroruski; stwniem. - starowysokoniemiecki; wed. - wedyjski; wschodniolit. - wschodniolitewski

acc. - accusativus; dial. - dialektalny; instr. - instrumentalis; loc. - locativus; pl. - pluralis; sg. - singularis

\section{Literatura}

Ambrazas V., 2006, Lietuviu kalbos istorine sintaksé, Vilnius.

BAKker E.J., 1993, Boundaries, Topics, and the Structure of Discourse. An Investigation of the Ancient Greek Particle Dé, „Studies in Language” 17, nr 2, s. 275-311, [on-line:] http:// dx.doi.org/10.1075/sl.17.2.02bak.

Benveniste E., 1960/1966, 'Etre' et 'avoir' dans leurs fonctions linguistiques, „Bulletin de la Société de Linguistique de Paris" 55, s. 113-134 [przedr.: idem, Problèmes de linguistique générale, Paris 1966, s. 187-207].

Boryś W., 2005, Słownik etymologiczny języka polskiego, Kraków.

Clark E.V., 1978, Locationals: Existential, Locative, and Possessive Constructions, [w:] J.H. Greenberg, Ch.A. Ferguson, E.A. Moravcsik (red.), Universals of Human Language, t. 4: Syntax, Stanford, s. 85-126.

Diessel H., 1997, Predicative Demonstratives, [w:] Proceedings of the Twenty-Third Annual Meeting of the Berkeley Linguistics Society: General Session and Parasession on Pragmatics and Grammatical Structure, s. 72-82, [on-line:] http://dx.doi.org/10.3765/bls.v23i1.1282.

Diessel H., 1999, The Morphosyntax of Demonstratives in Synchrony and Diachrony, „Linguistic Typology” 3, s. 1-49, [on-line:] https://doi.org/10.1515/lity.1999.3.1.1.

Dixon R.M.W., 2009, The Semantics of Clause Linking in Typological Perspective, [w:] R.M.W. Dixon, A. Aikhenvald (red.), The Semantics of Clause Linking. A Cross-Linguistic Typology, Oxford, s. 1-55.

DP: Postilla Catholicka. Tái est: Ižguldimas Ewangeliu kiekwienos Nedelos ir szwętes per wissús metús. Per Kúniga Mikaloiv Davkszą Kanonîką Médnikų... 1599, [w:] J. Palionis (red.), Mikalojaus Daukšos 1599 metų Postilè ir jos šaltiniai, Vilnius 2000.

ENDZELIN J., 1922, Lettische Grammatik, Riga.

Ford G.B, 1967, esti und yra in Vilentas' Enchiridion, „Zeitschrift für Slavische Philologie” 30, s. 353-357.

FORKER D., 2016, Toward a Typology for Additive Markers, „Lingua” 180, s. 69-100, [on-line:] https://doi.org/10.1016/j.lingua.2016.03.008.

Fraenkel E., 1962-1965, Litauisches etymologisches Wörterbuch, Heidelberg.

FrajZyngier Z., 1996, Grammaticalization of the Complex Sentence. A Case Study in Chadic, Amsterdam - Philadelphia.

Griffith A., 2011, The Etymology of OIr. ocus "and" and Methodology, [on-line:] https:// www.univie.ac.at/indogermanistik/download/Griffith/Marburg/The\%2oEtymology \%20of\%2oocus.pdf.

Haspelmath M., 2007, Coordination, [w:] T. Shopen (red.), Language Typology and Syntactic Description, t. 2: Complex Constructions, Cambridge, s. 1-51.

Heine B., 1997, Cognitive Foundations of Grammar, Oxford. 
Klingenschmitt G., 2008, Lit. úošvis, „Baltistica” 43, nr 3, s. 405-429, [on-line:] http:// dx.doi.org/10.15388/baltistica.43.3.1392.

König E., 1991, The Meaning of Focus Particles. A Comparative Perspective, London - New York.

Lehmann CH., 1995, Thoughts on Grammaticalization, München - Newcastle.

LKŽ: Lietuvių kalbos žodynas, Vilnius 1968-2002.

Lyons J., 1967, A Note on Possessive, Existential, and Locative Sentences, „Foundations of Language" 3 , nr 4, s. 390-396.

Malchukov A.L., 2004, Towards a Semantic Typology of Adversative and Contrast Marking, „Journal of Semantics” 21, nr 2, s. 177-198, [on-line:] https://doi.org/10.1093/jos/ 21.2.177.

Mithun M., 1988, The Grammaticization of Coordination, [w:] J. Haiman, S.A. Thompson (red.), Clause Combining in Grammar and Discourse, Amsterdam - Philadelphia, s. 181-225.

Nedoma R., 2011, Altisländisches Lesebuch. Ausgewählte Texte und Minimalwörterbuch des Altisländischen, Heidelberg.

Ostrowski N., 2014, Once again on the Postponed Neuter Pronoun -ti, „Baltistica” 49, nr 2, s. 265-278, [on-line:] http://dx.doi.org/10.15388/baltistica.49.2.2217.

Ostrowski N., 2015, The Origin of the Lithuanian Particle jùk, [w:] A. Judžentis, S. Kessler (red.), Contributions to Syntax and Morphology. Proceedings of the 4th Greifswald University Conference on Baltic Languages, Berlin, s. 201-215.

Ostrowski N., 2017, Non-verbal Predication in Baltic. Lithuanian yrà, [w:] M. Németh, B. Podolak, M. Urban (red.), Essays in the History of Languages and Linguistics. Dedicated to Marek Stachowski on the Occasion of his $60^{\text {th }}$ Birthday, Kraków, s. 463-471.

Ostrowsкi N., w druku, „Natural Coordination” and the Origin of the Lithuanian Conjunction beĩ 'and'. Remarks to Old Prussian-Lithuanian Language Contacts.

OwińsKi K., 2016, Rozwój funkcjonalny spójników „a” oraz „i” w języku czeskim do XVII wieku na tle stanu wspótczesnego, Uniwersytet Jagielloński, praca magisterska.

Payne J.R., 1985, Complex Phrases and Complex Sentences, [w:] T. Shopen (red.), Language Typology and Syntactic Description, t. 2: Complex Constructions, Cambridge, s. 3-41.

Petit D., 2010, On Presentative Particles in the Baltic Languages, [w:] N. Nau, N. Ostrowski, Particles and Connectives in Baltic, Vilnius, s. 151-170.

REJZEK J., 2001, Český etymologický slovník, Vozice.

Schmalstieg W.R., 1995, An Introduction to Old Russian, „Journal of Indo-European Studies Monograph Series", nr 15, Washington.

STANG CH.S., 1947/1970, Esti et yra dans les Punktay Sakimu de Szyrwid, „Norsk Tidskrift for Sprogvidenskap" 14, s. 87-97 [przedr.: idem, Opuscula linguistica. Ausgewählte Aufsätze und Abhandlungen, Oslo 1970, s. 172-180].

StAng Сн.S., 1963/1970 = [Станг Х.С.], Третье лицо глагола „быть” в литовском и латыциском языках, [w:] Ю. Маслов (ред.), Вопросы теории и истории языка. Сборник в честь Б.А. Ларина, Ленинград, s. 285-289 [przedr.: idem, Opuscula linguistica. Ausgewählte Aufsätze und Abhandlungen, Oslo 1970, s. 206-211].

STASSEN L., 2000, AND-Languages and WITH-Languages, „Linguistic Typology” 4, nr 1, s. 1-54, [on-line:] https://doi.org/10.1515/lity.200o.4.1.1.

Stassen L., 2001, Noun Phrase Coordination, [w:] M. Haspelmath i in. (red.), Language Typology and Language Universals, t. 2, Berlin - New York, s. 1105-1111. 
Traugott E.C., 1985, Conditional Markers, [w:] J. Haiman (red.), Iconicity in Syntax, Amsterdam - Philadelphia, s. 289-307.

VASMER-TRUbAČEV 1986 [= Фасмер], Зтимологический словарь русского языка, перевод с немецкого и дополнения члена-корреспондента АН СССР О.Н. Трубачева, т. I-II, Москва.

WACKERNAGeL J., 1924, Vorlesungen über Syntax mit besonderer Berücksichtigung von Griechisch, Lateinisch und Deutsch, Basel.

Watkins C., 1967/1994, Remarks on the Genitive, [w:] To Honor Roman Jakobson: Essays on the Occasion of his $70^{\text {th }}$ Birthday, t. 3: 2191-2198, The Hague - Paris [przedr.: idem, Selected Writings, Language and Linguistics, red. L. Oliver, t. 1, Innsbruck 1994].

Yong W., JIE X., 2013, A Systemic Typology of Existential and Possessive Constructions, „Functions of Language" 20, $\mathrm{nr}$ 1, s. 1-30, [on-line:] http://dx.doi.org/10.1075/fol.20.1.o1wan. ZINKEviČIUs Z., 1980, Lietuvių kalbos istorine gramatika, Vilnius.

Zwart J.-W., 2005, Some Notes on Coordination in Head-Final Languages, „Linguistics in the Netherlands" 22, nr 1, s. 231-242, [on-line:] http://dx.doi.org/10.1075/avt.22.21zwa.

Борковский В.И, Кузнецов П.С., 2006, Историческая грамматика русского языка, Москва.

\section{From comitative to conjunction. On the origin of the Slavic conjunction i and Lithuanian ir 'and; also' Summary}

The paper aims to describe the origin of the Slavic conjunction $i$ 'and' and its Baltic counterpart ir 'and; also' (Old Prussian ir 'also', Lithuanian 'and; also', Latvian 'and; also; even'). Common Baltic $i r$ traces back to the former ${ }^{{ }} \bar{i}-r$ that stems from the conflation of demonstrative pronoun (instr. sg.) ${ }^{*} h_{1} i-h_{1}$ and locative postposition $-r$. On the basis of Baltic data we can establish the primary character of Slavic $i$ 'and' which illustrates the functional change from comitative to coordinative conjunction. 
ETYMOLOGIA 

Marek Stachowski

Uniwersytet Jagielloński, Kraków

stachowski.marek@gmail.com

\section{POLSKIE PANTAŁYK I JEGO WSCHODNIOSŁOWIAŃSKIE, SŁOWACKIE I MORAWSKIE ODPOWIEDNIKI - UWAGI O POCHODZENIU}

Słowa klucze: etymologia, frazeologia, polski, morawski, słowacki, języki wschodniosłowiańskie Keywords: etymology, phraseology, Polish, Moravian, Slovak, Eastern Slavonic

W języku polskim wyraz pantałyk występuje tylko w zwrocie zbić z pantałyku, który zwykle objaśniany jest jako 'wprawić w zakłopotanie, stropić, pozbawić pewności siebie', a więc traktowany jest jak czasownik przechodni. Natomiast w zakończeniu artykułu Rytter (2016: 20) znajdujemy cytat z Komediantów Józefa Ignacego Kraszewskiego („Musi hrabia mieć resursa i nadzieje ukryte! Inaczej zbiłby z pantałyku, a trzyma się ostro"), w którym zwrotu tego użyto w znaczeniu nieprzechodnim: 'stropić się, stracić pewność siebie, czuć się zakłopotanym/niepewnie'.

We wspomnianym artykule nie pojawia się najczęściej przewijający się w rozmowach etymologicznych domysł, że wyraz ten jest w polszczyźnie pochodzenia turkijskiego, a to ze względu na ogromnie produktywny w językach turkijskich sufiks -łyk. O źródłosłowie tym jednak zwykle mówi się, dodając zaraz bezradne zastrzeżenie, że nie znamy w językach turkijskich wyrazu typu ${ }^{\star}$ pantałyk, ani nawet jego podstawy słowotwórczej, jakiegoś * panta (w dokładnie takiej bądź choćby podobnej formie fonetycznej), który by współgrał semantycznie z wyrażeniem polskim czy ogólniej: północnosłowiańskim. W tym świetle słusznie wyraz pol. pantałyk nie został uwzględniony w słowniku Stanisława Stachowskiego (2013)․․

1 Anonimowy recenzent artykułu zaleca wykorzystanie słownika etymologicznego Černycha (1993: 621). Nie wiem dlaczego. W tym miejscu czytelnikowi na pewno należy się słowo wyjaśnienia. 
Rytter nie daje wprawdzie klarownej odpowiedzi na pytanie o pochodzenie pantałyku, za to przytacza wiele poświadczeń z gwar polskich oraz z języków i gwar wschodniosłowiańskich. Nie jest przy tym dla mnie bez reszty zrozumiałe następujące ujęcie:

Sądzić wolno, że [ukr. - M.S.] зби́ти з пантели́ку w warunkach kultury materialnej szlachty i mieszczaństwa na południowo-wschodnich rubieżach utarło się w związku $\mathrm{z}$ używanym tam strojem wierzchnim - bekieszą, bogato zdobioną pętlicami (i cennymi guzami). Nazwa pętla, pętlica miała w ukraińszczyźnie odpowiednik nemля, петель i była regionalizmem, który w granicach zaboru austriackiego (monarchii austro-węgierskiej) zapożyczony został z austriackiego Band(e)l (Rytter 2016: 16).

Nie jestem pewien, czy rzeczywiście trzeba wyprowadzać pol. pętla, ukr. nemля́, пете́лька (роstaci петель nie notuje URS) z austriackiego Band(e)l. W każdym razie, jeśli rzeczywiście jest to zapożyczenie, to na poziomie pragermańsko-prasłowiańskim (Boryś 2005 s.v. pętla), a nie austro-węgierskim. Ale przede wszystkim nie potrafię sobie wytłumaczyć, czemu „zbicie z pętli, pętlicy, czyli w ogóle jakie-

Otóż Černych opowiada się tam za źródłosłowem turkijskim z powodu sufiksu -łyk właśnie i dalej podaje jako możliwe źródło wyraz ${ }^{\star}$ пӓнд-лыı, być może istniejący w jakimś języku turkijskim. Owa gwiazdka, dana przez Černycha, nie zniechęciła recenzenta, który pisze wprost „zwłaszcza polecam rosyjski słownik Černycha”. A powinna zniechęcić, ponieważ: (1) wyraz pänd-łyk nie istnieje („po pierwsze nie mamy armat”); (2) istnieć nawet nie może, ponieważ jest niepoprawny fonotaktycznie (najwidoczniej ani Černych, ani recenzent nie są świadomi, że sekwencja wokaliczna $\ddot{a}-y \mathrm{w}$ językach turkijskich nie jest dopuszczalna); (3) podstawą tego nieistniejącego wyrazu miałby być wyraz azerb. pänd 'хитрый; прием; искусство' (rozwoju semantycznego nikt nie tłumaczy; a nawet gdyby tłumaczył, to patrz wyżej (1)); (4) fonetycznie ani owo *pändłyk, ani karakałpackie (zob. niżej) panłyk 'duma' nie nadają się w sposób oczywisty na źródło słowiańskiego pantałyk; czemu by nie miały one dać refleksu po prostu w postaci słowiańskich ${ }^{\star}$ pendłyk albo * pantyk?; (5) ani Černych, ani recenzent nie wyjaśniają, w jaki sposób wyraz azerbejdżański albo karakałpacki miałby dostać się do języków słowiańskich, i to akurat m.in. morawskiego; (6) Černych sam nie jest przekonany do tego wyjaśnienia, co wyraźnie widać po jego ostrożnych sformułowaniach [podkr. moje - M.S.]: „Вероятно, заимствовано из тюркских языков [...]. В первой части могло быть тюркское слово [...] этим словом могло бы быть что-нибудь вроде $^{\star}$ пӓнд-льюк; ср. азерб. пӓнд [...]. Источником могло послужить и какое-нибудь другое тюркское слово. Ср. каракалп. панлык - 'гордость', 'чванство'. На украинской или русской почве слово могло быть несколько искажено под влиянием толк, толкать”. To ostatnie skojarzenie zapewne wyrasta ze zrównania cбить c пантальку = сбить $c$ толкy, ale wówczas trzeba założyć, że wyraz nанталыא nigdy nie występował w słowiańszczyźnie samodzielnie, tylko od razu stał się częścią wyrażenia frazeologicznego. Poza tym, w którym miejscu, w jaki sposób i dlaczego w ogóle nastąpiły procesy fonetyczne (wszak * pendłyk $\mathrm{i}^{\star}$ panłyk byłyby bez trudności wymawialne dla Słowian), które pozwalają mówić, że słowo to po zapożyczeniu mogło być „несколько искажено”? Czy wokalizm ros. -нma- = pol. -nta- nie sugeruje, że wyraz ros. < pol. lub na odwrót? Nota bene, trzeba być w wielkiej potrzebie etymologicznej, żeby odwoływać się do wyjaśnienia poprzez zniekształcenie nieistniejącego wyrazu. Doprawdy nie wiem, dlaczego recenzent zwłaszcza tę etymologię nam poleca. 
goś szamerunku (a choćby i z cennymi guzami)" miało oznaczać speszenie (się) czy wprawienie (siebie lub kogoś) w zakłopotanie.

Rzecz zaczyna się nieco wyjaśniać (acz bez związku z bekieszą), jeśli spojrzy się do słownika Vasmera (1987; Rytter 2016 cytuje go sub „Fasmer” w swej bibliografii, ale skrót ten nie pojawia się w ogóle w zasadniczym tekście studium). Znajdujemy w nim (s.v. пантальљ) informację podaną z pewnym sceptycyzmem, ale jednak uznaną za lepszą niż możliwość turkijska. Jest to mianowicie zinterpretowanie ukr. dial. nантали́к(a) 'wstęga, taśma', pol. dial. pętlik(a) 'pętla; tasiemka', sła. pántlik, mor. pentlík (obie formy przytoczone bez znaczenia) jako zapożyczeń z austr.-bawar. pantl 'taśma'. Nieco wprawdzie niepokoi ta okoliczność, że po dodaniu słowiańskiego sufiksu -ik oczekiwałoby się raczej postaci pantlik ( * pantlyk), które rzeczywiście odnajdujemy w formie słowackiej i morawskiej, ale derywacja taka nie wyjaśnia powstania wariantów trzysylabowych jak pol. pantałyk. Trudność tę można jednak przezwyciężyć. Forma górnoniemiecka powinna być bowiem raczej zapisana pantal (= niem. lit. Bandel Bändel 'wiązadło' = Bendel id [Paul 1961: 82]) i wówczas $\mathrm{z}^{*}$ pantəl+ik bez większego trudu otrzymamy ukr. пантели́к, brus. пантали́к i pol. pantałyk. W świetle postaci literackiej Bändel Bendel można by założyć formę górnoniemiecką ${ }^{\star}$ pental, która byłaby szczególnie dogodna jako etymon dla mor. pentlík. Kwestia fonetyczno-morfologiczna byłaby tym samym rozwiązana, ale nadal pozostaje niejasna semantyka.

Tu pomocna jest informacja, że $\mathrm{w}$ dawniejszym języku rosyjskim istniał też zwrot сбить с nахви́l/naxвéŭ id. Rytter (2016: 19) słusznie porównuje ten wyraz do stpol. pochwa, które objaśnia 'część uprzęży końskiej'. To ogólne znaczenie nic nam jednak jeszcze - właśnie przez swą ogólność - nie mówi. Jednakże Boryś (2005 s.v. pochwa) przytacza czeską postać l.mn. pochvy z jej archaicznym znaczeniem 'rzemień podogonowy w uprzęży końskiej' (co do liczby mnogiej por. wyżej ros. c naxвéŭ). Rzemień ten, zwany dziś po polsku zwykle podogonie, przymocowany jest z jednej strony do siodła, a na drugim końcu przechodzi w pętlę, przez którą przekłada się ogon konia. Rzemień podogonowy służy stabilizacji siodła, zwłaszcza w wypadku koni o niezbyt silnie wykształconym kłębie. Siodło bez podogonia - niehamowane przez zbyt niski kłąb - przesuwałoby się niebezpiecznie do przodu, stwarzając zagrożenie dla jeźdźca, na przykład w czasie skoków albo zjeżdżania w dół po stoku, gdy przód konia jest niżej niż jego zad. Łatwo można sobie wyobrazić, że jeździec $\mathrm{w}$ takiej sytuacji czuje się niepewnie, podczas gdy podogonie, stabilizujące pozycję siodła, daje mu właśnie poczucie pewności i bezpieczeństwa.

Łącząc powyższe informacje, pragnąłbym zasugerować następujący scenariusz:

Górnoniemiecki wyraz pant(a)l (? *pent(a)l) 'taśma, element wiążący' zapożyczony zostaje do języków słowiańskich, w których rozbudowywany jest o sufiks -ik $(\sim-y k)$. Tak powstały derywat ma postacie pantlik $\sim$ pantelyk $\sim$ pantalyk. Wszystkie one używane zapewne były w tym samym znaczeniu: *'rzemień podogonowy 
w uprzęży końskiej². Ewentualne skojarzenie z rodziną podobnie brzmiącego wyrazu pętla może, choć nie musi, być czynnikiem ułatwiającym zmianę semantyczną z 'rzemień' w ogóle na 'rzemień z pętlą (podogonową) na końcu'. Tak jak w starszym rosyjskim istniało wyrażenie cбums c naxвb́l, dosł. 'zbić z podogonia (w uprzęży)', tzn. 'utracić równowagę' 'pozbawić równowagi' (początkowo zapewne w języku jeździeckim i w rozumieniu dosłownym 'równowaga w siodle', potem przenośnie równowaga 'stabilność, zrównoważenie' $\rightarrow$ ‘spokój, pewność siebie'), tak w językach, które wytworzyły wyraz pantałyk, synonimiczny do ros. naxвá, stworzono wyrażenie $z$ bić $z$ pantałyku, oparte na dokładnie tym samym obrazie i tym samym przeniesieniu doświadczenia ze świata realiów jeździeckich do świata emocji i stanów psychicznych.

Jak dowodzi cytat z J.I. Kraszewskiego, przynajmniej w języku polskim była początkowo możliwa konstrukcja zbiłem z pantałyku w sensie 'zerwałem się z rzemienia' ( $\rightarrow$ 'straciłem równowagę $\rightarrow$ 'utraciłem spokój’). Dziś możliwe jest oczywiście tylko użycie przechodnie: zbić kogoś z pantałyku. Tu por. pol. zbić z trasy '1. zejść z obranej trasy; 2. zmusić do zejścia z obranej trasy'.

Nazywam powyższą propozycję nie etymologią, a jedynie scenariuszem, ponieważ nie umiem podać szczegółowych danych co do czasu i miejsca zapożyczenia i nie wiem też, jaka była trasa wędrówek derywatu wśród języków słowiańskich33.

2 Recenzent słusznie zauważa, że nie ma dowodu na takie znaczenie pierwotne tego wyrazu. Zakładam je na podstawie paralelizmu synonimicznych wyrażeń: pol. zbić z pantałyku i ros. cбums с пахвы/nахвей id., gdzie пахва/naxвbl, tak samo jak stpol. pochwa i cz. pochvy, oznacza 'rzemień podogonowy'. Rekonstrukcja ta, jak każda rekonstrukcja w ogóle, może zawierać błąd albo być nawet w całości błędna. Recenzent jednak ani nie nazywa tu żadnego błędu, ani nie daje kontrpropozycji, uniemożliwiając tym samym rzeczową dyskusję. Ponieważ, jak sam piszę w ostatnim akapicie, uważam ten artykuł za propozycję, a nie za gotową pod każdym względem etymologię, podlega ona oczywiście dyskusji, a przyjmowana przeze mnie semantyka jest konkretną propozycją, którą wolno korygować, o ile się potrafi przedstawić lepszą.

3 Recenzent pisze w tym kontekście następująco: „[...] stosowny frazeologizm najpierw pojawił się w języku ukraińskim, już na samym początku XVIII wieku, w rosyjskim i polskim znacznie później, dopiero w XIX w., to chyba coś mówi o pochodzeniu polskiego frazemu”. Niezupełnie. Czy chronologia koniecznie coś mówi o pochodzeniu i uznaniu formy ukraińskiej za wyjaśniającą to pochodzenie - to są rzeczy w najwyższym stopniu sporne, ale nie na tym miejscu trzeba by ten spór prowadzić. Tym bardziej że ja sam też najchętniej bym widział w wyrażeniu polskim refleks wyrażenia ukraińskiego, gdyby to tylko było realne i pewne. W języku ukraińskim wyraz nasz występuje bowiem w zasadzie w dwóch wypadkach: albo jako człon zwrotu збити з пантелику, albo jako apelatyw ze znaczeniem 'haczyk na ubrania' (Kuzela, Rudnyćkyj 1987: 539a). Należałoby w tej sytuacji najpierw wyjaśnić stosunki na gruncie ukraińskim. Czy znaczenie 'haczyk na ubrania' oraz zwrot typu 'zbić $\mathrm{z}$ haczyka' nadają się semantycznie na podstawę zwrotu o znaczeniu 'być skonfundowanym' > 'skonfundować'? Bo jeśli się nie nadają, a w każdym razie autorzy ukraińskiego słownika etymologicznego (Mel'nyčuk 2003: 278) mają tu wątpliwości, to trzeba je oddzielić od збити з пантелику, czyli że w ukraińskim nie ma apelatywu, który mógłby być podstawą zwrotu frazeologicznego. A dopóki się takiego apelatywu nie znajdzie lub jego braku nie wyjaśni, chronologia nie będzie miała większego znaczenia, bowiem wystarczy, że w polszczyźnie 
Dopóki nie ustali się tych detali, trzeba się będzie niestety wciąż liczyć z koniecznością wprowadzenia kiedyś jeszcze korekt. Mam jednak nadzieję, że istota tej propozycji, tzn. podany powyżej scenariusz, nie ulegnie zasadniczym zmianom.

\section{Skróty}

austr.-bawar. - austriacko-bawarski; azerb. - azerbejdżański; brus. - białoruski; cz. - czeski; dial. - dialektalny; lit. - literacki; mor. - morawski; niem. - niemiecki; pol. - polski; ros. rosyjski; sła. - słowacki; stpol. - staropolski; ukr. - ukraiński

\section{Literatura}

BORYś W., 2005, Stownik etymologiczny języka polskiego, Kraków.

С̆еRNYCH Р.JА., 1993 [= П.Я. Черных], Историко-этимологический словарь современного русского языка, т. 1, Москва.

KuZELA Z., RudnYćKYJ J.B., 1987, Ukrainisch-deutsches Wörterbuch, Wiesbaden.

MeL’NYčuк O.S., 2003 [= О.С. Мельничук], Етимологічний словник української мови, т. 4, Київ.

Paul H., 1961, Deutsches Wörterbuch, red. A. Schirmer, Halle (Saale).

RytTer G., 2016, Fraz. zbić z pantałyku 'stropićkogo, pozbawićpewności siebie', „Studia z Filologii Polskiej i Słowiańskiej” LI, s. 15-24, [on-line:] https://doi.org/10.11649/sfps.2016.002.

StaCHOWsKi S., 2013, Stownik historyczno-etymologiczny turcyzmów w języku polskim, Kraków.

URS: Kyryčenko I.M. (red.) [= I.M. Кириченко], Українсько-російський словник, Київ 1961.

VASmer M., 1987 [= М. Фасмер], Этимологический словарь русского языка, т. 3, Москва.

\section{Polish pantałyk and its Eastern Slavic, Slovak, and Moravian counterparts. Remarks about the origin Summary}

The Polish word pantałyk is only used in the expression zbić $z$ pantalyku 'put sb off his stride, confuse, upset, disconcert' (lit. 'strike sb off the pantatyk'). The original meaning and the etymology of the word have been unknown, and this is also valid for Moravian, Slovak and Eastern Slavonic. This author argues that it primarily was a riding term 'crupper', composed of a German loanword with a Slavonic suffix.

zwrot ten był długo poczuwany jako plebejski, żeby nie był odnotowywany w szanującym się piśmiennictwie i był pomijany w słownikach. Podobnie słownictwo rzemieślnicze czy flisackie (a tym bardziej taka frazeologia) istniało w języku dużo wcześniej, niż je poświadczono na piśmie. 

Krzysztof Tomasz Witczak

Uniwersytet Łódzki, Łódź

ktw@uni.lodz.pl

\title{
ŁACIŃSKIE LŌRUM W ŚWIETLE ETYMOLOGII
}

\author{
Professori Ignatio Richardo Dancae \\ octogenario
}

Słowa klucze: etymologia, języki indoeuropejskie, leksyka indoeuropejska, łacina, słowotwórstwo Keywords: etymology, Indo-European languages, Indo-European vocabulary, Latin language, word formation

Łaciński rzeczownik lōrum n. 'rzemień; pas; bicz, bat' (przenośnie 'amulet na rzemieniu noszony przez rzymskie dzieci; cienka gałązka winnej latorośli; członek męski'), pl. lōra (rzadziej lōrī) 'cugle, lejce' (Plezia 1998: 385-386) nie ma jednoznacznej etymologii. Nie można jednak wątpić w jego rodzimy, czysto italski charakter, gdyż wyraz ten tworzy rozbudowane gniazdo leksykalne, por. łac. lōreus adi. 'z rzemienia, rzemienny', lōrātus adi. 'związany rzemieniami', lōrāmentum n. 'rzemień, opaska', lōrārius m. 'rymarz', przenośnie 'niewolnik używany do wymierzania chłosty innym', lōrīca f. 'pancerz, zbroja (pierwotnie ze skóry, później z łusek lub ogniwek metalowych); warstwa czegoś, pokrywa, powłoka', także 'płot, parkan', lōrīcātiō f. 'osłona, pokrywa', lōrīcula f. 'małe przedpiersie', lōrīcō, -äre vb. 'opancerzyć, uzbroić w pancerz, zabezpieczyć; pokrywać, osłaniać', lōripēs, -pedis adi. 'krzywonogi, powłóczący nogami’ (ibid.: 385). Większość wymienionych wyrazów pojawia się w najstarszych zabytkach literatury łacińskiej, m.in. w pismach Katona i w komediach Plauta (de Vaan 2008: 349), co świadczy o żywotności wyrazu w języku łacińskim. Leksem jest kontynuowany na gruncie romańskim, por. port. loro 'podwójny rzemień, który podtrzymuje strzemię', astur. tsoru 'ts.', logodurskie loru 'półkolisty 
rzemień jarzmowy / halbkreisförmiger Jochriemen', stfr. lorel 'rzemień / Riemen' etc. (Meyer-Lübke 1935: 415, nr 5127; da Cunha 1998: 481). Co więcej, w łacinie ludowej pojawia się też wyraz lūra f. 'wór skórzany, miech', stanowiący prawdopodobne zapożyczenie $\mathrm{z}$ innych starożytnych języków italskich, w których zaszła regularna zmiana ie. ${ }^{{ }} \bar{o}>\bar{u}$, por. osk. Fluusaí $=$ łac. Flōrae (gen. sg.), osk. pru = łac. prō, umbr. poplu = łac. populō (abl. sg.), umbr. fertu = łac. fertō (Buck 1905: 29). Języki romańskie poświadczają także kontynuację tego łacińskiego wyrazu, por. fr. loure 'fujarka kobzy lub dud / Dudelsackpfeife', wen. lora, parm. lora, krem. lura f. 'lejek / Trichter' etc. (Meyer-Lübke 1935: 420, nr 5174).

\section{Uwagi o tradycyjnej etymologii łac. Iōrum}

Wyraz łac. lōrum dość powszechnie wyprowadza się z archetypu ie. *ulōrom n. 'ściągnięta skóra / abgezogene Haut' (urobionego od rdzenia ie. *uel- 'zdejmować, ściągać / abziehen', por. łac. vellō, albo od rdzenia ie. *uel- 'obracać, kręcić, owijać, toczyć', por. łac. volvō) i zestawia się z apelatywem orm. lar 'powróz, sznur, cięciwa łuku, mięsień / Strick, Schnur, Bogensehne, Muskel' (< ie. *ulorom) oraz z leksema-

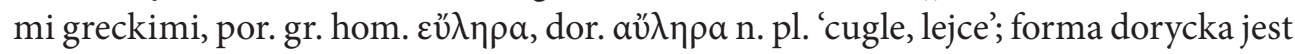

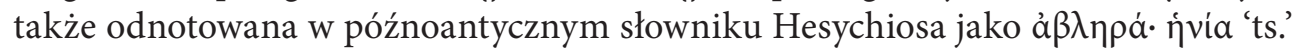
(Latte 1953: 8) < pgr. ${ }^{*} \bar{a}$-ulèrom, pl. ${ }^{*} \bar{a}$ - $u l e \bar{r} r a ̆$. Przytoczone wyżej wyrazy prezentowałyby rdzeń na trzech odmiennych stopniach przegłosu (Pokorny 1959: 1143):

(1) Postać pełna $\mathrm{z}$ wokalizmem podstawowym ${ }^{\star} \bar{e}\left(<\right.$ pie. $\left.{ }^{\star} e h_{1}\right)$ : pgr. ${ }^{*}(\bar{a})-$ ulērom.

(2) Postać pełna z wokalizmem apofonicznym ${ }^{{ }^{*}} \bar{o}\left(<\right.$ pie. ${ }^{{ }^{*}}$ oh $\left.{ }_{1}\right)$ : łac. lōrum.

(3) Postać zanikowa z wokalizmem ${ }^{\star} \partial\left(<\right.$ pie. $\left.{ }^{\star} h_{1}\right)$ : orm. lar.

Powyższe zestawienie było przychylnie przyjmowane w literaturze przedmiotu. Akceptowali je liczni lingwiści i etymologowie (Curtius 1879: 568; Vaniček 1881: 270; Prellwitz 1892: 107; Solmsen 1901: 168-169, 258; Lidén 1906: 100-101; Walde 1910: 441; Boisacq 1916: 295; Muller 1926: 557; Walde, Pokorny 1930: 304; Walde, Hofmann 1938: 822; Hofmann 1950: 98; Pokorny 1959: 1143; Frisk 1960: 588; Chantraine 1970: 385; Peters 1980: 49-50; Ernout, Meillet 2001: 367).

Wybitny językoznawca i etymolog holenderski Robert S.P. Beekes (1969: 64-65) zweryfikował etymologię wyrazu greckiego i doszedł do następujących konkluzji:

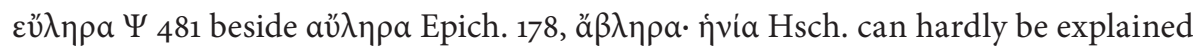
by ${ }^{\star} \hbar u l e \bar{r} r$-, since in that case one would rather expect ${ }^{\star} \hbar u l e \bar{r}$-, which would have given ${ }^{*} \dot{\nu} \lambda \eta \rho$. The connection with $\varepsilon i \lambda \dot{\varepsilon} \omega$ is difficult, since this word has no prothetic vowel. The link with Arm. lar 'bond, rope' is doubtful for the same reason. It must be asked whether we are in fact concerned here with a prothetic vowel: in structre this case differs from most - if not all - other cases to the extant that is has prothetic vowel before two sonants instead of before one. The word could be of non-IE origin [wyróżn. - K.T.W.]. 
W innych pracach holenderski uczony powtarza wyrażoną uprzednio opinię o nieindoeuropejskim charakterze wyrazu greckiego eủ $\eta \rho \alpha$ (Beekes 1988: 78, 2010: 480-481). Warto przytoczyć jego stanowisko wyrażone ostatnio w najnowszym słowniku etymologicznym języka greckiego:

One scholar has assumed ${ }^{*} \dot{\varepsilon}-F \lambda \eta \rho-0-,{ }^{*} \dot{\alpha}-F \lambda \eta \rho-o-(S c h w y z e r$ [1939 - K.T.W.]: 224) with prothetic vowel, combining Lat. lōrum 'rein', Arm. lar 'strick, rope, band', from IE ${ }^{*} u l \bar{e} r$-, ${ }^{*} u l o \bar{r}$-, ${ }^{*} u l \mathrm{Hr}$-, supposed to be a derivation in $-r$ - from a primary verb for 'turn, wind, twine' in $\mathbf{\varepsilon} i \lambda \dot{\varepsilon} \omega$ 2. Given the variation, which cannot be explained in IE terms, the words are probably Pre-Greek. For the interchange of à-/ż-, cf. ả $\mu \dot{v} \varsigma / \varepsilon \dot{\varepsilon} \mu v \dot{\varsigma}$ and Fur. 347ff. See also $\lambda \tilde{\omega} \mu \alpha$ (Beekes 2010: 480-481).

Wątpliwości Beekesa co do indoeuropejskiej genezy wyrazu greckiego i jego związku z wyrazem ormiańskim w znacznym stopniu wpłynęły na poglądy współczesnych badaczy dotyczące etymologii łac. lōrum. Peter Schrijver (1991: 123) wyraża opinię, że "the etymon may not belong here”, co oznacza odrzucenie związku etymologicznego pomiędzy łac. lōrum a wyrazami greckim i ormiańskim.

Michiel de Vaan (2008: 349), autor najnowszego słownika etymologicznego języka łacińskiego, ponownie zestawił łaciński leksem z przytoczonymi wyżej wyrazami greckimi oraz orm. lar, dodając następujący komentarz:

Beekes [...] regards the alternation $\varepsilon$-/ $\alpha$ - within Greek as inexplicable, he therefore

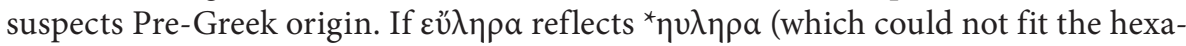
meter), Proto-Greek may have had ${ }^{*}$ un form ${ }^{\star} h_{2} e-h_{2} u l e \bar{r} r$, but the suffixation is strange. Thus, we may indeed be dealing with a loanword, but the ablaut Gr. $\bar{e}$ vs. Lat. $\bar{o}$ does look Indo-European. Maybe the giving language was a now exctint IE language? For lōrīca, a separate loanword etymology is often proposed, viz. from Gr. $\theta \dot{\omega} p a \xi$ 'cuirass', Ion. $\theta \dot{\omega} \rho a \xi$, or both could be from an unknown Mediterranean language. Yet WH [= Walde, Hofmann 1938: 822- K.T.W.] reject this solution, arguing that lōrica was originally made from leather, and hence belongs to lörum.

Autor tego hasła słownikowego uznaje tradycyjną etymologię łac. lōrum za teoretycznie możliwą, choć wskazuje istotne trudności, które się z nią wiążą. Lingwista holenderski udanie rekonstruuje archetyp pragrecki, co można uznać za osiągnięcie badawcze, ale jednocześnie sam przyznaje, że nie potrafi objaśnić jego struktury morfologicznej, gdyż zakładaną derywację sufiksalną określa jako „dziwną” („strange”). Zastrzeżeń wobec tradycyjnej etymologii można przytoczyć o wiele więcej.

Po pierwsze, struktura morfologiczna postulowanej praformy ital. *ulōrom jest niemożliwa do objaśnienia z punktu widzenia indoeuropejskiego słowotwórstwa. Nawet jeżeli założymy, że podstawą derywacyjną jest rdzeń czasownikowy ${ }^{*}$ uel-, to żaden z etymologów nie objaśnił dotychczas budowy morfologicznej zakładanego archetypu *ulōrom. W języku indoeuropejskim nie funkcjonował, jak wiadomo, 
przyrostek ${ }^{*}$-ōro-, a założenie formacji kolektywnej na ${ }^{*}$-ōr nie ma najmniejszego sensu w przypadku apelatywu dla 'rzemienia, pasa'.

Po drugie, wyraz grecki zawiera w nagłosie niewyjaśniony element wokaliczny. Możemy zgodzić się z opinią, że wariacja nagłosu sprowadza się do samogłoski długiej ${ }^{\star} \bar{a}$-. Problem polega jednak na tym, że takiej samogłoski nie posiada ani apelatyw ormiański, ani łaciński. Co więcej, przedrostek ${ }^{*} \bar{a}$ - nie funkcjonował także $\mathrm{w}$ języku indoeuropejskim.

Po trzecie, wyraz ormiański nie wykazuje śladów spółgłoski ${ }^{\star} u$ - w nagłosie. Warto podkreślić, że ie. ${ }^{*} u$ - w pozycji nagłosowej daje regularnie fonem orm. $g$-, a wyraz orm. lar takiego fonemu nie zawiera. Ponadto ormiański leksem nie ujawnia żadnego śladu po inicjalnym fonemie laryngalnym, który się często postuluje na bazie apelatywu greckiego.

Po czwarte, wymienionych form greckich, ormiańskich i łacińskich nie można wywodzić ze wspólnej indoeuropejskiej praformy. Ani wokalizm rdzenny nie daje się sprowadzić do jednolitej podstawy (co najwyżej do możliwej alternacji wokalicznej, przedstawionej wcześniej), ani też zakładana przez badaczy grupa spółgłoskowa $\left({ }^{*} u l-,{ }^{\star} h_{2} u l-\right.$ etc.) nie może być zaakceptowana dla wszystkich zestawianych apelatywów. Nagłos apelatywu łacińskiego lōrum daje się wyprowadzić z pie. ${ }^{*} l-,{ }^{*} s l$ lub ${ }^{\star} u l l$-, jednak nie może on kontynuować grupy konsonantycznej ${ }^{\star} h_{2} u l-$, por. łac. aurōra f. 'jutrzenka, zorza poranna' < pie. ${ }^{\star} h_{2}$ uss-ós- f., por. stind. uṣás- f. 'ts.. Wyraz orm. lar mógłby zawierać inicjalne ${ }^{*} l$ - lub ${ }^{*} s l$-, ale grupy konsonantyczne ${ }^{*} u l$ - oraz ${ }^{\star} h_{2} u l$ l- muszą być wykluczone z kręgu ewentualnych możliwości. Wszystko to sprawia, że postulowane zestawienie nie spełnia podstawowych wymagań stawianych językoznawstwu historyczno-porównawczemu.

Wydaje się, że zgłoszone powyżej wątpliwości co do poprawności tradycyjnego objaśnienia są na tyle umotywowane, że warto rozejrzeć się za odmienną etymologią wyrazu łac. lōrum.

\section{Nowa etymologia: łac. lörum < ital. *lösom}

Wielu etymologów i historyków języka greckiego przy omawianiu pochodzenia wy-

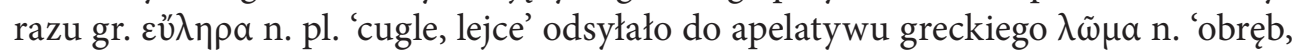
brzeg, kraj sukni’ (Abramowiczówna 1962: 60). Czynili tak autorzy podstawowych słowników etymologicznych języka greckiego (Frisk 1960: 588; Chantraine 1970: 385; Beekes 2010: 481), którzy przywoływali pod hasłem $\lambda \tilde{\omega} \mu \alpha$ cztery glosy Hesychiosa $\mathrm{z}$ Aleksandrii zawierające temat werbalny ${ }^{\star} \lambda \omega \sigma-$, np.

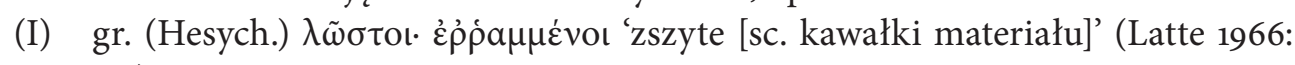
617);

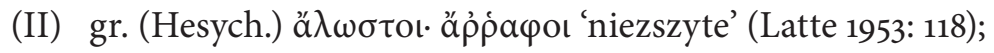

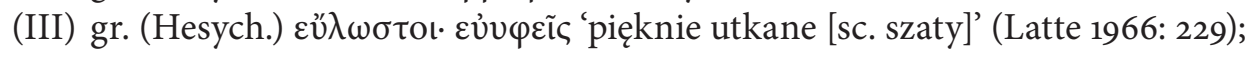




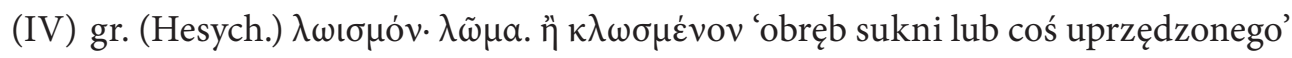
(< pgr. ${ }^{*}$ lōh-ismó- < ${ }^{*}$ lōs-ismó-) (ibid.: 616).

Nie ulega wątpliwości, że forma eol. $\lambda \tilde{\omega} \sigma \tau o l\left(<\right.$ pgr. $\left.{ }^{\star} \lambda \omega \sigma-\tau o-i\right)$, podobnie jak dwie

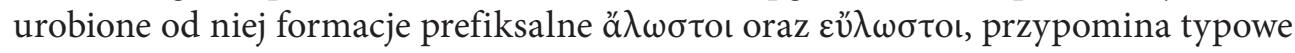
adiectivum verbale, utworzone sufiksem ${ }^{\star}$-tó- od morfemu werbalnego ${ }^{\star} \lambda \omega \sigma$-. Brak poświadczenia tego czasownika w zabytkach literatury greckiej można wytłumaczyć jego ograniczoną, dialektalną dystrybucją', a także naturalną skłonnością do unikania czasowników ułomnych. Powszechnie wiadomo, że fonem [s] w pozycji interwokalicznej przekształcał się $\mathrm{w}[\mathrm{h}]$, a następnie zanikał. Domniemana postać czasownikowa ${ }^{*} l o ̂ ́ s-\bar{o}>$ pgr. ${ }^{*} l o ́ h-\bar{o}$ musiała ulec wczesnej redukcji, skoro po zaniku $[\mathrm{s}]$ rdzeń werbalny ograniczał się do jednego tylko fonemu $\lambda$ [1]. Dlatego pozostały po nim nieliczne ślady, głównie w derywatach dewerbalnych.

Wyraz łac. lōrum n. 'rzemień; pas' może być łatwo wyprowadzony z archetypu ie. *lōs-o- $m \mathrm{n}$. 'ts.', gdyż interwokaliczny spirant bezdźwięczny [s] na gruncie łacińskim (italskim) ulegał udźwięcznieniu na skutek lenicji do [z], a konsekwencją tego procesu był tzw. rotacyzm, czyli regularna przemiana spółgłoski dźwięcznej [z] w fonem płynny [r]. Zjawisko to zaszło na wczesnym etapie rozwoju języka łacińskiego, poprzedzającym okres literacki. Dzięki przekazom historycznym i znaleziskom epigraficznym datuje się je zgodnie na połowę IV w. p.n.e. (Otrębski, Safarewicz 1937: 131; Tagliavini 1962: 103-104; Leumann 1977: 178-179; Sihler 1995: 172; Meier-Brügger 2003: 102; Meiser 2006: 95; Clackson, Horrocks 2007: 96; Weiss 2009: 151).

Bliskie odpowiedniki łacińskiego wyrazu lōrum n. 'rzemień; pas', derywowane od rdzenia ${ }^{*} \bar{l} s-\left(<\right.$ pie. $\left.{ }^{*} l e h_{3} s-\right)$, są poświadczone na gruncie indyjskim oraz irańskim. Apelatyw stind. rásnā-f. 'pas / girdle' (Monier-Williams 1999: 879) reprezentuje bez wątpienia ie. ${ }^{\star} l \bar{s} s-n \bar{a}$ f. 'ts.'. Z tego samego archetypu wywodzą się także wyrazy irańskie: chot. rrānä 'pasek / belt' (Bailey 1979: 361), oset. (iroń.) ron, (dig.) ronce 'pas / пояc' (Abajew 1973: 419-420) < irań. ${ }^{*}$ rāhnā- (< ie. $\left.{ }^{*} l \bar{s}-n \bar{a}-\right)$. W językach irańskich spotykane są także derywaty oraz złożenia: sogd. $r^{\prime} n$ ' $k h$ 'pasek / belt' (< irań. $\left.{ }^{*} r a ̄ h n \bar{a}-k a-\right)$, oset. ron-bast 'pas, talia / пояс, поясница, талия' (ibid.: 420), wachi ran-dáq, ran-dak 'skórzany rzemień / кожаный ремень' (< irań. ${ }^{*}$ rāhnataka-) (Steblin-Kamenskij 1999: 302).

Wyrazy indoirańskie sprowadzają się do jednolitego archetypu ${ }^{\star}$ rāsnā- f. $(<$ ie. *lōs-nā- f.) i jednocześnie wykazują znaczenie 'pas; skórzany rzemień', które jest zbieżne z podstawową semantyką łac. lōrum n. 'rzemień; pas' (< ital. *lōs-o-m n.), co nie pozostawia żadnych wątpliwości, że zestawienie tych wszystkich wyrazów pod względem semantycznym jest optymalne i bezdyskusyjne. Odpowiedniość fonologiczna między zestawionymi wyrazami łacińsko-indoirańskimi wydaje się

1 Eolski charakter omawianych glos Hesychiosa z Aleksandrii gwarantuje tzw. barytoneza eolska, czyli regularne przesunięcie akcentu oksytonicznego na drugą lub trzecią sylabę od końca wyrazu (Jurewicz 1999: 58-59), por. gr. (Hesych.) $\lambda \tilde{\omega} \sigma \tau o l<$ pgr. ${ }^{\star} \lambda \omega \sigma \tau o i ́$. 
nienaganna w odniesieniu do rdzenia nominalnego ${ }^{*} l \bar{s} s$. Odmienne są natomiast formanty derywacyjne: wyrazy indoirańskie zawierają sufiks ${ }^{*}-n \bar{a}$ - i sprowadzają się do formy żeńskiej ${ }^{*} \overline{l o s}-n \bar{a}-$-, natomiast wyraz łaciński należy do wyrazów rodzaju nijakiego o przyrostku ${ }^{*}-0-$.

Należy w tym miejscu odnotować, że w językach indoeuropejskich funkcjono-

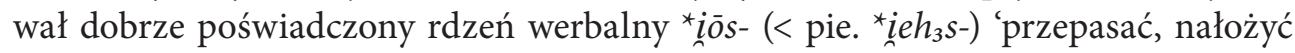
pas / gürten' (Pokorny 1959: 513; Rix 2001: 311; Cheung 2007: 210-211), por. awest.

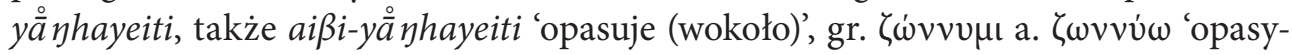
wać biodra; przepasywać, nakładać przepaskę’ (Abramowiczówna 1960: 403-404), alb. ngjesh 'opasuję' (< ${ }^{*}$ en-i $\left.i \bar{o} s-i \bar{o}\right)$, scs. po-jasati 'nałożyć pas, przepasać, lit. júosti 'opasać, przepasać, obwiązać, łot. juôst 'ts.' (Trautmann 1923: 108; Derksen 2015: 215). Od tego rdzenia indoeuropejskiego pochodzą liczne nomina deverbativa. Dla przykładu przytoczymy kilka najciekawszych formacji:

(1) awest. yāh n. 'cord of girdle / Gürtelschnur' (< ie. ${ }^{*} i \bar{s} s-\mathrm{n}$.);

(2) prasun (wasi-weri) yasē 'pas' (< nur. ${ }^{\star} y \bar{a} s a-<$ ie. ${ }^{*} i \bar{c} s-o-n$. lub m.); derywaty z przedrostkiem psł. “po-: scs. pojaš m. 'pas', ch. pöjās, pâs m., cz. pás m., ros. pójas m., pol. pas m. (< psł. ^ ${ }^{\star}$ o-jasz); z przedrostkiem psł. ${ }^{\star}$ ot-: cz. ocas m. 'ogon’ $\left(<\right.$ psł. ${ }^{*}$ ot-jasz);

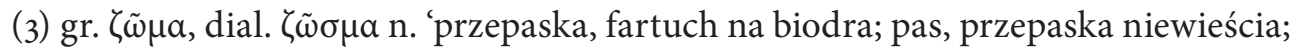
taśma niewieścia’ (< ie. ‘i iós-mnn n.), por. lit. juosmuõ, acc. sg. júosmeni m. 'miejsce dokoła tułowia na wysokości bioder, pas, talia', łot. jousmenis m. 'pas, przepaska';

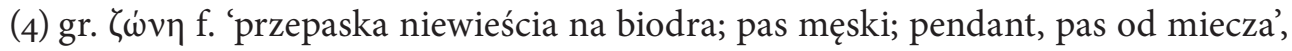
wtórnie 'talia, kibić; strefa ziemska; fryz (architektoniczny)' (< ie. ${ }^{\star} i \bar{c} s-n \bar{a} \mathrm{f}$.), por. chot. yāna- 'pas, pasek / girdle, belt' (Bailey 1979: 342) < irań. *yāhana-; npers. hamyān 'pas / girdle' (< irań. *ham-yāhana-);

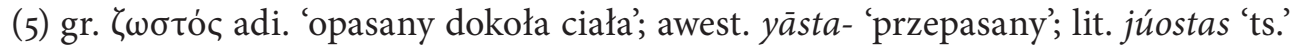
(<ie. $\left.{ }^{*} i \bar{o} s-t o ́-s\right)$;

(6) lit. júosta f. 'pas (tkany), przepaska, taśma', łot. juôsta f. 'pas'; stprus. gasto f. 'pas ziemi' (Smoczyński 2007: 239; Derksen 2015: 214).

Warto uwydatnić, że oba dyskutowane rdzenie ${ }^{*} l o ̄ s-\left(<\right.$ pie. $\left.{ }^{*} l e h_{3} s-\right)$ oraz ${ }^{\star} i \bar{c} s-$ (< pie. $\left.{ }^{\star} i e h_{3} s-\right)$ mają niemal identyczne znaczenie i bardzo podobną budowę, co sprawia, że można derywaty od tych rdzeni zaliczać do typowych „Reimwörter”. Podobieństwa pomiędzy derywatami od tych rdzeni są istotnie ważkie i godne odnotowania:

(a) derywaty o osnowie na -o-: łac. lōrum n., wtórnie lōrus m. 'rzemień; pas; bicz, bat' (przenośnie 'amulet na rzemieniu noszony przez rzymskie dzieci; cienka gałązka winnej latorośli; członek męski'), pl. lōra (rzadziej lōrī) 'cugle, lejce’ versus prasun

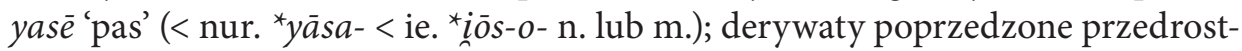
kami: scs. pojasz m. 'pas', ch. pöjās, pâs m., cz. pás m., ros. pójas m., pol. pas m. (< psł. ${ }^{\star}$ po-jasz); cz. ocas (m.) 'ogon' (< psł. ${ }^{*}$ ot-jasz); 
(b) derywaty z żeńskim przyrostkiem *-nā: stind. rásnā-f. 'pas'; chot. rrānä 'pasek';

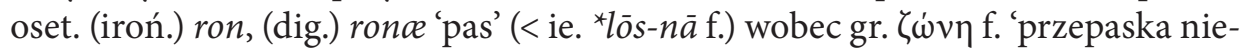
wieścia na biodra; pas męski; pendant, pas od miecza' (< ie. ${ }^{*} i \bar{o} s-n \overline{\mathrm{f}}$.);

(c) derywaty z przyrostkiem *-men-: gr. $\lambda \tilde{\omega} \mu \alpha$ n. 'obręb, brzeg, kraj sukni' (< ie. ${ }^{*} l_{o ́ s} s-m n n$ n.) versus gr. $\zeta \tilde{\omega} \mu \alpha \mathrm{n}$. 'przepaska, fartuch na biodra; pas, przepaska niewieścia; taśma niewieścia' (< ie. *iốs-mn n.), por. też lit. juosmuõ m. 'pas, talia', łot. jousmenis $\mathrm{m}$. 'pas, przepaska';

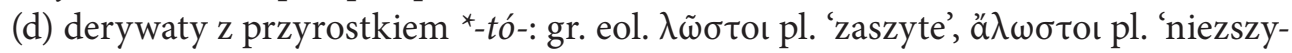

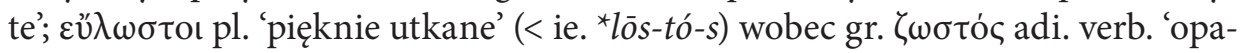
sany dokoła ciała'; awest. yāsta- 'przepasany'; lit. júostas 'ts.' (< ie. “iōs-tó-s).

Paralele derywacyjne wyraźnie potwierdzają istnienie w językach indoeuropejskich rdzenia ie. ${ }^{\star} l o s s-\left(<\right.$ pie. $\left.{ }^{\star} l e h_{3} s-\right)$, budującego regularne i oczekiwane derywaty w językach pochodnych, m.in. w grece, łacinie, sanskrycie oraz kilku językach irańskich, tj. chotańskim, sogdyjskim, osetyńskim i wachańskim. Wyraz łac. lōrum pozyskał dźwięczny fonem płynny [r] na skutek rotacyzmu spowodowanego lenicją. Zjawisko rotacyzmu było regularne i w pełni oczekiwane na gruncie języka łacińskiego oraz innych języków italskich.

\section{Rozważania nad genezą łac. lōrus}

W zasobie leksykalnym języka łacińskiego funkcjonuje nie tylko podstawowa forma łac. lōrum n. 'rzemień; pas; bicz, bat', pl. lōra 'cugle, lejce', ale także rzadsza postać męska lōrus, pl. lōrī, poświadczona w dziełach Petroniusza (57.8) i Apulejusza (Met.3, 13, 14) (Souter, Wyllie 1968: 1044; Plezia 1998: 385; Korpanty 2003: 211). W niniejszym miejscu chciałbym odnieść się krótko do prawdopodobnego pochodzenia formy męskiej. W prajęzyku indoeuropejskim obowiązywała bowiem zasada dystrybucyjna, zgodnie z którą nazwy działacza (nomina agentis) były rodzaju męskiego i żeńskiego (stosownie do płci osoby działającej), natomiast nazwy wszelkiego rodzaju narzędzi (nomina instrumenti) lub wytworów rąk ludzkich występowały zasadniczo w rodzaju nijakim. Forma łac. lōrum reprezentuje zatem zgodnie oczekiwaniami genus neutrum. Kiedy i dlaczego Rzymianie wprowadzili alternatywną formę męską?

Myślę, że podniesiony w tym miejscu problem można z powodzeniem rozwiązać i objaśnić zanikiem w języku łacińskim niektórych kategorii gramatycznych, które były żywotne w prajęzyku indoeuropejskim, ale na gruncie italskim stopniowo traciły swoją produktywność. Jedną z tych kategorii była liczba podwójna (numerus dualis), funkcjonująca w prajęzyku i zachowana w wielu historycznych językach indoeuropejskich (Fritz 2011; Witczak 2015: 102-104). Wykładnikiem liczby podwójnej była końcówka *-eh (dla rzeczowników żywotnych) oraz końcówka *-ihh (dla rzeczowników nieżywotnych) (Beekes 2011: 216-217; Witczak 2015: 106-107). Od wyrazu italskiego *lōsom n. 'rzemień, pas' można było utworzyć formę dualną * lōsōi 
'cugle, lejce' (< pie. *leh ${ }_{3} s o-i h_{1}$, dosłownie 'dwa rzemienie'), która w języku łacińskim powinna dać na skutek rotacyzmu regularną formę ${ }^{*}$ lōrì (pierwotnie nom.-acc. du. generis neutrius). Lejce składają się, jak wiadomo, $\mathrm{z}$ dwóch rzemieni służących do kierowania koniem, zatem postać dualna (w przeciwieństwie do pluralnej) była najzupełniej naturalna. Zanik liczby podwójnej jeszcze w okresie przedliterackim spowodował, że odziedziczoną formę dualną lōrī, która miała doskonałą motywację w apelatywie łac. lōrum n. 'rzemień' (pl. lōra 'rzemienie'), zinterpretowano jako formę liczby mnogiej należącą do tematów męskich II deklinacji łacińskiej. To dało asumpt do wytworzenia innowacyjnej formy rodzaju męskiego lōrus.

Zbliżone zjawisko zaszło także w przypadku wyrazu łac. frēnum n. 'wędzidło, uzda, lejc', który wykazuje dwie alternatywne formy pluralne: regularną i częstszą postać frēna, -ōrum 'wodze, lejce, cugle, ryzy' oraz nieregularną (relatywnie rzadszą) wariację frēnī, -ōrum 'ts.' (Plezia 1962: 589; Souter, Wyllie 1968: 733; Witczak 2015: 109). Druga (nieregularna) postać liczby mnogiej reprezentuje dawny dualis, co uwydatnił m.in. Michael Weiss (2009: 195, przyp. 9), mówiąc: „A possible trace of the neuter dual in Latin may be seen in frēnum n. 'rein', pl. frēn $\bar{\imath}$ '. Dawna forma liczby podwójnej frēnī uległa jednak gruntownej pluralizacji, co wyrażało się m.in. pozyskaniem odmiany pluralnej (gen. pl. frēnōrum, dat.-abl. pl. frēnīs itd.). Należy odnotować, że Rzymianie nie utworzyli innowacyjnej formy męskiej łfrēnus, dzięki czemu ślad dawnego dualu mógł być łatwo wskazany.

Innowacyjna forma męska mogła stosunkowo łatwo pojawić się na skutek błędnego zinterpretowania zachowanej i już niezrozumiałej postaci dualnej rodzaju nijakiego jako formy pluralnej rodzaju męskiego. Przykład taki przytacza M. Weiss (ibid.: 195), przywołując apelatyw łac. oculus m. 'oko', który jest rzeczownikiem rodzaju męskiego, wykazującym regularną formę mianownika liczby mnogiej: łac. oculī. Tymczasem nazwy 'oka' w językach indoeuropejskich są zazwyczaj rzeczownikami rodzaju nijakiego (Matasović 2004: 108) zarówno w liczbie pojedynczej (np. gr. ő $\mu \mu a$ n. 'oko', stind. ákși n., pol. oko n. 'ts.' < pie. $\left.{ }^{\star} h_{3} e k^{u}-\right)$, jak i podwójnej, por. gr. hom. ő $\sigma \sigma \varepsilon$ du. n. 'oczy', lit. aki, scs. oči du. n., pol. oczy pl. 'ts.' (< pie. ${ }^{\star} h_{3} e k^{u}-i h_{1}$ du. n. 'oczy'). Biorąc pod uwagę dostrzeżoną rozbieżność (w odniesieniu do rodzaju) pomiędzy łac. oculus i jego bliskimi odpowiednikami indoeuropejskimi, Alan Nussbaum sformułował hipotezę badawczą, zgodnie z którą nom. pl. m. oculī reprezentowało formą zdrobniałą utworzoną od nom.-acc. du. generis neutrius ${ }^{*}$ oqui $\left(<\right.$ ital. $\left.{ }^{*} k^{\prime} \bar{\imath}\right)$ 'oczy' za pomocą popularnego w językach indoeuropejskich przyrostka deminutywnego ${ }^{*}$-lo-, a Latynowie potraktowali dawny, odziedziczony z prajęzyka indoeuropejskiego dualis jako męską postać pluralną i od niej utworzyli sekundarny, typowo "męski” nom. sg. oculus. Hipoteza ta zyskała poparcie w środowisku diachronistów (Weiss 2009: 195; Witczak 2015: 109).

Nie ulega zatem wątpliwości, że Rzymianie stworzyli sekundarną formę męską lōrus dopiero po zaniku liczby podwójnej jako produktywnej kategorii w języku łacińskim, a powodem do wprowadzenia innowacji była odziedziczona po przodkach 
forma dualna lōrī '(dwa) cugle, lejce', błędnie zinterpretowana jako plurale tantum rodzaju męskiego.

Genezę wszystkich formacji łacińskich urobionych od łac. lōrum można podsumować w tabeli 1.

Tabela 1. Formy rzeczownika łac. lōrum w rozwoju historycznym

\begin{tabular}{|c|c|c|c|}
\hline Język & nom.-acc. sg. n. & nom.-acc. pl. n. & nom.-acc. du. n. \\
\hline italski & *lōsom 'rzemień' & ${ }^{*} l \bar{s} s \bar{a}$ 'rzemienie’ & ${ }^{*} l o ̄ s o \bar{\imath}$ 'dwa rzemienie' $\rightarrow$ 'cugle, lejce' \\
\hline prałaciński & *lōzom & ${ }^{\star} l \bar{o} z \bar{a}$ & $\begin{array}{l}\text { *lōzoi > *lözei nom.-acc. du. n. } \\
\text { '(dwa) cugle, lejce' }\end{array}$ \\
\hline $\begin{array}{l}\text { łaciński } \\
\text { (formy } \\
\text { dawne) }\end{array}$ & $\begin{array}{l}\text { lōrum n. sg. } \\
\text { 'rzemień; pas; } \\
\text { bicz, bat' itd. }\end{array}$ & $\begin{array}{l}\text { lōra n. pl. } \\
\text { 'rzemienie; pasy; } \\
\text { cugle, lejce; bicze, } \\
\text { baty' }\end{array}$ & $\begin{array}{l}\text { lōrī nieregularne pl. tantum 'cugle, lejce', } \\
\text { zinterpretowane jako nom. pl. m. }\end{array}$ \\
\hline $\begin{array}{l}\text { łaciński } \\
\text { (formy nowe) }\end{array}$ & & & $\begin{array}{l}\text { łac. lōrus m. sg. 'rzemień, lejc', wtórna } \\
\text { (innowacyjna) formacja powstała na bazie } \\
\text { lōri (pl. tantum) }\end{array}$ \\
\hline
\end{tabular}

Źródło: opracowanie własne.

\section{Konkluzje}

Przeprowadzona w niniejszej pracy historyczno-porównawcza analiza wyrazu łac. lōrum (wtórnie lōrus) doprowadziła do następujących rezultatów:

1. Tradycyjna etymologia zestawiająca łac. lōrum n. 'rzemień; pas' (itd.) z wyraza-

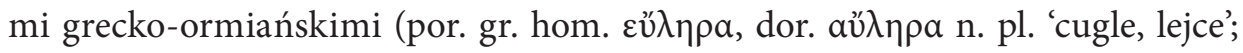
orm. lar 'powróz, sznur, cięciwa łuku, mięsień') nie może być zaakceptowana z kilku istotnych powodów. Po pierwsze, struktura morfologiczna postulowanej praformy italskiej *ulōrom jest niemożliwa do objaśnienia z punktu widzenia indoeuropejskiego słowotwórstwa. Po drugie, wyraz grecki zawiera niewyjaśniony element wokaliczny w nagłosie. Po trzecie, wyraz ormiański nie wykazuje w nagłosie śladów spółgłoski ${ }^{*} u$-. Po czwarte, wymienionych form nie daje się wyprowadzić ze wspólnej praformy.

2. Nowe objaśnienie, zaproponowane przez autora niniejszego artykułu, wywodzi łac. lōrum z praformy italskiej ^lōsom n. 'rzemień, pas'. Wywód ten potwierdzają odpowiedniki indoirańskie (por. stind. rấsnā- f. 'pas', chot. rrānä 'pas', sogd. r'n'( $k h)$, oset. ron, ron-bast 'ts.', wachi ran-dáq, ran-dak 'skórzany rzemień'), sprowadzające się do archetypu ie. *lōs-nā f. 'pas, rzemień'. Indoeuropejski rdzeń *lōs(< pie. $\left.{ }^{*} l e h_{3} s^{-}\right)$jest także zarejestrowany w języku greckim, por. gr. $\lambda \tilde{\omega} \mu \alpha \mathrm{n}$. 'ob- 
ręb, brzeg, kraj sukni' (< ie. *lốs-mn n.), eol. $\lambda \tilde{\omega} \sigma \tau$ to 'zszyte [kawałki]', ä- $\lambda \omega \sigma \tau o เ$ pl. 'niezszyte', عú- $\lambda \omega \sigma \tau$ to pl. 'pięknie utkane [szaty]' (< ie. $\left.{ }^{*} l o ̄ s-t o-\right)$.

3. Rzadka postać lōrus jest bez wątpienia innowacją języka łacińskiego, opartą na alternatywnej (nieregularnej) formie lōrī (pl. tantum) 'cugle, lejce', która onegdaj reprezentowała regularną formę liczby podwójnej (ital. * ${ }^{*} \bar{s} s o \overline{\mathrm{n}} \mathrm{n}$. du. 'dwa rzemienie', stąd 'cugle, lejce', od apelatywu *lōsom n. sg. 'rzemień', ‘lōsā n. pl. 'rzemienie'), por. łac. frēnī (pl. tantum, dawniej nom.-acc. du. n.) 'wodze, lejce, cugle, ryzy' urobione od apelatywu łac. frēnum n. 'wędzidło, uzda, lejc' (pl. frēna). Zanik liczby podwójnej spowodował potrzebę objaśnienienia dawnej formy dualnej rodzaju nijakiego jako formy pluralnej rodzaju męskiego (łac. lōrī nom. pl. m. $\leftarrow$ płac. ${ }^{\star} l \bar{z} z o \bar{\imath}$ nom.-acc. du. n.). W ten sposób w łacinie ludowej pojawiła się innowacyjna forma rodzaju męskiego lörus obok archaicznej formy rodzaju nijakiego lōrum.

\section{Skróty}

alb. - albański; astur. - asturiański; awest. - awestyjski; ch. - chorwacki; chot. - chotański; cz. - czeski; dig. - digorski (dialekt osetyńskiego); dor. - dorycki; eol. - eolski; fr. - francuski; gr. - grecki; hom. - homerycki; ie. - indoeuropejski; irań. - (pra)irański; iroń. - iroński (dialekt osetyńskiego); ital. - italski; krem. - kremoński (dialekt włoskiego); lit. - litewski; łac. - łaciński; łot. - łotewski; npers. - nowoperski; nur. - nurystański (kafirski); orm. ormiański; oset. - osetyński; osk. - oskijski; parm. - parmeński (dialekt włoskiego); pgr. pragrecki; pie. - praindoeuropejski; płac. - prałaciński; pol. - polski; port. - portugalski; psł. - prasłowiański; ros. - rosyjski; scs. - staro-cerkiewno-słowiański; sogd. - sogdyjski; stfr. - starofrancuski; stind. - staroindyjski; stprus. - staropruski; umbr. - umbryjski; wen. - wenecki (dialekt włoskiego)

\section{Literatura}

Авајеw W.I., 1973 [= В.И. Абаев], Историко-этимологический словарь осетинского языка, т. 2, Ленинград.

Aвramowiczówna Z. (red.), 1960-1962, Słownik grecko-polski, t. 2, 1960, t. 3, 1962, Warszawa.

BAiley H.W., 1979, Dictionary of Khotan Saka, Cambridge.

BeEkes R.S.P., 1969, The Development of the Proto-Indo-European Laryngeals in Greek, The Hague - Paris.

Beekes R.S.P., 1988, Laryngeal Developments: a Survey, [w:] A. Bammesberger (red.), Die Laryngaltheorie, Heidelberg, s. 59-105.

BeEkes R.S.P., 2010, Etymological Dictionary of Greek, Leiden - Boston.

BeEkes R.S.P., 20112 , Comparative Indo-European Linguistics. An Introduction, revised and corrected by M. de Vaan, Amsterdam - Philadelphia. 
BoIsACQ É., 1916, Dictionnaire étymologique de la langue grecque. Étudiée dans ses rapports avec les autres langues indo-européennes, Heidelberg - Paris.

Buck C.D., 1905, Elementarbuch der oskisch-umbrischen Dialekte, Heidelberg.

Chantraine P., 1970, Dictionnaire étymologique de la langue grecque. Histoire des mots, t. 2, Paris.

Cheung J., 2007, Etymological Dictionary of the Iranian Verb, Leiden - Boston.

Clackson J., Horrocks G., 2007, The Blackwell History of the Latin Language, London.

Da Cunha A.G., 1998², Dicionário etimológico Nova Fronteira da língua portuguesa, Rio de Janeiro.

Curtius G., 18795, Grundzüge der griechische Etymologie, Leipzig.

DeRKSEn R., 2015, Etymological Dictionary of the Baltic Inherited Lexicon, Leiden - Boston.

Ernout A., Meillet A., 20014 ${ }^{4}$ Dictionnaire étymologique de la langue latine. Histoire des mots, Paris.

FRISK H., 1960, Griechisches etymologisches Wörterbuch, t. 1, Heidelberg.

FRITZ M., 2011, Der Dual im Indogermanischen. Genealogischer und typologischer Vergleich einer grammatischen Kategorie im Wandel, Heidelberg.

Hofmann J.B., 1950, Etymologisches Wörterbuch des Griechischen, München.

JurewiCz O., 1999², Gramatyka historyczna języka greckiego, Warszawa.

Korpanty J. (red.), 2003, Słownik łacińsko-polski, t. 2, Warszawa 2003.

LatTe K., 1953-1966, Hesychii Alexandrini Lexicon, t. 1 (A-A), 1953, t. 2 (E-O), 1966, Hauniae.

Leumann M., 1977, Lateinische Laut- und Formenlehre, München.

LidÉn E., 1906, Armenische Studien, Göteborg.

Matasović R., 2004, Gender in Indo-European, Heidelberg.

MeIER-BrüGger M., 2003, Indo-European Linguistics, Berlin - New York.

MeISER G., 2006², Historische Laut- und Formenlehre der lateinische Sprache, Darmstadt.

MeYer-LüBKe W., 1935³, Romanisches etymologisches Wörterbuch, Heidelberg.

Monier-Williams M., 1999, A Sanskrit-English Dictionary, Delhi.

Muller F., 1926, Altitalisches Wörterbuch, Göttingen.

OtręвSKi J., SAFAREWiCz J., 1937, Gramatyka historyczna języka łacińskiego, Warszawa.

Peters M., 1980, Untersuchungen zur Vertretung der indogermanischen Laryngale im Griechischen, Wien.

Plezia M. (red.), 1962-1998, Słownik łacińsko-polski, t. 2, 1962, t. 3, 1998², Warszawa.

PoKorny J., 1959, Indogermanisches etymologisches Wörterbuch, Bern - München.

Prellwitz W., 1892, Etymologisches Wörterbuch der griechischen Sprache, Göttingen.

Rix H. (red.), 2001², Lexikon der indogermanischen Verben, Wiesbaden.

SchrijVer P., 1991, The Reflexes of the Proto-Indo-European Laryngeals in Latin, Amsterdam - Atlanta.

Schwyzer E., 1939, Griechische Grammatik, München.

Sihler A.L., 1995, New Comparative Grammar of Greek and Latin, New York - Oxford.

SMOCZYŃsKi W., 2007, Słownik etymologiczny języka litewskiego, Wilno.

Solmsen F., 1901, Untersuchungen zur griechischen Laut- und Verslehre, Strassburg.

Souter A., Wyllie J.M. (red.), 1968, Oxford Latin Dictionary, Oxford.

Steblin-Kamensкij I.M., 1999, Этимологический словарь ваханского языка / Etymological Dictionary of the Wakhi Language, Санкт-Петербург / Sankt Petersburg.

Tagliavini C., 1962, Fonetica e morfologia storica del latino, Bologna.

Trautmann R., 1923, Baltisch-Slavisches Wörterbuch, Göttingen. 
DE VAAn M., 2008, Etymological Dictionary of Latin and the Other Italic Languages, Leiden - Boston.

VANIČEK A., 1881², Etymologisches Wörterbuch der lateinischen Sprache, Leipzig.

WALDE A., 1910, Lateinisches etymologisches Wörterbuch, Heidelberg.

Walde A., Hoffmann J., 1938, Lateinisches etymologisches Wörterbuch, t. 1, Heidelberg.

Walde A., Pokorny J., 1930, Vergleichendes Wörterbuch der indogermanischen Sprachen, t. 1, Berlin - Leipzig.

WeIss M., 2009, Outline of the Historical and Comparative Grammar of Latin, Ann Arbor New York.

WitczaK K.T., 2015, Konsekwencje zaniku liczby podwójnej w języku łacińskim. Głos w sprawie dualnej genezy piątej deklinacji łacińskiej, „Roczniki Humanistyczne” LIII, z. 6, s. 101-120.

\section{Latin lörum in the light of etymology Summary}

The traditional etymology of Lat. lōrum n. 'strap, girdle, rein', according to which it is related to Arm.

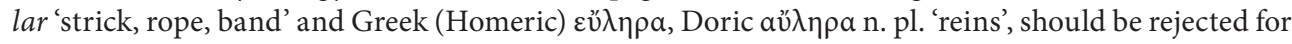
phonological and morphological reasons. The present author suggests a new explanation of the Latin term in question. It derives from the Italic archetype *lōsom n. 'strap, belt, girdle'. Close equivalents are attested in Indo-Iranian, cf. Old Indic rásnā- f. 'girdle' (< IE. *lōsnā); Khotan Saka rrānä 'belt', Ossetic ron 'belt, girdle' (< Iranian ${ }^{*} r a ̄ h n a \overline{-}$ < IE. $\left.{ }^{*} l o \bar{s} n \bar{a}\right)$, Sogdian $r^{\prime} n^{\prime}(k h)$ 'belt' (< Iran. $\left.{ }^{*} r a ̄ h n a \overline{-}-k a-\right)$; Wakhi ran-dáq, ran-dak 'leather strap' (< Iran. ${ }^{*}$ rāhna-taka-). The Indo-European root ${ }^{*} l o ̄ s-(<$ PIE. $\left.{ }^{*} l e h_{3} s-\right)$ is also attested in Ancient Greek, cf. Gk. $\lambda \tilde{\omega} \mu \alpha$ n. 'hem, fringe, border of cloths' (< IE. * ${ }^{\star} \bar{s}-m n$

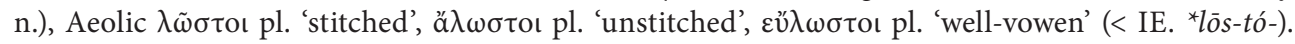
The author explains Latin lōrus (m.) as an innovative form created on the basis of the irregular plural lōrī, originally nom.-acc. du. n. ${ }^{*} l o \bar{s} s o-\bar{\imath}$ 'two straps, two reins' $\left(<\mathrm{PIE} .{ }^{*} l e h_{3} s o-i h_{1}\right)$. The loss of the dual number in the early pre-literary phase of the development of the Latin language caused the reinterpretation of preserved dual forms. It is emphasized that Lat. frēnum n. 'bit, cub, bridle' attests not only the regular plural frēna 'reins', but also the irregular frēnī (orig. nom.-acc. du. n.). 
SOCJOLINGWISTYKA 



\author{
Ewa Dzięgiel \\ Instytut Języka Polskiego Polskiej Akademii Nauk, Kraków \\ Uniwersytet Kardynała Stefana Wyszyńskiego, Warszawa \\ edziegiel5@gmail.com
}

\title{
ODMIANY TERYTORIALNE I SPOŁECZNE WSPÓŁCZESNEGO JĘZYKA POLSKIEGO NA UKRAINIE
}

Słowa kucze: mniejszość polska na Ukrainie, język polski na Ukrainie, polsko-ukraińskie kontakty językowe

Keywords: Polish minority in Ukraine, Polish language in Ukraine, Polish-Ukrainian language contacts

Zróżnicowanie współczesnego języka polskiego na Ukrainie świadczy o trwającym wiele stuleci i wielotorowym procesie kształtowania się skupisk mniejszości polskiej na tych ziemiach.

\section{Zróżnicowanie terytorialne}

Na sytuację języka polskiego na Ukrainie w XXI w. rzutują historyczne podziały geopolityczne regionów, w których obecnie pozostało najwięcej ludności polskiego pochodzenia. Istotnym wyróżnikiem polskiej mniejszości narodowej jest jej rozproszenie na dużym obszarze, obejmującym przede wszystkim regiony zachodnie (głównie obwody: lwowski, tarnopolski i rówieński), południowo-zachodnie (obwód czerniowiecki) oraz zachodnio-centralne (obwody: żytomierski, chmielnicki, winnicki, kijowski i miasto Kijów)․․ Wymienione trzy zespoły terytorialne różnią

1 Por. dane ukraińskiego spisu powszechnego z $2001 \mathrm{r}$. na stronie http://www.ukrstat.gov.ua (dostęp: 1 II 2017). 
się XX-wieczną (i dawniejszą) historią. W okresie międzywojennym znalazły się w granicach trzech państw: zachodnie w II Rzeczypospolitej, czerniowiecki (czyli północna Bukowina) w Rumunii, a zachodnio-centralne w Związku Sowieckim. $\mathrm{Na}$ każdym $\mathrm{z}$ tych trzech terytoriów państwowych język polski funkcjonował $\mathrm{w}$ odmiennych warunkach, w kontakcie z różnymi językami (oprócz ukraińskiego z niemieckim, rumuńskim i rosyjskim), co znajduje współcześnie odzwierciedlenie w stanie zachowania i właściwościach lokalnej polszczyzny. Na podział geograficzny nakłada się więc historyczny, kulturowy i polityczny.

Uzasadnienie polityczne ma również przeniesienie w pierwszej połowie XX w. języka polskiego wraz z Polakami z ziem ukraińskich do innych krajów. Na przykład rodowód ukraiński ma mniejszość polska w Kazachstanie, bowiem składa się przede wszystkim z potomków Polaków wysiedlonych podczas stalinowskich deportacji w latach 30. XX w. z sowieckiej części Ukrainy (por. Stroński 1994). Opracowania języka polskiego w Kazachstanie wzbogacają więc wiedzę o historii języka polskiego na dawnych Kresach południowo-wschodnich.

Momentem przełomowym w XX-wiecznej historii Europy był finał II wojny światowej, zaznaczony zmianami granic państwowych oraz przymusowymi migracjami ludności. Szacuje się, że tzw. repatriacja Polaków z Ukrainy - niemal w całości z zachodnich regionów - w nowe granice państwa polskiego objęła po $1945 \mathrm{r}$. ok. 1,5 mln osób (Eberhardt 1994: 174). Wobec tego badania językoznawcze realizowane na ziemiach zachodnich i północnych uwzględniają też przesiedlonych tam Polaków kresowych. Polszczyzna przesiedleńców z dawnych Kresów południowo-wschodnich stała się przedmiotem badań językoznawczych już w latach 50. XX w. (por. Łesiów 1957, 1959). Ten nurt badawczy jest obecny do dzisiaj (por. Zielińska 2013, tamże literatura).

Z położeniem geograficznym wiąże się nie tylko różnica na płaszczyźnie historii, sprzyjających bądź niesprzyjających warunków utrzymania języka polskiego czy specyfiki kontaktów językowych (np. na Bukowinie z językiem rumuńskim). Lokalizacja powoduje również odmienność językową na poziomie wpływu gwar ukraińskich. Mianowicie, wyspowe punkty z językiem polskim są rozsiane na dużym terytorium, odległość między skrajnie zachodnimi i wschodnimi w badanych obwodach zachodnich i zachodnio-centralnych sięga $500 \mathrm{~km}$. Oddziałują więc na nie różniące się między sobą dialekty ukraińskie, głównie naddniestrzański, podolski i wołyński. $\mathrm{Z}$ takiej przyczyny w niektórych regionach notowane są właściwości polszczyzny związane z wpływem miejscowych gwar ukraińskich, niespotykane gdzie indziej. Ilustrację może stanowić protetyczna spółgłoska $v$ - przed nagłosowymi samogłoskami o-, u-, np. vogrut, vobmyła, vusta, vupad, występująca systemowo w kilku polskich gwarach na zachodzie obwodu chmielnickiego. Jest to przykład fonetycznego wpływu ukraińskich gwar zachodniopodolskich na lokalną polszczyznę (Dzięgiel 2003b: 152-153). 


\section{Podział społeczny}

Na ziemiach ukraińskich historycznie ukształtowała się polszczyzna regionalna, odrębna od języka polskiego innych dzielnic I Rzeczypospolitej, różna także od języka polskiego na terenach litewskich i białoruskich. Polszczyzna lwowska (południowokresowa) i wileńska (północnokresowa) wpisywały się w terytorialne zróżnicowanie języka polskiego, które tradycyjnie ujmowano jako odmianę poznańską, krakowską i warszawską (Nitsch 1914). Dzielnicowe odrębności, zwłaszcza leksykalne, zostały uwypuklone w XIX w., gdy w okresie zaborów terytorium I Rzeczypospolitej zostało podzielone między Prusy (Poznań), Austro-Węgry (Kraków i Lwów) i Rosję (Warszawa i Wilno). Istotne zróżnicowanie regionalne polszczyzny w XIX stuleciu podkreślają historycy języka polskiego. Wojciech Ryszard Rzepka, odwołując się do tekstów Stanisława Wasylewskiego - znanego dziennikarza i literata, związanego zarówno ze Lwowem, jak i Poznaniem oraz Opolem - pisze:

Szerokie ich [regionalizmów - E.D.] rozpowszechnienie nadawało polszczyźnie potocznej tak wyraźne zabarwienie regionalne, iż (jak stwierdził S. Wasylewski) już po kilku zaledwie zdaniach można było bez trudu odróżnić „Galileusza” (mieszkańca zaboru austriackiego) od mieszkańca Kongresówki czy Poznaniaka, nie mówiąc już o mieszkańcach Lwowa czy Wilna (Rzepka 1997: 16).

Leksykalne regionalizmy lwowskie czy wileńskie były wyraźnie reprezentowane w słownikach doby nowopolskiej (SL, SWil, SW i SJPD). Jak wykazuje badanie statystyczne przeprowadzone przez Agnieszkę Piotrowską-Wojaczyk, w wymienionych słownikach najwięcej regionalizmów leksykalnych z zaznaczoną lokalizacją geograficzną wywodzi się właśnie z ówczesnych Kresów wschodnich - 1143 jednostki, tj. 54,64\% ogólnego zbioru (Piotrowska-Wojaczyk 2011: 175).

Właściwości regionalne lwowskiej polszczyzny są związane z oddziaływaniem adstratowym i substratowym języka ukraińskiego na gramatykę i słownictwo oraz jej odrębnym rozwojem w warunkach częściowej izolacji od innych regionów. Posługiwały się nią warstwy wykształcone, głównie miejskie, stąd nominacja: kulturalna polszczyzna południowokresowa czy polszczyzna lwowska. Właściwości polszczyzny przedwojennego Lwowa analizowała m.in. Zofia Kurzowa w znanej monografii z lat 80. Koncentrowała się na latach 30. XX w., traktując tę dekadę jako „ostatnie ogniwo w dziejach języka południowokresowego" (Kurzowa 1985/2006: XL).

Ze społecznym rozwarstwieniem języka dużych miast związane były tzw. gwary miejskie, czyli odmiany językowe miejskich warstw niższych. Jak zaznacza cytowany już W.R. Rzepka, odmiany te wykształciły się w wieku XIX w nowych miastach, jak Łódź, a także w starych aglomeracjach miejskich, takich jak Warszawa, Poznań, Kraków i Lwów, w których koncentrowały się różne środowiska i grupy zawodowe (Rzepka 1997: 15). Przedwojennej lwowskiej tzw. gwarze miejskiej poświęciła część wspomnianej monografii Z. Kurzowa, która zrekonstruowała jej cechy na podstawie 
tekstów humorystycznych dialogów radiowych ze Lwowa (Kazimierz Wajda, Henryk Vogelfänger, Szczepko i Tońko. Dialogi radiowe z „Wesołej lwowskiej fali”, nakładem Drukarni Urzędniczej, wyd. we Lwowie w 1934 r.) (Kurzowa 1985/2006: 309-339)².

Poza odmianą wielkomiejską język polski na Ukrainie występuje do dzisiaj w historycznych małych miasteczkach (Mościska, Sambor, Drohobycz i Gródek Podolski) oraz we wsiach. Jak wiadomo, polscy językoznawcy aż do końca lat 8o. XX w. ze względów politycznych nie mogli prowadzić eksploracji na prowincji ukraińskiej (por. Rieger 2012: 12).

Pionierem badań nad powojenną polszczyzną na Wschodzie był Wiaczesław Werenicz z Mińska. Efektem podjętych w latach 60. XX w. przez białoruskiego polonistę i jego zespół prac terenowych jest m.in. dwutomowa publikacja z 1973 r., z tym że językowi polskiemu na ziemiach ukraińskich został w niej poświęcony tylko jeden artykuł (por. Вярэніч 1973)³). Na podstawie zapisów dialektologicznych z tego okresu powstały publikowane później studia o gwarach polskich w okolicach Chmielnickiego na Ukrainie pióra Natalii Ananiewej z zespołu W. Werenicza.

Długofalowe i prowadzone na szeroką skalę badania terenowe na Ukrainie zainicjował na początku lat 9o. XX w. Janusz Rieger. Eksploracje prowadzone przez niego wraz z zespołem (głównie z Iwoną Cechosz-Felczyk i Ewą Dzięgiel), kontynuowane przez E. Dzięgiel, pozwoliły zbadać kilkadziesiąt wsi i miasteczek, w których zachował się język polski. Są to przede wszystkim miejscowości na terenie obwodów: lwowskiego, tarnopolskiego, chmielnickiego i żytomierskiego (częściowe wykazy badanych punktów wraz z mapami podano w publikacjach: Rieger, Cechosz-Felczyk, Dzięgiel 2002: 367, 2007: 341; Dzięgiel 2003b: 173)4.

Osiągnięciem ostatnich dekad są także badania polszczyzny na interesującym językowo i kulturowo pograniczu ukraińsko-rumuńskim, czyli na Bukowinie, rozpoczęte w latach 90. XX w. przez Kazimierza Feleszkę, kontynuowane przez Helenę Krasowską (por. m.in. Krasowska 2006)5.

Przywołane powyżej prace zespołów językoznawców, poświęcone polszczyźnie we wsiach i miasteczkach różnych regionów, przyniosły swego rodzaju odkrycia dotyczące kilku kwestii związanych ze zróżnicowaniem społecznym języka polskiego na ziemiach ukraińskich.

2 O tej szczególnej odmianie przedwojennej polszczyzny lwowskiej pisała Zofia Kurzowa jeszcze w kilku artykułach, por. bibliografia jej prac w: Kurzowa 1985/2006: XX-XXIX.

3 Bibliografia prac W. Werenicza zob. Rieger 2001: 21-27.

4 Na temat współczesnego języka polskiego na Ukrainie powstało pod kierunkiem Janusza Riegera siedem prac doktorskich - pięć opublikowanych (Rudnicki 2000; Cechosz 2001; Dzięgiel 2001; Czarnecka 2014; Zakhutska 2015) i dwie pozostające w maszynopisach (Tymbrowska 2001; Wieczorek 2012). Zestaw ten uzupełnia wydana drukiem rozprawa magisterska (Krawczyk 2007). Bibliografia prac J. Riegera zob.: Wolnicz-Pawłowska, Szulowska 2000: 299-312 oraz Dzięgiel, Czarnecka, Kowalska 2012: 415-423.

5 Bibliografia prac K. Feleszki zob.: Feleszko 2002: 191-200. 
Po pierwsze, zlokalizowano kilkadziesiąt miejscowości z ludnością o polskich korzeniach, w których do czasów współczesnych utrzymał się język polski, w części $\mathrm{z}$ nich bardzo dobrze - we wszystkich pokoleniach, w innych - jedynie u starszych mieszkańców. Są wśród nich nie tylko punkty z zachodniej Ukrainy oraz z Bukowiny, ale też z terenów na wschód od granicy ryskiej, które w międzywojniu znalazły się na terytorium sowieckiej Ukrainy.

Po drugie, ustalono, że polszczyzna w badanych punktach ukształtowała się przede wszystkim w wyniku polskiego osadnictwa na ówczesnych Kresach, głównie chłopskiego i drobnoszlacheckiego, stanowi więc kontynuację języka polskiego przeniesionego z etnicznej Polski. Kwestia genezy języka polskiego zdecydowanie odróżnia terytorium ukraińskie od Litwy i Białorusi. Wspomniany W. Werenicz podkreślał ten podział już na początku lat 9o. XX w.:

Wśród Polaków ukraińskich wybitnie przeważa element etnicznie polski, natomiast na Białorusi i Litwie absolutną większość społeczności polskich składają [stanowią E.D.] potomkowie spolonizowanej ludności białoruskiej lub litewskiej (Werenicz 1992/1996: 125$)^{6}$.

Potwierdzeniem etnicznie polskiego pochodzenia zlokalizowanych na Ukrainie skupisk są nie tylko dane historyczne dotyczące osadnictwa, poświadczają to również opracowania lingwistyczne z zakresu antroponimii i dialektologii, $\mathrm{w}$ tym pionierskie prace na temat kilku przedwojennych gwar polskich w granicach II Rzeczypospolitej (Harhala 1931; Hrabec 1955; Dejna 1956; Łesiów 1957, 1959). Badania dialektologiczne polskich gwar na wschód od Zbrucza oraz na zachodniej Ukrainie, a także na Bukowinie, pozwoliły ustalić utrzymane w nich wyjściowe cechy gwarowe, nieobecne w regionalnej (kulturalnej) polszczyźnie południowokresowej ani w języku ukraińskim. Do takich wyróżników można zaliczyć np. wyraziste polskie właściwości gwarowe występujące w Nowosielicy pod Połonnem: kontynuant dawnego a pochylonego jako o, jak trowa, dziod, czytom, czytosz, czyto itd.; relikty mazurzenia, np. zobocyła, pszeskodzało; końcówki czasownikowe, jak 1 os. lmn. piszema, chodzima; formy czasu przeszłego typu wzion, wzinna, wziny 'wziął, wzięła, wzięli'; formy czasu przeszłego typu robiut, chodziuł; imiesłowy typu zasiote [pole] 'zasiane'. Wymienione cechy pozostają w sprzeczności z ugruntowanym katalogiem właściwości regionalnych (kulturalnych) polszczyzny południowokresowej i przekonują, że gwara Nowosielicy została przeniesiona wraz z osadnikami z etnicznej Polski (więcej w: Dzięgiel 200o, 2003a).

6 Mowa tu o odmiennych proporcjach: na Ukrainie - przewaga ludności etnicznie polskiego pochodzenia (osiedlonej), na Białorusi i Litwie - ludności etnicznie niepolskiej (spolonizowanej). Na temat dyskusji o pochodzeniu języka polskiego na Litwie i Białorusi zob.: Grek-Pabisowa 1992; Maryniakowa 1992; Rieger 1995. 
Po trzecie, opisano podział społeczny i językowy między osadami z populacją polskiego pochodzenia historycznie chłopskimi a drobnoszlacheckimi, głównie na wschód od granicy ryskiej. Podział społeczeństwa na stan chłopski i drobnoszlachecki przestał istnieć w sensie prawnym w XIX w., jednak mentalnie i kulturowo został zachowany w różnych regionach Ukrainy aż do czasów współczesnych (Dzięgiel 2001: 25-26, 178-183, 2003b: 36-43). Te dwie grupy Polaków często określano na dawnych Kresach południowo-wschodnich odmiennymi nazwami: Mazury to ludność chłopska, Lachy - szlachecka, przy czym oba etnonimy uległy pejoratywizacji (więcej zob. Dzięgiel 2013). Mimo łączącej chłopów i drobną szlachtę przynależności do Kościoła rzymskokatolickiego obie warstwy zachowały odrębność obyczajową, kulturową, a także językową. Polskie gwary chłopskie na wschód od Zbrucza wyraźnie się odróżniają nie tylko od regionalnej (kulturalnej) polszczyzny południowokresowej, ale też od języka polskiego nieodległych osiedli szlacheckich, często odznaczają się ponadto niskim prestiżem. Język jest nośnikiem statusu społecznego, $\mathrm{w}$ tym kontekście polskie gwary chłopskie nierzadko stanowiły atrybut stygmatyzacji społecznej, a nawet podwójnej stygmatyzacji, najpierw jako język społeczności wiejskiej, niewykształconej, następnie jako język mniejszości narodowej. Mimo niekorzystnych warunków część z nich utrzymała się do czasów współczesnych.

Przywoływany już W. Werenicz zauważa, że utrzymanie we wsiach chłopskich rodzimego języka przez wiele stuleci (nierzadko od końca XVII w.) w obcym państwie, w innojęzycznym otoczeniu było wynikiem izolacji zarówno od ukraińskiej ludności chłopskiej - ze względu na odmienny język i wyznanie - jak i od rodaków ze stanu szlacheckiego - przez wzgląd na inną pozycję społeczną (Werenicz 1992/1996: 127). Ilustrację tego swoistego konserwatyzmu językowo-kulturowego polskich osad chłopskich może stanowić zaskakująca konstatacja, że jeszcze w latach 9o. XX w. w niektórych miejscowościach nawet na wschód od granicy ryskiej, czyli poza terytorium międzywojennej Rzeczypospolitej, spotykaliśmy starszych respondentów, którzy posługiwali się wyłącznie polską gwarą, nie władali językiem ukraińskim. Lepszą pozycję pod względem prestiżu miał język polski w osadach szlacheckich, był bowiem zbliżony do regionalnej (kulturalnej) polszczyzny południowokresowej, nie oznacza to jednak, że zachował się lepiej.

W ostatnich dekadach coraz wyraźniejsza jest tendencja do zanikania gwar polskich, zwłaszcza na terenach na wschód od Zbrucza, chociaż są także przykłady doceniania miejscowej polszczyzny jako wyróżnika własnej historii i związku z krajem przodków. W pewnym stopniu można porównać tę sytuację do szeroko opisywanego zanikania gwar w różnych regionach Polski, narastającego zwłaszcza od połowy XX w. i związanego z ich niską waloryzacją społeczną. Stąd zgromadzona w ostatnim ćwierćwieczu w kilku ośrodkach (przede wszystkim w Instytucie Języka Polskiego PAN oraz Instytucie Slawistyki PAN) dokumentacja dźwiękowa języka polskiego na Ukrainie stanowi trwały wkład w badania historii języka polskiego za granicą, a także problematyki kontaktów językowych, bilingwizmu i socjolingwistyki. 


\section{Podział ze względu na historię osiedlenia}

Kluczowe kryterium zróżnicowania języka polskiego w miasteczkach i wsiach na Ukrainie stanowi historia osadnictwa polskiego w poszczególnych punktach. Spektakularna różnica w tym względzie zachodzi między miejscowościami, w których Polacy osiedlili się jeszcze w czasach I Rzeczypospolitej, czyli w ostatniej ćwierci XVII i w XVIII w., a tymi, w których osiedlali się pod koniec XIX czy w początkach XX w. Najstarsze badane osady z ludnością polskiego pochodzenia mają metrykę sięgającą 300 lat, najmłodsze - 10o. Wczesna kolonizacja, szczególnie na wschód od Zbrucza, jest związana z wyludnieniem znacznych obszarów Ukrainy w drugiej połowie wieku XVII, w okresie wojny domowej i najazdów turecko-tatarskich, nazywanym w ukraińskiej historiografii Ruina. Na ziemiach ukraińskich były wówczas majątki polskich rodów magnackich - Potockich, Branickich, Czartoryskich, Lubomirskich, Sanguszków - i oni to zasiedlali je ludnością z różnych regionów, sprowadzali również chłopów z etnicznej Polski. Z tak wczesnym polskim osadnictwem mamy do czynienia m.in. na Podolu. Z kolei przypadki późnego osadnictwa - z drugiej połowy XIX w. - są łatwiejsze do jednoznacznego udokumentowania na podstawie źródeł archiwalnych, czasem dostępne są ponadto informacje o terenie wyjściowym osiedleńców. Na Bukowinę północną, jak podaje K. Feleszko (1991: 11-12), Polacy przybyli pod koniec XVIII i w XIX w. Rodowód XIX-wieczny mają również niektóre punkty na Wołyniu, np. wieś Korczunek pod Żytomierzem, do której pierwsze polskie rodziny przybyły w 1884 r., kolejne jeszcze na początku XX w. (por. Rudnicki 2000: 27). Polacy napływali na Ukrainę w XIX w. również jako kadra i robotnicy do rozwijającego się przemysłu. Przykładem takiej migracji jest kolonia na wschodzie kraju w ówczesnym mieście Kamieńskie, późniejszym Dnieprodzierżyńsku, zasiedlona w latach 8o. XIX w. przez Polaków, w tym kadrę inżynieryjno-techniczną i wykwalifikowanych robotników, sprowadzonych do organizowanych wówczas zakładów hutniczych (Krasowska 2012: 74; Швець 2015). O ile w 1896 r. miasto liczyło 18 tys. mieszkańców, to w roku 1913 już 40 407, w tym 14175 Polaków. W międzywojniu skupisko polskie w mieście było na tyle znaczne, że w okresie prowadzenia tzw. polityki korenizacji na sowieckiej Ukrainie, gdy publikowano polskojęzyczne gazety i czasopisma skierowane do mniejszości polskiej, w Kamieńskiem wydawano pismo zakładowe „Dzierżyniec” (1932-1933), przekształcone następnie w "Głos Metalowca” (1933-1935). Był to jedyny polskojęzyczny periodyk o zasięgu lokalnym na wschodzie ówczesnej Ukraińskiej SRS (por. Dzięgiel 2016; Dzięgiel i in. 2016). W mieście powstało jedno $\mathrm{z}$ wyjątkowych skupisk populacji o polskich korzeniach na wschodniej Ukrainie. Sytuację współczesnej, kilkutysięcznej mniejszości polskiej w południowo-wschodnich obwodach kraju wieloaspektowo przedstawiła H. Krasowska (2012, tamże literatura).

7 Dane takie przytaczają - bez podania źródła - Wikipedia (https://ru.wikipedia.org/wiki/Каменское (город) (dostęp: 24 VI 2017)), a także Anna Szweć (Швець 2015). 
Jasne jest, że trwanie wśród innojęzycznej ludności przez kilka stuleci, w izolacji od języka i kultury polskiej, działa na niekorzyść zachowania rodzimego języka, zaś tak dawne oddziaływanie języka ukraińskiego wpływa na proces zapożyczeń gramatycznych i leksykalnych. Dlatego pierwszoplanowym parametrem, który jest uwzględniany np. przy porównaniu skali zapożyczeń w lokalnej polszczyźnie, jest metryka osadnictwa.

Wyznaczenie okresu osiedlenia rzutuje też na kwalifikację właściwości językowych polszczyzny w badanym punkcie. Na przykład na ogół $ł$ (zębowe) w regionalnej (kulturalnej) polszczyźnie lwowskiej opisywane jest jako rodzima cecha archaiczna, utrzymana pod wpływem języka ukraińskiego i rosyjskiego. W historycznej polszczyźnie taka wymowa wycofywała się w XVII w. Inny kontekst interpretacyjny przedstawiają jednak gwary polskie z późnego osadnictwa, jak we wspomnianym Korczunku pod Żytomierzem, w którym pierwotną cechą fonetyczną było $u$ ( $u$ niezgłoskotwórcze), a ł (zębowe) zostało wprowadzone częściowo (u młodszych mieszkańców) pod wpływem języka ukraińskiego i rosyjskiego (Rudnicki 20oo: 161; Rieger, Cechosz-Felczyk, Dzięgiel 2002: 36). W gwarze Korczunka właściwość ta ma więc proweniencję innojęzyczną, a nie rodzimą (o dyskusji na temat archaizmów i interferencji w polszczyźnie południowokresowej zob. Kość 200o; Dzięgiel 2012a).

\section{Podsumowanie}

Z perspektywy ostatniego ćwierćwiecza można mówić o swego rodzaju zwrocie od opracowań regionalnej (kulturalnej) odmiany lwowskiej polszczyzny do badań języka polskiego w miasteczkach i wsiach w różnych regionach Ukrainy. Ta zmiana kierunku była możliwa dzięki przeobrażeniom politycznym - polscy lingwiści mogli podjąć prace terenowe faktycznie dopiero po likwidacji ZSRR (1991 r.). Ważną część nowszych badań stanowią nie tylko prace dialektologiczne czy komparatystyczne, lecz także socjolingwistyczne (np. na temat ewolucji języka polskiej mniejszości, różnic pokoleniowych, identyfikacji narodowej) lub z zakresu bilingwizmu (o bilingwizmie zob. Dzięgiel 2003b: 64-84; o młodzieży polskiego pochodzenia na Ukrainie zob. m.in. Zielińska 2011; Dzięgiel 2012b) ${ }^{8}$. Po ponad dwóch dziesięcioleciach badań terenowych i sukcesywnego wydawania opracowań polszczyzna na Ukrainie jawi się w nowym świetle. Na pierwszy plan wysuwa się jej zróżnicowanie terytorialne, społeczne oraz historyczne, które rzutuje na interpretację zjawisk językowych.

W ostatnich dekadach rozwija się na Ukrainie sieć placówek oświatowych z nauczaniem języka polskiego, kierująca swoją ofertę m.in. do osób polskiego pochodzenia (por. Placówki). Z tej perspektywy istotne stają się opracowania z zakresu

8 Zestawienie publikacji na temat ewolucji języka polskiej mniejszości na Ukrainie, różnic pokoleniowych, identyfikacji narodowej czy bilingwizmu wykracza poza ramy niniejszego artykułu. 
glottodydaktyki polonistycznej, uwzględniające problematykę interferencji językowych polsko-ukraińskich. Aktualność zyskują również badania dydaktyki języka polskiego jako języka przodków (w szerokim rozumieniu angielskiego terminu heritage language akcentującym różnicę między językiem przodków a językiem obcym). Termin heritage language może być odnoszony do opisu sytuacji, w której osoby czy grupy łączy pewien rodzaj więzi z językiem własnej mniejszości narodowej, choć niekoniecznie ten język znająa. Pod uwagę bierze się szerokie spektrum przypadków, od ograniczonej czynnej znajomości języka przodków (np. częściowo mówienia) bądź biernej znajomości (np. po części rozumienia) po sam udział w życiu rodzin czy społeczności, w których język ten jest używany. W tego typu kontekstach język przodków nie jest w ścisłym sensie językiem obcym (dyskusja o terminie heritage language por. np. Peyton, Ranard, McGinnis 2001; w polskiej literaturze glottodydaktycznej por. Lipińska, Seretny 2012). Z kolei nowe kierunki badań glottodydaktycznych i socjolingwistycznych zyskają niewątpliwie na uwzględnieniu dotychczasowej wiedzy o historii i zróżnicowaniu języka polskiego na Ukrainie.

\section{Literatura}

Cechosz I., 2001, Polska gwara Oleszkowiec na Podolu. Fleksja imienna i werbalna, Kraków. CzArneCKA K., 2014, Słowotwórstwo gwar polskich na Ukrainie. Czasownik, Kraków.

Dejna K., 1956, Gwara Milna, „Rozprawy Komisji Językowej Łódzkiego Towarzystwa Naukowego" IV, s. 5-41.

DzIĘGIEL E., 200o, Dawne a pochylone w kilku gwarach południowokresowych, [w:] E. Wolnicz-Pawłowska, W. Szulowska (red.), Kontakty językowe polszczyzny na pograniczu wschodnim. Prace ofiarowane Profesorowi Januszowi Riegerowi, Warszawa, s. 79-88.

DzIĘGIEL E., 2001, Polska gwara wsi Zielonej na Podolu na tle innych gwar południowokresowych. Fleksja imienna $i$ werbalna, Kraków.

DzięGiel E., 2003a, Kresowa gwara Nowosielicy koło Połonnego a gwary w rdzennej Polsce, [w:] E. Wrocławska, J. Zieniukowa (red.), Języki mniejszości i języki regionalne. Pamięci Profesora Zdzisława Stiebera, zasłużonego badacza języków mniejszościowych i pogranicz językowych, w stulecie urodzin, Warszawa, s. 375-388.

DzIĘGIEL E., 2003b, Polszczyzna na Ukrainie. Sytuacja językowa w wybranych wsiach chłopskich i szlacheckich, Warszawa.

DzIĘGIEL E., 2012a, Archaizmy a interferencje w kontaktach języków blisko spokrewnionych (przykład polsko-ukrainski), [w:] „Z Polskich Studiów Slawistycznych”, seria 12, Warszawa, s. 13-19.

DzIĘGIEl E., 2012b, Polacy czy cudzoziemcy? Kształtowanie się identyfikacji narodowej młodzieży polskiego pochodzenia na Ukrainie, [w:] E. Golachowska, A. Zielińska (red.), Konstrukcje i destrukcje tożsamości, t. 2: Tożsamość wobec wielojęzyczności, Warszawa, s. 235-246.

9 Tłumaczenie na język polski terminu heritage language jako język odziedziczony nie jest fortunne w sytuacji, gdy mowa o osobach lub grupach, które już w zasadzie nie znają języka przodków. 
DzIĘGIEL E., 2013, O losach etnonimów Lach $i$ Mazur na dawnych Kresach południowo-wschodnich, [w:] E. Dzięgiel, T. Korpysz (red.), Niejedno ma imię... Prace onomastyczne i dialektologiczne dedykowane Profesor Ewie Wolnicz-Pawłowskiej, Warszawa, s. 117-132.

DzIĘGIEL E. (red.), 2016, Prasa polskojęzyczna w początkach sowietyzacji Ukrainy. Wybór źródet, [on-line:] https://prasapolukr.ijp-pan.krakow.pl/ (dostęp: 24 VI 2017).

Dzięgiel E., Czarnecka K., Kowalska D.A. (red.), 2012, Polskie dziedzictwo językowe na dawnych Kresach. Prace ofiarowane Profesorowi Januszowi Riegerowi, „Język polski dawnych Kresów Wschodnich", t. 5, Warszawa.

DzIĘGIEL E. i in., 2016, Polskojęzyczna prasa na Ukrainie sowieckiej w latach 1918-1939. Przegląd tytułów i treści, Kraków.

Eberhardt P., 1994, Przemiany narodowościowe na Ukrainie XX wieku, „Biblioteka »Obozu«", nr 19, Warszawa.

FELESZKo K., 1991, Język polski na Bukowinie do roku 1945. Zarys problematyki, [w:] J. Rieger, W. Werenicz (red.), Studia nad polszczyzną kresowa, t. 6, Wrocław, s. 7-26.

Feleszko K., 2002, Bukowina moja miłość. Język polski na Bukowinie Karpackiej do 1945 roku, t. 1, red. A. Żor, Warszawa.

GREK-PABISOWA I., 1992, Język polski na kresach pótnocno-wschodnich. Legendy a rzeczywistość, [w:] „Z Polskich Studiów Slawistycznych”, seria 8, Warszawa, s. 55-62.

Harhala W., 1931, Gwara polska okolic Komarna, „Lud Słowiański” II, s. 55-91, 156-177.

Hrabec S., 1955, O polskiej gwarze wsi Duliby w byłym powiecie buczackim, „Rozprawy Komisji Językowej Łódzkiego Towarzystwa Naukowego" III, s. 31-76.

Kość J., 2000, Archaizmy a interferencje w strefie polsko-ukraińskich kontaktów językowych, „Slavia Orientalis” XLIX, z. 3, s. 451-462.

Krasowska H., 2006, Górale polscy na Bukowinie Karpackiej. Studium socjolingwistyczne i leksykalne, Warszawa.

KrasowsKa H., 2012, Mniejszość polska na południowo-wschodniej Ukrainie, Warszawa.

KraWCzy A., 2007, Zapożyczenia leksykalne w sytuacji wielojęzyczności. Ukrainizmy i rusycyzmy w gwarze Maćkowiec na Podolu, Warszawa.

Kurzowa Z., 1985/2006, Polszczyzna Lwowa i Kresów południowo-wschodnich do 1939 roku, [w:] eadem, Prace językoznawcze, t. 1, wybór i oprac. M. Szpiczakowska, M. Skarżyński, Kraków.

Lipińska E., Seretny A., 2012, Między językiem ojczystym a obcym. Nauczanie i uczenie się języka odziedziczonego na przykładzie szkolnictwa polonijnego w Chicago, Kraków.

Łesıów M., 1957, System fonetyczny gwary hutniańskiej, „Rozprawy Komisji Językowej Łódzkiego Towarzystwa Naukowego" V, s. 131-153.

Łesıów M., 1959, Uwagi o fleksji i składni gwary hutniańskiej, „Rozprawy Komisji Językowej Łódzkiego Towarzystwa Naukowego" VI, s. 95-112.

Maryniakowa I., 1992, Pótnocno-wschodnie obszary polszczyzny wobec języków wschodniosłowiańskich i bałtyckich, [w:] „Z Polskich Studiów Slawistycznych”, seria 8, Warszawa, s. $153-158$.

Nitsch K., 1914, Odrębności słownikowe Poznania, Krakowa, Warszawy, „Język Polski” II, S. 261-270.

Peyton J.K., Ranard D.A., McGinnis S. (red.), 2001, Heritage languages in America. Preserving a national resource, Washington.

PiotrowsкA-Wojaczyк A., 2011, Regionalizmy leksykalne w słownikach doby nowopolskiej, Poznań. 
Placów KI: Placówki oświatowe na Ukrainie. Informator, Warszawa 2015.

RIEGER J., 1995, W sprawie genezy i ewolucji polszczyzny w Wielkim Księstwie Litewskim, [w:] idem (red.), Studia nad polszczyzną kresowa, t. 8, Warszawa, s. 31-38.

Rieger J. (red.), 2001, Studia nad polszczyzna kresowa, t. 10, Warszawa.

Rieger J., 2012, Na jubileusz naszych badań nad polszczyzna kresowa, [w:] E. Dzięgiel, K. Czarnecka, D.A. Kowalska (red.), Polskie dziedzictwo językowe na dawnych Kresach. Prace ofiarowane Profesorowi Januszowi Riegerowi, „Język polski dawnych Kresów Wschodnich", t. 5, Warszawa, s. 11-18.

Rieger J., Cechosz-Felczy I., Dzięgiel E., 2002, Język polski na Ukrainie $w$ końcu XX wieku, cz. 1: Stan i status, cechy charakterystyczne. Polszczyzna w Lwowskiem, Tarnopolskiem i na Podolu. Teksty, Warszawa.

Rieger J., Cechosz-Felczy I., DzięGiel E., 2007, Język polski na Ukrainie w końcu XX wieku, cz. 2: Polszczyzna w Lwowskiem, Żytomierskiem i na Podolu. Teksty, Kraków.

Rudnicki S., 2000, Gwara polska wsi Korczunek koło Żytomierza. Fonetyka, fleksja, Warszawa.

RzEPKA W.R., 1997, Rodowód polszczyzny Wielkopolan, [w:] M. Gruchmanowa, B. Walczak (red.), Słownik gwary miejskiej Poznania, Warszawa - Poznań, s. 7-19.

SJPD: W. Doroszewski (red.), Słownik języka polskiego, Warszawa 1958-1969.

SL: S.B. Linde, Słownik języka polskiego, Lwów 1807-1814.

Stroński H., 1994, Polska droga do Kazachstanu, „Przegląd Wschodni” 3, z. 2, s. 145-164.

SW: J. Karłowicz, A.A. Kryński, W. Niedźwiedzki (red.), Słownik języka polskiego, Warszawa 1900-1927.

SWIL: A. Zdanowicz i in. (red.), Słownik języka polskiego, Wilno 1861.

Tyмвrowska G., 2001, Gwara wsi Czerwone Chatki na Żytomierszczyźnie, Instytut Języka Polskiego PAN, rozprawa doktorska.

WERENICZ W., 1992/1996, Uwagi do badań nad polskim dialektem kresowym na Ukrainie, [w:] J. Rieger (red.), Język polski dawnych Kresów Wschodnich, t. 1: Studia i materiały, Warszawa, s. 125-130.

WieCzOreK A., 2012, Słownictwo polskiej gwary kresowej na przykładzie Maćkowiec na Podolu. Charakterystyka funkcjonalna, Uniwersytet Warszawski, rozprawa doktorska.

Wolnicz-Pawıowska E., Szulowska W. (red.), 2000, Kontakty językowe polszczyzny na pograniczu wschodnim. Prace ofiarowane Profesorowi Januszowi Riegerowi, Warszawa.

Zaкнutsка O., 2015, Polszczyzna drobnoszlacheckiej wsi Siaberka na Wołyniu. Słownictwo, Warszawa.

ZielińsKa A., 2013, Mowa pogranicza. Studium o językach i tożsamościach $w$ regionie lubuskim, Warszawa.

ZIELIŃsKa M., 2011, Rola polszczyzny w życiu młodych użytkowników języka polskiego na Ukrainie Zachodniej, „Język, Komunikacja, Informacja” VI, s. 127-134.

Вярэніч В.Л. (ред.), 1973, Польские говоры в СССР, ч. 1-2, Минск.

Швець А.О., 2015, Фонетичні особливості польської мови мешканців Дніпродзержинсь$\kappa a$, „Науковий вісник Міжнародного гуманітарного університету” „Філологія” 19, T. 2, s. 69-72. 


\section{Territorial and societal variants of contemporary Polish in Ukraine Summary}

The article presents various types of differentiation in contemporary Polish language in Ukraine. It focuses primarily on 1) territorial factors - dispersion over a large area and the consequent diversification of political and cultural conditions, as well as influence from different languages and Ukrainian dialects, 2) societal factors - regional (cultural) Polish of former south-eastern Kresy in urban and rural centres, and the stratification of rural Polish into separate dialects of the peasantry and nobility, 3) historical factors - the influence that the history of Polish settlement in the region exerted on the shape of local Polish dialects. Referring to her own, 25-year long experience in studying Polish in Ukraine, and also to the literature on this topic, this author verifies previous views on the territorial and societal variations of the Polish language in Ukraine and revises the related interpretations of linguistic facts (e.g. the origin of the dental $t$ in Polish dialects in Ukraine). 


\section{JĘZYK JAKO ELEMENT ŚWIADOMOŚCI SPOLECZNEJ (NA PRZYKŁADZIE POLSKI PO 1918 ROKU) ${ }^{1}$}

Słowa klucze: świadomość społeczna, świadomość językowa, ideologie językowe, okres międzywojenny, historia języka polskiego

Keywords: social consciousness, linguistic consciousness, language ideologies, the interwar period, history of Polish

Pojęcie świadomości społecznej służy w socjologii do opisu funkcjonowania pewnych zjawisk, wartości, interesów ważnych dla mniejszych czy większych grup społecznych. Odwołania do tego pojęcia znajdziemy również w polskich pracach językoznawczych, jak też odwołania - bez użycia określenia społeczna - do świadomości pewnej wyodrębnionej przez badacza grupy (np. polszczyzna w świadomości: studentów, mieszkańców wsi vs. miasta, mniejszości etnicznej itp.).

W artykule wyjdziemy od socjologicznego ujęcia świadomości społecznej jako wspólnoty przekonań i postaw. Została ona zdefiniowana przez Stanisława Ossowskiego jako:

pojęcia, obrazy, przekonania i oceny, które są mniej lub więcej wspólne ludziom pewnego środowiska i które w świadomości poszczególnych jednostek umacnia wzajemna sugestia, umacnia przekonanie, że dzielą je również inni członkowie tej samej grupy (Ossowski 1957: 11).

1 Artykuł jest zmienioną i uzupełnioną wersją odczytu wygłoszonego w styczniu 2016 r. na posiedzeniu Komisji Językoznawstwa Oddziału PAN w Krakowie. 
Marek Ziółkowski zwraca uwagę na dwie podstawowe warstwy świadomości społecznej. Pierwsza warstwa to indywidualne przekonania ludzi komunikujących się ze sobą. Drugą warstwę stanowią „mowa, pismo, obraz i czyn”, a zatem wszystkie przekazy komunikacyjne, począwszy od błahych codziennych rozmów, przez debaty intelektualne, literaturę, prasę, reklamę, po mniej lub bardziej oficjalne uroczystości. Właśnie ich wagę podkreśla socjolog, wyróżniając je nie jako rzeczywisty wyraz postaw i opinii, ale ze względu na fakt, że mogą one wywierać wpływ na przekonania innych ludzi (Ziółkowski 2015: 50-51; zob. też Sztompka 2009: 293-299).

Rola języka w świadomości społecznej nie ogranicza się do bycia narzędziem przekazu, ,instrumentem idei”, jak nazywa go Piotr Sztompka (ibid.: 288). Język zajmuje tu ważne miejsce jako sama idea, a więc i przedmiot oceny. W antropologii lingwistycznej panujące $\mathrm{w}$ określonych społecznościach postawy, opinie, przekonania lub teorie dotyczące języka określane są mianem ideologii językowych (zob. Ahearn 2013: 33-35). W polskiej literaturze socjolingwistycznej Danuta Bartol-Jarosińska (1986) na oznaczenie „całości sądów i wyobrażeń o języku” wprowadziła pojęcie społecznej świadomości językowej. Sądy te i przekonania w ujęciu polskiego językoznawstwa są określane jednak najczęściej jako świadomość językowa, nakładając się na psycholingwistyczne rozumienie świadomości językowej jako zdolności do używania języka, kompetencji językowej (zob. Przybysz-Piwko 2005; Maćkowiak 2011: 27-44).

Świadomość społeczna jest wielopłaszczyznowa - cechuje małe grupy (środowiska), jak i większe: narody, obywateli globalnej wioski. Łączy postrzeganie języka jako wartości absolutnej z oceną poszczególnych elementów językowych i grup, które się nimi posługują. Dla jej badacza istotne jest nie tyle, które elementy są poprawne, pożądane, a które nie, ale dlacz ego - jakie są kryteria formułowanych ocen językowych. Świadomość wspólnoty języka podbudowuje tożsamość grupy, która jest powiązana najczęściej z jakimś terytorium, stąd też ważne są ograniczone geograficznie formy językowe (w tym regionalizmy, dialektyzmy), które pozwalają odróżnić tutejszych (naszych) od „niemców” (obcych). Również zmiany w systemie nazw własnych - tworzenie czy wybór określonych toponimów, antroponimów, choronimów, a także przesunięcia semantyczne - ujawniają społeczną wspólnotę przekonań co do ich wartości pozytywnej lub negatywnej.

Język obok terytorium i państwa jest jedną z częściej wymienianych cech narodu, choć nie niezbędną. Jednak zmiany w życiu społecznym, pojawienie się jakiegoś konfliktu, np. etnicznego, wymagają „określenia się”, samouświadomienia, często także językowego. Można przywołać tu przykład XIX-wiecznej historii, kiedy ruchy narodowościowe wykorzystywały kryterium językowe jako czynnik identyfikujący naród (w tym Polacy), jak i przykłady z najnowszej historii krajów bałkańskich i Europy Środkowo-Wschodniej (Bobrownicka 2006: 208-219; Gajda 2008; Lubaś 2009; Hobsbawm 2010; Iżykowska 2015).

„Ścisły związek między językiem a życiem narodu należy do prawd oczywistych, niezaprzeczonych. [...] Jest on rzeczywistym i najważniejszym dowodem odrębno- 
ści narodowej" - takimi słowami rozpoczynał Adam A. Kryński (1931: 7) pierwszy rozdział poradnika Jak nie należy mówić i pisać po polsku, którego pierwsza część ukazała się w 1920 r. Warto zwrócić uwagę na opinie językowe z okresu międzywojennego, których podłożem był wiek XIX. Nie tylko reprezentują one bowiem stan ówczesnej świadomości językowej, ale też obrazują ogólną świadomość społeczną Polaków, którzy w 1918 r. odzyskali własne państwo. Druga Rzeczpospolita to państwo $\mathrm{w}$ trakcie wewnętrznych procesów integracyjnych i ten aspekt należy podkreślić. Wcześniej przekonanie o ważności polszczyzny jako czynnika wspólnotowego pozwoliło kształtować nowoczesne polskie społeczeństwo bez wsparcia państwa narodowego.

Przedmiotem niniejszego artykułu jest społeczna świadomość językowa Polaków w okresie kilkunastu lat po odzyskaniu niepodległości, od roku 1918 do pierwszej połowy lat 30., kiedy żywotne jest jeszcze przekonanie o kulturowym i mentalnym zróżnicowaniu byłych zaborów. Świadomość językowa w dwudziestoleciu to zagadnienie historycznojęzykowe i możemy ją rekonstruować, dysponując wypowiedziami stosunkowo niewielkiej części społeczeństwa, przede wszystkim przedstawicieli ówczesnej inteligencji. Trzeba zaznaczyć, że analizy tego rodzaju, opierające się na ograniczonym materiale tworzonym przez ograniczoną grupę osób (np. „mniejszość piśmienną" w średniowieczu), wiążą się z wątpliwościami, czy nie jest to wyraz poglądów wąskiej grupy ludzi, a nie ogółu, jaki jest stopień językowej refleksji autora tekstu, czy mamy do czynienia z kreowaniem poglądów, ich narzucaniem, a nie z odpowiedzią na zapotrzebowanie społeczne (Maćkowiak 2011: 19-20; Sagan-Bielawa 2014: 68-69; Iżykowska 2015: 134). Konieczny jest dobór tekstów źródłowych, które można uznać za ważne dla szerzenia poglądów i kształtowania opinii publicznej.

Wydaje się, że postawy wobec polszczyzny po 1918 r. szerzyły się w dużym stopniu pod dyktando - opracowywanych i często wydawanych jeszcze przed I wojną poradników językowych, takich jak cytowany wyżej poradnik Kryńskiego ${ }^{2}$. Były one zestawieniem, jak głosił tytuł jednego z nich, „błędów najpospolitszych”, a więc takich form, które „się najbardziej upowszechniły, a przez to stały się najniebezpieczniejszymi dla czystości mowy naszej” (Czarkowski 1909/1920: 4), „najbardziej zagrażają czystości języka” (Krasnowolski 1919: 4), są „obce naturze języka polskiego" i mają "nieswojskie pochodzenie” (por. Kryński 1920: 1, 1931: 17). Większość z tych błędów miała powstać pod wpływem języków zaborców. Podobna tematyka poruszana była na łamach powstałych jeszcze przed odzyskaniem niepodległości czasopism „Poradnik Językowy” (od 1901 r.) i „Język Polski” (od 1913 r.) - w tym w działach listów do redakcji, w których powoływano się niejednokrotnie na opinię wspomnianego już A.A. Kryńskiego.

2 Poradnik Adama A. Kryńskiego powstał m.in. na podstawie cyklu publikowanego w lwowskim „Słowie Polskim” w latach 1908-1910. Druga jego część zawiera także przedruki wygłoszonych publicznych odczytów. 
Zagadnienia poprawności językowej, charakterystyka językowa grup społecznych, regionalnych czy etnicznych nie ograniczały się do wydawnictw językoznawczych. Ówczesna prasa codzienna, mająca różnych odbiorców i zasięg, zróżnicowana politycznie i światopoglądowo, także pokazuje pozycję polszczyzny w świadomości społecznej $j^{3}$. Po I wojnie światowej prasa odgrywała bardzo ważną rolę w kształtowaniu nowoczesnej opinii publicznej, rozwijające się radio nie miało jeszcze dużego zasięgu. Związek pomiędzy zachowaniami językowymi, rozumieniem normy językowej a innymi elementami świadomości społecznej podkreślali ówcześni inteligenci, ludzie nauki, dziennikarze, publikując na łamach prasy opinie, które moglibyśmy zamknąć stwierdzeniem antropologa, że w ocenach (ideologiach) językowych „chodzi o coś więcej niż tylko o język" (por. Ahearn 2013: 34).

Biorąc pod uwagę liczne odwołania do charakteru narodowego, duszy narodu, a również do ducha języka, natury języka, możemy stwierdzić, że w polskiej publicystyce okresu międzywojennego mamy do czynienia z psychologizującym portretowaniem narodu polskiego i jego języka, co odpowiada ideom Humboldta i Herdera - język wyraża ducha narodu. Władysław Tarnawski pisał w latach 30. XX w., że artykuły poruszające kwestie języka, które ma okazję czytać, są „prawdziwym zwierciadłem umysłów” i materiałem do badań „psychologii indywidualnej i dzielnicowej" (Tarnawski 1934b: 583).

Dopełnienie wizerunku dzielnicy pozaborowej - upowszechnianego na przykład w prasie - stanowiła mowa jej mieszkańców. Język miał odpowiadać ogólnej charakterystyce zaboru (Sagan-Bielawa 2014: 101-130). Jeśli więc Galicja była uznawana za serwilistyczną, to serwilistyczna musiała być też tamtejsza polszczyzna, czego wyrazem były liczne - rzeczywiste i pozorne - germanizmy. Jeśli Wielkopolsce przypisywano oszczędność i konkret, to potwierdzenia tych cech szukano również w języku. Taki sposób myślenia pokazywały też prowadzone w okresie międzywojennym terenowe badania socjologiczne nad świadomością mieszkańców Poznania (Znaniecki 1931) i Górnego Śląska (Chałasiński 1935), podczas których badacze m.in. otrzymywali - zbliżoną do opinii prasowych - charakterystykę językową współmieszkańców miejscowości, różniących się pochodzeniem etnicznym czy regionalnym.

Symboliczna była dominacja polszczyzny byłego zaboru rosyjskiego, a dokładniej Królestwa Polskiego i Warszawy jako stolicy. Przekonanie to podtrzymywało spopularyzowane przez Kryńskiego twierdzenie, że regionalizmy (czy prowincjonalizmy, jak wówczas je nazywano) pozostają poza odmianą, którą on nazywał językiem literackim ogólnym, ogólnym językiem polskim lub językiem ogólnie polskim, a jej podstawę normatywną widział przede wszystkim w Warszawie.

3 Tematyka językowa pojawia się np. w takich tytułach, jak „Czas”, „Ilustrowany Kurier Codzienny”, „Myśl Narodowa”, „Tygodnik Ilustrowany” (zob. Gabryś-Sławińska 2016), „Wiadomości Literackie", a także w dziennikach lokalnych. Niektóre artykuły prasowe były omawiane na bieżąco w „Poradniku Językowym” w dziale Co piszą o języku? 
Charakterystyczną dla tamtego okresu argumentację stanowiło uzasadnianie zróżnicowania języka podziałami zaborowymi. Skupienie na uproszczonym obrazie Polski złożonej z trzech rodzajów Polaków, byłych poddanych trzech obcych władców, pozostawiało na marginesie sprawę innych narodowości, mieszanej ludności Kresów Wschodnich, Pomorza i Górnego Śląska. Takiemu schematowi myślenia zostały podporządkowane również tradycyjne, starsze niż zabory, podziały dialektalne. Cechy właściwe polszczyźnie Warszawy „musiały” sięgać aż po północną Małopolskę, bo tam właśnie sięgała granica Królestwa Polskiego. Zróżnicowanie dialektu kulturalnego w Galicji rzadko docierało do świadomości ludzi z innych regionów; Kraków i Lwów według ich wyobrażenia powinny mówić tak samo. Łatwiej można było zaakceptować nowy wówczas zwyczaj nazywania wschodniej Galicji Małopolską Wschodnią, łącząc ją językowo, mentalnie i politycznie z historyczną Małopolską (ziemią krakowską).

Przekonanie, że granice wariantywności językowej nakładają się na granice zaborowe, było utrwalane przez nazewnictwo upowszechniane po 1918 r. paradoksalnie - z myślą o zacieraniu różnic zaborowych i głębszej integracji. O tych przemianowaniach pisał Michał Bobrzyński na łamach krakowskiego „Czasu”:

Niemogąc teraz dzielnic nazwać: austryacką, pruską i rosyjską szuka się dla nich nazw polskich i tryumfuje znalazłszy gotowe nazwy: Wielkopolskę, Małopolskę i Koronę! Niepytając o anachronizm historyczny, który w zastosowaniu tych nazw do dzielnic rozbiorowych leży, już się te nomenklatury zaczyna wprowadzać, już deklinuje się na wszystkie przypadki Małopolskę z Krakowem i Lwowem, ale bez Sandomierza i Lublina (Bobrzyński 1919: 1).

Bobrzyński ostrzegał, że granice nie zostaną przez to zniesione, ale zaniknie świadomość tradycyjnego podziału ziem polskich. Także Kazimierz Nitsch (1924) pisał ironicznie o Małopolanach „z Kołomyi lub choćby ze Lwowa”. Zwracał uwagę, odwołując się do własnych doświadczeń z życia naukowego, że nazwa Małopolska traci wyrazistość:

gdy chce się mówić o prawdziwej Małopolsce, tj. o dawnych województwach krakowskiem, sandomierskiem i lubelskiem [...], trzeba to wyraźnie zaznaczać (ibid.: 46).

Podobnie Wielkopolska utrwaliła się jako nazwa jednego zaboru, mimo że ziemie historycznej Wielkopolski należały częściowo do Królestwa Polskiego. Wielkopolanami nazywano na przykład delegatów Naczelnej Rady Ludowej, którzy w marcu 1919 r. spotykali się w Warszawie z Ignacym Paderewskim i Józefem Piłsudskim:

Wielkopolanie przestrzegają dość silnie swego dzielnicowego separatyzmu, bo twierdzą, że u nich są stosunki zdrowsze [...]. Nie chcą również brać z Królestwa urzędników, bo mówią, że widzą tu dużo próżniactwa, a mało obowiązkowości (O wojsko: 1). 
Historyczne nazwy Małopolska, b. Królestwo Polskie lub b. Kongresówka (rzadziej Mazowsze) i Wielkopolska oraz pochodne od nich nazwy mieszkańców zastępowały określenia kojarzące się z niewolą (jak Galicja, zabór) i stosowane były przez cały okres międzywojenny. Najbardziej popularne były w pierwszych latach po odzyskaniu niepodległości, kiedy dopiero kształtował się nowy podział administracyjny. Służyły one jako pożyteczne - z perspektywy ekonomii językowej - określenia byłych dzielnic zaborowych:

a wkońcu góruje nad salę z marszałkowskiego krzesła także Wielkopolanin p. Trąmpczyński, postać sympatyczna i typowa. Kieruje obradami bardzo uważnie i spokojnie; zawsze jednak w sprawach formalnych najwięcej rutyny i doświadczenia okazują posłowie „małopolscy” z dawnej Galicyi, którzy mają za sobą przeważnie wieloletnie parlamentarne tradycye i których zdania prezydyum często zasięga (Na sali: 1).

[...] powstaje wrzawa na ławach Wielkopolan, która trwa dłuższy czas. [...] Sprawa między Małopolską a Polską nie jest sprawą dzielnicową, trzeba ją oceniać ze stanowiska polityki Państwa względem jednej dzielnicy. [...] W Sejmie nie powinno się stawiać kwestyi tak, jakoby Małopolanie stawali na gruncie partykularyzmu dzielnicowego (Sejm walny: 2) .

To niezbyt precyzyjne nazewnictwo stosował A.A. Kryński w poradach poprawnościowych, przeciwstawiając zwyczaje językowe Galicjan ${ }^{6}$ (lub Małopolan) oraz Wielkopolan poczuciu językowemu „ogółu czytelników polskich”:

Słowa z przedrostkami przyimkowemi prze- i przy-, jak np. przechodzić i przychodzić, przepłacić i przypłacić, przykazać i przekazać i t. p.? - różniące się wyraźnie znaczeniem, bywają nieraz używane błędnie, jedne zamiast drugich, zarówno w mowie ustnej wielu jednostek w Małopolsce, jak i w piśmie, zwłaszcza w dziennikarstwie lwowskim (Kryński 1920: 286).

O „przypadkowych konstrukcjach zaborczych” pisał autor króciutkiej recenzji Mapy narzeczy polskich K. Nitscha z 1919 r., opublikowanej w krakowskim „Czasie”, podkreślając, że dzięki pracy dialektologa

4 Nazwy te zawierają stenogramy z posiedzeń sejmu, a także ustawy oraz rozporządzenia rządowe. Z czasem zastąpiły je nazwy województw, ale jeszcze do 1939 r. funkcjonowały nazwy firm, instytucji i organizacji typu: Centralna Małopolska Kasa Oszczędności we Lwowie, Związek Ociemniałych Żołnierzy na Województwo Małopolskie z siedzibą we Lwowie, Izba Aptekarska Małopolski Wschodniej.

5 Małopolska i Małopolanie pojawiają się w wypowiedziach posłów (Hermana Diamanda i Henryka Radziszewskiego), przytoczonych przez dziennikarza.

6 W drugim tomie poradnika pisał już o byłej Galicji (Kryński 1931).

7 Mieszanie tych przedrostków wynikało z południowokresowej redukcji nieakcentowanego $e$, o czym Kryński nie wspominał. 
nietylko [...] historyczna geografia, ale i żywa mowa ludowa protestuje przeciw płytkiemu utożsamianiu zaboru pruskiego z Wielkopolską a Galicyi z Małopolską (Nowe publikacje: 2).

Ale na łamach tego samego pisma znajdziemy także i przejawy owej „płytkiej” świadomości. Korespondent z sejmu donosił, że często rozlega się tam „wielkopolski twardy akcent” posłów z byłego zaboru niemieckiego, w tym Ślązaka Wojciecha Korfantego (Na sali: 1). O tzw. twardym akcencie i różnicach w wymowie pisał też w swoim amatorskim poradniku językowym dziennikarz i literat Jan Tadeusz Wróblewski, uwydatniając jednocześnie normotwórczą rolę Mazowsza:

Różne dzielnice Rzplitej przyswoiły sobie różną wymowę, a więc: Wielkopolska, Pomorze i Śląsk pod wpływem języka niemieckiego - przybrały (naogół biorąc) wymowę twardą i nieco chropowatą; Małopolska Zachodnia - pod wpływem tegoż języka niemieckiego, lecz w mniejszym stopniu - wymowę twardawą; Małopolska Wschodnia - pod przeważającym wpływem języka rusińskiego - nieco przeciągłą; Kresy Wschodnie i Wileńszczyzna - pod wpływem języka rosyjskiego - miękką i śpiewną. Mazowsze zaś z b. Kongresówką najmniej uległo pod tym względem wpływom języków b. zaborców, zachowując wymowę ogólno-polską, jaką zresztą posiłkują się rodacy nasi i w innych dzielnicach Polski wychowani, lecz odporniejsi na wpływy wymowy otoczenia (Wróblewski 1926: 122).

Wróblewski wzorem Kryńskiego przypisywał germanizmy określonym dzielnicom: „Swoją kawę, swoje dwa kufle piwa wypiłem. Tak mówią w Mało- i Wielkopolsce, popełniając zwykły germanizm" (ibid.: 38$)^{8}$.

Kształtowanie się nowego podziału Małopolska - Mazowsze - Wielkopolska można zaobserwować także na przykładzie „Poradnika Językowego”. W jednym z zeszytów z 1920 r. omawiano „nowotwory” zaistnieć (np. zaistnieją warunki) i cło$w y$, pochodzące z edyktów sądowych - jak pisał autor - małopolskich, czyli m.in. z Przemyśla, Sambora, Czortkowa, Brzeżan i Stanisławowa (PJ 1920: 24-25). W innej językowej opinii postawiono znak równości pomiędzy Kongresówką a Mazowszem:

Nie chcielibyśmy, aby się i do języka wkradł partykularyzm tego charakteru, że to, jak się mówi w Warszawie albo w ogólności na Mazowszu (b. Kongresówka), jest decydujące (PJ 1927: 41).

Ujednolicenie polszczyzny ogólnej i usuwanie wariantów jako wpływu obcego uznawano za działania służące integracji Polaków. Argumentowano, że porozumie-

8 Por. fragment poradnika Antoniego Krasnowolskiego (1919: 78), który rzadko uzasadniał używanie germanizmów czy rusycyzmów różnicami regionalnymi: „Rano wypiłem swoją kawę, a wieczorem swoje dwa kufle piwa. Jest to germanizm. Ma to niby znaczyć, że taka jest moja zwyczajna porcja albo wogóle moje przyzwyczajenie. Ale po polsku tak się nie mówi; zaimek swój jest tu zbyteczny [...]". 
nie i jedność w języku są „dla życia narodowego przydatniejsze niż wielobarwność” (Magiera 1920: 21). Jako wyraz „jeszcze dalej posuniętej unifikacji, jeszcze mocniej i ściślej zjednoliconej kultury narodowej” przedstawiano prace nad ujednoliceniem wymowy scenicznej (Klich 1927: 8). Integracja językowa miała wymiar praktyczny i symboliczny. Zdaniem Floriana Znanieckiego, badającego przemiany społeczne w Poznaniu, dla żyjących obok siebie autochtonów i przybyszów z innych regionów oczywista była potrzeba dążenia do przynajmniej powierzchownej harmonii, której elementami miały być wzajemny szacunek, poszanowanie godności, nierażenie cudzych uczuć i posługiwanie się wspólnym językiem „na pewnym poziomie estetycznym i gramatycznym” (Znaniecki 1931: 84-85). Jak uzyskać ową harmonię? Znaniecki stwierdzał:

Z punktu widzenia samego współżycia ludności poznańskiej jest to społecznie obojętne, czy np. ujednostajnienie języka ma się dokonać drogą przyswojenia właściwości mowy poznańskiej przez przybyszów, czy też wyzbycia się tych właściwości przez Poznańczyków: zasadniczem jest, że to ujednostajnienie jest wogóle odczuwane jako coś pożądanego (ibid.: 85).

Choć na poziomie ogólnych postulatów panowała zgoda, ścierały się różne wizje językowej integracji. Międzydzielnicowe konflikty przejawiały się właśnie w odmiennym pojmowaniu roli polszczyzny regionalnej - jako wyrazu bogactwa językowego, narzędzia asymilacji lub przeszkody w pełnej integracji. Zarówno orędownicy zachowania różnorodności terytorialnej języka, jak i zwolennicy niwelowania wariantywności i wprowadzenia jednolitej normy językowej widzieli stanowisko przeciwne jako zagrożenie dezintegrujące polskie społeczeństwo, wypełniając popularne wówczas pojęcia partykularyzm, separatyzm, prowincjonalizm różnymi treściami.

Traktowany przez jednych jako warunek utrzymania wspólnoty językowo-kulturowej puryzm językowy przyczyniał się jednocześnie do powstawania nowych antagonizmów, miał bowiem charakter egocentryczny ${ }^{9}$. W Megalomanii narodowej Jan Stanisław Bystroń nazywał „nietolerancją językową” zjawisko negatywnego wartościowania polszczyzny regionalnej Poznania przez ludność napływową, uznającą swój język za wzorzec (Bystroń 1924/1995: 71). Przed taką postawą lekceważenia i pogardliwego traktowania innej niż własna mowy mieszkańców Pomorza czy Śląska przestrzegał K. Nitsch (1922), pisząc, że działalność polskich „cywilizatorów” doprowadzi do odwrócenia się Kaszubów i Ślązaków od Polski. I Nitsch, i Bystroń zauważali, że u podłoża tych postaw leży - charakterystyczna dla świadomości społecznej wielu wspólnot - pierwotna skłonność do uznawania swojego języka za „pierwszy, jedynie prawdziwy” (Bystroń 1924/1995: 20) i do uznawania odmienności mowy za przejaw obcości, niższości czy nawet wrogości. Krytykując, nazywano taką postawę 
„prowincjonalnym patriotyzmem językowym” ${ }^{10}$, mówiono o „prowincjonalnych poprawnościowcach” (JP 1925: 13), „osobach prowincjonalnie myślących” (PJ 1930: 77). Warto zauważyć, że również dla osób niechętnych nadmiernemu zróżnicowaniu polszczyzny, które stawiały znak równości między prowincjonalizmami („nieznanymi językowi ogólnopolskiemu”, jak pisał Kryński) a błędami językowymi, prowincjonalność oznaczała ciasnotę poglądów i niski poziom świadomości językowej.

Sądy językowe odwołują się do utrwalonych pojęć, wspólnych doświadczeń i wartości, ale na poziomie jednostki często okazują się sprzeczne, wykluczają się. Za taki przykład mogą posłużyć oceny - innowacyjnej na początku XX w. - eliminacji form żeńskich nazwisk na -owa, -ówna itp. Piętnowano ją jako zjawisko narzucone z zewnątrz, co było poglądem „bezpiecznym”, bo odwołującym się do doświadczenia życia pod zaborami. Ale w zależności od wiedzy językowej krytykującego, a może bardziej od jego osobistych antypatii czy sympatii, pojawienie się takiej tendencji tłumaczono - z pełnym przekonaniem - albo wpływem niemieckim, albo żydowsko-niemieckim, albo rosyjskim (por. Czarkowski 1909/1920: 46; PJ 1919: 85; Wróblewski 1926: 32; Obrazek: 27).

Świadomość społeczna wydaje się bagatelizować rzetelność sądów, kształtowana jest bowiem i na poziomie wiedzy - w tym wiedzy naukowej - i na poziomie opinii (Sztompka 2009: 297-298; Ziółkowski 2015: 53-55). Ta druga może wynikać z pewnej wiedzy, ale jej podstawową cechą nie jest zgodność z rzeczywistością, prawdziwość sądów, ale przekonanie, że są to poglądy podzielane przez większość (tzw. opinię publiczną). Takie przekonanie o powszechności pewnych postaw wyraża autor poniższych wypowiedzi:

Dla tego też i takie okazy, jak: przedkładać i przedłożyć ['przedstawić', np. projekt M.S.-B.] sztucznością swojej budowy rażą i razić muszą poczucie językowe większości Polaków, nie przywykłych do wzorów niemieckich i niemieckiego myślenia, a wciąganie podobnych słów do mowy ogólnej nie da się niczym usprawiedliwić (Kryński 1920: 137).

Niema dziś - można śmiało powiedzieć - ani jednej osobistości pośród inteligientnych warstw narodu, któraby nie podzielała utyskiwań nad niepoprawnością dzisiejszego języka (Kryński 1931: 29).

Twierdzenia wykluczające inne warianty, akcentujące typowość i powtarzalność zaobserwowanych zachowań językowych, sugerujące posiadanie pewnej wiedzy na dany temat, np. „nikt tak nie mówi i nie pisze” (JP 1928: 120), „po użyciu tej ostatniej formy od razu poznajemy...” (JP 1949: 233), „czytam nagłówek listu i od razu wiem, skąd przyszedł" (Wasylewski 1930/1957: 120), ,jak się nie po raz pierwszy okazuje” (JP 1927: 31), można uznać za przejaw naiwnego realizmu, założenia, że „rzeczywistość jest taka właśnie, jaka jest, i każdy (normalny) człowiek powinien ją postrzegać

10 Tak pisał Artur Passendorfer (1911: 65) jeszcze przed zjednoczeniem zaborów. 
tak samo" (Ziółkowski 2015: 55). Badając świadomość społeczną, w tym świadomość językową, spotykamy się właśnie ze światem naiwnego realizmu, w którym dużą rolę odgrywają stereotypy z charakterystycznymi dla nich uproszczeniami, ambiwalencją, emocjami, skłonnością do przejaskrawień, a nawet fałszowania rzeczywistości (Quasthoff 1998: 12-13; Sztompka 2009: 300).

Stereotypy społeczne wykorzystuje, podtrzymuje i utrwala m.in. twórczość satyryczna. Przejaskrawiona, zgodnie ze specyfiką gatunku, charakterystyka Polaków z trzech zaborów i ich języka pojawiała się w utworach satyrycznych po $1918 \mathrm{r}$. Przedrukowywały je i komentowały „Język Polski” i „Poradnik Językowy” (zob. Warszawszczyzna; Rozmaitości; Co piszą: 183). Jedna z tego rodzaju opowiastek dowodzi na przykład, utrwalając stereotyp, że prowincjonalizmy w języku jej bohaterów (Galicjanina, Poznaniaka i Królewiaka) to po prostu błędy, których należy unikać:

A morał trochę komicznej tej historii jasny: Zamiast wzajemnie się wyśmiewać i szydzić, starajmy się lepiej poznać swe błędy i przez wzajemne zetknięcie się oczyścić język ze szpetnych naleciałości prowincjonalnych (Rozmaitości: 15).

Istotę międzydzielnicowych antagonizmów językowych i rolę polszczyzny w procesach integracyjnych ujmowała żartobliwa stylistyka felietonów $\mathrm{Na}$ końcu języka Stanisława Wasylewskiego:

[...] w takim jednym przydechu czy nazweczce skrył się cały symbol różnicy szczepowej czasem, towarzyskiej często tylko i zwyczajowej. U nas inaczej, u nas najlepiej! Coup de mot - coup de foudre!

Zastępuje i symbolizuje całą odrębność życia szkoły i wychowania, i kodeksu obyczajowego, jest wykładnikiem różnic dzielnicowych, sygnałem ostrzegawczym, który demaskuje „innorodca” lub hasłem porozumienia, które łączy dzielnice (Wasylewski 1930/1957: 121).

Felietony Wasylewskiego pokazywały też Warszawę jako źródło puryzmu egocentrycznego, np.:

Stosunkowo najskuteczniej działa w dziedzinie ujednolicenia języka wojsko, potem kolej i szkoła. [...] We wszystkich tych dziedzinach spieszy z pomocą cała armia rewizorów z Warszawy niosąc w najgłębsze prowincje ideał mody, obyczaju, słowa, frazesu. Choć czasem pełni rolę dentystów wyrywających bez bólu zdrowe zęby z paszczęki (ibid.: 9-10).

Zbliżone opisy znajdujemy w międzywojennej prasie codziennej, w czasopismach kulturalnych, w poradnikach językoznawczych, w publicystyce uniwersyteckich profesorów. Również tam ty pow y inteligent warszawski pojawiał się jako ten, który raczej nie upowszechnia poprawnej polszczyzny, ale narzuca wszystkim swoje zwyczaje językowe: 
Osobistości te za stały swój obowiązek uważają udowadnianie, że tylko w Warszawie mówi się poprawnie (czyli po warszawsku: prawidłowo = rosyj. prawilno) po polsku (Birkenmajer 1923: 90).

Wybitny uczony miejscowy [warszawski - M.S.-B.] piętnował szereg wyrażeń, które uznawał za niepoprawne. [...] Oto obrazek typowy, który przypomina się nieraz przy lekturze różnych artykułów językowych w prasie warszawskiej. Chyba tylko w Warszawie mogło się zdarzyć to, co mnie spotkało. W książce naukowej, po ostatniej korekcie autorskiej, pozmieniano mi takie formy nieodmienne, jak bitwa pod Bosworth lub Geoffrey z Monmouth na odmienne (Bosworthem, Monmouthu). Tam i korektorzy potrafią być dyktatorami. Oni lepiej wiedzą... (Tarnawski 1934a: 546).

O wpływie innego, równie popularnego stereotypu społecznego można mówić w wypadku opinii na temat stanu polszczyzny urzędowej. Jak bowiem głosili bohaterowie satyrycznego wierszyka, „wszystkiemu, Panie, winni są ci Galicjanie...” (Warszawszczyzna: 127). Po roku 1918 powszechne było utożsamianie całej sfery urzędniczej z dawną biurokracją Austro-Węgier, a ważnym elementem tego obrazu były kalki z języka niemieckiego, np. wodpowiedzi na..., w przypuszczeniu przychylnego załatwienia, przydzielony do mniejszych władz polskich, rozpisać wybory, wykorzystać 'wyzyskać', w międzyczasie, bank dla handlu i przemysłu, szukać za czymś. Wynajdowane w prasie i w drukach formy - zapożyczone „oczywiście jako towar wiedeński” (por. Kryński 1931: 63) - miały zdradzać autorstwo biurokraty z Galicji:

Zadowolenie, jakie odczuwamy z powstania nowego polskiego zakładu państwowego mącą jednak błędy językowe, wskazujące niedwuznacznie, że formularz ten układał były urzędnik austrjacki (Seredyński 1919: 83).

[...] znać w nich [dekretach - M.S.-B.] biurokratę galicyjskiego czystej wody, który drży przy każdym wyrazie, aby przypadkiem duch biurokratyczny nie uleciał z jego mozolnych referatów (PJ 1919: 25).

Z treści wynika, że to podanie urzędnika związanego z b. władzami krajowymi w Galicji (PJ 1921: 58).

Czasownik zastępować, użyty w tem znaczeniu ${ }^{11}$, pobudza warszawiaków i w ogólności rdzennych mieszkańców dawnego Królestwa Polskiego do zastrzeżeń i dowodzeń, że w tym przypadku jest to germanizm, wprowadzony do języka polskiego przez mieszkańców dawnej Galicji (Łoś 1928: 162).

Trzeba podkreślić, że cytowany wyżej Jan Łoś jako uczony zaznaczał swój dystans do obiegowych opinii o „dawnych Galicjanach”, bez ich udziału upowszechniało się bowiem w polszczyźnie ogólnej wiele innych zjawisk językowych pierwotnie

11 Chodzi o zwrot „strony muszą być zastępowane przez adwokatów” użyty w notatce Polskiej Agencji Telegraficznej. 
stosowanych w jednej dzielnicy. Omówienie popularnego wówczas - a nieznanego dziś w języku polskim - germanizmu semantycznego zastępca podsumował następująco:

W tych razach niepodobna być prorokiem i przepowiedzieć, co zwycięży; rozstrzygający głos ma ogól, który u nas w praktyce niewiele dba o teorje językoznawcze (ibid.: 164).

Najczęściej jednak dziennikarz czy felietonista, pisząc o „typowym obrazku”, sugerował, że jego przykład to nie pierwszy, ale kolejny z wielu przypadków („całej armii”), dowodzących, że Kongresówka, Galicja lub Wielkopolska są właśnie takie, a nie inne - $\mathrm{i}$ jest to wiadome. Mieszczące się w konwencji felietonu uproszczenia, niedopowiedzenia, przerysowanie cech, zwłaszcza kiedy pojawiały się w publikacjach autorstwa profesora uniwersytetu, mogły być uznawane przez czytelnika za niepodważalny fakt, przyjmowane jako ważna, wartościowa wskazówka i powtarzane. W ten sposób w odrodzonym państwie kształtowały się i ścierały poglądy na temat stanu polszczyzny.

Te czasami kłócące się z wiedzą naukową i upraszczające twierdzenia „ogółu” warto badać. Oprócz specjalistycznej normalizacji języka - za którą odpowiedzialni są m.in. językoznawcy i szkoła - kierunek rozwoju języka wyznacza również „językowa i ogólnokulturowa świadomość danej społeczności”, której znaczenie podkreślała Irena Bajerowa (200o). Procesy integracyjne okresu międzywojennego sprzyjały ograniczeniu wariantywności w języku polskim jako zbędnej, a nawet szkodliwej cechy „dzielnicowej”. W świadomości społecznej dzielnicowy, partykularny charakter miały również same dążenia normalizacyjne (Warszawa jako ośrodek normalizacji, Galicja jako jej opozycja), m.in. za sprawą działalności takich językoznawców, jak Kryński i Nitsch, kojarzonych z określonym zaborem.

Pozycja języka - lub jego odmian - w świadomości społecznej nie musi być stała. Istnieje pewna tradycja, czego przykładem jest manifestowanie przywiązania Polaków do „ojczyzny-polszczyzny”, a jednocześnie następuje modyfikacja przekonań i postaw wobec języka. Decydują o tym takie wydarzenia, jak budowa państwa, utrata i odbudowa niepodległości, ale również zjawiska o skali globalnej, natury politycznej, ekonomicznej, kulturowej i technologicznej - od wynalezienia druku po powstawanie nowych kanałów komunikacji. W ostatnich latach na stosunek do polszczyzny wpływa zyskujący na popularności dyskurs tożsamościowy. Można by zakładać, że w zglobalizowanym świecie stare hasła stracą na popularności, pozostając poza obszarem zainteresowania młodszych pokoleń. Ich żywotności w Polsce dowodzą powracające - a więc zachowane w świadomości społecznej - odwołania do poczucia tożsamości Polaków, często są to odwołania właśnie do okresu zaborowego i Drugiej Rzeczypospolitej, kiedy nie mówiono o tożsamości narodowej bez polszczyzny. Rola języka w tym dyskursie jest warta obserwacji. 


\section{Źródła}

Birkenmajer J., 1923, Wyjaśnienia do „ęzyka małopolskiego”, „Język Polski” VIII, s. 89-91. Bobrzyński M., 1919, O zespoleniu dzielnic Rzeczypospolitej, „Czas” LXXII, nr 185, s. 1.

Co PISzĄ: Co piszą o języku?, „Poradnik Językowy” 1934, nr 10, s. 181-183.

Czarkowski L., 1909/1920, Słowniczek najpospolitszych rusycyzmów, Wilno.

JP 1925-1949: „Język Polski” X-XXXIX, działy: Odpowiedzi na pytania, Odpowiedzi Redakcji.

KLICH E., 1927, Jak mówić po polsku na scenie?, „Kurier Poznański” nr 12, s. 8.

KrasnowOlski A., 1919, Najpospolitsze błędy językowe zdarzające się w mowie i piśmie polskiem, wyd. 3 popr., Warszawa.

KRYŃski A.A., 1920-1931, Jak nie należy mówić i pisać po polsku, cz. 1, 1920, cz. 2, 1931, Warszawa.

Ł[oś] J., 1928, Zastępować, zastępstwo, zastępca, „Język Polski” XIII, s. 162-164.

Magiera J., 1920, Porozumienie się językowe, „Poradnik Językowy” nr 12-13, s. 19-21.

NA SALI: Na sali sejmowej, „Czas” 1919, LXXII, nr 63, s. 1-2.

Nitsch K., 1922, O poszanowanie odrębności prowincjonalnych, „Język Polski” VII, s. 33-37.

Nitsch K., 1924, O nazwy dzisiejszych części Polski, „Język Polski” IX, s. 45-51.

Nowe PUbLIKACJe: Nowe publikacje, „Czas” 1919, LXXII, nr 287, s. 2.

O wојsко: O wojsko i nowych posłów, „Czas” 1919, LXXII, nr 58, s. 1.

OBRAZEK: Obrazek z życia TMJP (Jednanie członków a forma nazwisk żeńskich), „Język Polski” 1933, XVIII, s. 27-29.

Passendorfer A., 1911, Język literacki w Królestwie Polskim a w Galicji, „Poradnik Językowy" nr 11, s. 65-69.

PJ 1919-1930: „Poradnik Językowy” 1919-1930, XVI-XXV, działy: Zapytania i odpowiedzi, Roztrząsania.

Rozmaitości: Rozmaitości. Krótka rozmowa między Galicjaninem, Poznaniakiem i Królewiakiem, „Poradnik Językowy” 1931, nr 1, s. 14-15.

SEJM WALNY: Sejm walny. Dyskusya walutowa, „Gazeta Lwowska” 1920, CX, nr 12, s. 1-2.

SEREDYŃsKi M., 1919, Urzędowe uświęcanie błędów językowych, „Poradnik Językowy” nr 6, S. 83.

TARnAWSKi W., 1934a, Pro domo et pro lingua, „Myśl Narodowa” nr 37, s. 544-546.

Tarnawski W., 1934b, Pro Varsovia, „Myśl Narodowa” nr 40, s. 583-584.

WarszaWszczyzNa: Warszawszczyzna, „Język Polski” 1921, VI, s. 126-128.

WASYlEWSKI S., 1930/1957, Na końcu języka, Wrocław.

WróвLEwsкi J.T., 1926, 2000 błędów językowych, barbaryzmów, dziwolagów i nowotworów ze wszystkich dzielnic Polski zebranych wraz ze słowniczkiem jako też wzorki stylu urzędowego, Warszawa.

\section{Literatura}

Ahearn L.M., 2013, Antropologia lingwistyczna. Wprowadzenie, Kraków.

BAJERowa I., 2000, Tendencja do normalizacji jako główny czynnik rozwojowy polskiego języka ogólnego, [w:] K. Rymut, W.R. Rzepka (red.), Studia historycznojęzykowe 3. Rozwój polskiego systemu językowego, Kraków, s. 9-14.

BARTOL-JARosińsKa D., 1986, Świadomość językowa robotników warszawskich. Studium leksykalno-semantyczne, Warszawa. 
Bobrownicka M., 2006, Patologie tożsamości narodowej w postkomunistycznych krajach słowiańskich. Uwagi o genezie i transformacjach kategorii tożsamości, Kraków.

Bystroń J.S., 1924/1995, Megalomania narodowa, Warszawa.

ChaŁası́́ski J., 1935, Antagonizm polsko-niemiecki w osadzie fabrycznej „Kopalnia” na Górnym Śląsku. Studium socjologiczne, Warszawa [odb. z „Przeglądu Socjologicznego” 1935, t. 3].

Dubisz S., 1988, Między dawnymi a nowymi laty. Eseje o języku, Warszawa.

GABRYś-SŁAwIŃsKa M., 2016, Język jako wartość w „Tygodniku Ilustrowanym” w latach 1918-1928, „LingVaria” nr 2 (22), s. 279-294, [on-line:] http://dx.doi.org/10.12797.LV. 11.2016.22.18.

Gajda S. (red.), 2008, Tożsamość a język w perspektywie slawistycznej, Opole.

Hobsbawm E., 2010, Narody i nacjonalizm po 1780 roku. Program, mit, rzeczywistość, Warszawa.

IżY KOwsKA M., 2015, Język polski jako wartość w publicystyce śląskiej XIX wieku, [w:] J. Adamowski, M. Wójcicka (red.), Wartości w języku i kulturze, Lublin, s. 123-135.

Lubaś W., 2009, Polityka językowa, Opole.

Mас́кошіак K., 2011, U źródeł polskiej świadomości językowej (X-XV wiek), Poznań.

Ossowski S., 1957, Struktura klasowa w społecznej świadomości, Wrocław.

Przybysz-Pıw ко M., 2005, Świadomość językowa. Problem nie tylko lingwistyczny, „Poradnik Językowy" nr 7, s. 42-47.

Quasthoff U., 1998, Etnocentryczne przetwarzanie informacji. Ambiwalencja funkcji stereotypów w komunikacji międzykulturowej, [w:] J. Anusiewicz, J. Bartmiński (red.), Stereotyp jako przedmiot lingwistyki. Teoria, metodologia, analizy empiryczne, „Język a Kultura", t. 12, Wrocław, s. 11-30.

Sagan-Bielawa M., 2014, Dziedzictwo pozaborowe. Społeczna świadomość językowa Polaków w Drugiej Rzeczypospolitej, „Biblioteka LingVariów”, t. 18, Kraków.

SztompкA P., 2009, Socjologia. Analiza społeczeństwa, Kraków.

ZıóŁKowski M., 2015, Teoria socjologiczna a transformacja społeczeństwa polskiego, Warszawa.

Znaniecki F., 1931, Miasto w świadomości jego obywateli. Z badań Polskiego Instytutu Socjologicznego nad miastem Poznaniem, Poznań.

\section{Language as an element of the social consciousness (using the example of Poland after 1918) Summary}

This paper has been inspired by social sciences. According to Stanisław Ossowski, social consciousness is the sum of ideas, opinions and convictions shared by a society. Every community has the ability to construct its own language ideologies (denoted in Polish by the term świadomość językowa 'language awareness'). The paper describes how the part of social consciousness that is related to the language, was reflected in Polish press after the regaining of the independence. Attitudes towards variation and all the other linguistic phenomena seem to have been influenced by the previous partition of the country, and regional and political stereotypes. View of the language was based on both linguistic knowledge and the common opinion. The paper attempts to demonstrate that social consciousness consists largely of general and mutually exclusive opinions which a more detailed analysis does not support. Notwithstanding, these convictions do have an indirect influence on the development of the language. 
DIALEKTOLOGIA 



\section{VÝCHODOLAŠSKÁ NÁŘEČÍ VERSUS GWARA ZACHODNIOCIESZYŃSKA, CZYLI DIALEKTOLOGICZNA WOJNA O ZAOLZIE}

Słowa klucze: gwara, język etniczny, czesko-polskie pogranicze językowe, czeska część Śląska Cieszyńskiego, Adolf Kellner, Andrzej Sowa, Karol Dejna, Jaromír Bělič, Arnošt Lamprecht Keywords: dialect, ethnic language, Czech-Polish linguistic borderland, the Czech part of the Cieszyn/ Těšín region, Adolf Kellner, Andrzej Sowa, Karol Dejna, Jaromír Bělič, Arnošt Lamprecht

\section{Wprowadzenie}

Celem niniejszego artykułu jest omówienie problemu, na który zwykle nie zwraca się uwagi w pracach dotyczących (oddzielnie) dialektologii czeskiej lub polskiej, ponieważ wykracza on poza granice jednej i drugiej. Problem ten jest jednak ważny i - jak się okazuje - również niebywale emocjonujący. Przyjmując fakty dialektologiczne prezentowane $\mathrm{w}$ znanych i cenionych opracowaniach naukowych, często nie zauważamy obecności pewnych tematów tabu, miejsc przemilczanych lub niedoprecyzowanych i nawet nie przypuszczamy, jak ogromne znaczenie mają lub miały w konkretnej czasoprzestrzeni. Do refleksji tej skłoniła nas lektura przyczynków do trwającej kilkadziesiąt lat dyskusji o przynależności gwary zachodniocieszyńskiej do polskiego bądź czeskiego areału językowego.

$\mathrm{Na}$ wstępie należy udzielić czytelnikowi podstawowych informacji. Omawiana $\mathrm{w}$ artykule przestrzeń to tereny historycznego Księstwa Cieszyńskiego, które w 1920 r. zostało przyznane po części nowo powstałemu państwu polskiemu, a po części czechosłowackiemu. Po stronie zachodniej (czeskiej) granice dawnego 
księstwa sięgały aż po rzekę Ostrawicę i obejmowały tzw. Śląską (Polską) Ostrawę. To, co przez Polaków nazywane jest Zaolziem, a co zostało na niespełna rok przed wybuchem II wojny światowej włączone do Polski, to nieco węższy obszar przygraniczny czeskiego Śląska Cieszyńskiego, położony bardziej na wschód od wspomnianej rzeki'. Specyfika tego niewielkiego terenu (ok. $\left.800 \mathrm{~km}^{2}\right)$ tkwi w świadomości etnicznej tamtejszych mieszkańców, w ich propolskiej lub proczeskiej orientacji narodowej. Dla językoznawcy istotne jest to, że mowa potoczna ludności mniejszościowej (polskiej) i większościowej (czeskiej) jest tu w znacznym stopniu taka sama - jej podstawę tworzą tradycyjna gwara zachodniocieszyńska oraz naleciałości niemieckie, czeskie, (ogólno)polskie. Polska dialektologia traktuje gwarę zachodniocieszyńską jako polską, natomiast źródła czeskie starają się dowieść jej czeskiego (morawskiego, ewentualnie przejściowego/laskiego) charakteru, a każda $\mathrm{z}$ dialektologii narodowych dostrzega w tej odmianie cechy, które wykazywał bądź wykazuje do dziś jeden lub drugi zachodniosłowiański język etniczny².

Ta odmienna interpretacja afiliacji językowej Zaolzia stała się przyczyną zasygnalizowanego w tytule sporu, którego najważniejsze tezy czerpiemy przede wszystkim z prac Adolfa Kellnera Východolašská nářečí (1946-1949), Jaromíra Běliča Sedm kapitol o češtině (1955) i Nástin české dialektologie (1972) oraz Karola Dejny Polsko-laskie pogranicze językowe na terenie Polski (1951-1953), ale też z opublikowanych reakcji na wspomniane prace, $z$ reakcji na te reakcje itd. Badacze reprezentujący czeskie spojrzenie wychodzą z założeń panujących w ich dialektologii, i to co najmniej od II wojny światowej, czyli z podziału czeskiego języka etnicznego na cztery podstawowe zespoły dialektalne: 1) czeski sensu stricto (czeski właściwy, tzn. obejmujący zachodnie tereny języka czeskiego aż po Wyżynę Czesko-Morawską; w terminologii czeskiej: nářeční skupina česká v užším smyslu), 2) środkowomorawski (nářeční skupina středomoravská), 3) wschodniomorawski (nářeční skupina východomoravská) oraz 4) laski (nářeční skupina slezská, ewentualnie lašská). W czeskiej części Śląska czescy badacze rozróżniają tradycyjnie: 1) dialekt środkowolaski (centralny, ostrawski, střredolašské nářečí), 2) zachodniolaski (opawski, západolašské nářečí) i 3) „morawski”, południowy (występujący w okolicach Štramberka lub Frenštátu, štrambersko-frenštátské nářeč́, moravská podskupina slezských nářečíi). Po II wojnie

1 Należy podkreślić, że pojęcie „Zaolzie” jest znacznie upolitycznione, a rzeka Olza, o którą tu chodzi, nie wyznacza granicy państwowej wzdłuż całego swojego przebiegu, lecz tylko w pewnych jego odcinkach (szczegółowo zob. Bogocz 2016: 227 i n.).

2 Różnicę między gwarami przejściowymi a mieszanymi polscy i czescy dialektologowie formułują w sposób identyczny lub bardzo podobny, czyli mniej więcej tak, jak przedstawiła to Halina Karaś (2014). Fakt ten jednak nie znaczy, że ocena konkretnych narzeczy przez stronę polską i czeską jest pod tym względem taka sama. W dialektologii czeskiej obserwuje się wyraźną tendencję do udowadniania czeskiego charakteru Śląska Cieszyńskiego w Czechosłowacji (Republice Czeskiej), łącznie z używaną tam mową.

3 O dialektach czeskich oraz rozwoju czeskiej tradycji dialektologicznej zob. Bogoczová 2015, 2016. 
światowej czeska dialektologia wprowadziła w obieg za pośrednictwem publikacji A. Kellnera nowy termin - narzecza wschodniolaskie (východolašská nářečí), który można uważać za próbę uzasadnienia językowej (a nie tylko geopolitycznej) przynależności Zaolzia do czeskiego organizmu państwowego ${ }^{4}$.

W teorii Kellnera nářečí východolašská tworzą więc czwarty podzespół dialektów laskich. W tym podzespole dostrzega się (według dialektologów czeskich i polskich) następujące formacje gwarowe: 1) zachodnie pasmo przejściowe, 2) gwarę centralną (w okolicach Cieszyna, Trzyńca, Karwiny), 3) północną (skoncentrowaną w okolicach Bogumina) oraz 4) jabłonkowską. Bardziej dokładny podział wyszczególnia też odcinek nydecki (miejscowość Nydek/Nýdek znajduje się w pobliżu granicznej góry Czantorii) lub sam Jabłonków (w odróżnieniu od okolicznych wiosek).

\section{Stanowisko Adolfa Kellnera}

Streszczenie interesującej nas dyskusji rozpoczynamy od kontrowersyjnej z polskiego punktu widzenia pracy Kellnera Východolašská nářeč́s (1946-1949). Jej autor dobrze orientował się w dotychczasowych badaniach językoznawczych dotyczących gwary zachodniocieszyńskiej, łącznie z tymi, które prowadzili jego polscy koledzy. Omówił je pokrótce w przedmowie do drugiego tomu pracy (1949 II), wymieniając Lucjana Malinowskiego, Jana Bystronia i Kazimierza Nitscha, którego zasługi oceniał szczególnie wysoko. Podał też kilka nazwisk czeskich językoznawców: Alois Vojtěch Šembera, František Bartoš, Jan Loriš i in. Do zbadania gwary zachodniocieszyńskiej Kellner został wybrany w 1937 r. przez członków Komisji Dialektologicznej przy Macierzy Morawskiej, a prawdopodobnie - przez czołowych czeskich językoznawców bohemistów Františka Trávníčka i Bohuslava Havránka, którzy wykonanie prac badawczych zlecili młodszemu koledze rodem z laskiego Štramberka zapewne dlatego, że sami dotychczas nie wyrazili zdania na temat genezy gwar cieszyńskich i przynależności językowej czeskiej części Śląska Cieszyńskiego. Badania Kellnera miały więc wypełnić tę lukę. Przebywając na Zaolziu, Kellner zorientował się stosunkowo szybko nie tylko w tutejszej sytuacji językowej, ale także narodowościowej. Doszedł do wniosku, że używana tu gwara zachodniocieszyńska nie jest nieomylnym wskaźnikiem etniczności jej użytkownika. Na Zaolziu spędził około

4 Inne czeskie terminy odnoszące się do tego obszaru to lansowane nieco później przez Běliča polsko-czeskie pasmo mieszane (nářečí polsko-českého smíšeného pruhu), gwara zachodniocieszyńska (západotěšínské nářečí, np. Arnošt Lamprecht - patrz poniżej) lub gwary śląskopolskie (nářečí slezskopolská, np. Jan Balhar (2002)) - w przeciwieństwie do śląsko-morawskich, czyli laskich.

5 Adolf Kellner (1904-1953), który odbył staż naukowy m.in. u Kazimierza Nitscha, mógł się już wtedy wykazać pewnym dorobkiem badawczym. Gwarom śląskim poświęcił wcześniej artykuły: Slezsko po stránce jazykové (Kellner 1946a) oraz Jazykové poměry v levém horním Poodří (Kellner 1946b). 
dziewięciu miesięcy (1937-1938), po czym zebrany materiał przewiózł do Brna i tam (podczas II wojny światowej) opracowywał. Po wojnie wynik swej pracy przedstawił w dwutomowej monografii. Pierwszy tom (1946 I) zawiera opis systemu gwary wchodniolaskiej, drugi (1949 II) - fragmenty wypowiedzi jej użytkowników, słownik gwarowy, mapkę badanych terenów i wysunięte $z$ badań wnioski.

W jaki sposób Kellner zinterpretował dialekty wschodniolaskie? Przede wszystkim podał w wątpliwość ich genetycznie polski charakter (Kellner 1949 II: 60-61), uważając je za takie, w których występują cechy zarówno polskie, jak i czeskie, tzn. za „typowo przejściowe”, przy czym w ich słownictwie dostrzegał nawet przewage elementów czeskich, względnie śląskomorawsko-słowackich (ibid.: 60). Miał świadomość, że takie ujęcie sprawy jest niezgodne ze stanowiskiem przedwojennych polskich językoznawców (K. Nitscha, Mieczysława Małeckiego, Zdzisława Stiebera), wskazujących - przeciwnie - na cechy polskie występujące w sąsiednich gwarach laskich, które ich zdaniem zostały dopiero wtórnie sczechizowane.

Nie możemy w tym miejscu podać pełnej charakterystyki gwar „wschodniolaskich" dokonanej przez Kellnera, zwracamy więc uwagę na jej najbardziej dyskutowane szczegóły. W głosowni gwary zachodniocieszyńskiej Kellner za czeskie uważa: zmianę $e>y /$ 'i typu chlyb/chlib, jelyń/jeliń; niezmiękczone $s / z$ w pozycji przed miękkimi wargowymi (np. sp'yvać/spjyvać, smich) oraz przed miękkimi $l$ i $n$ (np. slifka, sńih), występujące w zachodnim pasie przejściowym; brak palatalizacji wargowych $\mathrm{w}$ wyrazach typu kamyń, řmmyń; brak przegłosu $e>o \mathrm{w}$ imiesłowach czasu prze-

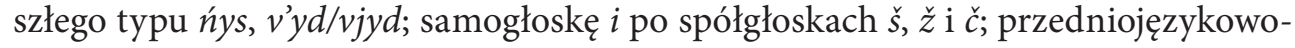
-zębowe $\downarrow$ (zamiast dwuwargowego); frykatywne $\check{r}$; obecność dźwięcznego $h$; przeważającą nieobecność labializacji $o\left({ }^{u} o\right.$ ) lub mazurzenia. We fleksji za czeskie uważa formy kozańi lub głupi (w rodz. n.); formy imiesłowów typu třit, třity; formę zaimka wskazującego ty zamiast te (M. i B. l. mn.) lub wstępujące tu - według Kellnera połączenie $d v^{\prime} e$ piva zamiast dva piva (por. Kellner 1949 II: 62-63) ${ }^{6}$. W odniesieniu do wspomnianego pasma przejściowego, znajdującego się na zachodzie opisywanego terenu, Kellner starał się uzasadnić zanotowaną tu rzekomo wymowę p’ińć, v'unzać, kunsek w ten oto sposób: miejscowa ludność, nieznająca ze swojego języka ojczystego (tzn. laskiej odmiany języka czeskiego lub języka czeskiego - ogólnego) nosówek, stara się je zastąpić (dosłownie: „reprodukować” ich brzmienie), korzystając z rodzimych połączeń samogłoski $+N$, które najbardziej odpowiadają nosowej wymowie (ibid.: 66). Ten asynchroniczny sposób wymowy, wraz ze zmianą $e N$ na ' $i N$, jest - zdaniem autora - świadectwem czeskiego pochodzenia obecnej ludności. Tak wypowiadał się autor, który w innym miejscu swojej pracy podkreślał, iż nie należy utożsamiać mowy mieszkańców $\mathrm{z}$ ich etnicznością. To tylko jedna $\mathrm{z}$ wielu sprzeczności zawartych w monografii Kellnera.

6 Przejściowego charakteru terenów zachodniocieszyńskich starał się Kellner dowieść, przytaczając 18 cech systemowych i 54 jednostki leksykalne (nieonimiczne). 
Użyty w tytule termin východolašská nářečí Kellner usprawiedliwiał tym, że praca miała zostać oddana do druku jeszcze podczas okupacji i że inny jej tytuł mógłby przyciągnąć niepożądaną uwagę ewentualnych cenzorów (Labocha 1997: 114), co nie zostało przez przeciwników Kellnera zaakceptowane. Kellner napisał dosłownie, że chodzi o „čistě dialektologický název”, przeciwstawny wobec terminów západolašský (opawski) i středolašský (ostrawski). Napisał też, że gwary wschodniolaskie nie ograniczają się do terenów po czeskiej stronie granicy państwowej, ale o tym, czy po stronie polskiej są takie same, nie mógł się przekonać z powodu napięcia panującego między oboma państwami. Na mapce zawartej w tomie drugim została wyznaczona granica czesko-wschodniolaska (czyli oddzielająca gwary czeskie od przejściowych, czesko-polskich), która przebiega między miejscowościami Vrbice i Hrušov, Petřvald i Michálkovice, Bartovice i Kunčice itd., z czego wynika, że gwary terenów po południowo-zachodniej stronie linii uważał autor za zdecydowanie czeskie.

Jak już zostało zasygnalizowane, autor Východolašských nářč́i niekonsekwentnie przestrzegał zapowiedzianej zasady odróżniania gwary od deklarowanej przez jej nosicieli etniczności oraz potrzeby odróżniania granicy gwarowej od granicy świadomości narodowej, podkreślając fakt, że tożsamość narodowa to o wiele bardziej złożone zjawisko społeczne, a kwestia językowa to tylko jedna strona tego problemu (Kellner 1946 I: XI, 1949 II: 47).

\section{Pierwsze reakcje Andrzeja Sowy}

Jak wynika z lektury prasy zaolziańskiej, uwagę na pracę Kellnera zwróciły miejscowym Polakom gazeta „Głos Ludu” i miesięcznik Polskiego Związku Kulturalno-Oświatowego „Zwrot”. Artykuły w „Głosie...” (z 22 VI 1950, 25 VI 1950, 13 VII 1950) zostały podpisane skrótem -et-, natomiast autorem tych, które zostały opublikowane w „Zwrocie”, był z całą pewnością Leon Derlich7, publicysta, pisarz, językoznawca amator ${ }^{8}$, a przede wszystkim zagorzały obrońca polskości Zaolzia, występujący tu pod pseudonimem Andrzej Sowa (tego pseudonimu używamy w odniesieniu do

7 Leon Derlich (1905-1964) urodził się i mieszkał przez całe życie w Karwinie na Zaolziu. W wieku 18 lat zachorował na zapalenie chrząstki stawowej, został sparaliżowany i resztę życia spędził przykuty do łóżka, całkowicie zależny od opieki siostry. Paraliż jednak nie pozbawił go jasności umysłu - pomimo choroby i wbrew tragicznemu losowi pogłębiał wiedzę językoznawczą i etnograficzną, by móc prowadzić fachowe polemiki z językoznawcami narodowości polskiej, czeskiej i niemieckiej. Zbierał i analizował materiał językowy z Zaolzia (udzielał rzekomo w tej sprawie konsultacji np. Nitschowi), pisał artykuły do miesięcznika kulturalnego „Zwrot”, a także do pism „Zaranie Śląskie” i „Język Polski”. Jest autorem satyrycznych wierszy i opowiadań (por. Kadłubiec 2005: 187; Upominat się o Zaolzie).

$8 \mathrm{Na}$ brak odpowiedniego wykształcenia językoznawczego Sowy wskazał Kellner w stanowczej obronie własnej interpretacji gwar wschodniolaskich opublikowanej na łamach historyczno-etnograficzno-socjologicznego pisma „Slezský sborník” pod wymownym tytułem Aby bylo jas- 
Derlicha także poniżej, por. Sowa 1950a-c). Sowa był prawdopodobnie najbardziej uważnym czytelnikiem pracy Kellnera i dostrzegał w niej być może także to, co nie zostało dosłownie napisane.

Sowa był oburzony pracą Kellnera, czego nie ukrywał. W 1950 r. w „Zwrocie” ukazały się trzy jego artykuły, oparte, co prawda, na wiarygodnych faktach językowych, lecz równocześnie utrzymane w niezwykle emocjonalnej, wręcz agresywnej i obelżywej retoryce. W pierwszym z nich (1950a: 3-4) autor przedstawił Kellnera jako pseudobadacza operującego z jednej strony „obiektywną prawdą”, z drugiej „nacjonalistyczną bajką”, między którymi „wesoło i swawolnie hasa faktyczna rzeczywistość gwarowa, pomyłki, przemilczenie znanych faktów, półprawdy i bzdurne fałsze" (ibid.: 3). Położył nacisk na to, że Kellner podczas pobytu na Zaolziu gościł w domu frysztackiego ${ }^{9}$ starosty Jaroslava Haeringa (czego zresztą Kellner nie ukrywał), z czego wynika, że badania przebiegały za zgodą i pod ochroną oficjalnych władz miasta, że materiał gromadził Kellner w ścisłej współpracy z napływowym nauczycielstwem czeskim oraz działaczami SMOL ${ }^{10} \mathrm{i}$ że nie poprosił o żadną konsultację nikogo z grona miejscowych nauczycieli szkół polskich lub osób zajmujących się, choćby w sposób nienaukowy, gwarą cieszyńską. Gdyby tak się stało - pisał Sowa być może nie popełniłby aż tak wielu błędów, szczególnie w hasłach słownikowych i transkrypcji tekstów gwarowych, takich jak np. nieujednolicony zapis wymowy samogłoski pośredniej między $o$ i $u$ oraz stosowanie litery $u$ (a nie $u$ ó $)$ w miejscach, gdzie powinno być $u_{\text {; }}$ labilność w zapisie nosówek w miejscach przed spółgłoskami szczelinowymi, gdzie do dziś dominuje wymowa synchroniczna (np. ov'yzi m'y so / ovjy źi mjyso), a nie asynchroniczna ( $y n)$, jak sugeruje Kellner.

Po kilku miesiącach pobytu na Zaolziu Kellner - zdaniem Sowy - „wyewakuował się” do Brna, by „pod fachowym nadzorem zleceniodawców” przeanalizować bogaty materiał językowy. Aluzje te miały na celu podważenie wiarygodności „może z góry uplanowanego celu przedsięwzięcia”, które zdaniem zaolziańskiego publicysty już od samego początku było niefortunne: powierzenie zadania niedoświadczonemu koledze, wpływ osób o wrogim nastawieniu wobec Polaków, zaściankowy charakter środowiska czeskich „doradców” itp. Kellner został pokazany jako przesadnie pokorny wobec autorytetów, poddający się ideologii nacjonalistycznej, jako pseudonaukowiec, który nawet $\mathrm{z}$ własnych badań nie potrafi wyciągnąć odpowiednich wniosków, lecz fałszuje je pod dyktando antypolskiej propagandy.

no... (Kellner 1951b). W kilkustronicowym elaboracie Kellner m.in. odmówił udzielania dalszych wyjaśnień osobom niekompetentnym (w domyśle Sowie).

9 Obecnie Frysztat/Fryštát to historyczne centrum górniczego miasta Karwina.

10 Chodzi o czeski odpowiednik Macierzy Szkolnej Księstwa Cieszyńskiego (pełna nazwa: Slezská Matice osvěty lidové), symbol „czechizacji ludu śląskiego”. Była to organizacja powstała na wzór polskiej Macierzy Szkolnej, a jej celem było m.in. „bronić interesów państwa czechosłowackiego” (Szymeczek 2013: 33). 
Drugi artykuł (Sowa 1950b), napisany w identycznym jak poprzedni duchu, Sowa poświęcił Gołężycom (Holasici), szczepowi słowiańskiemu zamieszkującemu w VIII-IX w. ziemie położone na wschód od Bramy Morawskiej. Jednocześnie podkreślał: „nauka nigdy prawdopodobnie nie orzeknie [...], do której rodziny dialektów, polskiej czy czeskiej, należała jego mowa”, ponieważ „zbyt dawne i mrokami zasłonięte to czasy, a wiadomo także, jak nikle i skąpo różniły się wtedy między sobą oba dzisiejsze języki" ${ }^{\prime \prime}$. Zajmując to stanowisko, Sowa krytycznie odniósł się do skłonności czeskich badaczy (nie wykluczając Kellnera) do nazywania mowy Gołężyców czeskim substratem. Sowa zwrócił uwagę na to, jak nieudolnie Kellner manewruje pomiędzy stanowiskiem o czeskim charakterze pierwotnego żywiołu zamieszkującego opisywane tereny a tezą o istnieniu w tym czasie niewielkich różnic między dialektami zachodniosłowiańskimi.

Kolejne zarzuty Sowy wobec Kellnera dotyczą etymologii nazwy zaolziańskiej miejscowości Błędowice oraz pochopnych wniosków wyciągniętych „z licznych przykładów oddziaływania czeszczyzny na narzecza śląskopolskie”². Artykuł Sowy pełen jest ironicznych docinków (np. „Wysoko uczony dialektolog jak gdyby nie wiedział..."), aluzji oraz niedwuznacznych złośliwości:

Rzeczy nieistotne, półprawdy i pomyłki, umyślne przemilczenia dowodowych faktów i posługiwanie się pseudonaukowym miętniactwem (sic) i matactwem oto „argumenty”, przy pomocy których dokonano w wydanej monografii „obalenia" tez obiektywnej nauki polskiej i czeskiej, stwierdzających pierwotną polskość mowy ziemi Cieszyńskiej. Dlatego też jak dźwięk triumfalnych fanfar na pogrzebie brzmią końcowe słowa monografii: „oblast východolašských dialektů i západní Čadecko náležely od původu $\mathrm{k}$ jazykovému souboru československému... polskost západního Těšínska, postulovaná polskými badateli, nemá prastarých kořenů, nýbrž je výsledkem kolonisačního proudění v poměrně nedávné minulosti” (II, str. 86). Błędne założenie i rachunek nieuczciwy, więc też i wynik fałszywy (ibid.: 10).

W trzeciej krytycznej ocenie monografii Kellnera Sowa (1950c) poświęcił uwagę procesom kolonizacyjnym w historii Śląska Cieszyńskiego. W związku z nimi zarzuca Kellnerowi, że z jednej strony podkreśla rzekomą kolonizację wschodniomorawską (i wpływ języka czeskiego), z drugiej - nie wspomina ani słowem o kolonizacji niemieckiej ${ }^{13}$, która pojawiła się co najmniej w dwu etapach, trwała dłużej i wywarła

11 Podobne stanowisko zarysował czeski badacz głosowni prasłowiańskiej, paleoslawista A. Lamprecht (1967: 42) - patrz poniżej.

12 Tymi przykładami były zdaniem Kellnera wyrazy z głoską $h$. W reakcji na to Sowa zaznaczał, że na Zaolziu istnieje „dość skromny i znaczeniowo ograniczony zasób napływowych wyrazów z czeskim dźwiękiem zawierających krtaniowe h" (hned, hruby, hruza, hrưm, miejscami też hledać), używany tu „obok ogromnej masy wyrazów z typowo polską głoską g” (Sowa 1950b: 9), np.: gańba, głůd, głos, noga, dłůgi, gưrnik, ganić itp.

13 Twierdzenie to nie do końca jest prawdziwe: Kellner (1949 II: 74) pisze o kolonizacji niemieckiej i germanizacji, ale odnośnie do regionu opawskiego. 
o wiele większy wpływ niż kolonizacja czeska. W przypadku XV- i XVI-wiecznych wpływów czeszczyzny na język polski stwierdza - tym razem zgodnie z Kellnerem - że nie zatrzymały się one na rzece Olzie i że czeszczyzna była w tym czasie pożądanym „dialektem kulturalnym, »językiem salonowym « szlachty i mieszczan” (ibid.: 4).

Błędna, zdaniem Sowy, jest też interpretacja Kellnera dotycząca napływu ludności wołoskiej (o ile nie chodziło o „umyślną niewiedzę”). Nic w tym dziwnego, gdyż czeski dialektolog odwołał się do „humorystycznej” pracy archiwariusza Václava Davídka Osídlení Těšínska Valachy (1940). W tym miejscu należy podkreślić, że Sowa nie kwestionuje „wołoskiej” (bałkańskiej, rumuńskiej) etniczności tego żywiołu napływowego, tak jak uczynił to M. Małecki, który już w 1938 r. zakładał, że kolonizacja ta wprawdzie została prawdopodobnie zainicjowana na Bałkanach, ale sam wołoski żywioł nie dotarł aż na tereny zachodniosłowiańskie, tylko wepchnął tu inny element słowiański (np. słowacki, rusiński) ${ }^{14}$.

Jeszcze większą różnicę zdań między Sową a Kellnerem dostrzegamy w sprawie imigracji taniej siły roboczej z austriackiej Galicji, którą Kellner nazywa polską kolonizacją i której przypisuje o wiele większy wpływ niż ten, jaki wywarła w rzeczywistości. Zdaniem Sowy język osadników z Galicji nie pozostawił prawie żadnego śladu w sytuacji językowej w Cieszyńskiem, gdzie pozycja języka polskiego była już w tym czasie dostatecznie stabilna:

[...] po prostu sprawdza się na tym przykładzie dobrze znane zjawisko w dziedzinie socjologii: żadna choćby masowa imigracja żywiołu etnicznie obcego nie zmienia języka tubylczej ludności, jeżeli żywioł napływowy jest cywilizacyjnie zapóźnionym i socjalnie upośledzanym (Sowa 1950c: 5).

Zresztą duża grupa przybyszów z Galicji osiadła też po zachodniej stronie Ostrawicy (w Morawskiej Ostrawie), gdzie stosunkowo szybko zasymilowała się z żywiołem czesko- lub niemieckojęzycznym, nie wpływając na niego ani dodatnio, ani ujemnie. Kellner ubolewał nad brakiem dowodów językowych („jazykových záznamů”), dokumentujących mowę ludności miejscowej sprzed 100-150 lat ${ }^{15}$, które potwierdzałyby polski charakter tej mowy. Mając takie dowody, można by, zdaniem Kellnera, dowieść słuszności tezy o polskości tego terenu przed przybyciem Galicjan, ale przy ich braku trzeba założyć czeskość gwary miejscowej (Kellner 1949 II: 85). Sam Sowa przytoczył pięć takich dowodów w postaci tekstów literackich i propagan-

14 Wałachem nazywano na Śląsku Cieszyńskim (i nie tylko) po prostu górala pasterza, podobnie jak mieszkańca nizin nazywano lachem. Wałach więc z rumuńską Wołoszczyzną nie musiał mieć nic wspólnego (por. Małecki 1938: 21, 29).

15 O ile Kellner miał na myśli zapisy dialektologiczne, należałoby się zastanowić, czy istnieją takie dawne świadectwa z jakichkolwiek innych terenów gwarowych, skoro dialektologia jako dyscyplina naukowa zaczęła się rozwijać dopiero w drugiej połowie XIX w. 
dowych ${ }^{16}$, wspominając na marginesie o niewykorzystanej przez Kellnera gwarowej „masie toponomastycznej”.

\section{Stanowisko Karola Dejny}

Prawdopodobnie pod wpływem sugestii Sowy ówczesny redaktor naczelny „Zwrotu” skierował do K. Nitscha prośbę o naukową opinię na temat pracy Kellnera. Siedemdziesięciosześcioletni Nitsch, usprawiedliwiając się chorobą oczu, zadaniem tym obarczył o wiele młodszego, niespełna czterdziestoletniego kolegę, K. Dejnę, który opracował taką opinię i przekazał redakcji „Zwrotu” (Dejna 1953).

Na wstępie Dejna, co prawda, wysoko ocenił „bardzo szczegółowe i ilustrowane doskonale materiałem omówienie dzisiejszego stanu głosek w gwarach zachodniocieszyńskich" (ibid.: 13), pozostała część opinii jest jednak zdecydowanie krytyczna, aczkolwiek mniej kąśliwa niż artykuły Sowy. Negatywnie odnosi się Dejna do samego tytułu pracy, czyli do terminu „narzecza wschodniolaskie”, który uważa za „najbardziej osobistą sprawę autora”, a nie za fakt językowy. Zdaniem Dejny termin ten jest sprzeczny z cechami, które narzecze to wykazuje, oraz z charakterem innych gwar śląskomorawskich (laskich):

Jeżeli bowiem jeden z dialektów czeskich nazywamy dialektem laskim i równocześnie o polskich gwarach zachodniocieszyńskich mówi się jako o wschodnim odłamie tego dialektu, to fakt ten ma swoją wymowę (ibid.).

Dejna uważał, że tytuł pracy świadczy o umyślnym przywłaszczeniu sobie przez czeską dialektologię terenu językowo polskiego, i zastanawiał się nad tym, co skłoniło Kellnera do takiego posunięcia, skoro „podawany przez niego materiał tego nie uzasadnia”. Nie przekonywało go tłumaczenie się obawami przed ewentualnymi sankcjami ze strony wojennych władz protektoralnych, ponieważ obawy te musiałby budzić sam udostępniony w pracy materiał językowy, który posiadał „prawie wszystkie cechy właściwe dialektom polskim” (ibid.). W odniesieniu do gwary cieszyńskiej Dejna nie używał sformułowania „czysto polski”, tak jak czynił to Sowa, ponieważ zdawał sobie sprawę z obecności obcych elementów językowych w każdej odmianie języka, tym bardziej - w odmianie sąsiadującej z innymi językami etnicznymi. Ważne są, zdaniem Dejny, charakter zapożyczeń, częstotliwość ich sto-

16 Sowa odesłał do oryginalnego tekstu religijnego Prawdziwa Jedźina do Nieba $z$ Pisma Świentego dokazana Droga z 1761 r.; wspominał zabiegi Leopolda Szersznika o zastąpienie czeskich podręczników w szkołach cieszyńskich podręcznikami polskimi; wymieniał powieść Zaraza gorzałki (1844), która wyszła spod pióra Morawianina, pastora Jana Vinklera, w języku polskim (a nie czeskim), by jej treść była dla ludu cieszyńskiego zrozumiała; podkreślał język polski prasy cieszyńskiej w latach 1848-1849 i następnych; wskazywał też na broszurkę agitacyjną napisaną w 1848 r. po polsku i adresowaną do ludności w okolicach Polskiej (Śląskiej) Ostrawy (Sowa 1950c: 6). 
sowania oraz stopień ich zadomowienia (tu autor cytował odpowiednie przykłady). Problem polegał według Dejny na tym, że Kellner starał się udowodnić, że „gwary południowo-zachodniej części Śląska są przejściowe" (ibid.), co nie jest zgodne z prawdą, ponieważ charakter przejściowy mają dopiero sąsiednie dialekty laskie, czyli - w terminologii Kellnera - środkowo- i zachodniolaskie (středo- i západolašké). Co do niesolidności argumentacji opartej na słownictwie nie warto niczego dodawać, na obszerniejszy komentarz zasługują wspomniane zjawiska systemowe. I tu następuje rzeczowe omówienie wszystkich (18) punktów wykładu Kellnera i cierpliwe, sukcesywne obalanie tez niemających naukowego uzasadnienia, świadczących albo o braku wiedzy ich autora, albo (co wydaje się bardziej wiarygodne) o istnieniu jakichś celów nadrzędnych, którymi się kierował.

Powyższe uwagi nie mają na celu ani nie potrafią obniżyć pełnej wartości monografii prof. Kellnera i ogromnej zasługi autora, który zebrał bardzo sumiennie i opracował tak cenny materiał gwarowy [...]. W naszych rozważaniach chodziło o zwrócenie uwagi, że na podstawie tak obiektywnie przedstawionego materiału autor wyciągnął wnioski, z którymi nie zawsze można się zgodzić

- kończy swoją opinię Dejna (1953: 15)

Niedługo po ukazaniu się pracy Kellnera Východolašská nářečí (1946-1949) Dejna opublikował swoją dwuczęściową monografię (Dejna 1951-1953), opisującą tereny gwarowe między Raciborzem a Karniowem (Krnov), Opawą i Hulczynem (Hlučín). I w tym wypadku chodzi o gwary laskie występujące na terenie państwa polskiego, których użytkownicy określani są jako Morawcy ${ }^{18}$. Zadania polegającego na ustaleniu granicy między polskim i czeskim językiem etnicznym podjął się Dejna prawdopodobnie niezależnie od Kellnera, i to już w 1948 r. Jak sam podkreślał we wstępie do tomu pierwszego, badaniami został objęty wycinek terenu należącego do ówczesnych powiatów raciborskiego, rybnickiego i głubczyckiego (łączna liczba badanych wsi wynosiła 51), czyli obszarów w okolicach rzek Troi i Psiny i ich dopływów, gdzie kontaktują (kontaktowały) się gwary polskie (śląskie) z laskimi. Jak już zostało

17 Na opinię Dejny zareagował czeski językoznawca František Kopečný (1953), ceniony etymolog i dialektolog. Nie wiemy, czy śledził on dotychczasową dyskusję na temat pogranicza czesko-polskiego, czy po prostu został poproszony o zabranie w niej głosu, w każdym razie ewidentnie starał się całą sprawę załagodzić, przyznając w niektórych punktach rację Dejnie, być może dlatego, że Kellner w tym czasie już nie żył. Czynił jednak Dejnie zarzut, że używany przez niego termin gwara zachodniocieszyńska jest tak samo nieodpowiedni, ponieważ orzeka tylko o położeniu geograficznym dialektu. Kopečný zaproponował poniekąd kuriozalne rozwiązanie terminologiczne w postaci nazwy slezská nářečí zahraniční (zagraniczne - z perspektywy polskiego języka etnicznego), która na szczęście nie zadomowiła się w dialektologii.

18 Wspólnota ta, nazywana morawską za sprawą dawnej przynależności do diecezji ołomunieckiej, żyła do 1742 r. w ramach monarchii habsburskiej, od 1743 - państwa pruskiego, powiatu głubczyckiego; w powojennej Polsce uległa stopniowej asymilacji językowej i kulturowej z resztą narodu polskiego. 
zauważone, drugie $\mathrm{z}$ wymienionych gwar uważał autor zgodnie z polską tradycją dialektologiczną za przejściowe, czesko-polskie.

Tereny te były penetrowane nie po raz pierwszy. Dejna nawiązał do opracowania Feliksa Steuera (1934, 1937), do artykułu Františka Stavařa (1930), do pracy Z. Stiebera (1934), ujmującego problem gwar laskich nieco szerzej, oraz do szczegółowego rozdziału B. Havránka Nářč́ česká (1934) umieszczonego w trzecim tomie pracy Československá vlastivěda - Jazyk. Wymienił również pracę Kellnera, zaznaczając, że jego (Dejny) praca opisuje tereny gwarowe sąsiadujące od południa z innymi polskimi terenami gwarowymi, które „dokładnie i szczegółowo opracował, tylko trochę dziwnie nazwał A. Kellner" (Dejna 1951 I: 10).

Praca Dejny jest równie obszerna i szczegółowa jak Východolašská nárečí. Kwestionariusz do badań terenowych zawiera ok. 500 pytań i sprawdza wszystkie istotne cechy fonologiczne, ewentualnie morfologiczne. Dodajmy, że wiele przykładów występuje zarówno w pracy Dejny, jak i Kellnera, np.: śnieg (śńyg/śńyk, sńich, śnich, śnich, śńych), siekierka (sekyrka, śekyrka, śek'yrka, śekjyrka, śekirka, sekirka) lub ciotka (četka, ćetka, ćotka). Do wspólnie (przez Dejnę i Kellnera) omawianych zjawisk należą np.: brak mazurzenia, frykatywne $\check{r}$, dwuwargowe $\ell$, głoska $h$, obecność grup $\check{c} i$, ži, ši, forma $d v$ 'e okna, M. i B. l. mn. ty, formy (on) ńys, umřit, umřity itp. W zakończeniu tomu drugiego (1953 II) Dejna podtrzymał stanowisko Nitscha (1909: 275), iż badane gwary laskie, które występują po południowo-zachodniej stronie przywołanej powyżej linii, to gwary przejściowe, natomiast obszary po stronie północno-zachodniej (gwary cieszyńskie) należą do polskiego języka etnicznego. I na tym polega podstawowa różnica między obiema pracami ${ }^{19}$. A przesuwanie przez Kellnera granicy językowej czesko-polskiej w kierunku północno-wschodnim Dejna skomentował w ten oto sposób:

Jeśli opieramy swoje rozważania na płaszczyźnie synchronicznej, to trudno uzasadnić w sposób przekonujący, dlaczego północno-wschodnie skupienie cech laskich,

19 Wymiana zdań pomiędzy Kellnerem i Dejną nie ograniczała się jednak do komentarzy odnoszących się do pracy Východolašská nárečí. Obaj prawdopodobnie z wielką czujnością i zainteresowaniem śledzili aktywność badawczą drugiej strony i informowali o niej szerszą publiczność. W tym miejscu możemy posłużyć się takim oto przykładem: Dejna opublikował artykuł Z najnowszej dialektologii śląskiej (1949), a rok później drugi - Pogranicze językowe ślasko-morawskie (1950/2009), na co natychmiast zareagował Kellner tekstem Na okraj nových polských prací o jazykovém pohraničí polsko-českém na Hlubčicku a Ratibořicku (1951a: 243-252). Czeski językoznawca najpierw wyraził swoje stanowisko na temat gwary w miejscowościach Tłustomosty i Rudyszwałd (Polska) oraz Děhylov i Šilheřovice (ówczesna Czechosłowacja, dziś Republika Czeska), nie zgadzając się z Dejną w niektórych interpretacjach poświadczonych zjawisk językowych. Cenne uwagi (zasygnalizowane zdaniem: „A nakonec ještě jednu poznámku”) zawierają dwa ostatnie akapity artykułu. Kellner odrzucił tezę Dejny, że w Raciborskiem i Głubczyckiem przebiega granica pomiędzy językiem polskim a polsko-czeskimi, tzn. mieszanymi gwarami laskimi, twierdząc, że „svým celkovým skladem hlásí se laština zřetelně do jazykového souboru českého” (ibid.: 252). 
wspólnych z językami czeskim i słowackim, jest na tyle ważniejsze, że ma zdolność wyznaczania językowej granicy czesko-polskiej, a skupienie cech laskich wspólnych z językiem polskim na pasie gór po obu stronach Bramy Morawskiej jest mniej ważne i zdolności wyznaczania językowej granicy polsko-czeskiej nie posiada (Dejna 1953 II: 237).

\section{Koncepcja Jaroslava Běliča}

J. Běličc, autor fundamentalnej monografii o gwarach języka czeskiego (1972) i naukowiec udzielający się w organizacji badań na rzecz Czeskiego atlasu językowego (Český jazykovýatlas I-VI (Balhar, Jančák 1992; Balhar 1997-2011)), wyłożył oficjalnie swoją teorię afiliacji gwar do języka etnicznego po raz pierwszy w połowie lat 50. w pracy Sedm kapitol o češtinè. Př́spěvky k problematice národního jazyka (1955). Miała ona znamiona ówczesnego językoznawstwa marksistowskiego, a nazwisko Stalina pojawiło się $\mathrm{w}$ każdym $\mathrm{z}$ siedmiu rozdziałó $\mathrm{w}^{20}$. W rozdziale Postavení moravské slovenštiny a laštiny (ibid.: 65-86) Bělič uzasadniał przynależność narzeczy uważanych wcześniej (np. przez B. Havránka i Václava Vážnego) za słowackie do czeskiego języka narodowego (dokładnie do grupy dialektów wschodniomorawskich) tym, że kwestia systemu języka lub jego odmiany nie jest tak istotna, liczy się to, kim czuje się jej użytkownik, z którym narodem się utożsamia, ponieważ gwary były tu od dawna, a narody (narodowe organizmy państwowe) - dopiero od pewnego czasu (mniej więcej od połowy XIX w.). O przynależności do narodu decyduje nie gwara, lecz odmiana kulturalna, która jest symbolem świadomości narodowej jednostki (ibid.: 74-75). Według Běliča fakt, że pewne gwary o odmiennym systemie językowym znalazły się w granicach innej jednostki politycznej (gwary słowackie - w Republice Czeskiej byłej Czechosłowacji), jest po prostu dziedzictwem dawnych czasów „před konstituováním národư" (ibid.: 75). Argumentacja oparta na podstawach czysto językowych była - zdaniem tego badacza - wykorzystywana przez nacjonalistyczną burżuazję w celach politycznych, podczas gdy jedyne właściwe rozwiązanie przynosiła filozofia Stalina, umożliwiająca użytkownikom gwary dokonanie swobodnego wyboru. W podobny sposób wyjaśnił Bělič powstanie czesko-polskiego pogranicza językowego (ibid.: 76-86): język narodowy nie jest mechaniczną sumą odmian dialektalnych, ale zawiera też sferę postaw, stanowisk i odczuć tych, którzy się z nim identyfikują (ibid.: 85). Běličowi spodobała się szczególnie metafora Stalina o rzekomym wlewaniu się dialektów do języka ogólnonarodowego (w domyśle: urzędowego, państwowego, ogólnego/literackiego), który w danym organizmie państwowym

20 Bělič cytował dwie prace Stalina, które zostały przetłumaczone na język czeski: Marxismus a národnostní a koloniální otázka (1949) oraz O marxismu v jazykovědě (1950). Współzawodniczenie w tym, kto jest gorliwszym marksistą i kto lepiej zrozumiał słowa Stalina, przypominała też wspomniana obrona Kellnera (1951b). 
jakoby pokrywa jednym dachem wszystkie (pozostałe) odmiany i rozstrzyga o ich przynależności do danego języka etnicznego (ibid.: 18).

Jak się okazuje, od lat 50. do początku lat 70. Bělič wyraźnie nie zmienił swojego poglądu (używał nawet bardzo podobnych sformułowań), chociaż o pracach Stalina już nie wspominał. W monografii Nástin české dialektologie (Bělič 1972) badacz ten pisze: „Granice geograficzne języka kulturalnego, który dana zbiorowość uważa za swój, stanowią w czasach nowoczesnych kryterium bardziej istotne niż anachroniczne izoglosy zjawisk dialektalnych" (ibid.: 17). Inaczej mówiąc, jednostka może uważać się za członka narodu A bez względu na to, że na co dzień używa gwary języka B.

O ile w Siedmiu rozdziałach o języku czeskim Bělič (1955) stał po stronie Kellnera, twierdząc, że użyta przez niego nazwa východolašská nárečí jest w pełni uzasadniona, o tyle w publikacji z 1972 r. wyrażał się o nim zdecydowanie mniej pochlebnie, pisząc, że wnioskowania Kellnera o pierwotnej czeskości opisywanego terenu są jednostronne, chybione i sporne (Bělič 1972: 340). Sam zresztą gwarę cieszyńską określił w inny sposób, wprowadzając do czeskiej dialektologii kolejny niezbyt fortunny termin náréčí polsko-českého smišeného pruhu².

\section{Kolejna reakcja Karola Dejny}

K. Dejna zareagował na obie prace Běliča. Praca Sedm kapitol o češtině została jego zdaniem - napisana pod wpływem "fascynacji artykułami Stalina” (Dejna 1977/2009). Nazwał ją „próbą sztucznego przysłaniania problemów mniejszości narodowościowych" (ibid.: 477). Dejna nie dostrzegał w teorii Běliča żadnej naukowości (używał określenia „zupełny nonsens”), pisząc:

Przy ustalaniu językowej przynależności gwar peryferyjnych musimy opierać się na konkretnych zjawiskach językowych [które Bělič doskonale znał - I.B.], a nie na poczuciu przynależności narodowościowej, kulturalnej, państwowej itd. ludzi mówiących danym narzeczem (ibid.)

i podając analogiczne przykłady gwar czeskich w okolicach Kudowy, Głubczyc, Bełchatowa czy gwar białoruskich na Białostocczyźnie, których polska dialektologia nie nazywa polskimi.

Fakt, że do czterech czeskich zespołów dialektalnych Bělič dołączył kolejny - zachodniocieszyński, polski językoznawca uważał za decyzję „wskroś osobliwą”, „,ównie bezpodstawną" jak ta, którą Bělič zaprezentował w pracy Sedm kapitol o češtině

21 Ostatecznie w czeskiej dialektologii zadomowił się staro-nowy termin nářeči slezskopolská, którego konsekwentnie używa np. Balhar (2002: 399) w haśle encyklopedycznym dotyczącym dialektów śląskich. 
(ibid.: 478), i wyjątkowo szkodliwą, ponieważ opublikowaną w podręczniku do nauki dialektologii języka czeskiego, czyli „w pracy, która będzie szeroko propagowała błędne według nas i wymierzone przeciw interesom polonijnych ośrodków w Czechosłowacji poglądy" (ibid.) $)^{22}$.

Do uwag Běliča, ale też Kellnera i innych czeskich dialektologów Dejna wracał niejednokrotnie, także w późniejszych swoich pracach. Był wtedy o wiele bardziej krytyczny, czemu nie można się dziwić, skoro od czasów ukazania się Východolašských nářečí upłynęło prawie 30 lat. Dejna prawdopodobnie przypuszczał, że sprawa została już dostatecznie wyjaśniona i zamknięta. Okazuje się, że bezpodstawnie, a ponowne przeinaczanie prawdy odczuwał bardzo boleśnie. W tym miejscu warto przytoczyć obszerniejszy fragment jego artykułu:

Te odcięte granicą państwową gwary polskie ostatnio dwukrotnie usiłowano włączyć do terytorium czeskiego językowego, traktując je jako jeden z czeskich zespołów gwarowych. Najpierw Adolf Kellner w doskonałej zresztą pod względem materiałowym pracy nazwał gwary polskie na zachód od polsko-czeskiej granicy państwowej terminem „východolašská nářeči”. [...] Ponieważ dialekt laski uważany jest powszechnie za jedno z narzeczy czeskich, nazwanie odciętych granicą polityczną polskich gwar południowej części dialektu śląskiego „narzeczem wschodniolaskim” miało swą przykrą dla Polaków zaolziańskich [...] wymowę, zwłaszcza że użycie tu terminu tego na pewno nie było przypadkowe, skoro na zakończenie swych wywodów autor powiedział wyraźnie: „Oblast východolašských dialektů náležela od původu k jazykovému souboru československému" i została, jak sobie wykalkulował A. Kellner, spolonizowana na skutek silnego przypływu ludności polskiej w ciągu XVII-XIX wieku. [...] „A tak polskost západního Těšínska, postulovaná polskými badateli, nemá prastarých kořenů [...]" (ibid.: 471-472).

W pracy Dialekty polskie (1973) w rozdziale o dialekcie śląskim (s. 261-266) Dejna przyjął jako fakt, że do polskiego zespołu dialektalnego należy „przyległy pas polskich gwar na lewym brzegu Olzy po dorzecze Lucyny” (cz. Lučina ${ }^{23}$ ) oraz „Czadeckie w dolinie Kysucy” (Słowacja) (ibid.: 261). Równocześnie podtrzymał (za Nitschem), że najbardziej na zachód położone językowo polskie miejscowości Śląska Cieszyńskiego to: Horní Lomná, Řeka, Komorní Lhotka, Dobratice, Domaslavice, Soběšovice, Václavovice, Horní Datyně, (Ostrava): Bartovice, Radvanice, Heřmani$\mathrm{ce}^{24}$ oraz Pudlov i Bohumín, a losy tych terenów ujął w słowa:

22 Z kolei uwadze Běliča nie umknęła praca Dejny Polsko-laskie pogranicze językowe na terenie Polski (1951-1953). W monografii Nástín české dialektologie (Bělič 1972) wyraził się o niej mniej więcej w ten oto sposób: publikacja Dejny jest w pewnym sensie polskim odpowiednikiem pracy Kellnera, ponieważ podobnie jak Východolašská nářečí zajmuje się przyczyną i afiliacją językową polsko-czeskich terenów pogranicznych. W przeciwieństwie do Kellnera Dejna miał do dyspozycji o wiele bogatszy dorobek dialektologii polskiej, ale także jemu nie udało się uniknąć błędów wynikających z przemieszania faktów językowych z faktami historycznymi (ibid.: 340). Niewielka rzeczka, która wpada do Ostrawicy na terenie miasta Ostrawy. 
Po pierwszej wojnie światowej na skutek specyficznego układu sił i błędów naszej polityki ta zachodnia część zwartego obszaru języka polskiego nie została włączona do Polski, lecz pozostała i do dziś pozostaje w obrębie państwa czeskiego (Dejna 1977/2009: 471).

\section{6. Łagodzące podejście Arnošta Lamprechta}

W sprawie domniemanego późniejszego osadnictwa polskiego na Śląsku Cieszyńskim Dejna powołał się na innego czeskiego językoznawcę, A. Lamprechta, konkretnie na rozdział jego autorstwa pt. Jazyková situace na širším Ostravsku (1967) dotyczący języka na czeskim Śląsku.

Choć Lamprecht należał do grona czeskich dialektologów, podkreślał piastowskie korzenie Śląska Cieszyńskiego, na które późniejsze przyłączenie tego regionu do ziem Korony Czeskiej (luksemburskiej) nie miało zasadniczego wpływu (ibid.: 47). Konsekwentnie odróżniał dwa pojęcia: dialekty slezskomoravské (laskie) i těšinské (západotěšínské), traktując drugie jako śląskie, ale polskie. Nie starał się rozstrzygnąć kwestii „narodowości” Gołężyców, uważając ich po prostu za szczep (zachodnio)słowiański. Wpływy dialektów laskich na zachodniocieszyńskie starał się uporządkować i przybliżyć (ibid.: 65), niestety z „kellnerowskimi” usterkami, które zostały już zakwestionowane przez Sowę (1950a-c) i Dejnę (1953). Wpływu czeskiego Lamprecht dopatrywał się również w konstrukcji składniowej: jo tam być, tak by śe ći níc nestało (Lamprecht 1967: 65), co może być bohemizmem składniowym przejętym przez informatora z potocznej ogólnej odmiany języka czeskiego, użytym przypadkowo (jednorazowo). Podobną wątpliwość budzą kolejne przykłady gwary zachodniocieszyńskiej, np.: rzekome bedym čakał zamiast čakoł (ze wzdłużeniem za sylabę -lr), B. l. poj. jedne cere zamiast jednưm cere (forma na - e występuje raczej w B. zaimka $t a-t e / t u m$ ), nie przekonuje niby-karwińskie $t v, k v, s v$ itp. wymawiane bez asymilacji progresywnejes.

Warto nadmienić, że Lamprecht jest też autorem artykułu-nekrologu (1953) poświęconego Kellnerowi, gdzie o zmarłym napisał: „Ačkoli nebyl př́telem polemického tónu a snažil se vždy o věcné podání, dovedl se odhodlaně a bojovně postavit za věc [...]" (ibid.: 10o), co jest niedwuznaczną aluzją do artykułu Kellnera (1951b).

25 Wręcz przeciwnie, właśnie bezdźwięczna wymowa, czyli $t f, k f$, $s f$, jest słyszalna do dziś nawet w mowie najmłodszej generacji użytkowników języka czeskiego w Ostrawie i na innych terenach śląsko-morawskich. 


\section{Podsumowanie}

Staraliśmy się odtworzyć polemikę na temat gwary zachodniocieszyńskiej, czyli cieszyńskiej po czeskiej stronie granicy państwowej, która toczyła się na przestrzeni ok. 30 lat (1949-1977). Dyskusja, w której uczestniczyli czołowi przedstawiciele czeskiej i polskiej dialektologii, nie ograniczała się do kręgów naukowych, lecz przeniosła się również na grunt publicystyki. Na to, co dzieje się w czeskiej dialektologii i jak traktuje ona tereny językowo polskie w Czechosłowacji, zwracano uwagę ludności zaolziańskiej w prasie lokalnej. Informacje przekazywane czytelnikom nie zawsze były jednak obiektywne. Artykuły odznaczały się ekwilibrystyczną grą słów, docinkami i ironią, eksponowały rzeczy mniej istotne, modyfikowały zawarte w pracach dialektologicznych treści.

Obserwując rozwój tej polemiki oraz analizując jej cechy, dochodzimy do przekonania, że dyskutowany temat należy do wyjątkowo zawiłych i mętnych, każda ze stron bowiem dostrzega w gwarze zachodniocieszyńskiej coś innego: czeska dialektologia dopatruje się w niej elementów czeskiego języka etnicznego (żywych lub archaicznych, podstawowych lub peryferyjnych), polska ocenia ją jako rdzennie polską. Kolejnym utrudnieniem były - jak się okazuje - pozajęzykowe czynniki natury ideologicznejej ${ }^{26}$, politycznej. Okazuje się, że na tle niełatwych okresów w historii obu narodów (pierwsza połowa lat 50., początek lat 70.) uprawianie językoznawstwa wymagało oprócz odpowiedniej erudycji i doświadczenia także pewnej osobistej odwagi.

Oprócz Kellnera, Běliča i Dejny w dyskusji zabierali głos inni polscy i czescy językoznawcy - nazwiska większości z nich zostały w powyższym tekście podane. Chociaż kolejny rozwój myśli dialektologicznej zaowocował wieloma innymi pracami na interesujący nas temat (ich autorami byli/są: K.D. Kadłubiec, Edward Lotko, Władysław Milerski, Janina Labocha, Zbigniew Greń, Jana Raclavská, Irena Bogocz(ová) i inni), wydaje się, że w dyskusji na temat gwary zachodniocieszyńskiej nie postawiono jeszcze kropki nad i.

\section{Literatura}

Balhar J. (red.), 1997-2011, Český jazykový atlas II-VI, Praha.

BAlHar J., 2002, Skupina nářeční slezská, [w:] P. Karlík, M. Nekula, J. Pleskalová (red.), Encyklopedický slovník češtiny, Praha, s. 396-399.

BAlHaR J., JANČÁK P. (red.), 1992, Český jazykový atlas I, Praha.

26 Jest rzeczą znaną i zrozumiałą, że w językoznawstwie sporo jest ideologii i że językoznawstwa nie da się uprawiać zupełnie bezstronnie, co wcale nie wartościuje tej dziedziny nauki negatywnie. Zdaniem Stanisława Borawskiego (2000: 9) ,ideologia nie jest zaprzeczeniem naukowości”, takim zaprzeczeniem jest mitologia. 
BĚLIČ J., 1955, Sedm kapitol o češtině (Př́ispěvky k problematice národního jazyka), Praha.

BĚLIČ J., 1972, Nástin české dialektologie, Praha.

Bogocz I., 2016, „Jak oni mówią?”, czyli próba interpretacji języka Polaków na Zaolziu, „LingVaria” nr 2 (22), s. 227-242, [on-line:] http://dx.doi.org/10.12797.LV.11.2016.22.15.

Bogoczová I., 2015, Szkice z dialektologii języka czeskiego. 1. Stratyfikacja czeskiego języka narodowego, „Bohemistyka” XV, nr 4, s. 311-331.

Bogoczová I., 2016, Szkice z dialektologii języka czeskiego. 2. Tradycje czeskiej dialektologii od jej zarania do II wojny światowej, „Bohemistyka” XVI, nr 2, s. 133-147.

BoraWski S., 200o, Wprowadzenie do historii języka polskiego. Zagadnienia historiozoficzne, Warszawa.

Davídek V., 1940, Osídlení Těšínska Valachy, Praha.

Dejna K., 1949, Z najnowszej dialektologii śląskiej, „Język Polski” XXIX, s. 206-215.

Dejna K., 1950/2009, Pogranicze językowe ślasko-morawskie, [w:] idem, Wybór pism polonistycznych i slawistycznych, red. S. Gala, Łódź, s. 337-344.

Dejna K., 1951-1953, Polsko-laskie pogranicze językowe na terenie Polski, t. I, 1951, t. II, 1953, Łódź.

DejnA K., 1953, Gwary zachodnio-cieszyńskie w pracy czeskiego uczonego, „Zwrot” V, nr 8-9 (45-46), s. 12-15.

Dejna K., 1973, Dialekty polskie, Wrocław - Warszawa - Kraków - Gdańsk.

Dejna K., 1977/2009, Przynależność językowa gwar zachodniocieszyńskich, [w:] idem, Wybór pism polonistycznych i slawistycznych, red. S. Gala, Łódź, s. 471-498.

Havránek B., 1934, Nářečí česká, [w:] Československá vlastivěda III. Jazyk, Praha, s. 84-219.

KadŁubiec K.D., 2005, Derlich Leon, [w:] L. Dokoupil, M. Myška, J. Svoboda (red.), Kulturněhistorická encyklopedie Slezska a severovýchodní Moravy II, Ostrava, s. 187.

Karaś H., 2014, Gwary przejściowe i mieszane, [w:] Dialekty i gwary polskie. Kompendium internetowe, red. eadem, [on-line:] http://www.dialektologia.uw.edu.pl/index.php ?l1=mapa-serwisu\&l2=gwary-przejsciowe-i-mieszane-mwr (dostęp: 22 VII 2014).

Kellner A., 1946a, Slezsko po stránce jazykové, [w:] J. Macůrek (red.), Slezsko, český stát a česká kultura (cyklus přednášek pořádaný Masarykovou universitou v Brně), Opava, s. 92-113.

Kellner A., 1946b, Jazykové poměry v levém horním Poodří, [w:] B. Sobotík (red.), Naše země, náš lid. Hlubčicko, Ratibořsko, Kozelsko, Opava, s. 75-94.

Kellner A., 1946-1949, Východolašská nářečí, t. I, 1946, t. II, 1949, Brno.

Kellner A., 1951a, Na okraj nových polských prací o jazykovém pohraničí polsko-českém na Hlubčicku a Ratibořsku, „Slezský sborník” 49, s. 243-252.

Kellner A., 1951b, Aby bylo jasno, „Slezský sborník” 49, s. 548-565.

KopečnÝ F., 1953, Ještě východolašská nářeči, „Slezský sborník” 51, s. 564-565.

Laвосна J., 1997, Polsko-czeskie pogranicze na Śląsku Cieszyńskim. Zagadnienia językowe, Kraków.

LAmprecht A., 1953, Za profesorem Kellnerem, „Slovo a slovesnost” XIV, s. 97-102.

LAMPRECHT A., 1967, Jazyková situace na širším Ostravsku, [w:] A. Knop, A. Lamprecht, L. Pallas (red.), Dějiny českého jazyka ve Slezsku a na Ostravsku, Ostrava, s. 42-70.

MaŁecki M., 1938, Język polski na południe od Karpat (Spisz, Orawa, Czadeckie, wyspy językowe), Kraków.

Nitsch K., 1909, Dialekty polskie Śląska (z mapa), „Materiały i Prace Komisji Językowej Akademii Umiejętności w Krakowie” IV, s. 85-356. 
SowA A., 1950a, Dyskurs o przebrzmiałej legendzie i żywym dokumencie mowy (Rzecz o monografii dr A. Kellnera „Východolašská nářeči”), „Zwrot” II, nr 7 (8), s. 3-4.

SowA A., 1950b, Dyskurs o przebrzmiałej legendzie i żywym dokumencie mowy (Od Gołężyców do Błędowic), „Zwrot” II, nr 8 (9), s. 8-10.

SowA A., 1950c, Dyskurs o przebrzmiałej legendzie i żywym dokumencie mowy (Kolonizacja), „Zwrot” II, nr 10 (11), s. 4-6.

Stalin J.V., 1949, Marxismus a národnostní a koloniální otázka, Praha.

Stalin J.V., 1950, O marxismu v jazykovědě, Praha.

STAVǍ̌ F., 1930, K charakteristice moravskoslezských nářečí, „Věstník Matice Opavské” XXXV, nr 3, s. 14-27.

Steuer F., 1934, Dialekt sulkowski, Kraków.

Steuer F., 1937, Narzecze baborowskie, Kraków.

Stieber Z., 1934, Geneza gwar laskich, Kraków.

SzymeczeK J., 2013, Matice slezská i mniejszościowe szkolnictwo czeskie na Zaolziu w okresie międzywojennym, [w:] S. Folwarczny, L. Kosiec, B. Kubiczek (red.), Tu jesteśmy... Szkolnictwo polskie na Zaolziu w pierwszej dekadzie XXI wieku, Czeski Cieszyn, s. 33-40.

UPOMINAE SIĘ O ZAOLZIE, „Zwrot” 18 VII 2015, [on-line:] http://zwrot.cz/2015/o7/upominalsie-o-zaolzie (dostęp: 2 VII 2017).

\section{Eastern Lachian dialects vs. Western Lachian dialects or the dialectological battle for the Zaolzie region Summary}

The article is devoted to the historical discussion which arose around the affiliation of the inhabitants of the Czech-Polish border area with the Czech or the Polish nationality and language. The bone of contention was the dialect used in the Czech part of the Cieszyn/Těšn region. Although the discussion was generally conducted in academic circles, it was also picked up on by the local press (i.e., the cultural monthly "Zwrot"). It concerned not only the interests of Czech (Czechoslovak) and Polish dialectology, but also posed existential questions for the Polish minority living in this part of former Czechoslovakia. The article describes the basic theses published in the 1950s-1970s. Engaged in the discussion were, among others, Adolf Kellner (who originated the debate with the publication of Východolašská nářcči I., II., 'Eastern Lachian Dialects I., II.' in 1946 and 1949 respectively), Jaromír Bělič, Arnošt Lamprecht, and, representing predominantly the attitudes of Polish dialectology, Karol Dejna. The polemics were marked by the Marxist ideology of the time, and the overall policy of the Czechoslovak state, which intent was to justify the affiliation of certain linguistic areas to Czechoslovakia. 


\section{SŁOWNICTWO ZWIĄZANE Z OBRÓBKĄ LNU I TKACTWEM W GWARACH GRODZIEŃSZCZYZNY NA TLE GWAR PODLASKICH}

Słowa klucze: gwary Podlasia, gwary Grodzieńszczyzny, obróbka lnu, tkactwo Keywords: dialects of Podlasie, dialects of the Grodno region, flax processing, weaving

Каб нагатаваи' н’итк'и и кросны, треба стаи'ива, навой, т'адо, наб'ил'н'ииьь, н'ччал'н'ицьь, б'ердо, пруг'и, качолк'и, чаўнок, иеукка, сукало, в'ирок, разматк'и, матав'ило, матачка, калаўродак, в'ерач'ано, прас'н'ица, ччотка, шпул'а (Галавачы) (SciaszMat 242²).

\section{Wstęp}

Ogólnie można stwierdzić, że tkactwo ludowe zarówno na Grodzieńszczyźnie, jak i na Podlasiu jest w stadium zanikania, chociaż w wielu wiejskich domach zachowały się narzędzia do obróbki lnu i warsztaty tkackie, a także wyroby tkactwa ręcznego. Na wsiach pozostały już tylko nieliczne aktywne tkaczki, w miastach są pojedynczy pasjonaci propagujący tkactwo ręczne. Chlubnym przykładem dbania o spuściznę jest amatorskie szkolne muzeum tkactwa funkcjonujące we wsi Hudziewicze pod Łunną koło Grodna, w którym regularnie odbywają się warsztaty z tej dziedziny

$1 \quad$ Wszystkie hasła słownikowe są podane w oryginalnej pisowni. 
rękodzieła. Jednocześnie należy zauważyć, że mimo zaniku omawianej profesji stopień znajomości jej techniki jest w miarę dobry wśród średniego pokolenia urodzonego i przynajmniej w okresie szkolnym mieszkającego na wsi oraz doskonały wśród starszego pokolenia ludności wiejskiej. Poświadcza to materiał leksykalny zebrany na terytorium Grodzieńszczyzny, który będzie przedmiotem naszego opracowania. Celem artykułu jest zestawienie leksyki w zakresie obróbki lnu i tkactwa występującej w polsko-białoruskim pasie przygranicznym i wskazanie wspólnego obszaru terminologicznego.

\section{Kilka uwag merytorycznych}

Przez Grodzieńszczyznę będziemy rozumieć nie cały współczesny obwód grodzieński, utworzony w dzisiejszym kształcie dopiero w 1954 r., i nie współczesny rejon grodzieński, utworzony w 1940 r., a tylko tak zwaną ścisłą Grodzieńszczyznę, czyli ziemie będące częścią dawnego powiatu grodzieńskiego, istniejącego w latach 1413-1939. Dzisiaj jego terytorium wchodzi w skład Polski (okolice Krynek i Kruszynian), Litwy (okolice Druskiennik) i Białorusi (rejony: brzostowicki, grodzieński, mostowski, wołkowyski). Taki wybór terenu badawczego jest bardziej sensowny i wiarygodny pod względem pozyskiwanego materiału, ponieważ wspólna ponadpięćsetletnia historia niewątpliwie miała wpływ zarówno na kulturę, jak i na gwary regionu. Dlatego mówiąc w tym artykule o gwarach Podlasia i Grodzieńszczyzny, będziemy mieć na myśli przede wszystkim gwary ścisłego pasa po obydwu stronach granicy polsko-białoruskiej, powstałej ostatecznie dopiero w 1946 r. na tak zwanej linii Curzona.

Po stronie polskiej są to najmniej zaludnione tereny państwa. Po stronie białoruskiej osadnictwo jest liczniejsze, jednak z powodu funkcjonowania tak zwanej strefy przygranicznej, w której poruszanie się ludności jest ograniczone, miejscowa społeczność jest homogeniczna, praktycznie brak tu ludności napływowej, co skutkuje archaicznością gwary i tradycyjnością społeczności wiejskiej. W związku ze specyficznym procesem osadnictwa ${ }^{2}$ na badanym obszarze występują na przemian różnorodne typy osad: dawne okolice szlacheckie i wsie chłopskie, wsie prawosławne i katolickie, a także mieszane wyznaniowo. W wąskim pasie przygranicznym ${ }^{3}$ częsta jest sytuacja, kiedy po stronie białoruskiej są osady z ludnością polskojęzyczną wyznania katolickiego, a po stronie polskiej - białoruskojęzyczną wyznania prawosławnego. $\mathrm{W}$ tych okolicznościach $\mathrm{z}$ czasem powstał interdialekt $\mathrm{z}$ wpływem

2 Szczegółowo na temat dziejów osadnictwa na tym obszarze zob. Wiśniewski 1964: 115-135, 1977: 7-80, 1980: 14-27.

3 O osobliwościach sytuacji socjolingwistycznej pasa przygranicznego w ujęciu diachronicznym zob. Снігірова 2014: 109-120. 
języków białoruskiego i polskiego na wszystkich poziomach systemowych, a także leksyki jidysz. Okoliczna ludność porozumiewała się nim i nadal się porozumiewa w kontaktach rodzinnych i sąsiedzkich. Do tej pory ten interdialekt jest nazywany przez jego użytkowników mówieniem „po prostu”. W związku z powyższymi uwagami w naszym artykule nie wskazujemy gwary, z której pochodzą omawiane leksemy, ponieważ biorąc pod uwagę analizowany materiał językowy, byłoby to raczej trudne do sprecyzowania.

\section{Materiałźródłowy}

Uprawa i obróbka lnu były przedmiotem licznych artykułów badaczy zarówno polskich, jak i białoruskich. Szczególną uwagę poświęciła temu zagadnieniu Barbara Falińska (zob. FalSłowTk). Jednak temat nie został jeszcze do końca opracowany, ponieważ:

przeprowadzanie badań już nie tylko w każdej wsi, ale nawet w każdej gromadzie, jest mimo większej obecnie niż kiedykolwiek liczby wykształconych badaczy terenowych niemożliwe do zrealizowania (Mocarska-Falińska 1958: 17).

Jako podstawa źródłowa artykułu posłużył zbiór leksyki regionalnej ${ }^{4}$ okolic Grodna pt. Скарбы народнай мовы (SkCych) przygotowany przez niezawodowego językoznawcę, nauczyciela z wykształcenia, Apanasa Cychuna. Odwiedzając w trakcie pełnienia obowiązków służbowych prawie każdą wieś Grodzieńszczyzny, znajdował on czas także na długie rozmowy z miejscową ludnością i notowanie leksyki regionalnej. Przez prawie 40 lat zebrał około 10 tys. leksemów, których zestawienie dzięki pomocy naukowców z uniwersytetu im. Janki Kupały ukazało się drukiem5. Specyfiką omawianego zbioru jest to, że została w nim zarejestrowana wyłącznie leksyka regionalna, co jawi się jako jego szczególna wartość. I chociaż w tytule wydania brak określenia słownik, można je uznać za źródło jak najbardziej wiarygodne, ponieważ zostało poddane redakcji naukowej językoznawców. Każda jednostka zbioru jest opatrzona półfonetycznym zapisem przykładu jej użycia oraz informacją o lokalizacji geograficznej, w której została zanotowana. Mimo że wydanie nie zawiera żadnych szczegółowych danych o informatorach ani o miejscowościach, w których był zbierany materiał, stanowi jednak cenne źródło leksyki gwarowej i jak dotąd pozostaje jedyną publikacją całkowicie poświęconą wyłącznie temu konkretnemu subregionowi. Ponadto jest pięknym przykładem realizacji myśli B. Falińskiej

4 O stanie badań systemowych regionalnej leksyki Grodzieńszczyzny zob. Ostrowski 2013: 31-40; Konczewska 2016: 109-123, 2017: 315-336.

5 W 2014 r. ukazało się drugie wydanie tego opracowania. W naszym artykule korzystamy z pierwszego, z 1993 r., pod red. Pawła Sciacki (SkCych). 
o konieczności współpracy dialektologów z miejscowymi nauczycielami i wartości pozyskiwanych w ten sposób materiałów.

Drugorzędnym źródłem przy opracowaniu artykułu był najstarszy słownik gwar grodzieńskich Mатэрыялы да слоўніка Гродзенскай вобласиі Tacc'any Sc'aškovič (SciaszMat), z którego zostały wyekscerpowane leksemy dotyczące omawianego terytorium bądź - jeżeli tego wymagały przykłady - innych regionów obwodu grodzieńskiego. Materiał ilustrujący gwary na terenie Polski został zaczerpnięty z: 1) Atlasu gwar wschodniosłowiańskich Białostocczyzny (AGWB), którego tom IX omawia słownictwo dotyczące obróbki lnu, w tym na terenie przygranicznym; 2) opracowania B. Falińskiej Polskie słownictwo tkackie na tle słowiańskim (FalSłowTk). Na potrzeby artykułu przeprowadzono także kwerendę w Kartotece Słownika gwar polskich PAN.

\section{Słownictwo}

\section{Wstępna obróbka lnu}

\section{Цермяць ${ }^{6}$}

'Zdrewniałe części suchych łodyg lnu lub konopi oddzielone od włókien': Mbl цермяцю падрубы у хаці апсыпалі, на столь сыпалі, кап ияплей было (Бандары) (SkCych 158).

Formy literackie: pol. paździerz, biał. кастрыца.

W Podlaskiem został poświadczony wyraz ciermieć (FalSłowTk I: 36).

AGWB, SciaszMat nie odnotowują tego słowa.

\section{Фira}

'Nieduży zwitek czesanego włókna lnianego': На кудзелю, як робіш, ma больш як тры фігі лёну йшло (Забагонікі) (SkCych 153); większa wiązka jest oznaczana leksemem клецка: У кудзелю ўлазіло дзве ат сілы клецкі лёну (Рудавіцы) (SkCych 70).

Formy literackie: pol. -, biał. - .

AGWB, FalSłowTk, SciaszMat nie poświadczają tego wyrazu.

\section{Ламак, ламачка}

'Narzędzie do pierwotnej obróbki lnu używane w celu połamania słomy i oddzielenia paździerzy, w kształcie drewnianej skrzyni i cepu': Cnачamкy лён трэш на тамак, а потым ужо на церніиу (Бакуны) (SkCych 78); Спярша лён ламалі на ламачках, а пасля ужэ иерлі на церніцах (Карозічы) (SkCych 78); Ламачка - то скрын'а з' дз'ерава и иапы, на ламачку ламайуи' л'он, а на йерн'ицы труи' (Лаша) (SciaszMat 256).

6 Podkreśleniami zostały zaznaczone sylaby akcentowane. 
Formy literackie: pol. -, biał. - .

AGWB nie poświadcza tego wyrazu. Występuje w FalSłowTk (I: 148).

\section{Павесма (павесмо)}

'Wiązka włókna lnianego po otrzepaniu, złożona z kilku garści': За раніuy, бывало, павесмаў шэсць-сем лёну натрэш (Хамякі) (SkCych 98).

Formy literackie: pol. -, biał. - .

W FalSłowTk (I: 234): powiesmo. AGWB (IX: 28) podaje, że leksem pav'esmo dominuje na wschodniej Białostocczyźnie, jednak w różnych miejscowościach inaczej jest precyzowana liczba garści lnu, które ono zawiera. Na Grodzieńszczyźnie pav'esmo to trzy wiązki lnu: Так’uх пав'есмаў па тры жм’ен’u баба натре дз'ес'аи' за дз'ен' и радуйаииза (Калантаі) (SciaszMat 322).

\section{Сцелішча}

'Miejsce, w którym ścielą len': Дл’а c’u’eлишча выб’ирайyu' роўно балото, с с'и'ел'ишча т’он звоз'аи' у шопу (Лаша) (SciaszMat 483).

Formy literackie: pol. -, biał. -.

AGWB, FalSłowTk nie poświadczają tego wyrazu.

\section{Сыравец}

'Len, który jeszcze nie został namoczony': Геть т'он сырав'еи, йон н'и мочаны, а тол'к'и адл'енаны (Рэпля) (SciaszMat 486).

Formy literackie: pol. -, biał. -.

AGWB, FalSłowTk nie poświadczają tego wyrazu.

\section{Шыплюқі (шыплюке)}

'Kołtuny na wełnie': A гэта што за праява: уся воўна ў адных шыплюках, машына ні зможа часащь, прыдзециа рукамі (Свіслач) (SkCych 173).

Formy literackie: pol. -, biał. - .

AGWB, FalSłowTk, SciaszMat nie poświadczają tego wyrazu.

\section{Трапачка}

'Narzędzie do trzepania włókna lnianego w celu usunięcia resztek paździerzy w kształcie deseczki zwężonej po bokach, z rączką': Трапачкy робяць з берасту, каб вашкай была і моцнай (Віцькі) (SkCych 145).

Formy literackie: pol. -, biał. - .

AGWB (IX: 20) poświadcza, że nazwa ta, zróżnicowana pod względem fonetycznym, występuje na całym badanym terenie. W FalSłowTk nie zanotowano.

\section{Przygotowanie włókna do tkania}

\section{Кавародак, калародак, калаўродак, караўдодак}

'Kołowrotek do nawijania nici na cewkę’: Унас, у Азёрах, бълті такія майстрэ, што кавароткі рабілі (Ліхачы) (SkCych 63); Калародак i ціпер у нас ёсиь, наша баба прадзе (Скідаль) (SkCусh 64); Збярэмсо с калаўроткамі і прасніцамі у адну хату, прадзем сабе, песні спяваям; хлопиь прыдуць 
(Бакуны) (SkCych 64); Во, натта ж добрыя карайлоткі Данілоўскі рабіў, лёхкія, прадзеш і ня чуяш (Свіслач) (SkCyсh 67).

Formy literackie: pol. kołowrotek, biał. сукала.

AGWB (IX: 94) poświadcza formę kałavrodok tylko w miejscowości Stare Masiewo, a karaŭvodak - w miejscowości Zubki (ibid.: 94). SciaszMat odnotowuje leksem калаўродак na Grodzieńszczyźnie: Дастала з гары калаўродак и с'ела прас'ичи воўну (Дзекалавічы) (SciaszMat 206) i Werenowszczyźnie (rozróżniając kołowrotek pionowy i poziomy): У нас майyu' калаўродак стайак, стайак'е высок'ийа, и калаўродак т’ажак, н’иск'и калаўродак (Куклі) (ibid.). Na Ostrowiecczyźnie odnotowano leksem калаўрот: Ц’an’ep прадз’м воўну на калаўротках (Чэхі) (ibid. 207). Na oznaczenie desygnatu ręcznego przyrządu bez koła do nawijania nici zarejestrowano także wyraz сукадло (сукайло): Сукадло кожны меў свае, сам мог зрабіць, ні трэбо было куплящь (Рацічы) (SkCусh 139); Сукайло ўнас есьщь, але яно нікомуні патрэбно, бо ніхто ні прадзе (Прывалка) (ibid.). Forma сукадло występuje również w okolicach Zelwy: Твайо сукадло н’икуды н’и годна (Конна) (SciaszMat 479); a w okolicach Zdzięcioła odnotowano formę сукала: $\mathrm{Ha}$ сукал'е цаўк'е сукаи' треба, цеукка ўс'а, скарей сучы (Нагародавічы) (ibid.). AGWB (IX: 94) rejestruje liczne formy nazwy sukadło, sukajto występujące $\mathrm{w}$ pasie wschodnim wzdłuż granicy z Białorusią od północy po Narew.

\section{Кругелькі (крагелькі)}

'Szkielet zrobiony z prętów, na który nawija się przędzę’: Сnaчamкy нiu̧i з маткой перамотваюиь на кругелькі, а тады ущжэ снуюиь на снойніиу (Пяслі) (SkCych 73); Надзеням маток на рашке, і давай накручваць ніткі на крагелькі (Копанькі) (ibid.).

Formy literackie: pol. -, biał. -.

AGWB (IX: 56) formę kruh'elki odnotowuje w miejscowościach: Studzianki, Krynki, Bołtryki. Forma krah'elak występuje w miejscowościach Małowista i Stara Kamienna, a krah'elek - tylko w Karpowiczach. FalSłowTk (I: 132) poświadcza leksem kruhelek. SciaszMat w tym znaczeniu odnotowuje w okolicach Zelwy wyraz вiтушкі: На в'итушк'и снуйуи' н'итк'и, на ком'инку сушаи' (Конна) (SciaszMat 84). Z Białostocczyzny formę tę zanotowano w Siemianówce (AGWB IX: 56).

\section{Перка}

'Część kołowrotu w kształcie metalowej sprzączki służąca do zamocowania szpulki’: Як выпадзя лерка, та ужжэ прасиі ні будзяш, шпулька станя (Круглікі) (SkCych 79).

7 Poświadcza go SStp (VIII: 503). 
Formy literackie: pol. -, biał. - .

AGWB, FalSłowTk, SciaszMat nie poświadczają tego wyrazu.

\section{Матаідло, матаілка}

'Przyrząd do motania nici uprzędzionych na kółku': Круияяча матаідло ні так просто зрабіць, яго заказвалі у майстра (Капцёўка) (SkCych 86); У міне матаілка ашчэ бабіна была, натта лёхка матала (Пяслі) (ibid.).

Formy literackie: pol. motowidło, biał. матавіла.

W okolicach Wołkowyska w tym znaczeniu zanotowano leksem матачка: $\mathrm{Ha}$ матачку н'ичал'н'ицы наматвайуи' (Лазы) (SciaszMat 283), a w okolicach Werenowa i Zelwy - матавідла (матавідло): Кал'и на маток треба наматаи' н'итк'и, то матайуи' на матав'идла (Бражэльцы) (ibid.); Наматала на матав'идло н'итк'и (Конна) (ibid.).

FalSłowTk (I: 173) poświadcza motoidło w Podlaskiem. AGWB nie notuje tego wyrazu.

\section{Ментка}

'Drewniany korbowód (deseczka) łączący pedał kołowrotka z korbą koła napędowego': Ментка рамушком прывязваласа да панажа, каб мацней трымаласа (Яскевічы) (SkCych 87).

Formy literackie: pol. -, biał. - .

AGWB (IX: 52) odnotowuje formę m'enta tylko w miejscowości Sokolany. FalSłowTk (I: 166) poświadcza w Podlaskiem leksem mięta. Na oznaczenie danego desygnatu w okolicach Grodna zarejestrowano wyraz немчык: $Я_{\kappa}$ спадзе немчьк, так калясэ і стане, прасьиі ні будзяш (Пад'ятлы) (SkCych 95). AGWB (IX: 52) odnotowuje identyczną formę w dwóch miejscowościach Białostocczyzny: Chilmony i Jaginty, usytuowanych na wysokości białoruskiej wsi Podjatły.

\section{Наба}

'Obręcz koła napędowego kołowrotka, do której są przymocowane szprychy': Наба робіциа тулько з бярозы, кап спіцыь добро трымаліса (Канюхі) (SkCych 90).

Formy literackie: pol. -, biał. - .

AGWB, FalSłowTk, SciaszMat nie poświadczają tego wyrazu.

\section{Развіткі}

'Przyrząd do rozwijania motków w kształcie dwóch drewnianych prętów zamocowanych na krzyż na ruchomej osi metalowej': Развіпкі зрабіцьь - нi велька штука, абы матэрыял быў, за вечар так і гатовыя (Прыгодзічы) (SkCych 120).

Formy literackie: pol. -, biał. - .

AGWB, FalSłowTk, SciaszMat nie poświadczają tego wyrazu. 


\section{Ражон}

'Oś wrzeciona, na którą nakłada się szpulkę (cewkę)': На ражон насадзіш иээуку - і тулькі буіць, так нітка ідзе, наматваецияа (Балічы) (SkCych 119). Formy literackie: pol. -, biał. -.

AGWB, FalSłowTk, SciaszMat nie poświadczają tego wyrazu.

\section{Рэпка}

'Nasadka z poziomym wałkiem na stołku kołowrotka': Рэnка як добро асаджана, та і шпулька лёхко ияягня (Казіміроўка) (SkCych 123).

Formy literackie: pol. -, biał. -.

AGWB (IX: 46) poświadcza ten leksem w miejscowościach Chilmony i Nowodziel. Podaje także informację o tym, że na Białorusi nazwa omawianego desygnatu została zarejestrowana tylko w gwarach poleskich. W okolicach Grodna w tym znaczeniu występuje także wyraz седала: Як седала добро пастаўляно, та і прасць добро, шнур ні будзя спадаць (Бакуны) (SkCych 128). Na Białostocczyźnie ta forma pojawia się na zwartym terenie na północ od Supraśla (AGWB IX: 46; FalSłowTk I: 270). Pod Grodnem został poświadczony także wariant стан-црубка: Стан-шрубку як добро вытачыши, та, можно сказаць, што палавіна работы зрабіў, калауродак гатовы (Круглікі) (SkCych 136). Na Białostocczyźnie odnotowano leksemy šruba (w miejscowościach Wesołowo, Nowodziel, Białogorce i Ogrodniki) i hołšruba (w Zawykach) (AGWB IX: 46; FalSłowTk I: 313). W SciaszMat wyraz рэnка, zanotowany w okolicach Zelwy, ma zupełnie inne znaczenie - 'wiązka opracowanego lnu': За дз'ен' дз'ес'аu' репак л'ону натрапала (Каралін) (SciaszMat 432).

\section{Рулька}

'Otwór osi wrzeciona, przez który przeciąga się nitkę': Бачыш, нітка спярша праз рульку ідзе, тадь - на серь, а потым ужэ наматваяица на шпульку (Бакуны) (SkCych 123).

Formy literackie: pol. -, biał. - .

AGWB, FalSłowTk, SciaszMat nie poświadczają tego wyrazu.

\section{Сіры (серы)}

'Drobne, zagięte pod kątem prostym druciki wbite w ramy wrzeciona': $H i$ садзі, дзетка, рукі ў сірь, бо абдзярэш, балещь будзя (Лойкі) (SkCych 128). Ten desygnat jest określany także jako шоркі: У шоркі пальцаў ні сунь, а то абдзяруць (Казіміроўка) (ibid. 170).

Formy literackie: pol. -, biał. -.

FalSłowTk (I: 271) odnotowuje w Podlaskiem sierki, KSGP poświadcza siry, siery. AGWB, SciaszMat nie rejestrują tego wyrazu.

\section{Стрыца (стрычка), трыца}

'Drugie kółko pasowe w kołowrotku połączone ze skrzydełkiem': Aднy столку шнура закладаяш на стрыцу, другую - на шпульку і тады ўжэ 
прадзеш (Казіміроўка) (SkCych 138); Паткруиі ляпей стрыиу, а то, бачыи, калаўродак добро ні ияягня (Свіслач) (ibid.).

Formy literackie: pol. -, biał. - .

W KSGP występuje leksem strycka. FalSłowTk (I: 291) odnotowuje strycka jako 'kółeczko obok szpulki'. AGWB (IX: 44) podaje w kilkunastu miejscowościach Białostocczyzny wyraz stryca i jego warianty jako 'krążek z rowkiem na obwodzie przy szpulce w kołowrotku’. Przytoczony przy naszym haśle pierwszy przykład (SkCych 138) świadczy raczej o nieprecyzyjnym określeniu danego desygnatu w AGWB: szpulka ma swoje kółko pasowe, zaś stryca - swoje, które łączy się ze skrzydełkiem. Kółka pasowe na szpulce i na skrzydełku nieznacznie różnią się średnicą i obracają się z różnymi prędkościami, dzięki czemu uzyskuje się jednoczesne skręcanie przędzy i nawijanie skręconej już nitki na szpulkę. Do napędu obu kółek wykorzystywano jedno, podwójnej długości cięgno (w przykładzie: sznur), z którego formowano ósemkę i po złożeniu na pół (stołka) zakładano na koła pasowe. Hasło w AGWB nie różnicuje tych dwóch rodzajów kółek. Być może jest to spowodowane tym, że obydwa kółka stanowią jeden element: $w$ jednym kawałku drewna są wyrzeźbione dwa kółeczka o różnych średnicach.

\section{Шлішпер}

'Część kołowrotka, metalowy szponek z rzeźbą, na którym trzyma się szpulka': Шлішпер з аднаго канца зусім тонкі, а з другога таўшчэйшь, зь дзірачкай, празь якую праиягваюиь нітку. Шлішперы аднекуль прывозілі, іх кавале ні рабілі (Круглікі) (SkCych 168).

Formy literackie: pol. -, biał. - .

AGWB, FalSłowTk, SciaszMat nie poświadczają tego wyrazu.

\section{Шнюр}

'Sznur w kołowrotku': Як дзе называлі, а у нас - шнюр называлі, я сама яго з ніцей рабіла, як трэбо было (Казіміроўка) (SkCych 169).

Formy literackie: pol. -, biał. -.

FalSłowTk (I: 302) poświadcza w Podlaskiem leksem sznur, z kolei AGWB i SciaszMat nie rejestrują go.

\section{Шворын (шворан)}

'Część kołowrotka, drewniana śruba z rzeźbą w nasadzie koła, która reguluje natężenie cięgna’: Паткруиі шворын, а то шнур спадая, добро ні наиягнуты (Бакуны) (SkCych 167).

Formy literackie: pol. -, biał. - .

FalSłowTk (I: 311): szworen. 


\section{Krosna}

\section{Адвязіч}

'Kawałek płótna ze sznurkami przywiązywany do osnowy w celu jej przedłużania przy kończeniu tkania': Калі мало асновы, бяру адвязіч і датыкаю кужаль (Свіслач) (SkCych 10).

Formy literackie: pol. -, biał. - .

AGWB (IX: 106) poświadcza identyczną formę w miejscowościach: Wołkusz, Kopciówka, Stara Chodorówka, Wyłudy, Łubianka, Oleszkowo, Studzianki, Nowodworce, Klepacze, Sobolewo, Baciuty, Lewickie, Podozierany, Jałówka, Hołówki Duże.

AGWB (IX: 106) podaje wzmiankę, że w gwarach na Białorusi dany wyraz nie występuje.

\section{Берда (бердо)}

'Płocha ze stalowymi (drewnianymi) szczebelkami': Берда i сталёвыя і дзеравяныя былі, мы дзеравянымі мешкавіну ткалі (Гліняны) (SkCусh 20).

Formy literackie: pol. płocha, biał. бëpдa.

AGWB (IX: 135) poświadcza formę b'erda stalovyja w następujących miejscowościach: Siderka, Ostrów Południowy, Białogorce. Autorzy opracowania zaznaczają, że jest ona lokalizowana wzdłuż wschodniej granicy Polski. We wzmiankach dotyczących białoruskich gwar grodzieńskich AGWB podaje zestawienia b'orda zaleznyja (SłPogr II: 135) i trasc'avoja b'erda (SłPogr V: 121). Omawiany wyraz został odnotowany w KSGP.

\section{Біла (біло)}

'Podłużne listewki płochy, między którymi znajdują się szczebelki': Замauyŭ білы клінкамі, а то кросна раз’едуция (Каленікі) (SkCych 20).

Formy literackie: pol. -, biał. -

AGWB (IX: 82) poświadcza formę b'iło w Rybołach, Jecewiczach, Dubiczach Osocznych, a formę b'iła - w Policznej. FalSłowTk (I: 21) odnotowuje formę bidło. W okolicach Grodna ten desygnat jest określany także jako трасце: Былі бёрда жалезныя, та у іх трасыие жалезна, а у дзеравяных 3 иввёрдаго дзерава (Свіслач) (SkCych 145). AGWB (IX: 82) zwraca uwagę na rozmaitość leksemów określających ten desygnat, wśród których zbliżone do podanej formy są tylko trzy: tras'cina (Stara Kamienna), trostka (Lewickie) i trestka (Siemianówka).

\section{Чаўнык}

'Element krosna tkackiego, drewniana łódeczka w warsztacie tkackim, w której się mieści szpulka z nićmi wątku, mechanicznie niepołączona z pozostałymi mechanizmami': Чаўныком буду ткаи' (Тупічаны) (SciaszMat 549). Formy literackie: pol. czółenko, biał. чаўнок. 
Forma čaŭnek została odnotowana w KSGP bez podania miejscowości. AGWB i FalSłowTk nie poświadczają tego wyrazu.

\section{Кацуба}

'Element w kształcie wygiętej pałki do podkręcania nawoju w krosnach': $Я_{\kappa}$ навой хочаш паткруціиь, каиубу падымящ - і паткруиіуй, колькі трэба (Рацічы) (SkCych 68). Na oznaczenie tego desygnatu zarejestrowano także leksem кульбака: Як трэбо, кульбаку падымям і колькі трэбо навой сабе пакруціш (Карозічы) (SkCych 75).

Formy literackie: pol. -, biał. -.

AGWB, FalSłowTk, SciaszMat nie poświadczają tego wyrazu.

\section{Кросны, кросно}

'Warsztat tkacki'

Formy literackie: pol. krosno, biał. кросньь.

FalSłowTk (I: 130): krosny. AGWB (IX: 66) poświadcza formę krosna tylko w liczbie pojedynczej. Leksem кросно został zanotowany w okolicach Wołkowyska: Пастав'ил'и кросно, будз'ам вытыкаи' дываны (Есенавіца) (SciaszMat 242). AGWB (IX: 66) podaje w tym znaczeniu wyraz varstat. W okolicach Zdzięcioła występuje forma варстат: Кал'и жанк'и пачынал'и ткаи, у кожнай хаи'а стайаў варстат (Нагорнікі) (ibid. 77). Z kolei na Nowogródczyźnie вapcmak występuje w znaczeniu 'podstawka, na której stawiają krosno': У м’ин'е н'ама свайго варстаку, н'ама на чым став'ии' кросны (Шчорсы) (ibid.).

\section{Набільніцы}

'Ruchoma rama krosien, w którą wkłada się płochę': Як ччэш, та набільніцамі прыстукваяш, кап нітка добро прыставала (Зарубічы) (SkCyсh 9о).

Formy literackie: pol. rama, biał. набілкі.

FalSłowTk (I: 175): nabilnice. AGWB (IX: 86) poświadcza identyczną formę w dwudziestu miejscowościach Białostocczyzny usytuowanych wzdłuż granicy z Białorusią od Grodna do Brzostowicy Małej. Na Werenowszczyźnie odnotowano formę набільніца: Наб'ил'н'ицы прыстуквайуи' палатно, каб было гушчейшо (Куклі) (SciaszMat 297). Na Białostocczyźnie na oznaczenie tego desygnatu jest używany licznie leksem lada (AGWB IX: 86), zarejestrowany również w okolicach Grodna i Nowogródka: Йак наладзиц л’aда, б’ерда добра ходз'аи' (Шчорсы) (ibid. 271).

\section{Навой}

'Wał w krosnach': Навой ткан'и - тонк'и, патсподн'и, йон уп'ерадз'и, на йим т'ажыи' ткан'и. Навой задн'и - тоўсты, в'ал'ик'и, на йим аснова т'ажыц' (Бражэльцы) (ibid. 30o).

Formy literackie: pol. nawój, biał. навой.

Jak świadczy przytoczony przykład, desygnaty oznaczające wał w krosnach, na który nawija się osnowa, i wał, na który nawija się płótno, mają wspólną 
nazwę, rozróżniają ją jedynie określenia $z$ przodu (na płótno) i $z$ tyłu (na osnowę). AGWB (IX: 68) precyzuje, że leksem nawój i jego derywaty w gwarach wschodniosłowiańskich Białostocczyzny są notowane powszechnie na północ od Narwi i Białowieży. Formę tę rejestruje także FalSłowTk (I: 178).

\section{Нічальніцы}

'Dwa sznury, pomiędzy którymi są rozpięte nici z oczkami': Як дзяўкамі былi, та выбірыстыя радна ткалі у шэсиьь і нават у восім нічальніи (Віцькі) (SkCych 96).

Formy literackie: pol. nicielnice, biał. нічальніцы.

Leksem poświadczono także w okolicach Werenowa: Н'uчал'ьн'uนь роб'au' з н’итак кручаных, таўс'и'ейшых (Бражэльцы) (SciaszMat 315).

AGWB (VIII: 50) i FalSłowTk (I: 179) odnotowują formę nicielnicy.

\section{Панажэ, панажайкі}

'Część krosien ze sznurkami, które mocują je do nicielnic': Ментка рамушком прывязваласа да панажа, каб мацней трымаласа (Яскевічы) (SkCych 87). Formy literackie: pol. pedał, biał. -.

NazwawystępujetakżewokolicachZdzięcioła:Панажоўбывайадва, чатыры, йак йак'и узор (Нагародавічы) (SciaszMat 347) i Werenowa: Укроснах йес'u' панажайк'и з в'аровачкам'и, прымацаваны к н'ичал'н'ицам, в'аровачка прымацована, каб н'и разыходз'ил'ис'а панажайк'и (Бражэльцы) (ibid.).

AGWB i FalSłowTk nie poświadczają tego wyrazu.

\section{Пруге}

'Nakładka na płótno do utrzymania jego stałej szerokości podczas tkania i do ochrony płochy’: Без пругоў кужалю ні выччаш, скручващиа будзя (Луцкаўляны) (SkCych 114).

Formy literackie: pol. -, biał. - .

AGWB (IX: 98) poświadcza ten wyraz w miejscowościach: Wołkusz, Siderka, Sokolany, Nowodziel, Krynki, Białogorce, Bobrowniki.

Identyczna forma została zarejestrowana w okolicach Zdzięcioła: C’apeдз'ина доччачак сашчаплайачиз, кал'и н'и будз'а сашчепл'ана, то пруге н'и будуи' пружым' (Нагародавічы) (SciaszMat 393).

\section{Пруток}

'Część wałka osnowowego': Як пачынаю ткащь, гляджу, кап прутоку навой добро залажыць,кап аснова ні выяхала (Балічы) (SkCych 114).

Formy literackie: pol. -, biał. - .

W okolicach Zdzięcioła leksem пруток ma znaczenie 'oś wrzeciona': Цеўку надз'авайуи' на пруток, кап иеўка с чалнука н’и выпадала (Нагародавічы) (SciaszMat 393).

AGWB i FalSłowTk nie poświadczają tego wyrazu. 


\section{Płótno, jego jakość}

\section{Абмылак}

'Defekt w płótnie samodziałowym': Нітка парваласа, як ні згледзіш зробіш абмылак (Свіслач) (SkCych 8).

Formy literackie: pol. -, biał. -.

AGWB, FalSłowTk i SciaszMat nie poświadczają tego wyrazu.

\section{Блізма (лізна)}

'Skaza wzdłuż tkaniny spowodowana przerwaniem wiązania w nicielnicach': Блізмаў нарабіла, брытко будзя людзям паказаиь (Зарубічы) (SkCych 20); Сляпая, ні бачыла, што нітка парваласа, блізнау нарабіла (Свіслач) (ibid.).

Formy literackie: pol. -, biał. - .

AGWB (IX: 110) stwierdza brak form z podobnym akcentowaniem w gwarach na Białorusi. Na terytorium Polski forma blizna została poświadczona w miejscowościach: Wołkusz, Jagłowo, Saczkowce, Nowodziel, Krukowszczyzna, Rybniki, Sokołda, Turośń Dolna, Klewinowo (AGWB IX: 110). Odnotowują ją także FalSłowTk (I: 24) i KSGP. SciaszMat poświadcza leksem блізна (блізня) w znaczeniu 'wada powstała na skutek zerwania się nitki w czasie tkania' w okolicach Zdzięcioła: Палатно йайе усс'о ў бл'изнах (Нагародавічы) (SciaszMat 53) i Werenowa: Бл'из'н'а то зам'етка, што н'аправ'ил'на идз'е аснова, йак н’итка зарв'еица адна, то дз'в'е ткуциа, а гета уужо бл'изн'а зав'еици (Бражэльцы) (ibid.). AGWB (IX: 110) podaje, że na Białostocczyźnie występują podobne formy. W AGWB znajdujemy ponadto wzmiankę, że wada powstała na skutek zerwania nitki jest określana w gwarach grodzieńskich także jako p’eramota, p’eram’ot. Jednak słowniki z tego regionu rejestrują omawiane leksemy w znaczeniu wady powstałej wskutek nie zerwania nitki, a nieodpowiedniego jej ukierunkowania: П'ерам'от зроб'uш, йак н'иправ'ил'на паложана н'итка, н'и на тойа м'еси, куды нал'ежыц' (Бражэльцы) (SciaszMat 367); Добрайа мас'и’арыиа, н’и адной n’eрамоты н’и палажыла (Нагародавічы) (ibid. 368); Трэбо добро глядзець, каб якой перамоты ні зрабіиъ, а то той рас нарабіла (Клінчаны) (SkCych 108).

\section{Камэля}

'Przędza z nitek zrobionych w zakładzie, nie samodziałowych': Помню, у нашай Юсты былі вытканыя с камэлі андараке такія (Свіслач) (SkCych 66).

Formy literackie: pol. -, biał. -.

AGWB i SciaszMat nie poświadczają takiego wyrazu. FalSłowTk (I: 91) odnotowuje kamle jako 'ręczne szczotki do czesania wełny', KSGP poświadcza formę kamlonki jako 'odpadki wełny pozostałe po czesaniu na szczotce'. Nasuwa to przypuszczenie, że być może w SkCych znaczenie hasłowego leksemu zostało określone nieprecyzyjnie, wyłącznie na podstawie usłyszanego zdania, 
bez dopytania o szczegóły, i kamela w gwarach grodzieńskich oznacza raczej przędzę zrobioną z gorszego gatunku lnu, z odpadków wełny.

\section{Недасек}

'Szczelina podłużna w płótnie powstała wskutek niedobicia nici przez płochę': Брытко каму паказаць кужаль, недасекаў нарабіла ткучы (Баброўнікі) (SkCych 95).

Formy literackie: pol. -, biał. - .

Identyczna forma została poświadczona $\mathrm{w}$ okolicach Zdzięcioła: Дренна ччещ, вун' кол'к'и н'идас'екаў (Нагародавічы) (SciaszMat 312). W tym samym znaczeniu na Nowogródczyźnie odnotowano leksem недабой: Йана н’идабойу шмат нараб'ила (Шчорсы) (ibid.).

AGWB i FalSłowTk nie poświadczają tego wyrazu.

\section{Перабірысты}

'Płótno tkane sposobem przebierania różnokolorowych nici': Некалi i я ткала перабірыстыя родна, Люба памагала (Каробчыцы) (SkCych 108).

Formy literackie: pol. -, biał. - .

W okolicach Ostrowca taki złożony sposób tkania nazywano nepaбop: Hama бапка у маладос'и'и вун' йак'ийа п'ираборы магла ткаи' (Міхайлішкі) (SciaszMat 365).

AGWB nie poświadcza tego wyrazu.

\section{Рубінка}

'Mały kawałek lnianego płótna gorszej jakości': Даўней ніякіх бінтоў ні было, завяжаш рану рубінкай і ходзіш, пакуль зажыве (Кунцаўшчына) (SkCych 123).

Formy literackie: pol. -, biał. - .

KSGP odnotowuje w tym znaczeniu leksem rubinek w miejscowości Huszcza na Podlasiu. AGWB, FalSłowTk i SciaszMat nie poświadczają tego wyrazu.

\section{Рукаўніна}

'Specjalnie tkana wąska tkanina samodziałowa, z której szyto rękawy koszul': Гэта ашчэ пакойная мама ткала рукаўніну, я ўжэ яе ні ткала (Кавалічы) (ibid.).

Formy literackie: pol. -, biał. -.

AGWB, FalSłowTk i SciaszMat nie poświadczają tego wyrazu.

\section{Свойчык}

'Zwój płótna': Кал'u палатно выб'ал'u', скатвайуu' у свойчык и кладуи' у куфбар (Лаша) (SciaszMat 443).

Formy literackie: pol. zwój płótna, biał. скрутак палатна.

FalSłowTk (I: 367 ) poświadcza w Wierzchlesiu na Podlasiu formę zwojczyk w znaczeniu 'płótno wytkane z jednej osnowy'. AGWB (IX: 132) odnotowuje 
formę svojčyk wzdłuż granicy na terenie od północy do Supraśli. W miejscowości Chilmony został poświadczony także leksem suvoj, występujący na Białorusi w okolicach Werenowa: Наткала тры сувойи кужал'у (Бражэльцы) (SciaszMat 478).

\section{Podsumowanie}

Przeanalizowawszy powyższe zestawienie, można pokusić się o wniosek, że leksyka dotycząca obróbki lnu i tkactwa występująca w ścisłym pasie pogranicza polsko-białoruskiego jest przeważnie wspólna dla gwar po obydwóch stronach granicy. Zwraca uwagę fakt, że znaczna część leksemów występujących na ścisłej Grodzieńszczyźnie, które zostały zarejestrowane w słowniku Apanasa Cychuna, nie jest poświadczana w innych ani polskich, ani białoruskich korpusach leksyki gwarowej. Szczególnie ciekawe jest spostrzeżenie, że często identyczne formy zostały zarejestrowane wyłącznie w miejscowościach usytuowanych na jednej szerokości geograficznej po obu stronach granicy. Potwierdza to nasze założenie badawcze, że najbardziej wiarygodnym terenem eksploracji w tym zakresie jest obręb jednej parafii, nawet jeżeli obecnie znajduje się ona po różnych stronach granicy. Interesujące byłoby przeprowadzenie wspólnych polsko-białoruskich badań etnograficznych i dialektologicznych w odnotowanych miejscowościach pasa przygranicznego w celu potwierdzenia, odrzucenia bądź podważenia tej hipotezy oraz sprawdzenia, czy obecni mieszkańcy rozumieją znaczenie leksemów odnotowanych w dawnych badaniach. Niezbędne wydaje się także sporządzenie szczegółowego opracowania wyników tych badań z koniecznym zamieszczeniem rysunków ilustrujących desygnaty, ponieważ, jak wynika $\mathrm{z}$ naszej analizy, same wypowiedzi informatorów zawarte $\mathrm{w}$ słownikach czasem nie są wystarczająco informatywne i wymagają sprecyzowania poprzez ilustracje. Takie opracowanie pomogłoby także sprostować bądź sprecyzować obecne informacje zawarte $\mathrm{w}$ polskich opracowaniach o niewystępowaniu w gwarach na terenie Białorusi leksemów, które jednak poświadcza SkCych.

\section{Literatura}

AGWB: I. Maryniakowa (red.), Atlas gwar wschodniostowiańskich Białostocczyzny, t. 9: Leksyka 5, Warszawa 2007.

FaLSŁowTк: B. Falińska, Polskie słownictwo tkackie na tle słowiańskim, Wrocław 1974-1984.

KonczewsKa K., 2016, Frazeologizmy i paremie białoruskich gwar grodzieńskich jako źródło rekonstrukcji obrazu świata mieszkańców wielonarodościowego regionu, [w:] M. Rak, K. Sikora (red.), Stowiańska frazeologia gwarowa, „Biblioteka LingVariów”, t. 23, Kraków, s. 109-123. 
KonczewsKa К., 2017, Да пьтання даследавання дыялекталагічнай спадчынь Гродзеншчьныь, [w:] R. Kaleta (red.), Białoruś w dyskursie naukowym. Lingwistyka, socjologia, politologia, Warszawa, s. 315-336.

KSGP: Kartoteka Słownika gwar polskich PAN w Zakładzie Dialektologii Polskiej IJP PAN w Krakowie.

Mocarska-Falińska B., 1958, Z badań dialektologicznych na Ziemi Płockiej, „Notatki Płockie" 3, $\mathrm{nr}$ 7, s. 17-23.

Ostrowski B., 2013, Białoruskie gwary Grodzieńszczyzny. Wybrane zagadnienia, Kraków. SciaszMat: Т.Ф. Сцяшковіч, Матэрыялы да слоўніка Гродзенскай вобласці, Мінск 1972.

SкСусн: А.П. Цыхун, Скарбы народнай мовы, рэд. П. Сцяцко, Гродна 1993.

SŁPogR: Ю.Ф. Мацкевіч (рэд.), Слоўнік беларускіх гаворак паўночна-заходняй Беларусі i яе пагранічча, Мінск 1979-1986.

SSTP: S. Urbańczyk (red.), Słownik staropolski, Kraków 1953-2002.

Wiśniewski J., 1964, Rozwój osadnictwa na pograniczu polsko-rusko-litewskim od końca XIV do połowy XVII wieku, „Acta Baltico-Slavica” 1, s. 115-135.

WiśnIEwsKi J., 1977, Osadnictwo wschodniej Białostocczyzny: geneza, rozwój oraz zróżnicowanie i przemiany etniczne, „Acta Baltico-Slavica” 11, s. 7-80.

Wiśniewski J., 1980, Zarys dziejów osadnictwa na Białostocczyźnie, [w:] S. Glinka, A. Obrębska-Jabłońska, J. Siatkowski (red.), Atlas gwar wschodniosłowiańskich Białostocczy$z$ ny, t. 1, Wrocław, s. 14-27.

Снігірова Н., 2014, Асаблівасці сащыялінгвістычнай сітуацыі у камунікатыўнай прасторы кантактнай зоны Беларусі і Польшчы (гістарычны аспект), „Socjolingwistyka” XXVIII, s. 109-120.

\section{Flax processing and weaving vocabulary in the dialects of the Grodno region, against the background of Podlasie dialects \\ Summary}

For the first time in the literature, the present paper compares flax processing and weaving vocabulary found strictly in the Polish-Belorussian borderland which was formerly part of a single Grodno county. The source material comprises well-known Polish lexicological works, and also a work on Grodno lexicon by Apanas Cychun which has not as yet been taken into consideration. Thanks to this, the paper notes lexemes unattested in previous corpora of dialectal vocabulary, and adds precision to the information contained in them. 
Z PRZESZł OŚCI JĘZYKOZNAWSTWA 

Maciej Rak

Uniwersytet Jagielloński, Kraków

maciej.rak@uj.edu.pl

\section{Z DZIEJÓW SŁOWNIKA GWAR POLSKICH JANA KARŁOWICZA. KARTOTEKA I DZIAŁANIA WYDAWNICZE}

Słowa klucze: Słownik gwar polskich Jana Karłowicza, Jan Karłowicz, polska leksykografia gwarowa, polska dialektologia

Keywords: Jan Karłowicz's Słownik gwar polskich 'A Dictionary of Polish Dialects', Jan Karłowicz, Polish dialectal lexicography, Polish dialectology

\section{Uwagi wstępne}

Słownik gwar polskich Jana Karłowicza (SKarł) był przedmiotem wielu recenzji i omówień1, od bardzo pochlebnych po bardzo krytyczne. Wyjątkowe miejsce (przez wzgląd na siłę oddziaływania na późniejszych badaczy) zajmuje tu szczegółowa recenzja autorstwa Kazimierza Nitscha (1911/1958), która sprawiła, że SKarł postrzegano jako dzieło przedwczesne, chaotyczne, niedopracowane i w wyniku tego w gruncie rzeczy mało wartościowe. Przywrócenie omawianemu słownikowi właściwego miejsca w polskiej dialektologii i leksykografii gwarowej zawdzięczamy głównie Henryce Perzowej (1979), Elżbiecie Koniusz (2001, 2005a), Joannie Okoniowej (2003, 2012, 2013) i Halinie Karaś (2011: 93-105, 2015). Badaczki te podkreślały m.in., że do dziś jest to jedyny ukończony polski słownik ogólnogwarowy (warto nadmienić, że pierwszy w krajach słowiańskich), którego ocenę można przeprowadzać tylko na tle

$1 \quad$ Ich przegląd wraz z zestawieniem wspólnych argumentów, czy to mających na celu pochwałę SKarł, czy też krytykę tego dzieła, zob. Karaś 2011: 100-105. 
epoki, czyli właściwie początków polskiej dialektologii. Jest to też ważne źródło do badań leksyki kresowej, co udowodniła zwłaszcza E. Koniusz (2001). Z kolei niedociągnięcia, które wytknął K. Nitsch, w dużej mierze są wynikiem stanu ówczesnej wiedzy na temat gwar polskich i metod ich badania.

Celem niniejszego artykułu jest omówienie kartoteki SKarł i działań wydawniczych podejmowanych w związku z tym słownikiem za życia i po śmierci jego autora. Impulsem do napisania tego tekstu było zidentyfikowanie przekazanej w $2007 \mathrm{r}$. z Biblioteki Naukowej PAU i PAN do Archiwum Nauki PAN i PAU w Krakowie kartoteki, którą sklasyfikowano jako Słownik języka polskiego. Dyrektor Archiwum Rita Majkowska² zwróciła się w maju 2017 r. do Mirosława Skarżyńskiego z pytaniem, o jaki właściwie słownik chodzi. Aby się upewnić co do swoich - jak się potem okazało właściwych - przypuszczeń, M. Skarżyński posłał e-mailem $31 \mathrm{~V} 2017 \mathrm{r}$. próbkę zasobu (zdjęcia fiszek z hasłem BYĆ) do piszącego te słowa i do H. Karaś. Odpowiedź obydwojga była taka sama - to kartoteka SKarł.

\section{Kartoteka SKarł}

Kartoteka mieści się w ośmiu tekturowych pudłach, które podpisano: Hasła do Słownika języka polskiego. W szczegółach wygląda to w następujący sposób:

\begin{tabular}{lll} 
Lp. & Zakres haseł & Wielkość zasobu w m.b. \\
\hline 1 & A - GAŁTAĆ & 0,54 \\
2 & GAŁUCH - KUDRÁK & 0,49 \\
3 & KUDRYS - NOWOTA & 0,48 \\
\hline 4 & NOWSIE - POSTRZEBA & 0,57 \\
\hline 5 & POSTRZEDNI - SKAPCANIAŁY & 0,48 \\
\hline 6 & SKAPSUNIEĆ - TRZY & 0,49 \\
7 & UORAĆ - ZAGONKA & 0,43 \\
\hline & TRZYĆ - TŹ, & 0,34 \\
\hline
\end{tabular}

Pudła 1-3 oraz 5-8 mają jednakowe wymiary: 270 x 335 x 105 mm, większe od nich jest pudło 4: $260 \times 430 \times 100 \mathrm{~mm}$. Poza fiszkami zostały w nich umieszczone przekładki tekturowe i drewniane, wskazujące, gdzie zaczynają się hasła na daną literę.

2 Bardzo dziękuję dr Ricie Majkowskiej za udostępnienie zbiorów Archiwum Nauki PAN i PAU w Krakowie. 
W ostatnim pudle jest 76 przekładek ułożonych obok siebie. Można domniemywać, że były wykorzystywane podczas przygotowywania kartoteki do druku.

\subsection{Fiszki - informacje ogólne}

Uwagi na temat fiszek należy poprzedzić informacją o charakterze ogólnym, a przy tym wpływającą na ocenę tego zbioru, mianowicie kartoteka powstawała przez około 30 lat (Kryński 1904: 125). Widać więc w tym zasobie upływ czasu i nie chodzi tu tylko o stopień uszkodzenia poszczególnych fiszek i różnice w dbałości o czytelność zapisu. Świadectwem powstawania kartoteki jest m.in. naklejanie fiszek jedna na drugą. Karłowicz starał się w ten sposób uniknąć dubletów, a także połączyć hasła powiązane morfologicznie (np. na fiszce ODECNĄĆ zostały doklejone fragmenty dwóch kolejnych, zob. fot. 1). Robił to sam (na naklejanych fiszkach i fiszkach podstawowych widnieje jego pismo), co dowodzi, że podczas ekscerpcji wydawanych przez lata materiałów ludoznawczych i dialektologicznych uzupełniał wcześniejszy zasób. Na niektórych doklejonych fiszkach jest pismo innych osób, czyli - jak można sądzić - informatorów przysyłających Karłowiczowi swoje zbiory. Z kolei świadectwem pracy redakcyjnej są różnokolorowe (czerwone, niebieskie, żółte, zielone) podkreślenia ważniejszych form, a także przekreślenia cytatów (zob. fot. 2, 3). Pojawiają się one przede wszystkim w pudłach 1-4, można więc założyć, że są dziełem Karłowicza (do druku przygotował w całości dwa pierwsze tomy SKarł i początek trzeciego, do litery $O$ ).

Na przykładzie fiszek widać, jak przybywało prac naukowych. Jako jedno z ważniejszych źródeł do SKarł posłużył Lud Oskara Kolberga. Cytaty z tomów od Sandomierskiego do Kujaw są na fiszkach oznaczane cyframi ujętymi w kółko, np.: (2), a z późniejszych tomów pieczątkami, np.: Kg.Krak-2-475. Rozszyfrowanie tego i podobnych skrótów nie jest trudne: Kg - Kolberg, Krak - Krakowskie, 2 - numer tomu, 475 - numer strony. Pieczątki zostały też przygotowane np. dla „Rozpraw Komisji Językowej AU” (RA), „Prac Filologicznych” (PFil) i pracy Jana Świętka Lud nadrabski (od Gdowa po Bochnię) (Świętek). Ostatecznie w SKarł zastosowano inne skróty, odpowiednio: Krak., Rozpr., Pr. fil. i Święt.

W zdecydowanej większości fiszki mają rozmiar 75 x $140 \mathrm{~mm}$, są ułożone w pozycji pionowej (krótszym bokiem do góry). Niewielka część pochodzi z innego zbioru. Mają taką samą wielkość, ale zostały przygotowane na grubszym i ciemniejszym papierze. Pierwotnie były ułożone w inny sposób, na co wskazują (poza orientacją pisma) uszkodzenia wzdłuż dłuższego boku (zob. fot. 4). Co to za fiszki i skąd pochodzą? Najprawdopodobniej jest to część kartoteki Słownika warszawskiego (SW). Jak wiadomo, J. Karłowicz równolegle pracował nad trzema słownikami, które Erazm Majewski nazwał „trzema piramidami” (1904: 24): SW, SKarł i Słownikiem wyrazów obcego a mniej jasnego pochodzenia używanych w języku polskim (SWOKarł). 
266

MACIEJ RAK

Zebrane do SW słownictwo, które miało charakter gwarowy, ostatecznie w większości zostało włączone do SKarł. Przemawiają za tym także kwalifikatory umieszczone na tych właśnie fiszkach - prow. i gm. Jest rzeczą zrozumiałą, że tego typu informacje w kartotece słownika gwarowego nie miałyby sensu, przecież całość zgromadzonego tam słownictwa - używając ówczesnej terminologii - miała charakter prowincjonalny czy też gminny. Są to kartki ze zbioru, gdzie takie kwalifikatory miały znaczenie. Dodajmy, że spotykamy je regularnie w SW (por. Spis skróceń (SW I: VII-VIII)). Mając dostęp do obydwu kartotek, Karłowicz włączył fiszki gwarowe z kartoteki SW do kartoteki SKarł. Także redaktorzy SW korzystali z SKarł. Dotyczą tego listy Mieczysława Karłowicza do Jana Łosia z 4 i 14 V 1905 r. (sygn. Bibl. Nauk. PAU i PAN, Rkps 2270), w których prosi on o udostępnienie im kolejnych złożonych do druku materiałów słownikowych.

Odeenpé.

kel. xxy, 386.

Odechinac Krasn. 306

(4) 197

Iof 41 "odeck = "Ocknal"?

Go144 ödeck Tyocrynces

$\mathrm{Kg} \cdot \mathrm{POZN}$ - \& $22^{\mathrm{X}} \mathrm{Z}$ odesnij $=$ "ode

Aniej" (olueds's)

Ciss: 1/10b rtencely

liss: 1/133 obcenui

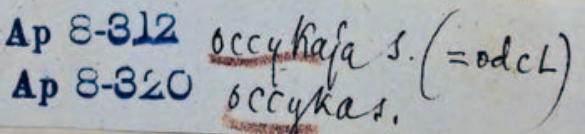

Cise, ifo odesion

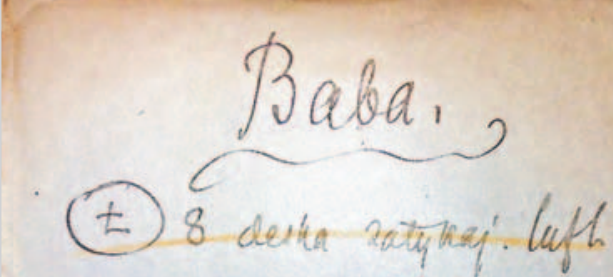

$\mathrm{KgMn2}^{2}-93$ = Anuserha

KgK $1-7$ riadi baba, bafuany

- Checinauh W.habio DwP.al Pfil 3 - 359 rot, pece $a=a_{\text {kaicha }}$

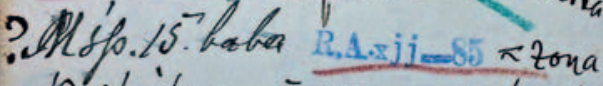

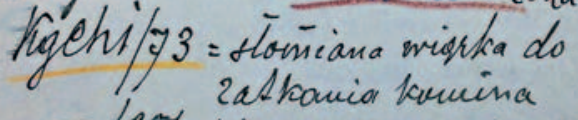

- $125 \%$ 位

$4.14-28$ baluy fat Gruesed)

$1 / 214 / 133$ babki = Griaecy/Hejaik

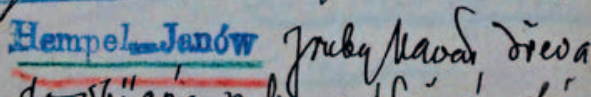

तovbyana pali, oyffacana oleju NK. 94 2c16oia. of "ide 26 abget i6. $132=18$ tar, ccoorkien.

Fot. 1

Fot. 2 


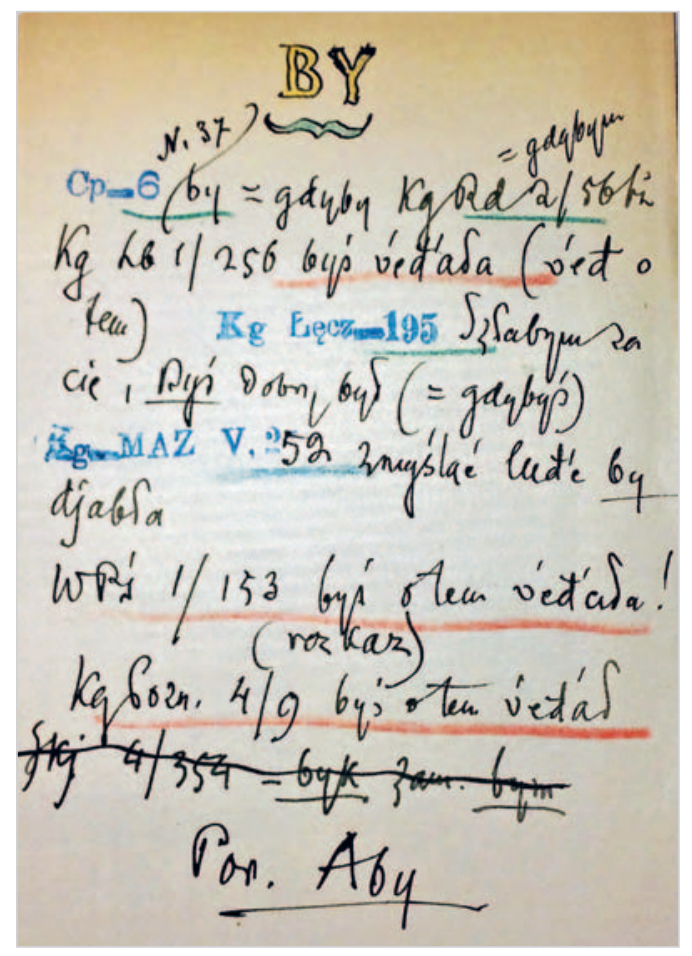

Fot. 3

\section{Obciaglac ' prow. naciaggnace = zedréc, obedréc}

- Sekara manuf ucrcivego', ten was nie obciggnie, a un "rovic mosie. Kionkurs Gas. Inviaf.r. 1893.

Fot. 4

Najczęściej fiszki są zapisane jednostronnie (w przypadku bogatszego hasła informacje pojawiają się na obydwu stronach), niektóre zostały wycięte z kartek wcześniej zużytych, z jednej strony zadrukowanych. Jeśli kilka lub kilkanaście fiszek składa się na rozbudowane hasło (np. BYĆ, BY, TRZY, ZA), to ponumerowano je w górnym prawym rogu i włożono w papierową okładkę z nagłówkiem. 


\subsection{Fiszki a wydrukowany SKarł - różnice}

Łącznie fiszki zajmują 3,82 m.b., z kolei SKarł zawiera około 50 tys. haseł wraz z odsyłaczami (Koniusz 2001: 27; Karaś 2011: 97). Karłowicz w korespondencji do Akademii Umiejętności (patrz niżej) raz podawał liczbę 50 tys. fiszek (PAU KSG 3251/1898), raz 60 tys. (PAU KSG 3604/1899). Jeśli przyjąć, że $1 \mathrm{~cm}$ b. to 100 fiszek (takie obliczenia stosuje zespół redakcyjny SGP w odniesieniu do swojej kartoteki), to w pudłach powinno być nieco mniej niż 40 tys. kartek. Być może mamy tu do czynienia z zawyżającą pomyłką Karłowicza albo też chodziło mu o liczbę haseł słownikowych. Jak pokazuje przykład fiszki GIZD (zob. fot. 5a, 5b), na jednej kartce (zapisanej z obydwu stron) znajduje się dziewięć wyrazów powiązanych morfologicznie, por.: gizd (r.m.), gizda (r.ż.), gizdała, gizdawy, gizdoń, giździć, giździak, gizdak, gizdula, które w SKarł (II: 78-79) zostały ujęte w siedem haseł słownikowych.
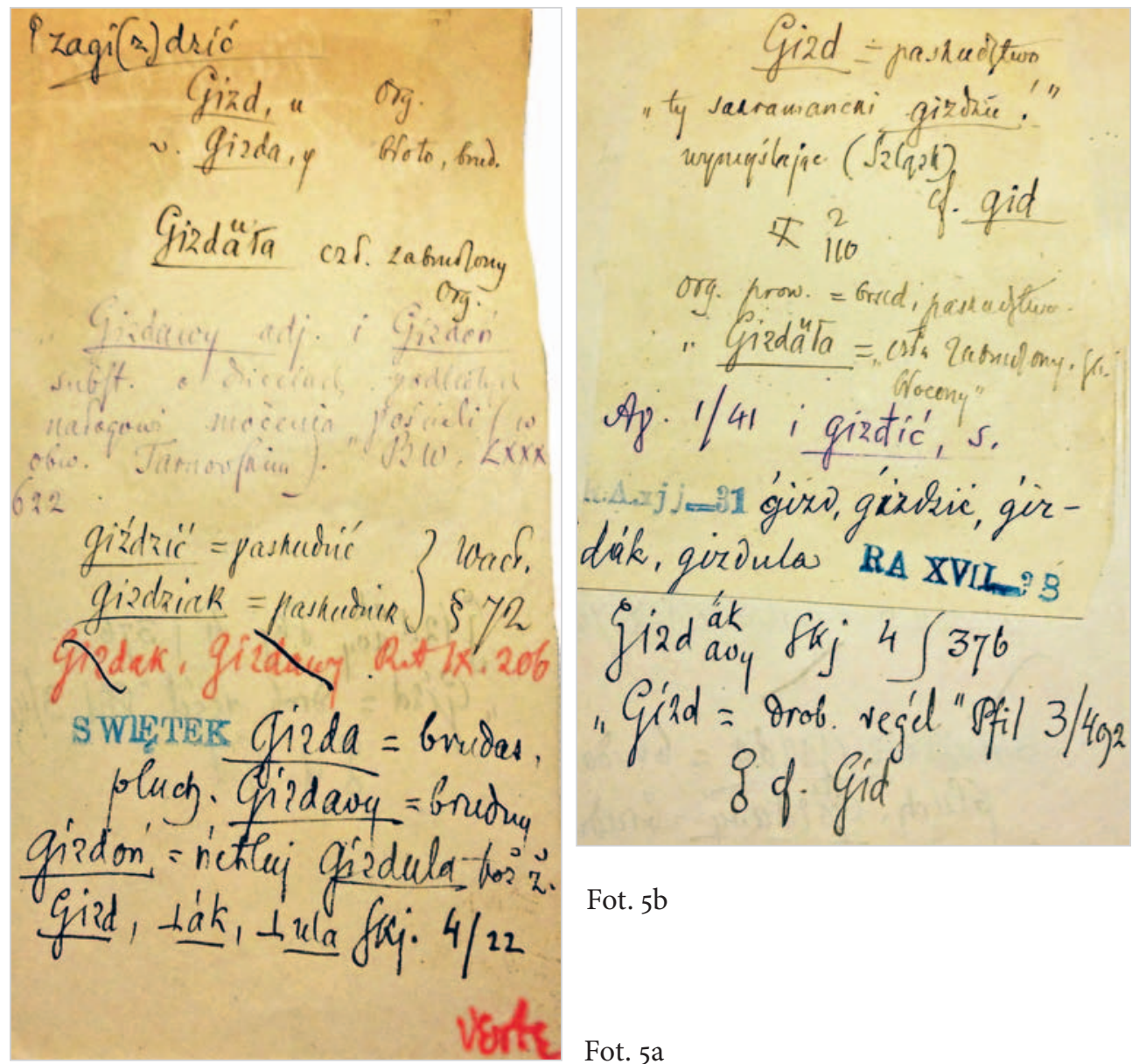

Fot. 5b

Fot. 5a 
Różnice między fiszkami a opracowanymi na ich podstawie hasłami SKarł mogą dotyczyć kilku rzeczy (poza wskazanymi już niezgodnościami w zakresie skrótów źródeł oraz nieadekwatnością liczby fiszek do liczby haseł):

1) nagłówek na fiszce czasem jest rozbudowany o dodatkowe informacje, np.: BIJAK $i z d r o b n$. albo $\underline{\mathrm{BYCH}} z a m$. bym. Oczywiście w SKarł mamy tylko hasło BIJAK (I: 85), z kolei fiszka $\underline{\mathrm{BYCH}}$ zam. bym została włączona do hasła BY (I: 144-146).

2) w kartotece pojawiają się fiszki opracowane na podstawie pól znaczeniowych (SKarł nie respektuje takiego układu, bo jest to słownik wyrazowy, a nie tematyczny). I tak, na fiszce, dla której nadrzędny jest kwalifikator łow., został umieszczony następujący zapis: skromny - zając tłusty; kraśny - jeleń tłusty; sadlisty - dzik tlusty; oblany, żerny - ptak (czasem i zwierze) tłusty; pyszna v. piczna - kuropatwa tlusta; sytna - gęś ttusta. Informacje te figurują w SKarł jako jedno ze znaczeń haseł: SKROMNY (V: 158), KRAŚNY (II: 471), SADLISTY (V: 95), OBLANY (III: 358), PYSZNY (IV: 460) i PICZNY (IV: 85). Przy hasłach SYTNY (V: 278) i ŻERNY (VI: 443) nie ma podanego znaczenia łowieckiego ani przykładów, które by je obrazowały, a jedynie przy haśle PICZNY znajdziemy kwalifikator myśl.

Z kolei na fiszce GROŃ zostało umieszczone odesłanie do JUHASA i REDYKAĆ. Ta relacja (przynależności do jednego pola znaczeniowego - 'Pasterstwo wysokogórskie') nie została jednak w żaden sposób zasygnalizowana w SKarł.

3) przy niektórych wyrazach podano ich pochodzenie, np.: SKARPNY $z$ czesk.; SKIERZEWA $z$ czesk.; GRAP niem. Grapen; GROŃ słc. Karłowicz ostatecznie pominął te informacje w SKarł, gdyż przygotowywał osobny słownik poświęcony etymologii (wspomniany już SWOKarł3). W 1878 r. przesłał na konkurs leksykograficzny im. Samuela B. Lindego Słownik wyrazów cudzoziemskich w języku polskim używanych, ze szczególnym względem na ich słoworód. Znalazły się tu hasła od a do chwat ${ }^{4}$. Praca ta została nagrodzona (II nagroda) na początku 1879 r., a później rozszerzona do SWOKarł.

4) w kartotece liczniej niż w SKarł pojawiają się kwalifikatory socjolektalne, np.: łow. (WYNOSIĆ - o wilku 'zjadać'), złodziejs. (MAJCHER 'nóż'), które w inny sposób zostały oddane w SKarł. Zamiast łow. wprowadzono skrót myśl., znajdziemy go np. w hasłach PICZNY (IV: 85) i WYNOSIĆ (VI: 215). Z kolei w przypadku wyrazu MAJCHER zamiast skrótu mamy informację opisową: 'nóż' (w gwarze złodziejskiej) (III: 99).

5) w kartotece częściej niż w SKarł pojawiają się informacje geograficzne. Służą temu niekonsekwentne skróty, np. słownictwo zanotowane w Galicji jest określane

3 Słownik ten był już przedmiotem kilku opracowań (Koniusz 2005b; Karaś 2014; Rutkovska, Praškevič 2016).

4 Taki zakres hasłowy tej pracy został podany we wstępie (Od rodziny autora) do SWOKarł. Z kolei Czesław Pankowski (1979: 415) i Halina Karaś (2014: 190) za Haliną Horodyską (1989) podają, że zgłoszony na konkurs słownik obejmował hasła od $a$ do chrzest. 
na dwa sposoby: w Galicji (np. SKARZYĆ), galic. (WYTYCZYĆ), leksyka góralska została oznaczona jako: Karp. (BABA ‘żona'), góral. (SOŁEK - góral. SANDEC) i podhal. (GROŃ). Oczywiście, można to próbować wyjaśnić w taki sposób, że Karp. to oznaczenie leksyki z gwar karpackich od Śląska po Huculszczyznę (słownictwo huculskie też w pewnym zakresie znalazło się w SKarł, co skrytykował Nitsch (1911/1958: 198-199)). Jednak, jak pokazują cytaty, chodzi tu głównie o Podhale i tereny przyległe od północy, np. Sądecczyznę5. Leksyka śląska jest opatrzona kwalifikatorem Szlązk (np. BYCH, STEMPEL). Poza tym mamy jeszcze inne odesłania geograficzne: od Suwałk (SŁABIDUDA), litews. (SPORZYZNA), Lida (GARŁO), $z$ nad Pilicy (jedno ze znaczeń przyimka ZA), Czerw. Ruś (WYTŁOCZYĆ), lubel. (NIESPORY), podlas. (SMOLONY) i sand. (jedno ze znaczeń modulantu PRAWIE).

W SKarł najczęściej tych informacji brak (co - jako jedno z najpoważniejszych zaniedbań - podniósł Nitsch we wspomnianej już recenzji), o zasięgu geograficznym słownictwa można jedynie wnioskować na podstawie pochodzenia cytatów z poszczególnych regionów. Czasem jest to też ujęte w formie opisowej, np. SOŁEK spichlerz u górali w Sądeczczyznie (SKarł V: 188).

6) informacje fleksyjne są bogatsze w kartotece niż w SKarł. Na fiszce SKARZYĆ zam. S... SIE znajdujemy odmianę tego czasownika, por.: skardzyła, skardzi sie, skar-zyło, skardzyć, skardzyli, skardzy (hasło SKARŻYĆ (SKarł V: 141) jest pod tym względem uboższe). Informacje fleksyjne rozsiane tu i ówdzie na fiszkach i w dużo mniejszym stopniu w SKarł (tę niekonsekwencję krytykował Nitsch) być może Karłowicz gromadził z myślą o przygotowaniu wzoru odmian. W Przyczynkach do projektu wielkiego słownika polskiego pisał bowiem:

odmiany wyrazów, skoro należą do zasad, którym ulega pewna znaczna gromada słów, powinny by się znajdować w kształcie wzorów na początku każdego tomu; pod wyrazem przeto, mówiąc o jego odmienni, odprawiłoby się czytelnika do odpowiedniego wzoru... (Karłowicz 1876: 23).

7) ikonografia. Na fiszce SPISEK (zob. fot. 6) ręką Karłowicza został narysowany tzw. krzyżyk niespodziany, według góralskich legend jeden ze znaków ukrycia skarbów, ale także apotropeion, symbol przynoszący szczęście. Był to podobno ulubiony znak M. Karłowicza, został więc wykuty na granitowym obelisku, który stoi w miejscu jego śmierci, u podnóża Małego Kościelca w Tatrach Wysokich. Oczywiście w SKarł nie ma ikonografii (nad czym ubolewał Nitsch (1911/1958: 219)), krzyżyk niespodziany został więc pominięty.

5 Jak Karłowicz traktował granice Podhala i czy w ogóle temat ten go zajmował - dziś nie sposób rozstrzygnąć, pewne jest natomiast to, że w jego czasach, jeśli idzie o Karpaty, najwięcej wiedziano o słownictwie podhalańskim i huculskim. 


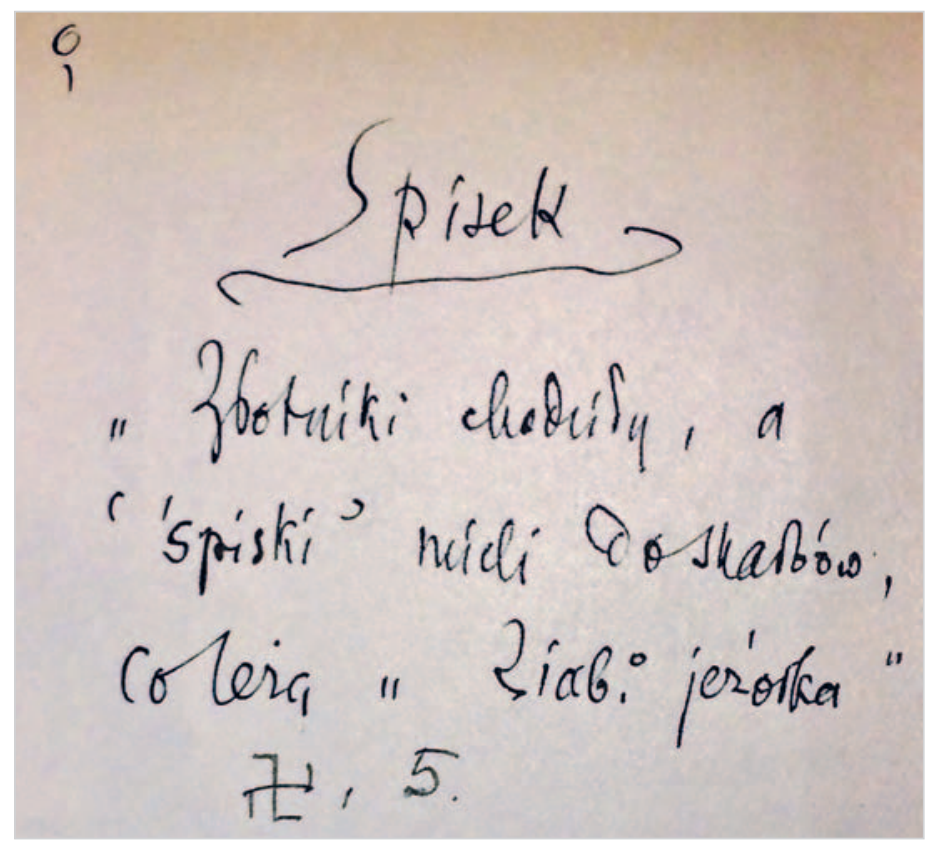

Fot. 6

\subsection{Znak 9}

Na większości fiszek znajduje się znak (por. fot. 5a, 6). Co on oznacza? Podpowiedź znajdziemy w przywoływanych już Przyczynkach do projektu wielkiego słownika polskiego (Karłowicz 1876; więcej zob. Sokólska 2013). Tę właściwie pierwszą w polskim słownikarstwie pracę z zakresu metodologii pisania słowników należy widzieć w kontekście rozwoju nauki. Wraz z utworzeniem w Krakowie Akademii Umiejętności (1872 r.) pojawiły się głosy, by Komisja Językowa AU zadbała o nowy słownik języka polskiego, lepszy niż SWil i aktualniejszy niż SL, czyli właśnie Wielki słownik polski. Jego wielkość miała polegać na zgromadzeniu całości polskiego słownictwa. W Przyczynkach... Karłowicz wyłożył m.in. Pogląd na słowozbiór polski (Karłowicz 1876: 1-6), w którego obrębie wyróżnił wyrazy czystopolskie i obce, powszechne (wszechpolskie) i mniej powszechne (prowincjonalne oraz techniczne), a także dawnopolskie i nowopolskie. Wyrazy prowincjonalne zdefiniował w następujący sposób:

[są - M.R.] używane w niektórych tylko okolicach kraju, po większéj części przez lud niepiśmienny; wyrazy te można nazwać ludowémi, niepiśmiennémi, nieksiążkowémi, lub, jak chcą niektórzy, powiatowszczyznami (ibid.: 4).

Jak widać, chodzi tu o słownictwo gwarowe (przekonuje o tym również Objaśnienie skróceń do SWOKarł, wśród których 9 a. gw. = wyraz gwarowy (prowincjonalizm) (SWOKarł: 411)). Dziś prowincjonalizm ma inne znaczenie (bliskie regionali- 
zmowi, ale z negatywną konotacją), a powiatowszczyzna ${ }^{6}$ została całkiem zarzucona (zob. Karaś 1961: 165). Regionalizmy we współczesnym ujęciu według Karłowicza (1876: 4) należą do słownictwa powszechnego (wszechpolskiego).

Sprawa prowincjonalizmów, czyli słownictwa gwarowego, w planowanym Wielkim słowniku polskim nie była jednak przesądzona, skoro Karłowicz zaznaczył:

Rozstrzygnięcie zasady, czy prowincjonalizmy mają wejść w skład Wielkiego Słownika radzę odłożyć także do tegoż trzylecia. Tymczasem zaś nikt nie wątpi, że prowincjonalizmy gromadzić należy; jeżeli zaś ostatecznie postanowiono będzie, iż nie wejdą do Słownika, to się ogłoszą oddzielnie, a czas użyty na ich zbiéranie z pewnością nie będzie stracony (ibid.: 5).

W dwóch miejscach w Przyczynkach... znajdujemy precyzyjne uwagi na temat znaku $\mathrm{P}$ :

Na pewne wyrazy, bardzo często mające się powtarzać w Słowniku, proponowałbym pewne umówione znaczki, np. na wyrażenie prowincjonalności znaczku $९$ (ibid.: 10).

[...] prowincyjonalizmy polskiego pochodzenia powinny być wymienione i pod pniem odpowiednim, z nadmienieniem wszakże, iż są prowincyjonalizmami; dla krótkości pisma raczyłbym je odróżniać umówionym znaczkiem 9 (ibid.: 44).

Przykładowe hasło gazda również zostało zaopatrzone w omawiany znak, dzięki czemu od razu widać, że jest to wyraz gwarowy, por.: „९Gazda. m. i ż? = gospodarz” (ibid.: 56). Znak $Q$ był także stosowany w SWOKarł, np.: $९$ Atwor (SWOKarł: 19); QCiwun, ९Cywun, QCiun, ९Cijun, PTywon, QTywun, QTywun (ibid.: 103); PKierdel, QKirdyl, QKyrdel, [...] QSkierdź (ibid.: 269).

Jakie konsekwencje ma ten cały wywód dla fiszek i kartoteki SKarł? Dowodzi, że Karłowicz przynajmniej przez pewien czas brał pod uwagę możliwość włączenia zbiorów gwarowych do Wielkiego słownika polskiego. Jak się okazało, nie doszło to do skutku. Niezależnie ukazały się więc SKarł i SW.

\subsection{Znak ${ }^{\circ}$}

Ten z kolei znak nie pojawia się ani w innych dziełach leksykograficznych Karłowicza, ani też w Przyczynkach... Jego znaczenia i funkcji można się jedynie domyślać na podstawie użycia na fiszkach (zob. fot. 5b). Najprawdopodobniej jest to odsyłacz do wyrazu podstawowego, od którego pochodzą inne.

6 Terminu tego Karłowicz używał także w innych pracach. W Poradniku dla zbierających rzeczy ludowe (Karłowicz 1871: 4) wyrażał przekonanie o potrzebie przygotowania słownika prowincjonalizmów (powiatowszczyzn). 
Mieści się to w programie leksykograficznym Karłowicza, w którym ważne miejsce zajmował postulat oddzielenia słownictwa rodzimego od obcego:

Uwzględniając przeto czysto praktyczną potrzebę, sądzę, że najwygodniéj będzie podzielić wyrazy Słownika na następujące skupienia:

I. Wyrazy czystopolskie nowsze, powszechne, czyli wszechpolskie.

II. Staropolskie.

III. Prowincyjonalne (polskiego i obcego pochodzenia).

IV. Obce, własne i odwłasnoimienne.

V. Techniczne (polskiego i obcego pochodzenia).

VI. Pnie i może spisy rostków (o których $\$ 14$ ) (Karłowicz 1876: 3-4).

Droga do tego prowadziła przez ustalanie wyrazów podstawowych - dopiero w obrębie tej grupy można było dokonać szczegółowego podziału.

\section{Proces wydawniczy kartoteki SKarł w świetle materiałów źródłowych ${ }^{7}$}

Pierwszym śladem działań Karłowicza mających na celu opublikowanie SKarł jest list z 8 V 1898 r. przechowywany w krakowskim Archiwum Nauki (PAU KSG 3251/1898), w którym zwracał się on do AU o pokrycie kosztów druku, por.:

Do Prześwietnej Akademii Umiejętności w Krakowie

Od lat kilkunastu ${ }^{8}$ zbierałem wyrazy gwar polskich, przeważnie ze źródeł drukowanych i obecnie posiadam ich około 50 tysięcy. Przed kilku laty rozpocząłem układanie ich w słownik szczegółowy, zawierający przytoczenia frazesów i wskazanie dzieła, tomu i strony, skąd frazes został wypisany. Doprowadziłem obecnie robotę do połowy głoski $K^{9}$ i jeżeli los da mi pożyć jeszcze 3 do 4 lat, mam nadzieję dzieło ukończyć. Na wypadek wcześniejszej śmierci mojej, sporządziłem wskazówki dla osób, które by mogły dokończyć pracę moją i obmyśliłem sposoby ku zabezpieczeniu lokalu ${ }^{10} \mathrm{i}$ książek, niezbędnych ku temu celowi. Obecnie pragnąłbym rozpocząć druk gotowej części rękopisu, lecz nie posiadam środków na to, postanowiłem udać się do Akademii z zapytaniem, czyby nie raczyła wyłożyć kosztów na ogłoszenie Słownika gwar polskich, który w całości objąć może około stu arkuszy w ósemce większej. Honorariów nie pragnę, korektę sam bym prowadził, własność dzieła przekazałbym

7 Do większości z tych dokumentów dotarła wcześniej E. Koniusz (2001), nie podała ich jednak w całości. W niniejszym artykule prezentuję materiały źródłowe dotyczące SKarł bez żadnych skróceń i z odpowiednim komentarzem.

8 Nie jest to precyzyjna informacja. Jak już pisałem, gromadzenie słownictwa gwarowego do SKarł trwało ok. 30 lat.

9 Wynika $\mathrm{z}$ tego, że w połowie $1898 \mathrm{r}$. do druku były już przygotowane dwa pierwsze tomy SKarł.

10 Jak wynika z korespondencji Mieczysława Karłowicza (BN PAU i PAN, Rkps 2270), kartoteka do SKarł znajdowała się w warszawskim domu Karłowiczów (ul. Jasna 10). 
Akademii, prosząc dla siebie tylko o kilkanaście egzemplarzy Słownika. Jeżeli prośba moja okaże się wykonalna, a Akademia tego zażąda, gotów jestem nadesłać cząstkę pracy mojej na okaz. Druk można by niezwłocznie rozpocząć.

Oczekując łaskawej odpowiedzi, zasyłam wyrazy głębokiego poważania

Jan Karłowicz

5 maja 1898 r., Warszawa, Jasna, 10.

AU skorzystała z gotowości przesłania przez Karłowicza próbki słownika, na co wskazuje kolejny list z 24 II 1899 r. (PAU KSG 3599/1899), adresowany do Stanisława Smolki, sekretarza generalnego AU:

Szanowny Panie Profesorze,

22.2.1899, Warszawa, Jasna, 10

Stosownie do pozwolenia Pańskiego przesyłam próbkę słownika mojego gwar polskich, donosząc, że gotów jestem druk jego rozpocząć chociażby niezwłocznie. O zwrot próbki upraszam (przez księgarnię Gebethnera).

Łączę przy tym wyrazy prawdziwego poważanie dla Szanownego Pana Profesora.

Sługa powolny

J. Karłowicz

Jako załącznik do tego listu Karłowicz umieścił przedmowę (PAU KSG 3599/1899) do SKarł znacznie szerszą niż umieszczona w I tomie, por.:

\section{Przedmowa tymczasowa do Słownika gwar polskich}

Zamierzając, po ukończeniu całości druku Słownika, dodać obszerniejszą przedmowę ${ }^{11}$, w której opowiem dzieje ułożenia jego, wymienię szczegółowo źródła, z których go czerpałem i osoby ${ }^{12}$, które mi zasobów dostarczały, oraz zastanowię się nad potrzebą i pożytecznością Słownika, dołączam tymczasem słów kilka ku wyjaśnieniu zasad i sposobów, których się trzymałem przy sporządzaniu jego, mianowicie na względzie przytoczeń i pisowni.

Pragnąłem Słownik mój uczynić źródłowym, to jest, pomieszczając w nim dosłownie powtórzone teksty ze źródeł gwaroznawczych, oszczędzić korzystającym z niego osobom zaglądania do tych źródeł. Urosła znacznie przez to objętość Słowni$k a$, ale, być może, zwiększyła się jego użytecznośćc ${ }^{13}$.

Zapisywano u nas teksty ludowe najrozmaitszemi pisowniami. Na pierwszy rzut oka, zdawać by się mogło, że obowiązkiem słownikarza byłoby zupełnie wierne po-

11 Jest to zaskakująca informacja, gdyż przywykliśmy, że przedmowę umieszcza się na początku wielotomowej publikacji, a nie na końcu.

12 Spis osób nie został ostatecznie przygotowany.

13 Posunięcie to należy oczywiście uznać za właściwie. Dzisiejsza praktyka leksykograficzna (zwłaszcza jeśli idzie o słowniki gwarowe) przypisuje cytatom bardzo duże znaczenie. Nie tylko służą one potwierdzeniu znaczenia ujętego w definicji, ale także wskazują na łączliwość wyrazu i przekazują informacje etnograficzne, których obecności w słownikach gwarowych dziś już nikt nie neguje. 
wtarzanie tekstów, bez zmiany pisowni (transkrypcji). Lecz krótkie zastanowienie się przekona każdego, że taki sposób wytworzyłby w Słowniku istną wieżę Babel: dosyć jest bowiem zajrzeć do „Zbioru Wiadomości do Antropologii Krajowej” (obecnie „Materiałów Antropologiczno-Archeologicznych i Etnograficznych”), do dzieł Kolberga i innych zbieraczów rzeczy ludowych, do „Wisły” i do jej „Biblioteki”, do „Rozpraw Wydziału Filologicznego” [AU - M.R.], do „Sprawozdań Komisji Językowej” i do licznych innych źródeł naszych ludoznawczych, aby się przekonać, jaka panuje rozmaitość w oddawaniu tych samych brzmień gwarowych.

Zdawało mi się przeto, iż nakazane było ujednostajnienie pisowni, gdy chodziło o kodyfikację, że tak powiem, gwar naszych. Najprostszą drogą do ujednostajnienia tego wydawało mi się przyjęcie ortografii literackiego języka naszego za podstawę, na której znakami różnicującemi można było (przynajmniej do pewnego stopnia) wycieniować rozmaitość wymawiania gwarowego. Zupełna wierność i dokładność w odtwarzaniu jego, jak wiadomo, nie daje się całkowicie osiągnąć pismem: pewna ilość odcieni zawsze pozostawiona być musi własnemu badaniu lub domyślności czytelnika. W Słowniku mniej jeszcze, aniżeli w monografiach gwaroznawczych, można było marzyć o tem; toteż niektóre drobniejsze odcienie wymawiania musiały być w nim pominięte, co nie przeszkadza, że w obszernej przedmowie, dodać się mającej po ukończeniu dzieła, wymienione będą wszystkie źródła Słownika i wskazane te w nich opisane odcienie wymawiania, które z konieczności opuszczono w Słowniku; takich zresztą jest stosunkowo niewiele ${ }^{14}$.

Podaję tutaj znaki, których użyłem na wyrażenie pewnych brzmień gwarowych, w taki sposób, aby pisownia literacka nie przestawała być podstawową. Spis poprzedzam uwagą ogólną, że tam tylko oznaczałem różnicę wymawiania, gdzie źródło ją w ten lub inny sposób wskazało.

1. Utrzymuję znak á na wyrażenie brzmienia a długiego, a w zabarwieniu składającego się ku o, oŭ, np. dziád, gádá itp.

2. Na $a$ nosowe (= francus. en, an) wolałem nie używać ą, dla uniknięcia dwuznaczności; uciekłem się do znaku ã, np. gãba (gamba), gałãziaty (gałanziaty), gádajã (godajom) itp.

3. Na etacyzm, czyli skłanianie się w wymawianiu $a, i, o, u, y$ ku $e$, używam znaków $\stackrel{e}{a}, i \stackrel{e}{i}, \stackrel{e}{O}, u^{e}, \stackrel{e}{y}$, np. råno, pi ${ }^{e} \nmid a, k \stackrel{e}{o c h} a c, p \stackrel{e}{y} s z n y^{i} i t p$.

4. A, pochylające się brzemieniem ku ó, oraz ę przybierające odcień é wyrażam znakami ó,ę, np. sód (sónd), klọtwa (klóntwa), rę́ka (rénka), bę́dzie (béndzie) itp.

5. Zwykle używane znaki é, ó stosuję przede wszystkim do tych gwar, w których się słyszy „prawdziwe” é, ó, tj. pośredniczące między $e-i, y, o-u$; lecz powtarzam też znaki i z takich źródeł, gdzie one tego brzmienia nie mają.

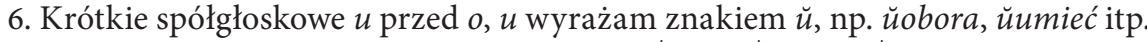

7. Na wymawianie $y$ prawie jak $i$ stosuję znak $\stackrel{i}{y}$, np. s syn, młod $y^{i}$ itp.

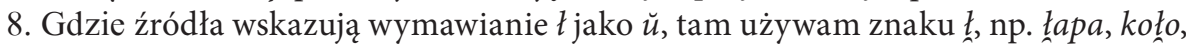
nazywát itp.

14 Mimo to Nitsch (1911/1958: 210) poddał krytyce ortografię zastosowaną w SKarł, zarzucając autorowi chaos, zwłaszcza w sprowadzaniu zapisów kaszubskich do ogólnopolskich. 
9. Kaszubskie $k, g$ upodniebienione oddaję znakami $k^{\prime}, g$, np. po̊ wszïstḱemu, gafelki $i^{e}$ ǵibki, droǵi itp.

10. Rozdzielność w wymawianiu $r z$ wyrażam znakiem $r . z$, np. bar.zo, knár.z itp.

Skróceń używam następnych:

a. $=$ albo

Ust. = ustnie dostarczony wyraz

List. = listownie dostarczony wyraz

Inne skrócenia wyrazów pospolitych nie potrzebują objaśnień.

Źródła ${ }^{15}$ :

Aten. = „Ateneum”

Bal. = Baliński, Powieści ludu

Bar. = Barącz, Bajki, Fraszki itd.

Bibl. War. = „Biblioteka Warszawska”

Bisk. = Biskupski, Die Sprache der brodnitzer Kaschuben

Cen. = Cenova, Zarés do Grammatikj

Chełch. = Chełchowski, Powieści [i opowiadania ludowe - M.R.] z okolic Przasnysza

Cheł. = Kolberg, Chetmskie

Ciesz. $=$ Cieszyński, Der polnischer Apotheker

Cinc. $=$ Cinciała, Przysłowia... w Cieszyńskiém

Cisz. $=$ Ciszewski, Krakowiacy

Choc. $=$ Chociszewski, Powieści i podania

Czark. = Dr Czarkowski, Słowniczek gwarowy z Podlasia ${ }^{16}$

Del. = D(elavaux), Górale Beskidowi

Derd. = Derdowski, O panu Czorlinscim

Derd. J. = Derdowski, Jasiek z kniei

Doman. = Rękopis gwarowy od Domaniewic, w Łowickiem

Dyg. $=$ Dygasiński ${ }^{17}$

Fed. = Fedorowski, Lud okolic Żarek...

Gliń. = Gliński, Bajarz polski

Gluz. = Gliziński, Włościanie polscy (w Wójcickiego Archiwum Dom.)

Goszcz. = Goszczyński, Dziennik podróży do Tatrów

Hemp. = Słowniczek gwarowy $z$ Lubelskiego, rękopis p. Hempla ${ }^{18}$

Hilf. = Gilbferdingъ, Ostatki Slavjanヶ

Jastrz. = Szczęsnego Jastrzębskiego, Słowniczek gwary radomskiej, rękopis

Jaworze. = Ustnie z Jaworza, na Szląsku

Kal. = Kolberg, Kaliskie

Kam. = Kamiński, Chłop polski

Kętrz. = Kętrzyński, O Mazurach

Kiel. = Kolberg, Kieleckie

15 Podane niżej skróty pozostawiam bez rozwinięcia, gdyż dokonał tego J. Łoś (SKarł VI: 457-470). Wyjątek zrobiłem tylko dla tych prac, których tytuł w SKarł jest inny niż w niniejszym wykazie. 
Klecz. = Kleczyński, Melodie zakopańskie

Kon. = Konopka, Pieśni ludu krak[owskiego]

Koz. $=$ Kozłowski, Lud (czerski) ${ }^{19}$

Krak. = Kolberg, Krakowskie

Kolb. = Kolberg, Pieśni ludu pols[kiego]

Kopern. = Izydor Kopernicki, glosy na Słowniczku w tomie III „Rozpraw Wydziału Filologicznego"2o

Krasn. = Krasnowolski, Język [ludowy polski] w ziemi chetmińskiej (w Albumie uczacej się młodzieży na cześć Kraszewskiego ${ }^{21}$ )

Kuj. = Kolberg, Kujawy

L. = Słownik Lindego

Lip. = Lipiński, Piosnki ludu wielkopolskiego

Lub. = Kolberg, Lubelskie

„Lud” = „Lud. Organ T[owarzyst]wa Ludoznawczego we Lwowie”

Łęcz. = Kolberg, Łęczyckie

J. Łoś = Jana Łosia rękopiśmienny Słownik gwary sandomier [skiej] $]^{22}$

Łys. = Łyskowski, Pieśni [gminne i przysłowia] ludu [polskiego] w Prusach Zachodnich

Maj. = E. Majewski, Słownik nazwisk botan[icznych $]$ i zoolo[gicznych $]^{23}$

Malin. = Luc. Malinowski, Oppelnische Mundart (patrz Opol.)

Matusiak Kw. = Matusiak, Nasze kwiaty polne

Mát. P. = Mátyás, Podania i baśnie [krakowskie]

Mát. Szczep. = Mátyás, Podania ze Szczepanowa

Maz. = Kolberg, Mazowsze

Mrong. = Mrongowiusa, Słowniki $i^{24}$

Nadm. = Nadmorski, Kaszuby i Kociewie

O. = Słownik języka polskiego wydany przez Orgelbranda

Oles. = Wacław z Oleska, Pieśni [polskie i ruskie] ludu galicyjskiego

Opol. = Luc. Malinowski, Oppelnische Mundart ${ }^{25}$

Osip. = Osipowicza rękopiśmienny Słownik gwary augustowskiej

Parcz. = M(elani)i Parczewskiej rękopiśm[ienny] Słowniczek gwary kaliskiej

Pauli = Pauli, Pieśni ludu pol[skiego] $w$ Galicji

Pawł. = Pawłowicz, rękopisy gwaroznawcze z Galicji ${ }^{26}$

Petr. $=$ A. Petrow, rękopisy gwaroznawcze ${ }^{27}$

Piątk. = I. Piątkowska[-Kuczkowska], rękopiśm[ienny] Słownik gwary sieradzkiej

19 Poprawnie: Pieśni, podania, baśnie, zwyczaje i przesądy ludu z Mazowsza czerskiego.

20 Chodzi tu o rękopiśmienny Słowniczek gwary góralskiej.

21 Poprawnie: Album uczącej się młodzieży polskiej, poświęcone J.I. Kraszewskiemu.

22 W SKarł: Słowniczek gwary opoczyńskiej (niektóre wyrazy z Opatowskiego).

23 W SKarł: Stownik nazwisk zoologicznych i botanicznych polskich.

24 Dokładniej: Nowy słownik polsko-niemiecki, w którym osobliwie na dobrą niemczyznę wzglad miano, Kwidzyn 1794, Słownik niemiecko-polski. Deutsch-polnisches Handwörterbuch nach Adelung und Linde bearbeitet, t. 1-2, Gdańsk 1820-1823.

25 Prawidłowo: Ueber die Oppelnsche Mundart in Oberschlesien.

26 W SKarł: Stowniczek gwary od Tarnowa.

27 W SKarł: Słowniczek gwary Polaków litewskich. 
Pleszcz. = Pleszczyński, Bajarzy międzyrzeccy

Pobł. = Pobłocki, Słownik kaszubski

Połuj. = Połujański, Wędrówki po gub. augustowskiej

Pozn. = Kolberg, Poznańskie

Pr. Fil. = „Prace Filologiczne”

Prac. $=$ J. Prackiego rękop[iśmienny] Słownik wyrazów leśniczych i in. ${ }^{28}$

Przem. = Kolberg, Przemyskie

Przyj. ludu = „Przyjaciel ludu” (dawny)

Rad. = Kolberg, Radomskie

Ram. = Ramułt, Słownik języka pomorskiego [czyli kaszubskiego]

Roczn. = „Rocznik [ces.-król.] Towarzystwa Nauk[owego] Krakowskiego”, t. XLI

Rog. = Roger, Pieśni ludu pol[skiego] $w$ Górnym Szląsku

Rozp. $=$ „Rozprawy [i Sprawozdania z posiedzeń] wydziału filologicznego Akademii

Krak[owskiej]"29

Rud. = Polaczek, Wieś Rudawa [(pod Krakowem)]

Ryk. = Rykaczewski, Słownik języka polskiego ${ }^{30}$

Sab. = A. Stopka, Sabała

Sand. = Kolberg, Sandomierskie

Siark. $=$ Siarkowski materiały rękopiśm[ienne $\mathrm{z}$ Kieleckiego ${ }^{31}$

Siem. = Siemieński, Podania i legendy [polskie, ruskie i litewskie]

Sien. = Sieniawski, Biskupstwo warmińskie

Skrz. = Skrzyńska, Kobieta $w$ pieśni ludowej [(ziemi Lubelskiej)]

Stęcz. = Stęczyński, Tatry $[w$ dwudziestu czterech obrazach $]$

Spr. = „Sprawozdania Komisji Językowej [Akademii Umiejętności w Krakowie]”

Star. przysł. = Starodawne przysłowia dla ochronek

Święt. = Świętek, Lud nadrabski [(odGdowapo Bochnię)] i słowniczek rękop[iśmienny $]^{32}$

Tyg. ilustr. = „Tygodnik ilustrowany”

Udz. = Sew[eryn] Udziela, słowniczek rękop[iśmienny] od Gorlic i Grybowa ${ }^{33}$

Wal. = Walicki, Błędy nasze $w$ mowie i piśmie

Was. = Wasilewski, Jagodne [(wieś w pow. łukowskim, gminie Dąbie)]

Wisła $=$ „Wisła. Miesięcznik gieograficzno-etnograficzny”

Wit. = Witwicki, O Hucułach

Wójc. = Wójcicki, Pieśni ludu Białochorwatów [Mazurów i Rusi znad Bugu]

Wójc. Klech. = Wójcicki, Klechdy [starożytne podania i pieśni ludowe]

Wrześ. = Wrześniowski, Spis wyrazów podhalskich

Wrześ. dod. = Wrześniowski dodatek rękopiśmienny do Spisu wyrazów

Wrześ. T. = Wrześniowski, Tatry i Podhale

28 Łoś (SKarł VI: 462) zidentyfikował tę pozycję jako Słowniczek gwary rybackiej z różnych okolic.

29 Prawidłowo: [...] Akademii Umiejętności w Krakowie.

30 Łoś pominął tę pozycję w wykazie skrótów do SKarł. Chodzi tu o Słownik języka polskiego podług

Lindego i innych nowszych źródeł, wypracowany przez E. Rykaczewskiego, t. 1-2, Berlin 1866. 
Zaw. = Zawiliński, Z powieści i pieśni górali beskidowych

Zb. = „Zbiór Wiadomości do Antropologii Krajowej”

Zejsz. = Zejszner, Pieśni [ludu] Podhalan

Zmor. = Zamorski, Podania i baśni ludu w Mazowszu.

W lutym 1899, Warszawa

Jan Karłowicz

Z tego dokumentu niewątpliwie korzystał J. Łoś. Umieszczony w SKarł (VI: 457-470) Spis skróceń, którego autorstwo zostało właśnie jemu przypisane (Nitsch 1911/1958: 204; Karaś 2011: 95), jest w rzeczywistości rozwinięciem umieszczonego w Przedmowie tymczasowej... wykazu źródeł. Poza rozszerzeniem tego spisu Łoś dokonał również kilku zmian, które nie zawsze szły w dobrym kierunku. Pominął na przykład odesłanie Malin. = Luc. Malinowski, Oppelnische Mundart (patrz Opol.), co Nitsch (1911/1958: 205) niesłusznie uznał za błąd Karłowicza.

Chronologicznie kolejny dokument pokazujący dzieje wydawnicze słownika to Objaśnienia do słownika gwarowego (PAU KSG 3604/1899), które Karłowicz doręczył osobiście Józefowi Tretiakowi, sekretarzowi Wydziału I AU, 6 III 1899 r.:

Do przesłanej próbki Słownika gwar polskich winienem następujące objaśnienia dołączyć.

Doprowadziłem obrobienie Stownika do połowy głoski $K$ i mam kartki po to miejsce w takim stanie gotowości do druku, jak część głoski $G$ przesłana poprzednio Akademii ${ }^{34}$.

Dalszym ciągiem obrabiania zajmuję się nieprzerwanie i mam nadzieję, jeżeli tylko żyć będę, dojść do zupełnego ukończenia Stownika w ciągu lat 3-4.

Ażeby dać pojęcie, co w pracy mojej nazywam obrabianiem materiału, dołączam trzy kartki w naturze, wyjęte z 6o-tysięcznego zasobu Słownika; widać na nich zapiski moje czynione podczas wyzyskiwania źródeł, pisane są one skróceniami, których dokładne wyjaśnienie dołączam do testamentowego zapisu mojego (o którym niżej); tymczasem podaję tutaj te tylko wskazówki skrótów, które są potrzebne do zrozumienia trzech kartek. Obok kartki podaję obrobienie, czyli taki jej wygląd, jaki mieć winna po wypisaniu in extenso odpowiednich ustępów ze wskazanych źródeł. Zestawienie kartki z jej uzupełnieniem daje wyobrażenie o sposobie i mierze roboty, potrzebnej do ostatecznego ułożenia rękopisu.

34 W księgach inwentarzowych Archiwum Nauki PAN i PAU nie ma informacji o przesyłce, która by obejmowała opracowane przez Karłowicza hasła na literę $G$. 


\section{Obrobienie, tj. uzupełnienie tej kartki}

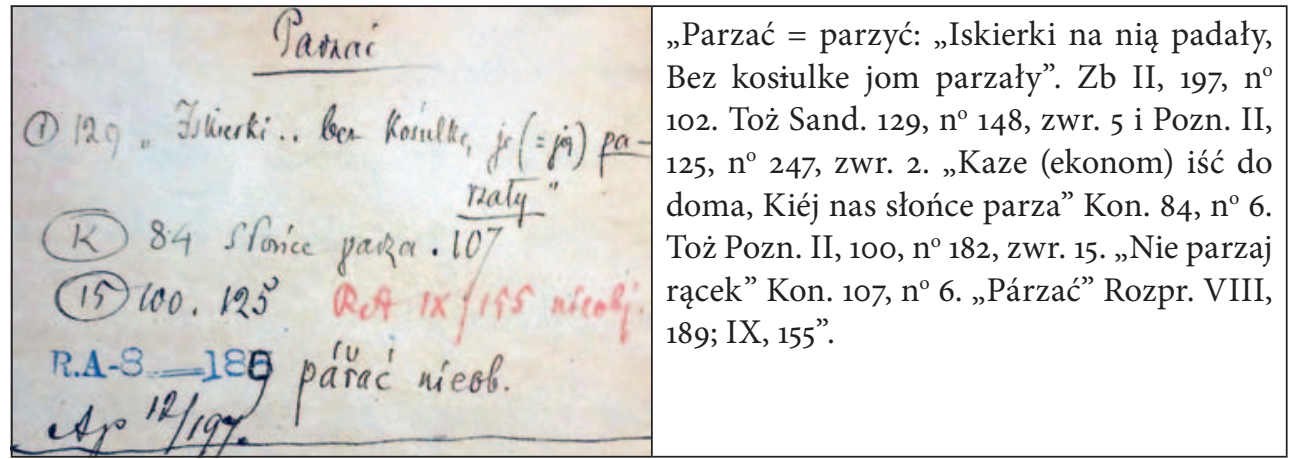

Objaśnienia skróceń:

(1) = Kolberg, Sandomierskie

K = Konopka, Pieśni ludu krak.

(15) = Kolberg, Krakowskie II

$\mathrm{RA}=$ Rozprawy Akademii wydziału filol.

Ap. = Zbiór Wiadomości do Antropologii Krajowej

Porównując obrobienie wyrazu tego z notatką na kartce, widzimy:

1. Że na tej ostatniej używałem nieraz ułatwionej pisowni (transkrypcji) polskiej, zamieniając znakiem zmiękczenia $i$ miękczące (np. $\underline{s}, \underline{c}, \underline{d z}$ itp. zamiast $\underline{s i}, \underline{c i}, \underline{d z i}$ przed samogłoskami), pisząc $\underline{\underline{c}}, \underline{\underline{s}}, \underline{\underline{r}}$ zamiast $\underline{c z}, \underline{s z}, \underline{r z}, \underline{v}$ zamiast $\underline{w}, \underline{\hbar}$ zamiast $\underline{c h}, \underline{d}$ zamiast $\underline{d z}$, $\underline{\text { z }}$ zamiast $\underline{d \dot{z}}$ itp.

2. Że podobne formą i treścią cytaty umieszczałem obok siebie.

Żeby rzecz bliżej wyjaśnić, podaję jeszcze dwa wyrazy na dwóch kartkach i obok nich ostateczne obrobienie. Zobaczymy tu, że:

3. Grupowałem znaczenia, gdy zachodziła tego potrzeba.

4. Starałem się uwydatnić brzmienie gwarowe, gdziekolwiek źródła je wskazywały.

5. Przytaczając źródło, podawałem nie tylko stronę, ale numer pieśni lub ustępu, zwrotki, paragrafu itd.

6. Gdzie opisy zwyczajów były obszerniejsze, tam podawałem tylko treść ich główną, malującą wyraz, a umieszczonym w nawiasach wyrazem opis zwracałem uwagę czytelnika na znajdowanie się dalszych szczegółów w źródle.

7. Opuszczałem notatki odnoszące się do innych kartek. 
Z DZIEJÓW SŁOWNIKA GWAR POLSKICH JANA KARŁOWICZA...

281

Obrobienie tj. wypełnienie tej kartki

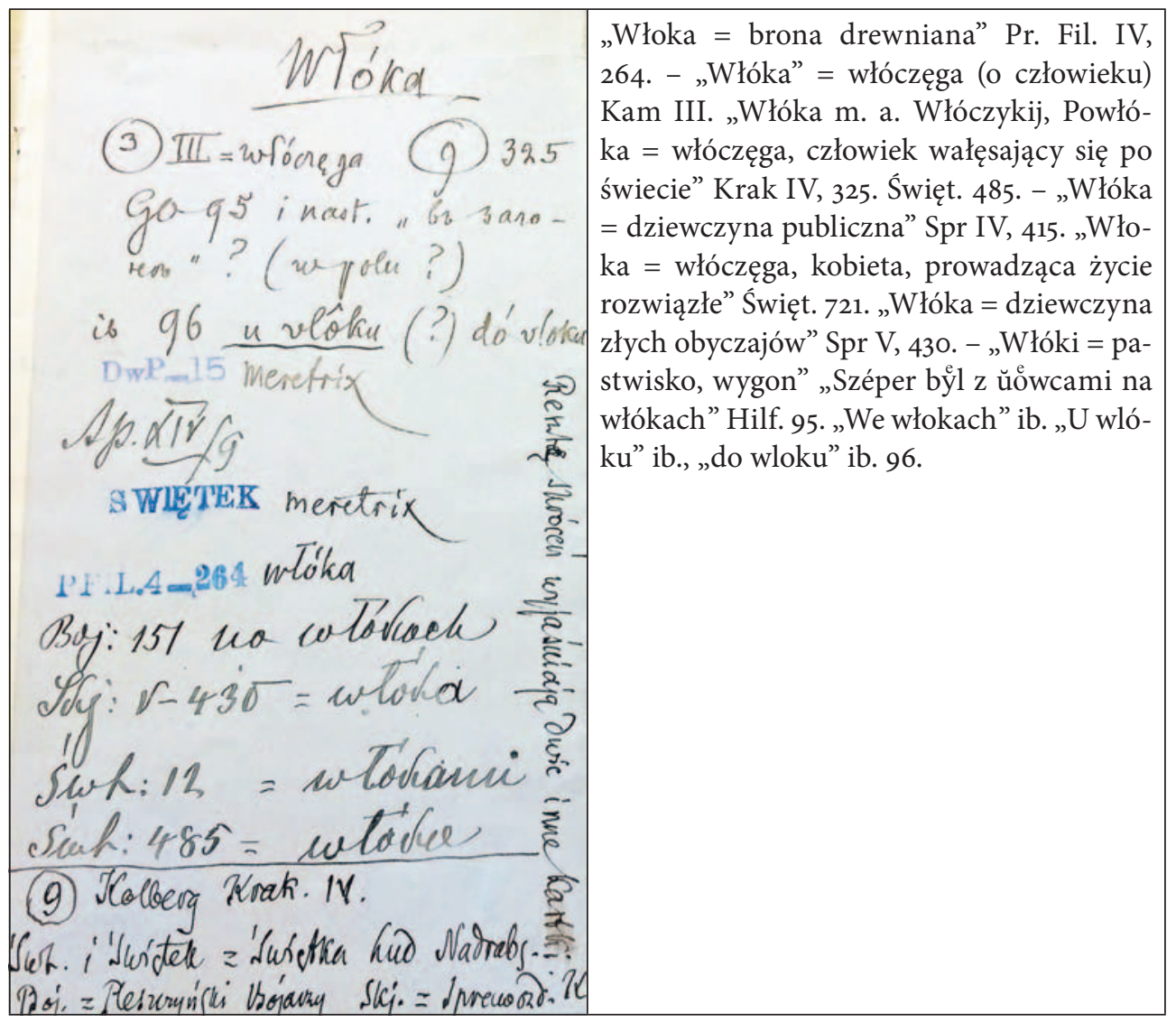




\section{Objaśnienie, tj. wypełnienie tej kartki}

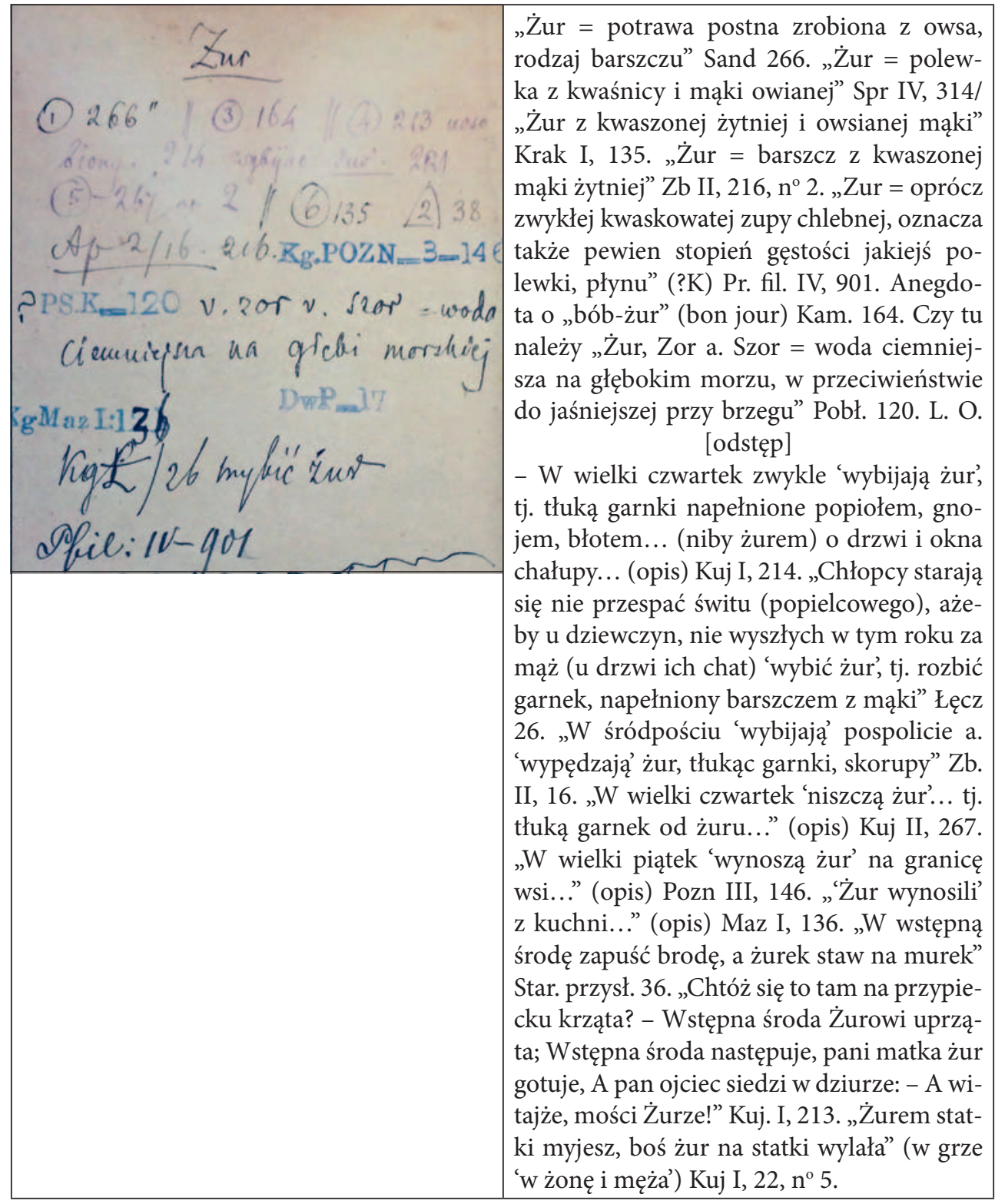

W razie, gdyby śmierć przerwała mi dokończenie Słownika, pragnąłbym, aby inna osoba lub inne osoby tem się zajęły, zachęcone do tego przez Akademię. Zdaje mi się, że dokonanie dzieła poszłoby bez trudności, bo cały materiał aż do końca abecadła 
mam zgromadzony, potrzeba więc tylko obrobić go aż do końca, trzymając się wskazówek, które 1) powyżej podałem, 2) które wynikają z porównania wydrukowanej już części Słownika z kartkami pierwotnemi i 3) których dopełnienie podaję w dołączonym tu zapisie moim testamentowym.

Jeżeli Akademia raczy się zgodzić na niezwłoczne rozpoczęcie druku Słownika, to pośpieszę nadesłać jej formalnie podpisany i poświadczony zapis mój testamentowy, z którego poniżej główny ustęp tymczasem wypisuję.

...Przewidując możebność niedokończenia pracy mojej nad Słownikiem gwar polskich za życia mojego, proszę spadkobierców moich, ażeby dołożyli wszelkich starań, iżby rozpoczęty Słownik został ukończony.

W tym celu rozporządzam, aby:

1. Zaraz po śmierci mojej zapytali Akademię Umiejętności w Krakowie, komu mają wręczyć wyrażone poniżej przedmioty i ażeby po otrzymaniu odpowiedzi, osobie lub osobom wskazanym przez Akademię wręczyli: a) skrzynkę blaszaną z napisem Do Słownika gwarowego, zawierającą rękopisy odnoszące się do Słownika z wypisanem na każdym przeznaczeniem jego; b) dwa pudła z kartkami pierwotnemi, formatu jak trzy, posłane do Krakowa; na pudłach znajduje się napis Kartki do Słownika gwarowego; jest tam ich około 60000 w 85 przegródkach pięciopiętrowych; c) książek około dwuchset, których spis zawiera się w zeszycie in 4 to zatytułowanym: Wskazówki do ukończenia Słownika gwarowego; książki te, mieszczące w sobie źródła Słownika, mają być zwrócone spadkobiercom moim po ukończeniu rękopisu Słownika; d) paczki z gotowemi do druku kartkami, formatu 8-ki mniejszej, ile ich się znajdzie w szufladach biura mojego, z napisem na każdej: Słownik gwarowy.

2. Jeżeliby osoba lub osoby mające wykańczać Słownik zamieszkiwały w Warszawie, w takim razie może by najwłaściwiej było umieścić kartki i książki w lokalu, w którym się opracowuje i opracowywać będzie wydawany przez nas Słownik języka polskiego, co zresztą do woli i uwagi Akademii ma być zostawione.

3. Mam nadzieję, że Akademia własnemi środkami ukończy obrobienie reszty i druk Słownika gwarowego, ponieważ posiada na to specjalny fundusz Czabana ${ }^{35}$; jeżeliby jednak dla jakichkolwiek powodów zachodziły w tym względzie trudności lub przeszkody, polecam spadkobiercom moim, aby na żądanie Akademii wypłacili jej sumę rubli trzy tysiące, lecz nie inaczej jak ratami w ciągu trzech lat od śmierci mojej.

4. Wybór osób, mających być wezwanemi do ukończenia Słownika gwarowego pozostawiam zupełnie uznaniu i woli Akademii.

Jan Karłowicz

4 marca 1899, Warszawa.

Po śmierci J. Karłowicza (14 VI 1903) początkowo sprawa ukończenia słownika nie była rozstrzygnięta. M. Karłowicz zwrócił się najpierw do Aleksandra Brücknera, później do Wacława Taczanowskiego i wreszcie do J. Łosia. W liście M. Karło-

35 Chodzi o 50 tys. rubli, które przekazał Akademii Umiejętności w swoim testamencie przedsiębiorca Edward Czaban. Kwota ta miała być przeznaczona na badania naukowe i publikacje z zakresu dialektologii polskiej. 
wicza do Hieronima Łopacińskiego (BN PAU i PAN, Rkps 2270) z 29 VII 1903 r. znajdujemy wypis z korespondencji A. Brücknera, gdzie nie wprost odmawia on dokończenia pracy:

Przyczynię się chętnie do wydania spuścizny leksykograficznej. Rzecz przedstawia się jednak, ile z listu Pańskiego wnosić mogę, bardzo fatalnie, to znaczy, że od litery $O$ (czy nie już i wcześniej) są tylko wypisane gołe pozycje, a nie ma tego, co najważniejsze, tj. wyjaśnień, za czem nie przez kwadranse tylko, lecz przez całe miesiące na darmo się szuka [...]. Przed ukończeniem tych dwóch dzieł (obszernego dzieła o Mikołaju Reju dla Akademii Krakowskiej i obszernej historii literatury rosyjskiej) do żadnej pracy wprzągać się nie mogę i tak nie wiem, jakim cudem z zobowiązań się wywinę.

Z kolei w przypisie od redakcji umieszczonym w książce Życie $i$ prace Jana Karłowicza (Źycie i prace) znajduje się następująca informacja: „Przygotowaniem do druku tomu IV-go [SKarł - M.R.] i następnych z rękopisów zajmuje się p. Wacław Taczanowski" (ibid.: 177). W liście do Bolesława Ulanowskiego (PAU KSG 2341/1903) z 5 XI 1903 r. Łopaciński rekomendował Taczanowskiego następującymi słowami:

Pan Wacław Taczanowski, pomocnik bibliotekarza w Bibl[iotece] Głównej w Warszawie, od lat kilku pracuje w redakcji Słownika języka polskiego i dał się poznać ze strony najlepszej jako bardzo sumienny i uzdolniony filolog. Śp. Jan Karłowicz wyrażał się o nim z wielkim uznaniem i dał dowód najlepszy, że uważa go za odpowiedzialnego do prowadzenia w dalszym ciągu Słownika gwar, skoro wymienił go w swym testamencie, z którego wypis złożony jest w Akademii Umiejętności [...].

Cieszyć się należy, że Akademia nie pozwoli dziełu utknąć w połowie i że w osobie p. T. znalazł się chętny pracownik, który Słownik do końca będzie mógł doprowadzić. Ja zaś, ze względu na cześć, jaką żywię do niezapomnianego mistrza oraz na ważność publikacji dla leksykografii naszej, najchętniej podejmuję się nadzoru nad pracą p. Taczanowskiego oraz przeglądania oraz konfrontowania przygotowywanego przez niego rękopisu.

Jak wynika z korespondencji M. Karłowicza do Łopacińskiego (BN PAU i PAN, Rkps 2270), AU zgodziła się na to, by pracę nad słownikiem podjął Taczanowski (list Z 20 XII 1903 r.), ustalono nawet wysokość jego wynagrodzenia - 20 rubli za opracowanie arkusza SKarł i przeprowadzenie korekty (list z 7 X 1903 r.).

Po śmierci Taczanowskiego na wojnie japońskiej ukończenie słownika przypadło Łosiowi (dotyczy tego m.in. korespondencja Łosia z Łopacińskim (Starnawski 1965: 55-56)), któremu miał pomagać Edward Klich. Zostało to sformalizowane w postaci umowy (PAU KSG 3312/1904) między nim i spadkobiercą praw autorskich, M. Karłowiczem: 


\section{Umowa}

zawarta pomiędzy pp. Prof. Drem Janem Łosiem a Mieczysławem Karłowiczem w sprawie opracowania drugiej połowy Słownika gwar polskich śp. Jana Karłowicza.

I. Profesor Jan Łoś zobowiązuje się:

1. Przygotować do druku resztę Słownika gwar polskich, pozostałą po wydaniu trzech pierwszych tomów, tj. opracować do druku materiał kartkowy, dostarczony przez p. Mieczysława Karłowicza.

2. Zwrócić p. Mieczysławowi Karłowiczowi przysłane przez niego pomocnicze książki. Zwrot książek nastąpi zaraz po ukończeniu pracy nad Słownikiem.

3. Pozostawić na okładce dalszych tomów Słownika tytuł dotychczasowy, tj. Słownik gwar polskich ułożył Jan Karłowicz. Tom IV, zastrzegając sobie jednak prawo umieszczenia na tymże tytule po wyrazach Tom IV itd.: wydany pod redakcja Jana Łosia. Na karcie tytułowej specjalnie tomu IV będzie jeszcze zaznaczone, że w części tom ten był redagowany przez W. Taczanowskiego i H. Łopacińskiego.

4. Wydrukować przedmowę do tomu IV dopiero po zaaprobowaniu jej tekstu przez p. Mieczysława Karłowicza.

5. Druk Słownika ukończyć w możliwie najkrótszym czasie (w przybliżeniu w przeciągu lat trzech).

6. W celu przyśpieszenia pracy dobrać sobie pomocnika.

II. P. Mieczysław Karłowicz zobowiązuje się:

1. Wypłacić za pośrednictwem Akademii Umiejętności w Krakowie p. prof. Łosiowi sumę rb. 3000 (trzy tysiące rubli), jako wynagrodzenie za pracę nad pozostałą częścią Słownika gwar polskich. Do prof. Łosia będzie również należało honorarium, wypłacane przez Akademię Umiejętności w sumie 400 (czterysta) koron za tom. (Z sum powyższych prof. Łoś zobowiązuje się opłacać pomocnika).

2. Sumę 3000 rubli wypłacić Zarządowi Akademii Umiejętności w trzech ratach rocznych po 1000 (tysiąc) rubli.

3. Wypłacić pierwszą ratę w sumie tysiąca rubli w ciągu lutego r. 1905, drugą w lutym 1906 r., trzecią - w lutym 1907 r.

III. Prócz tego niżej podpisani wyrażają zgodę swoją na punkty następujące:

1. Pieniądze, otrzymane od p. Mieczysława Karłowicza przez Zarząd Akademii Umiejętności będą składane na osobną książeczkę Kasy Oszczędności jako fundusz imienia śp. Jana Karłowicza i procent będzie doliczany do tej sumy.

2. Z sumy tej Akademia będzie wypłacała do rąk prof. Łosia miesięcznie z góry 240 koron, licząc od dnia 1 listopada $1904 \mathrm{r}$.

3. Honorarium od Akademii, według brzmienia jej statutu, prof. Łoś pobierać będzie po wydrukowaniu każdego tomu.

4. Jeżeli po wydrukowaniu całego Słownika gwar polskich pozostanie jaka reszta z funduszu im. śp. Jana Karłowicza, będzie ona wypłacona prof. Łosiowi bez względu na jej wysokość, wraz z narosłemi procentami.

5. W razie, gdyby prof. Łoś dla jakichkolwiek bądź przyczyn od p. Mieczysława Karłowicza niezależnych i nie przez niego, ani przez innych spadkobierców śp. Jana Karłowicza spowodowanych, musiał pracę nad Słownikiem przedwcześnie przerwać, 
wtedy nie będzie miał prawa do niczego więcej ponad to, co przed przerwaniem swej pracy, jako wymienione w punktach 2 i 3 ust. III honoraria czy to $z$ funduszu śp. Jana Karłowicza, czy też od Akademii pobierze.

6. Gdyby, wbrew przewidywaniom, druk Słownika nie został ukończony przed wyczerpaniem się funduszu śp. Jana Karłowicza, pozostałą część Słownika prof. Jan Łoś zobowiązuje się wykończyć bez żadnego honorarium od spadkobierców śp. Jana Karłowicza.

Jan Łoś, Kraków, 22 XII 1904

Mieczysław Karłowicz, Warszawa, 19 grudnia 1904 r.

\section{Podsumowanie}

Kartoteka SKarł pośrednio dostarcza wiadomości na temat powstawania pierwszego polskiego słownika ogólnogwarowego. Na podstawie fiszek i ich porównania z opublikowanymi tomami słownika można z pewnym przybliżeniem określić, jak wyglądała metoda leksykograficzna Karłowicza. Informacje na ten temat zostały, co prawda, wyłożone w Przyczynkach... (Karłowicz 1876), jednak tam mamy uwagi teoretyczne, a kartoteka jest ilustracją ich stosowania. Jest także świadectwem ambitnego, choć ostatecznie niezrealizowanego projektu leksykograficznego - Wielkiego słownika polskiego, obejmującego słownictwo ogólnopolskie i gwarowe, także $\mathrm{w}$ ujęciu etymologicznym.

Kartoteka łącznie z materiałami archiwalnymi dotyczącymi jej przygotowania do druku to przyczynek do historii polskiej dialektologii. Przyczynek ważny, bo pokazujący początek tej nauki.

\section{Źródła rękopiśmienne}

Biblioteka Naukowa PAU i PAN, Kraków

BN PAU i PAN, Rkps 2270: Listy Mieczysława Karłowicza do Hieronima Łopacińskiego. Archiwum Nauki PAN i PAU, Kraków

PAU KSG 3604/1899: J. Karłowicz, Objaśnienia do słownika gwarowego.

PAU KSG 3599/1899: J. Karłowicz, Przedmowa tymczasowa do Słownika gwar polskich.

PAU W I-191A: Kartoteka Słownika gwar polskich Jana Karłowicza.

PAU KSG 2341/1903: List Hieronima Łopacińskiego do Bolesława Ulanowskiego.

PAU KSG 3251/1898: List Jana Karłowicza do Akademii Umiejętności w Krakowie.

PAU KSG 3599/1899: List Jana Karłowicza do Stanisława Smolki.

PAU KSG 3312/1904: Umowa między Mieczysławem Karłowiczem a Janem Łosiem. 


\section{Literatura}

Hodoryska H., 1989, Dzieje konkursu leksykograficznego im. Samuela Bogumiła Lindego (1876-1922), Wrocław.

Karaś H., 2011, Polska leksykografia gwarowa, Warszawa.

KARAś H., 2014, $Z$ dziejów Słownika wyrazów obcego a mniej jasnego pochodzenia... Jana Karłowicza. Rękopis a druk, „Prace Filologiczne” LXV, s. 187-204.

KARAś H., 2015, Jan Karłowicz jako językoznawca, „Laboratorium Kultury” 4: Jan Aleksander Karłowicz, s. 29-63.

Karaś M., 1961, Z historii badań nad słownictwem gwarowym, „Język Polski” XLI, s. 161$-180,355-369$.

KarŁowicz J., 1871, Poradnik dla zbierajacych rzeczy ludowe, Warszawa.

KarŁowicz J., 1876, Przyczynki do projektu wielkiego słownika polskiego, „Rozprawy i Sprawozdania z Posiedzeń Wydziału Filologicznego Akademii Umiejętności” IV, s. XIV-XCIV.

Koniusz E., 2001, Polszczyzna z historycznej Litwy w Słowniku gwar polskich Jana Karłowi$c z a$, Kielce.

Koniusz E., 2005a, Jan Karłowicz jako językoznawca, etnograf i folklorysta - w setna rocznice śmierci (1836-1903), „Studia Filologiczne Akademii Świętokrzyskiej” 18, s. 7-17.

Koniusz E., 2005b, O Karłowiczowskim Słowniku wyrazów obcego a mniej jasnego pochodzenia używanych w języku polskim i niektórych etymologiach w nim zawartych, [w:] E. Siemieniec-Gołaś, M. Pomorska (red.), Turks and non-Turks. Studies on the history of linguistic and cultural contacts, „Studia Turcologica Cracoviensia”, t. 10, Kraków, S. 209-216.

KryŃsKi A.A., 1904, Jan Karłowicz jako językoznawca, [w:] Życie i prace, s. 120-164.

Majewski E., 1904, Jan Karłowicz (zarys życia), [w:] Życie i prace, s. 1-30.

Nitsch K., 1911/1958, Recenzja Słownika gwar polskich J. Karłowicza, „Rocznik Slawistyczny" IV, s. 199-243 [przedr. w: idem, Wybór pism polonistycznych, t. 4: Pisma dialektologiczne, Wrocław 1958, s. 195-225].

ОкоnıонA J., 2003, Jan Karłowicz. W setnq rocznicę śmierci, „Język Polski” LXXXIII, S. $246-250$.

ОкоNіоша J., 2012, Jan Karłowicz - uczony okresu przełomu, „LingVaria” nr 1 (13), s. 141-150.

Окоnіоwa J., 2013, Słownik gwar polskich Jana Karłowicza. Dziedzictwo. Inspiracje. Wyzwania, „Prace Filologiczne” LXIV, s. 245-258.

Pankowski Cz., 1979, Jan Karłowicz jako współtwórca Słownika warszawskiego, „Poradnik Językowy" nr 9, s. 410-425.

Perzowa H., 1979, Jan Karłowicz jako dialektolog, „Poradnik Językowy” nr 9, s. 426-436.

Rutkovska K., PrašKevič E., 2016, Słownik wyrazów obcego a mniej jasnego pochodzenia... Jana Karłowicza - wyrazem wiedzy i zamiłowań lituanistycznych autora, „Acta Baltico-Slavica" 40, s. 93-108, [on-line:] https://doi.org/10.11649/abs.2016.017.

SGP: Słownik gwar polskich, red. M. Karaś (Źródła, t. 1), J. Reichan (t. 2-9, z. 2), S. Urbańczyk (t. 2-5), J. Okoniowa (t. 6-9, z. 2), B. Grabka (t. 7-9, z. 2), R. Kucharzyk (t. 9, z. 2), t. 1-3: Wrocław - Warszawa - Kraków 1977-1991, t. 4-9, z. 2: Kraków 1992-2015.

SKARŁ: J. Karłowicz, Słownik gwar polskich, t. I-VI (t. IV-VI do druku przygot. J. Łoś), Kraków 1900-1911.

SL: S.B. Linde, Słownik języka polskiego, t. I-VI, Warszawa 1807-1814. 
SokóLSKa U., 2013, Przyczynki do projektu wielkiego słownika polskiego Jana Karłowicza jako źródło wiedzy o warsztacie leksykografa końca XIX w., „Prace Filologiczne” LXIV, s. 351-366.

STARNAWSKI J. (oprac.), 1965, Korespondencja Jana Łosia z Hieronimem Łopacińskim, „Język Polski” XLV, s. 44-63.

SW: J. Karłowicz, A.A. Kryński, W. Niedźwiedzki (red.), Słownik języka polskiego, Warszawa 1900-1927.

SWIL: A. Zdanowicz i in. (red.), Słownik języka polskiego, Wilno 1861.

SWOKARє: J. Karłowicz, Słownik wyrazów obcego a mniej jasnego pochodzenia używanych w języku polskim, Kraków 1894-1905.

ŻyCIE I PRACE: Życie i prace Jana Karłowicza (1836-1903). Książka zbiorowa wydana staraniem i nakładem redakcji „Wisły”, Warszawa 1904.

\section{From the history of Jan Karłowicz's Słownik gwar polskich ‘A Dictionary of Polish Dialects'. Card index and publishing efforts \\ Summary}

The paper is devoted to the card index to Jan Karłowicz's Słownik gwar polskich 'A Dictionary of Polish Dialects' which was identified by the end of May $2017^{\text {th }}$ and is currently stored at the Archive of Science of the Polish Academy of Sciences and the Polish Academy of Learning in Cracow. The index provides indirect information about the creation of the first general dictionary of Polish dialects, and principally about the lexicographic method employed by Karłowicz. It is also a testimony to an ambitious, though eventually unrealized lexicographic project that was Wielki słownik języka polskiego 'A Great Dictionary of Polish' which was meant to comprise general Polish and dialectal vocabulary, and also include the etymological aspect.

Archival materials related to the history of publication of the card index are a slice of the history of Polish dialectology which is all the more important in that it exposes the beginnings of this field. 
DEBIUTY NAUKOWE 

Joanna Wołoszyn ${ }^{1}$

Uniwersytet Warmińsko-Mazurski, Olsztyn

joanna.01.91@gmail.com

\section{CZASOWNIKOWE WYKŁADNIKI NAKŁANIANIA KOGOŚ DO CZEGOŚ Z PERSPEKTYWY SEMANTYCZNEJ. REKONESANS BADAWCZY}

Słowa klucze: językoznawstwo, semantyka strukturalna, jednostka językowa Keywords: linguistics, formal semantics, lexical item

1. Celem artykułu jest prezentacja dotychczasowego stanu badań nad wykładnikami nakłaniania kogoś do czegoś oraz wyłonienie spośród wyrażeń nazywających różne rodzaje wpływania na kogoś takich, które należą do badanej kategorii. Tekst będzie więc składał się z dwóch części - w pierwszej, sprawozdawczej, przywołam wybrane, najważniejsze prace językoznawcze dotyczące interesujących mnie wyrażeń, w drugiej zaś, analitycznej, postaram się ustalić wstępną listę jednostek językowych reprezentujących badaną kategorię oraz wskazać rysujące się już na początku problemy badawcze. Na tym etapie badań nie podejmuję się szczegółowej charakterystyki właściwości składniowo-semantycznych poszczególnych predykatów. Celem niniejszej analizy jest jedynie wstępne rozpoznanie badanej grupy, wyznaczenie jej przybliżonych granic oraz wskazanie podstawowych reprezentantów. Dlatego chcę podkreślić, że hipotezy zawarte w tym artykule są - jako zapis pierwszych intuicji jeszcze bardzo słabe, a ich weryfikacja będzie mogła nastąpić dopiero po szczegółowej analizie pojęcia nakłaniania.

1 Autorka pozostaje pod opieką naukową dr hab. Marioli Wołk. 
2. Na wstępie chciałabym zaznaczyć, że badania prowadzę zgodnie z metodami semantyki strukturalnej². Temat wykładników nakłaniania kogoś do czegoś był już, oczywiście, w językoznawstwie poruszany wielokrotnie pod różnymi etykietami kategoryzacyjnymi, a szczególnym zainteresowaniem cieszyły się zagadnienia perswazji i manipulacji. Jednak - o ile wiem - omawiano je głównie jako zjawiska tekstowe, a nie systemowe. Warto podkreślić, że powstała rozprawa doktorska o czasownikach nakłaniania - praca Moniki Czekańskiej Polskie czasowniki nakłaniania jako nazwy tzw. czynności perlokucyjnych (2015). Autorka zajmuje się znaczeniem takich predykatów, jak namawiać czy nakłaniać, zwracając szczególną uwagę na kwestie pragmatyczne (punktem wyjścia jest dla niej teoria Austina). Zdanie sprawy ze stanu badań nad wykładnikami nakłaniania kogoś do czegoś zacznę od prac, które dotyczą opisu zjawisk tekstowych nazywanych przez interesujące mnie wyrażenia, a następnie przywołam teksty, w których podjęto refleksję nad znaczeniem samych tych ciągów.

2.1. Perswazja najczęściej rozpatrywana jest jako realizacja impresywnej funkcji języka w różnych kontekstach. Dariusz Galasiński (1992) pokazuje m.in., że chwaląc się, możemy jednocześnie próbować kogoś do czegoś (lub też o czymś) przekonać. Z kolei artykuł Małgorzaty Kity (1993) zawiera tezę, że wprowadzanie do tekstu niepotocznego elementów kolokwialnych służy perswazji, ponieważ niweluje dystans pomiędzy nadawcą a odbiorcą. Zagadnieniu perswazji w języku reklamy poświęcona jest książka Jerzego Bralczyka (200o), która zawiera analizę wielu tekstów reklamowych i wskazuje, w jaki sposób ich autorzy nakłaniają nas do kupienia czegoś. Koncepcję badań nad perswazją próbuje opracować Artur Mamcarz (1996).

Zagadnieniom manipulacji został poświęcony jeden z tomów „Czerwonej serii” (Krzyżanowski, Nowak 2004). W większości zawartych w nim artykułów nad rozważaniami teoretycznymi przeważają jednak analizy tekstów: autorzy opisują zjawisko manipulacji w prasie (np. Ryszard Tokarski, Manipulacja to zniewalanie. A cóż poczać $z$ „urodzonymi w niewoli”?), w telewizji (Urszula Żydek-Bednarczuk, Zmiany $w$ zachowaniach komunikacyjnych a problem strategii i manipulacji), w polityce (Katarzyna Kłosińska, Rola procesów nominacyjnych w tworzeniu opozycji „my”/,oni” w języku polityki po 1989 roku). Refleksje teoretyczne pojawiają się przede wszystkim w otwierającym tom tekście Ireny Kamińskiej-Szmaj Propaganda, perswazja, manipulacja - próba uporządkowania pojęć. Badaczka dokonuje przeglądu powstałych do tej pory definicji tytułowych terminów, aby ustalić, na czym właściwie polegają opisywane przez nią zjawiska, oraz wskazać różnice między nimi. Omawianymi pojęciami zajmuje się głównie jako

2 Podstawowe założenia omawiane są szerzej przede wszystkim w pracach Andrzeja Bogusławskiego (np. Bogusławski 1976, 1988), Anny Wierzbickiej (np. Wierzbicka 1969, 2006) i Macieja Grochowskiego (np. Grochowski 2008). 
terminami naukowymi służącymi do opisania [...] odmiany funkcjonalnej języka ogólnego reprezentowanej przez teksty tworzone i stosowane przez polityków i ludzi z nimi związanych (Kamińska-Szmaj 2004: 14),

chociaż opracowuje również swego rodzaju scenariusze manipulacji i perswazji, które mogą okazać się przydatne w analizowaniu tych wyrażeń. W całym tomie dominuje jednak koncentracja na zjawiskach tekstowych, a nie namysł nad samym pojęciem, nad znaczeniem wyrażenia nazywającego te zjawiska.

Krystyna Kleszczowa i Kamila Termińska (1983) zajmują się tym, jak możemy nakłaniać kogoś do czegoś, nie mówiąc wprost, o co nam chodzi. Analizują zdania, które można nazwać nakłaniającymi, natomiast nie odnoszą się do samego pojęcia nakłaniania kogoś do czegoś. W późniejszym artykule (Kleszczowa, Termińska 1999) autorki zarysowują pole działań nakłaniających, które według nich obejmują wszelkie celowe działania X-a, mające przez zrobienie czegoś spowodować, że Y zrobi coś innego. Zakreślona przez nie klasa jest bardzo szeroka, ponieważ obejmuje zarówno wypowiedzenia opisujące nakłanianie, jak i te, za pomocą których nakłanianie realizujemy (ibid.: 55). Ponadto autorki wprowadzają podział czasowników opisujących nakłanianie na dwie grupy: dotyczące działań wyłącznie werbalnych (jak np. namawiać) oraz obejmujące również działania niewerbalne (jak nakłaniać) (ibid.: 57).

W ustalaniu kształtu jednostek językowych reprezentujących pojęcia nakłaniania, namawiania i skłaniania kogoś do czegoś pomoże książka Małgorzaty Marcjanik (1980), w której autorka analizuje łączliwość m.in. interesujących mnie predykatów - nakłonić, namówić i skłonić. Ta sama badaczka w pracy nieco późniejszej wyodrębnia podgrupę czasowników adresatywnych, dla której proponuje ogólną eksplikację „mówię, że chcę spowodować, żebyś coś zrobił” (ibid.: 98) (zalicza do niej m.in. takie predykaty, jak: namawiać, skłaniać, odwodzić).

2.2. Dalsze przywoływane prace dotyczą już problemów znaczenia. Najpierw należałoby wspomnieć o dwóch klasyfikacjach semantycznych czasowników opracowanych przez Romana Laskowskiego (1999) i Zofię Zaron (2000, 2001, 2002). Według ustaleń Laskowskiego czasowniki „perswazyjne” (przekonywać, nakłaniać, zachęcać) należą do klasy czasowników działania, czyli takich, które opisują celowe powodowanie zmiany stanu obiektu. W semantycznym podziale orzeczeń dokonanym przez Z. Zaron (2000, 2001, 2002) czasownikom nakłaniania najbliżej byłoby zapewne do grupy orzeczeń chcenia3. We wcześniejszej pracy (Zaron 1980) badaczka umieściła predykat nakłonić w jednej grupie z takimi wyrażeniami, jak: namówić, agitować, kusić, podmawiać, podpuszczać, podburzać, skłaniać czy podjudzać.

3 Monika Czekańska w swojej rozprawie doktorskiej uznaje czasowniki nakłaniania za czasowniki werbalnych działań złożonych według klasyfikacji Zofii Zaron (Czekańska 2015: 79), ale trzeba pamiętać, że w pracy tej rozpatrywane są wyłącznie czasowniki nazywające akty mowy. 
Tekst Jadwigi Puzyniny (1992) poświęcony jest manipulacji jako wyrażeniu językowemu, jednak podana przez autorkę definicja

$\mathrm{X}$ manipuluje Y-em = X oddziałuje na Y-a w taki sposób, aby Y, poprzez swoją postawę i/lub zachowanie był narzędziem realizacji jakichś celów X-a. X działa bez użycia przemocy, ale tak, że Y nie wie, jaki jest cel działań X-a. Nadawca ocenia działanie $\mathrm{X}$-a jako niemoralne (ibid.: 214)

zawiera wiele wyrażeń równie złożonych semantycznie jak słowo definiowane, a zatem - z punktu widzenia założeń semantyki strukturalnej, która za cel stawia sobie redukcję pojęć złożonych do prostych i uniwersalnych - nie jest idealna.

Puzynina badała również czasownik zmusić oraz wyrażenia bliskoznaczne, czego wynikiem jest następująca eksplikacja pojęcia zmuszania: „ $x$ stara się spowodować, żeby y zachował się zgodnie $\mathrm{z}$ jego wolą, tj. żeby $y$, mimo że tego nie chce, $P_{2} ; \mathrm{x}$ w tym celu $P_{n}$ '” (Puzynina 1982/1983: 125). Jak zaznaczyła sama autorka, jej celem był „opis powierzchniowych struktur składniowych [...] predykatów oraz [...] opis ich znaczeń, bez próby sięgania do indefinibiliów" (ibid.: 123), co powoduje, że podawane przez nią definicje z całą pewnością nie wyczerpują tematu.

Artykuł Andrzeja Bogusławskiego (1994) jest zapisem przemówienia otwierającego sesję poświęconą zjawisku manipulacji. Bogusławski proponuje wstępną definicję manipulacji, zaznaczając, że ma świadomość jej niedoskonałości i że traktuje ją jedynie jako „punkt zaczepienia [...] myśli” (ibid.: 221) dla innych uczestników sesji:

osoba działająca D manipuluje inna osobą O

D tworzy sytuację S taką, że

(1) $\mathrm{S} w$ rozumieniu D uprawdopodabnia to, że O znajdzie się w stanie mentalnym $\mathrm{M}$, co do którego D przypuszcza, że O ze znacznym prawdopodobieństwem nie znalazłby się w M w przypadku spełnienia koniunkcji następujących warunków dotyczących $\mathrm{O}$ :

a) ma możliwie pełną wiedzę o tym, co jest istotne dla M i czego częścią nie jest $S$

b) nie znalazł się w $S$

c) nie znalazł się w innej niż S sytuacji uprawdopodabniającej jego stan $\mathrm{M}$

(2) S nie polega na indywidualnie adresowanym do $\mathrm{O}$ wywołaniu adekwatnej i jednoznacznej świadomości $O$ na temat tego, co jest istotne dla jego stanu $\mathrm{M}$ i co jest znane D lub w rozumieniu D może być znane D, przy czym (2) jest oceniane negatywnie (ibid.).

Na tym etapie nie podejmuję dyskusji z propozycjami Bogusławskiego ani z propozycjami innych badaczy, ograniczam się jedynie do zdania sprawy z zasadniczych tez i kierunków interpretacji. Do poszczególnych rozwiązań zamierzam odnieść się przy okazji szczegółowych analiz znaczenia poszczególnych predykatów, prawdopodobnie w odrębnych tekstach. 
Powstały również dwie analizy czasownika kusić, do których będę się jeszcze w tym tekście odwoływać: M. Czekańskiej (2001) oraz Izabeli Duraj-Nowosielskiej (2007), przy czym ta druga praca realizuje założenia metodologiczne semantyki strukturalnej, a zatem może okazać się interesującym punktem odniesienia w analizach znaczenia innych jednostek.

Warto także wspomnieć o dwóch pracach, w których autorki analizują ciąg ktoś jest przekonany, $\dot{z} e_{-}$. Anna Wierzbicka (1971: 119) poświęca tej jednostce zaledwie stronę, ale podaje jej definicję: „X jest przekonany, że $\mathrm{Z}=$ trudno byłoby spowodować, żeby X przestał sądzić, że Z”. Magdalena Danielewiczowa (2002) uznaje jednak, że fakt, iż własne przekonania niełatwo zmienić, nie może być cechą definicyjną predykatu być przekonanym, $\dot{z} e_{-}$, i proponuje następującą eksplikację:

a jest przekonany, żep

[T] a,

[TD] który jest gotów powiedzieć, że wie coś takiego, że coś jest zgodne z p i $\sim \mathrm{p}$, i że wie coś takiego, że coś $\neq \operatorname{sos}_{\mathrm{q}}$ i coś $\neq \mathrm{q}$,

[R] jest gotów powiedzieć, że jeśli ktoś wie cośs, to niemożliwe jest, żeby wiedział coś $\mathrm{i}$ nie był gotów powiedzieć, że p (ibid.: 237-238).

Bycie przekonanym jest jednak stanem, który, co prawda, może być rezultatem czynności przekonywania, ale sam czynnością nie jest, a zatem trudno na tym etapie badań powiedzieć, na ile ustalenia Wierzbickiej i Danielewiczowej wpłyną na analizę semantyczną pojęcia przekonywania.

Znaczenie czasowników nakłaniania stało się również przedmiotem, przywołanej na wstępie tego przeglądu prac, rozprawy doktorskiej M. Czekańskiej Polskie czasowniki nakłaniania jako nazwy tzw. czynności perlokucyjnych (2015), w której nakłanianie nie jest już traktowane tak szeroko jak w pracy Kleszczowej i Termińskiej (1999). Autorka bierze pod uwagę wyłącznie czasowniki nazywające akty mowy implikujące osiągnięcie skutków perlokucyjnych. Czekańska definiuje kilkanaście z nich: namawiać, nakłaniać, odwodzić, podburzać, podjudzać, podmawiać, poduszczać, podżegać, wyperswadować, buntować i werbować. Jej praca zawiera wiele ciekawych refleksji na temat nakłaniania, ale z niektórymi z nich można by podjąć dyskusję, a ograniczenie przez autorkę czasowników nakłaniania wyłącznie do tych nazywających akty mowy powoduje, że pozostają do zanalizowania wyrażenia, które implikują nie tylko mówienie, ale też inne działania, jak np. skłonić czy manipulować.

Jak widać, wiele na temat nakłaniania już napisano, jednak kategoria czasowników nakłaniania jest bardzo pojemna i da się znaleźć w niej jeszcze pewne obszary, które można by zbadać.

3. Po zdaniu sprawy ze stanu badań nad wykładnikami nakłaniania kogoś do czegoś można przystąpić do ustalenia listy wyrażeń, które to pojęcie reprezentują. Spójrzmy 
na kilkanaście przykładowych zdań opisujących, zgodnie z założeniami Kleszczowej i Termińskiej (1999), różne rodzaje nakłaniania:

(1) Bartek poradził Zosi, żeby zabrała parasol.

(2) Nowak zagroził Kowalskiemu, że zabije jego córkę.

(3) Babcia ostrzegła Zuzię, że się przewróci, jeśli nie przestanie biegać.

(4) Mama kazała Antkowi iść do sklepu.

(5) Tata poprosił Anię o wyniesienie śmieci.

(6) Michał szantażuje Pawła, że jeśli nie dostanie pieniędzy, powie żonie Pawła o jego romansie.

(7) Andrzej namówił Beatę do wzięcia udziału w konkursie.

(8) Piotr nakłonił Adama do wyjazdu z Polski.

(9) Łomnicki skłonił Barańczaka do tłumaczenia Szekspira.

(10) Ewa przekonała Marka do zmiany pracy.

(11) Matka wyperswadowała Marii wyjazd do Tajlandii.

(12) Dyrektor wymógł na Janie zgodę na publikację wyników jego badań.

(13) Potocki manipuluje Nowakiem.

(14) Mama przekupiła Agę czekoladą, żeby pomogła młodszej siostrze w lekcjach.

Już przy wstępnym przyjrzeniu się powyższym zdaniom można zauważyć, że przykłady (1)-(6) różnią się od (7)-(14). W pierwszej grupie mamy do czynienia z nazwami prostych dyrektywnych aktów mowy, które na ogół są krótkimi, jednorazowymi wypowiedziami, zamykającymi się zwykle w granicach jednego zdania, w drugiej zaś - z nazwami działań bardziej złożonych. Choć nie można wykluczyć, że da się kogoś do czegoś nakłonić/namówić/przekonać itp. jednym zdaniem, najczęściej wymaga to większego wysiłku, np. użycia kombinacji kilku takich aktów mowy. Warto zauważyć, że wypowiedzenie

(15) Tata poprosił Anię o wyniesienie śmieci, żeby nakłonić ją do wyniesienia śmieci.

jest poprawne, natomiast zdanie

(16) ${ }^{\star}$ Tata nakłonił Anię do wyniesienia śmieci, żeby poprosić ją o wyniesienie śmieci.

jest sprzeczne wewnętrznie, co nie tylko wskazuje na to, że choć prośba może służyć temu, by kogoś do czegoś nakłonić, nakłanianie nie może mieć na celu poproszenia kogoś o coś, lecz także odsłania rodzaj skomplikowania/złożoności, o które tu idzie.

W tym miejscu warto zastanowić się - choćby wstępnie - nad znaczeniem predykatu ktoś nakłonił kogoś do czegoś. Szczegółowa analiza pojęcia nakłaniania będzie wymagała czasu, jednak na tym etapie badań chciałabym przyjąć przynajmniej wstępną definicję tego predykatu za redaktorami ISJP: 
nakłonić 'Jeżeli ktoś nakłonił nas do czegoś, to sprawił, że z własnej woli zrobiliśmy to' (ISJP I: 932).

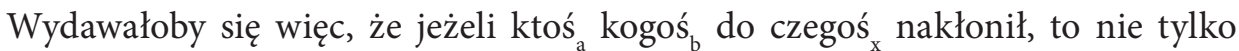
chciał, żeby ktoś coś $_{\mathrm{x}}$ zrobił, lecz także spowodował, że właśnie tak się stało. Spójrzmy na dwa przykładowe zdania:

(17) ?Piotr nakłonił Adama do zmiany pracy, ale Piotr nie spowodował, że Adam zmienił pracę.

(18) ?Maria nakłoniła Jana do założenia różowej koszuli, ale Maria nie spowodowała, że Jan założył różową koszulę.

Jeżeli - jak w wypowiedzeniu (17) - Piotr nakłonił Adama do zmiany pracy, to wydaje się oczywiste, że Piotr spowodował, że Adam zmienił pracę. Tak samo jest w przypadku zdania (18) - to, że Maria nakłoniła Jana do założenia różowej koszuli, zdaje się implikować to, że spowodowała, że Jan rzeczywiście tę koszulę założył. Wprowadzenie do wypowiedzeń (17) i (18) zaprzeczenia tych hipotez sprawia, że zdania wydają się sprzeczne wewnętrznie, co potwierdzałoby założenie, że jeżeli ktoś kogoś $_{\mathrm{b}}$ do czegoś $\mathrm{x}_{\mathrm{x}}$ nakłonił, to spowodował, że ktoś coś $_{\mathrm{x}}$ zrobił. Po dłuższym zastanowieniu dałoby się chyba jednak do wypowiedzeń (17) i (18) dobudować takie konteksty, w których wewnętrznej sprzeczności nie będzie (stąd poprzedzenie komentowanych wyżej przykładów znakiem zapytania, a nie gwiazdką), np.:

(19) Piotr nakłonił Adama do zmiany pracy, ale Piotr nie spowodował, że Adam zmienił pracę, ponieważ kiedy Adam chciał złożyć wypowiedzenie, dowiedział się, że dostał awans i podwyżkę.

(20) Maria nakłoniła Jana do założenia różowej koszuli, ale Maria nie spowodowała, że Jan założył różową koszulę, gdyż okazało się, że ta koszula ma plamę.

Zdania (19) i (20) wskazują więc na to, że nakłaniając kogoś do czegośs, niekoniecznie powodujemy to, że ktoś to $_{\mathrm{x}}$ zrobi - zwykle tak jest, jednak mogą zajść nieprzewidziane okoliczności, które uniemożliwią nakłanianemu dane działanie. Nakłanianie byłoby zatem nie tyle powodowaniem, że ktośs $\cos _{\mathrm{x}}$ zrobi, ile - zgodnie $\mathrm{z}$ intuicjami redaktorów WSJP4 - powodowaniem, że ktoś ${ }_{\mathrm{b}}$ zdecyduje się $\operatorname{coś}_{\mathrm{x}}$ zrobićs. Wypowiedzenia

(21) *Piotr nakłonił Adama do zmiany pracy, ale Piotr nie spowodował, że Adam zdecydował się zmienić pracę.

4 WSJP podaje następującą definicję: nakłonić 'za pomocą argumentów sprawić, że ktoś zdecydował się na coś' (wsjp.pl/do_druku.php?id_hasla=28538\&id_znaczenia=4761783).

5 Mam świadomość, że wyrażenie to nie jest proste semantycznie i - jako kandydat na komponent semantyczny definicji - wymaga rozłożenia na elementy prostsze, najlepiej niedefiniowalne. Na obecnym etapie badań traktuję to jako zadanie na przyszłość. 
(22) *Maria nakłoniła Jana do założenia różowej koszuli, ale Maria nie spowodowała, że Jan zdecydował się założyć różową koszulę.

są sprzeczne wewnętrznie, co - na obecnym etapie badań - pozwala uznać powodowanie decyzji o zrobieniu czegoś za jeden z komponentów nakłaniania.

Wróćmy jednak do zdań (1)-(6). Wspominałam już, że nakłanianie jest prawdopodobnie bardziej złożone niż działania, o których mowa w tych przykładach. Kolejną istotną różnicę między predykatami występującymi w wypowiedzeniach (1)-(6) a nakłanianiem można zaobserwować przy porównywaniu zdań z czasownikami w aspekcie dokonanym, kiedy relacjonujemy czynności z perspektywy ich zakończenia, a nie trwania. Otóż jeżeli ktoś komuś ${ }_{\mathrm{b}}$ coś $_{\mathrm{x}}$ poradził lub doradził, rozkazał $\operatorname{coś}_{\mathrm{x}}$ zrobić, poprosił kogośs ${ }_{\mathrm{b}}$ o coś, ostrzegł kogoś ${ }_{\mathrm{b}}$ przed czymśs..., to - upraszczając - powiedział coś do kogoś ${ }_{\mathrm{b}}$ po to, żeby ten ktoś coś $_{\mathrm{x}}$ zrobił, ale niekoniecznie spowodował, że rzeczywiście ktoś ${ }_{\mathrm{b}}$ zdecydował się to $\mathrm{z}_{\mathrm{x}}$ robić. Zauważona przeze mnie właściwość predykatów występujących w zdaniach (1)-(6) sugeruje, że jednostki te nie nazywają rodzajów nakłaniania kogoś do czegoś, a jedynie próby spowodowania, żeby ktoś zachował się w określony sposób.

(23) Bartek poradził Zosi, żeby zabrała parasol, ale Bartek nie spowodował, że Zosia zdecydowała się zabrać parasol.

(24) Nowak zagroził Kowalskiemu, że zabije jego córkę, ale Nowak nie spowodował, że Kowalski zdecydował się zrobić to, czego Nowak od niego chciał.

(25) Babcia ostrzegła Zuzię, że się przewróci, jeśli nie przestanie biegać, ale babcia nie spowodowała, że Zuzia zdecydowała się przestać biegać.

(26) Mama kazała Antkowi iść do sklepu, ale mama nie spowodowała, że Antek zdecydował się iść do sklepu.

(27) Tata poprosił Anię o wyniesienie śmieci, ale tata nie spowodował, że Ania zdecydowała się wynieść śmieci.

(28) Michał zaszantażował Pawła, że jeśli nie dostanie pieniędzy, powie żonie Pawła o jego romansie, ale Michał nie spowodował, że Paweł zdecydował się dać mu pieniądze.

Przykłady (23)-(28) są poprawne, co potwierdza, że wziętej pod uwagę grupy czasowników nazywających akty mowy nie można uznać za wykładniki nakłaniania.

W związku z tym, że w zdaniu (26) wystąpił czasownik kazać, mogą pojawić się wątpliwości dotyczące włączenia do badanej kategorii związanych z nim predykatów rozkazać, nakazać i zakazać, które wydają się wskazywać na większy stopień

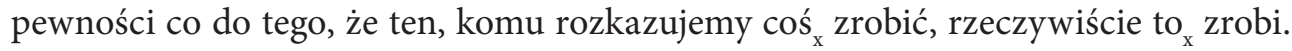
Leksemy rozkaz, nakaz i zakaz sugerują, że rozkazujący jest uprawniony do kierowania zachowaniem danej osoby oraz że w razie jej nieposłuszeństwa ma do dyspozycji jakieś sankcje. Nie znaczy to chyba jednak, że ktośs, komu się rozkazuje, zawsze zrobi to $_{x}$, czego $_{x}$ się od niego oczekuje. Zdanie 
(29) Kapral rozkazał szeregowemu strzelać, ale szeregowy odmówił wykonania rozkazu / nie zdecydował się wykonać rozkazu.

jest poprawne, a więc mimo że szeregowego mogłyby czekać (i zapewne czekałyby) poważne konsekwencje, ma on możliwość odmowy. Rozkazywanie, nakazywanie i zakazywanie należy zaliczyć do aktów mowy, które są jedynie próbami spowodowania czegoś - i tym samym wykluczyć je z kategorii wykładników nakłaniania kogoś do czegoś.

4. Wróćmy jednak do zdań (7)-(14). Wydaje się, że wszystkie występujące w nich czasowniki można uznać za wykładniki nakłaniania kogoś do czegoś. Jeżeli bowiem ktoś kogoś do czegoś namówił, skłonił, przekonał, ktoś kogoś crymś $_{\mathrm{b}}$ przekupił czy ktoś komuś coś $_{\mathrm{x}}$ wyperswadował, to rzeczywiście spowodował, że ktoś ${ }_{\mathrm{b}}$ postanowił coś ${ }_{x}$ zrobić, co potwierdza wewnętrzna sprzeczność poniższych zdań:

(30) *Andrzej namówił Beatę do wzięcia udziału w konkursie, ale Andrzej nie spowodował, że Beata zdecydowała się wziąć udział w konkursie.

(31) ‘ Łomnicki skłonił Barańczaka do tłumaczenia Szekspira, ale Łomnicki nie spowodował, że Barańczak zdecydował się tłumaczyć Szekspira.

(32) ${ }^{\star}$ Ewa przekonała Marka do wyjazdu z Polski, ale Ewa nie spowodowała, że Marek zdecydował się wyjechać z Polski.

(33) *Matka wyperswadowała Marii wyjazd do Tajlandii, ale matka nie spowodowała, że Maria zdecydowała się nie wyjeżdżać do Tajlandii.

(34) *Dyrektor wymógł na Janie zgodę na publikację wyników jego badań, ale dyrektor nie spowodował, że Jan zdecydował się zgodzić się na publikację wyników swoich badań.

(35) *Mama przekupiła Agę czekoladą, żeby pomogła młodszej siostrze w lekcjach, ale mama nie spowodowała, że Aga zdecydowała się pomóc młodszej siostrze w lekcjach.

W zdaniu (13) wystąpił leksem manipulować, który wydaje się nazywać dość szczególny rodzaj nakłaniania. Najczęściej pojawia się on właśnie w aspekcie niedokonanym, choć można, jak w przykładzie (36) (zob. poniżej), użyć go również $\mathrm{w}$ aspekcie dokonanym. Niemniej jednak nawet jako czasownik niedokonany predykat ten zawiera w swym znaczeniu komponent powodowania określonego działania - żeby można było mówić o manipulowaniu jakąś osobą, musi ona zacząć postępować zgodnie z planami manipulującego, o czym świadczy fakt, że zdanie (37) jest dewiacyjne.

(36) Potocki zmanipulował Nowaka.

(37) ${ }^{\star}$ Potocki manipulował Nowakiem, ale Potocki nie powodował, że Nowak decydował się robić to, czego chciał Potocki. 
Nieakceptowalność przykładu (37) może budzić wątpliwości. Wydaje się jednak, że manipulowanie kimś ${ }_{\mathrm{b}}$ polega na takim działaniu manipulującego, które powoduje, że ktoś postępuje zgodnie $\mathrm{z}$ jego wolą, a zatem dopóki ktoś się od niego oczekuje, nie możemy mówić o manipulowaniu, a jedynie o próbie manipulowania. Jest to jednak niewątpliwie kwestia, nad którą trzeba się będzie głębiej zastanowić przy analizie predykatu manipulować.

Wydaje się, że do wykładników nakłaniania kogoś do czegoś można by zaliczyć również czasownik kusić. Zdanie

(38) *Jan skusił Marię, żeby skoczyła na bungee, ale Jan nie spowodował, że Maria zdecydowała się skoczyć na bungee.

jest sprzeczne wewnętrznie, co potwierdza, że kuszenie można zaliczyć do kategorii wykładników nakłaniania kogoś do czegoś. Trzeba jednak będzie rozważyć to, czy wszystkie jednostki językowe reprezentujące to pojęcie rzeczywiście opisują powodowanie jakiejś decyzji odbiorcy, ponieważ - zgodnie z przywoływaną już pracą I. Duraj-Nowosielskiej (2007) - predykatu tego można użyć zarówno do opisu kuszenia jako aktu mowy, jak i do nazwania działania innego rodzaju powodującego wpływanie na kogoś. Co ciekawe, różnica znaczenia w przypadku tego czasownika nie musi pociągać za sobą zmiany struktury zdania, co widać w przykładzie:

(39) Jan kusi Marię, żeby skoczyła na bungee.

Zdanie (39) możemy interpretować zarówno jako opis aktu mowy, w którym Jan mówi Marii, że na pewno spodobałoby się jej skakanie na bungee, jak i jako opis sytuacji, w której Jan jest tak zachwycony własnym skokiem, że Maria, widząc to, również zaczyna mieć na takie działanie ochotę. Według Duraj-Nowosielskiej czasownik kusić zawiera implikację kauzatywną jedynie w zdaniach drugiego typu (czyli w interpretacjach takich, jak przykład (40), zob. poniżej), natomiast nie ma jej w zdaniach opisujących akty mowy (takich jak przykład (41), zob. poniżej), por.:

(40) Jan kusi Marię, żeby skoczyła na bungee, i Marię rzeczywiście kusi, żeby skoczyć na bungee.

(41) Jan kusi Marię, żeby skoczyła na bungee (mówiąc jej, żeby to zrobiła), ale Marii wcale nie kusi, żeby skoczyć na bungee.

Innego zdania jest M. Czekańska (2001: 124), która zdania takie jak (41) uznaje za sprzeczne wewnętrznie, gdyż uważa, że bodziec w sytuacji kuszenia musi być odpowiednio atrakcyjny dla kuszonego, a jeżeli - jak w przykładzie (41) - taki nie jest, nie zachodzi sytuacja kuszenia. Wydaje się, że aby działanie można było nazwać kuszeniem, to, czym kusimy, powinno być dla kuszonego czymś atrakcyjnym, ale na tym etapie badań nie jestem w stanie rozstrzygnąć, czy rzeczywiście tak być musi, zwłaszcza że ciągi ktoś kusi kogoś i kogoś kusi coś występujące w zdaniu (41) prezentują dwie odmienne perspektywy - kuszenie jako intencję i jako skutek. 
Wydaje się również, że nawet jeżeli kusimy czymś, co kuszonego rzeczywiście przyciąga, wówczas to, co miałby on zrobić, w jakiś sposób kłóci się z jego systemem wartości - na taką właściwość badanego predykatu zwraca uwagę Czekańska (ibid.: 121). Powszechnie znaną biblijną sy tuację możemy opisać zdaniem (42), ale raczej nie zastosujemy do niej wypowiedzenia (43) (por. poniżej):

(42) Wąż skusił Ewę, żeby zerwała owoc.

(43) ?Wąż nakłonił Ewę, żeby zerwała owoc.

Co więcej, nakłanianie kogoś do czegoś prawdopodobnie jest działaniem intencjonalnym, podejmowanym świadomie, natomiast kusić kogoś można, zupełnie nie wiedząc, że nasze działanie sprawia, że coś kogoś kusi, na co wskazuje sama struktura predykatowo-argumentowa możliwych zdań z tym czasownikiem:

(44) Skusiło ją to ciastko.

(45) *Nakłoniło ją to ciastko.

Ciąg coś skusiło kogoś (jak w zdaniu (44)) jest poprawny, nieakceptowalny natomiast jest ciąg ${ }^{*}$ coś nakłoniło kogoś z argumentem lewostronnym odnoszącym się do bytów innych niż osoby oraz wyelidowanym prawostronnym argumentem nieprzedmiotowym (por. zdanie (45)). Trudno więc na tym etapie badań jednoznacznie rozstrzygnąć, na ile pojęcie kuszenia wpisuje się w kategorię wykładników nakłaniania kogoś do czegoś.

Bliskie kuszeniu wydaje się zachęcanie kogoś do czegoś, które - tak samo jak czasownik kusić - daje się w zdaniach interpretować dwojako. Przykład

(46) Tomek zachęcił Alę, żeby zamówiła kolejne ciastko.

może opisywać zarówno słowną zachętę do zamówienia ciastka, jak i np. taki sposób jedzenia go, że Ala nabiera ochoty na kolejny przysmak. W obu przypadkach Tomek jakoś na Alę wpłynął, ale czy do czegoś ją nakłonił? Ciąg zdaniowy

(47) Tomek zachęcił Alę, żeby zamówiła kolejne ciastko, ale Tomek nie spowodował, że Ala zdecydowała się zamówić kolejne ciastko. Mimo że miała na nie ogromną ochotę, powstrzymała się, bo była na diecie.

jest w moim odczuciu poprawny - można sobie relacjonowaną w nim sytuację wyobrazić, ponieważ czasownik zachęcać opisuje nie powodowanie jakiejś decyzji, ale powodowanie chęci zrobienia czegoś, a zatem nie może być wykładnikiem nakłaniania kogoś do czegoś.

Podobną właściwość można by przypisać predykatowi zniechęcić, opisującemu sytuację odwrotną - powodowanie niechęci zrobienia czegoś. Jest jeszcze jednak inny, zbliżony do 'zniechęcania' czasownik, który wydaje się wpisywać w badaną kategorię, mianowicie odwieść. Jeżeli ktoś odwiódł kogoś od czegoś, to - jak się 
zdaje - spowodował, że tamten porzucił jakiś swój zamiar, zrezygnował ze zrobienia czegoś, co potwierdza wewnętrzna sprzeczność zdań:

(48) *Karol odwiódł Anię od zamiaru wyjazdu, ale Karol nie spowodował, że Ania zdecydowała się nie wyjeżdżać.

(49) ${ }^{\star}$ Tomek odwiódł Alę od zamiaru zamówienia kolejnego ciastka, ale Tomek nie spowodował, że Ala zdecydowała się nie zamawiać kolejnego ciastka.

Wprawdzie nakłanianie wydaje się oznaczać powodowanie, żeby ktoś coś zrobił, ale powstrzymanie się od zrobienia czegoś też jest działaniem, więc odwodzenie kogoś od czegoś można chyba uznać za wykładnik nakłaniania kogoś do czegoś.

Należałoby tu wspomnieć o jeszcze dwóch czasownikach - motywować i dopingować [kogoś do czegoś] - które również można by chyba uznać za wykładniki nakłaniania kogoś do czegoś. Wydaje się, że motywując lub dopingując kogoś do czegoś, wpływamy na jego chęć zrobienia czegoś, co zbliżałoby te predykaty do omawianego powyżej zachęcania, a zatem i wykluczałoby je z badanej kategorii. $Z$ drugiej jednak strony zdania (50) i (51) są sprzeczne wewnętrznie, co wskazywałoby na związek czasowników motywować i dopingować z predykatem nakłaniać.

(50) *Michał zmotywował Maćka do udziału w konkursie, ale Michał nie spowodował, że Maciek zdecydował się wziąć udział w konkursie.

(51) *Ola zdopingowała Zosię do startu w zawodach, ale Ola nie spowodowała, że Zosia zdecydowała się wystartować w zawodach.

Jest jeszcze kilka czasowników, które - choć mieszczą się w kategorii powodowania, że ktoś coś robi - od nakłaniania kogoś do czegoś zdają się dość znacząco różnić, choć Czekańska (2015) włącza dwa z nich do grupy badanych wyrażeń. Mam tu na myśli czasowniki podburzać i podpuszczać oraz sprowokować.

(52) Najwyraźniej ktoś podpuścił studentów, żeby zrobili aferę.

(53) Firlej podburzył dowódcę Tykocina, by odmówił wprowadzenia do zamku panów koronnych z trumną króla.

(54) Młody sprowokował kumpla do bójki ze Zbyszkiem.

Nie da się zaprzeczyć, że podpuszczając, podburzając czy prowokując kogoś do czegoś, wpływamy na jego zachowanie, ale czy wpływamy na jego decyzję? Zdania:

(55) ?Najwyraźniej ktoś podpuścił studentów, żeby zrobili aferę, ale nikt nie spowodował, że studenci zdecydowali się zrobić aferę.

(56) ?Firlej podburzył dowódcę Tykocina, by odmówił wprowadzenia do zamku panów koronnych z trumną króla, ale Firlej nie spowodował, że dowódca Tykocina zdecydował się odmówić wprowadzenia do zamku panów koronnych $\mathrm{z}$ trumną króla. 
(57) ?Młody sprowokował kumpla do bójki ze Zbyszkiem, ale Młody nie spowodował, że jego kumpel zdecydował się pobić się ze Zbyszkiem.

w moim odczuciu budzą pewne wątpliwości, a podburzanie, podpuszczanie i prowokowanie wydają się odbiegać od czasowników omówionych powyżej. Różnicę między nimi trudno mi przy tym wstępnym rozpoznaniu sprecyzować, chociaż wydaje się, że może ona mieć związek z tym, że nakłanianie kogoś do czegoś oparte jest na przemyślanym, racjonalnie przeprowadzonym - nawet jeśli nieuczciwym, jak w przypadku manipulacji - działaniu, natomiast w przypadku prowokowania, podpuszczania i podburzania raczej działa się spontanicznie, może nawet żywiołowo, i gra na emocjach osoby czy też grupy osób, na które się wpływa. Trudno uznać podburzanie, podpuszczanie, a zwłaszcza prowokowanie za działania prowadzące do racjonalnego decydowania o czymś. Zaliczenie tych predykatów do wykładników nakłaniania kogoś do czegoś lub wykluczenie ich z tej kategorii wymagać będzie kolejnych, zapewne bardziej wnikliwych, analiz.

Wątpliwości pojawiają się również w przypadku czasownika zmusić, który od początku badań intuicyjnie włączałam do grupy wykładników nakłaniania. Zmuszanie na pewno jest powodowaniem tego, że ktoś coś robi, co potwierdza dewiacyjność zdań:

(58) ${ }^{\star}$ Ojciec zmusił Jasia do zjedzenia warzyw, ale ojciec nie spowodował, że Jaś zjadł warzywa.

(59) *Ciotka zmusiła Henia do włożenia pomarańczowego swetra, ale ciotka nie spowodowała, że Henio włożył pomarańczowy sweter.

Czy jednak ktoś, kto jest zmuszony do zrobienia czegoś, decyduje się to zrobić? Ten problem wymaga głębszego namysłu. Wydaje się jednak, że o ile nakłaniając kogoś do czegoś, pozostawiamy mu możliwość wyboru tego, co zrobi, o tyle zmuszając kogoś do czegoś, nie pozwalamy mu na samodzielną decyzję. Spójrzmy na kilka przykładów:

(6o) Ojciec nakłonił Jasia do zjedzenia warzyw, ale ojciec zakładał, że Jaś może odmówić zjedzenia warzyw / nie zjeść warzyw.

(61) ${ }^{\star}$ Ojciec zmusił Jasia do zjedzenia warzyw, ale ojciec zakładał, że Jaś może odmówić zjedzenia warzyw / nie zjeść warzyw.

(62) Ciotka nakłoniła Henia do włożenia pomarańczowego swetra, ale ciotka zakładała, że Henio może odmówić włożenia swetra / nie włożyć tego swetra.

(63) ${ }^{\star}$ Ciotka zmusiła Henia do włożenia pomarańczowego swetra, ale ciotka zakładała, że Henio może odmówić włożenia swetra / nie włożyć tego swetra.

Powyższe zdania udowadniają, że pomiędzy zmuszaniem a nakłanianiem kogoś do czegoś rzeczywiście zachodzi różnica pozwalająca na wykluczanie czasownika 
zmuszać z badanej kategorii - zmuszanie polega na spowodowaniu zamierzonego skutku ze świadomym pominięciem elementu decydowania, który jest bardzo istotny w nakłanianiu. Dodatkowo podkreśla to fakt, że o ile można powiedzieć, że ktoś delikatnie / dyplomatycznie / $z$ dużym taktem nakłonił kogoś do czegoś, o tyle nie da się uznać ciągów *ktoś delikatnie / dyplomatycznie / $z$ dużym taktem zmusił kogoś do czegoś za poprawne.

5. Listę czasowników będących wykładnikami nakłaniania kogoś do czegoś prawdopodobnie trudno jeszcze uznać za zamkniętą. Na tym etapie gotowa byłabym do nich zaliczyć następujące wyrażenia:

a) ktoś nakłonił kogoś do czegoś;

b) ktoś namówił kogoś do czegoś;

c) ktoś skłonił kogoś do czegoś;

d) ktoś wyperswadował coś komuś;

e) ktoś zmanipulował kogoś;

f) ktoś przekonał kogoś do czegoś;

g) ktoś wymógł coś na kimś;

h) ktoś przekupił kogoś czymś;

i) ktoś skusił kogoś czymś;

j) ktoś zmotywował kogoś do czegoś;

k) ktoś zdopingował kogoś do czegoś.

Zapewne można by umieścić tutaj również pewne wyrażenia nacechowane pragmatycznie, takie jak ktoś molestuje kogoś o coś czy ktoś męczy kogoś o cośt, oraz frazeologizmy, jak np. ciosać komuś kołki na głowie i wiercić komuś dziurę w brzu$c h u^{7}$. Przedstawiona lista wykładników nakłaniania ma jednak charakter wstępny, roboczy i - w wyniku kolejnych obserwacji - na pewno będzie podlegała selekcji. $\mathrm{Z}$ dalszych badań trzeba będzie zapewne wyłączyć jednostki leksykalne zbadane z dobrym skutkiem w rozprawie doktorskiej Czekańskiej. Niewykluczone jednak, że warto byłoby przyjrzeć się uważnie czasownikom namówić i nakłonić, które są podstawowymi reprezentantami grupy wykładników nakłaniania. Nie wydaje się również, żeby trzeba było zajmować się szczegółową analizą ciągu ktoś skusił kogoś czymś, skoro jednostki zawierające czasownik kusić zostały zadowalająco zdefiniowane przez Duraj-Nowosielską (2007: 256-268). Tak ograniczona lista wciąż jest dość obszerna, a zatem można chyba uznać, że mimo iż powstała cała praca poświęcona czasownikom nakłaniania, nadal pozostały pewne obszary i problemy badaw-

6 Wydaje się, że te dwa ciągi występują wyłącznie w aspekcie niedokonanym - raczej nie powiemy ${ }^{\star} k$ toś zmolestował kogoś o coś czy *ktoś zmęczył kogoś o coś. Może to mieć związek z tym, że działania takie jak męczenie czy molestowanie kogoś o coś są długotrwałe i właśnie z tego powodu uciążliwe, co powoduje ujmowanie tych czynności z perspektywy ich trwania, a nie zakończenia (to sugerowałby aspekt dokonany).

7 Wyłącznie w aspekcie niedokonanym. 
cze, które warto byłoby poddać szczegółowym obserwacjom. Chciałabym zwrócić uwagę na kilka $\mathrm{z}$ nich, mimo że rozwiązać je będzie można zapewne dopiero po szczegółowej analizie pojęcia nakłaniania kogoś do czegoś.

Po pierwsze, na pewno warto zastanowić się nad tym, czy - chociaż mówienie jest jednym z podstawowych sposobów nakłaniania - we wszystkich omawianych wyrażeniach będzie stanowiło komponent znaczenia. Wydaje się, że można kusić czy nawet manipulować, nic do kogoś nie mówiąc, ale problem ten wymaga dalszych analiz.

Po drugie, interesujące będzie spojrzenie na predykat ktoś manipuluje kimś jako na wyrażenie języka naturalnego właśnie, a nie określenie wykorzystywane do specjalistycznego opisu zjawisk językowych czy pewnych tendencji w polszczyźnie.

Po trzecie, niewątpliwie trzeba będzie też rozstrzygnąć wątpliwości, które pojawiły się przy okazji refleksji na temat kuszenia, oraz sprawdzić, czy również w przypadku innych czasowników możliwa jest dwojaka interpretacja zdań o takiej samej strukturze i czy rzeczywiście różnica ta wpływa na zaliczenie danej jednostki do kategorii wykładników nakłaniania kogoś do czegoś.

Podsumowując, grupa czasowników, którą chciałabym zbadać, choć była już analizowana, w tym także pod kątem znaczenia, wciąż zawiera predykaty, którym warto by się dokładnie przyjrzeć. Skłonna jestem zaliczyć do nich następujące jed-

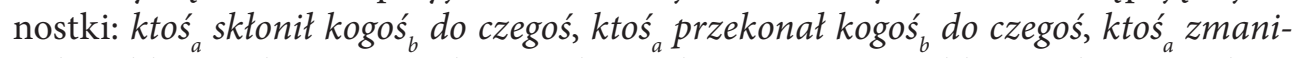
pulował kogoś, ktośs wymógł coś na kimśs, ktoś zmotywowat kogośs do czegoś, ktośs $z$ dopingował kogoś ${ }_{b}$ do czegoś. Mam nadzieję, że niniejszy tekst - mimo że przedstawia zaledwie wstępne hipotezy i kierunki dalszych badań - pokazuje, jak pojemna jest kategoria wykładników nakłaniania kogoś do czegoś oraz że warto je właśnie z semantycznego punktu widzenia szczegółowo przeanalizować.

\section{Literatura}

BogusŁawski A., 1976, O zasadach rejestracji jednostek języka, „Poradnik Językowy” nr 8, S. 356-364.

BogusŁaWSKI A., 1988, Język w stowniku. Desiderata semantyczne do wielkiego stownika polszczyzny, Wrocław.

BogusŁawski A., 1994, O manipulacji, [w:] idem, Sprawy słowa, Warszawa, s. 219-223.

BRALCZyK J., 200o, Język na sprzedaż, Gdańsk.

CzekAńsкA M., 2001, O strukturze predykatowo-argumentowej czasownika kusić, „Prace Filologiczne" XLVI, s. 117-126.

Czekańska M., 2015, Polskie czasowniki nakłaniania jako nazwy tzw. czynności perlokucyjnych, Uniwersytet Warszawski, rozprawa doktorska.

Danielewiczowa M., 2002, Wiedza i niewiedza. Studium polskich czasowników epistemicznych, Warszawa.

Duraj-Nowosielska I., 2007, Robić coś i coś powodować. Opozycja agentywności i kauzatywności w języku polskim, Warszawa. 
GALASIŃsKi D., 1992, Chwalenie się jako perswazyjny akt mowy, Kraków.

Grochowsкi M., 2008, Rola dewiacji w uzasadnianiu hipotez semantycznych. Wprowadzenie do problematyki, „Biuletyn Polskiego Towarzystwa Językoznawczego” LXIV, s. 25-36.

ISJP: M. Bańko (red.), Inny słownik języka polskiego, Warszawa 2000.

Kamińska-Szmaj I., 2004, Propaganda, perswazja, manipulacja - próba uporzadkowania pojęć, [w:] P. Krzyżanowski, P. Nowak (red.), Manipulacja w języku, Lublin, s. 13-27.

Kita M., 1993, Perswazyjne użycie języka potocznego w kontekście ogólnym, [w:] A. Wilkoń, J. Warchala (red.), Z problemów wspótczesnego języka polskiego, Katowice, s. 33-41.

Kleszczowa K., Termińska K., 1983, Nakłaniające zdania aluzyjne, „Język Polski” LXIII, S. 33-41.

Kleszczowa K., Termińska K., 1999, Werbalne i niewerbalne sposoby nakłaniania, [w:] W. Banyś, L. Bednarczuk, S. Karolak (red.), Studia lingwistyczne ofiarowane profesorowi Kazimierzowi Polańskiemu na 7o-lecie Jego urodzin, Katowice, s. 54-62.

Krzyżanowski P., NowaK P. (red.), 2004, Manipulacja w języku, Lublin.

LASKOWsKi R., 1999, Kategorie morfologiczne języka polskiego - charakterystyka funkcjonalna, [w:] R. Grzegorczykowa, R. Laskowski, H. Wróbel (red.), Gramatyka współczesnego języka polskiego. Morfologia, Warszawa, s. 151-224.

MAMCARZ A., 1996, Metodologia badań nad językiem nakłaniania. Zarys problematyki, „Poradnik Językowy" nr 10, s. 14-24.

Marcjanik M., 1980, Czasowniki modalno-kauzatywne we współczesnej polszczyźnie. Analiza łączliwości czasowników oznaczających rozkaz, prośbę, namowę, zakaz, pozwolenie, Zielona Góra.

Puzynina J., 1982/1983, O polskich czasownikach zmuszać, zmusić i predykatach wobec nich bliskoznacznych, „Polonica” VIII, s. 123-146.

PuZYnina J., 1992, Słowo manipulacja w języku polskim, [w:] eadem, Język wartości, Warszawa, s. 203-223.

Wierzbicka A., 1969, Dociekania semantyczne, Wrocław.

WierzBicKA A., 1971, Kocha, lubi, szanuje. Medytacje semantyczne, Warszawa.

Wierzbicka A., 2006, Semantyka. Jednostki elementarne i uniwersalne, Lublin.

WSJP: P. Żmigrodzki (red.), Wielki słownik języka polskiego PAN, [on-line:] wsjp.pl.

ZARoN Z., 1980, Ze studiów nad składnia i semantyka czasownika. Polskie czasowniki $z$ uzupetnieniem werbalnym oznaczające relację osobowa z argumentem zdarzeniowym, Wrocław.

Zaron Z., 200o, Właściwości semantyczne orzeczeń. Preparacje składniowe, cz. I, „Prace Filologiczne” XLV, s. 681-691.

Zaron Z., 2001, Właściwości semantyczne orzeczeń. Preparacje składniowe, cz. II, „Prace Filologiczne" XLVI, s. 673-682.

Zaron Z., 2002, Właściwości semantyczne orzeczeń. Preparacje składniowe, cz. III, „Prace Filologiczne" XLVII, s. 443-46o. 


\section{Verbal indicators of inducing someone to do something from the semantic perspective. \\ Research reconnaissance \\ Summary}

The goal of this paper is to perform a preliminary investigation of the notion of inducing someone to do something. The first part of the text presents the state of research into indicators of inducing someone to do something, while the second is an attempt to compile a list of expressions which represent the notion in question. 



\section{BIBLIOTEKA „LingVariów"}

t. 1: Listy Jana Baudouina de Courtenay do Henryka Ułaszyna z lat 1898-1929, oprac. M. Skarżyński i M. Smoczyńska, Kraków 2007.

t. 2: W kręgu języka. Materialy konferencji „Słowotwórstwo - słownictwo - polszczyzna kresowa" poświęconej pamięci Profesor Zofii Kurzowej. Kraków 16-17 maja 2008 r., pod red. M. Skarżyńskiego i M. Szpiczakowskiej, Kraków 2009.

t. 3: Język $z$ różnych stron widziany. Materiaty ogólnopolskiej doktorancko-studenckiej konferencji naukowej „Z zagadnień metodologii badań językoznawczych”. Kraków 10-11 marca 2008 r., pod red. M. Skarżyńskiego i A. Czelakowskiej, Kraków 2009.

t. 4: J. Godyń, Studia historycznojęzykowe, edytorskie, kulturalnojęzykowe, Kraków 2009.

t. 5: Polszczyzna mówiona ogólna i regionalna. Materiały ogólnopolskiej konferencji naukowej, Kraków, 25-26 września 2008 r., pod red. B. Dunaja i M. Raka, Kraków 2009.

t. 6: A. Czelakowska, Opisy fleksyjne w gramatykach polskich lat 1817-1939, Kraków 2010.

t. 7: H. Ułaszyn, Z Kopiowatej na katedry uniwersyteckie. Wspomnienia, Z rękopisu opracował, opatrzył przypisami i wydał M. Skarżyński, Kraków 2010.

t. 8: A. Czelakowska, M. Skarżyński, Materiały do dziejów polskiego językoznawstwa. Listy Jana Baudouina de Courtenay, Jana Łosia, Kazimierza Nitscha, Jana Rozwadowskiego, Henryka Ułaszyna, Kraków 2011.

t. 9: Symbolae grammaticae in honorem Boguslai Dunaj, pod red. R. Przybylskiej, J. Kąsia i K. Sikory, Kraków 2010.

t. 10: Silva rerum philologicarum. Studia ofiarowane Profesor Marii Strycharskiej-Brzezinie z okazji Jej jubileuszu, pod red. J.S. Gruchały i H. Kurek, Kraków 2010.

t. 11: M. Rak, Materiały etnograficzne z Podhala Ignacego Moczydłowskiego, Kraków 2011.

t. 12: T. Kurdyła, Funkcje formantów rzeczownikowych w polszczyźnie ludowej (na przykładzie trzech wsi podkarpackich), Kraków 2011. 
t. 13: W. Cockiewicz, Metaforyka Leśmiana (Analiza lingwistyczna), Kraków 2011.

t. 14: Badania historycznojęzykowe. Stan, metodologia, perspektywy, pod red. B. Dunaja i M. Raka, Kraków 2011.

t. 15: Języki słowiańskie w ujęciu socjolingwistycznym. Prace przygotowane na XV Międzynarodowy Kongres Slawistów, Mińsk 2013, pod red. H. Kurek, Kraków 2013.

t. 16: K. Tutak, O dedykacjach $w$ drukach polskich XVI i XVII w. (grafia i interpunkcja), Kraków 2013.

t. 17: Badania dialektologiczne. Stan, perspektywy, metodologia, pod red. M. Raka i K. Sikory, Kraków 2014.

t. 18: M. Sagan-Bielawa, Dziedzictwo pozaborowe. Społeczna świadomość językowa Polaków w Drugiej Rzeczypospolitej, Kraków 2014.

t. 19: M. Rak, Kulturemy podhalańskie, Kraków 2015.

t. 20: A. Sieradzka-Mruk, „Radość i nadzieja, smutek i trwoga” w nabożeństwie drogi krzyżowej. Wybrane aspekty ewolucji dyskursu religijnego w XX wieku na przykładzie leksyki dotyczącej uczuć, Kraków 2016.

t. 21: Materiały do dziejów polskiego językoznawstwa. II: Jan Baudouin de Courtenay, Teksty mniej znane, Wybór, przekład i opracowanie M. Skarżyński, Kraków 2016.

t. 22: M. Rak, Materiały do etnografii Podhala, Kraków 2016.

t. 23: Stowiańska frazeologia gwarowa, pod red. M. Raka i K. Sikory, Kraków 2016.

t. 24: M. Karaś, Ze studiów leksykologicznych i onomastycznych, Wybór i opracowanie J. Reichan i M. Rak, Kraków 2017.

\section{BIBLIOTEKA „LingVariów". Glottodydaktyka}

t. 1: Programy nauczania języka polskiego jako obcego. Poziomy A1-C2. Praca zbiorowa, pod red. I. Janowskiej, E. Lipińskiej, A. Rabiej, A. Seretny i P. Turka, Kraków 2011; wyd. 2 popr., Kraków 2016.

t. 2: T. Czerkies, Tekst literacki w nauczaniu języka polskiego jako obcego (z elementami pedagogiki dyskursywnej), Kraków 2012.

t. 3: B. Ligara, W. Szupelak, Lingwistyka i glottodydaktyka języków specjalistycznych na przykładzie języka biznesu. Podejście porównawcze, Kraków 2012.

t. 4: A. Prizel-Kania, Rozwijanie sprawności rozumienia ze słuchu w języku polskim jako obcym, Kraków 2013.

t. 5: E. Lipińska, A. Seretny, Integrowanie kompetencji lingwistycznych $w$ glottodydaktyce. Na przykładzie nauczania języka polskiego jako obcego/drugiego. Poradnik metodyczny z ćwiczeniami, Kraków 2013.

t. 6: P.E. Gębal, Modele kształcenia nauczycieli języków obcych w Polsce i w Niem- 
czech. W stronę glottodydaktyki porównawczej, Kraków 2013.

t. 7: P.E. Gębal, Krakowska szkoła glottodydaktyki porównawczej na tle rozwoju glottodydaktyki ogólnej i polonistycznej, Kraków 2014.

t. 8: A. Seretny, Słownictwo w dydaktyce języka. Świat słów na przykładzie języka polskiego jako obcego, Kraków 2015.

t. 9: D. Gałyga, Skuteczność nauczania cudzoziemców języka polskiego jako obcego na przykładzie działalności Instytutu Polonijnego Uniwersytetu Jagiellońskiego w latach 1996-2004, Kraków 2015.

t. 10: Umiejętność rozumienia $i$ tworzenia tekstów $w$ świetle standardów wymagań egzaminacyjnych oraz Europejskiego systemu opisu kształcenia jezykowego. Monografia zbiorowa, pod red. E. Lipińskiej i A. Seretny, Kraków 2015.

t. 11: M. Stawicka, W poszukiwaniu nowej równowagi w nauczaniu języków obcych w szkole wyższej na przykładzie projektu edukacyjnego English++, Kraków 2015.

t. 12: Tłumaczenie dydaktyczne w nowoczesnym kształceniu językowym. Monografia zbiorowa, pod red. E. Lipińskiej i A. Seretny, Kraków 2016.

t. 13: Język, literatura i kultura polska $w$ świecie. Monografia zbiorowa pod red. W. Miodunki i A. Seretny, Kraków 2016.

t. 14: Bilingwizm polsko-obcy dziś. Od teorii i metodologii badań do studiów przypadków. Monografia zbiorowa, pod red. R. Dębskiego i W.T. Miodunki, Kraków 2016.

t. 15: O lepsze jutro studiów polonistycznych w świecie. Glottodydaktyka polonistyczna dziś. Monografia zbiorowa, pod red. I. Janowskiej i P.E. Gębala, Kraków 2016.

t. 16: W.T. Miodunka, Glottodydaktyka polonistyczna. Pochodzenie - stan obecny perspektywy, Kraków 2016.

Sprzedaż prowadzi

\section{KSIĘGARNIA AKADEMICKA}

ul. św. Anny 6, 31-0o8 Kraków

e-mail: akademicka@akademicka.pl

Księgarnia internetowa

www.akademicka.pl 



\section{INFORMACJE DLA AUTORÓW}

1. Objętość artykułów nie powinna przekraczać 27000 znaków ze spacjami.

2. Prosimy o nadsyłanie pliku pocztą elektroniczną. W wypadku użycia znaków specjalnych (np. fonetycznych oraz fontów niełacińskich) prosimy dołączyć plik artykułu w PDF.

3. Do artykułu prosimy dołączyć streszczenie (10-15 wierszy) i słowa klucze w języku angielskim lub polskim.

4. Autorów, którzy pierwszy raz przysyłają do nas tekst, prosimy o podawanie stopnia lub tytułu naukowego, nazwy ośrodka, w którym pracują lub w którym są doktorantami, adresu pocztowego, adresu e-mail.

5. Artykuły doktorantów przeznaczone do działu „Debiuty naukowe” przyjmujemy wyłącznie po zaakceptowaniu ich przez opiekunów naukowych.

6. Redakcja zastrzega sobie prawo skracania zbyt długich tekstów, jak również nieprzyjęcia tekstu w innej postaci niż tu określona.

7. Zasady kwalifikowania artykułów do publikacji.

a) Podstawą zakwalifikowania artykułów do druku są dwie pozytywne recenzje językoznawców - specjalistów z zakresu, którego dotyczy artykuł - niezwiązanych z Wydziałem Polonistyki UJ. W wypadku zasadniczo sprzecznych ocen redakcja zastrzega sobie prawo powołania trzeciego recenzenta, którego opinia będzie rozstrzygająca.

b) W postępowaniu recenzyjnym zachowywana jest zasada anonimowości autora i recenzenta. Lista recenzentów współpracujących z czasopismem w danym roku jest zamieszczana w 2 numerze rocznika.

c) O wyniku postępowania recenzenckiego autor jest powiadamiany przez redakcję, otrzymuje także kopie recenzji.

8. Autor jest zobowiązany podać informację o osobach, które w jakikolwiek sposób przyczyniły się do powstania artykułu. Takie postępowanie ma celu uniknięcie sytuacji określanej jako ghostwriting, czyli ukrywanie udziału w powstaniu artykułu osób innych niż oficjalnie figurujące w nagłówku tekstu. Należy więc podawać 
wszystkich współautorów artykułu, z ich afiliacją, oraz informacje, kto jest autorem koncepcji, założeń, metod itp. wykorzystywanych przy przygotowaniu publikacji. Jeśli w grę wchodzi pomoc osób trzecich lub instytucji, właściwą adnotację należy zamieścić w przypisie.

Sprzecznym z naukową rzetelnością zjawiskiem jest podawanie jako współautorów osób, które nie wniosły żadnego wkładu w publikację (tzw. guest authorship).

9. Jeśli artykuł związany jest $z$ badaniami finansowanymi z grantu NCN lub innej instytucji czy stowarzyszenia, autor jest zobowiązany w przypisie podać tę informację wraz z numerem grantu.

10. Odpowiedzialność za zgodne z prawdą zamieszczenie informacji, o których mowa w pkt. 8-9, spoczywa na osobie zgłaszającej tekst do redakcji.

11. Informacje techniczne:

a) Przypisy tekstowe robimy w wersji „dolne”, tj. u dołu strony, natomiast przypisy bibliograficzne w wersji tzw. oksfordzkiej, tj. (Grzegorczykowa 2007) lub (Grzegorczykowa 2007: 23).

b) Wykresy i fotografie (te drugie $\mathrm{w}$ formacie JPEG lub TIFF) itp. prosimy dołączać w osobnych plikach, natomiast w tekście wyraźnie oznaczać miejsca, w których mają być umieszczone.

c) Tytuły czasopism podajemy w cudzysłowach, tytuły książek, rozdziałów i artykułów kursywą bez cudzysłowów.

d) Krótkie cytaty umieszczone w tekście zapisujemy w cudzysłowie, dłuższe (ponad trzy wiersze) w osobnych akapitach, mniejszą czcionką niż podstawowa $\mathrm{w}$ danym artykule.

e) Omawiane wyrazy, zwroty, zdania oraz zwroty obcojęzyczne wyodrębniamy kursywą.

f) Objaśnienia znaczeń wyrazów podajemy w łapkach.

g) Po adresie bibliograficznym należy podać numer DOI, jeśli publikacja go posiada.

h) Opis bibliograficzny w „Literaturze” po tekście artykułu podajemy następująco:

Grochowski M., 2004, Jednostki leksykalne o postaci ba jako komentarz metatekstowy, „Poradnik Językowy” nr 2, s. 18-26. DOI: XXXX.

Pastuchowa M., 2000, Kierunki leksykalizacji struktur słowotwórczych, [w:] K. Kleszczowa, L. Selimski (red.), Stowotwórstwo a inne sposoby nominacji. Materiaty z 4 konferencji Komisji Stowotwórstwa przy Międzynarodowym Komitecie Slawistów, Katowice 27-29 września 2000 r., Katowice, s. 197-202. DOI: XXXX.

SARct: A. Krasnowolski, W. Niedźwiedzki (oprac.), M. Arcta słownik staropolski, Warszawa 1920, [on-line:] bc.wbp.lublin.pl/dlibra/docmetadata?id=3296. 


\section{Recenzenci rocznika 2017}

prof. dr hab. Mirosław Bańko, Uniwersytet Warszawski

prof. dr hab. Wiesław Boryś, Instytut Slawistyki PAN

dr hab. Renata Bura, Uniwersytet Jagielloński

prof. dr hab. Elżbieta Chrzanowska-Kluczewska, Uniwersytet Jagielloński

prof. dr hab. Barbara Falińska, Uniwersytet w Białymstoku

prof. dr hab. Adam Fałowski, Uniwersytet Jagielloński

prof. dr hab. Maciej Grochowski, Uniwersytet Mikołaja Kopernika

prof. dr hab. Włodzimierz Gruszczyński, Instytut Języka Polskiego PAN

dr hab. Mariola Jakubowicz, prof. w Instytucie Slawistyki PAN

prof. dr hab. Irena Kamińska-Szmaj, Uniwersytet Wrocławski

prof. dr hab. Halina Karaś, Uniwersytet Warszawski

проф. Свгенія А. Карпіловська, Національна академія наук України

prof. dr hab. Aleksander Kiklewicz, Uniwersytet Warmińsko-Mazurski

prof. dr hab. Krystyna Kleszczowa, Uniwersytet Śląski

dr hab. Katarzyna Kłosińska, Uniwersytet Warszawski

проф. Алла Кравчук, Львівський національний університет

ім. Івана Франка

dr hab. Tomasz Mika, prof. Uniwersytetu im. Adama Mickiewicza

prof. dr hab. Alicja Nagórko, Humboldt-Universität zu Berlin

dr hab. Stanisława Niebrzegowska-Bartmińska, prof. Uniwersytetu

Marii Curie-Skłodowskiej

dr hab. Aleksandra Niewiara, prof. Uniwersytetu Śląskiego

prof. dr hab. Joanna Okoniowa, Państwowa Wyższa Szkoła Zawodowa

w Tarnowie

prof. dr hab. Anna Pajdzińska, Uniwersytet Marii Curie-Skłodowskiej

prof. dr hab. Alicja Pihan-Kijasowa, Uniwersytet im. Adama Mickiewicza

prof. dr hab. Janusz Rieger, Instytut Slawistyki PAN

prof. dr hab. Elżbieta Sękowska, Uniwersytet Warszawski

prof. dr hab. Marek Stachowski, Uniwersytet Jagielloński

dr hab. Dorota Szumska, Uniwersytet Jagielloński

prof. dr hab. Krystyna Waszakowa, Uniwersytet Warszawski

prof. dr hab. Bogusław Wyderka, Uniwersytet Opolski

prof. dr hab. Aleksander Zajda, Uniwersytet Jagielloński

prof. dr hab. Zofia Zaron, Uniwersytet Warszawski

prof. dr hab. Piotr Żmigrodzki, Instytut Języka Polskiego PAN

prof. dr hab. Urszula Żydek-Bednarczuk, Uniwersytet Śląski 
